Digitized by the Internet Archive in 2012 with funding from University of Alberta Libraries

http://archive.org/details/forestryguidestand96albe 
This document was prepared for:

\begin{tabular}{|l|c|}
\hline Administrators & $\checkmark$ \\
\hline Counsellors & $\checkmark$ \\
\hline General Audience & \\
\hline Parents & \\
\hline Students & \\
\hline Teachers & $\checkmark$ \\
\hline
\end{tabular}

Program/Level: Career and Technology Studies/Secondary

ISBN 0-7732-1959\%5

Copyright (C1996, the Crown in Right of Alberta, as represented by the Minister of Education. Permission is given by the copyright owner for any person to reproduce this publication or any part thereof for educational purposes and on a non-profit basis.

Every effort has been made to acknowledge original sources and comply with copyright regulations. Please notify Alberta Education if there are cases where this has not been done. Shaded areas within this document have been approved for optional implementation. Assessment conditions and criteria are in draft form and will be validated 1994-97.

\section{SUMMARY OF CHANGES}

This June 1996 version of the Guide to Standards and Implementation differs from the June 1995 version as follows:
Section A No change
Section B Updated Scope \& Sequence
Section $C \quad$ Minor edits to Planning for Instruction

Sections $D, E, F$ All conditions and criteria have been revised to include references to assessment tools

Section $G \quad$ Assessment tools have been revised and expanded

Section $\mathrm{H} \quad$ Information on linkages and transitions have been updated and reorganized

Section I Resource lists have been updated to include new resource approvals

Section J Sample student learner guides have minor revisions, particularly to "HOW will your mark be determined?" and "WHICH resources may you use?"

Section $\mathrm{K} \quad$ Acknowledgments are not included in this version

In May 1997, the Guides to Standards and Implementation will be revised again in preparation for provincial implementation in September 1997.

Questions or comments about this Guide to Standards and Implementation are welcome and should be directed to:

Career and Technology Studies Unit, Curriculum Standards Branch, Alberta Education, Devonian Building West, 11160 Jasper Avenue, Edmonton, Alberta, T5K OL2.

Telephone: (403) 422-4872, Fax: (403) 422-0576 


\section{TABLE OF CONTENTS}

\section{Career and Technology Studies}

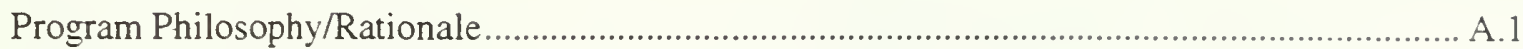

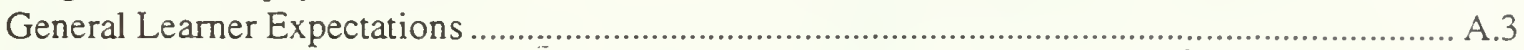

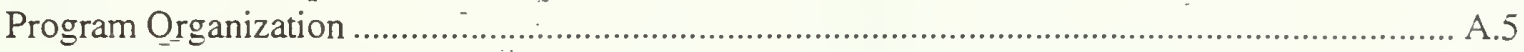

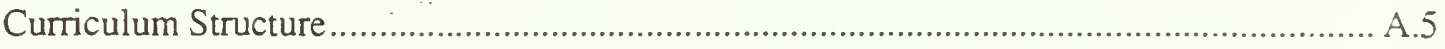

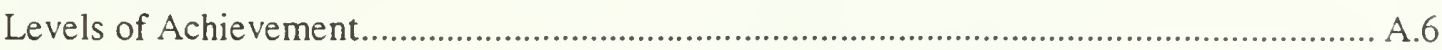

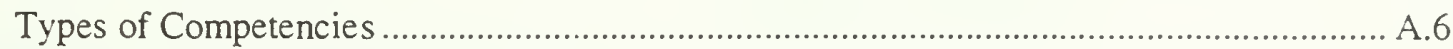

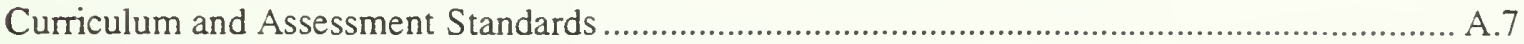

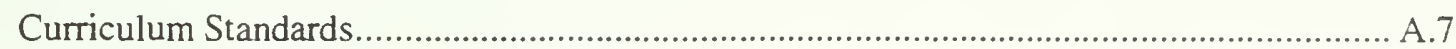

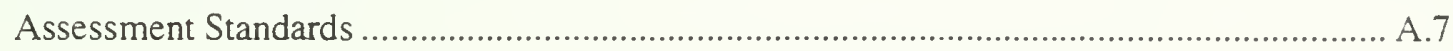

\section{Forestry}

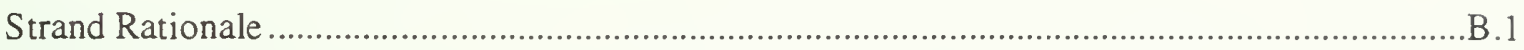

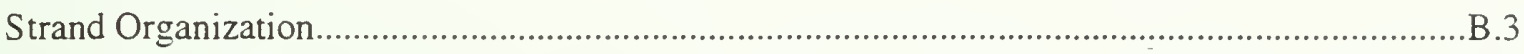

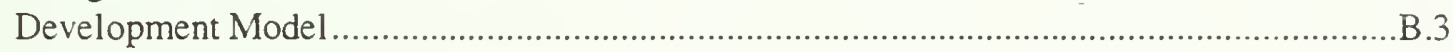

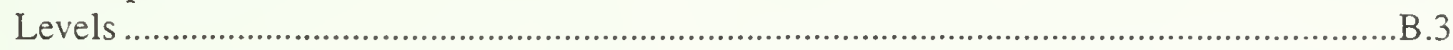

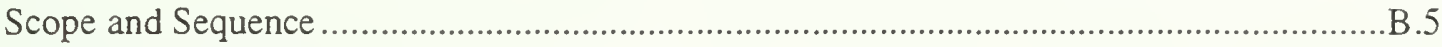

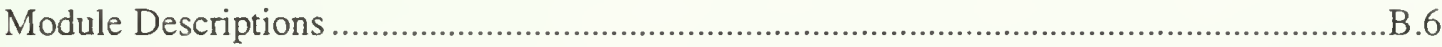

Planning for Instruction

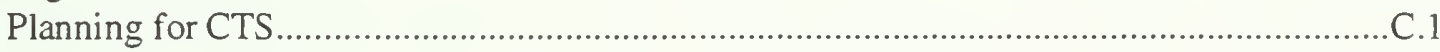

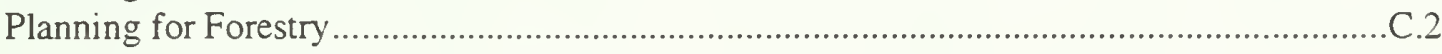

Module Curriculum and Assessment Standards: Introductory Level ................................... D.1

Module Curriculum and Assessment Standards: Intermediate Level ....................................... E.1

Module Curriculum and Assessment Standards: Advanced Level .......................................F.1

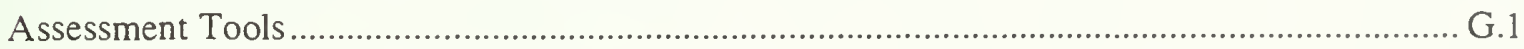

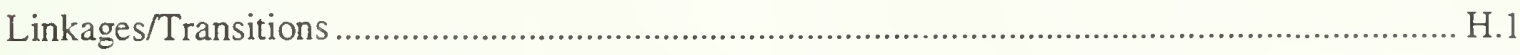

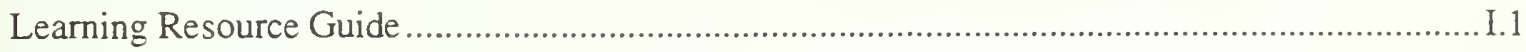

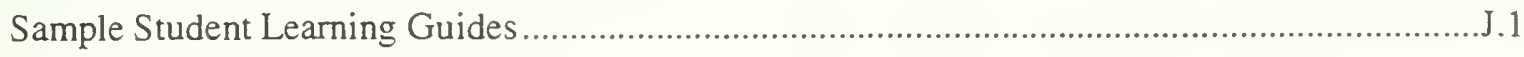

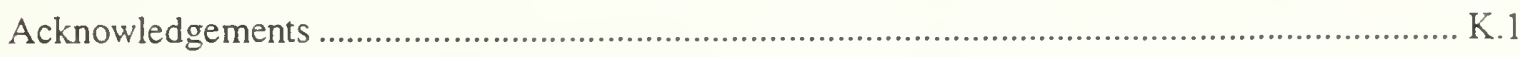




\section{CAREER AND TECHNOLOGY STUDIES}

\section{PROGRAM PHILOSOPHY/RATIONALE}

Through Career and Technology Studies (CTS), secondary education in Alberta is responding to the many challenges of modern society, helping young people develop daily living skills, and nurturing a flexible, well-qualified work force.

In Canada's information society, characterized by rapid change in the social and economic environment, students must be confident in their ability to respond to change and successfully meet the challenges they face in their own personal and work lives. In particular, they must make decisions about what they will do when they finish high school. Many students will enter the work force, others will continue their education. All students face the challenges of growing independence and responsibility, and of entering the highly competitive workplace and/or post-secondary programs.

Secondary schools also face challenges. They must deliver, on a consistent basis, high quality, costeffective programs that students, parents and community find credible and relevant.

CTS helps schools and students meet these challenges. Schools can respónd more efficiently and effectively to student and community needs and expectations by using the opportunities in the CTS curriculum to design courses and access school, community and distance learning resources. Students can develop the confidence they need as they move into adult roles by assuming increased responsibility for their learning; cultivating their individual talents, interests and abilities; and defining and acting on their goals.

As an important component of basic education in Alberta secondary schools, CTS promotes students' achievement by setting clear expectations and recognizing students' success. Students in CTS develop competencies-that is, the knowledge, skills and attitudes students must demonstrate, or what they know and can do.

These competencies can be applied now and in the future as students make a smooth transition into adult roles in the family, community, workplace and/or further education. To help ensure this transition for students, clearly stated expectations and standards have been defined with the assistance of teachers, business and industry representatives and post-secondary educators.

CTS offers all students important leaming opportunities. Regardless of the particular area of study chosen, students in CTS will:

- develop skills that they can apply in their daily lives now and in the future

- refine career-planning skills

- develop technology-related skills

- enhance employability skills

- apply and reinforce learnings developed in other subject areas. 
In CTS, students build skills they can apply in their everyday lives. For example, in the CTS program, particularly at the introductory levels, students have the opportunity to improve their ability to make sound consumer decisions, and to appreciate environmental and safety precautions.

A career encompasses more than activities related to a person's job or occupation; it involves one's personal life in both local and global contexts; e.g., as a family member, a friend, a community volunteer, a citizen.

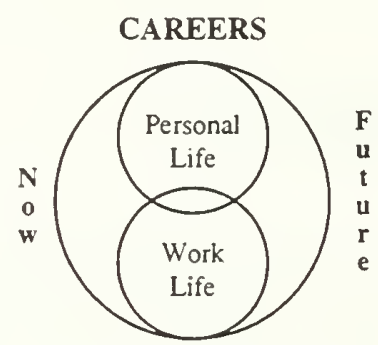

The integration of careers throughout the CTS program helps students make effective career decisions and target their efforts. Students in CTS will have the opportunity to expand their knowledge about careers, occupations and job opportunities and the education and/or training requirements involved. As well, they will recognize the need for lifelong learning.

Students in CTS will have the opportunity to use and apply technology and systems effectively and efficiently, which involves:

- a decision regarding which processes and procedures best suit the task at hand

- the appropriate selection and skilled use of the tools or resources that are available

- an assessment of and management of the impact the use of the technology may have on themselves, on others and on the environment.

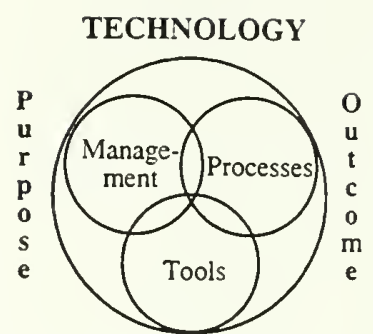

Integrated throughout CTS are employability skills, those basic competencies that help students develop their personal management and social skills. Personal management skills are improved as students take increased responsibility for their learning, design innovative solutions to problems or challenges, and manage resources effectively and efficiently. Students' social skills improve through learning experiences that require them to work effectively with others, demonstrate teamwork and leadership, and maintain high standards in safety and accountability.

Further enhancing the employability skills, CTS reinforces and enhances learnings developed in core and other complementary courses. The curriculum emphasizes, as appropriate, the effective application of communication and numeracy skills.

Finally, in addition to the common outcomes described above, those students who focus on a particular area of study will develop career-specific competencies that support entry into the workplace and/or related post-secondary programs. Careerspecific competencies can involve understanding and applying appropriate terminology, processes and technologies related to a specific career, occupation or job. 


\section{GENERAL LEARNER EXPECTATIONS}

General learner expectations describe the basic competencies that are integrated throughout the CTS program.

Within an applied context that is relevant to personal goals, aptitudes and abilities, the student in Career and Technology Studies will:

- demonstrate the basic knowledge, skills and attitudes necessary for achievement and fulfillment in personal life

- develop an action plan that relates personal interests, abilities and aptitudes to career opportunities and requirements

- use technology effectively, linking and applying available tools, management and processes to produce a desired outcome

- develop personal management skills by:

- linking theory and practice, using resources, tools, technology and processes responsibly and efficiently (managing learning)

- applying effective and innovative decisionmaking and problem-solving strategies in the design, production, marketing and consumption of goods and services (being innovative)

- selecting relevant, goal-related activities, ranking them in order of importance, allocating necessary time, and preparing and following schedules (managing resources)
- improve social interaction skills by:

- demonstrating flexibility and cooperative work and communication behaviors (working with others)

- participating as a team member by working cooperatively with others and contributing to the group with ideas, suggestions and effort (teamwork and leadership)

- demonstrating high standards of diligence, attendance and punctuality, following safe procedures consistently, and recognizing and eliminating potential hazards (demonstrating responsibility)

- demonstrate appropriate verbal, written, composition, summarization and presentation skills

- use basic computation and measurement principles accurately and efficiently. 


\section{PROGRAM ORGANIZATION}

\section{CURRICULUM STRUCTURE}

Career and Technology Studies is organized into strands and modules.

Strands in CTS define competencies that help students:

- build daily living skills

- investigate career options

- use technology (managing, processes, tools) effectively and efficiently

- prepare for entry into the workplace and/or related post-secondary programs.

In general, strands relate to selected industry sectors that offer positive occupational opportunities for students. Some occupational opportunities require further education after high school, and some allow direct entry into the workplace. The industry sectors encompass both goods-producing industries, such as agriculture, manufacturing and construction, and service-producing industries, such as business services, health services, and finance and insurance services.

Modules are the building blocks for each strand. They define what a student is expected to know and be able to do (exit-level competencies). Modules also specify prerequisites and facility and instructional parameters, where necessary.

The competencies a student must demonstrate to achieve success in a module are defined through the module learner expectations. Senior high school students who can demonstrate the module learner expectations (i.e., have the designated competencies) will qualify for one credit towards their high school diploma.

Module learner expectations are a culmination of the specific learner expectations, which provide a more detailed framework for instruction. They define the scope and depth of knowledge, skills and attitudes the student should acquire.
The following chart shows the 22 strands that comprise the CTS program and the number of modules available in each strand.

\begin{tabular}{|c|c|}
\hline Strand & $\begin{array}{l}\text { No. of } \\
\text { Modules }\end{array}$ \\
\hline 1. Agriculture & 31 \\
\hline 2. Career Transitions & 23 \\
\hline 3. Communication Technology & 32 \\
\hline 4. Community Health & 31 \\
\hline 5. Construction Technologies & 46 \\
\hline 6. Cosmetology & 58 \\
\hline 7. Design Studies & 31 \\
\hline 8. Electro-Technologies & 37 \\
\hline 9. Energy and Mines & 27 \\
\hline 10. Enterprise and Innovation & 8 \\
\hline 11. Fabrication Studies & 41 \\
\hline 12. Fashion Studies & 29 \\
\hline 13. Financial Management & 15 \\
\hline 14. Foods & 37 \\
\hline 15. Forestry & 21 \\
\hline 16. Information Processing & 43 \\
\hline 17. Legal Studies & 13 \\
\hline 18. Logistics & 12 \\
\hline 19. Management and Marketing & 21 \\
\hline 20. Mechanics & 53 \\
\hline 21. Tourism Studies & 24 \\
\hline 22. Wildlife & 17 \\
\hline
\end{tabular}

Note: As of September 1996, all 22 strands are available for optional implementation in Alberta junior and high schools. Provincial implementation of all strands is scheduled for September 1997. 


\section{LEVELS OF ACHIEVEMENT}

Modules are organized into three levels of achievement: introductory, intermediate and advanced. As students progress through the levels, they will be expected to meet higher standards and demonstrate increased degree of competence, both in the general learner expectations and the module learner expectations.

Introductory level modules help students build daily living skills and form the basis for further learning. Introductory modules are developed for students who have no previous experience in the strand.

Intermediate level modules build on the competencies developed at the introductory level. They provide a broader perspective, helping students recognize the wide range of related career opportunities available within the strand.

Advanced level modules demand a higher level of expertise and help prepare students for entry into the workplace or a related post-secondary program.

The following illustrates the relative emphasis on the aspects of career planning at each of the levels.

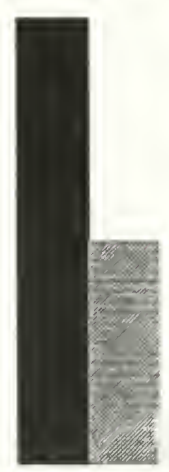

Introductory Level

Personal Use

Career Awareness/Exploration

Preparation for the Workplace or Further Education

\section{TYPES OF COMPETENCE}

Two types of competence are defined within the CTS program: basic and career-specific.

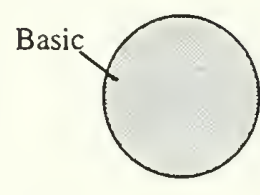

Basic Competencies are generic to any career area and are developed within each module. Basic competencies include:

- personal management; e.g., managing learning, being innovative, ethics, managing resources

- social; e.g., communication, teamwork, leadership and service, and demonstrating responsibility (safety and accountability).

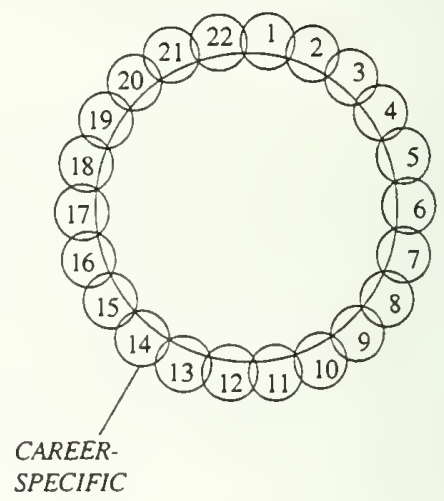

Career-specific Competencies relate to a particular strand. These competencies build daily living skills at the introductory levels and support the smooth transition to the workplace and/or postsecondary programs at the intermediate and advanced levels.

The following model shows the relationship of these two types of competencies within the 22 strands of CTS (numbers refer to the chart on page A.5):

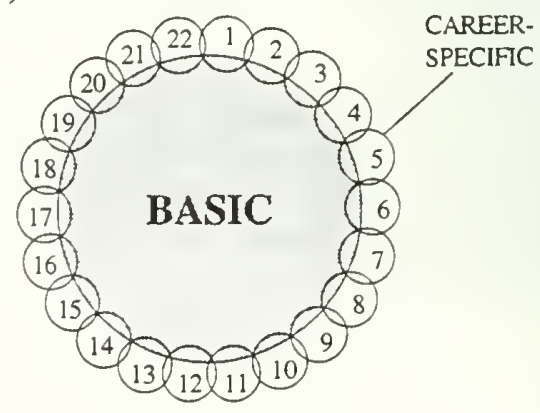




\section{CURRICULUM AND ASSESSMENT STANDARDS}

\section{CURRICULUM STANDARDS}

Curriculum standards in CTS define what students must know and be able do. Curriculum standards are expressed through general learner expectations for CTS, and through module and specific learner expectations for each strand.

\section{ASSESSMENT STANDARDS}

Assessment standards define how the student's performance will be judged. In CTS, each assessment standards defines the conditions and criteria to be used for assessing the competencies defined in each module learner expectation. Students must fully meet each assessment standard, including all of the criteria and conditions defined for the module. Assessment standards are in draft form, as are tools and weightings, and will be validated 1994-97.
Teachers throughout the province will be able to ensure students receive a fair and reliable assessment. Students will use the assessment standards to guide their efforts, ensuring they participate more effectively and successfully in the learning and assessment process. Standards at advanced levels are as much as possible linked to workplace and post-secondary entry-level requirements.

The following pages describe the Forestry strand in the Career and Technology Studies program. 


\section{FORESTRY}

\section{STRAND RATIONALE}

Forests are a valuable source of natural wealth and cover almost two-thirds of Alberta. The resources found on or beneath these public lands are important to our economic strength and quality of life. Forested lands in Alberta and Canada provide wildlife habitat, vital watersheds, grazing lands, non-renewable resource development sites, outdoor recreation and tourism opportunities, and at the same time support the development of the forest products industry.

Achieving harmony among these diverse and sometimes competing needs associated with forested lands is a vital and continuous task. Integrated resource management ensures a balanced use of forest resources through public involvement and a team approach.

Recently, public concern for forests at global levels has expanded to embrace practices that ensure sustainable use of forest ecosystems. Sustainable use of resources and the environment today will not damage prospects for their use by future generations. ${ }^{\star}$
Forestry, a strand in Career and Technology Studies, will provide opportunities for students to learn about the dynamics of a forest ecosystem, as well as the many benefits and opportunities associated with forests. Conservation is viewed throughout the strand as a process for managing human use of the forest environment to ensure such use is sustainable. Students will develop practical knowledge of industry practices that support the integrated and sustainable development of forest resources.

Within the philosophy of Career and Technology Studies, students in Forestry will develop the knowledge, skills, attitudes, motivation and commitment to work individually and collectively, as private citizens and members of the work force, toward the conservation and responsible use of water, land, air, forests and wildlife. In order to achieve these competencies, the student will:

- develop greater awareness of the economic, environmental and social significance of the forest resource in Alberta and the rest of the world, and the benefits and costs of resource development

* Parks Canada and the Canadian Wildlife Service. The Nature of Canada: A Primer on Spaces and Species. Ottawa, ON: Environment Canada, 1993. 
- describe relationships among production, processing and marketing systems within the forests products industry

- describe technologies and research programs designed to develop, conserve, protect, enhance and sustain the productivity of forested lands

- translate sustainable development and conservation goals into viable plans for managing use of the forest resource

- develop competencies and behaviours that have broad application to environmental career paths, and specific application to careers within Alberta's forest industries.

Although students are at various stages of cognitive development, many will continue to use concrete operational thinking. Each module in Forestry provides opportunities for students to link concrete and psychomotor learning experiences to more abstract thought processes and levels of thinking. Students will be encouraged to transfer the competencies they have developed in other core and complementary school courses as well as through hobbies, interests and past experiences. As students learn to relate theory and practice in participatory situations, confidence will further their ability to meet personal and professional challenges. 


\section{STRAND ORGANIZATION}

\section{DEVELOPMENT MODEL}

The development model depicts major emphases within the Forestry strand. Three dimensions that provide a basis for selecting and organizing content are represented in the model.

- The KNOWLEDGE, SKRLS AND ATTITUDES, represented on the upper face of the model, provide structure for the course and focus attention on learning goals common to all CTS courses.

- The LEARNING CONTEXTS, represented on the right face of the model, foster the development of knowledge and behaviours that will enable students to meet the demands of daily living, further training and the workplace.
The THEMES provide situational and concrete learning experiences that support the development of knowledge, skills and attitudes relevant to each of the learning contexts. Each theme focuses attention on the sustainable use of species and ecosystems. Blended together, the themes enable students to understand how it is possible to fulfill social, cultural, aesthetic and economic goals through resource development, while embracing a conservation ethic so as to maintain essential ecological process, genetic diversity and an adequate resource base for future generations.

\section{LEVELS}

Forestry, like other Career and Technology Studies curricula, is organized into three levels of learning: introductory, intermediate and advanced.

\section{KNOWLEDGE, SKILLS AND ATTITUDES}

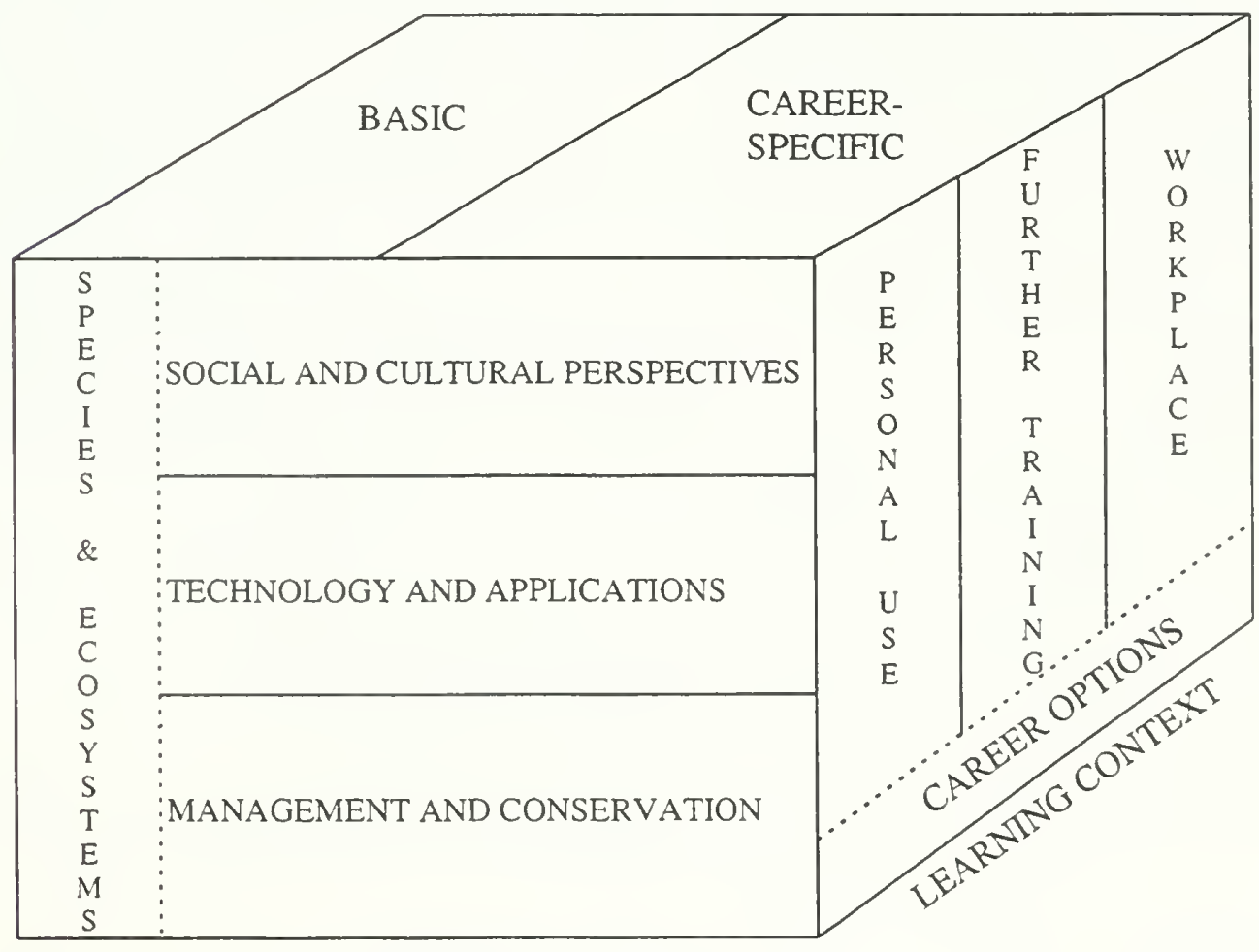


Introductory modules enable students to develop basic knowledge of forest regions and ecosystems, and skills necessary for functioning in a forest environment. Intermediate and advanced level modules develop more specialized knowledge of silviculture practices, and the harvest, processing and marketing of forest products. Students examine forest management policies and programs, and develop plans for the sustainable development of forested lands. 


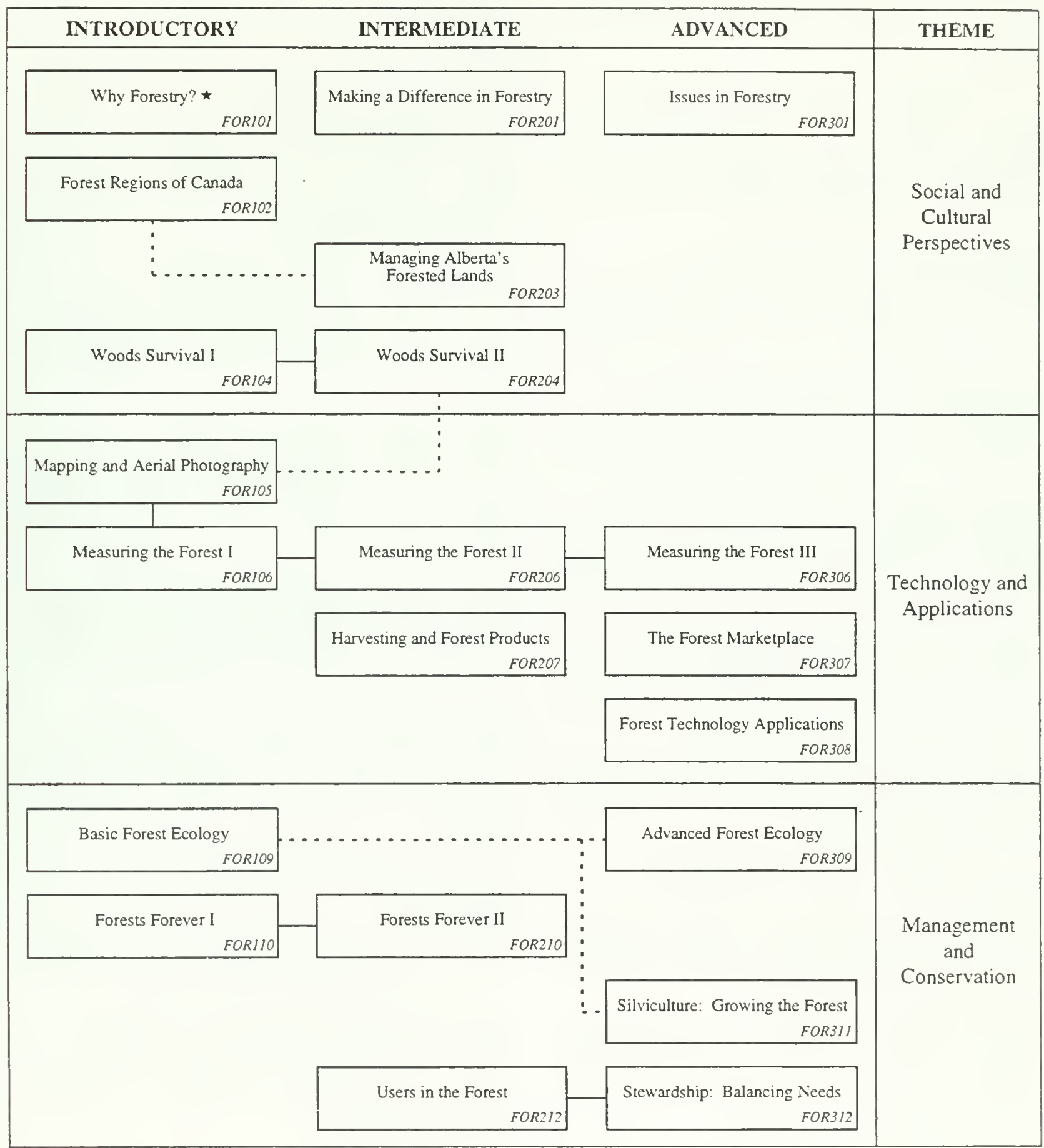

$\star$ This module provides a strong foundation for further learning in this strand. 


\section{MODULE DESCRIPTIONS}

\section{Module FOR101: Why Forestry?}

Students explain the social and environmental significance of forests, describe the impact of individuals on forests, and investigate career paths in forestry.

\section{Module FOR102: Forest Regions of Canada}

Students identify factors that determine the distribution of forests, and research forest regions of Canada (with emphasis on specific species and forest associations found in Alberta).

\section{Module FOR104: Woods Survival I}

Students demonstrate basic skills required for responsible participation in a range of outdoor activities in the forest.

\section{Module FOR105: Mapping and Aerial}

\section{Photography}

Students interpret information conveyed through different types of maps and aerial photographs.

\section{Module FOR106: Measuring the Forest I}

Students demonstrate basic forest measurement skills and apply these skills in sampling fibre values in a forested region.

\section{Module FOR109: Basic Forest Ecology}

Students investigate forest ecosystems and explain the structure and functioning of trees.

\section{Module FOR110: Forests Forever I}

Students describe past and present uses of Canada's forests, and explain how research and technology assist in forest management.

\section{Module FOR201: Making a Difference in \\ Forestry}

Students analyze the impact of lifestyle on forests, and propose individual and shared actions that foster environmental stewardship.

\section{Module FOR203: Managing Alberta's Forested Lands}

Students research agencies and frameworks used to manage forested lands in Alberta.

Module FOR204: Woods Survival II

Students plan, prepare for and conduct an extended outdoor wilderness trip in the forest.
Module FOR206: Measuring the Forest II Students research current forest inventory practices and demonstrate appropriate strategies for sampling the fibre and non-fibre value of forests.

\section{Module FOR207: Harvesting and Forest Products}

Students research the steps involved in harvesting and processing the fibre resource.

\section{Module FOR210: Forests Forever II}

Students explain forest management goals in Alberta, and describe current management practices used to address these goals.

Module FOR212: Users in the Forest

Students identify different users in the forest and explain the planning principles that are used in developing an integrated resource management plan.

Module FOR301: Issues in Forestry

Students analyze local and global issues in forest management, and demonstrate individual and shared actions that foster environmental stewardship.

\section{Module FOR306: Measuring the Forest III}

Students explain management applications of data collected from a forest survey, and examine the role of technology in current forest inventory practices.

Module FOR307: The Forest Marketplace Students describe the range of consumer products and services derived from Canada's forests, and research the production and marketing of forest products.

Module FOR308: Forest Technology Applications

Students examine applications of research and technology in the forest industry, and changing career opportunities in the forestry sector.

Module FOR309: Advanced Forest Ecology

Students investigate interrelationships among soil, water, air, trees and the environment, and explain how forests change. 
Module FOR311: Silviculture: Growing the Forest

Students demonstrate knowledge of the techniques used in establishing, growing and harvesting tree crops.

Module FOR312: Stewardship: Balancing

Needs

Students develop and present an integrated plan for sustainable development of the forest resource. 


\section{SECTION C: PLANNING FOR INSTRUCTION}

CTS provides increased opportunity for junior and senior high schools to design courses based on the needs and interests of their students and the circumstances within the school and community. Some strands may be appropriately introduced at the junior high school level. Other strands are more appropriately introduced at the senior high school level or to Grade 9 students. Refer to this section for recommendations regarding the Forestry strand, or the CTS Manual for Administrators, Counsellors and Teachers for a summary of the recommended grade levels for each strand.

\section{PLANNING FOR CTS}

\section{Defining Courses}

Schools determine which strands and modules will be offered in a particular school, and will combine modules into courses.

Each module was designed for approximately 25 hours of instruction. However, this time frame is only a guideline to facilitate planning. The CTS curricula are competency based, and the student may take more or less time to gain the designated competencies within each module.

A course will usually consist of modules primarily from the same strand but, where appropriate, may include modules from two or more strands. Refer to the CTS Manual for Administrators, Counsellors and Teachers for more information on course names and course codes.

Module selection and sequencing must consider the module parameters, which define:

- prerequisite and corequisites (entry-level competencies)

- instructional qualifications, if specialized

- equipment and facility requirements, if specialized.

The module parameters are defined for each module in Sections D, E and F of this Guide.

\section{Degree of Flexibility}

The CTS program, while designed using the modular structure to facilitate flexible time-tabling and instructional delivery, does not mandate the degree of flexibility a school or teacher will offer. The teacher and school will determine the degree of flexibility available to the student. Within the instructional plan established by the school, the student may:

- be given the opportunity to progress at a rate that is personally challenging

- have increased opportunity to select modules that develop competencies he or she finds most relevant.

\section{Integrating Basic Competencies}

Basic competencies are also developed throughout the CTS program and within each module. Selected basic competencies will be emphasized within a module, depending on the nature of the career-specific competencies defined for the module.

Refer to Section G (Assessment Tools) of this Guide for the description of student behaviours expected at each of the four developmental stages defined for the basic competencies.

Assessment of basic competencies could include input and reflection involving the student, teacher(s), peers and others. Description of the observed behaviour could be provided through a competency profile for the module. Positive, ongoing interaction between the student and teacher will support motivation for student growth and improvement.

Assessment of student achievement on the basic competencies is integrated throughout the other module learner expectations.

\section{Assessing Student Achievement}

Assessing the student's competency is a process of gathering information by way of observations of process, product and student interaction. 
Where appropriate, assessment tools have been defined to assist the teacher and student in the assessment. Refer to Section G (Assessment Tools) of this Guide to Standards and Implementation for copies of the various tools (worksheets, checklists, sample questions, etc.).

A suggested emphasis for each module learner expectation has also been established. The suggested emphasis provides a guideline to help teachers determine time allocation and/or a percentage grade for students.

\section{Recognizing Student Achievement}

At the high school level, successful demonstration of the exit-level competencies in a module qualifies the student for one credit. Refer to Section A of this Guide for more detailed information about how curriculum and assessment standards are defined in CTS. Refer to the CTS Manual for Administrators, Counsellors and Teachers for more information on how student achievement can be recognized and reported at the school and provincial levels.

\section{Resources}

A comprehensive resource base, including print, software and audio-visual, has been identified to support the Forestry strand. It is intended that these resources will form the basis of a resource centre, encouraging teachers and students to access a wide selection of resources and other information sources throughout the learning process. Unless otherwise noted, these resources are considered to be suitable for both junior and senior high school students.

Authorized resources may be obtained from the Learning Resources Distributing Centre or directly from the publisher or distributor. Refer to Section I (Learning Resource Guide) for the complete resource list including curriculum correlations and resource annotations. Additional sources refer to non-commercial or government agencies that offer resources that may be of assistance in this strand.

In addition to the resources, sample Student Learning Guides are available. These samples, designed for individual student or small group use, provide an instructional plan for selected modules and include the following components:
- Why take this module?

- What are the entry-level competencies?

- What are the exit-level competencies?

- What resources may be accessed?

- What assignments/activities must be completed?

- What are the time lines?

- How will the final mark be calculated?

Sample Student Learning Guides have been developed for the following modules in Forestry:

- Forest Regions of Canada

- Woods Survival I

- Woods Survival II

- Basic Forest Ecology

- Advanced Forest Ecology.

Copies of these sample learning guides can be obtained, by request, from the CTS Unit in print and/or disk format (Microsoft Word).

\section{PLANNING FOR FORESTRY}

The following suggestions are provided to assist teachers and school and school system administrators as they plan to deliver modules from the Forestry strand.

\section{Selecting Modules}

The scope and sequence chart in Section B provides an overview of the Forestry modules, indicating prerequisites and theme areas. Brief descriptions of the modules follow the scope and sequence chart in Section B.

Course planning should take into consideration module sequences that link with both physical and human resources present in the school and community. Although not required, it is recommended that FOR 101: Why Forestry? be a prerequisite/corequisite to all modules in the Forestry strand. 


\section{Forestry in Junior High}

The introductory level modules may be offered at the junior high level. As each school and community will vary in terms of available resources, it is important to consider potential education partners prior to selecting module sequences.

The number of modules will vary according to time available throughout Grades 7,8 and 9. Two sample courses based on introductory level modules are outlined below.

Sample A: 50 hours of instruction

\begin{tabular}{|c|}
\hline COURSE EMPHASIS \\
\hline Introduction to Forestry \\
\hline MODULES \\
\hline $\begin{array}{l}\text { Why Forestry? (FORI01) } \\
\text { Forest Regions of Canada (FOR 102) }\end{array}$ \\
\hline RATIONALE/KEY LEARNINGS \\
\hline $\begin{array}{l}\text { Students examine the economic, } \\
\text { environmental and social significance of } \\
\text { forests, describe the impact of individuals on } \\
\text { forests, and conduct research on forest regions } \\
\text { of Canada. }\end{array}$ \\
\hline $\begin{array}{l}\text { The course complements the junior high } \\
\text { science and social studies programs, and can be } \\
\text { linked with other CTS strands including } \\
\text { Tourism and Wildlife. }\end{array}$ \\
\hline
\end{tabular}

Sample B: 75 hours of instruction

\begin{tabular}{|l|}
\hline \multicolumn{1}{|c|}{ COURSE EMPHASIS } \\
\hline Personal/Recreational Use of Forests \\
\hline MODULES \\
\hline Basic Forest Ecology (FOR109) \\
Woods Survival I (FOR 104) \\
Making a Difference in Forestry (FOR201) \\
\hline \multicolumn{1}{|c|}{ RATIONALE/KEY LEARNINGS } \\
\hline $\begin{array}{l}\text { Students investigate the structure and } \\
\text { functioning of forest ecosystems, develop } \\
\text { basic skills required for responsible } \\
\text { participation in a range of outdoor forest } \\
\text { activities, and propose individual and shared } \\
\text { actions that foster environmental stewardship. } \\
\text { The course complements the junior high core } \\
\text { science program and complementary } \\
\text { Environmental and Outdoor Education } \\
\text { program, and can be linked with other CTS } \\
\text { strands including Tourism and Wildlife. }\end{array}$ \\
\hline
\end{tabular}

Where appropriate, junior high school students may also take intermediate level modules, particularly in the Technology and Applications theme.

Modules may be combines into courses and offered within a school year or over a span of a few years.

\section{Forestry in Senior High}

Three sample courses, based on intermediate and advanced level modules and designed to be delivered to senior high school students, are as outlined below: 
Sample C: 75 hours of instruction

\begin{tabular}{|c|}
\hline COURSE EMPHASIS \\
\hline $\begin{array}{l}\text { Forest Inventory } \\
\text { (assuming junior high background) }\end{array}$ \\
\hline MODULES \\
\hline $\begin{array}{l}\text { Measuring the Forest II (FOR206) } \\
\text { Measuring the Forest III (FOR306) } \\
\text { Forest Technology Applications (FOR308) }\end{array}$ \\
\hline RATIONALE/KEY LEARNINGS \\
\hline $\begin{array}{l}\text { Students demonstrate appropriate strategies } \\
\text { for sampling fibre and non-fibre values of the } \\
\text { forest, explain management applications of } \\
\text { data collected from a forest survey, and } \\
\text { research applications of technology in forest } \\
\text { inventory practices. }\end{array}$ \\
\hline $\begin{array}{l}\text { This course can be linked with other CTS } \\
\text { strands including Agriculture, Career } \\
\text { Transitions, Information Processing, Tourism } \\
\text { and Wildlife. }\end{array}$ \\
\hline
\end{tabular}

Sample D: 100 hours of instruction

\begin{tabular}{|c|}
\hline COURSE EMPHASIS \\
\hline $\begin{array}{l}\text { Silviculture and Forest Harvest } \\
\text { (assuming junior high background) }\end{array}$ \\
\hline MODULES \\
\hline $\begin{array}{l}\text { Advanced Forest Ecology (FOR309) } \\
\text { Silviculture: Growing the Forest (FOR311) } \\
\text { Harvesting and Forest Products (FOR207) } \\
\text { The Forest Marketplace (FOR307) }\end{array}$ \\
\hline RATIONALE/KEY LEARNINGS \\
\hline $\begin{array}{l}\text { Students investigate relationships among soil, } \\
\text { water, air, trees and the environment, } \\
\text { demonstrate techniques in establishing, } \\
\text { growing, harvesting and processing tree crops, } \\
\text { and research the production and marketing of } \\
\text { forest products in Canada. }\end{array}$ \\
\hline $\begin{array}{l}\text { The course can be linked with other CTS } \\
\text { strands including Career Transitions, } \\
\text { Management and Marketing, Mechanics and } \\
\text { Wildlife. }\end{array}$ \\
\hline
\end{tabular}

Sample E: 125 hours of instruction

\begin{tabular}{|c|}
\hline COURSE EMPHASIS \\
\hline $\begin{array}{l}\text { Forest Management } \\
\text { (assuming junior high background) }\end{array}$ \\
\hline MODULES \\
\hline $\begin{array}{l}\text { Managing Alberta's Forested Lands } \\
\text { (FOR203) }\end{array}$ \\
\hline Forests Forever II (FOR210) \\
\hline Users in the Forest (FOR 212) \\
\hline Issues in Forestry (FOR301) \\
\hline Stewardship: Balancing Needs (FOR312) \\
\hline RATIONALE/KEY LEARNINGS \\
\hline $\begin{array}{l}\text { Students research the goals of forest } \\
\text { management, and agencies/frameworks used } \\
\text { to manage forested lands in Alberta. The } \\
\text { module focuses attention on different users in } \\
\text { the forest, the planning principles involved in } \\
\text { integrated resource management, and } \\
\text { individual/shared actions that foster } \\
\text { environmental stewardship. }\end{array}$ \\
\hline $\begin{array}{l}\text { This course can be linked with other CTS } \\
\text { strands including Agriculture, Career } \\
\text { Transitions, Energy and Mines, Legal Studies, } \\
\text { Tourism and Wildlife. }\end{array}$ \\
\hline
\end{tabular}

Modules could also be grouped into comprehensive courses that develop competencies relevant to career paths within a specific industry.

\section{Organizing for Learning}

A "learn by doing" approach is recommended for the Forestry strand. Essentially, the teacher's role will become that of guide and partner in the learning process. The "learn by doing" approach requires the teacher to be facilitator and coach, rather than subject-based expert, as students actively participate in learning by doing and discovering. 
Small group instruction is a good way to foster learning by doing and discovering. Small groups enable students to be active participants in learning, and develop independent and responsible learning habits. As students work in small group situations they will share information, solve problems, develop consensus, and help each other learn content and processes.

The community has a key role in education and can be an effective partner in the learning process. The use of community members and resources should be integrated into course planning. Business, industry, post-secondary and government agencies offer a wide range of services and resources, as do local clubs, service groups and institutions. When planning for the use of community resources, teachers should ensure that related presentations and/or activities:

- are consistent with student knowledge and skill levels

- demonstrate sound pedagogy

- are exemplary of approved health and safety standards

- provide a balanced approach to curriculum topics and related issues.

Before selecting modules, teachers should check the module parameters outlined in each module (see Sections D, E and F of the Guide). These module parameters describe:

- prerequisite or corequisite modules,

- facility and equipment requirements, if required, and

- instructional qualifications, if required.

Modules can be delivered sequentially, concurrently or combined. For example, although the modules from the Technology and Applications theme are sequential, they can be combined with modules from the Social and Cultural Perspectives theme or the Management and Conservation theme.
Scenario A

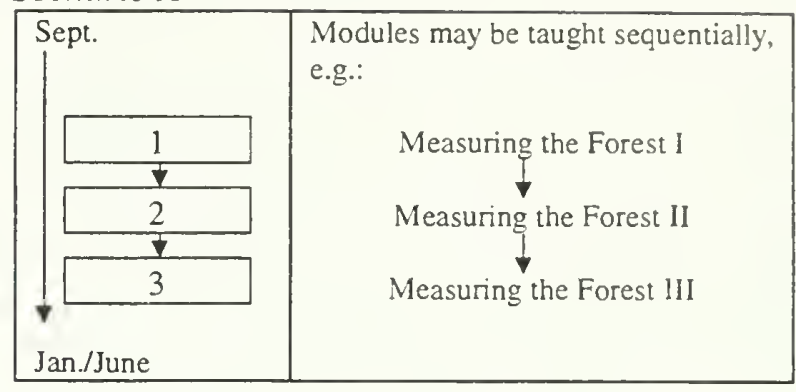

Scenario B

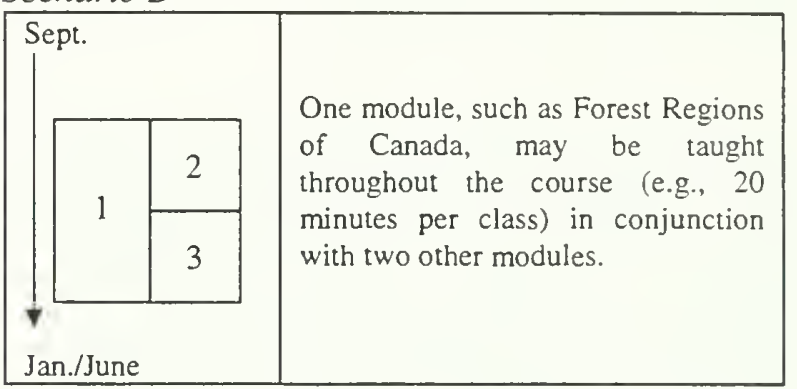

Teachers can also allow students to progress at a rate that is personally challenging; e.g.:

\section{Scenario $C$}

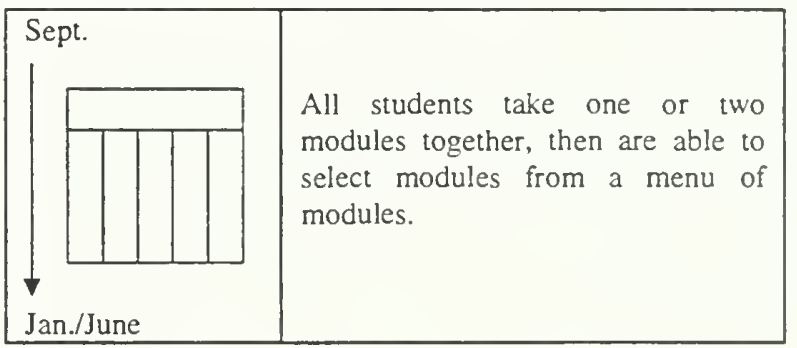

Scenario D

\begin{tabular}{|l|l|}
\hline$\square$ Sept. & $\begin{array}{l}\text { From a menu of modules defined by } \\
\text { the teacher, the students select } \\
\text { which ones they will work on and, } \\
\text { in consultation with the teacher, } \\
\text { establish timelines for completion } \\
\text { and submission of assignments, etc. }\end{array}$ \\
\hline$\square$
\end{tabular}


Plans for learning must address social, economic and environmental perspectives related to sustainable forest use and provide opportunities for students to become involved in learning experiences that reflect a broad understanding of issues related to forest use. Presentations of course content that reflect a singular or narrow view of social, economic or environmental concerns are not consistent with learner expectations and must be avoided. For clarification of policy in this regard, refer to Alberta Education's Policy on Controversial Issues located in the Alberta Education Policy Manual (1989).

As in all CTS strands, students will identify, explore and prepare for future career opportunities. It is recommended that course planning include the integration of relevant career investigations throughout each module, rather than as a singular or isolated study. Career profiles, interviews and jobshadowing will acquaint students with the many technical and professional careers associated with the forest industry.

\section{Addressing Safety in Off-Campus Excursions}

Outdoor trips and field-based investigations are recommended and should be an important part of teaching and learning throughout the Forestry strand. Safety must be a prime consideration in planning off-campus learning experiences. Both teachers and students should engage in activities at their level of training and ability. Adequate instructional support, guidance and supervision must be provided at all times. Local jurisdiction and school policies must be understood by principals, teachers, parents, supervisors and students.

\section{Preparation and Risk Anticipation}

The preparation stage is an important part of any off-campus learning experience. At this stage of planning, potential risks can be anticipated and either avoided or moderated. The preparation stage should focus attention on:
- trip administration, including the use of parental permission forms, health information forms, school/system authorization forms and accident report forms as required

- a review of laws and regulations relevant to the learning site and activities that will be undertaken

- assessment of the learning site in terms of potential hazards and risks that may be present

- group size and the level of supervision that will be required (i.e., supervisor/student ratio)

- a briefing of parents, school administrators, government/industry authorities or others who should be informed regarding itineraries, participants and emergency response plans

- pre-trip logistics, including transportation, equipment, facility and departure date/time considerations

- student preparation, including the development of background knowledge/experience and training in specific skill areas.

\section{On-Site Risk Management}

Safety and risk management involves exercising situation-specific judgement throughout the course of off-campus learning. Judgement is the product of experience, and may include recognizing factors such as dangers imposed by equipment or animals, deteriorating weather, a decline in physical strength, or a more challenging task. Many of the hazard recognition skills can be taught in the classroom in the preparation stage.

A significant aspect of on-site risk management is group management. Teachers can exercise appropriate group management strategies by focusing attention on:

- pacing, including speed of travel, rest stops, distance travelled, and fitness level of students

- maintaining a safe distance for observations

- group control, including position of leader, signal systems and buddy systems

- the establishment of group rules and norms

- clearly defined task allocations for each student

- objective hazard recognition in the field, including machinery and equipment, weather, terrain, flora and fauna 
- subjective hazard recognition in the field, including level of group energy and level of cooperation.

\section{Emergency Response}

If students have been well prepared for field-based learning experiences and appropriate group management strategies exercised, the teacher will have maximized opportunities for effective response to an emergency situation. An effective emergency response action plan should include consideration of:

- a suitable approach to the accident site

- first-aid supplies and techniques

- a strategy for signalling assistance

- an evacuation plan

- group management throughout the emergency situation.

\section{Identifying Linkages}

Section $\mathrm{H}$ of this Guide describes linkages within CTS and with core and complementary programs.

Note that project and practicum modules from the Career Transitions strand may be combined with modules from Forestry to provide increased opportunity for students to develop expertise, refine their competencies and/or obtain credentials.

Project and practicum modules are not designed to be offered as distinct courses and should not be used to extend Work Experience 15, 25, and 35 courses.
Improving Smooth Transitions to the Workplace and/or Post-secondary Programs

Refer to Section $\mathrm{H}$ of this Guide for potential transitions students may make into:

- the workplace

- related post-secondary programs or other avenues for further learning. 


\section{MODULE CURRICULUM AND ASSESSMENT STANDARDS: SECTION D: INTRODUCTORY LEVEL}

The following pages define the curriculum and assessment standards for the introductory level of Forestry.

Introductory level modules help students build daily living skills and form the basis for further learning. Introductory modules are developed for students who have no previous experience in the strand.

Module learner expectations define the competencies a student must demonstrate to achieve success in a module. Assessment standards define the conditions and criteria to be used for assessing the competencies defined in the module learner expectations. These assessment standards and the accompanying assessment tools are in draft form and will be validated from 1994 to 1996.

Specific learner expectations provide a detailed framework for instruction to help students build the competencies defined in the module learner expectations. Additional information and suggestions for instruction are provided in the Notes column; teachers may wish to use this space to record their ideas for instruction or student projects.

Module FOR101:

Why Forestry?.

D.3

Module FOR 102:

Forest Regions of Canada

D.7

Module FOR 104:

Woods Survival I

D. 11

Module FOR 105:

Mapping and Aerial Photography.

D. 17

Module FOR 106:

Measuring the Forest I

D. 21

Module FOR109:

Basic Forest Ecology

D. 25

Module FOR110:

Forests Forever I

D.29 


\section{MODULE FOR101: WHY FORESTRY?}

\section{Level: $\quad$ Introductory}

Theme: $\quad$ Social and Cultural Perspectives

Prerequisite: None

Module Parameters: Access to government, industry and community resources

Students explain the social and environmental significance of forests, describe the impact of individuals on forests, and investigate career paths in forestry.

\section{Curriculum and Assessment Standards}

\begin{tabular}{|c|c|c|}
\hline $\begin{array}{c}\text { Module Learner } \\
\text { Expectations }\end{array}$ & Assessment Criteria and Conditions (Draft) & $\begin{array}{l}\text { Suggested } \\
\text { Emphasis }\end{array}$ \\
\hline $\begin{array}{l}\text { The student will: } \\
\text { describe the social, } \\
\text { cultural, economic and } \\
\text { environmental } \\
\text { significance of forests }\end{array}$ & $\begin{array}{l}\text { Assessment of student achievement will be based on: } \\
\text { - identifying and explaining six or more ways in which } \\
\text { local forests (regional or provincial) have: } \\
\text { - social and cultural significance (e.g., recreational, } \\
\text { spiritual, aesthetic, medicinal) } \\
\text { - economic significance (e.g., employment, product } \\
\text { export, tourism, subsistence, tax base) } \\
\text { - environmental significance (e.g., air, water and } \\
\text { soil cycles) } \\
\text { Assessment Tools } \\
\text { Knowledge/Application Assessment: Significance } \\
\text { of Forests, FORIOI-1 } \\
\text { Sample Timeline: Forestry in North America, } \\
\text { FORIO1-2 } \\
\text { Standard } \\
\text { Respond to a standard of } 1 \text { on the rating scale } \\
\text { a comprehensive list of forest products and services } \\
\text { Standard } \\
\text { Identify and describe } 20 \text { products and } 10 \text { services } \\
\text { derived from Canadian forests }\end{array}$ & 40 \\
\hline
\end{tabular}


MODULE FOR101: WHY FORESTRY? (continued)

\begin{tabular}{|c|c|c|}
\hline $\begin{array}{c}\text { Module Learner } \\
\text { Expectations }\end{array}$ & Assessment Criteria and Conditions (Draft) & $\begin{array}{l}\text { Suggested } \\
\text { Emphasis }\end{array}$ \\
\hline $\begin{array}{l}\text { The student will: } \\
\text { - explain how personal } \\
\text { needs, wants, beliefs and } \\
\text { actions may influence } \\
\text { the forest resource }\end{array}$ & 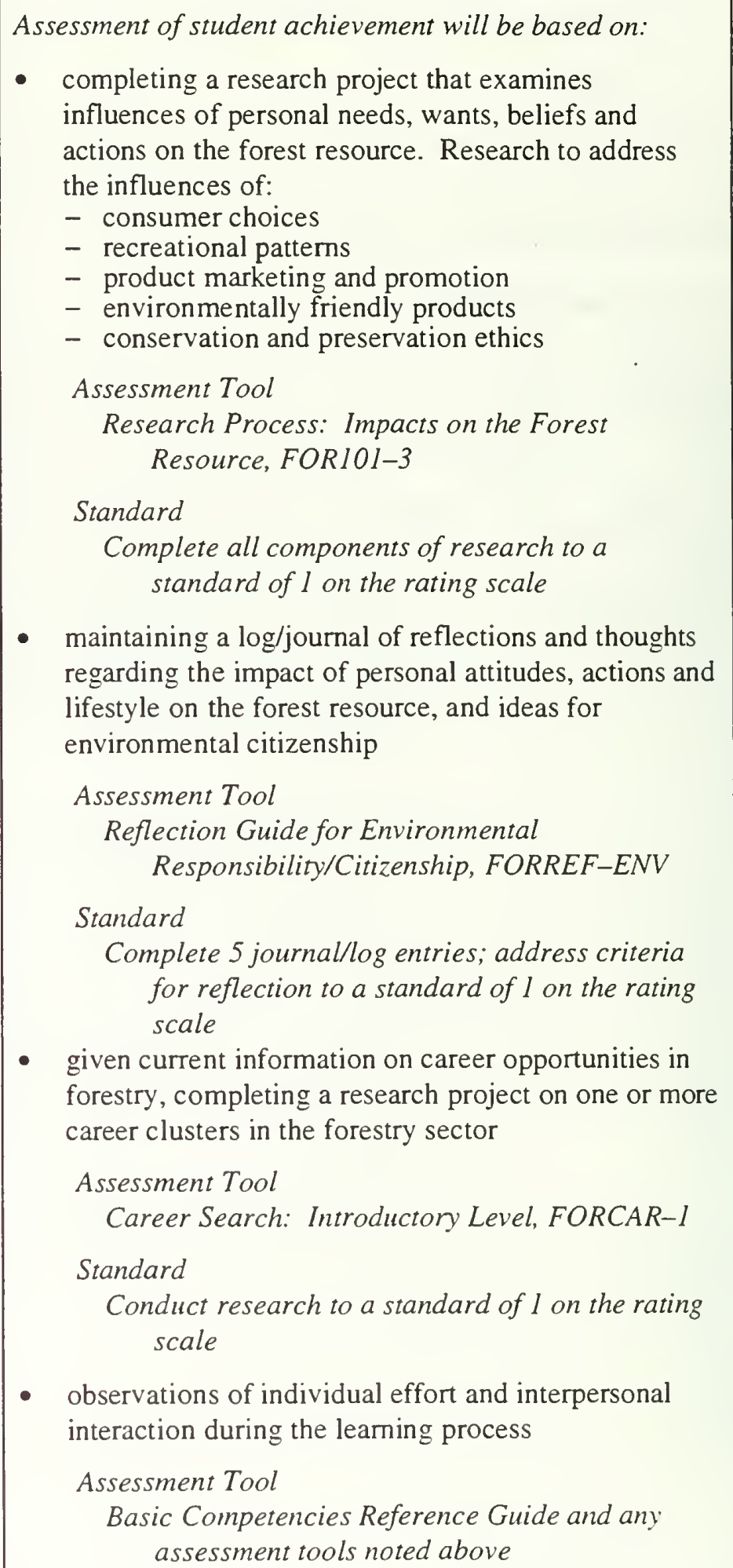 & $\begin{array}{l}\text { Integrated } \\
\text { throughout }\end{array}$ \\
\hline
\end{tabular}


MODULE FOR101: WHY FORESTRY? (Continued)

\begin{tabular}{|c|c|c|}
\hline Concept & Specific Learner Expectations & Notes \\
\hline Forest Role & 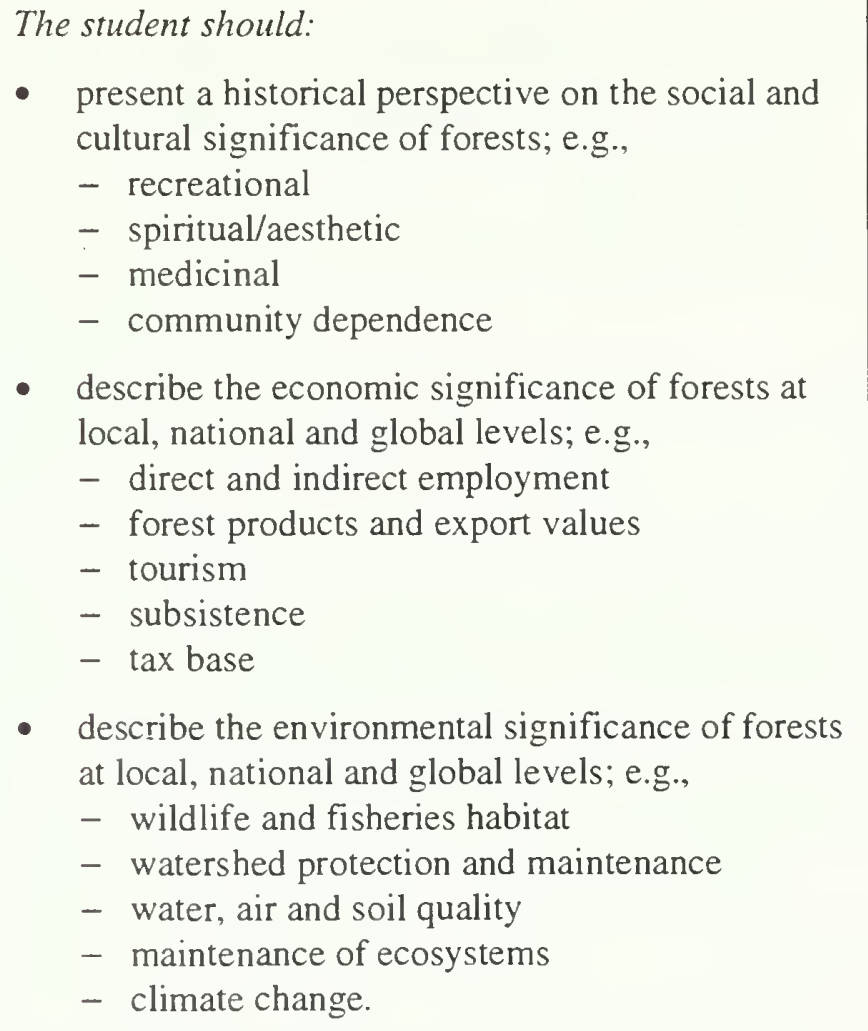 & $\begin{array}{l}\text { Interview people for } \\
\text { whom the forest has a } \\
\text { historical significance } \\
\text { (e.g., seniors within the } \\
\text { community, aboriginal } \\
\text { peoples). } \\
\text { Monitor the performance } \\
\text { of forest industry in the } \\
\text { stock market. } \\
\text { Interview local industry } \\
\text { representatives }\end{array}$ \\
\hline Personal Impact & $\begin{array}{l}\text { - describe the impact of individual attitudes, actions } \\
\text { and lifestyle on the forest resource; e.g., } \\
\text { - conservation ethic } \\
\text { - preservation ethic } \\
\text { - consumer practices } \\
\text { - recreational patterns } \\
\text { - describe how consumer and marketing trends in } \\
\text { society may affect the forest resource; e.g., } \\
\text { - needs versus wants } \\
\text { - media exaggeration } \\
\text { - use of environmental friendly products }\end{array}$ & $\begin{array}{l}\text { Prepare an inventory of } \\
\text { household materials } \\
\text { used each day. How } \\
\text { many of these materials } \\
\text { are derived from the } \\
\text { forest resource? } \\
\text { Distinguish between wants } \\
\text { and needs. Analyze the } \\
\text { impact of } \\
\text { advertisements on } \\
\text { television. }\end{array}$ \\
\hline
\end{tabular}


MODULE FOR101: WHY FORESTRY? (Continued)

\begin{tabular}{|c|c|c|}
\hline Concept & Specific Learner Expectations & Notes \\
\hline $\begin{array}{l}\text { Personal Impact } \\
\text { (continued) }\end{array}$ & $\begin{array}{l}\text { The student should: } \\
\text { - propose personal strategies for using forests } \\
\text { wisely that foster the attainment of social, } \\
\text { cultural, economic and environmental goals; e.g., } \\
\text { - personal actions } \\
\text { - leadership roles. }\end{array}$ & $\begin{array}{l}\text { Analyze and debate a } \\
\text { controversial issue. } \\
\text { Reference activities } \\
\text { outlined in Decisions, } \\
\text { Decisions: The } \\
\text { Environment (software } \\
\text { and print material } \\
\text { available from Tom } \\
\text { Snyder Productions, } \\
\text { Inc.) } \\
\text { Contact the Environmental } \\
\text { Law Centre for } \\
\text { resources that support } \\
\text { issue analysis and } \\
\text { conflict resolution. }\end{array}$ \\
\hline Career Paths & $\begin{array}{l}\text { - research career clusters and the range of } \\
\text { occupational opportunities within the forestry } \\
\text { sector: } \\
\text { - professional } \\
\text { - technical } \\
\text { - labour-based } \\
\text { - gather employment statistics within one or more } \\
\text { career clusters; e.g., } \\
\text { - types of careers } \\
\text { - number of workers } \\
\text { - employment trends } \\
\text { infer career opportunities and trends from } \\
\text { employment statistics } \\
\text { infer impacts of the marketplace on employment } \\
\text { opportunities } \\
\text { consider possible forest industries in the future, } \\
\text { and resulting career opportunities. }\end{array}$ & $\begin{array}{l}\text { Interview people } \\
\text { employed in the } \\
\text { forestry sector. Identify } \\
\text { general areas of } \\
\text { specialization; e.g.: } \\
\text { - resource inventory } \\
\text { - biology/ecology } \\
\text { - resource protection } \\
\text { - resource harvest } \\
\text { - forest products } \\
\text { - environmental } \\
\text { management } \\
\text { - recreation } \\
\text { - education. } \\
\text { Review National } \\
\text { Occupational Profiles } \\
\text { (NOC). } \\
\text { Contact the "Career } \\
\text { Hotline" (telephone } \\
\text { 1-800-661-3753). } \\
\end{array}$ \\
\hline
\end{tabular}




\section{MODULE FOR102: FOREST REGIONS OF CANADA}

Level: $\quad$ Introductory

Theme:

Social and Cultural Perspectives

Prerequisite: $\quad$ Knowledge of geographic regions of Canada (Recommended)

\section{Module Parameters: Access to government and library resources}

Students identify factors that determine the distribution of forests, and research forest regions of Canada (with emphasis on specific species and forest associations found in Alberta).

\section{Curriculum and Assessment Standards}

\begin{tabular}{|c|c|c|}
\hline $\begin{array}{c}\text { Module Learner } \\
\text { Expectations }\end{array}$ & Assessment Criteria and Conditions (Draft) & $\begin{array}{l}\text { Suggested } \\
\text { Emphasis } \\
\end{array}$ \\
\hline $\begin{array}{l}\text { The student will: } \\
\text { - identify factors that } \\
\text { determine the type and } \\
\text { distribution. of forests }\end{array}$ & $\begin{array}{l}\text { Assessment of student assessment will be based on: } \\
\text { - conducting laboratory and/or field investigations to } \\
\text { determine the effect of temperature, moisture or soil } \\
\text { on plant growth } \\
\text { Assessment Tool } \\
\text { Lab Investigations: Factors Affecting Plant } \\
\text { Growth, FOR IO2-1 } \\
\text { Standard } \\
\text { Complete lab and/or field investigations to a } \\
\text { standard of } 1 \text { on the rating scale } \\
\text { explaining ways in which climate and land form affect } \\
\text { the growth and distribution of forests } \\
\text { Assessment Tool } \\
\text { Knowledge/Application Assessment: Growth and } \\
\quad \text { Distribution of Forests, FORIO2-2 } \\
\text { Standard } \\
\text { Respond to a standard of } 1 \text { on the rating scale } \\
\text { given outline maps of Canada and Alberta, locating } \\
\text { and describing: } \\
\text { - the eight forest regions of Canada and major tree } \\
\text { species within each region } \\
\text { the three forest regions present in Alberta and } \\
\text { major tree species within each region } \\
\text { Assessment Tool } \\
\text { Task Checklist for Mapping, FORMAP } \\
\text { Standard } \\
\text { Complete applicable mapping tasks to a standard } \\
\text { of the rating scale }\end{array}$ & 10 \\
\hline
\end{tabular}


MODULE FOR102: FOREST REGIONS OF CANADA (continued)

\begin{tabular}{|c|c|c|}
\hline $\begin{array}{c}\text { Module Learner } \\
\text { Expectations }\end{array}$ & Assessment Criteria and Conditions (Draft) & $\begin{array}{l}\text { Suggested } \\
\text { Emphasis }\end{array}$ \\
\hline $\begin{array}{l}\text { The student will: } \\
\text { identify and describe } \\
\text { trees that grow in } \\
\text { specific regions of } \\
\text { Canada and Alberta }\end{array}$ & $\begin{array}{l}\text { Assessment of student assessment will be based on: } \\
\text { - given access to actual (or photographed) tree, shrub } \\
\text { and/or plant species within a forest region of Canada, } \\
\text { preparing (following museum conservation rules) a } \\
\text { leaf or twig collection including at least } 20 \text { native } \\
\text { species. Each species to be identified using common } \\
\text { and scientific names. (At least } 50 \% \text { of the species } \\
\text { identified and collected to be trees. If photographs } \\
\text { are used in place of actual specimens, collection to } \\
\text { include both closeup and full-view photos of each } \\
\text { species.) } \\
\text { Assessment Tool } \\
\text { Museum Conservation Rules for Leaf/Twig } \\
\text { Collection, FOR102-3 } \\
\text { Standard } \\
\text { Prepare each specimen in the collection to a } \\
\text { standard of } 2 \text { on the rating scale } \\
\text { observations of individual effort and interpersonal } \\
\text { interaction during the learning process } \\
\text { Assessment Tool } \\
\text { Basic Competencies Reference Guide and any } \\
\text { assessment tools noted above. }\end{array}$ & $\begin{array}{l}\text { Integrated } \\
\text { throughout }\end{array}$ \\
\hline
\end{tabular}

\begin{tabular}{|c|l|l|}
\hline Concept & \multicolumn{1}{|c|}{ Specific Learner Expectations } & Notes \\
\hline \multirow{3}{*}{ Determining Factors } & $\begin{array}{l}\text { The student should: } \\
\text { identify factors that enhance the development of } \\
\text { forests and determine the distribution of living } \\
\text { organisms within forest regions; e.g., } \\
- \text { land form } \\
- \text { climate } \\
\text { describe relationships between climatic factors } \\
\text { and the growth of trees; e.g., } \\
- \text { temperature } \\
- \text { moisture }\end{array}$ & $\begin{array}{l}\text { Suggested resource: } \\
\text { Forest Regions of } \\
\text { Canada (Rowe, 1972). }\end{array}$ \\
& $\begin{array}{l}\text { Perform a lab that } \\
\text { demonstrates the effect } \\
\text { of moisture on tree } \\
\text { growth. }\end{array}$ \\
\hline
\end{tabular}


MODULE FOR102: FOREST REGIONS OF CANADA (continued)

\begin{tabular}{|c|c|c|}
\hline Concept & Specific Learner Expectations & Notes \\
\hline $\begin{array}{l}\text { Determining Factors } \\
\quad \text { (continued) }\end{array}$ & $\begin{array}{l}\text { The student should: } \\
\text { - describe relationships between land forms and the } \\
\text { distribution of forests; e.g., } \\
\text { - topography } \\
\text { - soil conditions } \\
\text { - suggest reasons for the distribution of trees in } \\
\text { natural regions in Canada and Alberta. }\end{array}$ & $\begin{array}{l}\text { Using a local map, } \\
\text { indicate heavy } \\
\text { concentrations of } \\
\text { particular tree species. } \\
\text { Suggest reasons for the } \\
\text { distributions noted. }\end{array}$ \\
\hline Forest Regions & $\begin{array}{l}\text { locate and describe the eight forest regions of } \\
\text { Canada; e.g., } \\
\text { - Boreal } \\
\text { - Subalpine } \\
\text { - Montane } \\
\text { - Coast } \\
\text { - Columbia } \\
\text { - Deciduous } \\
\text { - Great Lakes/St. Lawrence } \\
\text { - Acadian } \\
\text { read, interpret and create visual representations of } \\
\text { species distribution in Canada and Alberta. }\end{array}$ & $\begin{array}{l}\text { See Alberta's Focus on } \\
\text { Forests (Activity } 4.1- \\
\text { Trees of Alberta and } \\
\text { Canada). } \\
\text { Resources available from } \\
\text { Canada Forestry } \\
\text { Service include: } \\
\text { - Forest Regions of } \\
\text { Canada } \\
\text { - Native Trees of Canada. } \\
\text { Match common trees with } \\
\text { their respective } \\
\text { locations. } \\
\text { Mapping exercises. }\end{array}$ \\
\hline Tree Identification & $\begin{array}{l}\text { identify common trees and other plants that grow } \\
\text { in specific regions of Canada and Alberta; e.g., } \\
\text { - tree and shrub identification } \\
\text { - non-woody plant identification } \\
\text { prepare a display of details that help to identify } \\
\text { local trees, shrubs and non-woody plants; e.g., } \\
\text { - leaves } \\
\text { - flowers/cones } \\
\text { - twigs } \\
\text { - bark. }\end{array}$ & $\begin{array}{l}\text { Conduct field trips to } \\
\text { locate and identify trees } \\
\text { on-site. } \\
\text { Use a key to assist in the } \\
\text { identification of tree } \\
\text { species. } \\
\text { Leaf and twig collections. }\end{array}$ \\
\hline
\end{tabular}




\section{MODULE FOR104: WOODS SURVIVAL I}

Level: $\quad$ Introductory

Theme: $\quad$ Social and Cultural Perspectives

Prerequisite/

Corequisite:

Current certification in Emergency First Aid

Module Parameters: Access to an outdoor forest environment and gear for outdoor expeditions; instructor must have current personal certification in Standard First Aid (St. John Ambulance)

Information regarding student safety and instructor certification is provided in Sections $\mathrm{C}$ and $\mathrm{H}$ of this Guide to Standards and Implementation.

Students demonstrate basic skills required for responsible participation in a range of outdoor activities in the forest.

Curriculum and Assessment Standards

\begin{tabular}{|c|c|c|}
\hline $\begin{array}{c}\text { Module Learner } \\
\text { Expectations }\end{array}$ & Assessment Criteria and Conditions (Draft) & $\begin{array}{l}\text { Suggested } \\
\text { Emphasis }\end{array}$ \\
\hline $\begin{array}{l}\text { The student will: } \\
\text { - demonstrate knowledge, } \\
\text { skills and attitudes that } \\
\text { are necessary for safe } \\
\text { and comfortable outdoor } \\
\text { experiences in the forest }\end{array}$ & $\begin{array}{l}\text { Assessment of student achievement will be based on: } \\
\text { identifying five or more physical hazards that may be } \\
\text { imposed by a forest environment, and explaining } \\
\text { appropriate steps to take in avoiding/preventing and } \\
\text { responding/dealing with each hazard } \\
\text { Assessment Tool } \\
\text { Knowledge/Application Assessment: Hazards in } \\
\text { the Forest Environment, FOR 104-1 } \\
\text { Standard } \\
\text { Respond to a standard of } 2 \text { on the rating scale } \\
\text { a teacher-prepared assessment in which the student } \\
\text { demonstrates knowledge of strategies for dealing with } \\
\text { hypothermia, frostbite, fatigue, dehydration and fear } \\
\text { in the outdoors } \\
\text { Assessment Tool } \\
\text { Sample Assessment Items: Woods Survival } 1 \text {, } \\
\text { FOR104-2 } \\
\text { Standard } \\
\text { Response indicating } 80 \% \text { mastery }\end{array}$ & 20 \\
\hline
\end{tabular}


MODULE FOR104: WOODS SURVIVAL (continued)

\begin{tabular}{|c|c|c|}
\hline $\begin{array}{c}\text { Module Learner } \\
\text { Expectations }\end{array}$ & Assessment Criteria and Conditions (Draft) & $\begin{array}{l}\text { Suggested } \\
\text { Emphasis }\end{array}$ \\
\hline $\begin{array}{l}\text { participate in a range of } \\
\text { outdoor forest activities } \\
\text { that have minimal } \\
\text { impact on the forest } \\
\text { environment }\end{array}$ & $\begin{array}{l}\text { Assessment of student achievement will be based on: } \\
\text { - planning and assembling gear for a three-day trip in } \\
\text { the outdoors } \\
\text { Assessment Tool } \\
\text { Task Checklist: Woods Survival I, FORI04-3 } \\
\text { Standard } \\
\text { Achieve a performance rating of } 2 \text { in applicable } \\
\quad \text { areas of task assessment } \\
\text { within a continuous timeframe of } 20 \text { or more hours, } \\
\text { and through access to an outdoor forest environment, } \\
\text { conducting safe outdoor activities that have minimal } \\
\text { impact on the forest environment. Outdoor activities } \\
\text { to demonstrate knowledge of safe techniques for: } \\
\text { - packing and transporting gear required for a three- } \\
\text { day trip in the outdoors. Transportation to be by } \\
\text { human conveyance (e.g., backpack, sled) } \\
\text { - using and maintaining outdoor tools and } \\
\quad \text { equipment, including knives, axes, saws, shovels, } \\
\text { stoves and lanterns } \\
\text { - building and using outdoor fires } \\
\text { - constructing a fallen tree shelter, lean-to shelter, } \\
\text { snow cave shelter or other type of shelter } \\
\text { - maintaining hygiene and sanitation while in the } \\
\text { outdoors } \\
\text { Assessment Tools } \\
\text { Task Checklist: Woods Survival } 1, \text { FORIO4-3 } \\
\text { Lab Assessment: Outdoor Forest Experiences, } \\
\text { Standard } \\
\text { Achieve a performance rating of } 2 \text { in task } \\
\quad \text { assessment and lab assessment }\end{array}$ & 80 \\
\hline
\end{tabular}


MODULE FOR104: WOODS SURVIVAL (continued)

\begin{tabular}{|c|c|c|}
\hline $\begin{array}{c}\text { Module Learner } \\
\text { Expectations }\end{array}$ & Assessment Criteria and Conditions (Draft) & $\begin{array}{l}\text { Suggested } \\
\text { Emphasis }\end{array}$ \\
\hline $\begin{array}{l}\text { demonstrate basic } \\
\text { competencies. }\end{array}$ & $\begin{array}{l}\text { Assessment of student achievement will be based on: } \\
\text { - maintaining a log/journal of outdoor experiences that } \\
\text { provides summative reflection on individual and } \\
\text { group preparedness, cooperation, responsibility and } \\
\text { environmental ethics } \\
\text { Assessment Tool } \\
\text { Reflection Guide for Outdoor Experiences, } \\
\text { FORREF-OUT } \\
\text { Standard } \\
\text { Complete } 5 \text { log/journal entries; address criteria } \\
\text { for reflection to a standard of I on the rating } \\
\text { scale } \\
\text { observations of individual effort and interpersonal } \\
\text { interaction during the learning process } \\
\text { Assessment Tool } \\
\text { Basic Competencies Reference Guide and any } \\
\text { assessment tools noted above. }\end{array}$ & $\begin{array}{l}\text { Integrated } \\
\text { throughout }\end{array}$ \\
\hline
\end{tabular}

\begin{tabular}{|c|c|c|}
\hline Concept & Specific Learner Expectations & Notes \\
\hline $\begin{array}{l}\text { Outdoor Survival } \\
\text { Skills }\end{array}$ & $\begin{array}{l}\text { The student should: } \\
\text { - } \quad \text { identify, assess, avoid and/or respond to physical } \\
\text { hazards that may be imposed by the forest } \\
\text { environment; e.g., } \\
\text { - particular terrain and conditions, including } \\
\text { avalanche, lake and river ice, and bush travel } \\
\text { - wildlife that may be encountered, including } \\
\text { bears, bees, ticks, non-edible plants } \\
\text { - changes in weather conditions that may affect } \\
\text { personal and group safety } \\
\text { identify, assess, avoid and/or respond to } \\
\text { physiological and psychological factors often } \\
\text { associated with outdoor experiences in the forest; } \\
\text { e.g., } \\
\text { - dealing with hypothermia, frostbite and } \\
\text { dehydration. } \\
\text { - understanding fatigue and when not to move } \\
\text { - coping with adversities, such as getting lost or } \\
\text { hurt }\end{array}$ & $\begin{array}{l}\text { Forest hazards to be aware } \\
\text { of: } \\
\text { - dead-topped trees } \\
\text { - bees } \\
\text { - poisonous plants } \\
\text { - other wildlife } \\
\text { - unfamiliar waters } \\
\text { - forest fires. } \\
\text { View films and slide } \\
\text { shows of forest } \\
\text { expeditions that involve } \\
\text { physical hazards. } \\
\text { Invite guest speakers/ } \\
\text { community resource } \\
\text { persons to present } \\
\text { information and advice } \\
\text { on expeditions in the } \\
\text { forest. } \\
\text { Potential linkages with } \\
\text { "Wilderness First Aid" } \\
\text { certification course } \\
\text { (Canadian Red Cross). }\end{array}$ \\
\hline
\end{tabular}


MODULE FOR104: WOODS SURVIVAL (continued)

\begin{tabular}{|c|c|c|}
\hline Concept & Specific Learner Expectations & Notes \\
\hline $\begin{array}{l}\text { Outdoor Survival } \\
\text { Skills } \\
\text { (continued) }\end{array}$ & $\begin{array}{l}\text { The student should: } \\
\text { - list and explain necessary steps to take in } \\
\text { emergency and survival situations in the forest; } \\
\text { e.g., } \\
\text { - what to do if lost or separated from the group } \\
\text { - first aid and emergency response to injury } \\
\text { - construction of emergency shelters } \\
\text { - how to gather food from edible plants } \\
\text { - en route organizational strategies, including } \\
\text { lead and sweep, regrouping procedures, pacing } \\
\text { select appropriate personal and group gear for } \\
\text { outdoor forest activities; e.g., } \\
\text { - personal gear, with consideration to } \\
\text { maintaining body temperature and protection } \\
\text { from injury } \\
\text { - group gear, to meet requirements for food, } \\
\text { shelter, travel and emergencies } \\
\text { demonstrate safe use and appropriate care of } \\
\text { outdoor hand tools, including knives, axes and } \\
\text { saws } \\
\text { demonstrate safe procedures for building and } \\
\text { using outdoor fires; e.g., } \\
\text { - signalling } \\
\text { - warming } \\
\text { - cooking } \\
\text { explain techniques used to plan, pack, carry and } \\
\text { prepare foods during outdoor forest expeditions; } \\
\text { e.g., } \\
\text { - nutritional requirements } \\
\text { - portability and preservation factors } \\
\text { - food preparation techniques } \\
\text { - safe use of campfires } \\
\text { - wain techniques required for maintaining } \\
\text { - personal cleanliness } \\
\text { - group hygiene. }\end{array}$ & $\begin{array}{l}\text { Determine appropriate } \\
\text { first-aid supplies. } \\
\text { Engage students in } \\
\text { simulation activities, } \\
\text { role-playing and case } \\
\text { studies. } \\
\text { Review basic first aid and } \\
\text { involve students in } \\
\text { emergency response } \\
\text { situations. } \\
\\
\text { Have students present a } \\
\text { "fashion show" or } \\
\text { produce a video that } \\
\text { demonstrates } \\
\text { appropriate equipment } \\
\text { and its use. } \\
\text { Conduct an equipment } \\
\text { maintenance clinic. } \\
\text { Practise fire building } \\
\text { techniques-then plan } \\
\text { and carry out a school } \\
\text { yard "cookout". } \\
\text { Involve students in menu } \\
\text { planning for a } \\
\text { hypothetical or } \\
\text { proposed field trip. } \\
\text { Invite guest speakers from } \\
\text { a health department or } \\
\text { from } \\
\text { national/provincial } \\
\text { parks. }\end{array}$ \\
\hline
\end{tabular}


MODULE FOR104: WOODS SURVIVAL (continued)

\begin{tabular}{|c|c|c|}
\hline Concept & Specific Learner Expectations & Notes \\
\hline Forest Expeditions & $\begin{array}{l}\text { The student should: } \\
\text { - plan and conduct safe outdoor expeditions in the } \\
\text { forest; e.g., } \\
\text { - research information from a variety of sources, } \\
\text { including maps, aerial photographs, } \\
\text { guidebooks, journals and local experts } \\
\text { - interpret route information by selecting } \\
\text { reasonable destinations, estimating travel time } \\
\text { and anticipating obstacles } \\
\text { - apply knowledge and skills while en route, } \\
\text { including map reading and compass skills, } \\
\text { knowledge of terrain and route selection, and } \\
\text { mapping of key landmarks and directions } \\
\text { use different modes of travel to confidently } \\
\text { participate in a variety of forest activities; e.g., } \\
\text { - snowshoes, skis, walking staff and canoe } \\
\text { - hiking, backpacking, cross-country skiing, } \\
\text { canoeing and bird-watching } \\
\text { acquire and apply minimal impact skills while } \\
\text { participating in outdoor forest expeditions; e.g., } \\
\text { - proper trail use, including the avoidance of } \\
\text { trail widening } \\
\text { - campsite care, including the use of fires and } \\
\text { stoves, tent site selection, and firewood } \\
\text { selection } \\
\text { - waste disposal techniques, including latrines, } \\
\text { waste water disposal and garbage. }\end{array}$ & $\begin{array}{l}\text { Examine maps, research } \\
\text { books, reference } \\
\text { materials, etc., on } \\
\text { particular field sites to } \\
\text { be visited. } \\
\text { Access alternative routes } \\
\text { with regard to time and } \\
\text { preparation required for } \\
\text { each. } \\
\text { Conduct map reading and } \\
\text { basic orienteering } \\
\text { exercises in school } \\
\text { yard. } \\
\text { Plan and implement a } \\
\text { sequence of skill } \\
\text { development activities } \\
\text { with a follow-up } \\
\text { excursion. } \\
\text { Discuss principles of } \\
\text { "eccoourism". Consider } \\
\text { carrying capacity of a } \\
\text { forested area in relation } \\
\text { to minimum } \\
\text { environmental impact. } \\
\text { Set up a model campsite } \\
\text { in the school yard or a } \\
\text { local park. }\end{array}$ \\
\hline
\end{tabular}




\section{MODULE FOR105: MAPPING AND AERIAL PHOTOGRAPHY}

\section{Level:}

Theme:

Prerequisite:

Module Parameters: Access to forest maps and aerial photographs

Students interpret information conveyed through different types of maps and aerial photographs.

\section{Curriculum and Assessment Standards}

\begin{tabular}{|c|c|c|}
\hline $\begin{array}{c}\text { Module Learner } \\
\text { Expectations }\end{array}$ & Assessment Criteria and Conditions (Draft) & $\begin{array}{l}\text { Suggested } \\
\text { Emphasis }\end{array}$ \\
\hline $\begin{array}{l}\text { The student will: } \\
\text { - describe different types } \\
\text { of maps and aerial } \\
\text { photographs used in } \\
\text { forestry }\end{array}$ & $\begin{array}{l}\text { Assessment of student achievement will be based on: } \\
\text { preparing and presenting a portfolio that includes: } \\
\text { - four or more different types of maps used in } \\
\text { forestry, and explanations of the characteristics } \\
\text { and applications of each } \\
\text { - } \text { a one-page report on the National Topographic } \\
\text { Grid System and its application in providing } \\
\text { legal land descriptions } \\
\text { - the results of research conducted on the goals } \\
\text { and techniques of aerial photography } \\
\text { Assessment Tool } \\
\text { Portfolio Assessment: Maps Used in Forestry, } \\
\quad \text { FOR105-1 } \\
\text { Standard } \\
\text { Complete all portfolio components to a standard } \\
\quad \text { of I on the rating scale } \\
\text { performing practical orienteering tasks that involve } \\
\text { the use of information conveyed through maps. Tasks } \\
\text { to include: } \\
\text { - orienting a map through inspection of } \\
\text { surroundings and use of a compass } \\
\text { - obtaining bearings from a map using a compass } \\
\text { - measuring direction using a Douglas protractor } \\
\text { - given a legal land description, locating the parcel } \\
\text { of land on a map } \\
\text { Assessment Tool } \\
\text { Task Checklist: Orienteering, FORIO5-2 } \\
\text { Lab Assessment: Outdoor Forest Experiences, } \\
\text { FORLAB } \\
\text { Standard } \\
\text { Achieve a performance rating of } 1 \text { in task } \\
\quad \text { assessment and lab assessment }\end{array}$ & 60 \\
\hline
\end{tabular}


MODULE FOR105: MAPPING AND AERIAL PHOTOGRAPHY (continued)

\begin{tabular}{|c|c|c|}
\hline $\begin{array}{c}\text { Module Learner } \\
\text { Expectations }\end{array}$ & Assessment Criteria and Conditions (Draft) & $\begin{array}{l}\text { Suggested } \\
\text { Emphasis }\end{array}$ \\
\hline $\begin{array}{l}\text { demonstrate procedures } \\
\text { used to create maps }\end{array}$ & $\begin{array}{l}\text { Assessment of student achievement will be based on: } \\
\text { - describing topography and forest cover for a given } \\
\text { area based on information gathered from: } \\
-\quad \text { an aerial photograph and corresponding parts of } \\
\text { a forest type map } \\
\text { - two or more different types of aerial photographs } \\
\text { (e.g., black and white, colour, infrared, satellite } \\
\text { imagery) } \\
\text { Assessment Tool } \\
\text { Knowledge/Application Assessment: Reading and } \\
\text { Interpreting Forest Maps, FORIO5-3 } \\
\text { Standard } \\
\text { Respond to a standard of I on the rating scale } \\
\text { constructing a simple map that represents a local } \\
\text { forested area. Map to display scale, legend, major } \\
\text { land and forest features and topography } \\
\text { Assessment Tool } \\
\text { Task Checklist for Mapping, FORMAP } \\
\text { Standard } \\
\text { Complete applicable mapping tasks to a standard } \\
\text { of I on the rating scale } \\
\text { observations of individual effort and interpersonal } \\
\text { interaction during the learning process } \\
\text { Assessment Tool } \\
\text { assessment tools noted above }\end{array}$ & $\begin{array}{l}\text { Integrated } \\
\text { throughout }\end{array}$ \\
\hline
\end{tabular}

\begin{tabular}{|c|l|l|}
\hline \multicolumn{1}{|c|}{ Concept } & \multicolumn{1}{|c|}{ Specific Learner Expectations } & Notes \\
\hline & The student should: & \\
Applications of & $\begin{array}{l}\text { describe different types of maps used in forestry; } \\
\text { Maps and Aerial }\end{array}$ & $\begin{array}{l}\text { Contact the Canadian } \\
\text { Forest Services or local } \\
\text { forest industries and } \\
\text { request different types } \\
\text { of maps. }\end{array}$ \\
& $\begin{array}{l}\text { e.g., } \\
\text { Photographs }\end{array}$ & $\begin{array}{l}\text { Request class sets of maps } \\
\text { and photos of locally } \\
\text { known areas from } \\
\text { Alberta Environmental } \\
\text { Protection. }\end{array}$ \\
\hline
\end{tabular}


MODULE FOR105: MAPPING AND AERIAL PHOTOGRAPHY (continued)

\begin{tabular}{|c|c|c|}
\hline Concept & Specific Learner Expectations & Notes \\
\hline $\begin{array}{l}\text { Applications of } \\
\text { Maps and Aerial } \\
\text { Photographs } \\
\text { (continued) }\end{array}$ & $\begin{array}{l}\text { The student should: } \\
\text { - describe components and applications of the } \\
\text { National Topographic Grid System and the } \\
\text { Western Grid Survey System } \\
\text { - explain the purpose and techniques of aerial } \\
\text { photography } \\
\text { describe applications of different types of film } \\
\text { used in aerial photography; e.g., } \\
\text { - black and white } \\
\text { - black and white infrared } \\
\text { - colour } \\
\text { - colour infrared } \\
\text { research information-gathering technologies and } \\
\text { their applications in mapping; e.g., } \\
\text { - satellite imagery } \\
\text { - Global Positioning Systems (GPS). }\end{array}$ & $\begin{array}{l}\text { See related topics and } \\
\text { resources in the } \\
\text { Agriculture strand } \\
\text { (AGR312: Soils } \\
\text { Management II). } \\
\text { Contact industry and/or } \\
\text { government resource } \\
\text { persons. } \\
\text { See "JFW Green Tree } \\
\text { Trailblazer Leader } \\
\text { Manual", Woods-travel, } \\
\text { pp. 117-216). } \\
\\
\text { Contact RADARSAT } \\
\text { International ( } 3851 \\
\text { Shell Road, Suite 200, } \\
\text { Richmond, British } \\
\text { Columbia) for up-to- } \\
\text { date information } \\
\text { regarding applications } \\
\text { of satellite remote } \\
\text { sensing in mapping } \\
\text { Canada"s forest } \\
\text { resources. }\end{array}$ \\
\hline $\begin{array}{c}\text { Interpreting Maps } \\
\text { and Aerial } \\
\text { Photographs }\end{array}$ & $\begin{array}{l}\text { - orient forestry maps through: } \\
\text { - inspection } \\
\text { - use of a compass } \\
\text { obtain bearings from a map using a forestry } \\
\text { compass } \\
\text { - measure direction using a Douglas protractor } \\
\text { read and interpret maps and aerial photographs, } \\
\text { explaining information conveyed through: } \\
\text { - legend and symbols } \\
\text { - scale } \\
\text { - colours } \\
\text { - contour lines } \\
\text { iocate a specific parcel of land on a map by using } \\
\text { its legal survey description }\end{array}$ & $\begin{array}{l}\text { Read and interpret } \\
\text { maps/photos of locally } \\
\text { known areas. } \\
\text { See basic map } \\
\text { interpretation activities } \\
\text { provided in: } \\
\text { - Orienteering, Level/ } \\
\text { - Orienteering, Level II } \\
\text { Progress through a series } \\
\text { of mapping activities- } \\
\text { start with locating dots } \\
\text { in the classroom, then } \\
\text { markers around the } \\
\text { school, and finally } \\
\text { markers around a park } \\
\text { or wooded area. } \\
\text { See related topics and } \\
\text { resources in the } \\
\text { Agriculture strand } \\
\text { (AGR312: Soils } \\
\text { Management II). }\end{array}$ \\
\hline
\end{tabular}


MODULE FOR105: MAPPING AND AERIAL PHOTOGRAPHY (continued)

\begin{tabular}{|c|c|c|}
\hline Concept & Specific Learner Expectations & Notes \\
\hline $\begin{array}{c}\text { Interpreting Maps } \\
\text { and Aerial } \\
\text { Photographs } \\
\text { (continued) }\end{array}$ & $\begin{array}{l}\text { The student should: } \\
\text { - construct a mental image of land terrain from } \\
\text { information conveyed through maps } \\
\text { - estimate and calculate distance and area on maps } \\
\text { - demonstrate applications of aerial photographs in } \\
\text { the stereoscopic viewing of topographic features } \\
\text { - compare details of forest type maps and aerial } \\
\text { photographs with existing ground conditions. }\end{array}$ & $\begin{array}{l}\text { Consider links with the } \\
\text { mathematics program: } \\
\text { - scale diagrams } \\
\text { - ratio and proportion } \\
\text { - estimation. } \\
\text { Discuss theory behind } \\
\text { stereoscopic vision and } \\
\text { techniques to train the } \\
\text { eye. }\end{array}$ \\
\hline Making Maps & $\begin{array}{l}\text { construct a map that provides information about a } \\
\text { forested area; e.g., } \\
\text { - pace/measure area to be mapped } \\
\text { - gather information regarding land/forest } \\
\text { - features } \\
\text { - determine map scale } \\
\text { - prepare a legend } \\
\text { - plot major land/forest features. } \\
\text { explain how information from aerial photographs } \\
\text { is used to construct two-dimensional maps } \\
\text { compare details of an aerial photograph with } \\
\text { corresponding parts of a forest type map. }\end{array}$ & $\begin{array}{l}\text { Create a simple } \\
\text { topographical map of a } \\
\text { local area. } \\
\\
\text { Use aerial photographs to } \\
\text { create a simple map. } \\
\text { If time permits, create a } \\
\text { photo mosaic by } \\
\text { arranging consecutive } \\
\text { aerial photographs } \\
\text { along a flight path. }\end{array}$ \\
\hline
\end{tabular}




\section{MODULE FOR106: MEASURING THE FOREST I}

\section{Level: $\quad$ Introductory}

Theme: $\quad$ Technology and Applications

Prerequisite

Corequisite: $\quad$ Mapping and Aerial Photography (FOR105; Recommended)

\section{Module Parameters: Demonstration forest and measurement tools}

Students demonstrate basic forest measurement skills and apply these skills in sampling fibre values in a forested region.

\section{Curriculum and Assessment Standards}

\begin{tabular}{|c|c|c|}
\hline $\begin{array}{c}\text { Module Learner } \\
\text { Expectations }\end{array}$ & Assessment Criteria and Conditions (Draft) & $\begin{array}{l}\text { Suggested } \\
\text { Emphasis }\end{array}$ \\
\hline $\begin{array}{l}\text { The student will: } \\
\text { - explain the general goals } \\
\text { and techniques of } \\
\text { conducting forest } \\
\text { surveys }\end{array}$ & $\begin{array}{l}\text { Assessment of student achievement will be based on: } \\
\text { completing a research project on the goals and } \\
\text { techniques of conducting a forest survey. Research to } \\
\text { address: } \\
\text { - reasons for conducting forest surveys } \\
\text { - techniques used to sample a forested area } \\
\text { - how sample data is used to estimate forest } \\
\text { populations. } \\
\text { Assessment Tool } \\
\text { Research Process: Forest Surveys, FOR } 106-1 \\
\text { Standard } \\
\text { Conduct research to a standard of } 1 \text { on the rating } \\
\text { scale } \\
\text { using a compass in the outdoors to orient a map, } \\
\text { obtain a bearing, and perform a closed traverse (error } \\
\text { in closure no greater than } 5 \% \text { of perimeter distance) } \\
\text { Assessment Tool } \\
\text { Task Checklist: Orienteering, FORI06-2 } \\
\text { Lab Assessment: Outdoor Forest Experiences, } \\
\text { FORLAB } \\
\text { Standard } \\
\text { Achieve a performance rating of } 1 \text { in task } \\
\text { assessment and lab assessment }\end{array}$ & 10 \\
\hline
\end{tabular}


MODULE FOR106: MEASURING THE FOREST I (continued)

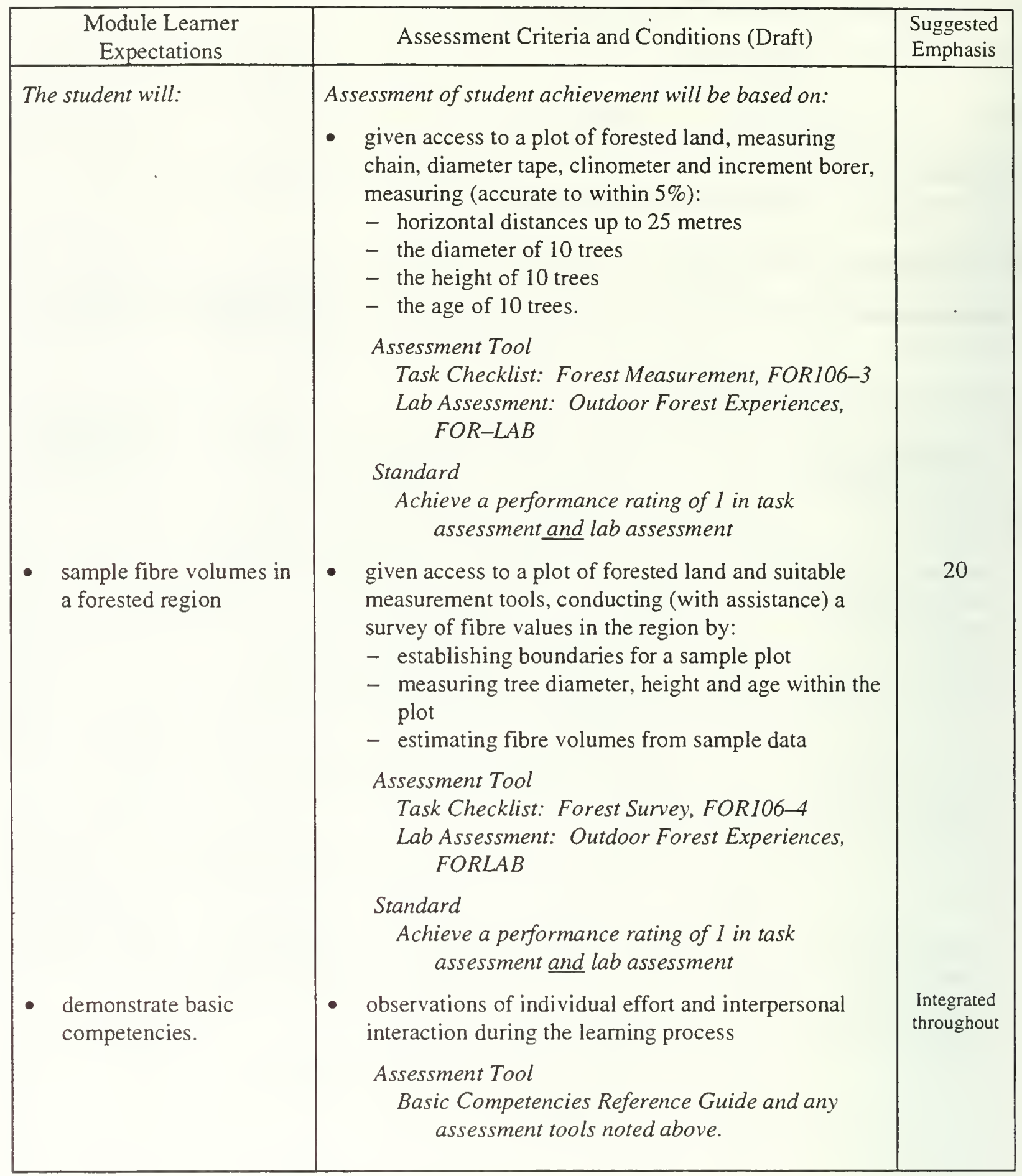


MODULE FOR106: MEASURING THE FOREST I (continued)

\begin{tabular}{|c|c|c|}
\hline Concept & Specific Learner Expectations & Notes \\
\hline Forest Surveys & $\begin{array}{l}\text { The student should: } \\
\text { - } \quad \text { suggest reasons for conducting a forest survey; } \\
\text { e.g., } \\
\text { - types of information gathered } \\
\text { - questions that are answered } \\
\text { - distinguish between forest samples and forest } \\
\text { populations } \\
\text { - describe basic techniques used to sample a } \\
\text { forested area; e.g., } \\
\text { - layout of sample plots } \\
\text { - data collection techniques } \\
\text { explain how sample data may be used to estimate } \\
\text { fibre volumes and other non-fibre forest } \\
\text { resources. }\end{array}$ & $\begin{array}{l}\text { Obtain assistance from } \\
\text { government, industry or } \\
\text { private forestry } \\
\text { personnel. } \\
\text { See Alberta's Focus on } \\
\text { Forests (Activity } 4.3- \\
\text { Surveying the Forest } \\
\text { Resource). }\end{array}$ \\
\hline $\begin{array}{l}\text { Compass and } \\
\text { Measurement } \\
\text { Skills }\end{array}$ & $\begin{array}{l}\text { - apply basic compass skills to establish direction } \\
\text { in the forest; e.g., } \\
\text { - orient a map } \\
\text { - establish and follow a bearing } \\
\text { measure horizontal distance in the forest using } \\
\text { pacing and chaining skills } \\
\text { perform open and closed traverses in the forest } \\
\text { using compass and chaining skills } \\
\text { measure the diameter of trees using a diameter } \\
\text { tape or other suitable equipment } \\
\text { measure the height of trees using a clinometre and } \\
\text { measuring tape or other suitable equipment } \\
\text { demonstrate techniques used to determine the age } \\
\text { of trees. }\end{array}$ & $\begin{array}{l}\text { Develop basic skills in } \\
\text { measuring direction and } \\
\text { distance in the forest. } \\
\text { Invite resource person } \\
\text { from local govern- } \\
\text { mentindustry to } \\
\text { demonstrate: } \\
\text { - compass and chain } \\
\text { skills } \\
\text { techniques in measuring } \\
\text { the forest. } \\
\text { Borrow necessary } \\
\text { equipment from local } \\
\text { governmentindustry. } \\
\text { Use short pieces of logs. }\end{array}$ \\
\hline Sampling Technique & $\begin{array}{l}\text { - apply compass and chaining skills to establish } \\
\text { boundaries for a sample forest plot } \\
\text { - identify safety practices and policies relevant to } \\
\text { gathering sample data in the forest } \\
\text { - gather data regarding one or more aspects of the } \\
\text { fibre resource within the sample forest plot; e.g., } \\
\text { - tree height/diameter } \\
\text { - number and distribution of species } \\
\text { - age of trees }\end{array}$ & \\
\hline
\end{tabular}


MODULE FOR106: MEASURING THE FOREST I (continued)

\begin{tabular}{|c|l|c|}
\hline \multicolumn{1}{|c|}{ Concept } & \multicolumn{1}{|c|}{ Specific Learner Expectations } & \multicolumn{1}{c|}{ Notes } \\
\hline $\begin{array}{l}\text { Sampling Technique } \\
\text { (continued) }\end{array}$ & $\begin{array}{l}\text { The student should: } \\
\text { record sample data in appropriate tables and/or } \\
\text { charts } \\
\text { interpret sample data to make inferences } \\
\text { regarding tree populations and fibre values in the } \\
\text { forest region } \\
\text { manipulate sample data as required to estimate } \\
\text { fibre volumes. }\end{array}$ & $\begin{array}{c}\text { Contact local govern- } \\
\text { ment/industry to obtain } \\
\text { existing sample data. }\end{array}$ \\
\hline
\end{tabular}


MODULE FOR109: BASIC FOREST ECOLOGY

Level:

Content Focus:

Prerequisite:

\section{Module Parameters: Science laboratory and forest environment}

Students investigate forest ecosystems and explain the structure and functioning of trees.

Curriculum and Assessment Standards

\begin{tabular}{|c|c|c|}
\hline $\begin{array}{c}\text { Module Learner } \\
\text { Expectations }\end{array}$ & Assessment Criteria and Conditions (Draft) & $\begin{array}{l}\text { Suggested } \\
\text { Emphasis }\end{array}$ \\
\hline $\begin{array}{l}\text { The student will: } \\
\text { describe the } \\
\text { interrelatedness of } \\
\text { elements in the forest } \\
\text { ecosystem }\end{array}$ & $\begin{array}{l}\text { Assessment of student achievement will be based on: } \\
\text { - given access to information on forest ecology, } \\
\text { completing a research project that examines: } \\
\text { - interrelationships among at least three living and } \\
\text { three nonliving elements } \\
\text { - predator-prey-decomposer relationships } \\
\text { - distribution of species on the basis of habitat } \\
\text { requirements } \\
\text { Assessment Tool } \\
\text { Research Process: Forest Ecosystems, FOR l09-1 } \\
\text { Standard } \\
\text { Complete all components of research to a } \\
\text { standard of } 1 \text { on the rating scale } \\
\text { identifying and describing major tree parts (including } \\
\text { roots, trunk, branches, leaves, flowers), their function } \\
\text { and relationship to one another } \\
\text { Assessment Tool } \\
\text { KnowledgelApplication Assessment: Structural } \\
\quad \text { Units of the Tree, FORIO9-2 } \\
\text { Assessment Criteria: Diagrams and Technical } \\
\text { Drawings, FORDRA } \\
\text { Standard } \\
\text { Respond to a standard of I on the rating scale }\end{array}$ & 50 \\
\hline
\end{tabular}


MODULE FOR109: BASIC FOREST ECOLOGY (continued)

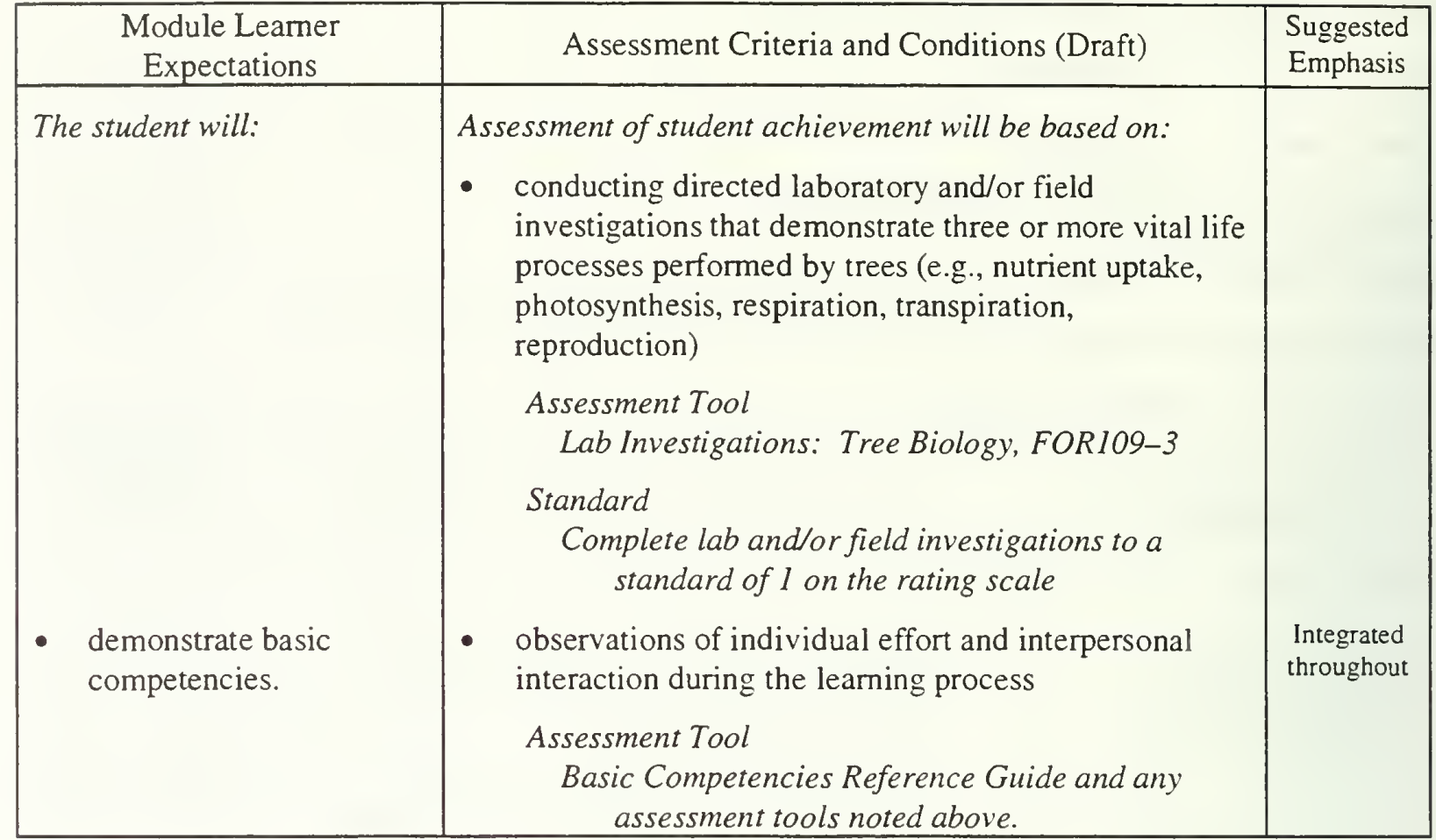

\begin{tabular}{|c|c|c|}
\hline Concept & Specific Learner Expectations & Notes \\
\hline Forest Ecosystems & 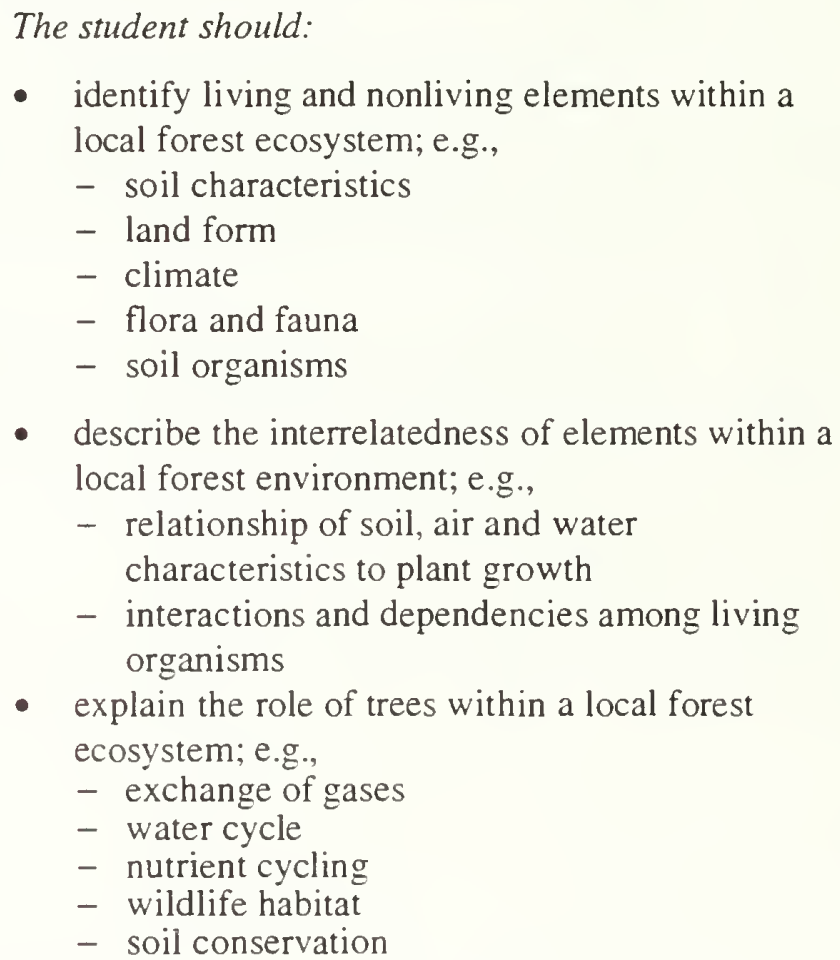 & $\begin{array}{l}\text { Involves application of } \\
\text { science concepts in a } \\
\text { forest environment. } \\
\text { Use field trips to identify } \\
\text { ecosystem components } \\
\text { based on first-hand } \\
\text { observations. } \\
\text { Conduct experiments to } \\
\text { demonstrate the } \\
\text { interrelatedness of air, } \\
\text { water, soil and plant } \\
\text { growth. } \\
\text { Observe evidence of plant } \\
\text { growth being affected } \\
\text { by particular } \\
\text { environmental } \\
\text { conditions (e.g., light, } \\
\text { soil, moisture, } \\
\text { crowding). } \\
\text { Draw food webs/energy } \\
\text { chains based on } \\
\text { observations. }\end{array}$ \\
\hline
\end{tabular}


MODULE FOR109: BASIC FOREST ECOLOGY (continued)

\begin{tabular}{|c|c|c|}
\hline Concept & Specific Learner Expectations & Notes \\
\hline $\begin{array}{l}\text { Forest Ecosystems } \\
\quad(\text { continued })\end{array}$ & 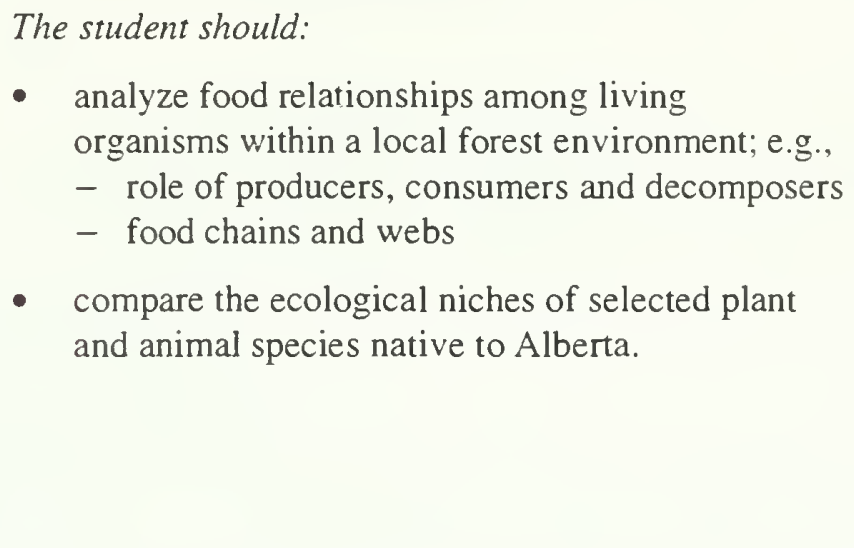 & $\begin{array}{l}\text { Draw food webs/energy } \\
\text { chains based on } \\
\text { observations. } \\
\text { Observe evidence of insect } \\
\text { or other animal life } \\
\text { living on a tree or } \\
\text { shrub. Collect and } \\
\text { observe samples of } \\
\text { insects by placing a } \\
\text { sheet of plastic under } \\
\text { the plant and tapping } \\
\text { branches with a stick. }\end{array}$ \\
\hline Tree Biology & $\begin{array}{l}\text { - explain the vital life processes performed by trees } \\
\text { and other forest plants; e.g., } \\
\text { - nutrient intake and transportation } \\
\text { - photosynthesis } \\
\text { - respiration and transpiration } \\
\text { - reproduction } \\
\text { - phrenology (leaf flushings, leaf fall, flowering } \\
\text { and cone production) } \\
\text { describe structural units and component parts of } \\
\text { the tree, and their function in performing vital life } \\
\text { processes; e.g., } \\
\text { - root } \\
\text { - trunk/stem } \\
\text { - leaf } \\
\text { - flower } \\
\text { infer interrelationships among tree structures, } \\
\text { their functions, and vital life processes that are } \\
\text { performed } \\
\text { illustrate the approximate range of one or more } \\
\text { tree species throughout North America. }\end{array}$ & $\begin{array}{l}\text { Laboratory experiments } \\
\text { and demonstrations. } \\
\text { Perform laboratory } \\
\text { experiments to } \\
\text { demonstrate life } \\
\text { functions. } \\
\text { Draw and label a cross- } \\
\text { section of a tree (top to } \\
\text { bottom) that illustrates } \\
\text { all components. } \\
\text { Use a small tree to prepare } \\
\text { a model that has the } \\
\text { parts of the tree labeled. }\end{array}$ \\
\hline
\end{tabular}




\section{MODULE FOR110: FORESTS FOREVER I}

Level:

Theme:

Prerequisite:

Module Parameters:

\section{Introductory}

Management and Conservation

None

Access to resources available from government and industry organizations responsible for forest management and protection (e.g., Alberta Environmental Protection, Canadian Forestry Service)

Students describe past and present uses of Canada's forests, and explain how research and technology assist in forest management.

\section{Curriculum and Assessment Standards}

\begin{tabular}{|c|c|c|}
\hline $\begin{array}{c}\text { Module Leamer } \\
\text { Expectations }\end{array}$ & Assessment Criteria and Conditions (Draft) & $\begin{array}{l}\text { Suggested } \\
\text { Emphasis }\end{array}$ \\
\hline $\begin{array}{l}\text { explain how increased } \\
\text { demands on the forest } \\
\text { have created a need for } \\
\text { conservation and } \\
\text { management of forested } \\
\text { regions }\end{array}$ & $\begin{array}{l}\text { Assessment of student achievement will be based on: } \\
\text { identifying and explaining: } \\
\text { - past and present uses of forests in Alberta and } \\
\text { Canada } \\
\text { ways in which changes in forest use (and } \\
\text { management) have affected the economy and the } \\
\text { environment } \\
\text { Assessment Tool } \\
\text { Knowledge/Application Assessment: Forest Use, } \\
\text { FORI10-I } \\
\text { Standard } \\
\text { Respond to a standard of I on the rating scale } \\
\text { definitions and examples of sustainable yield and } \\
\text { sustainable development within the context of } \\
\text { Alberta's forested regions } \\
\text { Assessment Tool } \\
\text { Knowledge/Application Assessment: } \\
\quad \text { Sustainability, FORIIO-2 } \\
\text { Standard } \\
\text { Respond to a standard of } 1 \text { on the rating scale } \\
\text { given a current issue regarding the management of a } \\
\text { forested region: } \\
\text { negotiating and debating the issue while assuming } \\
\text { the role of one or more stakeholder groups } \\
\text { - preparing and presenting a position paper that } \\
\text { outlines a responsible course of action } \\
\text { Assessment Tool } \\
\text { Negotiation and Debate, FORNEG-1 } \\
\text { Position Paper: Forest Management, FORI10-3 } \\
\text { Standard } \\
\text { Address criteria in negotiation/debate and the } \\
\quad \text { position paper to a standard of I on the rating } \\
\text { scale }\end{array}$ & 20 \\
\hline
\end{tabular}


MODULE FOR110: FORESTS FOREVER I (continued)

\begin{tabular}{|c|c|c|}
\hline $\begin{array}{c}\text { Module Learner } \\
\text { Expectations }\end{array}$ & Assessment Criteria and Conditions (Draft) & $\begin{array}{l}\text { Suggested } \\
\text { Emphasis } \\
\end{array}$ \\
\hline $\begin{array}{l}\text { The student will: } \\
\text { - research the role of } \\
\text { technology in forest } \\
\text { protection }\end{array}$ & $\begin{array}{l}\text { Assessment of student achievement will be based on: } \\
\text { - completing a research project on major components of } \\
\text { forest protection } \\
\text { Assessment Tool } \\
\text { Research Process: Components of Forest } \\
\text { Protection, FOR110-4 } \\
\text { Standard } \\
\text { Complete all components of research to a } \\
\quad \text { standard of I on the rating scale } \\
\text { given access to a forest environment, identifying } \\
\text { instances of pest and/or fire damage. Identification } \\
\text { will involve: } \\
\text { - collecting and/or photographing pest problems } \\
\text { - correctly identifying } 4 \text { or more forest pests } \\
\text { - recommending appropriate prevention/control } \\
\text { strategies for each pest identified } \\
\text { Assessment Tool } \\
\text { Task Checklist: Identifying Forest Pests, } \\
\text { FORI10-5 } \\
\text { Identification Key for Forest Pests, FORIIO-6 } \\
\text { Lab Assessment: Outdoor Forest Experiences, } \\
\text { FORLAB } \\
\text { Standard } \\
\text { Achieve a performance rating of I in task } \\
\text { assessment and lab assessment } \\
\text { interaction during the learning process } \\
\text { Assessment Tools } \\
\text { Basic Competencies Reference Guide and any } \\
\text { assessment tools noted above }\end{array}$ & $\begin{array}{l}\text { Integrated } \\
\text { throughout }\end{array}$ \\
\hline
\end{tabular}


MODULE FOR110: FORESTS FOREVER I (continued)

\begin{tabular}{|c|c|c|}
\hline Concept & Specific Learner Expectations & Notes \\
\hline Forest History & $\begin{array}{l}\text { The student should: } \\
\text { - describe changing patterns of forest use in Canada } \\
\text { and Alberta from past to present } \\
\text { - describe the history of the management of } \\
\text { forested lands in Canada and Alberta } \\
\text { - infer the impact of historical trends in forest use } \\
\text { and ownership on people, the economy and the } \\
\text { environment } \\
\text { make predictions about the use of Canada's forest } \\
\text { resources in the future. }\end{array}$ & $\begin{array}{l}\text { Trace the development of } \\
\text { Alberta's forest land } \\
\text { acts, policies, agencies } \\
\text { and resource allocation. } \\
\text { Supplementary reference } \\
\text { materials include: } \\
\text { - A Forest Journey - } \\
\text { The Role of Wood in } \\
\text { the Development of } \\
\text { Civilization (Harvard } \\
\text { University Press) } \\
\text { - Canadian Forestry - } \\
\text { The View Beyond the } \\
\text { Trees (Macmillan of } \\
\text { Canada). }\end{array}$ \\
\hline $\begin{array}{c}\text { Conservation and } \\
\text { Management }\end{array}$ & $\begin{array}{l}\text { - compare different uses of forested regions in } \\
\text { terms of their advantages and disadvantages; e.g., } \\
\text { - environmental } \\
\text { - economic } \\
\text { - social } \\
\text { research the roles of different interest groups in } \\
\text { managing the forest resource; e.g., } \\
\text { - government } \\
\text { - forest industry } \\
\text { - general public } \\
\text { - other stakeholder groups } \\
\text { relate concepts of sustainable development and } \\
\text { sustained yield to practical strategies for } \\
\text { managing the forest resource; e.g., } \\
\text { - reforestation } \\
\text { - stand improvement } \\
\text { debate an issue regarding sustainable } \\
\text { development and/or sustained yield; e.g., } \\
\text { - conduct research } \\
\text { - develop a position } \\
\text { - participate in debate } \\
\text { examine demands that are placed on forested } \\
\text { regions of Canada and Alberta; e.g., } \\
\text { - industry } \\
\text { - recreation } \\
\text { - wildlife } \\
\text { - environment }\end{array}$ & $\begin{array}{l}\text { Invite resource persons } \\
\text { from relevant } \\
\text { government agencies } \\
\text { and local forest } \\
\text { industry. } \\
\\
\text { Prepare a poster/ } \\
\text { collage/display that } \\
\text { depicts different aspects } \\
\text { of forest use. }\end{array}$ \\
\hline
\end{tabular}


MODULE FOR110: FORESTS FOREVER I (continued)

\begin{tabular}{|c|c|c|}
\hline Concept & Specific Learner Expectations & Notes \\
\hline $\begin{array}{c}\text { Conservation and } \\
\text { Management } \\
\text { (continued) }\end{array}$ & $\begin{array}{l}\text { The student should: } \\
\begin{array}{l}\text { - develop consensus regarding a plan for the } \\
\text { integrated use of a local forested area; e.g., } \\
\text { - conduct research } \\
\text { - generate alternatives } \\
\text { - agree to a workable solution. }\end{array}\end{array}$ & $\begin{array}{l}\text { Examine existing } \\
\text { management plans. }\end{array}$ \\
\hline Forest Protection & $\begin{array}{l}\text { cite reasons for protecting the forest resource; } \\
\text { e.g., } \\
\text { - material and non-material benefits } \\
\text { - environmental impact } \\
\text { identify and describe major components of forest } \\
\text { protection; e.g., } \\
\text { - forest fire management } \\
\text { - soil conservation and land reclamation } \\
\text { - pest and disease control } \\
\text { explain basic goals and techniques of forest fire } \\
\text { management, soil conservation and land } \\
\text { reclamation } \\
\text { identify and describe symptoms of common forest } \\
\text { pests and diseases } \\
\text { compare different methods of pest and disease } \\
\text { control; e.g., } \\
\text { - biological methods } \\
\text { - forest management } \\
\text { - chemical methods. }\end{array}$ & $\begin{array}{l}\text { Prepare a display of } \\
\text { technologies used in } \\
\text { forest protection. } \\
\text { Invite a local forest ranger } \\
\text { to explain components/ } \\
\text { techniques of forest } \\
\text { protection. } \\
\text { Explain the fire triangle } \\
\text { and how to control a } \\
\text { fire by removing one or } \\
\text { more legs of the } \\
\text { triangle. }\end{array}$ \\
\hline
\end{tabular}




\section{MODULE CURRICULUM AND ASSESSMENT STANDARDS:}

\section{SECTION E: INTERMEDIATE LEVEL}

The following pages define the curriculum and assessment standards for the intermediate level of Forestry.

Intermediate level modules help students build on the competencies developed at the introductory level and focus on developing more complex competencies. They provide a broader perspective, helping students recognize the wide range of related career opportunities available within the strand.

Module FOR201: Making a Difference in Forestry

E.3

Module FOR203:

Managing Alberta's Forested Lan

E.9

Module FOR204:

Woods Survival II

E.15

Module FOR206:

Measuring the Forest II.

E.21

Module FOR207:

Harvesting and Forest Products

E. 25

Module FOR210:

Forests Forever II

E. 31

Module FOR212:

Users in the Forest

E. 35 
Forestry /E.2

CSB: 960607

(Interim 1994) 


\section{MODULE FOR201: MAKING A DIFFERENCE IN FORESTRY}

Level:

Intermediate

Theme:

Social and Cultural Perspectives

Prerequisite:

None

Module Parameters:

Access to resources available from government and industry organizations regarding sustainable forest development and environmental stewardship

Students analyze the impact of lifestyle on forests, and propose individual and shared actions that foster environmental stewardship.

Note: Although this module will involve some analysis of background data regarding the impact of lifestyle on forests, the major emphasis is on "the doing" (i.e., commitment/empowerment through personal and shared actions).

\section{Curriculum and Assessment Standards}

\begin{tabular}{|c|c|c|}
\hline $\begin{array}{c}\text { Module Learner } \\
\text { Expectations }\end{array}$ & Assessment Criteria and Conditions (Draft) & $\begin{array}{l}\text { Suggested } \\
\text { Emphasis }\end{array}$ \\
\hline $\begin{array}{l}\text { The student will: } \\
\text { assess the impact of } \\
\text { personal attitudes, } \\
\text { actions and lifestyle on } \\
\text { the forest resource }\end{array}$ & $\begin{array}{l}\text { Assessment of student achievement will be based on: } \\
\text { - maintainirg a log/journal of reflections and inferences } \\
\text { regarding the impact of daily living activities on the } \\
\text { forest environment } \\
\text { Assessment Tool } \\
\text { Reflection Guide for Environmental } \\
\text { Responsibility/Citizenship, FORREF-ENV } \\
\text { Guide to Inferences: Personal Impact on Forests, } \\
\text { FOR201-1 } \\
\text { Standard } \\
\text { Complete } 5 \text { log/journal entries; address criteria } \\
\text { for reflection and inferences to a standard of } 2 \\
\text { on the rating scale } \\
\text { completing all components of a research project on } \\
\text { four or more products recently developed through } \\
\text { recycling techniques } \\
\text { Assessment Tool } \\
\text { Research Process: Recycling Techniques, } \\
\text { FOR201-2 } \\
\text { Standard } \\
\text { Complete research to a standard of } 2 \text { on the rating } \\
\text { scale }\end{array}$ & 30 \\
\hline
\end{tabular}


MODULE FOR201: MAKING A DIFFERENCE IN FORESTRY (continued)

\begin{tabular}{|c|c|c|}
\hline $\begin{array}{c}\text { Module Learner } \\
\text { Expectations }\end{array}$ & Assessment Criteria and Conditions (Draft) & $\begin{array}{l}\text { Suggested } \\
\text { Emphasis }\end{array}$ \\
\hline $\begin{array}{l}\text { demonstrate } \\
\text { commitment to } \\
\text { environmental } \\
\text { responsibility/citizenship } \\
\text { through personal and } \\
\text { shared actions }\end{array}$ & 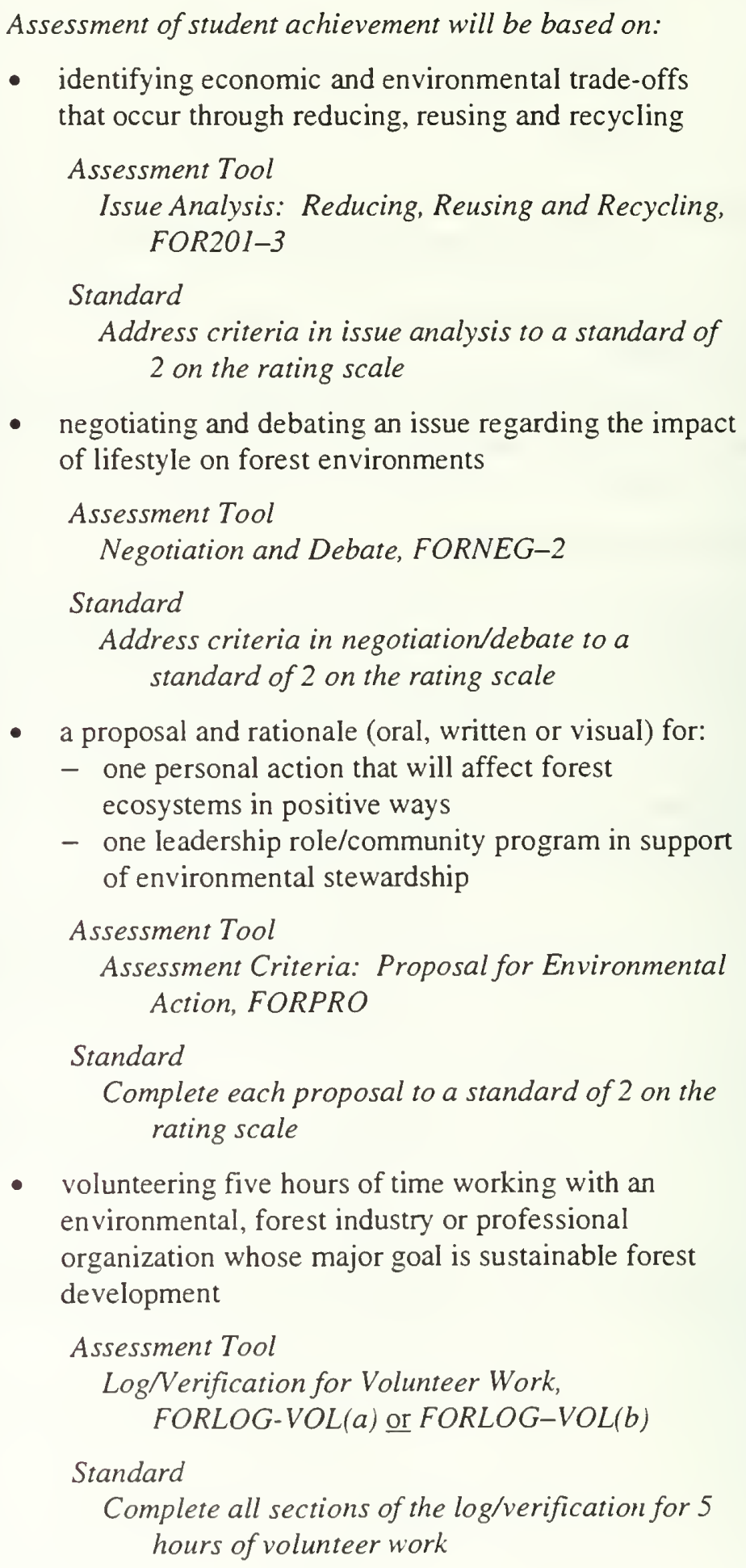 & 60 \\
\hline
\end{tabular}


MODULE FOR201: MAKING A DIFFERENCE IN FORESTRY (continued)

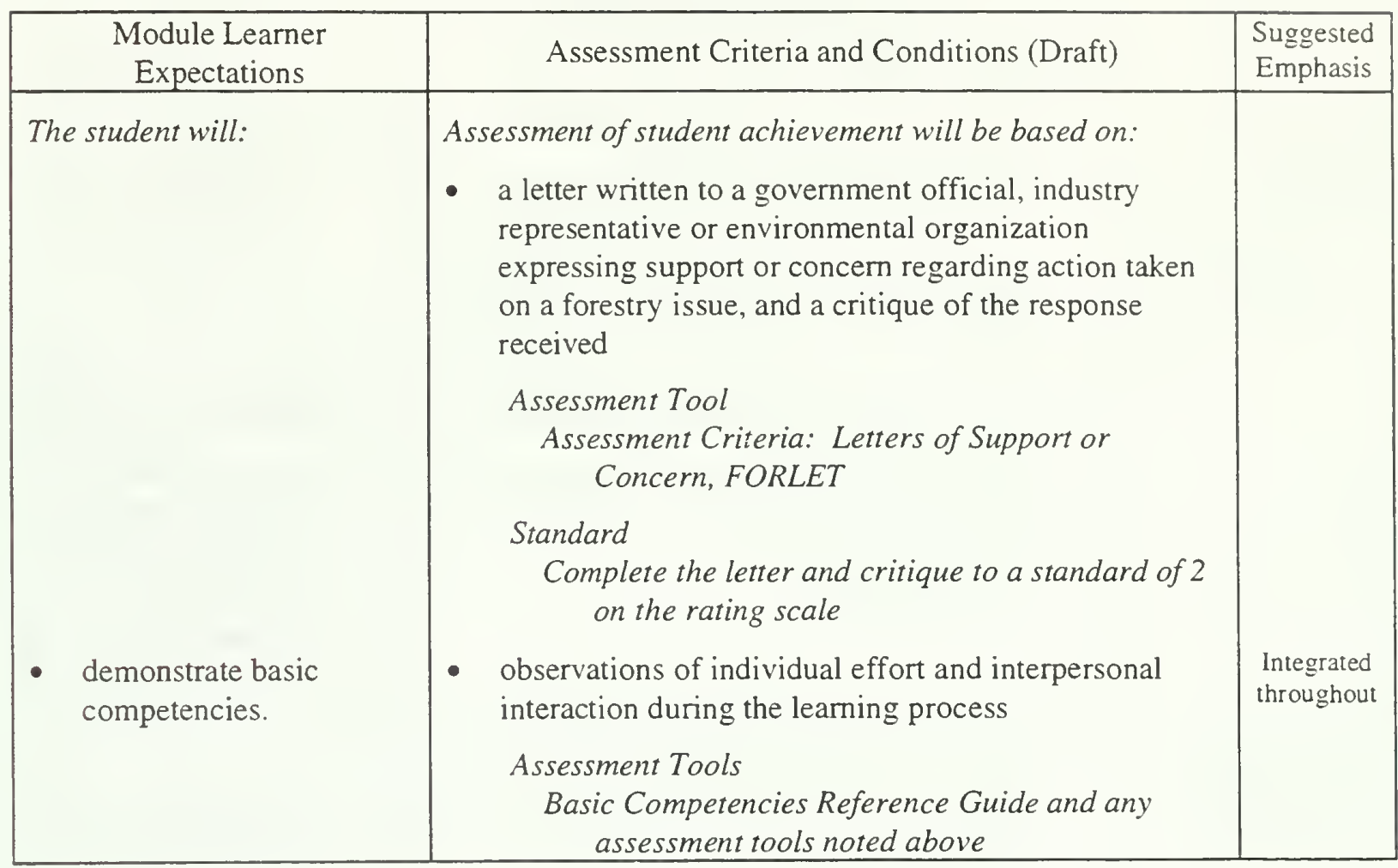

\begin{tabular}{|c|c|c|}
\hline Concept & Specific Learner Expectations & Notes \\
\hline $\begin{array}{l}\text { Attitudes, Actions } \\
\text { and Lifestyle }\end{array}$ & $\begin{array}{l}\text { The student should: } \\
\text { - explain how societal attitudes, actions and } \\
\text { lifestyle may affect the forest resource; e.g., } \\
\text { - conservation ethic } \\
\text { - consumer practices } \\
\text { - recreational patterns } \\
\text { - describe factors that influence consumer and } \\
\text { marketing trends, and how these trends may affect } \\
\text { the forest resources; e.g., } \\
\text { - social } \\
\text { - economic } \\
\text { - environmental } \\
\text { compile a personal inventory of possessions and } \\
\text { material purchases made over the last year } \\
\text { distinguish among personal needs and wants, as } \\
\text { reflected through personal inventory } \\
\text { assess the impacts of personal actions and } \\
\text { lifestyle on the forest resource. }\end{array}$ & $\begin{array}{l}\text { Plan for student-directed } \\
\text { projects. Encourage } \\
\text { students to express } \\
\text { personal views and } \\
\text { values. } \\
\text { Consider } 10 \text { personal } \\
\text { actions and their } \\
\text { consequences on the } \\
\text { forest. } \\
\text { See Alberta's Focus on } \\
\text { Forests (Activity 5.6- } \\
\text { What's in the Waste- } \\
\text { basket-Reassessing Our } \\
\text { Needs). }\end{array}$ \\
\hline
\end{tabular}


MODULE FOR201: MAKING A DIFFERENCE IN FORESTRY (continued)

\begin{tabular}{|c|c|c|}
\hline Concept & Specific Learner Expectations & Notes \\
\hline $\begin{array}{l}\text { Reduce, Reuse and } \\
\text { Recycle }\end{array}$ & $\begin{array}{l}\text { The student should: } \\
\text { - describe and assess societal trends in the } \\
\text { consumption of material goods } \\
\text { - identify common refuse that can be reused in } \\
\text { practical and economical ways } \\
\text { - conduct research on materials that are being } \\
\text { recycled and the products that are produced } \\
\text { analyze trade-offs that occur through reducing, } \\
\text { reusing and recycling; e.g., } \\
\text { - economic } \\
\text { - environmental. }\end{array}$ & $\begin{array}{l}\text { Consider linkages with } \\
\text { Energy and Mines } \\
\text { (ENM109: } \\
\text { Fundamentals of } \\
\text { Recycling). } \\
\text { Examples: } \\
\text { - fence posts } \\
\text { - jewelry } \\
\text { - paper } \\
\text { - synthetic fibres. } \\
\text { Consider the advantages } \\
\text { and disadvantages of } \\
\text { - disposable cups versus } \\
\text { reusable cups } \\
\text { - disposable diapers } \\
\text { versus cloth diapers. }\end{array}$ \\
\hline $\begin{array}{l}\text { Environmental } \\
\text { Responsibility/ } \\
\text { Citizenship }\end{array}$ & $\begin{array}{l}\text { - propose personal strategies for using the forest } \\
\text { resource that foster the attainment of social, } \\
\text { cultural, economic and environmental goals; e.g., } \\
\text { - personal actions } \\
\text { - leadership roles } \\
\text { plan, conduct and assess a school-wide campaign } \\
\text { to increase awareness of lifestyle, conservation } \\
\text { and the environment; e.g., } \\
\text { - establish goals } \\
\text { - plan and conduct } \\
\text { - assess results } \\
\text { debate an issue regarding the impacts of lifestyle } \\
\text { on the forest resource; e.g., } \\
\text { - conduct research } \\
\text { - develop a position } \\
\text { - participate in debate }\end{array}$ & $\begin{array}{l}\text { Develop consensus on a } \\
\text { relevant issue. } \\
\text { Ask students to prepare a } \\
\text { contract expressing } \\
\text { personal commitment to } \\
\text { environmental } \\
\text { stewardship. Review } \\
\text { the contract after a } \\
\text { period of time to } \\
\text { ascertain if contract } \\
\text { obligations are being } \\
\text { met. } \\
\text { Consider case studies and } \\
\text { simulations provided in } \\
\text { A Forest For All, a } \\
\text { multi-media kit } \\
\text { developed by the } \\
\text { Canadian Forest } \\
\text { Products Association } \\
\text { and distributed by } \\
\text { Marwil Communi- } \\
\text { cations. }\end{array}$ \\
\hline
\end{tabular}


MODULE FOR201: MAKING A DIFFERENCE IN FORESTRY (continued)

\begin{tabular}{|c|c|c|}
\hline Concept & Specific Learner Expectations & Notes \\
\hline $\begin{array}{l}\text { Environmental } \\
\text { Responsibility/ } \\
\text { Citizenship } \\
\text { (continued) }\end{array}$ & $\begin{array}{l}\text { The student should: } \\
\text { - identify constructive ways in which individuals } \\
\text { can influence public decisions that affect the } \\
\text { forest and all its resources; e.g., } \\
\text { - voting } \\
\text { - lobbying } \\
\text { - seeking office } \\
\text { - supporting compatible interest groups } \\
\text { - assess the goals and objectives of one or more } \\
\text { conservation groups. }\end{array}$ & $\begin{array}{l}\text { Write letters to } \\
\text { government agencies, } \\
\text { industry and/or } \\
\text { environmental groups. } \\
\text { Critique response } \\
\text { received. }\end{array}$ \\
\hline
\end{tabular}


MODULE FOR203: MANAGING ALBERTA'S FORESTED LANDS

Level: $\quad$ Intermediate

Theme: $\quad$ Social and Cultural Perspectives

Prerequisite/

Corequisite:

Forest Regions of Canada (FOR102; Recommended)

Module Parameters: Access to government agencies responsible for forest management (e.g., Alberta Environmental Protection, Parks Canada)

Students research agencies and frameworks used to manage forested lands in Alberta.

Curriculum and Assessment Standards

\begin{tabular}{|c|c|c|}
\hline $\begin{array}{c}\text { Module Learner } \\
\text { Expectations }\end{array}$ & Assessment Criteria and Conditions (Draft) & $\begin{array}{l}\text { Suggested } \\
\text { Emphasis } \\
\end{array}$ \\
\hline $\begin{array}{l}\text { The student will: } \\
\text { - explain how Alberta's } \\
\text { forested lands are } \\
\text { administered }\end{array}$ & $\begin{array}{l}\text { Assessment of student achievement will be based on: } \\
\text { - preparing and presenting a report (written, oral or } \\
\text { multi-media) that explains how Alberta's forested } \\
\text { lands are administered. Report to include: } \\
\text { - a timeline of changes that have occurred in the } \\
\text { ownership and administration of forested lands } \\
\text { - a map and explanation of different land tenures } \\
\text { (public and private) } \\
\text { - a list of five or more agencies responsible for } \\
\text { managing forested lands within Alberta's } \\
\text { boundaries, and the mandates of each agency } \\
\text { Assessment Tools } \\
\text { Presentations/Reports: Managing Alberta's } \\
\text { Forested Lands, FOR203-1 } \\
\text { Sample Timeline: Management History of } \\
\text { Alberta's Forested Lands, FOR203-2 } \\
\text { Task Checklist for Mapping, FORMAP } \\
\text { Standard } \\
\text { Complete all components of the report to a } \\
\text { standard of } 2 \text { on the rating scale }\end{array}$ & 20 \\
\hline
\end{tabular}


MODULE FOR203: MANAGING ALBERTA'S FORESTED LANDS (continued)

\begin{tabular}{|c|c|c|}
\hline $\begin{array}{c}\text { Module Learner } \\
\text { Expectations }\end{array}$ & Assessment Criteria and Conditions (Draft) & $\begin{array}{l}\text { Suggested } \\
\text { Emphasis }\end{array}$ \\
\hline $\begin{array}{l}\text { The student will: } \\
\text { - research government } \\
\text { legislation and policies } \\
\text { affecting the forest } \\
\text { resource }\end{array}$ & $\begin{array}{l}\text { Assessment of student achievement will be based on: } \\
\text { - } \quad \text { summarizing the general intent and major roles of: } \\
\text { - important government acts in managing the forest } \\
\text { - regulations and/or guidelines established in } \\
\text { association with government acts for managing the } \\
\text { forest } \\
\text { Assessment Tool } \\
\text { Sample Acts and Regulations for Managing } \\
\text { Alberta's Forests, FOR203-3 } \\
\text { Standard } \\
\text { Summarize } 4 \text { important government acts and } 4 \\
\text { regulations and/or guidelines } \\
\text { given access to current resources on forest } \\
\text { management in Alberta, completing a research project } \\
\text { that examines the intent of five or more: } \\
\text { - timber dispositions issued by Alberta Land and } \\
\text { Forest Services } \\
\text { - other types of dispositions used to manage non- } \\
\text { fibre aspects of forest use } \\
\text { Assessment Tool } \\
\text { Research Process: Allocation Procedures for } \\
\text { Land and Timber, FOR203-4 } \\
\text { Standard } \\
\text { Complete all components of research to a } \\
\text { standard of } 2 \text { on the rating scale } \\
\text { observations of individual effort and interpersonal } \\
\text { Assessment Tools } \\
\text { Basic Competencies Reference Guide and any } \\
\text { assessment tools noted above }\end{array}$ & $\begin{array}{l}\text { Integrated } \\
\text { throughout }\end{array}$ \\
\hline
\end{tabular}


MODULE FOR203: MANAGING ALBERTA'S FORESTED LANDS (continued)

\begin{tabular}{|c|c|c|}
\hline Concept & Specific Learner Expectations & Notes \\
\hline $\begin{array}{l}\text { Administration of } \\
\text { Forested Lands }\end{array}$ & $\begin{array}{l}\text { The student should: } \\
\text { - describe major changes that have occurred from } \\
\text { past to present in the ownership and } \\
\text { administration of forested lands in Alberta: } \\
\text { - Federal jurisdiction } \\
\text { - Provincial status } \\
\text { - Natural Resource Transfer Act } \\
\text { - describe different land tenures in Alberta today: } \\
\text { - public (provincial and federal crown lands) } \\
\text { - private } \\
\text { identify, locate and compare different land } \\
\text { management areas in Alberta: } \\
\text { - white area } \\
\text { - green area } \\
\text { - describe the mandates of agencies or groups } \\
\text { responsible for managing forested lands within } \\
\text { Alberta's boundaries, and the proportion of land } \\
\text { under their jurisdiction }\end{array}$ & $\begin{array}{l}\text { Use archives, films and } \\
\text { library resources to } \\
\text { research the history of } \\
\text { forestry in Alberta. } \\
\text { Research how the } \\
\text { management of } \\
\text { Alberta's forested lands } \\
\text { became a responsibility } \\
\text { of the provincial } \\
\text { govermment. } \\
\text { Contact Alberta } \\
\text { Environmental } \\
\text { Protection to request } \\
\text { maps of land } \\
\text { management areas in } \\
\text { Alberta. } \\
\text { Construct a circle graph } \\
\text { depicting land owner- } \\
\text { ship distribution in } \\
\text { Alberta (e.g., provincial } \\
\text { public, provincial } \\
\text { private, federal public, } \\
\text { aboriginal lands). } \\
\text { For example, } \\
\text { - Alberta Environmental } \\
\text { Protection (Land and } \\
\text { Forest Services, Parks } \\
\text { Services, Fish and } \\
\text { Wildlife Services) } \\
\text { - Parks Canada } \\
\text { - private ownership } \\
\text { - Metis or Native Indian } \\
\text { - Forestry Canada. }\end{array}$ \\
\hline
\end{tabular}


MODULE FOR203: MANAGING ALBERTA'S FORESTED LANDS (continued)

\begin{tabular}{|c|c|c|}
\hline Concept & Specific Learner Expectations & Notes \\
\hline $\begin{array}{l}\text { Government } \\
\text { Legislation and } \\
\text { Policies }\end{array}$ & $\begin{array}{l}\text { The student should: } \\
\text { explain how activities in Alberta's forests are } \\
\text { subject to a variety of government acts and } \\
\text { regulations } \\
\text { research the role of important government acts in } \\
\text { managing the forest } \\
\text { - } \\
\text { research the role of regulations and guidelines } \\
\text { established in association with government acts in } \\
\text { further managing the forest } \\
\text { assess the short- and long-term effects of selected } \\
\text { government acts and regulations on forested land. }\end{array}$ & $\begin{array}{l}\text { Contact Alberta } \\
\text { Environmental } \\
\text { Protection (or Queen's } \\
\text { Printer, Province of } \\
\text { Alberta) to request } \\
\text { various acts, regulations } \\
\text { and guidelines used in } \\
\text { managing forested } \\
\text { lands. } \\
\text { For example, } \\
\text { - Forest Act } \\
\text { - Forest Reserves Act } \\
\text { - Forest and Prairie } \\
\text { Protection Act } \\
\text { - Provincial Parks Act } \\
\text { - Wilderness Areas, } \\
\text { Ecological Reserves } \\
\text { and Natural Areas Act. } \\
\text { For example, } \\
\text { - Timber Management } \\
\text { Regulation } \\
\text { - Timber Operating } \\
\text { Groundrules } \\
\text { - Reforestation Standards } \\
\text { - Forest and Prairie } \\
\text { Protection Regulation } \\
\text { (Part I and II) } \\
\text { - Forest Land Use } \\
\text { Regulation (Recreation, } \\
\text { Mineral, Pipeline, } \\
\text { Grazing) } \\
\text { Avoid detailed analysis of } \\
\text { acts and regulations- } \\
\text { OVERVIEW ONLY. }\end{array}$ \\
\hline $\begin{array}{l}\text { Allocation } \\
\text { Procedures }\end{array}$ & $\begin{array}{l}\text { - identify criteria used to establish forest land and } \\
\text { timber dispositions }\end{array}$ & $\begin{array}{l}\text { For example, } \\
\text { authorizations in the } \\
\text { form of permits, } \\
\text { licences or other legal } \\
\text { agreements. } \\
\text { Consider different public } \\
\text { land users/uses. For } \\
\text { example, } \\
\text { - fibre production } \\
\text { - recreation } \\
\text { - agriculture } \\
\text { - wildlife habitat } \\
\text { - integrated use. }\end{array}$ \\
\hline
\end{tabular}


MODULE FOR203: MANAGING ALBERTA'S FORESTED LANDS (continued)

\begin{tabular}{|c|c|c|}
\hline Concept & Specific Learner Expectations & Notes \\
\hline $\begin{array}{l}\text { Allocation } \\
\text { Procedures } \\
\text { (continued) }\end{array}$ & $\begin{array}{l}\text { The student should: } \\
\text { - explain the intent of different timber dispositions } \\
\text { issued by the Alberta Forest Service, and the } \\
\text { responsibilities of holders of these dispositions } \\
\text { describe other types of dispositions that are used } \\
\text { to manage non-fibre aspects of forest use } \\
\text { research the role of consultation (with other } \\
\text { resource users) and public involvement in } \\
\text { establishing land and timber dispositions. }\end{array}$ & $\begin{array}{l}\text { For example, } \\
\text { - Forest Management } \\
\text { Agreements (FMAs) } \\
\text { - Quota Certificates } \\
\text { - Timber Licences } \\
\text { - Commercial Timber } \\
\text { Permits Local } \\
\text { - Timber Permits. } \\
\text { For example, } \\
\text { - grazing } \\
\text { - hunting, fishing and } \\
\text { trapping } \\
\text { - energy and mineral } \\
\text { development } \\
\text { - commercial trail riding. } \\
\text { Role-playing. }\end{array}$ \\
\hline
\end{tabular}




\section{MODULE FOR204: WOODS SURVIVAL II}

Level: $\quad$ Intermediate

Theme:

Social and Cultural Perspectives

Prerequisite:

Woods Survival I (FOR104); current certification in Emergency First Aid

Prerequisite/

Corequisite:

Mapping and Aerial Photography (FOR105; Recommended)

Module Parameters: Access to an outdoor forest environment and gear for outdoor expeditions; instructor must have current personal certification in Standard First Aid (St. John Ambulance)

Information regarding student safety and instructor certification is provided in Sections $\mathrm{C}$ and $\mathrm{H}$ of this Guide to Standards and Implementation.

Students plan, prepare for and conduct an extended outdoor wilderness trip in the forest.

Curriculum and Assessment Standards

\begin{tabular}{|c|c|c|}
\hline $\begin{array}{c}\text { Module Learner } \\
\text { Expectations }\end{array}$ & Assessment Criteria and Conditions (Draft) & $\begin{array}{l}\text { Suggested } \\
\text { Emphasis }\end{array}$ \\
\hline $\begin{array}{l}\text { The student will: } \\
\text { - plan and prepare for an } \\
\text { extended outdoor } \\
\text { wilderness trip in the } \\
\text { forest }\end{array}$ & $\begin{array}{l}\text { Assessment of student achievement will be based on: } \\
\text { developing and presenting collaborative group plans } \\
\text { for an extended outdoor wilderness trip in the forest } \\
\text { Assessment Tools } \\
\text { Task Checklist: Woods Survival II, FOR204-1 } \\
\text { Trip Planning, LRDC } \\
\text { Standard } \\
\text { Complete each component of trip planning to a } \\
\text { standard of } 2 \text { on the rating scale } \\
\text { within a continuous timeframe of at least 72-hours, } \\
\text { and through access to an outdoor forest environment, } \\
\text { demonstrating procedures for setting up camp, } \\
\text { preparing meals, complying with pertinent legislation, } \\
\text { breaking camp, and ensuring least possible } \\
\text { environmental impact } \\
\text { Assessment Tools } \\
\text { Task Checklist: Woods Survival II, FOR204-1 } \\
\text { Lab Assessment: Outdoor Forest Experiences, } \\
\text { FORLAB } \\
\text { National Occupational Standards for Outdoor } \\
\text { Guide, LRDC } \\
\text { Standard } \\
\text { Conduct and conclude the trip to a standard of } 2 \\
\text { on the rating scale }\end{array}$ & 80 \\
\hline
\end{tabular}


MODULE FOR204: WOODS SURVIVAL II (continued)

\begin{tabular}{|c|c|c|}
\hline $\begin{array}{c}\text { Module Learner } \\
\text { Expectations }\end{array}$ & Assessment Criteria and Conditions (Draft) & $\begin{array}{l}\text { Suggested } \\
\text { Emphasis }\end{array}$ \\
\hline $\begin{array}{l}\text { demonstrate basic } \\
\text { competencies. }\end{array}$ & $\begin{array}{l}\text { Assessment of student achievement will be based on: } \\
\text { - successfully participating in four or more activities } \\
\text { while en route that involve personal interaction with } \\
\text { the wilderness environment } \\
\text { Assessment Tool } \\
\text { Task Checklist: Woods Survival II, FOR204-1 } \\
\text { Lab Assessment: Outdoor Forest Experiences, } \\
\text { FORLAB } \\
\text { Standard } \\
\text { Complete } 4 \text { of the activities (as outlined in the task } \\
\text { checklist) that involve personal interaction } \\
\text { with the wilderness environment to a standard } \\
\text { of } 2 \text { on the rating scale } \\
\text { a post-trip assessment that provides observations and } \\
\text { personal impressions, and summarizes: } \\
\text { - activities well done } \\
\text { - problems encountered and suggested solutions } \\
\text { - recommendations regarding future trips } \\
\text { Assessment Tool } \\
\text { Post-Trip Assessment for Woods Survival II, } \\
\text { FOR204-2 } \\
\text { Standard } \\
\text { Achieve a performance rating of } 2 \text { in applicable } \\
\text { areas of post-trip assessment } \\
\text { interaction during the learning process } \\
\text { Assessment Tools } \\
\text { Basic Competencies Reference Guide and any } \\
\text { absent tools noted above }\end{array}$ & $\begin{array}{l}\text { Integrated } \\
\text { throughout }\end{array}$ \\
\hline
\end{tabular}


MODULE FOR204: WOODS SURVIVAL II (continued)

\begin{tabular}{|c|c|c|}
\hline Concept & Specific Learner Expectations & Notes \\
\hline $\begin{array}{l}\text { Trip Planning and } \\
\text { Preparation }\end{array}$ & $\begin{array}{l}\text { The student should: } \\
\text { - establish specific objectives for an outdoor } \\
\text { wilderness trip; e.g., } \\
\text { - goals and expectations } \\
\text { - length of trip } \\
\text { - destination } \\
\text { - general schedule and agenda } \\
\text { - incorporate guidelines for environmental } \\
\text { awareness into trip planning and preparations; } \\
\text { e.g., } \\
\text { - principles of ecotourism } \\
\text { - consideration for carrying capacity } \\
\text { - strategies for minimum impact land use } \\
\text { identify and obtain appropriate supplies, } \\
\text { equipment and personal gear for the trip; e.g., } \\
\text { - water, food and grub box } \\
\text { - tents, stoves, ax } \\
\text { - first aid and survival kits } \\
\text { - clothing and foot wear } \\
\text { - toiletries } \\
\text { - obrepare supplies, equipment and personal gear for } \\
\text { transportation } \\
\text { - conduct a pre-trip assessment of supplies, } \\
\text { equipment and personal gear; e.g., } \\
\text { - compare to trip checklist } \\
\text { - assess quality, quantity and condition } \\
\text { plan for weather and seasonal conditions; e.g., } \\
\text { - identify hazards particular to the area } \\
\text { - listen to weather and news reports and } \\
\text { forecasts }\end{array}$ & $\begin{array}{l}\text { Hold pre-trip meeting to } \\
\text { confirm trip details. } \\
\text { Obtain information } \\
\text { regarding special needs } \\
\text { (e.g., physical } \\
\text { limitations, special } \\
\text { dietary requirements). } \\
\text { Discuss trip } \\
\text { expectations. } \\
\text { List potential } \\
\text { environmental impacts } \\
\text { of the trip. Write } \\
\text { before-and-after journal } \\
\text { entries to document } \\
\text { affect on a campsite. } \\
\\
\text { Contact local outdoor gear } \\
\text { supplier for information } \\
\text { and instruction on } \\
\text { supplies and equip- } \\
\text { ment. List all } \\
\text { supplies/equipment to } \\
\text { be taken on trip. } \\
\text { Identify items that may } \\
\text { have significant } \\
\text { environmental impact- } \\
\text { consider alternatives } \\
\text { that would lesson } \\
\text { impact. } \\
\text { Establish methods of } \\
\text { regular and emergency } \\
\text { communication, and a } \\
\text { contingency plan to be } \\
\text { used if regular } \\
\text { communication is } \\
\text { interupted. } \\
\text { Compare supplies and } \\
\text { checklist. Ensure all } \\
\text { equipment is in } \\
\text { satisfactory working } \\
\text { condition. Pack } \\
\text { supplies/equipment in } \\
\text { waterproof containers. }\end{array}$ \\
\hline
\end{tabular}


MODULE FOR204: WOODS SURVIVAL II (continued)

\begin{tabular}{|c|c|c|}
\hline Concept & Specific Learner Expectations & Notes \\
\hline $\begin{array}{l}\text { Trip Planning and } \\
\text { Preparation } \\
\text { (continued) }\end{array}$ & $\begin{array}{l}\text { The student should: } \\
\begin{array}{l}\text { - } \quad \text { plan courses of action to cope with potential } \\
\text { emergency situations in the wilderness; e.g., } \\
\text { - extreme weather conditions } \\
\text { - fire or flood } \\
\text { - injury and illness } \\
\text { - avalanche. }\end{array}\end{array}$ & $\begin{array}{l}\text { Potential linkages with } \\
\text { "Wildemess First Aid" } \\
\text { certification course } \\
\text { (Canadian Red Cross). } \\
\text { Outline requirements for } \\
\text { survival and first- aid } \\
\text { kits. }\end{array}$ \\
\hline $\begin{array}{l}\text { Conducting and } \\
\text { Concluding the } \\
\text { Trip }\end{array}$ & $\begin{array}{l}\text { follow guidelines for safe travel in the forest; e.g., } \\
\text { - inform responsible person of travel plans } \\
\text { - follow travel schedule as planned } \\
\text { - use orientation and navigational skills } \\
\text { - identify potential hazards and take necessary } \\
\text { precautions } \\
\text { - dress according to mode of travel, weather and } \\
\text { - season } \\
\text { - watch for changes in current weather } \\
\text { conditions } \\
\text { set up a wildemess camp site, following } \\
\text { guidelines for comfort, safety and least possible } \\
\text { environmental impact; e.g., } \\
\text { - select camp site considering } \\
\text { - site exposure and drainage } \\
\text { - access to water and firewood } \\
\text { - impact on flora and fauna } \\
\text { - proximity to potential dangers } \\
\text { - erect tent or lean-to } \\
\text { - assemble other amenities } \\
\text { - protect food from wildlife and spoilage } \\
\text { - protect equipment from the elements } \\
\text { follow minimal impact guidelines in establishing: } \\
\text { - latrine location and toilet procedures } \\
\text { - wash area and procedures } \\
\text { - fire site and use } \\
\text { - methods of garbage and waste water disposal }\end{array}$ & $\begin{array}{l}\text { Students need a written } \\
\text { plan so everyone knows } \\
\text { who is responsible for } \\
\text { each function. Become } \\
\text { familiar with hazards } \\
\text { particular to the area. } \\
\text { Listen to news and } \\
\text { weather reports. Carry } \\
\text { survival equipment. } \\
\text { Reroute, postpone or } \\
\text { cancel trip if conditions } \\
\text { threaten safety. } \\
\text { Select dry, level ground. } \\
\text { Consider potential } \\
\text { hazards including fire, } \\
\text { rock slides, avalanches, } \\
\text { dead materials close to } \\
\text { shelter, etc. }\end{array}$ \\
\hline
\end{tabular}


MODULE FOR204: WOODS SURVIVAL II (continued)

\begin{tabular}{|c|c|c|}
\hline Concept & Specific Learner Expectations & Notes \\
\hline $\begin{array}{l}\text { Conducting and } \\
\text { Concluding the } \\
\text { Trip (continued) }\end{array}$ & $\begin{array}{l}\text { The student should: } \\
\text { - comply with local, provincial and federal } \\
\text { legislation relevant to activities that are } \\
\text { undertaken } \\
\text { - assume outdoor camp duties on a rotational basis; } \\
\text { e.g., } \\
\text { - meal preparation } \\
\text { - camp maintenance and hygiene } \\
\\
\text { demonstrate practical knowledge and skills in at } \\
\text { least three areas relevant to wilderness travel; } \\
\text { e.g., } \\
\text { - closed compass traverse } \\
\text { - tree/shrub/vegetation/twig identification } \\
\text { - animal track and scat identification } \\
\text { - use of equipment } \\
\text { - survival skills } \\
\text { monitor the activities of wildlife in the area and } \\
\text { take precautions to avoid dangerous situations } \\
\text { follow appropriate procedures to break camp; e.g., } \\
\text { - pack supplies, equipment and personal gear } \\
\text { - take down shelter } \\
\text { - clean site } \\
\text { - do circle tour of site }\end{array}$ & $\begin{array}{l}\text { Consider land use, } \\
\text { permits, seasonal } \\
\text { restrictions, quotas, etc. } \\
\text { Seek clarification if } \\
\text { necessary. Report } \\
\text { violations. } \\
\text { Students should practise } \\
\text { food preparation at } \\
\text { home first. Have } \\
\text { students participate in } \\
\text { all areas of preparation, } \\
\text { operation and clean-up. } \\
\text { Alternate chores during } \\
\text { trip. }\end{array}$ \\
\hline
\end{tabular}


MODULE FOR204: WOODS SURVIVAL II (continued)

\begin{tabular}{|c|c|c|}
\hline Concept & \multicolumn{1}{|c|}{ Specific Learner Expectations } & \multicolumn{1}{c|}{ Notes } \\
\hline $\begin{array}{c}\text { Conducting and } \\
\text { Concluding the } \\
\text { Trip (continued) }\end{array}$ & $\begin{array}{l}\text { The student should: } \\
\text { conclude the wilderness trip and conduct a post- } \\
\text { trip assessment; e.g., } \\
- \text { observations and personal impressions } \\
- \text { problems encountered } \\
- \text { recommendations regarding future trips. }\end{array}$ & $\begin{array}{l}\text { Have students "bring back } \\
\text { in image" of a favourite } \\
\text { spot or something they } \\
\text { considered special } \\
\text { about the trip. Develop } \\
\text { images through } \\
\text { drawings or descriptive } \\
\text { writings. }\end{array}$ \\
& & $\begin{array}{l}\text { Develop a slide/tape } \\
\text { presentation based on } \\
\text { the outdoor wilderness } \\
\text { trip. } \\
\text { Consider: } \\
\end{array}$ \\
& & $\begin{array}{l}\text { satisfaction with } \\
\text { equipment and supplies } \\
\text { suitability of } \\
\text { environment or route } \\
\text { inconsistencies between } \\
\text { trip and expectations. }\end{array}$ \\
\end{tabular}




\section{MODULE FOR206: MEASURING THE FOREST II}

Level: Intermediate

Theme: $\quad$ Technology and Applications

Prerequisite: $\quad$ Measuring the Forest I (FOR106)

Module Parameters: Access to a demonstration forest and tools used in forest measurement

Students research current forest inventory practices and demonstrate appropriate strategies for sampling the fibre and non-fibre value of forests.

\section{Curriculum and Assessment Standards}

\begin{tabular}{|c|c|c|}
\hline $\begin{array}{c}\text { Module Learner } \\
\text { Expectations }\end{array}$ & Assessment Criteria and Conditions (Draft) & $\begin{array}{l}\text { Suggested } \\
\text { Emphasis }\end{array}$ \\
\hline $\begin{array}{l}\text { The student will: } \\
\text { - } \quad \text { research specific } \\
\text { sampling techniques } \\
\text { used to gather } \\
\text { information about the } \\
\text { forest resource }\end{array}$ & $\begin{array}{l}\text { Assessment of student achievement will be based on: } \\
\text { - } \\
\text { completing a research project on random and } \\
\text { systematic sampling techniques and their application } \\
\text { in gathering data about fibre and non-fibre forest } \\
\text { values. Research to address problems related to bias, } \\
\text { error, and the use of sample data in estimating forest } \\
\text { populations } \\
\text { Assessment Tool } \\
\text { Research Process: Random and Systematic } \\
\quad \text { Sampling Techniques, FOR206-1 } \\
\text { Standard } \\
\text { Complete all components of research to a } \\
\text { standard of } 2 \text { on the rating scale } \\
\text { designing a sampling technique (transect and plot) for } \\
\text { gathering information about a specific fibre and non- } \\
\text { fibre resource (e.g., trees, rabbits, soil, grass, insects). } \\
\text { Design to address: } \\
\text { - goals/outcomes for the forest survey } \\
\text { - type and amount of data to be collected } \\
\text { - suitable sampling techniques } \\
\text { - boundary for sample area } \\
\text { - a data collection sheet } \\
\text { Assessment Tool } \\
\text { Task Checklist: Sampling Fibre and Non-Fibre } \\
\text { Forest Values, FOR206-2 } \\
\text { Standard } \\
\text { Design the sampling technique(as outlined in the } \\
\quad \text { task checklist) to a standard of } 2 \text { on the rating }\end{array}$ & 30 \\
\hline
\end{tabular}


MODULE FOR206: MEASURING THE FOREST II (continued)

\begin{tabular}{|c|c|c|}
\hline $\begin{array}{c}\text { Module Learner } \\
\text { Expectations }\end{array}$ & Assessment Criteria and Conditions (Draft) & $\begin{array}{l}\text { Suggested } \\
\text { Emphasis }\end{array}$ \\
\hline $\begin{array}{l}\text { demonstrate basic } \\
\text { competencies. }\end{array}$ & $\begin{array}{l}\text { Assessment of student achievement will be based on: } \\
\text { - collecting and recording sample data on 0.01\% of a } \\
\text { representative forested area, and compiling sample } \\
\text { data in order to estimate the fibre and non-fibre } \\
\text { resource within the forested area. Fibre data sampling } \\
\text { to involve transects and plots, and to be accurate } \\
\text { within } 10 \% \\
\text { Assessment Tool } \\
\text { Task Checklist: Sampling Fibre and Non-Fibre } \\
\text { Forest Values, FOR206-2 } \\
\text { Sample Data Sheet: Fibre and Non-Fibre Forest } \\
\text { Values, FOR206-3 } \\
\text { Lab Assessment: Outdoor Forest Experiences, } \\
\text { FORLAB } \\
\text { Standard } \\
\text { Collect, record and compile sample data (as } \\
\text { outlined in the task checklist and lab } \\
\text { assessment) to a standard of } 2 \text { on the rating } \\
\text { scale } \\
\text { - }\end{array}$ & $\begin{array}{l}\text { Integrated } \\
\text { throughout }\end{array}$ \\
\hline
\end{tabular}


MODULE FOR206: MEASURING THE FOREST II (continued)

\begin{tabular}{|c|c|c|}
\hline Concept & Specific Learner Expectations & Notes \\
\hline Sample Designs & $\begin{array}{l}\text { The student should: } \\
\text { - research different sampling designs and } \\
\text { techniques: } \\
- \text { random } \\
\text { - systematic } \\
\text { - describe sample designs and techniques most } \\
\text { suited to gathering data about specific forest } \\
\text { components } \\
\text { identify bias and error in sampling design, and } \\
\text { problems related to the use of sample data in } \\
\text { estimating forest populations. }\end{array}$ & $\begin{array}{l}\text { Investigate applications of } \\
\text { - transects } \\
\text { - plots/nested plots } \\
\text { - surveys and } \\
\text { questionnaires. } \\
\text { For example: } \\
\text { - distribution of tree } \\
\text { species } \\
\text { - growth, age and/or } \\
\text { volume of trees } \\
\text { - soil, water and/or } \\
\text { wildlife characteristics } \\
\text { - potential for recreation } \\
\text { and/or agriculture. }\end{array}$ \\
\hline $\begin{array}{l}\text { Fibre and Non-fibre } \\
\text { Values }\end{array}$ & $\begin{array}{l}\text { - } \quad \text { establish goals/outcomes for a forest survey } \\
\text { identify the type and amount of information } \\
\text { regarding the forest resource that is required } \\
\text { - design techniques for sampling the forest region } \\
\text { that are most suited to gathering the type of } \\
\text { information required } \\
\text { - measure and locate the boundary of the sample } \\
\text { area within the forest region } \\
\text { identify safety practices and policies relevant to } \\
\text { gathering sample data in the forest } \\
\text { gather data regarding the volume and/or condition } \\
\text { of timber resources within the sample plots }\end{array}$ & $\begin{array}{l}\text { PLAN AND SHARE - } \\
\text { LEARN FROM } \\
\text { OTHERS. } \\
\text { Develop, as a class } \\
\text { project, a sampling } \\
\text { design appropriate to } \\
\text { surveying a specific } \\
\text { forest resource. Use the } \\
\text { sampling design to } \\
\text { collect data. } \\
\\
\\
\text { For example, } \\
\text { - tree heightdiameter } \\
\text { - age of trees } \\
\text { number and distribution } \\
\text { of species }\end{array}$ \\
\hline
\end{tabular}


MODULE FOR206: MEASURING THE FOREST II (continued)

\begin{tabular}{|l|l|l|}
\hline \multicolumn{1}{|c|}{ Concept } & \multicolumn{1}{|c|}{ Specific Learner Expectations } & \multicolumn{1}{c|}{ Notes } \\
\hline $\begin{array}{l}\text { Fibre and Non-Fibre } \\
\text { Values } \\
\text { (continued) }\end{array}$ & $\begin{array}{l}\text { The student should: } \\
\text { gather data regarding the nature of other non-fibre } \\
\text { resources present within the sample plots }\end{array}$ & $\begin{array}{l}\text { For example, } \\
\text { soil and water quality } \\
\text { distribution of wildlife } \\
\text { potential for } \\
\text { recreation/agriculture. }\end{array}$ \\
& $\begin{array}{l}\text { record sample data regarding fibre and non-fibre } \\
\text { resources in appropriate tables and charts } \\
\text { compile sample data-as required to estimate fibre } \\
\text { volumes and other non-fibre values within the } \\
\text { forest region } \\
\text { assess the strengths and weaknesses of the sample } \\
\text { data and statements made about the forest } \\
\text { resource. }\end{array}$ & $\begin{array}{l}\text { Make estimates regarding } \\
\text { forest population based } \\
\text { on data collected. }\end{array}$ \\
$\begin{array}{c}\text { Discuss validity/ } \\
\text { reliability of results. }\end{array}$ \\
\hline
\end{tabular}




\section{MODULE FOR207: HARVESTING AND FOREST PRODUCTS}

Level: Intermediate

Theme: Technology and Applications

Prerequisite: $\quad$ None

Module Parameters: Access to forest harvest areas and forest products industries

Students research the steps involved in harvesting and processing the fibre resource.

Curriculum and Assessment Standards

\begin{tabular}{|c|c|c|}
\hline $\begin{array}{c}\text { Module Learner } \\
\text { Expectations }\end{array}$ & Assessment Criteria and Conditions (Draft) & $\begin{array}{l}\text { Suggested } \\
\text { Emphasis }\end{array}$ \\
\hline $\begin{array}{l}\text { The student will: } \\
\text { - identify major } \\
\text { components of a plan for } \\
\text { forest harvest }\end{array}$ & $\begin{array}{l}\text { Assessment of student achievement will be based on: } \\
\text { - } \text { identifying major components of a plan for forest } \\
\text { harvest, including: } \\
\text { - when and how much to cut } \\
\text { - methods of harvest (e.g., clear cutting, shelter } \\
\text { wood method) and logging (e.g., hand, } \\
\text { mechanical) } \\
\text { - regeneration and environmental protection } \\
\text { Assessment Tool } \\
\text { Knowledge/Application Assessment: Forest } \\
\text { Harvest, FOR207-1 } \\
\text { Sample Checklist: Forest Harvest Plans, } \\
\text { FOR207-2 } \\
\text { Standard } \\
\text { Respond to a standard of } 2 \text { on the rating scale } \\
\text { a teacher-prepared assessment in which the student } \\
\text { demonstrates knowledge of major components and } \\
\text { considerations relevant to harvest planning } \\
\text { Assessment Tool } \\
\text { Sample Assessment Items: Forest Harvest, } \\
\text { FOR207-3 } \\
\text { Standard }\end{array}$ & 20 \\
\hline
\end{tabular}


MODULE FOR207: HARVESTING AND FOREST PRODUCTS (continued)

\begin{tabular}{|c|c|c|}
\hline $\begin{array}{c}\text { Module Leamer } \\
\text { Expectations }\end{array}$ & Assessment Criteria and Conditions (Draft) & $\begin{array}{l}\text { Suggested } \\
\text { Emphasis } \\
\end{array}$ \\
\hline $\begin{array}{l}\text { The student will: } \\
\text { - describe the mechanics } \\
\text { of harvesting trees }\end{array}$ & $\begin{array}{l}\text { Assessment of student achievement will be based on: } \\
\text { - a presentation or report that describes major stages in } \\
\text { the harvesting procedure from stump to mill. } \\
\text { Presentation/report to address: } \\
\text { - methods of falling, bucking, delimbing, skidding, } \\
\text { loading, hauling, slash disposal and site } \\
\text { rehabilitation } \\
\text { - technologies (e.g., machines, processes) used in } \\
\text { the harvesting procedure } \\
\text { - safety considerations (e.g., legislation, equipment, } \\
\text { procedures) relevant to the harvesting operation } \\
\text { Assessment Tool } \\
\text { Presentations/Reports, FORPRE-2 } \\
\text { Standard } \\
\text { Achieve a minimum rating of } 2 \text { on the rating scale } \\
\quad \text { for Presentations/Reports } \\
\text { completing a research project on fibre utilization and } \\
\text { product formation. Research to address: } \\
\text { - major categories/types of forest products } \\
\text { - steps involved in converting a log into lumber, } \\
\text { pulp and one other forest product } \\
\text { - new developments in milling and pulping } \\
\text { technology } \\
\text { Assessment Tool } \\
\text { Research Process: Fibre Utilization and Product } \\
\text { Formation, FOR207-4 } \\
\text { observations of individual effort and interpersonal } \\
\text { interaction during the learning process } \\
\text { Assessment Tools } \\
\text { Basic Competencies Reference Guide and any } \\
\quad \text { standard of } 2 \text { on the rating scale } \\
\text { Coment tools noted above }\end{array}$ & $\begin{array}{l}\text { Integrated } \\
\text { throughout }\end{array}$ \\
\hline
\end{tabular}


MODULE FOR207: HARVESTING AND FOREST PRODUCTS (continued)

\begin{tabular}{|c|c|c|}
\hline Concept & Specific Learner Expectations & Notes \\
\hline Harvest Plan & $\begin{array}{l}\text { The student should: } \\
\text { - } \quad \text { identify major components of a plan for } \\
\text { harvesting the forest: } \\
\text { - when and how much to cut } \\
\text { - method of harvest (e.g., clear cutting, shelter } \\
\text { wood method) and logging (e.g., hand, } \\
\text { mechanical) } \\
\text { - regeneration and environmental protection } \\
\text { relate the concepts of allowable cut, sustained } \\
\text { yield and multiple use to forest harvest practices } \\
\text { explain applications of forest inventory } \\
\text { information in establishing a plan for harvest: } \\
\text { - identification of tree species } \\
\text { - determining timber quality, volume and age } \\
\text { - layout of cutting area and landing sites } \\
\text { - planning for forest access } \\
\text { describe applications of different methods of } \\
\text { forest harvest: } \\
\text { - clearcutting } \\
\text { - selective cutting } \\
\text { - shelter wood cutting } \\
\text { - } \\
\text { describe applications of different methods of } \\
\text { forest regeneration: } \\
\text { - natural } \\
\text { - artificial } \\
\text { - protection of sensitive areas } \\
\text { - impact on downstream values } \\
\text { - landslide and erosion hazards. } \\
\text { - }\end{array}$ & $\begin{array}{l}\text { Investigation of a harvest } \\
\text { plan establishes } \\
\text { background knowledge } \\
\text { for FOR212 (Users in } \\
\text { the Forest) and } \\
\text { FOR312 (Stewardship: } \\
\text { Balancing Needs). } \\
\text { Discuss essential } \\
\text { components of a forest } \\
\text { harvest plan-DO NOT } \\
\text { make a plan. Use } \\
\text { resource persons from } \\
\text { government and } \\
\text { industry if possible. } \\
\text { The following videos, } \\
\text { relevant to harvest } \\
\text { planning, are available } \\
\text { from Alberta Pacific } \\
\text { Forest Industries } \\
\text { (phone: } 1-800-661 \text { - } \\
\text { 5210): } \\
\text { - A Pledge to the } \\
\text { Future: The Alberta } \\
\text { Pacific Story (23 } \\
\text { minutes) } \\
\text { - With Eyes on } \\
\text { Tomorrow ( } 38 \\
\text { minutes). } \\
\text { Discuss considerations in } \\
\text { determining size and } \\
\text { location of harvesting } \\
\text { tracts. } \\
\text { Consider plans for } \\
\text { establishing roads and } \\
\text { landings needed for a } \\
\text { local harvest operation. } \\
\text { Discuss the scheduling of } \\
\text { equipment and } \\
\text { estimated completion } \\
\text { date for harvest } \\
\text { operations. } \\
\text { a }\end{array}$ \\
\hline
\end{tabular}


MODULE FOR207: HARVESTING AND FOREST PRODUCTS (continued)

\begin{tabular}{|c|c|c|}
\hline Concept & Specific Learner Expectations & Notes \\
\hline Harvest Techniques & $\begin{array}{l}\text { The student should: } \\
\text { - identify stages in the harvesting procedure from } \\
\text { stump to mill: } \\
\text { - falling, bucking and delimbing } \\
\text { - skidding } \\
\text { - loading and hauling } \\
\text { research techniques and equipment used to fell, } \\
\text { buck and delimb trees in a forest harvest } \\
\text { operation } \\
\text { research techniques and equipment used to } \\
\text { transport logs from stump to landing site in a } \\
\text { forest harvest operation } \\
\text { research techniques and equipment used to } \\
\text { transport logs from landing site to mill in a forest } \\
\text { harvest operation } \\
\text { research techniques used in slash disposal and site } \\
\text { rehabilitation following logging operations in a } \\
\text { forest area } \\
\text { identify safety legislation and requirements } \\
\text { relevant to visiting a forest harvest site. }\end{array}$ & $\begin{array}{l}\text { Plan for field-based } \\
\text { instruction that will } \\
\text { enable students to } \\
\text { follow the tree from } \\
\text { harvest to finished } \\
\text { product. } \\
\text { Have students orally } \\
\text { describe the processes } \\
\text { to follow in felling, } \\
\text { bucking and delimbing } \\
\text { a tree. } \\
\text { For example, } \\
\text { - horses } \\
\text { - mechanical skidders. } \\
\text { Use print material and } \\
\text { guest speakers from } \\
\text { forest industry and } \\
\text { forest industry } \\
\text { suppliers. } \\
\text { Have students work with a } \\
\text { local landowner in } \\
\text { reclaiming an eroded } \\
\text { forest area. } \\
\text { Discuss safety measures } \\
\text { used in felling and } \\
\text { transporting trees. } \\
\text { Contact Occupational } \\
\text { Health and Safety for: } \\
\text { - Logging Safery } \\
\text { Manual } \\
\text { - Chain Saw Safety } \\
\text { Manual } \\
\text { - Safery Log } \\
\text { Transport Manual. }\end{array}$ \\
\hline Fibre Products & $\begin{array}{l}\text { identify major categories of forest products and } \\
\text { give examples of each: } \\
\text { - pulp and paper } \\
\text { - lumber } \\
\text { - veneer and plywood } \\
\text { - board products } \\
\text { - chemical and medicinal products }\end{array}$ & $\begin{array}{l}\text { Prepare reports based on } \\
\text { information gathered } \\
\text { through visits to a } \\
\text { sawmill and pulpmill. } \\
\text { Make a list of general } \\
\text { duties performed at a } \\
\text { sawmill. }\end{array}$ \\
\hline
\end{tabular}


MODULE FOR207: HARVESTING AND FOREST PRODUCTS (continued)

\begin{tabular}{|c|c|c|}
\hline Concept & Specific Learner Expectations & Notes \\
\hline $\begin{array}{l}\text { Fibre Products } \\
\text { (continued) }\end{array}$ & $\begin{array}{l}\text { The student should: } \\
\text { - research the steps and processes involved in log } \\
\text { utilization at a sawmill } \\
\text { - research the steps and processes involved in fibre } \\
\text { utilization at a pulp mill: } \\
\text { - mechanical } \\
\text { - chemical. }\end{array}$ & $\begin{array}{l}\text { Demonstrate techniques } \\
\text { and processes involved } \\
\text { in producing a fibre } \\
\text { product (e.g., paper). } \\
\text { View Weyerhaeuser - OSB } \\
\text { Production, a } 30- \\
\text { minute video } \\
\text { distributed by Ranson } \\
\text { Productions, Edmonton } \\
\text { (phone: } 437-3400 \text { ). } \\
\text { Prepare a list of safety } \\
\text { regulations pertinent to } \\
\text { sawmills and pulp } \\
\text { mills. }\end{array}$ \\
\hline
\end{tabular}




\section{MODULE FOR210: FORESTS FOREVER II}

Level: $\quad$ Intermediate

Theme: $\quad$ Management and Conservation

Prerequisite: $\quad$ Forests Forever I (FOR110)

Module Parameters: Access to resources available from government and industry organizations responsible for forest management and protection (e.g., Alberta Environmental Protection, Canadian Forestry Service)

Students explain forest management goals in Alberta, and describe current management practices used to address these goals.

Curriculum and Assessment Standards

\begin{tabular}{|c|c|c|}
\hline $\begin{array}{c}\text { Module Learner } \\
\text { Expectations }\end{array}$ & Assessment Criteria and Conditions (Draft) & $\begin{array}{l}\text { Suggested } \\
\text { Emphasis }\end{array}$ \\
\hline $\begin{array}{l}\text { The student will: } \\
\text { - explain the goals of } \\
\text { forest management in } \\
\text { Alberta }\end{array}$ & $\begin{array}{l}\text { Assessment of student achievement will be based on: } \\
\text { - developing a rationale for forest management in } \\
\text { Alberta that involves: } \\
- \text { identifying economic, environmental and social } \\
\text { needs addressed through forest management } \\
\text { - definitions and examples of sustainable } \\
\text { development, sustained yield and allowable cut } \\
\text { Assessment Tool } \\
\text { Knowledge/Application Assessment: Forest } \\
\quad \text { Management Goals, FOR210-1 } \\
\text { Standard } \\
\text { Respond to a standard of } 2 \text { on the rating scale } \\
\text { analyzing current issues related to different types of } \\
\text { forest use. Analysis to include: } \\
\text { - a list of current uses/values of Alberta's forests } \\
\text { - a summary of the views of different forest } \\
\text { stakeholder groups } \\
\text { - an explanation of potential conflicts among } \\
\text { stakeholder groups } \\
\text { - strategies for compromise and/or conflict } \\
\text { resolution } \\
\text { Assessment Tool } \\
\text { Issue Analysis: Forest Use, FOR210-2 } \\
\text { Standard } \\
\text { Address criteria in issue analysis to a standard of } \\
2 \text { on the rating scale }\end{array}$ & 30 \\
\hline
\end{tabular}


MODULE FOR210: FORESTS FOREVER II (continued)

\begin{tabular}{|c|c|c|}
\hline $\begin{array}{c}\text { Module Leamer } \\
\text { Expectations }\end{array}$ & Assessment Criteria and Conditions (Draft) & $\begin{array}{l}\text { Suggested } \\
\text { Emphasis }\end{array}$ \\
\hline $\begin{array}{l}\text { The student will: } \\
\text { - describe current } \\
\text { practices used to manage } \\
\text { and protect Alberta's } \\
\text { forested lands }\end{array}$ & $\begin{array}{l}\text { Assessment of student achievement will be based on: } \\
\text { - completing a research project on forest management } \\
\text { practices in Alberta. Research to address: } \\
\text { - definitions and examples of conservation and } \\
\text { preservation } \\
\text { - different philosophies regarding forest } \\
\text { management and protection } \\
\text { - the mandates of agencies responsible for managing } \\
\text { Alberta's forested lands } \\
\text { - the intent of different agreements, permits and/or } \\
\text { licences that make Alberta's forests available for } \\
\text { commercial or private use } \\
\text { - factors likely to influence future forest } \\
\text { management in Alberta } \\
\text { Assessment Tool } \\
\text { Research Process: Forest Management Practices, } \\
\text { FOR2I0-3 } \\
\text { Standard } \\
\text { Complete all components of research to a } \\
\text { standard of } 2 \text { on the rating scale } \\
\text { observations of individual effort and interpersonal } \\
\text { interaction during the learning process } \\
\text { Assessment Tools } \\
\text { Basic Competencies Reference Guide and any } \\
\text { assessment tools noted above }\end{array}$ & $\begin{array}{l}\text { Integrated } \\
\text { throughout }\end{array}$ \\
\hline
\end{tabular}

\begin{tabular}{|c|c|c|}
\hline Concept & Specific Learner Expectations & Notes \\
\hline $\begin{array}{l}\text { Forest Management } \\
\quad \text { Goals }\end{array}$ & $\begin{array}{l}\text { The student should: } \\
\text { - explain the goals of sustainable development } \\
\text { within the context of Alberta's forests } \\
\text { - relate the concept of sustained yield to a system } \\
\text { of harvesting and reforestation } \\
\text { - explain applications of "annual allowable cut" in } \\
\text { forest management practices }\end{array}$ & $\begin{array}{l}\text { Refer to Our Growing } \\
\text { Resource: Alberta's } \\
\text { Forest Industry... } \\
\text { Meeting “Global } \\
\text { Challenges (Alberta } \\
\text { Forest Products } \\
\text { Association). }\end{array}$ \\
\hline
\end{tabular}


MODULE FOR210: FORESTS FOREVER II (continued)

\begin{tabular}{|c|c|c|}
\hline Concept & Specific Learner Expectations & Notes \\
\hline $\begin{array}{l}\text { Forest Management } \\
\text { Goals } \\
\text { (continued) }\end{array}$ & $\begin{array}{l}\text { The student should: } \\
\text { - identify scientific, economic and social factors } \\
\text { addressed through the management of forested } \\
\text { lands in Alberta }\end{array}$ & $\begin{array}{l}\text { Possible factors to } \\
\text { consider: } \\
\text { - the silvics of trees } \\
\text { growing in the area } \\
\text { - a cycle for utilization } \\
\text { and replacement } \\
\text { the goals of different } \\
\text { stakeholder groups. }\end{array}$ \\
\hline $\begin{array}{l}\text { Forest Uses and } \\
\text { Users }\end{array}$ & $\begin{array}{l}\text { - compare current uses and values of Alberta's } \\
\text { forests: } \\
\text { - recreation and aesthetics } \\
\text { - wildlife habitat } \\
\text { - fibre production } \\
\text { - range lands } \\
\text { - coal and petroleum projects } \\
\text { - hunting and trapping } \\
\text { - water, air and soil quality } \\
\text { - ecosystem maintenance } \\
\text { - job creation } \\
\\
\text { describe the views of different forest stakeholder } \\
\text { groups and potential conflicts that may arise: } \\
\text { - recreational } \\
\text { - environmental } \\
\text { - industrial } \\
\text { explain the need for consultation with other } \\
\text { resource users and public involvement in forest } \\
\text { management. }\end{array}$ & $\begin{array}{l}\text { See Alberta's Focus on } \\
\text { Forests (Activity 4.3- } \\
\text { Forest Perspectives; } \\
\text { Activity 5.1-Forest } \\
\text { Values). } \\
\text { Supplementary reference } \\
\text { materials include: } \\
\text { - A Forest Journey-The } \\
\text { Role of Wood in the } \\
\text { Development of } \\
\text { Civilization (Harvard } \\
\text { University Press) } \\
\text { - Canadian Foresty- }- \\
\text { The View Beyond the } \\
\text { Trees (Macmillan of } \\
\text { Canada). } \\
\\
\text { Role-playing. } \\
\text { Discussion. } \\
\text { Interviewing. }\end{array}$ \\
\hline $\begin{array}{l}\text { Forest Management } \\
\text { Practices }\end{array}$ & $\begin{array}{l}\text { - identify components of conservation and } \\
\text { utilization in current forest management practices } \\
\text { - describe the mandates of agencies responsible for } \\
\text { managing Alberta's forested lands }\end{array}$ & $\begin{array}{l}\text { Contact resource persons } \\
\text { from relevant agencies } \\
\text { For example: } \\
\text { - Alberta Forest Service } \\
\text { - Fish and Wildlife } \\
\text { - Public Lands } \\
\text { - Land lnformation } \\
\text { Services. }\end{array}$ \\
\hline
\end{tabular}


MODULE FOR210: FORESTS FOREVER II (continued)

\begin{tabular}{|c|l|l|}
\hline \multicolumn{1}{|c|}{ Concept } & \multicolumn{1}{|c|}{ Specific Learner Expectations } & \multicolumn{1}{c|}{ Notes } \\
\hline $\begin{array}{l}\text { Forest Management } \\
\text { Practices } \\
\text { (continued) }\end{array}$ & $\begin{array}{l}\text { The student should: } \\
\text { describe current management practices that make } \\
\text { Alberta's productive forests available to industry } \\
\text { for commercial harvest: } \\
- \text { forest management agreements } \\
- \text { quota certificates } \\
- \text { commercial timber permits } \\
- \text { local timber permits } \\
\text { consider factors likely to influence future forest } \\
\text { management practices }\end{array}$ & $\begin{array}{l}\text { Group research and } \\
\text { presentations. }\end{array}$ \\
& $\begin{array}{l}\text { Possible factors to } \\
\text { consider include: } \\
\text { new knowledge and } \\
\text { technology } \\
\text { increased public } \\
\text { participation in decision } \\
\text { making } \\
\text { population trends } \\
\text { recreation and tourism } \\
\end{array}$ & $\begin{array}{l}\text { natural resource } \\
\text { extraction. }\end{array}$ \\
\hline
\end{tabular}




\section{MODULE FOR212: USERS IN THE FOREST}

Level: $\quad$ Intermediate

Theme: $\quad$ Management and Conservation

Prerequisite: None

Module Parameters: Access to forest management plans available from government and industry organizations (e.g., Alberta Environmental Protection, Alberta Forest Products Association)

Students identify different users in the forest and explain the planning principles that are used in developing an integrated resource management plan.

\section{Curriculum and Assessment Standards}

\begin{tabular}{|c|c|c|}
\hline $\begin{array}{l}\text { Module Learner } \\
\text { Expectations }\end{array}$ & Assessment Criteria and Conditions (Draft) & $\begin{array}{l}\text { Suggested } \\
\text { Emphasis }\end{array}$ \\
\hline $\begin{array}{l}\text { The student will: } \\
\text { - identify different uses of } \\
\text { the forest and the needs } \\
\text { of each forest user }\end{array}$ & $\begin{array}{l}\text { Assessment of student achievement will be based on: } \\
\text { - identifying four or more major categories of forest use } \\
\text { (e.g., industry, recreation, tourism, environmental) } \\
\text { and examples of forest users within each category } \\
\text { Assessment Tool } \\
\text { Knowledge/Application Assessment: Users in the } \\
\text { Forest, FOR212-1 } \\
\text { Standard } \\
\text { Respond to a standard of } 2 \text { on the rating scale } \\
\text { - completing a research project on the principles of } \\
\text { multiple and integrated land use. Research to } \\
\text { address: } \\
\text { - definitions and Alberta examples of multiple and } \\
\text { integrated land use } \\
\text { - a comparison of multiple land use and integrated } \\
\text { land use principles } \\
\text { Assessment Tool } \\
\text { Research Process: Multiple and Integrated Land } \\
\text { Use, FOR } 21-2 \\
\text { Standard } \\
\text { Complete all components of research to a } \\
\text { standard of } 2 \text { on the rating scale }\end{array}$ & 30 \\
\hline
\end{tabular}


MODULE FOR212: USERS IN THE FOREST (continued)

\begin{tabular}{|c|c|c|}
\hline $\begin{array}{c}\text { Module Learner } \\
\text { Expectations }\end{array}$ & Assessment Criteria and Conditions (Draft) & $\begin{array}{l}\text { Suggested } \\
\text { Emphasis }\end{array}$ \\
\hline $\begin{array}{l}\text { The student will: } \\
\text { - research the } \\
\text { development of a plan } \\
\text { for integrated resource } \\
\text { management }\end{array}$ & $\begin{array}{l}\text { Assessment of student achievement will be based on: } \\
\text { - a flowchart that outlines basic components of } \\
\text { integrated resource management. Flowchart to } \\
\text { provide an overview of processes used to: } \\
\text { - establish planning teams } \\
\text { - determine management goals and objectives } \\
\text { - ensure public involvement in planning } \\
\text { - obtain approval for the management plan } \\
\text { Assessment Tool } \\
\text { Assessment Criteria: Flow Charts, FORFLO } \\
\text { Standard } \\
\text { Complete flow chart to a standard of } 2 \text { on the } \\
\text { rating scale } \\
\text { negotiating and presenting a plan for the integrated } \\
\text { use of a local forested area. Plan to address: } \\
\text { - the needs of at least four different users } \\
\text { - strategies for compromise among users } \\
\text { Assessment Tools } \\
\text { Alberta's Focus on Forests (Section } 5.5 \text { : } \\
\text { Integrated Resource Management), LRDC } \\
\text { Negotiation and Debate, FORNEG-2 } \\
\text { Standard } \\
\text { Negotiate and present the plan to a standard of } 2 \\
\text { on the rating scale } \\
\text { interaction during the learning process } \\
\text { Assessment Tools } \\
\text { assessment tools noted above }\end{array}$ & $\begin{array}{l}\text { Integrated } \\
\text { throughout }\end{array}$ \\
\hline
\end{tabular}


MODULE FOR212: USERS IN THE FOREST (continued)

\begin{tabular}{|c|c|c|}
\hline Concept & Specific Learner Expectations & Notes \\
\hline Forest Uses & $\begin{array}{l}\text { The student should: } \\
\text { - identify and describe major types of forest use; } \\
\text { e.g., } \\
\text { - industrial } \\
\text { - recreational } \\
\text { - wildlife habitat } \\
\text { - water, air and soil quality } \\
\text { - research specific uses and multiple demands } \\
\text { placed upon forested land; e.g., } \\
\text { - wood fibre production } \\
\text { - wildlife management } \\
\text { - grazing and range management } \\
\text { - watershed } \\
\text { - oil, gas and mining } \\
\text { - recreation } \\
\text { - protected areas } \\
\text { explain why forests can and should serve many } \\
\text { purposes } \\
\text { cite examples of the multiple use of Alberta's } \\
\text { forests; e.g., } \\
\text { - using different parts of the forest for different } \\
\text { - purposes } \\
\text { - moing the same area of the forest to obtain } \\
\text { more than one benefit. }\end{array}$ & $\begin{array}{l}\text { This module lends itself to } \\
\text { group study rather than } \\
\text { independent study. } \\
\text { Prior credit in at least } \\
\text { three other modules in } \\
\text { Forestry will establish } \\
\text { sufficient background } \\
\text { knowledge. }\end{array}$ \\
\hline $\begin{array}{l}\text { Multiple and } \\
\text { Integrated Land } \\
\text { Use }\end{array}$ & $\begin{array}{l}\text { - demonstrate how integrated land use involves } \\
\text { using a common area of forested land for two or } \\
\text { more purposes; e.g., } \\
\text { - wood fibre } \\
\text { - range } \\
\text { - wildlife } \\
\text { - recreation } \\
\text { - mining } \\
\text { cite examples of the integrated use of local } \\
\text { forested lands } \\
\text { compare principles of integrated land use with } \\
\text { principles of multiple use management } \\
\text { explain the goals of Integrated Resource Planning } \\
\text { (IRP) in establishing policy and guidelines for } \\
\text { managing forested land. }\end{array}$ & $\begin{array}{l}\text { Contact a Land Use } \\
\text { Officer (Alberta Land } \\
\text { and Forest Services) for } \\
\text { research materials. } \\
\text { Role-playing. }\end{array}$ \\
\hline
\end{tabular}


MODULE FOR212: USERS IN THE FOREST (continued)

\begin{tabular}{|c|c|c|}
\hline Concept & Specific Learner Expectations & Notes \\
\hline $\begin{array}{c}\text { Integrated Resource } \\
\text { Management }\end{array}$ & $\begin{array}{l}\text { The student should: } \\
\text { - identify and describe the basic components of } \\
\text { Integrated Resource Planning (IRP); e.g., } \\
\text { - establishing a planning team } \\
\text { - setting goals and objectives } \\
\text { - soliciting public involvement } \\
\text { - obtaining approval for the plan } \\
\text { - prepare a flow chart that outlines relationships } \\
\text { among the components of Integrated Resource } \\
\text { Planning (IRP) } \\
\text { research two or more forest management plans } \\
\text { having different goals, and identify components } \\
\text { of Integrated Resource Planning (IRP)that are } \\
\text { present in each; e.g., } \\
\text { - forest protection } \\
\text { - access management } \\
\text { - harvest planning } \\
\text { - range management } \\
\text { - wildlife management } \\
\text { develop a plan for the integrated use of a local } \\
\text { forested area; e.g., } \\
\text { - conduct research } \\
\text { - generate alternatives } \\
\text { - agree to a workable solution. }\end{array}$ & $\begin{array}{l}\text { See Alberta's Focus on } \\
\text { Forests: } \\
\text { - Activity 5.1-Forest } \\
\text { Perspectives } \\
\text { - Activity 5.2-Decisions } \\
\text { for Change } \\
\text { - Activity 5.5-Integrated } \\
\text { Resource Management }\end{array}$ \\
\hline
\end{tabular}




\section{MODULE CURRICULUM AND ASSESSMENT STANDARDS: SECTION F：ADVANCED LEVEL}

The following pages define the curriculum and assessment standards for the advanced level of Forestry.

Advanced level modules demand a higher level of expertise and help prepare students for entry into the workplace or a related post-secondary program.

Module FOR301: Issues in Forestry

F.3

Module FOR306: Measuring the Forest III.

F.7

Module FOR307: The Forest Marketplace

F.11

Module FOR308: Forest Technology Applications.....

F.15

Module FOR309: Advanced Forest Ecology

F.19

Module FOR311: Silviculture: Growing the Forest

F.25

Module FOR312: Stewardship: Balancing Needs

F.29 


\section{MODULE FOR301: ISSUES IN FORESTRY}

Level:

Theme:

Prerequisite:

Module Parameters:
Advanced

Social and Cultural Perspectives

None

Access to resources available from government, industry and community organizations (e.g., special-interest groups) regarding local and/or global issues in forestry

Students analyze local and global issues in forest management, and demonstrate individual and shared actions that foster environmental stewardship.

\section{Curriculum and Assessment Standards}

\begin{tabular}{|c|c|c|}
\hline $\begin{array}{c}\text { Module Learner } \\
\text { Expectations }\end{array}$ & Assessment Criteria and Conditions (Draft) & $\begin{array}{l}\text { Suggested } \\
\text { Emphasis }\end{array}$ \\
\hline $\begin{array}{l}\text { The student will: } \\
\text { - identify social, } \\
\text { economic and } \\
\text { environmental } \\
\text { perspectives associated } \\
\text { with current issues in } \\
\text { forest management }\end{array}$ & $\begin{array}{l}\text { Assessment of student achievement will be based on: } \\
\text { - for each of five current issues in forest management, } \\
\text { identifying and explaining three or more: } \\
\text { - immediate and/or long-term consequences } \\
\text { - possible alternatives for dealing with the issue. } \\
\text { Consequences and alternatives to address social, } \\
\text { economic and environmental perspectives } \\
\text { Assessment Tool } \\
\text { Issues in Forestry: Analyzing Issues, FOR3OI-1 } \\
\text { Assessment Framework: Issue Analysis, CTSISS } \\
\text { Standard } \\
\text { Analyze } 5 \text { issues to a standard of } 3 \text { on the rating } \\
\text { scale } \\
\text { a critique of one newspaper/magazine article or video } \\
\text { documentary regarding an issue in forest } \\
\text { management. Critique to address: } \\
\text { - range of viewpoints/biases evident } \\
\text { - validity/reliability of information presented } \\
\text { - recommended course of action } \\
\text { Assessment Tool } \\
\text { Issues in Forestry: Analyzing Issues, FOR3OI-I } \\
\text { Guide to Critiquing Media Information, FORMED } \\
\text { Standard } \\
\text { Critique one piece of media information to a } \\
\text { standard of } 3 \text { on the rating scale }\end{array}$ & 30 \\
\hline
\end{tabular}


MODULE FOR301: ISSUES IN FORESTRY (continued)

\begin{tabular}{|c|c|c|}
\hline $\begin{array}{c}\text { Module Learner } \\
\text { Expectations }\end{array}$ & Assessment Criteria and Conditions (Draft) & $\begin{array}{l}\text { Suggested } \\
\text { Emphasis } \\
\end{array}$ \\
\hline $\begin{array}{l}\text { The student will: } \\
\text { - explain how issues and } \\
\text { trends involving } \\
\text { Canada's forests may be } \\
\text { similar to those in other. } \\
\text { parts of the world }\end{array}$ & 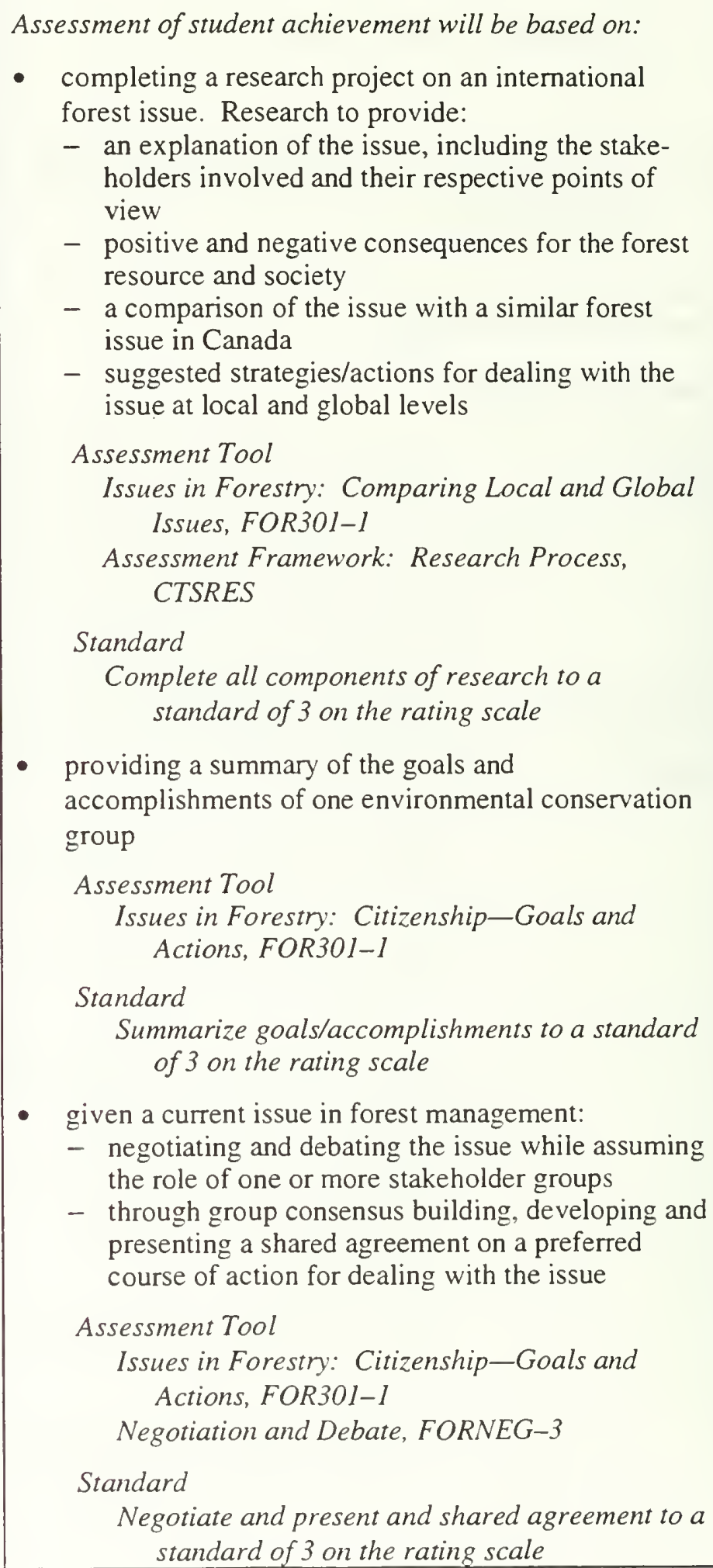 & 40 \\
\hline
\end{tabular}


MODULE FOR301: ISSUES IN FORESTRY (continued)

\begin{tabular}{|l|c|c|}
\hline \multicolumn{1}{|c|}{$\begin{array}{c}\text { Module Learner } \\
\text { Expectations }\end{array}$} & Assessment Criteria and Conditions (Draft) & $\begin{array}{c}\text { Suggested } \\
\text { Emphasis }\end{array}$ \\
\hline $\begin{array}{l}\text { The student will: } \\
\text { demonstrate basic } \\
\text { competencies. }\end{array}$ & $\begin{array}{c}\text { Assessment of student achievement will be based on: } \\
\text { observations of individual effort and interpersonal } \\
\text { interaction during the learning process }\end{array}$ & $\begin{array}{c}\text { Integrated } \\
\text { throughout }\end{array}$ \\
& $\begin{array}{c}\text { Assessment Tools } \\
\text { Basic Competencies Reference Guide and any } \\
\text { assessment tools noted above }\end{array}$ & \\
\hline
\end{tabular}

\begin{tabular}{|c|c|c|}
\hline Concept & Specific Learner Expectations & Notes \\
\hline $\begin{array}{l}\text { Issues Involve } \\
\text { Alternatives }\end{array}$ & $\begin{array}{l}\text { The student should: } \\
\text { - describe past and present trends in the } \\
\text { consumptive and non-consumptive use of forests } \\
\text { analyze differing points of view regarding how } \\
\text { and to what degree Canada's forests should be } \\
\text { used } \\
\text { identify positive and negative effects of forest } \\
\text { industry development on people, industry and the } \\
\text { environment } \\
\text { assess the pros and cons of different forest } \\
\text { harvesting practices; e.g., } \\
\text { - clearcutting } \\
\text { - selective harvesting } \\
\text { research issues related to the expansion and } \\
\text { management of Alberta's forest industry; e.g., } \\
\text { - access management } \\
\text { - herbicide use in timber management } \\
\text { - old growth management } \\
\text { - maintenance of biodiversity } \\
\text { describe ways in which different forest } \\
\text { stakeholders make use of the judicial, legislative } \\
\text { and regulatory systems in working toward their } \\
\text { objectives. }\end{array}$ & $\begin{array}{l}\text { Discuss issues from a } \\
\text { variety of perspectives } \\
\text { (e.g., social, economic, } \\
\text { environmental). } \\
\text { Discuss different } \\
\text { perspectives regarding } \\
\text { how and to what degree } \\
\text { Canada's forests should } \\
\text { be used. } \\
\text { Analyze the pros and cons } \\
\text { regarding three different } \\
\text { forest harvest practices. } \\
\\
\text { Identify issues related to } \\
\text { the expansion of forest } \\
\text { management in Alberta. }\end{array}$ \\
\hline
\end{tabular}


MODULE FOR301: ISSUES IN FORESTRY (continued)

\begin{tabular}{|c|c|c|}
\hline Concept & Specific Learner Expectations & Notes \\
\hline $\begin{array}{l}\text { Global Issues and } \\
\text { Trends }\end{array}$ & $\begin{array}{l}\text { The student should: } \\
\text { - compare issues involving Canada's forests with } \\
\text { similar issues in other parts of the world; e.g., } \\
\text { - land use } \\
\text { - expansion of the forest industry } \\
\text { - forest renewal processes } \\
\text { - management of old growth forests } \\
\text { - climate change and forest ecosystems } \\
\text { - extensive versus intensive management } \\
\text { assess global impacts of the recreational and } \\
\text { commercial use of forests; e.g., } \\
\text { - social and cultural } \\
\text { - economic } \\
\text { - environmental } \\
\text { infer the long-range effects of the sustainable use } \\
\text { of forests in Canada and other parts of the world. }\end{array}$ & $\begin{array}{l}\text { Research a forest issue in } \\
\text { another country. } \\
\text { Compare to the } \\
\text { Canadian situation. }\end{array}$ \\
\hline $\begin{array}{l}\text { Individual and } \\
\text { Shared Actions }\end{array}$ & $\begin{array}{l}\text { compare and contrast different philosophies, } \\
\text { ethics and alternatives regarding the forest } \\
\text { resource and how best to ensure its health and } \\
\text { sustainability } \\
\text { assess the goals and objectives of one or more } \\
\text { forest conservation or preservation groups } \\
\text { debate a global issue regarding the consumptive } \\
\text { and/or non-consumptive use of forests; e.g., } \\
\text { - conduct research } \\
\text { - develop a position } \\
\text { - participate in debate } \\
\text { develop a plan for the use of a forested region; } \\
\text { e.g., } \\
\text { - conduct research } \\
\text { - generate alternatives } \\
\text { - agree to a plan that meets an acceptable level } \\
\text { of needs } \\
\text { initiate responsible and ethical actions in relation } \\
\text { to the forest and its many resources; e.g., } \\
\text { - individual actions } \\
\text { - shared actions } \\
\text { - leadership roles. }\end{array}$ & $\begin{array}{l}\text { See Alberta's Focus on } \\
\text { Forests: } \\
\text { - Activity 3.6-An Urban } \\
\text { Wilderness at School } \\
\text { - Activity 5.1-Forest } \\
\text { Values } \\
\text { - Activity 5.3-Forest } \\
\text { Perspectives. }\end{array}$ \\
\hline
\end{tabular}




\section{MODULE FOR306: MEASURING THE FOREST III}

Level:

Theme:

Prerequisite:

Module Parameters:

\section{Advanced}

Technology and Applications

Measuring the Forest II (FOR206)

Access to forest inventory technology and forest survey data used by public and private organizations in the forestry sector (e.g., Alberta Environmental Protection, Canadian Forestry Service, Canadian Centre for Remote Sensing); access to forestry maps available from private vendors; background knowledge and/or resources in population sampling and design will be an asset

Students explain management applications of data collected from a forest survey, and examine the role of technology in current forest inventory practices.

\section{Curriculum and Assessment Standards}

\begin{tabular}{|c|c|c|}
\hline $\begin{array}{c}\text { Module Learner } \\
\text { Expectations }\end{array}$ & Assessment Criteria and Conditions (Draft) & $\begin{array}{l}\text { Suggested } \\
\text { Emphasis } \\
\end{array}$ \\
\hline $\begin{array}{l}\text { The student will: } \\
\text { - explain the applications } \\
\text { of forest survey data in } \\
\text { resource management }\end{array}$ & $\begin{array}{l}\text { Assessment of student achievement will be based on: } \\
\text { identifying and explaining applications of timber } \\
\text { cruise data and non-fibre data in resource } \\
\text { management } \\
\text { Assessment Tool } \\
\text { Knowledge/Application Assessment: Forest } \\
\quad \text { Survey Data, FOR } 306-1 \\
\text { Standard } \\
\text { Respond to a standard of } 3 \text { on the rating scale } \\
\text { demonstrating applications of a sample set of forest } \\
\text { survey data by: } \\
\text { - identifying bias, error and other limitations in the } \\
\text { sample data } \\
\text { - extrapolating the data to estimate forest } \\
\text { populations } \\
\text { - using the survey data to establish effective forest } \\
\text { management practices } \\
\text { - modifying the sample design to increase accuracy } \\
\text { of the survey } \\
\text { Assessment Tool } \\
\text { KnowledgelApplication Assessment: Forest } \\
\text { Survey Data, FOR306-1 } \\
\text { Standard } \\
\text { Respond to a standard of } 3 \text { on the rating scale }\end{array}$ & 60 \\
\hline
\end{tabular}


MODULE FOR306: MEASURING THE FOREST III (continued)

\begin{tabular}{|c|c|c|}
\hline $\begin{array}{c}\text { Module Learner } \\
\text { Expectations }\end{array}$ & Assessment Criteria and Conditions (Draft) & $\begin{array}{l}\text { Suggested } \\
\text { Emphasis }\end{array}$ \\
\hline $\begin{array}{l}\text { The student will: } \\
\text { research the role of } \\
\text { technology in current } \\
\text { forest inventory } \\
\text { practices } \\
\text {. }\end{array}$ & $\begin{array}{l}\text { Assessment of student achievement will be based on: } \\
\text { - completing a research project on applications of } \\
\text { technology in data collection, manipulation and/or } \\
\text { storage. Research to address: } \\
\text { - aerial photography } \\
\text { - satellite imagery } \\
\text { - computer-based mapping systems } \\
\text { - applications of ground truthing in verifying data } \\
\text { gathered through remote sensing } \\
\text { Assessment Tool } \\
\text { Research Process: Role of Technology in Forest } \\
\quad \text { Inventory, FOR306-2 } \\
\text { Standard } \\
\text { Complete all components of research to a } \\
\quad \text { standard of } 3 \text { on the rating scale } \\
\text { given information regarding a current forest } \\
\text { inventory research project (e.g., an Alberta Research } \\
\text { Council project, an initiative of the Canadian } \\
\text { Forestry Service), a presentation or report that } \\
\text { summarizes: } \\
\text { - the research problem/question } \\
\text { - research design and expected results } \\
\text { - accomplishments and challenges encountered to } \\
\text { date } \\
\text { - immediate and long-range implications of the } \\
\text { research project } \\
\text { professional worker), completing a research project } \\
\text { on one or more careers in forest management } \\
\text { Assessment Tool } \\
\text { Presentations/Reports, FORPRE-3 } \\
\text { Standard }\end{array}$ & 10 \\
\hline
\end{tabular}


MODULE FOR306: MEASURING THE FOREST III (continued)

\begin{tabular}{|l|c|c|}
\hline \multicolumn{1}{|c|}{$\begin{array}{c}\text { Module Learner } \\
\text { Expectations }\end{array}$} & Assessment Criteria and Conditions (Draft) & $\begin{array}{c}\text { Suggested } \\
\text { Emphasis }\end{array}$ \\
\hline $\begin{array}{l}\text { The student will: } \\
\text { - demonstrate basic } \\
\text { competencies. }\end{array}$ & $\begin{array}{c}\text { Assessment of student achievement will be based on: } \\
\text { observations of individual effort and interpersonal } \\
\text { interaction during the learning process } \\
\text { Assessment Tools } \\
\text { Basic Competencies Reference Guide and any } \\
\text { assessment tools noted above }\end{array}$ & $\begin{array}{c}\text { Integrated } \\
\text { throughout }\end{array}$ \\
& $\begin{array}{l}\text { as } \\
\end{array}$ & \\
\hline
\end{tabular}

\begin{tabular}{|c|c|c|}
\hline Concept & Specific Learner Expectations & Notes \\
\hline Data Interpretation & $\begin{array}{l}\text { The student should: } \\
\text { - explain applications of timber cruise data in } \\
\text { resource management; e.g., } \\
\text { - estimating total fibre volume } \\
\text { - projecting future forest growth } \\
\text { - planning harvest operations } \\
\text { - xplain applications of non-fibre data in resource } \\
\text { management; e.g., } \\
\text { - monitoring water and soil quality } \\
\text { - determining potential for agriculture/ } \\
\text { recreation } \\
\text { - monitoring wildlife population densities and } \\
\text { trends } \\
\text { - planning conservation practices } \\
\text { interpret a set of sample forest survey data; e.g., } \\
\text { - consider bias, error and other limitations in the } \\
\text { sample data } \\
\text { - extrapolate the data to estimate forest } \\
\text { populations } \\
\text { - suggest applications of data in resource } \\
\text { management } \\
\text { - consider modification to sample design that } \\
\text { may increase accuracy of the survey. }\end{array}$ & $\begin{array}{l}\text { Contact resource persons } \\
\text { from: } \\
\text { - Canadian Forestry } \\
\text { Service } \\
\text { - Alberta Land and } \\
\text { Forest Services. } \\
\text { Perform mathematical } \\
\text { calculations to } \\
\text { determine timber } \\
\text { volumes. } \\
\text { Obtain sample data from } \\
\text { local governmenU } \\
\text { industry. } \\
\text { Use paper and pencil OR } \\
\text { computer programs to } \\
\text { interpret data. } \\
\\
\text { Background information } \\
\text { in forest measurement } \\
\text { applications is provided } \\
\text { in: } \\
\text { - Natural Resources } \\
\text { Measurements by } \\
\text { Thomas Avery } \\
\text { (McGraw Hill Book } \\
\text { Co., 1975) } \\
\text { - Forest Mensuration (3 } 3^{\text {rd }} \\
\text { Edition) by Bertram } \\
\text { Husch, Charles Miller } \\
\text { and Thomas Beers } \\
\text { (John Wiley and Sons } \\
\text { Inc., 1982). }\end{array}$ \\
\hline
\end{tabular}


MODULE FOR306: MEASURING THE FOREST III (continued)

\begin{tabular}{|c|c|c|}
\hline Concept & Specific Learner Expectations & Notes \\
\hline Role of Technology & $\begin{array}{l}\text { The student should: } \\
\text { - research applications of technology in gathering } \\
\text { and storing data about the forest resource; e.g., } \\
\text { - aerial photography } \\
\text { - satellite imagery } \\
\text { - computer-based mapping systems } \\
\text { - explain the importance of ground truthing in } \\
\text { verifying data gathered through remote sensing } \\
\text { make predictions regarding forest inventory } \\
\text { technologies and practices in the future } \\
\text { outline the objectives of a current forest inventory } \\
\text { research project; e.g., } \\
\text { - an initiative of the Canadian Forestry Service } \\
\text { - an Alberta Research Council project. }\end{array}$ & $\begin{array}{l}\text { Expose students to various } \\
\text { technologies through } \\
\text { field studies. } \\
\text { Contact the following } \\
\text { agencies for } \\
\text { information on current } \\
\text { data-gathering } \\
\text { technologies: } \\
\text { - Canadian Centre for } \\
\text { Remote Sensing } \\
\text { (Ottawa, Ontario) } \\
\text { - RADARSAT } \\
\text { International } \\
\text { (Richmond, B.C.). } \\
\\
\text { Consider future uses of } \\
\text { computers and } \\
\text { advances in GIS. } \\
\\
\text { Investigate potential } \\
\text { applications of Global } \\
\text { Positioning Systems } \\
\text { (GPS). }\end{array}$ \\
\hline Career Paths & $\begin{array}{l}\text { outline career paths and the range of occupational } \\
\text { opportunities in forest measurement } \\
\text { present the results of research on one or more } \\
\text { career paths in forest measurement; e.g., } \\
\text { - nature of the work } \\
\text { - number of workers/employment trends } \\
\text { - entry requirements/competencies } \\
\text { - education/training opportunities } \\
\text { - opportunity for advancement. }\end{array}$ & $\begin{array}{l}\text { Review National } \\
\text { Occupational Profiles } \\
\text { (NOC). } \\
\text { Interview persons } \\
\text { involved in conducting } \\
\text { forest inventories. } \\
\text { Work experience. } \\
\text { Job shadowing. }\end{array}$ \\
\hline
\end{tabular}


MODULE FOR307: THE FOREST MARKETPLACE

Level:

Theme:

\section{Prerequisite/}

Corequisite:

Module Parameters: Access to resources available from the forest products industry and forest service industry

Students describe the range of consumer products and services derived from Canada's forests, and research the production and marketing of forest products.

Curriculum and Assessment Standards

\begin{tabular}{|c|c|c|}
\hline $\begin{array}{c}\text { Module Learner } \\
\text { Expectations }\end{array}$ & Assessment Criteria and Conditions (Draft) & $\begin{array}{l}\text { Suggested } \\
\text { Emphasis }\end{array}$ \\
\hline $\begin{array}{l}\text { The student wiil: } \\
\text { - describe fibre and non- } \\
\text { fibre products and } \\
\text { services derived from } \\
\text { Canada's forests }\end{array}$ & $\begin{array}{l}\text { Assessment of student achievement will be based on: } \\
\text { - given a range of relevant in-school/community } \\
\text { resources, identifying and describing: } \\
\text { - fibre and non-fibre products and services derived } \\
\text { from Alberta's forests } \\
\text { - forecasts regarding the future use of forests in } \\
\text { Alberta and Canada } \\
\text { Assessment Tool } \\
\text { Knowledge/Application Assessment: Forest } \\
\text { Products and Services, FOR307-1 } \\
\text { Standard } \\
\text { Respond to a standard of } 3 \text { on the rating scale } \\
\text { preparing flowcharts that depict the sequence of steps } \\
\text { involved in developing three forest products and/or } \\
\text { services } \\
\text { Assessment Tool } \\
\text { Assessment Criteria: Flow Charts, FORFLO } \\
\text { Standard } \\
\text { Complete flow charts to a standard of } 3 \text { on the } \\
\text { rating scale } \\
\text { completing a research project on recent applications } \\
\text { of milling and/or pulping technology in the } \\
\text { development of one or more forest products/services } \\
\text { Assessment Tool } \\
\text { Research Process: Milling and/or Pulping } \\
\text { Technology, FOR307-2 } \\
\text { Standard } \\
\text { standard of } 3 \text { on the rating scale }\end{array}$ & 30 \\
\hline
\end{tabular}


MODULE FOR307: THE FOREST MARKETPLACE (continued)

\begin{tabular}{|c|c|c|}
\hline $\begin{array}{c}\text { Module Leamer } \\
\text { Expectations }\end{array}$ & Assessment Criteria and Conditions (Draft) & $\begin{array}{l}\text { Suggested } \\
\text { Emphasis }\end{array}$ \\
\hline $\begin{array}{l}\text { The student will: } \\
\text { research marketing } \\
\text { systems and trends, and } \\
\text { develop a marketing } \\
\text { plan for a forest product } \\
\text { or service }\end{array}$ & $\begin{array}{l}\text { Assessment of student achievement will be based on: } \\
\text { - developing and presenting a multi-media marketing } \\
\text { plan for a new forest product or service. Plan to } \\
\text { involve consideration of: } \\
\text { - factors that influence market trends } \\
\text { - product diversification and/or specialization } \\
\text { - potential markets in North America, the Pacific } \\
\text { Rim, Europe and two other selected regions } \\
\text { - materials and processes involved in product/ } \\
\text { service development } \\
\text { - effective marketing strategies and systems } \\
\text { Assessment Tool } \\
\text { Assessment Criteria: A Marketing Plan, } \\
\text { FOR307-3 } \\
\text { Standard } \\
\text { Develop and present the marketing plan to a } \\
\text { standard of } 3 \text { on the rating scale } \\
\text { observations of individual effort and interpersonal } \\
\text { interaction during the learning process } \\
\text { Assessment Tools } \\
\text { Basic Competencies Reference Guide and any } \\
\text { assessment tools noted above }\end{array}$ & $\begin{array}{l}\text { Integrated } \\
\text { throughout }\end{array}$ \\
\hline
\end{tabular}

\begin{tabular}{|c|c|c|}
\hline Concept & Specific Learner Expectations & Notes \\
\hline $\begin{array}{c}\text { Products and } \\
\text { Services }\end{array}$ & $\begin{array}{l}\text { The student should: } \\
\begin{array}{l}\text { - identify market-based products and services } \\
\text { derived from Alberta's forests; e.g., } \\
\text { - primary wood products } \\
\text { - wood-fabricated materials } \\
\text { - wood pulp and paper products } \\
\text { - chemical products } \\
\text { - trapping, fishing and hunting } \\
\text { - guiding and outfitting } \\
\text { - tourism and recreational pursuits }\end{array}\end{array}$ & $\begin{array}{l}\text { Contact the Alberta Forest } \\
\text { Products Association } \\
\text { for current resources } \\
\text { and information. } \\
\text { See Alberta's Focus on } \\
\text { Forests (Activity 4.2- } \\
\text { Products From } \\
\text { Canada's Forests). } \\
\text { Identify major industries } \\
\text { that require wood. } \\
\text { Identify common products } \\
\text { derived from a } \\
\text { particular tree species. }\end{array}$ \\
\hline
\end{tabular}


MODULE FOR307: THE FOREST MARKETPLACE (continued)

\begin{tabular}{|c|c|c|}
\hline Concept & Specific Learner Expectations & Notes \\
\hline $\begin{array}{l}\text { Products and } \\
\text { Services } \\
\text { (continued) }\end{array}$ & $\begin{array}{l}\text { The student should: } \\
\text { - identify psychological benefits and extra-market } \\
\text { values derived from Alberta's forests; e.g., } \\
\text { - ecological values } \\
\text { - aesthetic and spiritual values } \\
\text { - bequest value for future generations } \\
\text { analyze trends in the consumptive and non- } \\
\text { consumptive use of forests in Canada and } \\
\text { Alberta; e.g., } \\
\text { - recreation } \\
\text { - trapping } \\
\text { - logging } \\
\text { - oil and gas development. }\end{array}$ & $\begin{array}{l}\text { Identify a range of forest } \\
\text { products and services } \\
\text { that could be derived } \\
\text { from a selected site. } \\
\text { Supplementary reference } \\
\text { materials include: } \\
\text { A Forest Journey - The } \\
\text { Role of Wood in the } \\
\text { Development of } \\
\text { Civilization (Harvard } \\
\text { University Press) } \\
\text { - Canadian Forestry- } \\
\text { The View Beyond the } \\
\text { Trees (Macmillan of } \\
\text { Canada). }\end{array}$ \\
\hline Processing & $\begin{array}{l}\text { - classify and sequence the steps that are involved } \\
\text { in producing a fibre commodity; e.g., } \\
\text { - harvest and transportation } \\
\text { - processing techniques } \\
\text { - grading, packing and storage } \\
\text { identify materials and services that are required at } \\
\text { each stage in the production of a fibre } \\
\text { commodity; e.g., } \\
\text { - human and natural resources } \\
\text { - energy and technologies } \\
\text { - inspection and regulation } \\
\text { describe recent developments in milling and } \\
\text { pulping technology and their impact on the forest } \\
\text { industry; e.g., } \\
\text { - fibre utilization } \\
\text { - environmental stewardship } \\
\text { identify new and emerging products and services } \\
\text { derived from Alberta's forests; e.g., } \\
\text { - cattle food } \\
\text { - methane gas }\end{array}$ & $\begin{array}{l}\text { See Alberta's Focus on } \\
\text { Forests: } \\
\text { - Activity 4.4-From Pulp } \\
\text { to Paper and Back } \\
\text { Again - } \\
\text { - Activity 4.5-Pulp and } \\
\text { Paper: The } \\
\text { Technology- } \\
\text { Environment } \\
\text { Connection. } \\
\text { Draw posters that depict } \\
\text { what happens to a tree } \\
\text { from stump to } \\
\text { consumer. }\end{array}$ \\
\hline $\begin{array}{l}\text { Marketing Systems } \\
\text { and Trends }\end{array}$ & $\begin{array}{l}\text { determine the nature and extent of Canada's } \\
\text { market share in North America, the Pacific Rim, } \\
\text { Europe and other locations } \\
\text { describe systems used to market Canada's forest } \\
\text { products and services at local, national and } \\
\text { international levels }\end{array}$ & $\begin{array}{l}\text { Marketing modules in the } \\
\text { Agriculture strand and } \\
\text { Management and } \\
\text { Marketing strand offer } \\
\text { additional instructional } \\
\text { strategies. }\end{array}$ \\
\hline
\end{tabular}


MODULE FOR307: THE FOREST MARKETPLACE (continued)

\begin{tabular}{|c|c|c|}
\hline Concept & Specific Leamer Expectations & Notes \\
\hline $\begin{array}{l}\text { Marketing Systems } \\
\text { and Trends } \\
\text { (continued) }\end{array}$ & $\begin{array}{l}\text { The student should: } \\
\text { - identify social, economic and environmental } \\
\text { factors that influence consumer trends and market } \\
\text { demands for forest products and services } \\
\text { - assess the impact of developing technologies on } \\
\text { Canada's fibre and non-fibre forest products; e.g., } \\
\text { - efficiency of production processes } \\
\text { - improved utilization } \\
\text { - focus on value-added and knowledge intensive } \\
\text { commodities } \\
\text { - identify market opportunities that arise from } \\
\text { product diversification and specialization, } \\
\text { international trade and participation in a global } \\
\text { economy } \\
\text { formulate a plan for identifying new market } \\
\text { opportunities, developing a forest product, and } \\
\text { managing the venture. }\end{array}$ & $\begin{array}{l}\text { Obtain Dr. Suess: The } \\
\text { Lorax (a video that } \\
\text { addresses } \\
\text { environmental issues in } \\
\text { marketing) from the } \\
\text { National Film Board or } \\
\text { your local } \\
\text { Urban/Regional } \\
\text { Resource Centre. } \\
\\
\text { Visit a sawmill and wood- } \\
\text { product distributor to } \\
\text { discover traditional and } \\
\text { new uses of wood. } \\
\text { Prepare plans for } \\
\text { Christmas tree } \\
\text { production and } \\
\text { marketing. }\end{array}$ \\
\hline
\end{tabular}


MODULE FOR308: FOREST TECHNOLOGY APPLICATIONS

Level:

Advanced

Theme:

Technology and Applications

Prerequisite:

None

Module Parameters: Access to resources available from the forest products industry and relevant government organizations (e.g., Alberta Environmental Protection, Canadian Forestry Service, Alberta Research Council)

Students examine applications of research and technology in the forest industry, and changing career opportunities in the forestry sector.

Curriculum and Assessment Standards

\begin{tabular}{|c|c|c|}
\hline $\begin{array}{c}\text { Module Learner } \\
\text { Expectations }\end{array}$ & Assessment Criteria and Conditions (Draft) & $\begin{array}{l}\text { Suggested } \\
\text { Emphasis }\end{array}$ \\
\hline $\begin{array}{l}\text { The student will: } \\
\text { describe different areas } \\
\text { of forest research being } \\
\text { conducted in Canada and } \\
\text { Alberta }\end{array}$ & $\begin{array}{l}\text { Assessment of student achievement will be based on: } \\
\text { - identifying major areas of forest research being } \\
\text { conducted in Canada and, where possible, Alberta } \\
\text { Assessment Tool } \\
\text { Forest Technology Applications: Industry } \\
\text { Research, FOR308-1 } \\
\text { Standard } \\
\text { Identify six major areas of forest research to a } \\
\text { standard of } 3 \text { on the rating scale } \\
\text { given information regarding a current forest research } \\
\text { project in Canada (e.g., enhanced utilization, forest } \\
\text { management), summarizing: } \\
\text { - research objectives and participating agencies } \\
\text { - information-gathering strategies } \\
\text { - project status and implications for forest industry } \\
\text { Assessment Tool } \\
\text { Forest Technology Applications: Industry } \\
\text { Research, FOR308-1 } \\
\text { Presentations/Reports, FORPRE-3 } \\
\text { Standard } \\
\text { Summarize one current forest research project to a } \\
\text { standard of } 3 \text { on the rating scale }\end{array}$ & 30 \\
\hline
\end{tabular}


MODULE FOR308: FOREST TECHNOLOGY APPLICATIONS (continued)

\begin{tabular}{|c|c|c|}
\hline $\begin{array}{c}\text { Module Leamer } \\
\text { Expectations }\end{array}$ & Assessment Criteria and Conditions (Draft) & $\begin{array}{l}\text { Suggested } \\
\text { Emphasis }\end{array}$ \\
\hline $\begin{array}{l}\text { The student will: } \\
\text { - give examples of current } \\
\text { and emerging } \\
\text { technologies used in the } \\
\text { forest industry }\end{array}$ & $\begin{array}{l}\text { Assessment of student achievement will be based on: } \\
\text { - completing a research project on applications of three } \\
\text { technologies in different sectors of the forest industry } \\
\text { (e.g., greenhouse/nursery operations, silviculture, } \\
\text { forest harvest, wood production/utilization, forest } \\
\text { inventory/protection). For each technology, research } \\
\text { to address: } \\
\text { - specific problems/needs being addressed } \\
\text { - basic components and principles of operation } \\
\text { - advantages/disadvantages with respect to social, } \\
\text { economic and environmental factors } \\
\text { Assessment Tool } \\
\text { Forest Technology Applications: Technology } \\
\text { Application, FOR308-1 } \\
\text { Sample Research Topics: Technology Application, } \\
\text { FOR308-2 } \\
\text { Research Process, CTSRES } \\
\text { Standard } \\
\text { Complete research on three technologies to a } \\
\text { standard of } 3 \text { on the rating scale }\end{array}$ & 50 \\
\hline $\begin{array}{l}\text { research career } \\
\text { opportunities and trends } \\
\text { within the forestry sector }\end{array}$ & $\begin{array}{l}\text { - given current information on career opportunities and } \\
\text { trends in the forestry sector, completing a research } \\
\text { project on one or more related career clusters } \\
\text { Assessment Tool } \\
\text { Forest Technology Applications: Technology } \\
\text { Careers, FOR30-1 } \\
\text { Career Search: Advanced Level, FORCAR-3 } \\
\text { Standard } \\
\text { Complete research to a standard of } 3 \text { on the rating } \\
\text { scale }\end{array}$ & 20 \\
\hline $\begin{array}{l}\text { - demonstrate basic } \\
\text { competencies. }\end{array}$ & $\begin{array}{l}\text { observations of individual effort and interpersonal } \\
\text { interaction during the learning process } \\
\text { Assessment Tools } \\
\text { Basic Competencies Reference Guide and any } \\
\text { assessment tools noted above }\end{array}$ & $\begin{array}{l}\text { Integrated } \\
\text { throughout }\end{array}$ \\
\hline
\end{tabular}


MODULE FOR308: FOREST TECHNOLOGY APPLICATIONS (continued)

\begin{tabular}{|c|c|c|}
\hline Concept & Specific Learner Expectations & Notes \\
\hline Research & $\begin{array}{l}\text { The student should: } \\
\text { - identify and describe different areas of forest } \\
\text { research being conducted in Canada and Alberta; } \\
\text { e.g., } \\
\text { - silviculture } \\
\text { - harvesting systems } \\
\text { - forest products } \\
\text { - forest protection } \\
\text { - wildlife inventories } \\
\text { - ecological studies } \\
\text { - integrated resource management } \\
\text { compare the goals and priorities of local agencies } \\
\text { whose mandate is to conduct research related to } \\
\text { Iorestry and forest ecosystems; e.g., } \\
\text { - individuals } \\
\text { - corporations } \\
\text { - colleges and universities } \\
\text { - government agencies } \\
\text { explain the role of the Alberta Forest Research } \\
\text { Advisory Council in coordinating forest research } \\
\text { activities in Alberta } \\
\text { describe applications of data banks and } \\
\text { information systems in making forest } \\
\text { management decisions } \\
\text { identify major components of a research plan for } \\
\text { the enhanced utilization and/or management of } \\
\text { forests; e.g., } \\
\text { - goals and objectives of the plan } \\
\text { - economic, political, scientific and related } \\
\text { factors } \\
\text { - methodologies and strategies } \\
\text { - outcomes and types/kinds of data obtained } \\
\text { may be lacking or incomplete. }\end{array}$ & $\begin{array}{l}\text { Contact Northern Forestry } \\
\text { Centre (Canadian } \\
\text { Forestry Services) for } \\
\text { current resource } \\
\text { materials and } \\
\text { information. }\end{array}$ \\
\hline Technologies & $\begin{array}{l}\text { describe past and present applications of } \\
\text { technology in the forest industry; e.g., } \\
\text { - greenhouse and nursery operations } \\
\text { - silviculture } \\
\text { - harvesting technologies } \\
\text { - wood production and utilization } \\
\text { - biotechnology }\end{array}$ & \\
\hline
\end{tabular}


MODULE FOR308: FOREST TECHNOLOGY APPLICATIONS (continued)

\begin{tabular}{|c|c|c|}
\hline Concept & Specific Learner Expectations & Notes \\
\hline $\begin{array}{l}\text { Technologies } \\
\text { (continued) }\end{array}$ & $\begin{array}{l}\text { The student should: } \\
\text { - describe emerging applications of technology in } \\
\text { the forest industry; e.g., } \\
\text { - pulping procedures } \\
\text { - effluent treatment and pollution control } \\
\text { - assess the advantages and disadvantages of a } \\
\text { recent technology designed to enhance our } \\
\text { utilization and/or management of forests; e.g., } \\
\text { - social } \\
\text { - economic } \\
\text { - environmental. }\end{array}$ & \\
\hline Career Trends & $\begin{array}{l}\text { predict ways in which research, technology, social } \\
\text { values and land use priorities may affect forest } \\
\text { industries in the future } \\
\text { predict future career clusters and occupational } \\
\text { opportunities within the forestry sector, and the } \\
\text { education/training that may be required to gain } \\
\text { employment and advance in related fields } \\
\text { research career clusters and the range of } \\
\text { occupational opportunities available within the } \\
\text { forestry sector; e.g., } \\
\text { - forest inventory } \\
\text { - forest biology/ecology } \\
\text { - forest protection } \\
\text { - forest harvest } \\
\text { - forest products industry } \\
\text { - forest management } \\
\text { research one or more career paths in forestry; e.g., } \\
\text { - job description/working conditions } \\
\text { - entry requirements/competencies } \\
\text { - educational/training opportunities } \\
\text { - opportunity for advancement } \\
\text { - opportunity for self-employment and } \\
\text { entrepreneurship. }\end{array}$ & $\begin{array}{l}\text { Review National } \\
\text { Occupational Profiles } \\
\text { (NOC). } \\
\\
\text { Contact the "Career } \\
\text { Hotline" (telephone 1- } \\
\text { 800-661-3753). } \\
\text { Interview persons } \\
\text { employed in the } \\
\text { forestry sector. }\end{array}$ \\
\hline
\end{tabular}




\section{MODULE FOR309: ADVANCED FOREST ECOLOGY}

Level:

Theme:

Prerequisite:
Advanced

Management and Conservation

Basic Forest Ecology (FOR109) and/or Biology 20; Soils Management I and Soils Management II (AGR212 and AGR312) recommended

\section{Module Parameters: Access to a forest environment}

Students investigate interrelationships among soil, water, air, trees and the environment, and explain how forests change.

Curriculum and Assessment Standards

\begin{tabular}{|c|c|c|}
\hline $\begin{array}{c}\text { Module Learner } \\
\text { Expectations }\end{array}$ & Assessment Criteria and Conditions (Draft) & $\begin{array}{l}\text { Suggested } \\
\text { Emphasis }\end{array}$ \\
\hline $\begin{array}{l}\text { The student will: } \\
\text { - analyze the effects of } \\
\text { soil, air and water } \\
\text { characteristics on forest } \\
\text { ecosystems }\end{array}$ & $\begin{array}{l}\text { Assessment of student achievement will be based on: } \\
\text { - identifying and describing: } \\
\text { - organic and inorganic components of forest soils } \\
\text { and their function in forest ecosystems } \\
\text { - major types of air pollutants and their affect on } \\
\text { forest ecosystems } \\
\text { Assessment Tool } \\
\text { Knowledge/Application Assessment: Soil, Air and } \\
\quad \text { Water Characteristics, FOR309-1 } \\
\text { Standard } \\
\text { Respond to a standard of } 3 \text { on the rating scale } \\
\text { conducting field investigations on the effects of soil } \\
\text { pH, temperature and water quantity on plant growth } \\
\text { Assessment Tool } \\
\text { Field Investigations: Soil, Air and Water } \\
\text { Characteristics, FOR309-2 } \\
\text { Standard } \\
\text { Conduct field investigation to a standard of } 3 \text { on } \\
\text { the rating scale } \\
\text { describing causal relationships and making inferences } \\
\text { regarding the effects of: } \\
\text { - local forests on soil, water, weather and biotic } \\
\text { factors } \\
\text { global forests on global climate } \\
\text { Assessment Tool } \\
\text { Guide to Inferences: Forest Ecosystems, } \\
\text { Fon } 309-3 \\
\text { Make ten inferences (as outlined in FOR309-3) to } \\
\text { a standard of } 3 \text { on the rating scale } \\
\text { - Ford }\end{array}$ & 40 \\
\hline
\end{tabular}


MODULE FOR309: ADVANCED FOREST ECOLOGY (continued)

\begin{tabular}{|c|c|c|}
\hline $\begin{array}{c}\text { Module Leamer } \\
\text { Expectations }\end{array}$ & Assessment Criteria and Conditions (Draft) & $\begin{array}{l}\text { Suggested } \\
\text { Emphasis }\end{array}$ \\
\hline $\begin{array}{l}\text { The student will: } \\
\text { research factors that } \\
\text { determine the ability of } \\
\text { tree species and forest } \\
\text { ecosystems to occur in } \\
\text { particular environments }\end{array}$ & 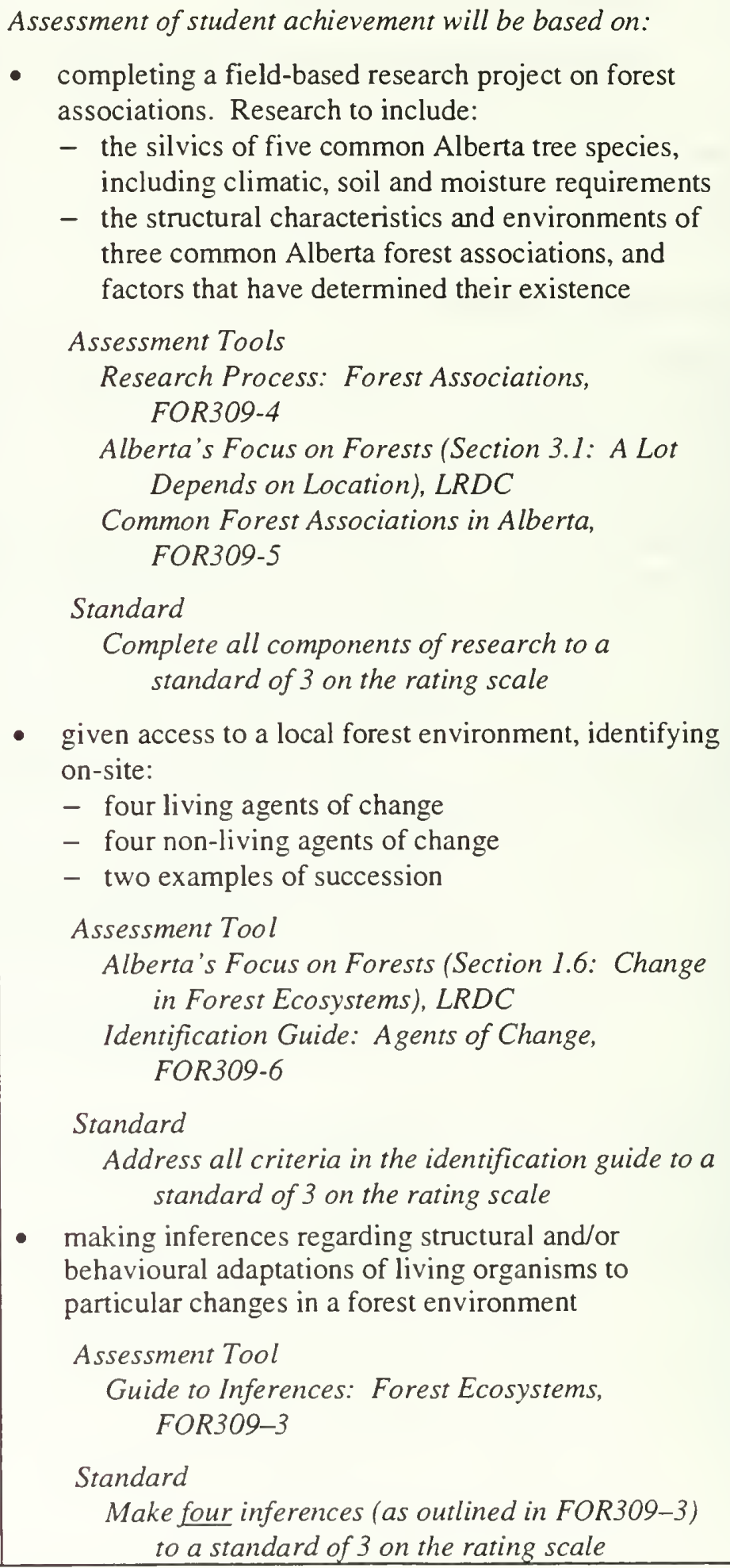 & 30 \\
\hline
\end{tabular}


MODULE FOR309: ADVANCED FOREST ECOLOGY (continued)

\begin{tabular}{|c|c|c|}
\hline $\begin{array}{l}\text { Module Learner } \\
\text { Expectations }\end{array}$ & Assessment Criteria and Conditions (Draft) & $\begin{array}{l}\text { Suggested } \\
\text { Emphasis }\end{array}$ \\
\hline $\begin{array}{l}\text { The student will: } \\
\text { - demonstrate basic } \\
\text { competencies. }\end{array}$ & $\begin{array}{l}\text { Assessment of student achievement will be based on: } \\
\text { observations of individual effort and interpersonal } \\
\text { interaction during the learning process } \\
\text { Assessment Tools } \\
\text { Basic Competencies Reference Guide and any } \\
\text { assessment tools noted above }\end{array}$ & $\begin{array}{l}\text { Integrated } \\
\text { throughout }\end{array}$ \\
\hline
\end{tabular}

\begin{tabular}{|c|c|c|}
\hline Concept & Specific Leamer Expectations & Notes \\
\hline Forest Ecosystems & $\begin{array}{l}\text { The student should: } \\
\text { - describe physical characteristics used to classify } \\
\text { forest soils, and the effect of different soils on } \\
\text { plant growth; e.g., } \\
\text { - texture } \\
\text { - porosity } \\
\text { - explain the function of organic and inorganic } \\
\text { components of forest soils; e.g., } \\
\text { - micro- and macro-organisms } \\
\text { - gases and minerals } \\
\text { - organic matter } \\
\text { - water } \\
\text { analyze the effects of soil acidity, alkalinity and } \\
\text { temperature on the growth of trees and other } \\
\text { forest plants } \\
\text { describe indicators of water quantity in the forest, } \\
\text { and its effects on trees and other plants; e.g., } \\
\text { - surface water } \\
\text { - ground water } \\
\text { describe the effects of known air pollutants on } \\
\text { forest ecosystems; e.g., } \\
\text { - ozone } \\
\text { - particulate matter } \\
\text { - oxides and nitrogen } \\
\text { - sulphur dioxide }\end{array}$ & $\begin{array}{l}\text { See Alberta's Focus on } \\
\text { Forests: } \\
\text { - Activity 1.4-How } \\
\text { Forests Affect the } \\
\text { Environment } \\
\text { - Activity 1.5-Biosphere. } \\
\text { Dig a soil pit. } \\
\text { Use a soil test kit. } \\
\\
\text { Design and perform } \\
\text { experiments that } \\
\text { monitor the effects of } \\
\text { soil composition, air } \\
\text { quality and water } \\
\text { quality on tree growth. }\end{array}$ \\
\hline
\end{tabular}


MODULE FOR309: ADVANCED FOREST ECOLOGY (continued)

\begin{tabular}{|c|c|c|}
\hline Concept & Specific Learner Expectations & Notes \\
\hline $\begin{array}{l}\text { Forest Ecosystems } \\
\quad(\text { continued })\end{array}$ & $\begin{array}{l}\text { The student should: } \\
\text { - analyze the effects of a forest on the local } \\
\text { environment; e.g., } \\
\text { - soil and water } \\
\text { - weather } \\
\text { - other wildlife } \\
\text { infer the effects of forests worldwide on global } \\
\text { climates. }\end{array}$ & $\begin{array}{l}\text { Measure/infer rates of } \\
\text { transpiration and infer } \\
\text { effects on weather and } \\
\text { wildlife. }\end{array}$ \\
\hline Forest Associations & $\begin{array}{l}\text { explain that each tree species has unique site and } \\
\text { climatic requirements that determine its ability to } \\
\text { grow in particular environments } \\
\text { research the general characteristics, life history, } \\
\text { site and climatic requirements of several Alberta } \\
\text { tree species; e.g., } \\
\text { - tree form } \\
\text { - growth patterns and life cycle } \\
\text { - soil } \\
\text { - moisture } \\
\text { - aspect and elevation } \\
\text { describe the general structural characteristics and } \\
\text { environments of some common forest } \\
\text { associations in Alberta; e.g., } \\
\text { - soil } \\
\text { - moisture } \\
\text { - position on slope. }\end{array}$ & $\begin{array}{l}\text { Field trip to classify } \\
\text { growth sites. } \\
\text { See Alberta's Focus on } \\
\text { Forests: } \\
\text { - Activity } 2.4- \\
\text { Differences in Design } \\
\text { - Activity 3.1-A Lot } \\
\text { Depends on Location. } \\
\\
\\
\text { Determine "most-likely } \\
\text { site" to find particular } \\
\text { tree species. }\end{array}$ \\
\hline Forest Change & $\begin{array}{l}\text { - identify living and non-living agents of change in } \\
\text { a local forest environment } \\
\text { infer structural and/or behavioural adaptations of } \\
\text { living organisms to particular changes in the } \\
\text { forest environment; e.g., } \\
\text { - adaptations to site conditions } \\
\text { - reproductive adaptations } \\
\text { consider the impacts of specific environmental } \\
\text { changes on a forest community; e.g., } \\
\text { - short-term consequences } \\
\text { - long-term consequences } \\
\text { give examples of primary and secondary } \\
\text { successional stages in a local forest environment }\end{array}$ & $\begin{array}{l}\text { See Alberta's Focus on } \\
\text { Forests: } \\
\text { - Activity 1.6-Change in } \\
\text { Forest Ecosystems } \\
\text { - Activity } 3.5- \\
\text { Controlling Fire } \\
\\
\text { Relate to forest } \\
\text { associations. } \\
\\
\text { Example: aspen/spruce } \\
\text { understory. }\end{array}$ \\
\hline
\end{tabular}


MODULE FOR309: ADVANCED FOREST ECOLOGY (continued)

\begin{tabular}{|c|l|c|}
\hline Concept & \multicolumn{1}{|c|}{ Specific Learner Expectations } & \multicolumn{1}{c|}{ Notes } \\
\hline $\begin{array}{c}\text { Forest Change } \\
\text { (continued) }\end{array}$ & $\begin{array}{l}\text { The student should: } \\
- \text { describe Alberta's natural forest history; e.g., } \\
- \text { role of other agents. }\end{array}$ & $\begin{array}{l}\text { Visit a mature forest and } \\
\text { clear cut area. } \\
\text { Differentiate between } \\
\text { the two areas and make } \\
\text { predictions regarding } \\
\text { the areas in five years. }\end{array}$ \\
\hline
\end{tabular}


MODULE FOR311: SILVICULTURE: GROWING THE FOREST

Level:

Advanced

Theme:

Management and Conservation

Prerequisite:

Basic Forest Ecology (FOR109; Recommended)

Module Parameters: Demonstration forest

Students demonstrate knowledge of the techniques used in establishing, growing and harvesting tree crops.

Curriculum and Assessment Standards

\begin{tabular}{|c|c|c|}
\hline $\begin{array}{c}\text { Module Learner } \\
\text { Expectations }\end{array}$ & Assessment Criteria and Conditions (Draft) & $\begin{array}{l}\text { Suggested } \\
\text { Emphasis }\end{array}$ \\
\hline $\begin{array}{l}\text { The student will: } \\
\text { describe silviculture and } \\
\text { the silvics of Alberta } \\
\text { tree species }\end{array}$ & $\begin{array}{l}\text { Assessment of student achievement will be based on: } \\
\text { - identifying and describing: } \\
\text { - major components of silviculture, including stand } \\
\text { establishment, stand management and harvest } \\
\text { - the silvics of five Alberta tree species } \\
\text { Assessment Tool } \\
\text { Knowledge/Application Assessment: Silviculture, } \\
\text { FOR311-1 } \\
\text { Sample Format: Silvics of a Tree Species, } \\
\text { FOR311-2 } \\
\text { Standard } \\
\text { Respond to a standard of } 3 \text { on the rating scale } \\
\text { conducting laboratory and/or field-based } \\
\text { investigations that demonstrate regeneration by: } \\
\text { - natural methods, including natural seed supply and } \\
\text { vegetative reproduction } \\
\text { - artificial methods, including direct seeding, bare- } \\
\text { root and container seedlings } \\
\text { Assessment Tool } \\
\text { Lab Investigations: Natural and Artificial } \\
\text { Regeneration, FOR311-3 } \\
\text { Observation Checklist for Field-Based } \\
\text { Investigations, FOROBS } \\
\text { Standard } \\
\text { Conduct lab investigations to a standard of } 3 \text { on } \\
\text { the rating scale and/or complete all sections of } \\
\text { the observation checklist for field-based } \\
\text { investigations }\end{array}$ & 25 \\
\hline
\end{tabular}


MODULE FOR311: SILVICULTURE: GROWING THE FOREST (continued)

\begin{tabular}{|c|c|c|}
\hline $\begin{array}{c}\text { Module Leamer } \\
\text { Expectations }\end{array}$ & Assessment Criteria and Conditions (Draft) & $\begin{array}{l}\text { Suggested } \\
\text { Emphasis }\end{array}$ \\
\hline $\begin{array}{l}\text { research growth/harvest } \\
\text { relationships and } \\
\text { appropriate methods of } \\
\text { harvesting tree species }\end{array}$ & 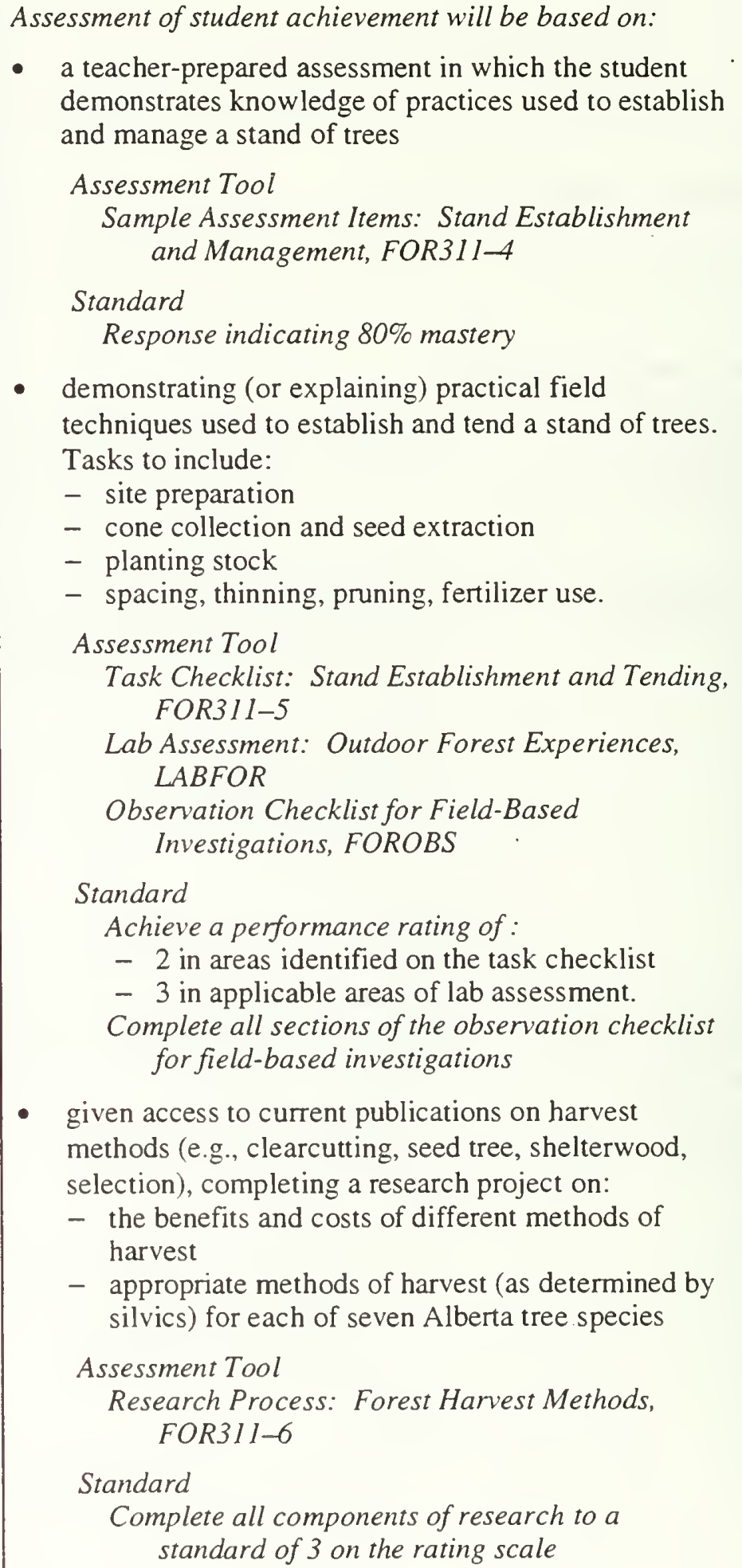 & 10 \\
\hline
\end{tabular}


MODULE FOR311: SILVICULTURE: GROWING THE FOREST (continued)

\begin{tabular}{|c|c|c|}
\hline $\begin{array}{l}\text { Module Learner } \\
\text { Expectations }\end{array}$ & Assessment Criteria and Conditions (Draft) & $\begin{array}{l}\text { Suggested } \\
\text { Emphasis }\end{array}$ \\
\hline $\begin{array}{l}\text { The student will: } \\
\text { - demonstrate basic } \\
\text { competencies. }\end{array}$ & $\begin{array}{l}\text { Assessment of student achievement will be based on: } \\
\text { observations of individual effort and interpersonal } \\
\text { interaction during the learning process } \\
\text { Assessment Tool } \\
\text { Basic Competencies Reference Guide and any } \\
\text { assessment tools noted above. }\end{array}$ & $\begin{array}{l}\text { Integrated } \\
\text { throughout }\end{array}$ \\
\hline
\end{tabular}

\begin{tabular}{|c|c|c|}
\hline Concept & Specific Learner Expectations & Notes \\
\hline $\begin{array}{l}\text { Regeneration and } \\
\text { Stand Treatment }\end{array}$ & $\begin{array}{l}\text { The student should: } \\
\text { - demonstrate methods of regeneration where } \\
\text { seedlings are established by natural methods; e.g., } \\
\text { - naturally supplied seeds } \\
\text { - vegetative reproduction } \\
\text { - demonstrate methods of regeneration where } \\
\text { seedlings are established by artificial methods; } \\
\text { e.g., } \\
\text { - planting bare-root and container seedlings } \\
\text { - broadcasting seeds } \\
\text { assess the pros and cons of natural and artificial } \\
\text { methods of regeneration } \\
\text { demonstrate techniques for site preparation and } \\
\text { the care and planting of seeds and seedlings } \\
\text { demonstrate intermediate stand tending } \\
\text { techniques; e.g., } \\
\text { - cleaning } \\
\text { - thinning } \\
\text { - pruning } \\
\text { - fertilizing } \\
\text { - protecting } \\
\text { identify safety practices and policies relevant to } \\
\text { site preparation, tree planting and stand tending } \\
\text { distinguish between intensive and extensive stand } \\
\text { management practices. }\end{array}$ & $\begin{array}{l}\text { Contact Alberta Land and } \\
\text { Forest Services prior to } \\
\text { module delivery for } \\
\text { information regarding } \\
\text { seedling availability, } \\
\text { sites for tour and } \\
\text { equipment availability. } \\
\text { See Alberta's Focus on } \\
\text { Forests (Activity 5.4- } \\
\text { Reforestation: Forests } \\
\text { or Tree Farms). } \\
\text { Practical experiences in } \\
\text { establishing a stand of } \\
\text { trees and manipulating } \\
\text { growing conditions to } \\
\text { favour particular } \\
\text { species. } \\
\text { Potential exists for } \\
\text { additional projects in } \\
\text { seed collection and tree } \\
\text { planting. May also be } \\
\text { used as a school } \\
\text { fundraiser. }\end{array}$ \\
\hline
\end{tabular}


MODULE FOR311: SILVICULTURE: GROWING THE FOREST (continued)

\begin{tabular}{|c|c|c|}
\hline Concept & Specific Learner Expectations & Notes \\
\hline Cutting Methods & $\begin{array}{l}\text { The student should: } \\
\text { - identify factors important in choosing a suitable } \\
\text { method of harvest; e.g., } \\
\text { - growth characteristics } \\
\text { - intended utilization } \\
\text { - regeneration of species } \\
\text { - describe current applications of different methods } \\
\text { of harvesting trees; e.g., } \\
\text { - clearcutting method } \\
\text { - seed tree method } \\
\text { - shelterwood method } \\
\text { - selection method } \\
\text { assess the advantages and disadvantages of } \\
\text { different methods of harvesting trees } \\
\text { relate appropriate harvest methods to individual } \\
\text { tree species. }\end{array}$ & $\begin{array}{l}\text { See Alberta's Focus on } \\
\text { Forests (Activity } 4.6- \\
\text { Cutting Styles). } \\
\text { Teacher Reference: } \\
\text { Timber Harvesting } \\
\text { Guidelines (Alberta } \\
\text { Forest Service). } \\
\\
\text { Select three sites that } \\
\text { possess different timber } \\
\text { characteristics. Have } \\
\text { students physically } \\
\text { examine the sites to } \\
\text { determine timber } \\
\text { condition and } \\
\text { harvesting } \\
\text { considerations. }\end{array}$ \\
\hline $\begin{array}{l}\text { Silviculture and } \\
\text { Silvics }\end{array}$ & $\begin{array}{l}\text { - define silviculture as the science and art of } \\
\text { growing and tending forest crops to obtain more } \\
\text { and better benefits from forests including wood } \\
\text { identify major components of silvicultural } \\
\text { systems; e.g., } \\
\text { - stand establishment } \\
\text { - stand management } \\
\text { - harvest and re-establishment } \\
\text { - explain that individual tree species have unique } \\
\text { ecological requirements that determine suitable } \\
\text { silvicultural practices } \\
\text { compare and contrast the ecological requirements } \\
\text { and silvics for two or more Alberta tree species } \\
\text { describe one or more research programs designed } \\
\text { to improve silvicultural practices; e.g., } \\
\text { - genetic selection } \\
\text { - geographic information systems } \\
\text { - harvesting operations. }\end{array}$ & $\begin{array}{l}\text { Invite a professional } \\
\text { forester to explain } \\
\text { components of } \\
\text { silviculture. }\end{array}$ \\
\hline
\end{tabular}




\section{MODULE FOR312: STEWARDSHIP: BALANCING NEEDS}

Level:

Theme:

Prerequisite:

Module Parameters:
Advanced

\author{
Management and Conservation
}

Users in the Forest (FOR212)

Access to resources available from government, industry and community organizations regarding forest management and environmental stewardship (e.g., Alberta Environmental Protection, Alberta Forest Products Association, special-interest groups)

Students develop and present an integrated plan for sustainable development of the forest resource.

Curriculum and Assessment Standards

\begin{tabular}{|c|c|c|}
\hline $\begin{array}{l}\text { Module Learner } \\
\text { Expectations }\end{array}$ & Assessment Criteria and Conditions (Draft) & $\begin{array}{l}\text { Suggested } \\
\text { Emphasis }\end{array}$ \\
\hline $\begin{array}{l}\text { develop a plan for the } \\
\text { sustainable development } \\
\text { and integrated use of } \\
\text { forested land }\end{array}$ & $\begin{array}{l}\text { Assessment of student achievement will be based on: } \\
\text { - definitions and Alberta examples of sustainable } \\
\text { development, sustained yield, integrated land use and } \\
\text { multiple use management } \\
\text { Assessment Tool } \\
\text { Knowledge/Application Assessment: Forest } \\
\quad \text { Management Principles, FOR312-1 } \\
\text { Standard } \\
\text { Respond to a standard of } 3 \text { on the rating scale } \\
\text { developing and presenting a plan for the sustainable } \\
\text { development and integrated use of a forested region. } \\
\text { Plan to address: } \\
\text { - short- and long-term goals and objectives } \\
\text { - the views of relevant stakeholder groups } \\
\text { - a process for public involvement } \\
\text { - proposed management standards and guidelines } \\
\text { - a schedule of development activities } \\
\text { - forest boundaries, access, physical features, cover } \\
\text { and other resources } \\
\text { - permits, licences and/or other legal agreements } \\
\text { that may be required } \\
\text { - a strategy for monitoring use and resolving } \\
\text { potential conflicts } \\
\text { Assessment Tools } \\
\text { Assessment Criteria: Developing A Forest } \\
\text { Management Plan, FOR312-2 } \\
\text { Presentations/Reports, FORPRE-3 } \\
\text { Standard } \\
\text { Achieve a minimum performance rating of: } \\
\text { - } 2 \text { in developing the management plan } \\
\text { - } 3 \text { in presenting the management plan }\end{array}$ & 90 \\
\hline
\end{tabular}


MODULE FOR312: STEWARDSHIP: BALANCING NEEDS (continued)

\begin{tabular}{|l|c|c|}
\hline \multicolumn{1}{|c|}{$\begin{array}{c}\text { Module Learner } \\
\text { Expectations }\end{array}$} & Assessment Criteria and Conditions (Draft) & $\begin{array}{c}\text { Suggested } \\
\text { Emphasis }\end{array}$ \\
\hline $\begin{array}{l}\text { The student will: } \\
\text { demonstrate basic } \\
\text { competencies. }\end{array}$ & $\begin{array}{c}\text { Assessment of student achievement will be based on: } \\
\text { observations of individual effort and interpersonal } \\
\text { interaction during the learning process }\end{array}$ & $\begin{array}{c}\text { Integrated } \\
\text { throughout }\end{array}$ \\
& $\begin{array}{c}\text { Assessment Tools } \\
\text { Basic Competencies Reference Guide and any } \\
\text { assessment tools noted above }\end{array}$ & \\
\hline
\end{tabular}

\begin{tabular}{|c|c|c|}
\hline Concept & Specific Learner Expectations & Notes \\
\hline Basic Principles & $\begin{array}{l}\text { The student should: } \\
\text { - explain sustainable development and sustained } \\
\text { yield within the context of Canada's forests } \\
\text { - compare principles of integrated land use with } \\
\text { principles of multiple use management by citing } \\
\text { examples of each within Alberta } \\
\text { research local opportunities for consultation and } \\
\text { public involvement in forest management } \\
\text { decisions. }\end{array}$ & $\begin{array}{l}\text { A summative module } \\
\text { requiring background } \\
\text { knowledge of } \\
\text { forestry—should be the } \\
\text { last module studied in a } \\
\text { sequence of Forestry } \\
\text { modules. }\end{array}$ \\
\hline Planning Process & $\begin{array}{l}\text { establish short- and long-term goals for the } \\
\text { management of forested land on an integrated } \\
\text { basis; e.g., } \\
\text { - recreation } \\
\text { - forage } \\
\text { - wildlife habitat } \\
\text { - wood fibre } \\
\text { - oil and gas } \\
\text { identify scientific, economic and social factors to } \\
\text { be addressed through the management plan; e.g., } \\
\text { - the objectives of different stakeholders } \\
\text { - relevant government acts and regulations } \\
\text { - forest inventory requirements } \\
\text { - the silvics of tree species and appropriate } \\
\text { harvest methods } \\
\text { - consumer trends and markets for forest } \\
\text { - products } \\
\text { potential applications of research and } \\
\text { technology }\end{array}$ & $\begin{array}{l}\text { Have students interview a } \\
\text { local land-owner to } \\
\text { determine long-range } \\
\text { desires and plans for a } \\
\text { forested region. } \\
\text { Prepare written } \\
\text { management plans } \\
\text { consistent with the } \\
\text { landowner's long-range } \\
\text { goals. Compare with } \\
\text { recommendations of a } \\
\text { professional forester. }\end{array}$ \\
\hline
\end{tabular}


MODULE FOR312: STEWARDSHIP: BALANCING NEEDS (continued)

\begin{tabular}{|c|c|c|}
\hline Concept & Specific Learner Expectations & Notes \\
\hline $\begin{array}{l}\text { Planning Process } \\
\text { (continued) }\end{array}$ & $\begin{array}{l}\text { The student should: } \\
\text { - } \text { survey the views of different stakeholders in the } \\
\text { forest and resolve conflicts that may arise; e.g., } \\
\text { - recreational } \\
\text { - environmental } \\
\text { - aboriginal } \\
\text { - industrial } \\
\text { - agricultural } \\
\text { incorporate consultation with other resource users } \\
\text { and public involvement into the planning process } \\
\text { identify alternative means of achieving the } \\
\text { management goals, and select the preferred } \\
\text { alternatives } \\
\text { elaborate upon permits, licences or other legal } \\
\text { agreements that may be required } \\
\text { develop a set of actions and present the } \\
\text { management plan; e.g., } \\
\text { - a general description of the forested area } \\
\text { - long-term management objectives } \\
\text { - short-term management objectives } \\
\text { - proposed management standards and } \\
\text { describe techniques for monitoring the } \\
\text { management plan to ensure that goals are being } \\
\text { achieved. } \\
\text { - a schedule of short-term development } \\
\text { - activities } \\
\text { prepare a map to accompany and elaborate upon } \\
\text { the management plan; e.g., } \\
\text { - boundaries of the forested area } \\
\text { - forest cover and other resources within the } \\
\text { - area } \\
\text { - hhysical features } \\
\text { - road access }\end{array}$ & $\begin{array}{l}\text { Specific management } \\
\text { plans will vary, but } \\
\text { need to address some } \\
\text { common actions }\end{array}$ \\
\hline
\end{tabular}




\section{FORESTRY}

\section{SECTION G: ASSESSMENT TOOLS}

(DRAFT)

TABLE OF CONTENTS

The following pages include background information and strategies for assessing student achievement and the assessment tools that are listed in Sections D, E and F of this Guide.

This section of the Guide to Standards and Implementation has been designed to provide a common base of understanding about the level of competencies students are expected to demonstrate to successfully complete a module. The goal is to establish assessment standards for junior and senior high school students that are fair, credible, and challenging.

These tools will assist teachers throughout the province to more consistently assess student achievement. The purpose of expanding on the assessment standards is to:

- increase confidence among students, parents, business/industry and postsecondary that students can demonstrate the competencies specified in the modules they have completed

- encourage fairness and equity in how students' efforts are judged

- enable learners to focus effort on key learnings

- support teachers and community partners in planning and implementing CTS.

These tools are in draft form and are being validated between now and 1997 during the optional stage of CTS implementation.

\section{ASSESSING STUDENT ACHIEVEMENT}

Assessing Student Achievement in CTS

Assessing Student Achievement in Forestry

Assessment Tools Generic to CTS

Basic Competencies Reference Guide

Generic Rating Scale

Frameworks for Assessment

CTSISS: Issue Analysis

CTSLAB: Lab Investigations

CTSNEG: Negotiation and Debate

CTSPRE: Presentations/Reports

G.11

CTSRES: Research Process 
Assessment Tools Generic to Forestry

FORPRE-1: Presentations/Reports (Introductory) ..............................................16

FORPRE-2: $\quad$ Presentations/Reports (Intermediate) ............................................... 17

FORPRE-3: $\quad$ Presentations/Reports (Advanced) ................................................. 18

FORCAR-1: Career Search (Introductory) ..........................................................19

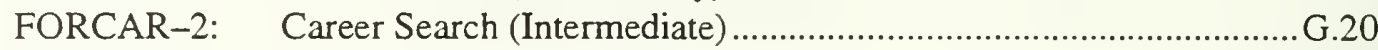

FORCAR-3: Career Search (Advanced) .............................................................. 21

FORNEG-1: Negotiation and Debate (Introductory) ............................................2.

FORNEG-2: Negotiation and Debate (Intermediate).............................................23

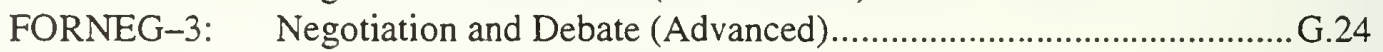

FORLAB: $\quad$ Lab Assessment: Outdoor Forest Experiences .................................25

FORLET: $\quad$ Assessment Criteria: Letters of Support or Concern ..........................26

FORMAP: $\quad$ Task Checklist for Mapping ..........................................................27

FORMED: Guide to Critiquing Media Information...........................................28

FORLOG-VOL:Log/Verification of Volunteer Work .............................................29

FORREF-OUT: Reflection Guide for Outdoor Experiences .....................................3.

FORREF-ENV: Reflection Guide for Environmental Responsibility/Citizenship ....G.33

FORPRO: $\quad$ Assessment Criteria: Proposal for Environmental Action ..................34

FORDRA: Assessment Criteria: Diagrams and Technical Drawings...................35

FORFLO: Assessment Criteria: Flow Charts ...................................................36

FOROBS: $\quad$ Observation Checklist for Field-Based Investigations ......................37

Assessment Tools Specific to Modules in Forestry

FOR101-1: Knowledge/Application Assessment: Significance of Forests ..................39

FOR101-2 Sample Timeline: Forestry in North America .........................................4. 40

FOR101-3: Research Process: Impacts on the Forest Resource ...................................4. 42

FOR102-1: Lab Investigations: Factors Affecting Plant Growth ................................43

FOR102-2: Knowledge/Application Assessment: Growth and

Distribution of Forests ......................................................................44

FOR102-3: Museum Conservation Rules for Leaf/Twig Collection ............................45

FOR104-1: Knowledge/Application Assessment: Hazards in the

Forest Environment...................................................................... 46

FOR 104-2: Sample Assessment Items: Woods Survival I......................................47

FOR 104-3: Task Checklist: Woods Survival I ........................................................49

FOR 105-1: Portfolio Assessment: Maps Used in Forestry .........................................5.51

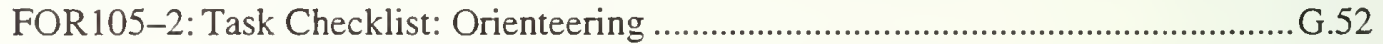

FOR105-3: Knowledge/Application Assessment: Reading and

Interpreting Forest Maps ................................................................ 53

FOR 106-1: Research Process: Forest Surveys........................................................5.54

FOR 106-2: Task Checklist: Orienteering …........................................................5.

FOR106-3: Task Checklist: Forest Measurement ...................................................56

FOR 106-4: Task Checklist: Forest Survey …...........................................................5.57

FOR 109-1: Research Process: Forest Ecosystems....................................................5.58

FOR 109-2: Knowledge/Application Assessment: Structural Units of the Tree ...........59

FOR 109-3: Lab Investigations: Tree Biology .......................................................60

FOR 110-1: Knowledge/Application Assessment: Forest Use .................................6.61

FOR 110-2: Knowledge/Application Assessment: Sustainability ..............................6.62

FOR 1 10-3: Position Paper: Forest Management ........................................................6.63

FOR 1 10-4: Research Process: Components of Forest Protection ................................64 
FOR110-5: Task Checklist: Identifying Forest Pests..........................................6.65

FOR1 10-6: Identification Key for Forest Pests ...................................................6.66

FOR201-1: Guide to Inferences: Personal Impact on Forests ............................... 71

FOR201-2: Research Process: Recycling Techniques ............................................. 72

FOR201-3: Issue Analysis: Reducing, Reusing and Recycling ..............................73

FOR203-1: Presentations/Reports: Managing Alberta's Forested Lands ................... . 74

FOR203-2: Sample Timeline: Management History of Alberta's Forested Lands ....G.75

FOR203-3: Sample Acts and Regulations for Managing Alberta's Forests ............... 76

FOR203-4: Research Process: Allocation Procedures for Land and Timber .............G.78

FOR204-1: Task Checklist: Woods Survival II ...................................................... 79

FOR204-2: Post-Trip Assessment for Woods Survival II .......................................81

FOR206-1: Research Process: Random and Systematic Sampling Techniques .........G.82

FOR206-2: Task Checklist: Sampling Fibre and Non-Fibre Forest Values .................83

FOR206-3: Sample Data Sheet: Fibre and Non-Fibre Forest Values ......................... 84

FOR207-1: Knowledge/Application Assessment: Forest Harvest .............................86

FOR207-2: Sample Checklist: Forest Harvest Plans ............................................87

FOR207-3: Sample Assessment Items: Forest Harvest .........................................8. 88

FOR207-4: Research Process: Fibre Utilization and Product Formation .................. G.92

FOR210-1: Knowledge/Application Assessment: Forest Management Goals ........... G.93

FOR210-2: Issue Analysis: Forest Use .................................................................9. 94

FOR210-3: Research Process: Forest Management Practices ..................................95

FOR212-1: Knowledge/Application Assessment: Users in the Forest .......................96

FOR212-2: Research Process: Multiple and Integrated Land Use .......................... G.97

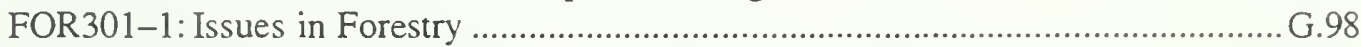

FOR306-1: Knowledge/Application Assessment: Forest Survey Data .................... 100

FOR306-2: Research Process: Role of Technology in Forest Inventory ................... 101

FOR307-1: Knowledge/Application Assessment: Forest Products and Services.....G.102

FOR307-2: Research Process: Milling and/or Pulping Technology .......................... 103

FOR307-3: Assessment Criteria: A Marketing Plan............................................... 104

FOR308-1: Forest Technology Applications …................................................... 105

FOR308-2: Sample Research Topics: Technology Application .............................107

FOR309-1: Knowledge/Application Assessment: Soil, Air and

Water Characteristics ................................................................. 108

FOR309-2: Field Investigations: Soil, Air and Water Characteristics .......................109

FOR309-3: Guide to Inferences: Forest Ecosystems .......................................... 110

FOR309-4: Research Process: Forest Associations .................................................. 111

FOR309-5: Common Forest Associations in Alberta ............................................. 112

FOR309-6: Identification Guide: Agents of Change ........................................... 115

FOR311-1: Knowledge/Application Assessment: Silviculture .............................. 120

FOR31 1-2: Sample Format: Silvics of a Tree Species .........................................121

FOR311-3: Lab Investigations: Natural and Artificial Regeneration ....................... 123

FOR31 1 -4: Sample Assessment Items: Stand Establishment and Management ......G. 124

FOR311-5: Task Checklist: Stand Establishment and Tending............................. 126

FOR31 1-6: Research Process: Forest Harvest Methods ............................................ 129

FOR312-1: Knowledge/Application Assessment: Forest Management Principles .. G. 130

FOR312-2: Assessment Criteria: Developing A Forest Management Plan ................ 131 


\section{ASSESSING STUDENT ACHIEVEMENT IN CTS}

The CTS assessment standards assess two basic forms of competency:

- What a student can do?

- make a product (e.g., wood bowl, report, garment)

- demonstrate a process

- strand-related competencies (e.g., keyboarding, hair cutting, sewing techniques, lab procedures)

- basic competencies (e.g., resource use, safety procedures, teamwork).

- What a student knows?

- knowledge base needed to demonstrate a competency (link theory and practice).

\section{CTS Defines Summative Assessment Standards}

The assessment standards and tools defined for the CTS modules, referenced in Sections D, E and $F$ of this Guide, focus on the final (or summative) assessment of student achievement.

Assessment throughout the learning period (or formative assessment) will continue to assess how students are progressing. Teachers direct and respond to students' efforts to learnsetting and marking tasks and assignments, indicating where improvement is needed, sending out interim reports, congratulating excellence, etc.

Teachers will decide which instructional and assessment strategies to apply during the formative learning period. As formative and summative assessment are closely linked, some teachers may wish to modify the tools included in this section to use during the instructional process. Teachers may also develop their own summative assessment tools as long as the standards are consistent with the minimum expectations outlined by Alberta Education.
Grading and Reporting Student Achievement

When a student can demonstrate ALL of the exit-level competencies defined for the module (Module Learner Expectations), the teacher will designate the module as "successfully completed." The teacher will then use accepted grading practices to determine the percentage grade to be given for the module-a mark not less than $50 \%$.

The time frame a teacher allows a student to develop the exit-level competency is a local decision. NOTE: The Senior High School Handbook specifies that students must have access to 25 hours of instruction for each credit. Students may, however, attain the required competencies in less time and may proceed to other modules.

Teachers are encouraged to consult their colleagues to ensure grading practices are as consistent as possible.

High school teachers may wish to refer to "Directions for Reporting Student Achievement in CTS" for information on how to use the CTS course codes to report credits students have earned to Alberta Education. (Copies of this document have been forwarded to superintendents and senior high school principals.)

\section{Components of Assessment Standards in CTS}

The following components are included in each module:

- module learner expectations (shaded left column of the module) define the exit-level competencies students are expected to achieve to complete a module. Each MLE defines and describes critical behaviours that can be measured and observed. The student must meet the standard specified for ALL MLEs within a module to be successful. (MLEs will not change until 1997 when minor adjustments may be made to update and clarify wording.) 
- suggested emphasis (right column of the module) provides a guideline for the relative significance of each MLE and can be used to organize for instruction. (In draft until early 1997, revisions to selected modules will be distributed in June 1995 and 1996 with final revisions in June 1997.)

- conditions and criteria (middle column of the module) set the framework for the assessment of student competency, specifying the minimum standard for performance and including a reference to assessment tools, where appropriate. (In draft until early 1997, revisions to selected modules will be distributed in June 1995 and 1996 with final revisions in June 1997.)

Conditions outline the specifications under which a student's competency can be judged. For example, the conditions could specify whether the assessment should be timed or not, or if the student should be allowed to access to support resources or references.

Criteria define the behaviours that a student must demonstrate to meet the designated standard. For example, the criteria could describe the various techniques that must be demonstrated when using a tool, and/or describe the minimum components of a project the student must complete.

Standard may be defined by (1) assessment tools, which are referenced in this section (or sometimes in approved learning resources) and/or (2) "illustrative examples" of student work (to be developed and distributed in June 1997).

Assessment Tools included in this section of the Guide tend to be of two types:

- tools generic to a strand or to the entire CTS program; e.g., a standard 5-point rating scale is used in all strands. Other generic tools include assessing reports and presentations and lab safety checklists. (Names of these tools include the strand code (e.g., "INF" for Information Processing) and a code for the type of tool (e.g., "TDENT" for Text-Data Entry).)

- tools specific to a module; e.g., assessment checklist for assessing a venture plan in Enterprise and Innovation or a checklist for sketching, drawing and modelling in Design Studies. (Names of these tools include the module code; e.g., "INF101-1" indicating that it is the first modulespecific tool used in Information Processing Module 101.)

- Illustrative Examples: Selected examples of student work in print, audio, video and/or CD-ROM formats are scheduled to be available by June 1997 . These examples will supplement the assessment tools and help teachers decide if a student's work is at standard, above standard, or not yet at standard.

\section{Development and Validation Processes}

The "Conditions and Criteria" and "Suggested Emphasis" columns are being validated 1994 97, with extensive input from teachers, professional associations/contacts and postsecondary institutions. The goal is to prepare well-structured assessment standards and related assessment tools that:

- establish an appropriate level of challenge and rigour

- relate directly to the type of learning described in the curriculum standard

- are easy to understand

- are efficient to implement

- can provide a consistent measure of what was expected to be measured. 


\section{ASSESSING STUDENT ACHIEVEMENT IN FORESTRY}

Assessing student achievement in Forestry involves gathering information about what a student knows and is able to do, and comparing this information with learning outcomes defined by the curriculum (i.e., module learner expectations, assessment conditions and criteria, illustrative examples/reference sets).

Summative assessment for each module in Forestry will focus attention on process (e.g., how the student approaches/performs particular tasks) and product (e.g., quality characteristics of the task performed, item produced or service rendered). While there are also knowledgebased components of learning within each module, a greater emphasis has been suggested for learning that involves the transfer/ application of knowledge in task- or serviceoriented situations.

\section{Assessment Strategies and Tools}

A variety of assessment tools are provided for assessing student performance within each module. Each tool communicates, through a 5point rating scale, a minimum standard for the completion of a learning task. Criteria for assessing the "basic competencies" students are expected to demonstrate throughout the learning process have been integrated with other performance criteria in each tool.

The assessment tools, when used collectively for a particular module, will assist teachers to assess successful module completion in an equitable and consistent manner. Depending on the way the classroom is organized, assessment tools may be used with individual students upon completion of specific learning tasks, or with the entire class at the end of a learning period.

\section{Tools Generic to Forestry}

Assessment tools generic to Forestry have been developed to assist in assessing student performance in key areas of learning across the scope and sequence. The generic tools communicate minimum performance standards for:

- conducting research, preparing reports and making presentations

- performing practical tasks in stand establishment, tending and maintenance

- conducting laboratory and field-based investigations

- analyzing, negotiating and debating forestry- and environment-related issues

- proposing personal/shared actions that foster environmental citizenship

- exploring career trends and conducting searches of employment opportunities.

The generic tools, referenced as applicable throughout each module in the conditions and criteria column, are identified with a six- or nine-letter code (e.g., FOROBS, FORLOGVOL). Generic tools developed for use in modules at a specific level are further identified by a number (e.g., FORPRE-1 for introductory, FORPRE-2 for intermediate, FORPRE-3 for advanced).

\section{Tools Specific to Forestry Modules}

Other assessment tools have been developed to assess competencies that are unique to specific modules within the Forestry strand. These "module-specific" tools, also referenced in the conditions and criteria column for each module, are identified by the module number followed by a tool number (e.g., FOR107-1 for the first module-specific tool in module FOR107).

In some instances, authorized learning resources have been identified as assessment tools for specific modules. These learning resources usually contain test banks and other assessment strategies considered effective in establishing minimum standards for achievement.

Where appropriate, "Illustrative Examples" or "Sample Assignments/Projects" have been provided in a further attempt to communicate realistic expectations and acceptable standards of achievement. 


\section{BASIC COMPETENCIES REFERENCE GUIDE}

(This checklist is still being validated)

The following chart outlines basic competencies which students will endeavor to develop and enhance in each of the CTS strands and modules. Students' basic competencies should be assessed through observations involving the student, teacher(s), peers and others as they complete the requirements for each module. In general, there is a progression of task complexity and student initiative as outlined in the Development Framework*. As students progress through the Stages 1, 2, 3 and 4 of this reference guide, they build on the competencies gained in earlier stages. Students leaving high school should set themselves a goal of being able to demonstrate Stage 3 performance.

Suggested strategies for classroom use include:

- having students rate themselves and each other

- using for a reflective conversation between teacher and student

- highlighting areas of strength

- tracking growth in various CTS strands

- highlighting areas upon which to focus

- including in student's portfolio

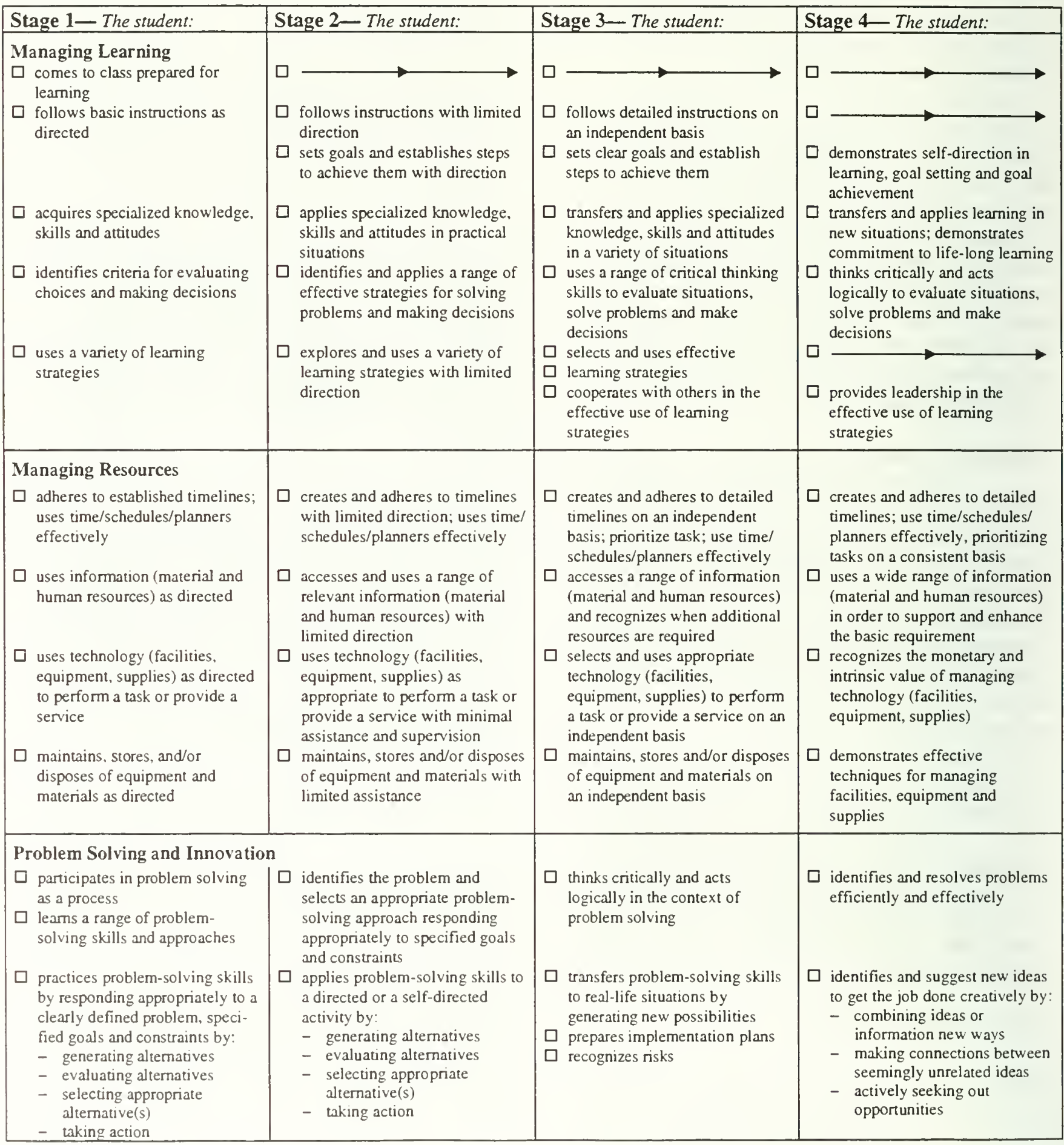




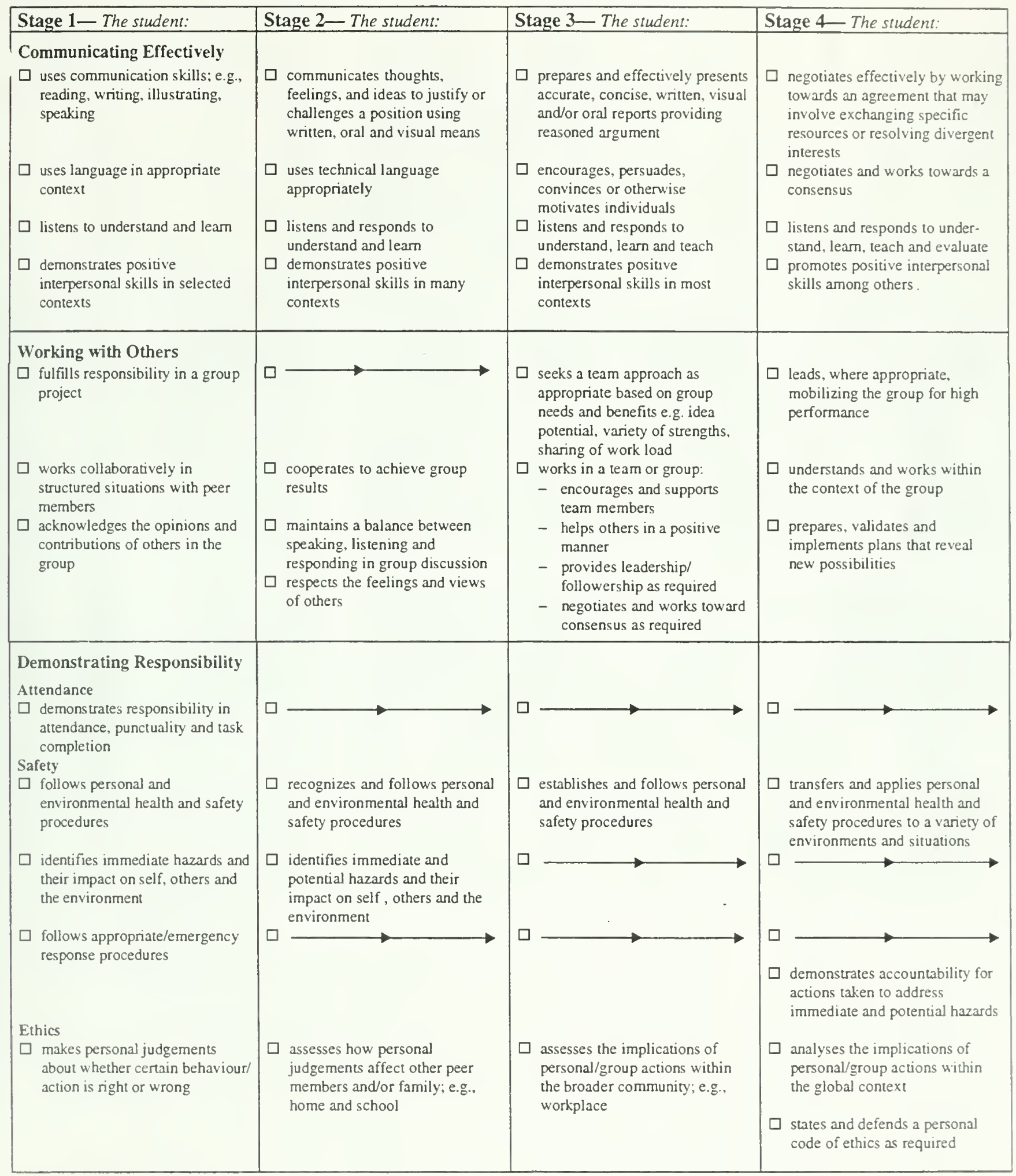

\begin{tabular}{|l|l|l|l|}
\hline Developmental Framework & & & \\
- Simple task & - Task with limited variable & - Task with multiple variables & Complex task \\
- Directed learning & - Less structured environment & - Flexible environment & Open environment \\
& - Limited direction & $\begin{array}{l}\text { Self-directed learning. } \\
\text { seeking assistince as required }\end{array}$ & Self-directed/self-motivated \\
\hline
\end{tabular}




\begin{tabular}{|c|c|c|c|c|c|}
\hline 总总 & & 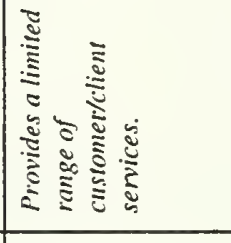 & 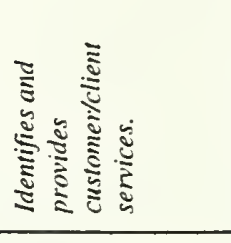 & 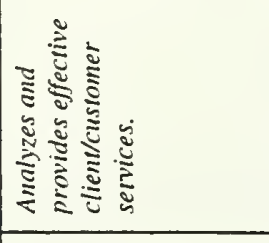 & 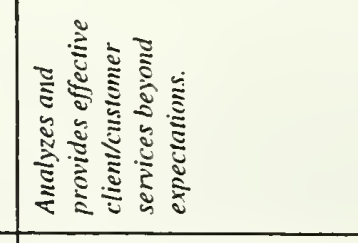 \\
\hline 养言 & & 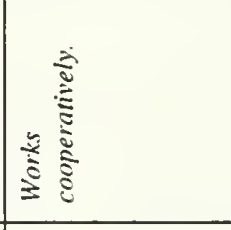 & 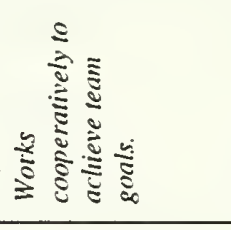 & 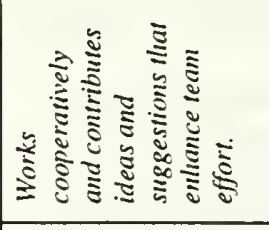 & 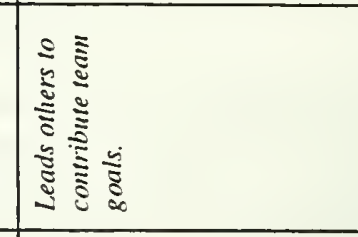 \\
\hline 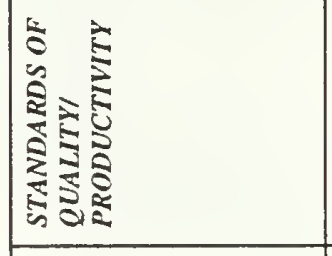 & & 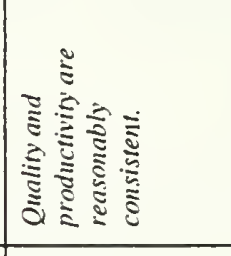 & 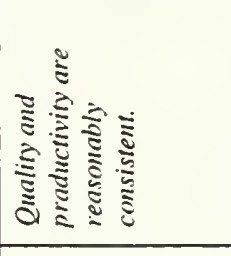 & 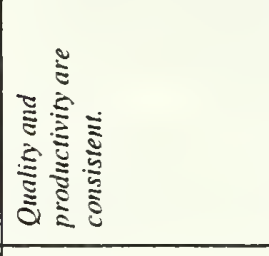 & 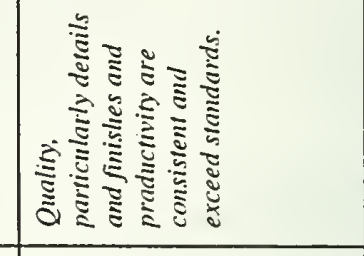 \\
\hline 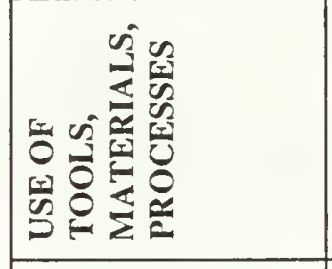 & 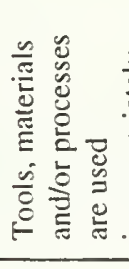 & 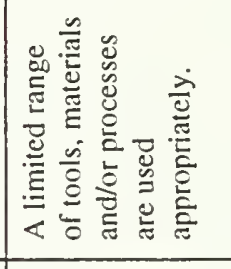 & 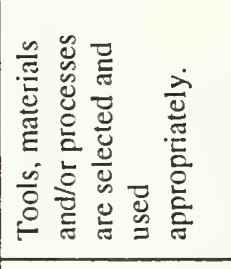 & 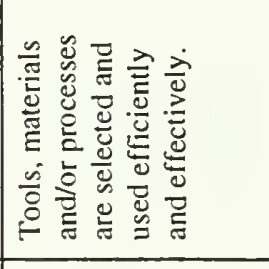 & 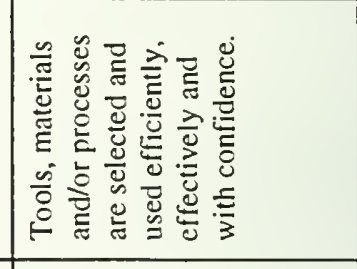 \\
\hline 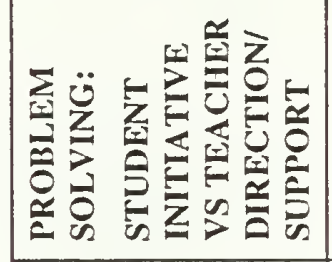 & & 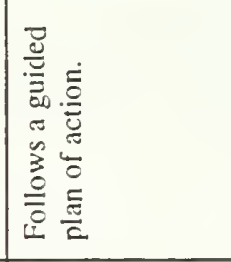 & 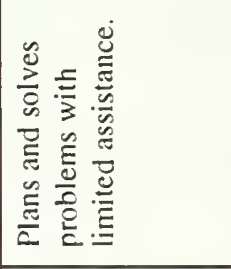 & 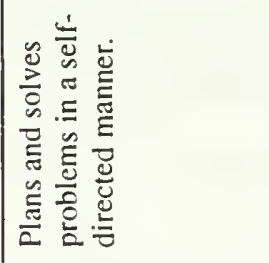 & 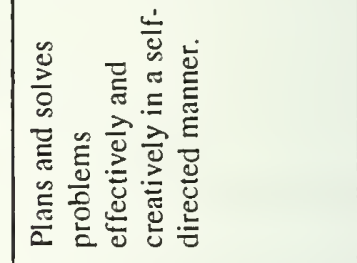 \\
\hline 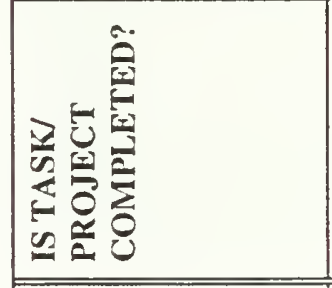 & 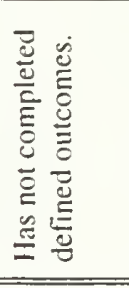 & 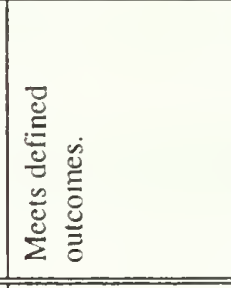 & 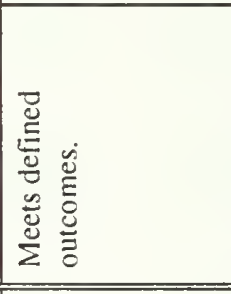 & 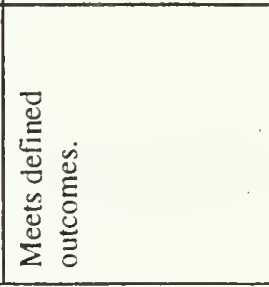 & 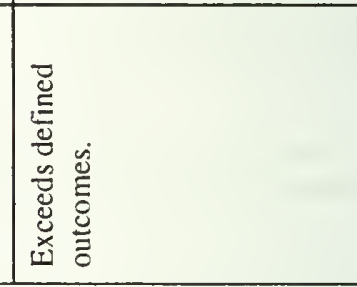 \\
\hline 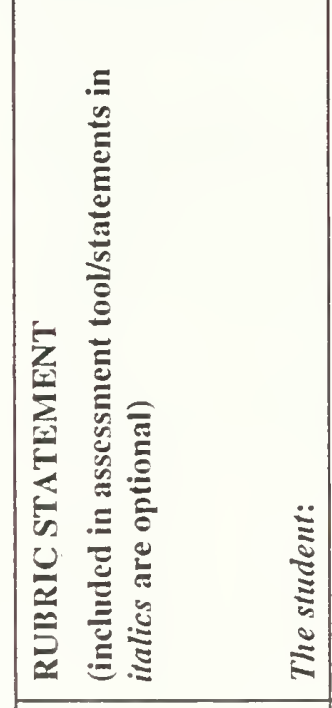 & 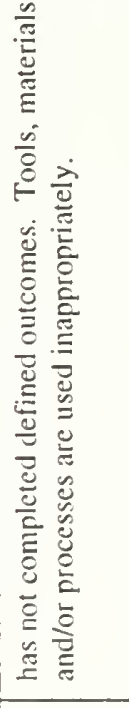 & 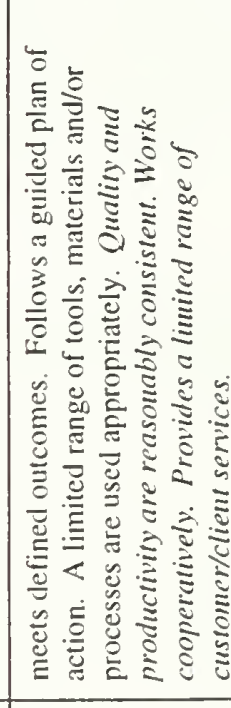 & 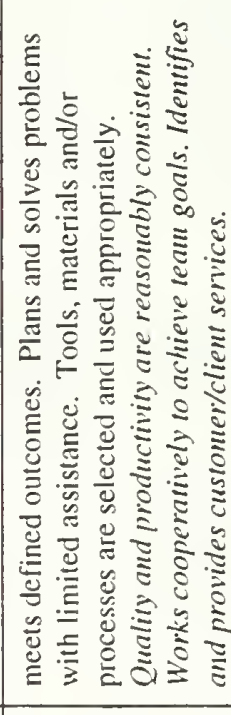 & 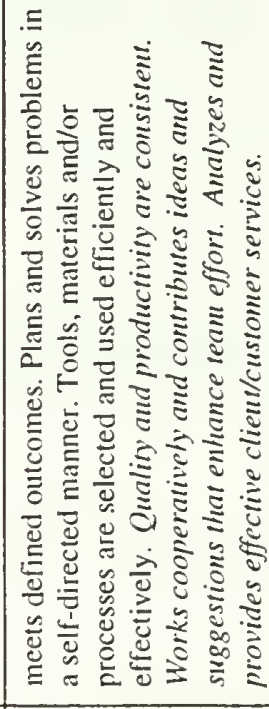 & 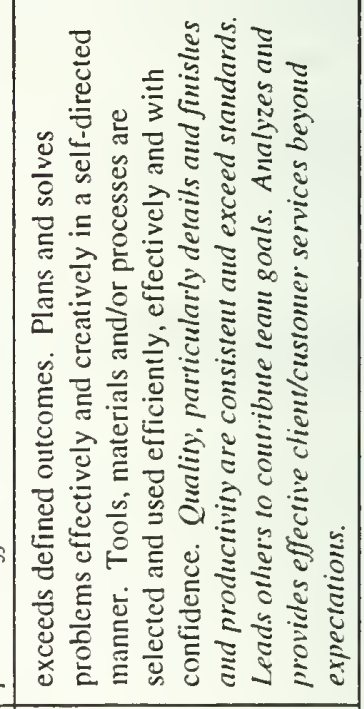 \\
\hline$\infty 0<2 \infty$ & 0 & - & 4 & $m$ & $\theta$ \\
\hline
\end{tabular}




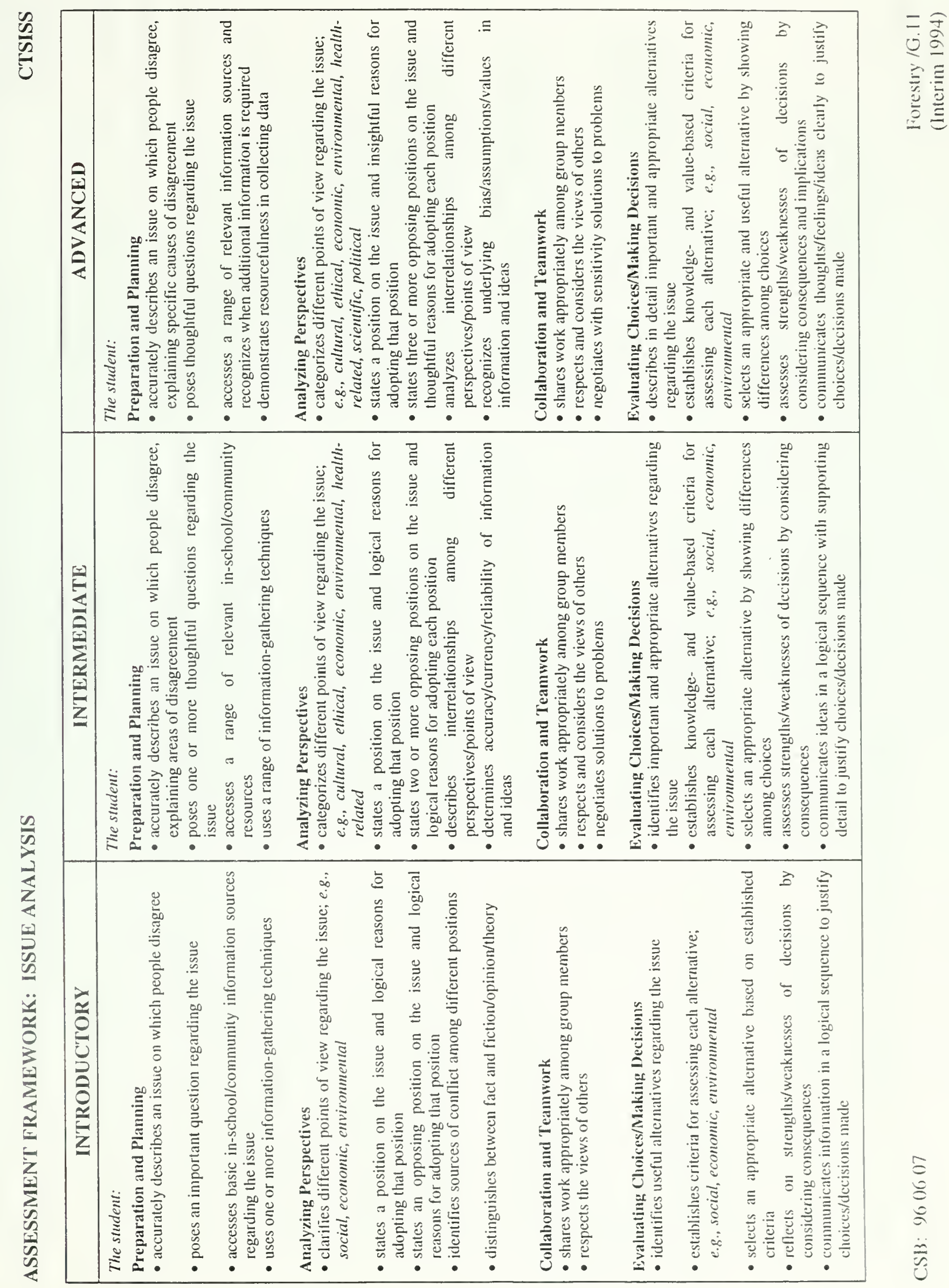




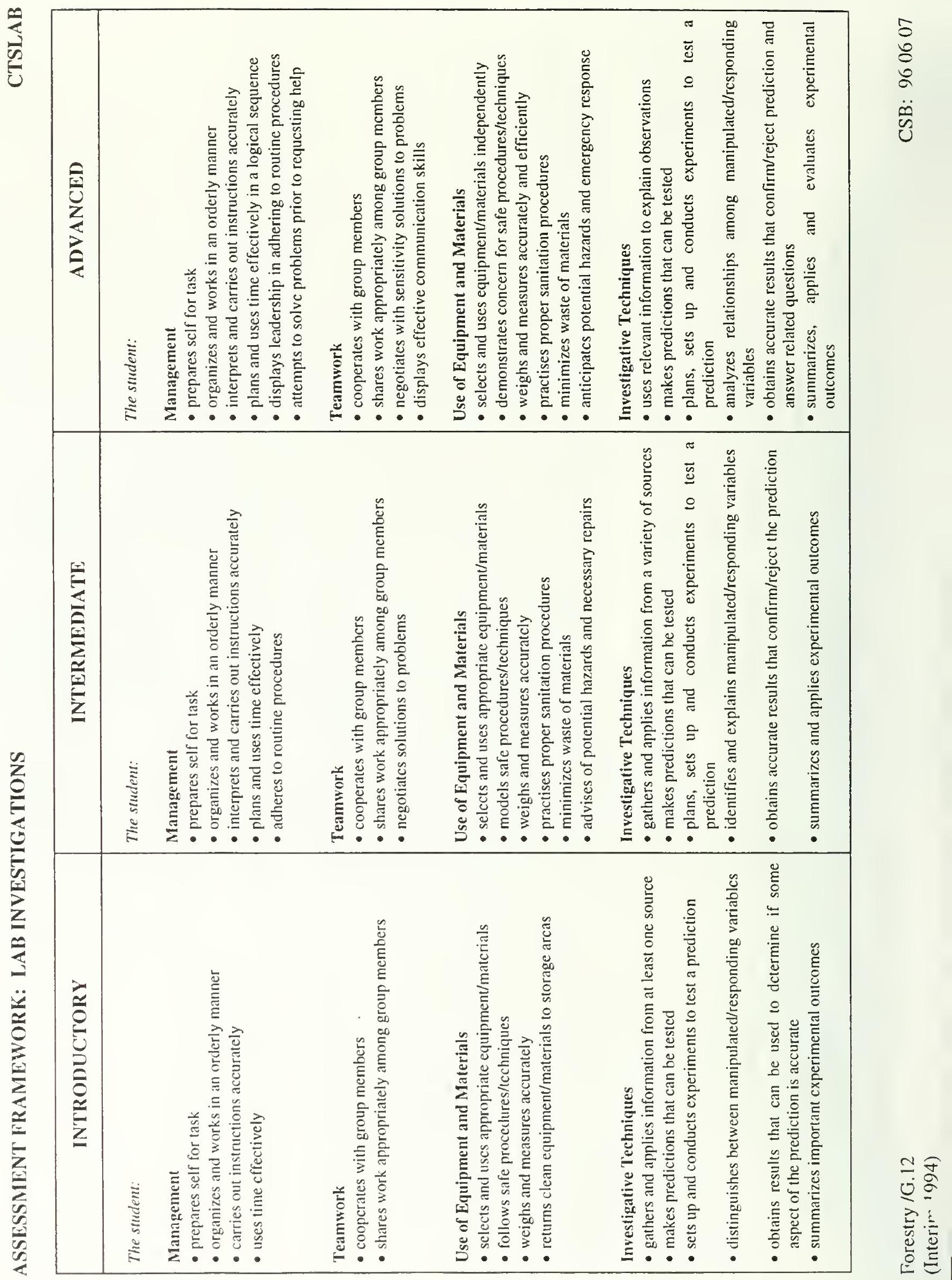




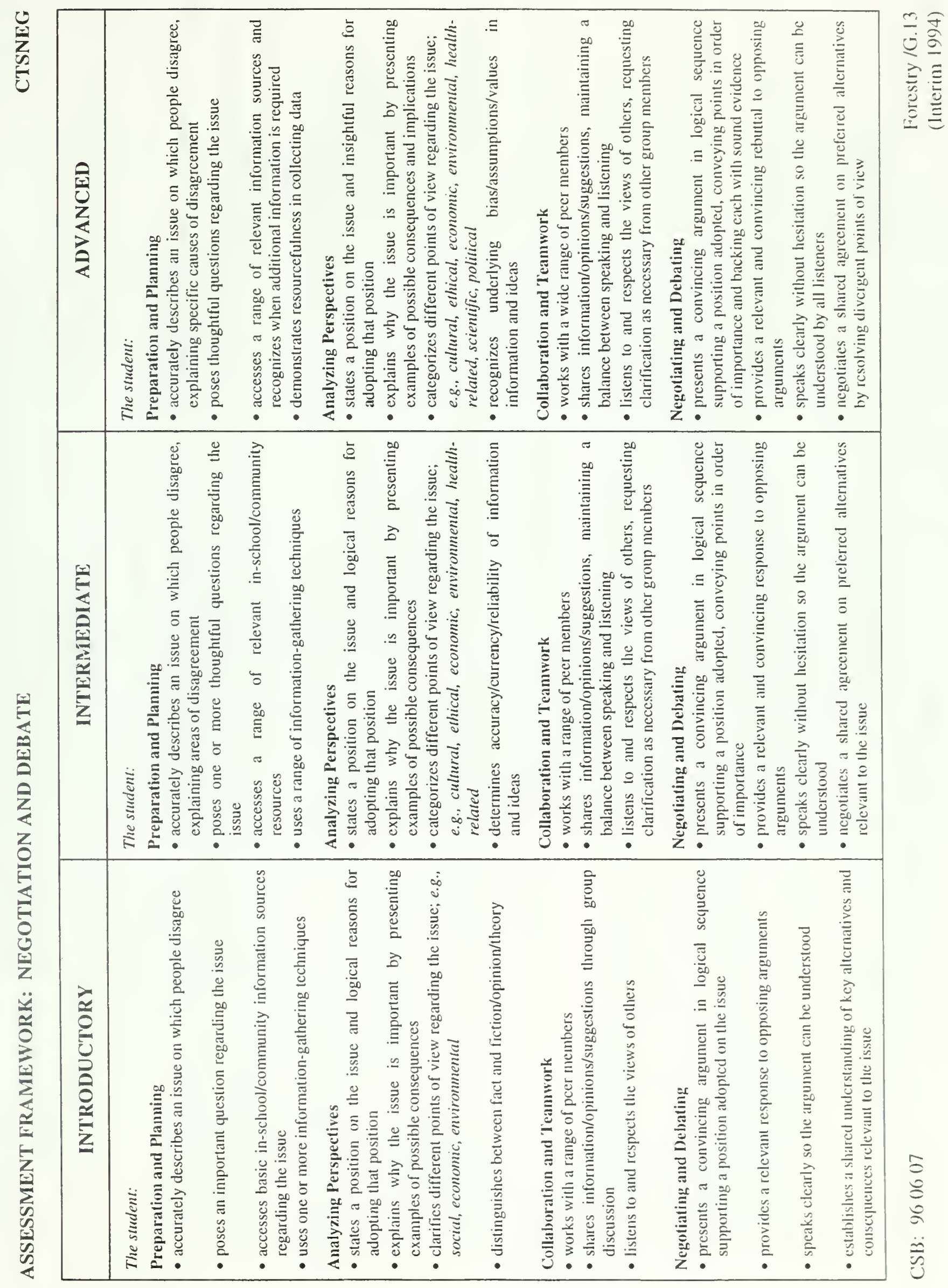




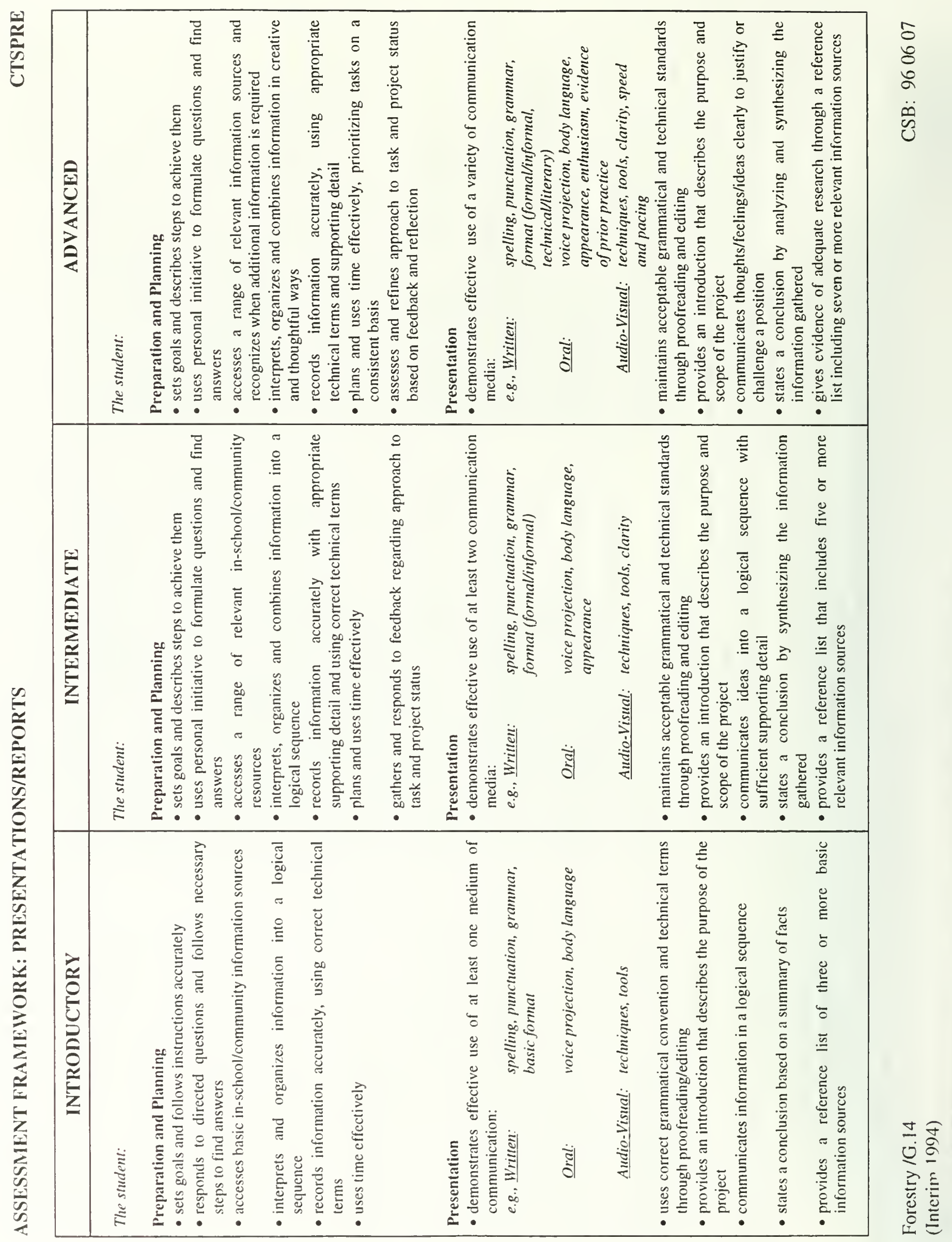




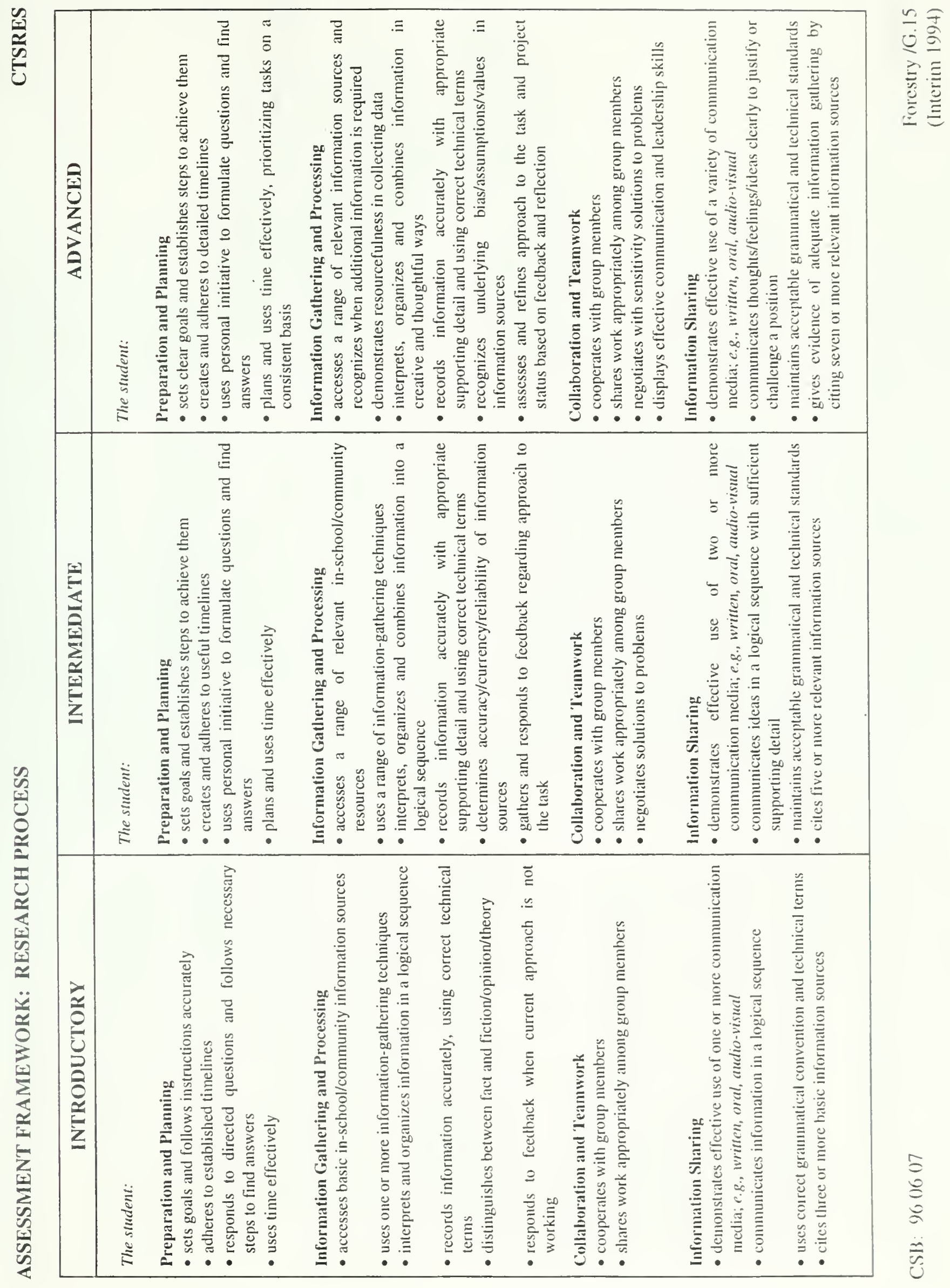



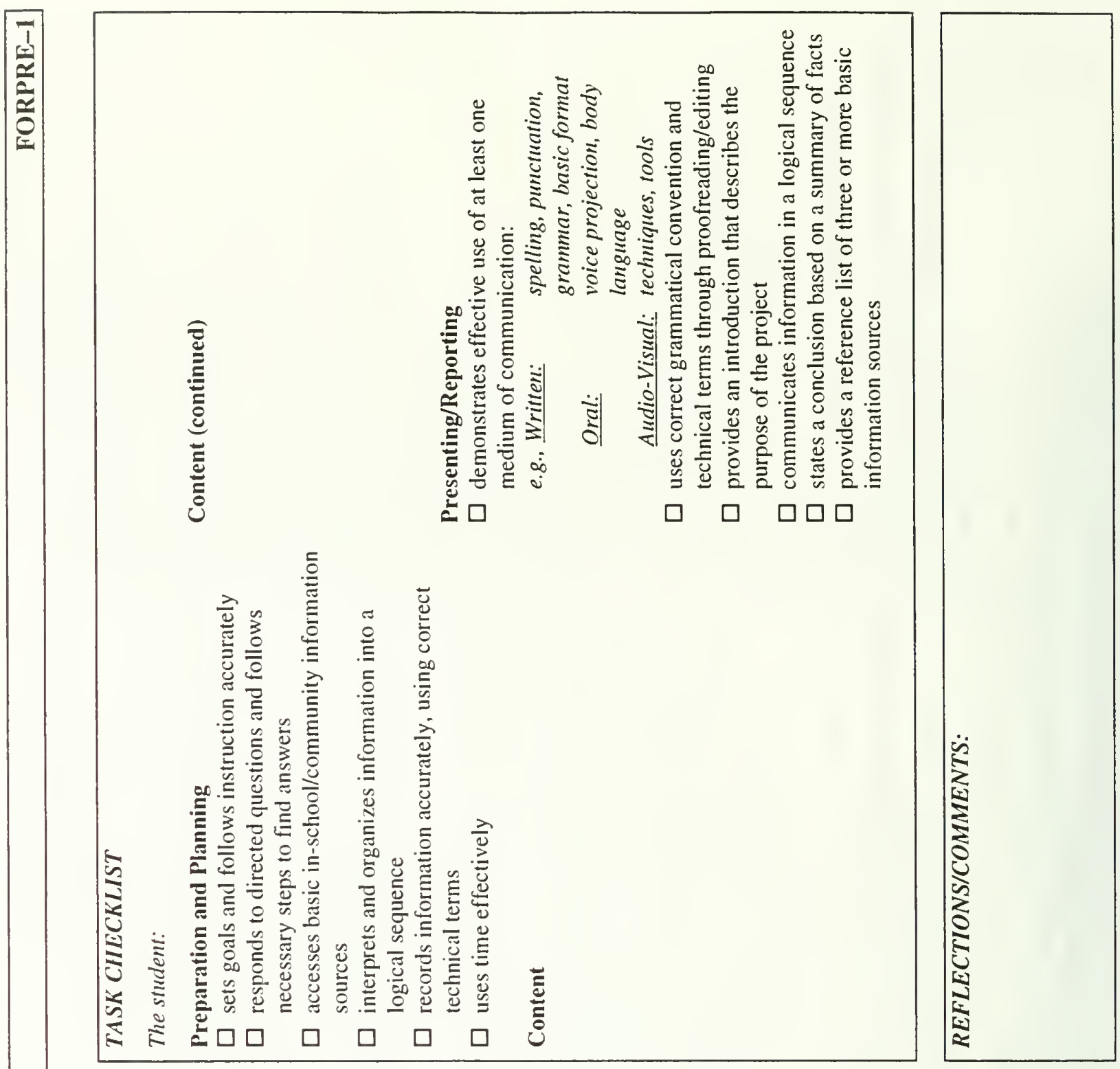

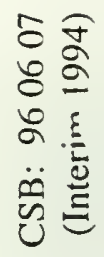
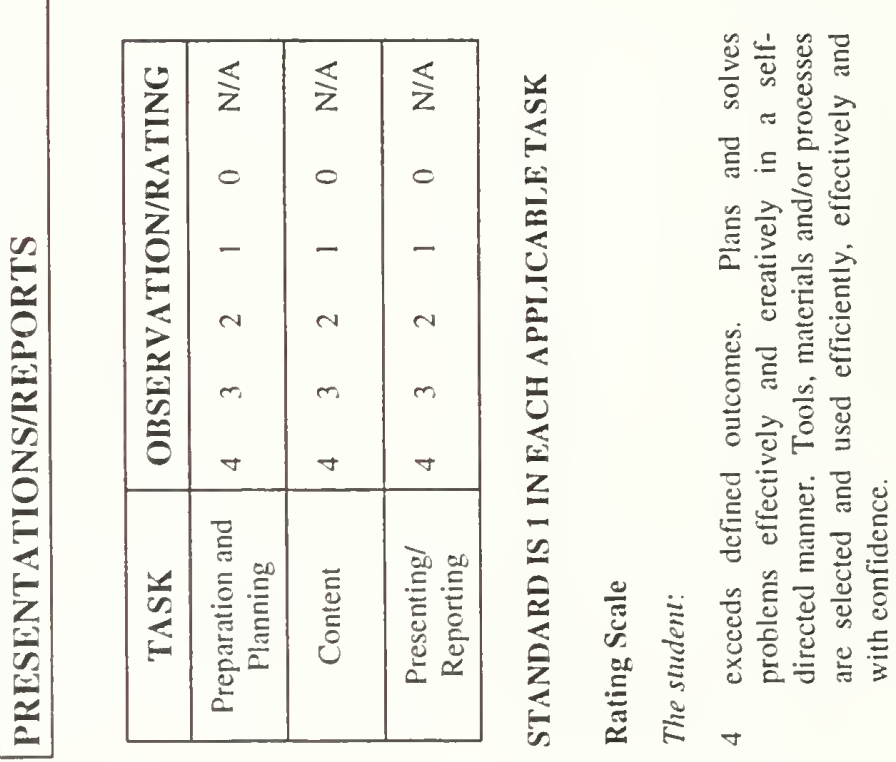

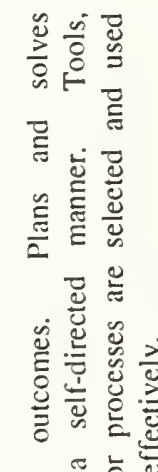

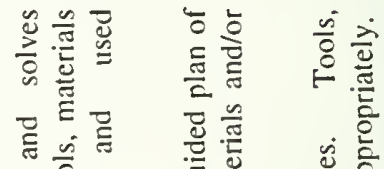

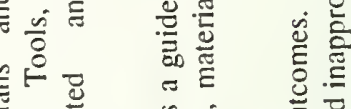

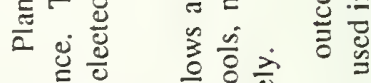

व

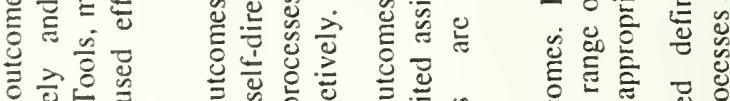

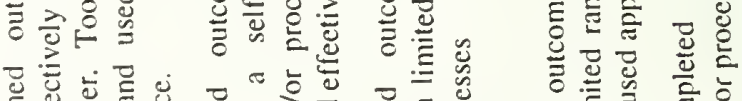

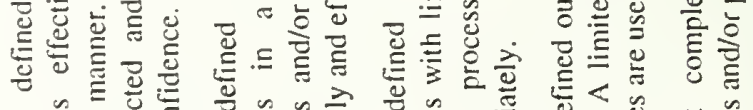

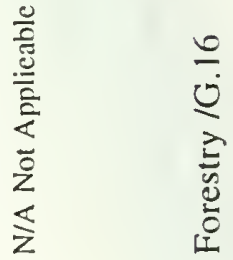



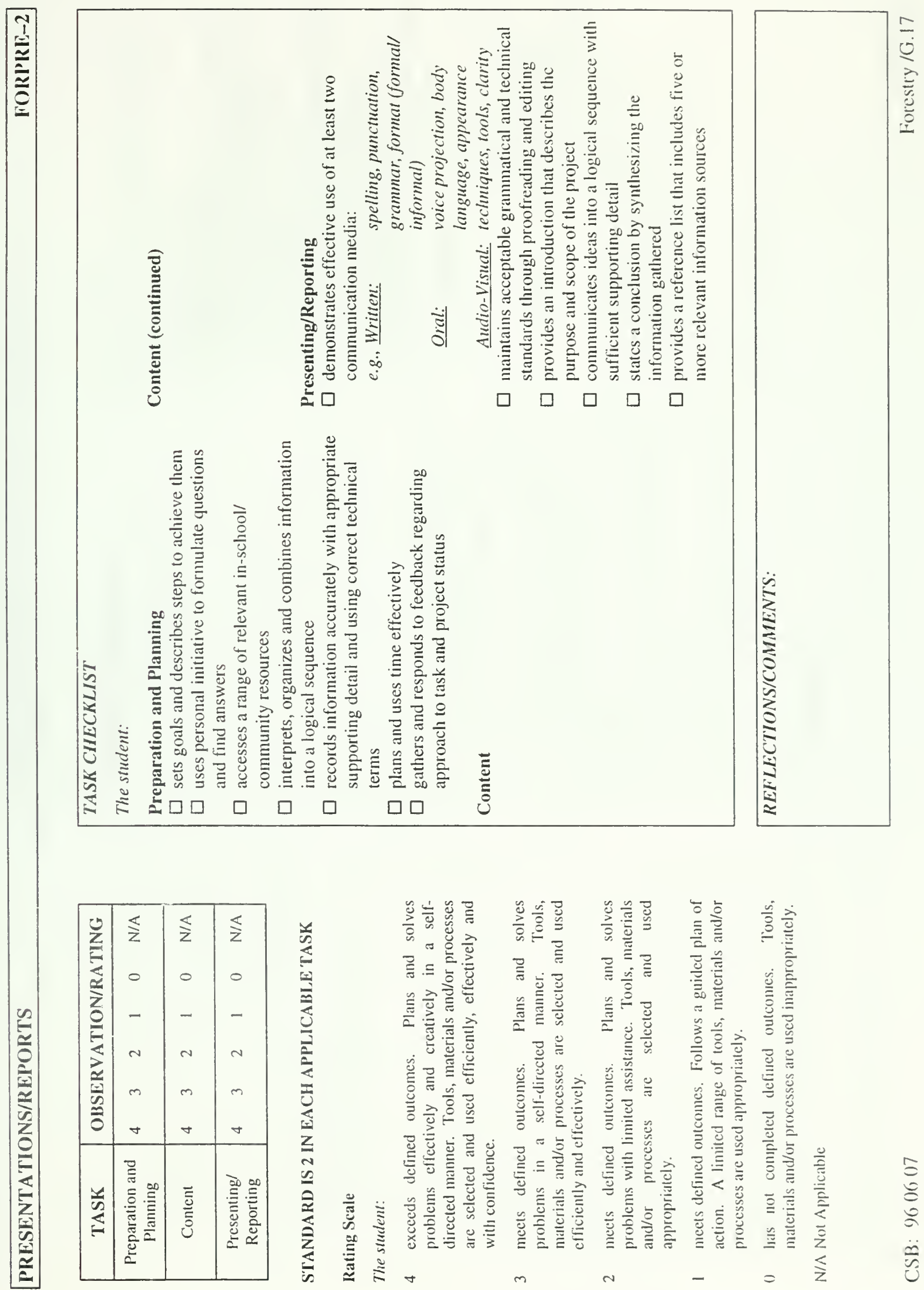

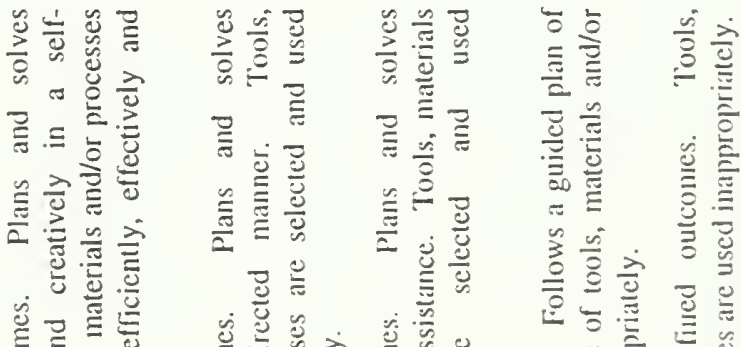

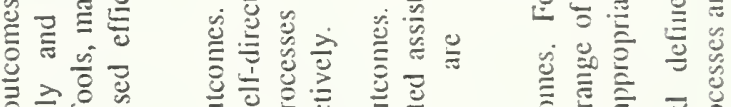

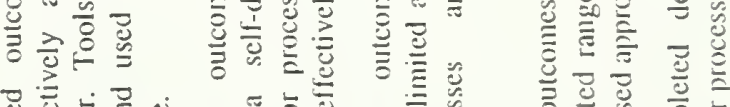

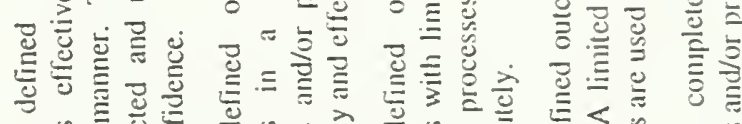

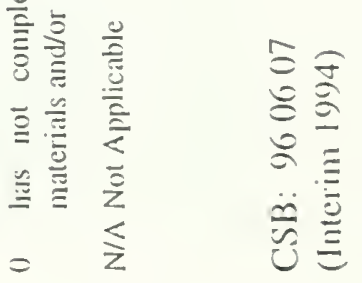



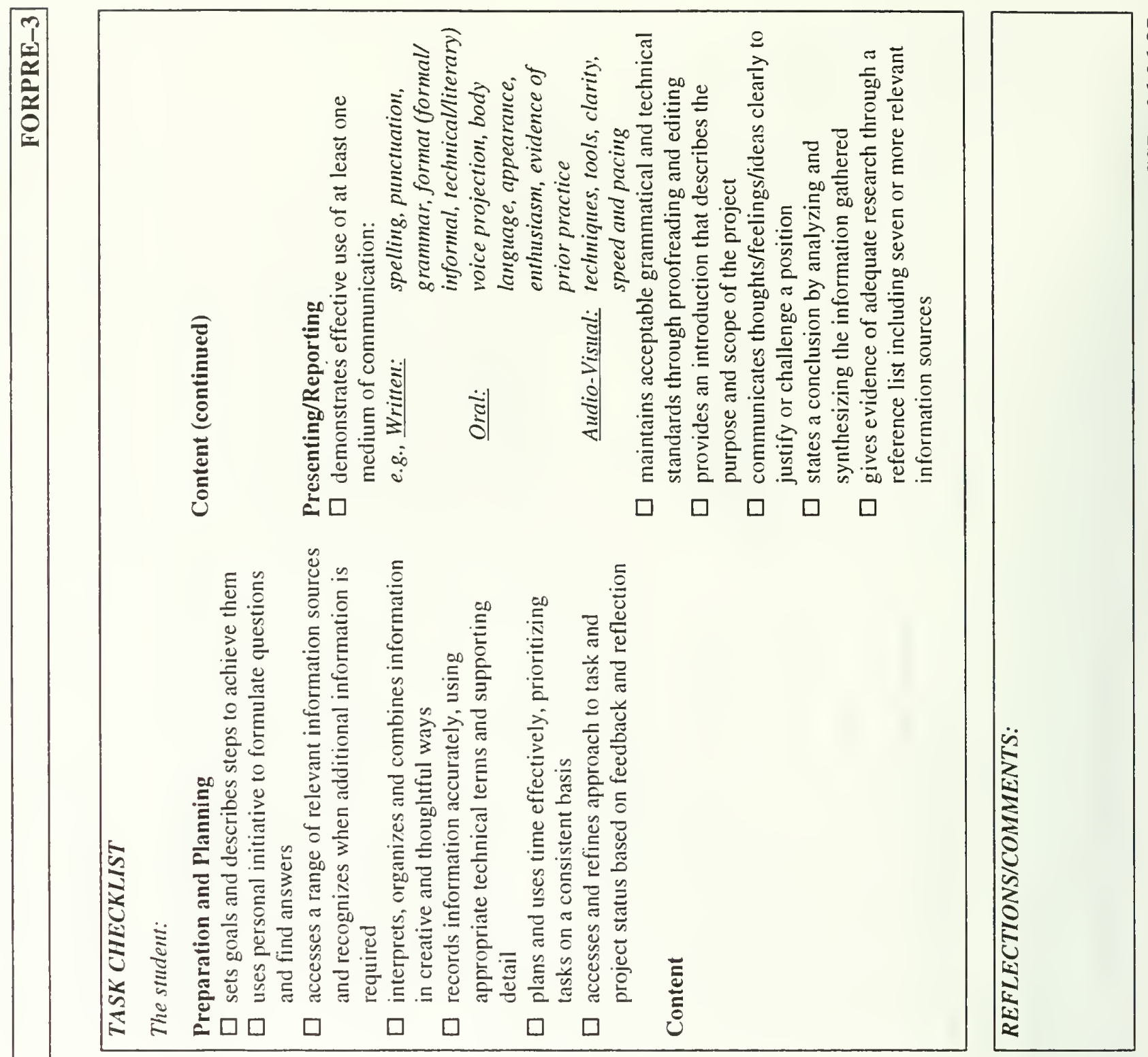

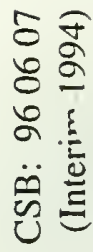
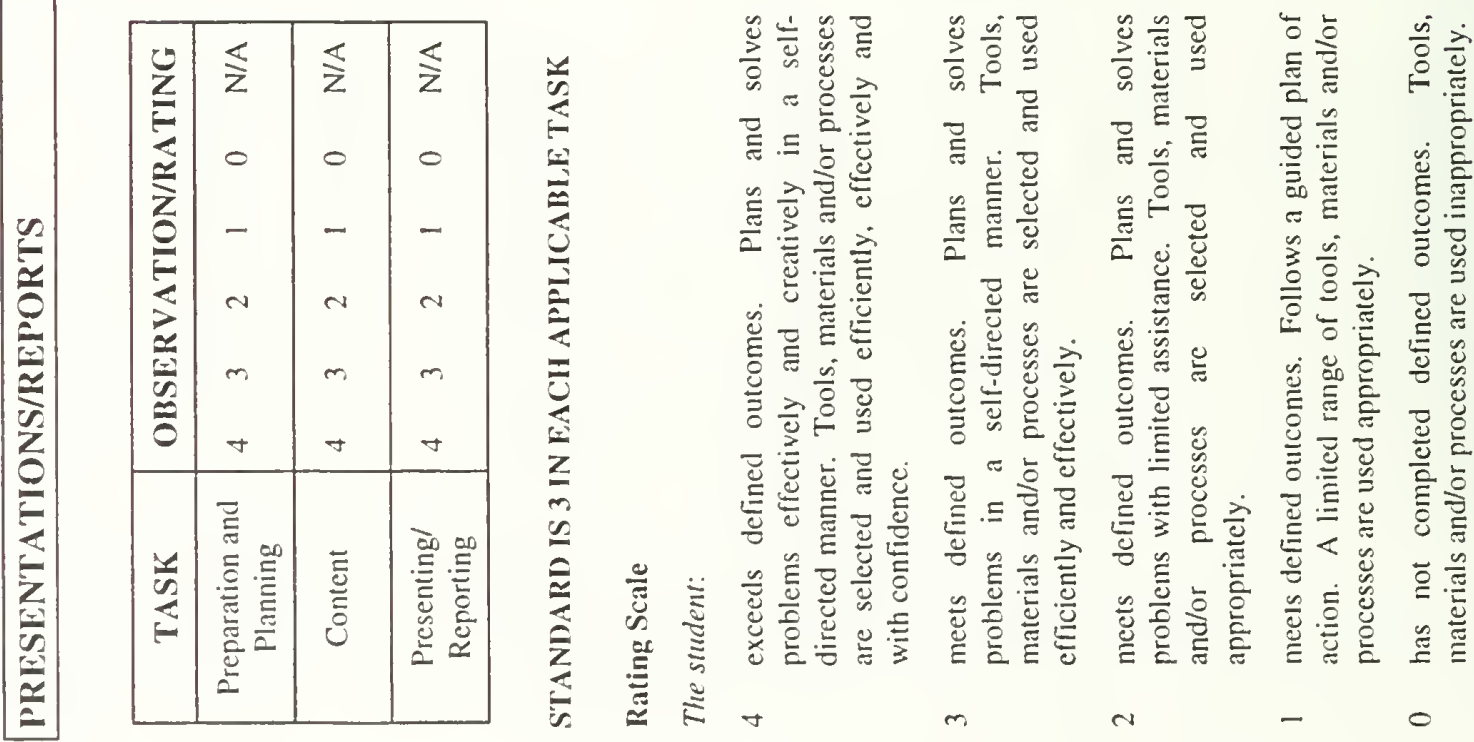

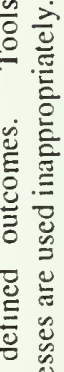

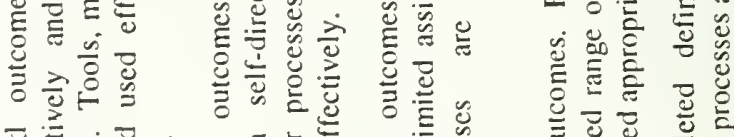

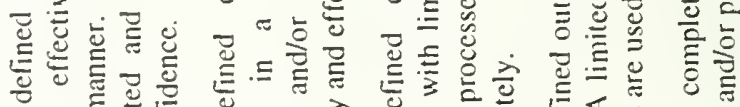

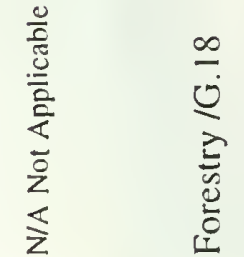



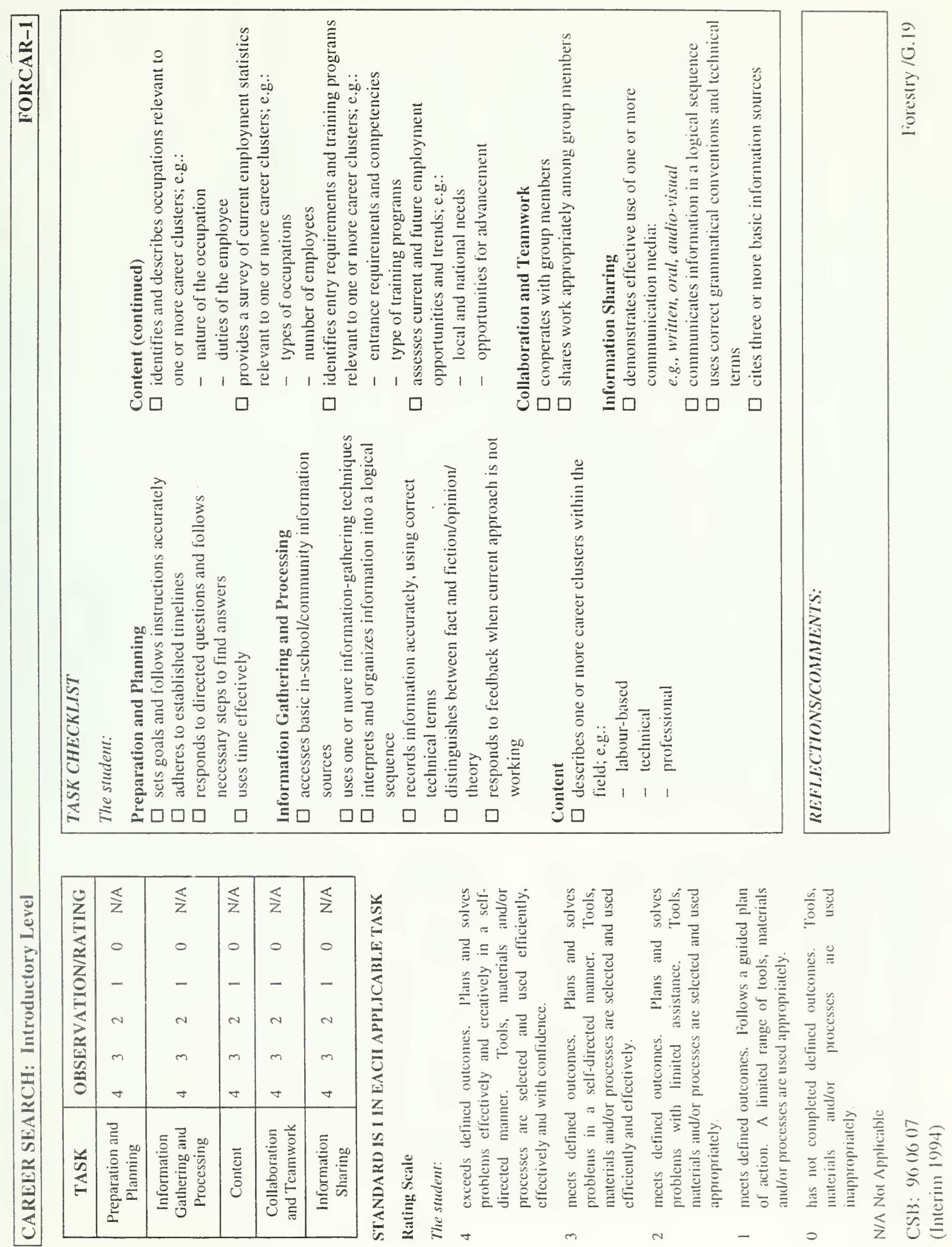

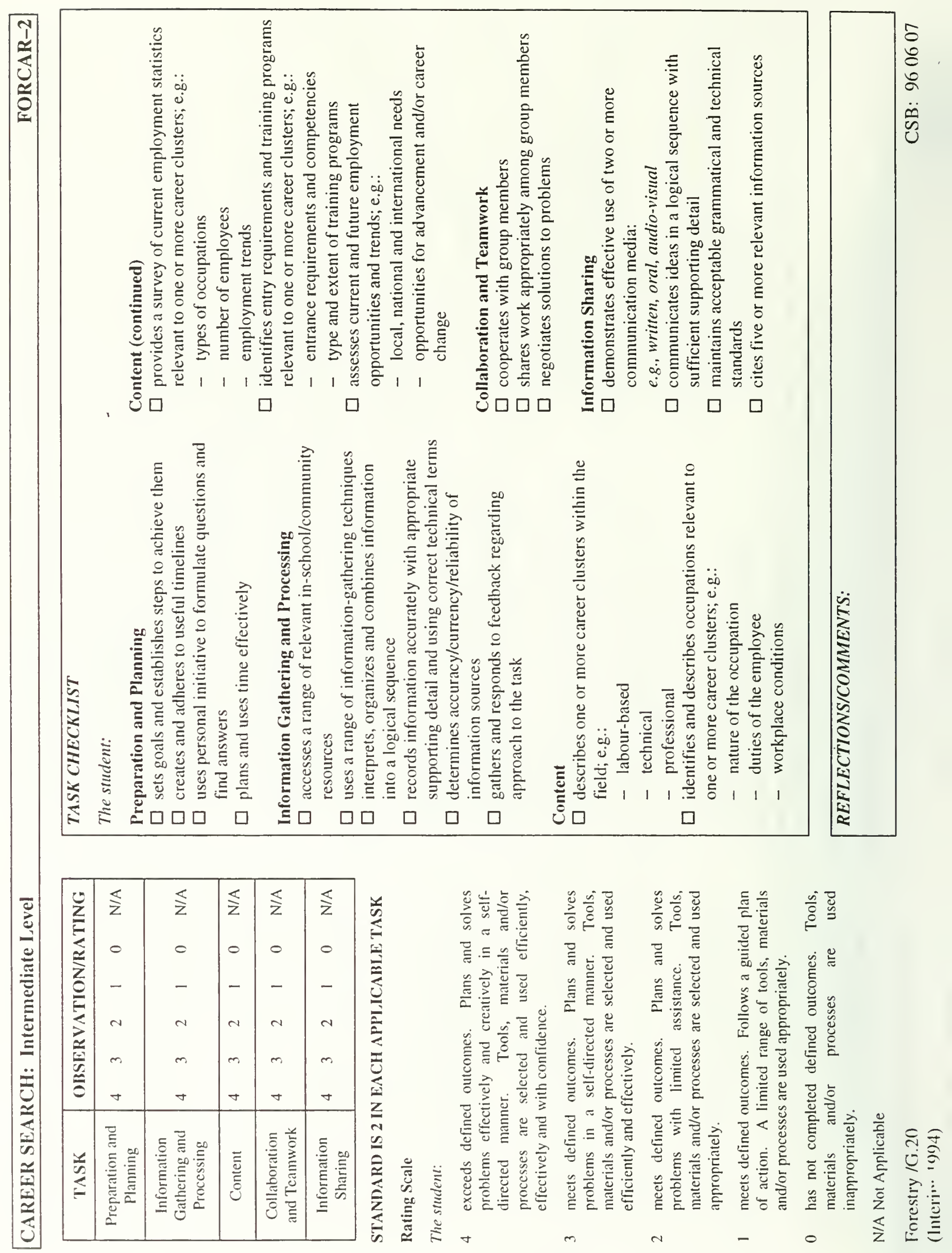

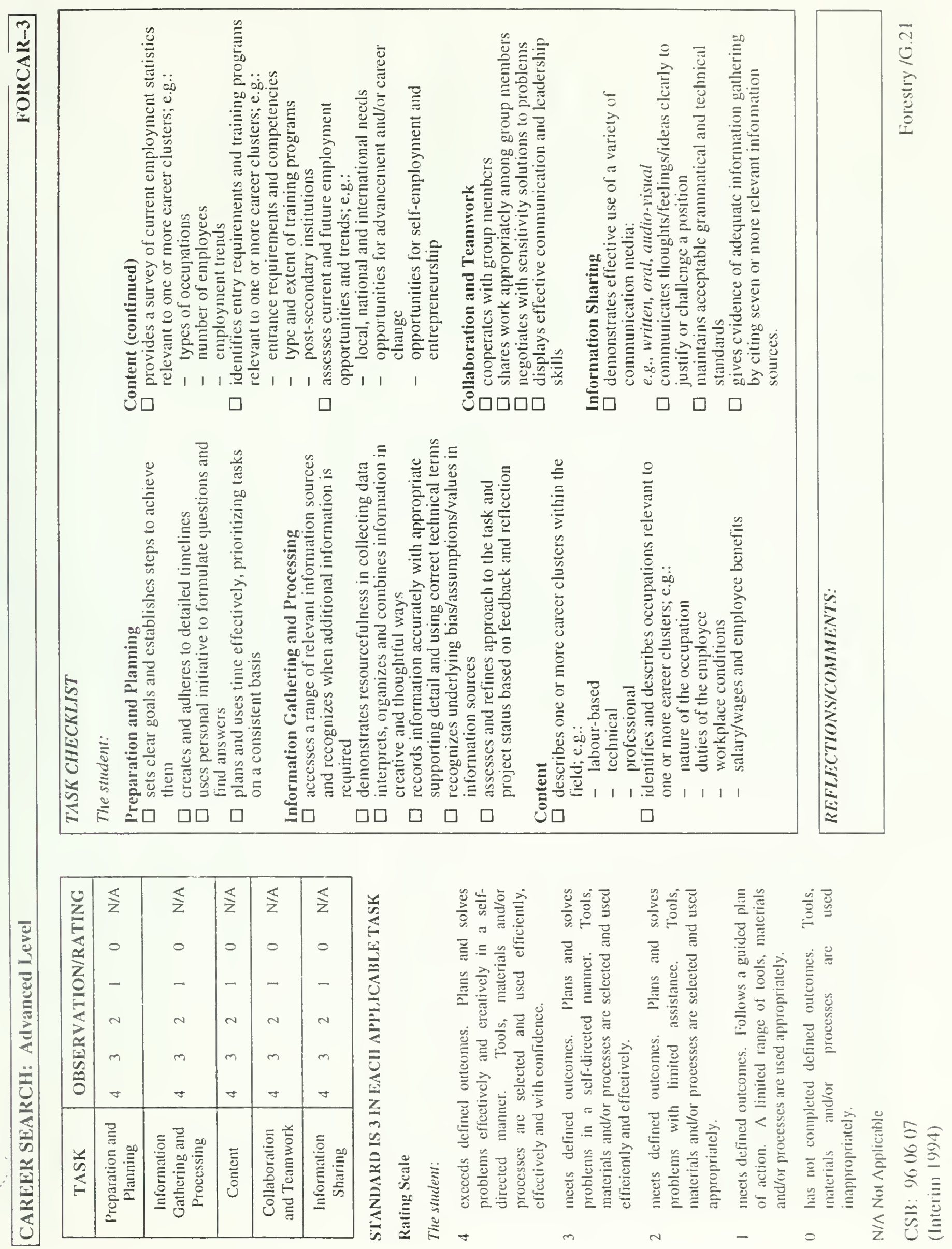

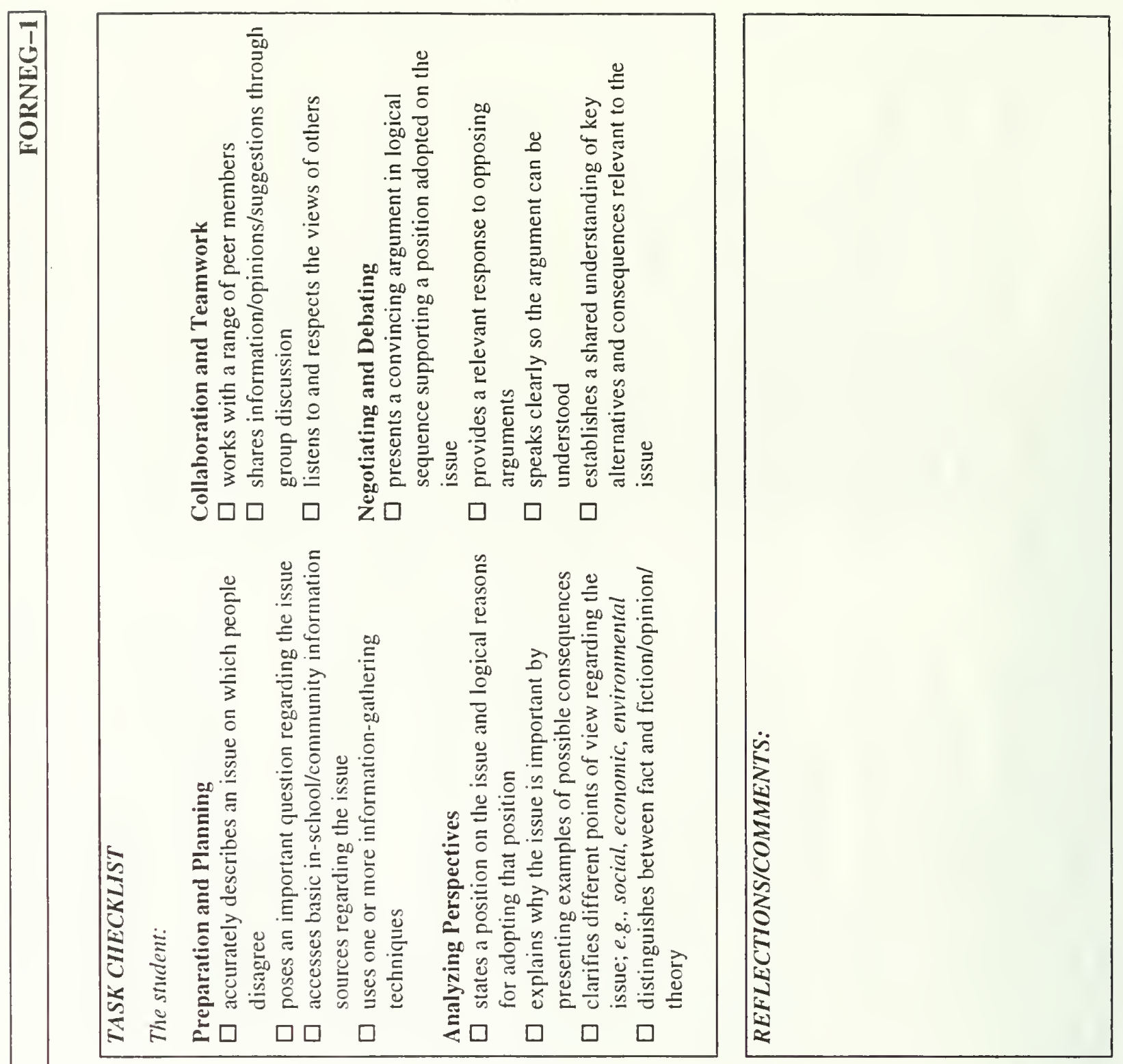

5
8
0
0
0
0

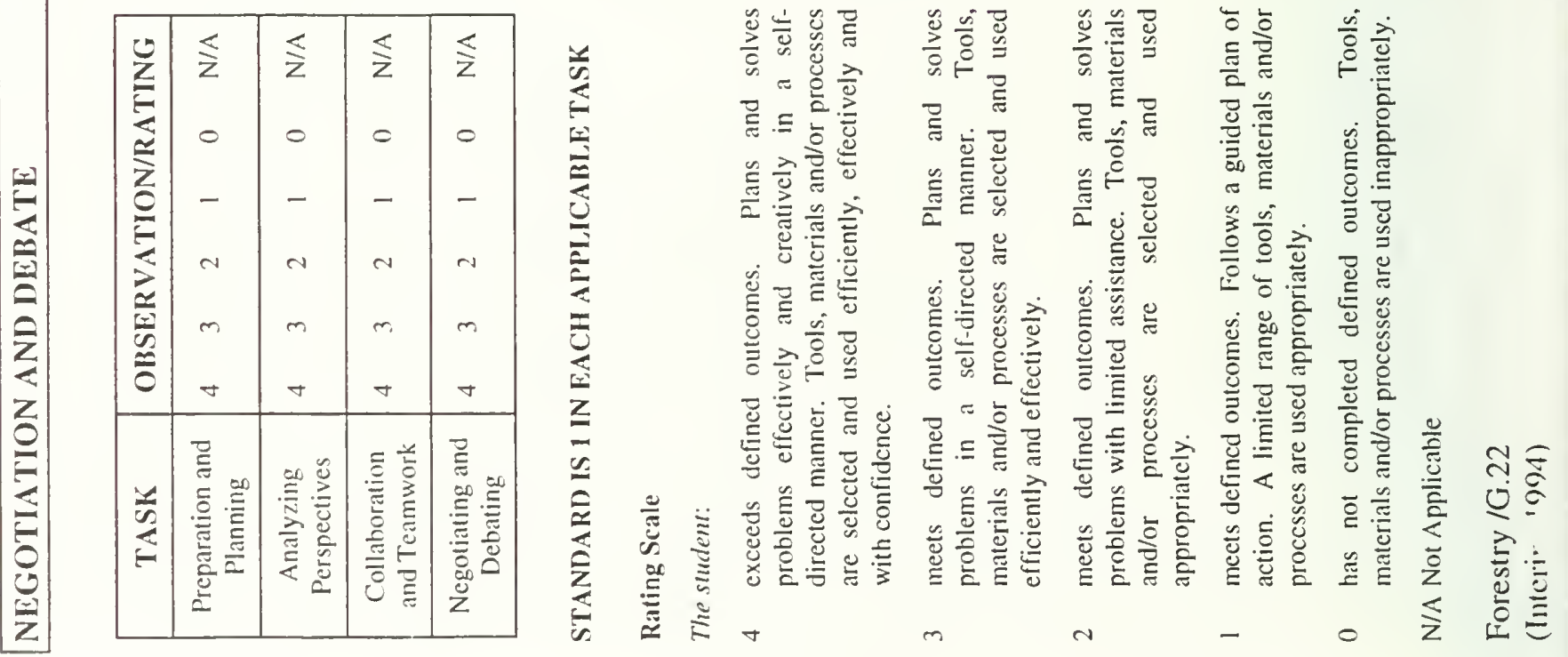



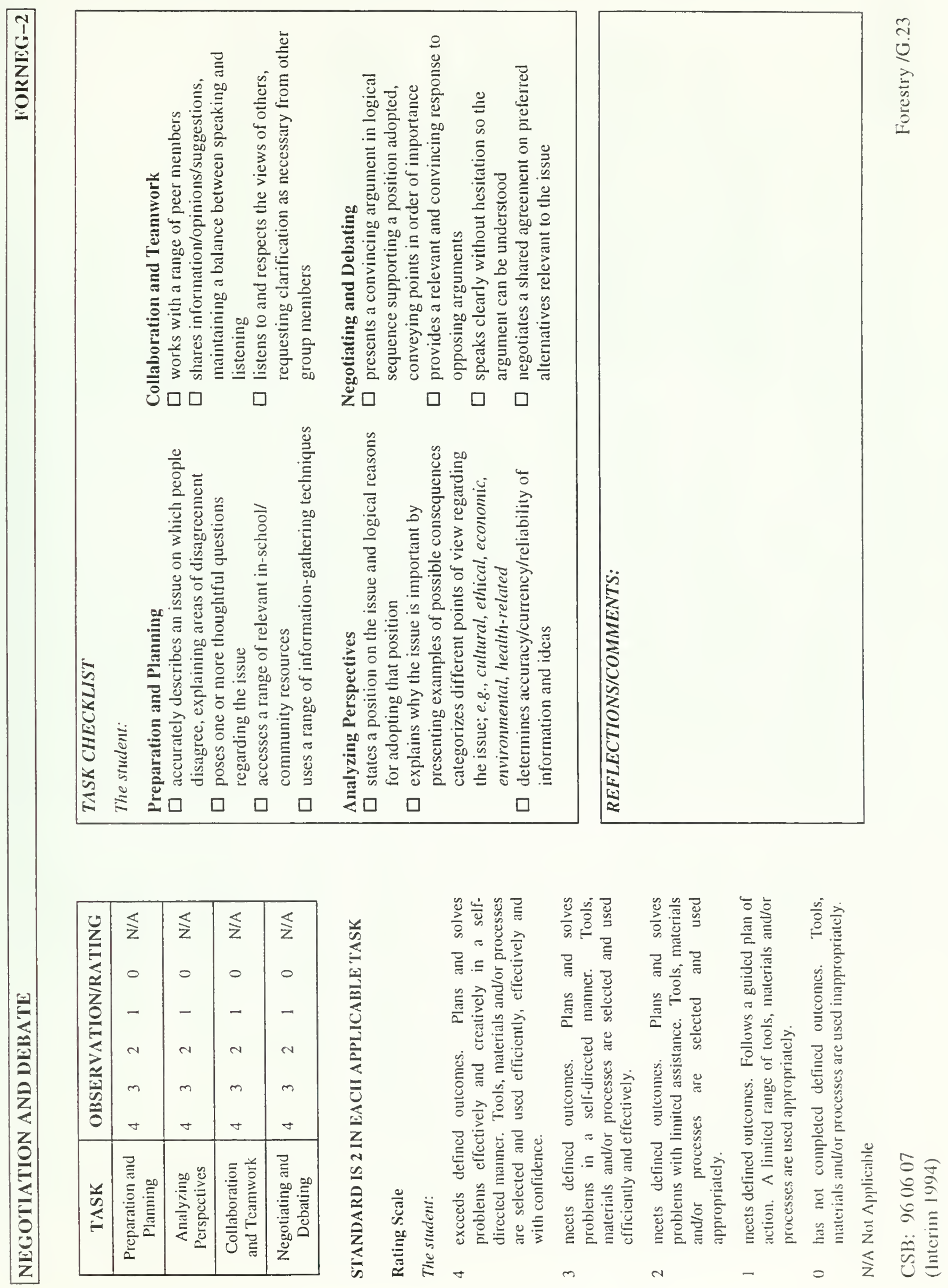

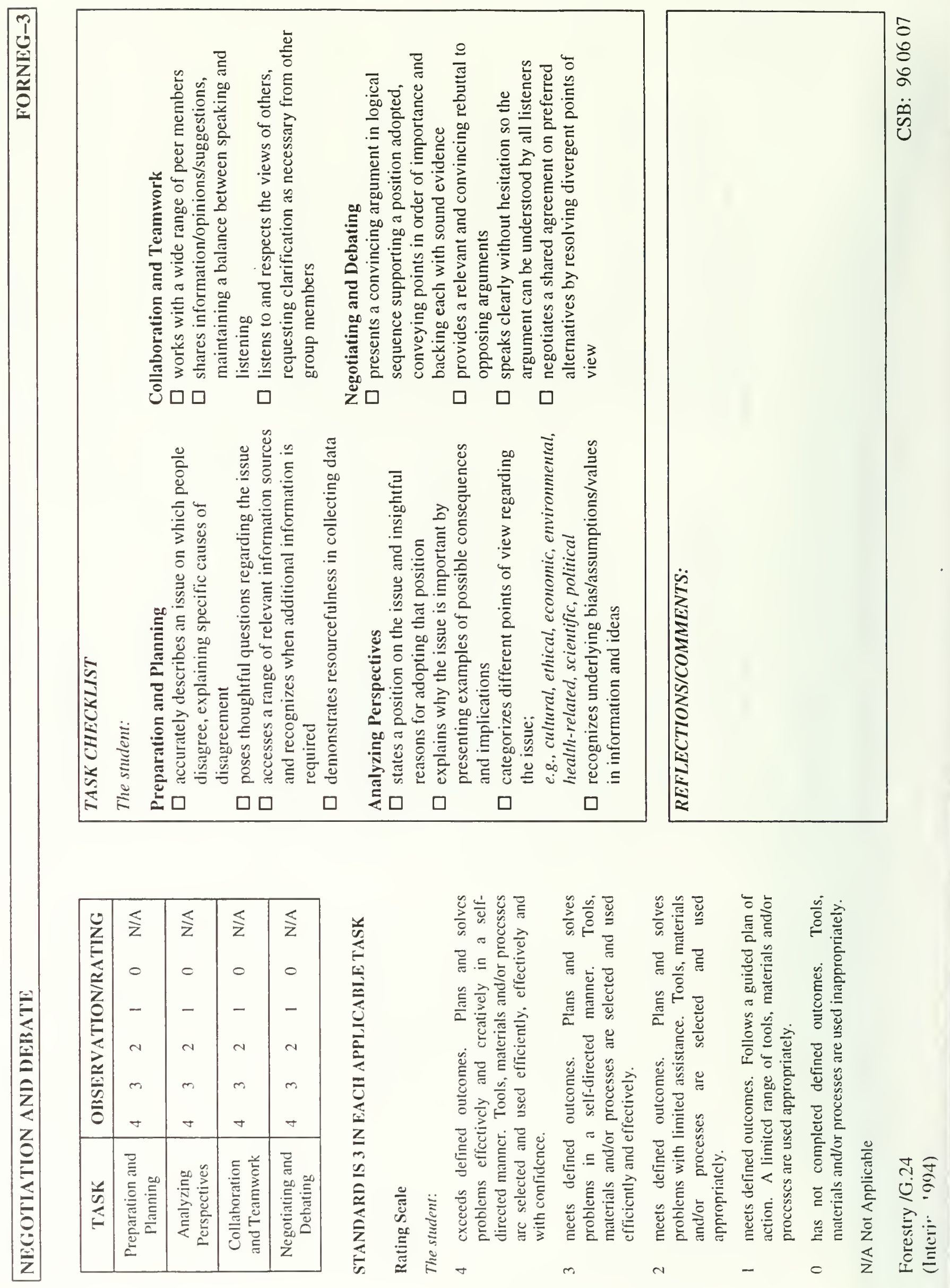


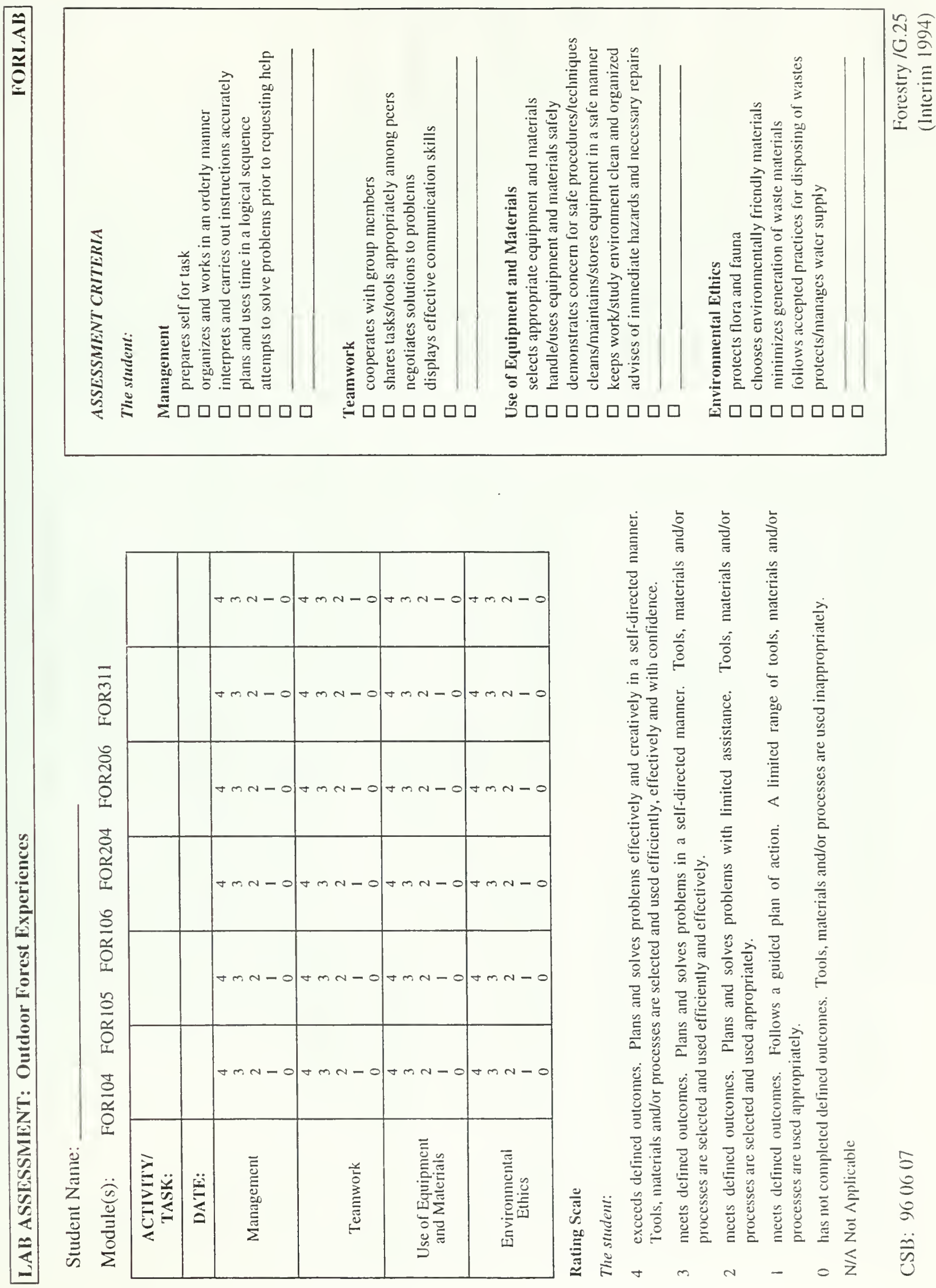




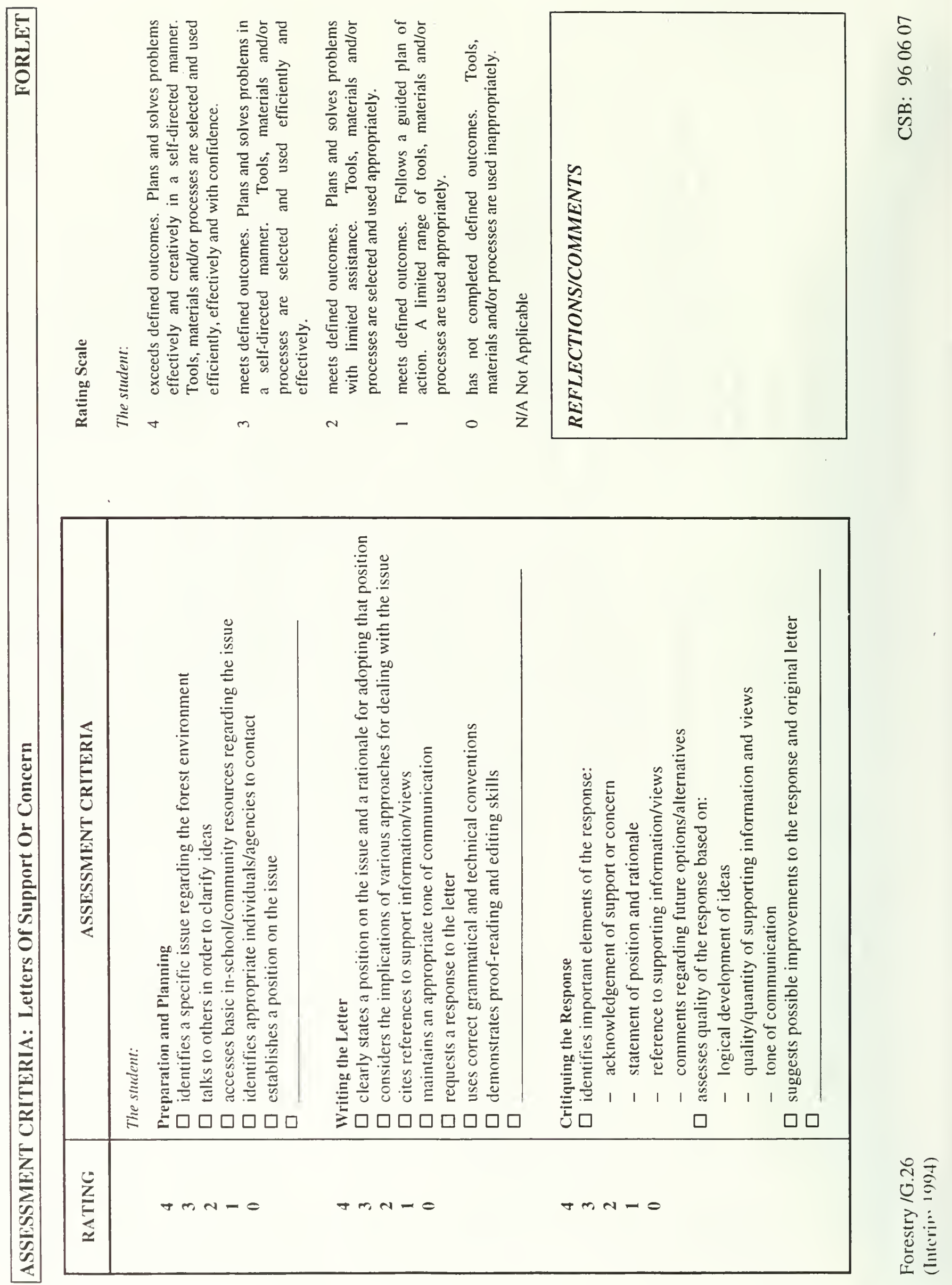



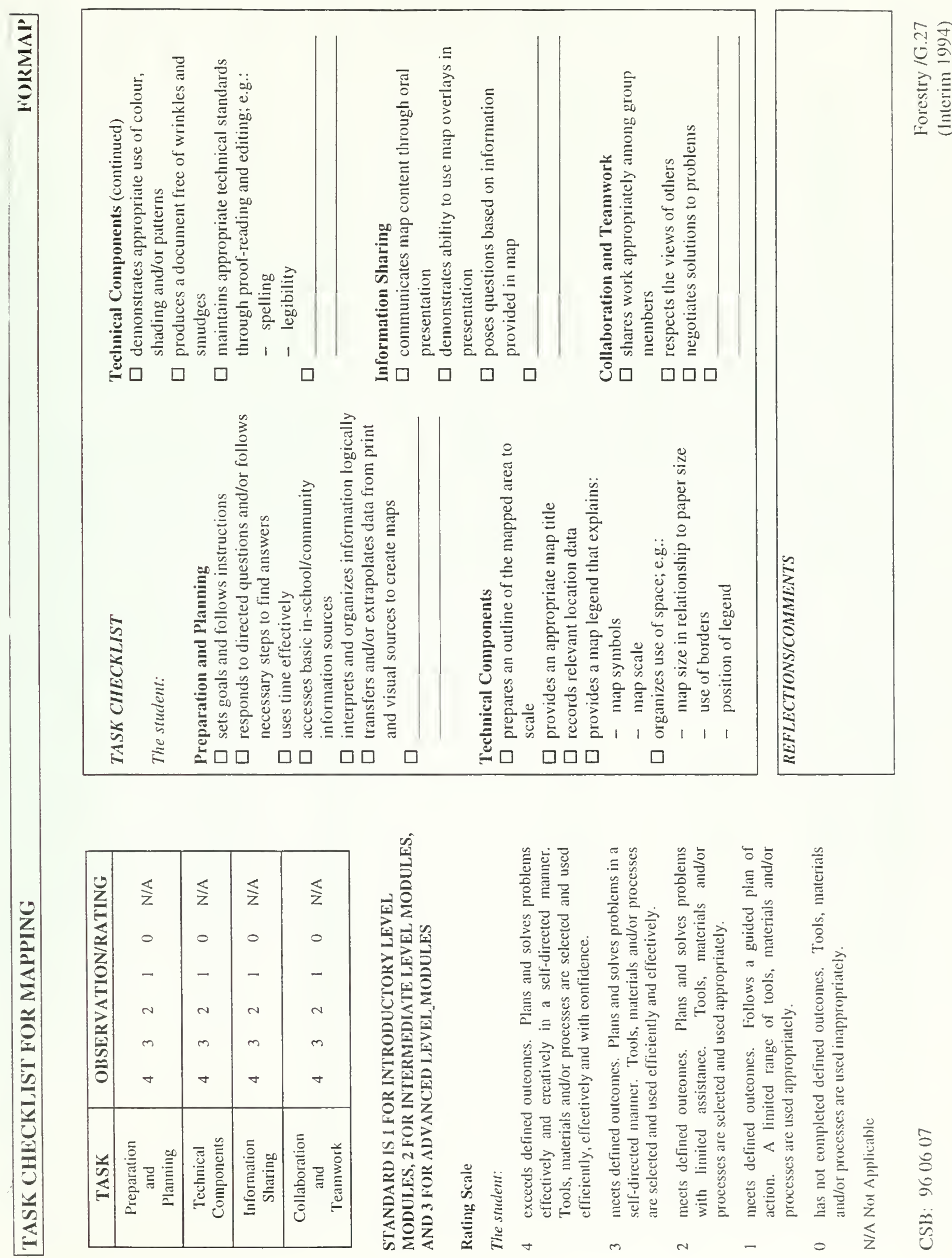

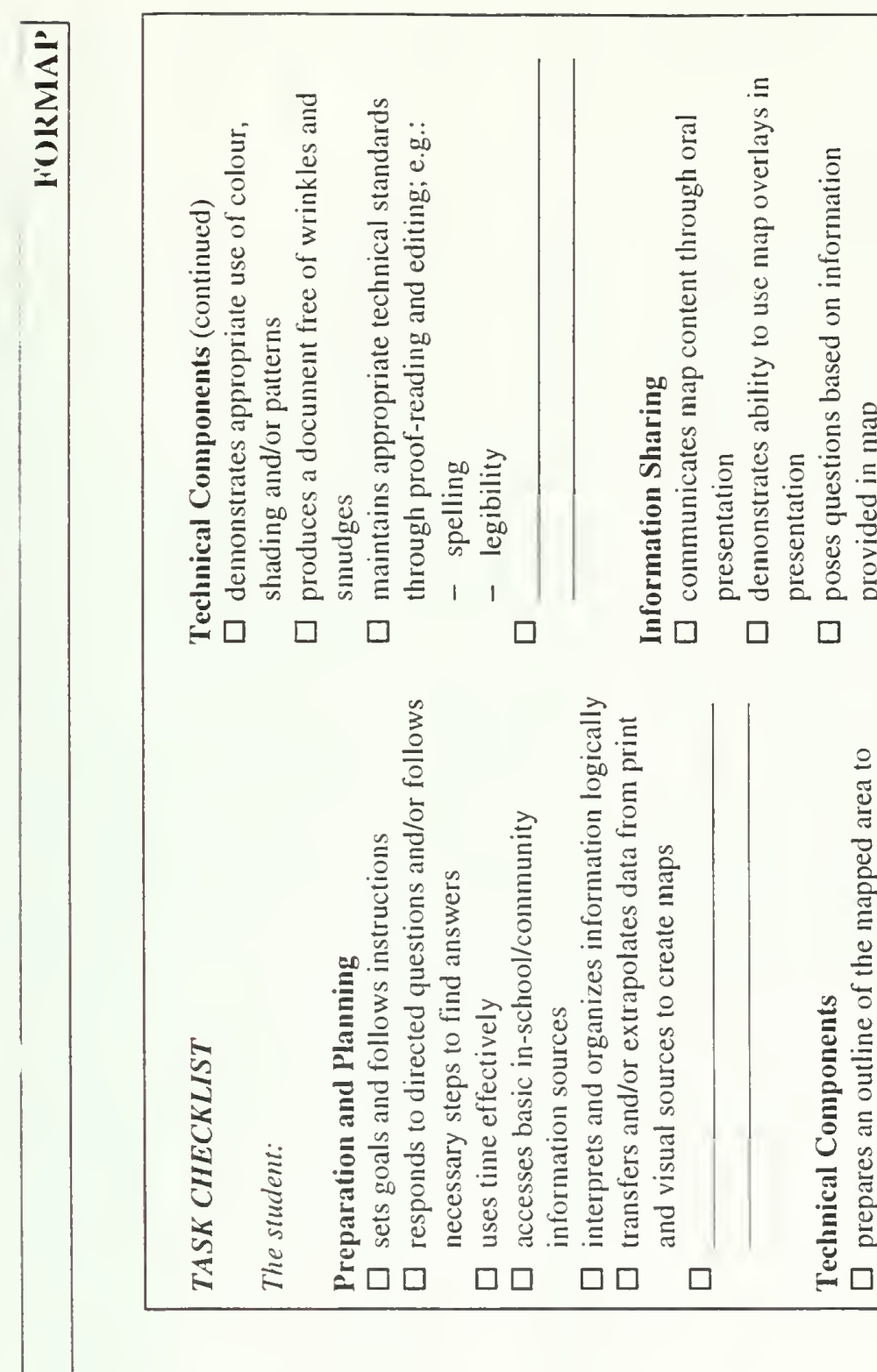

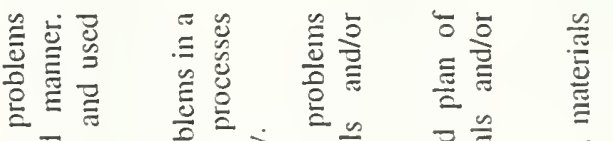

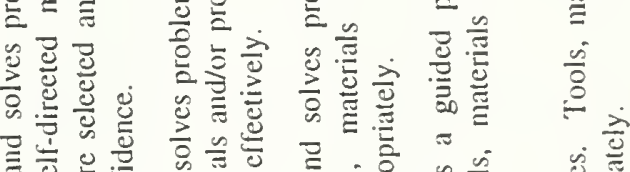

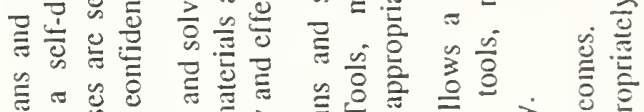

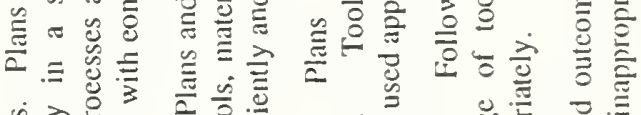

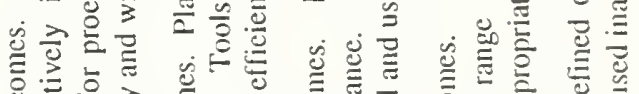

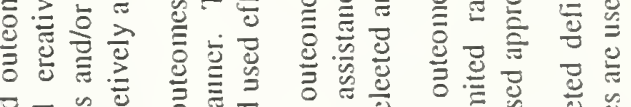

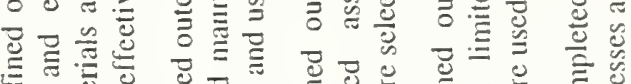

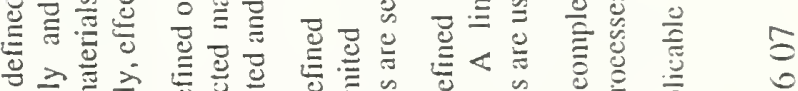

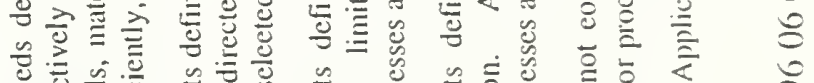

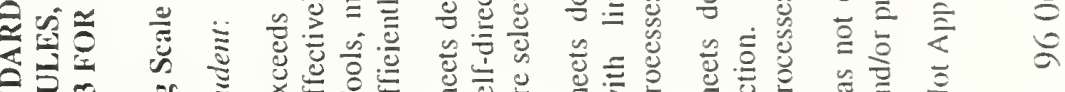

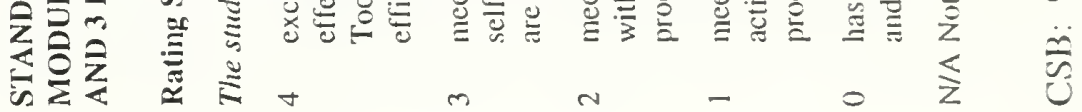




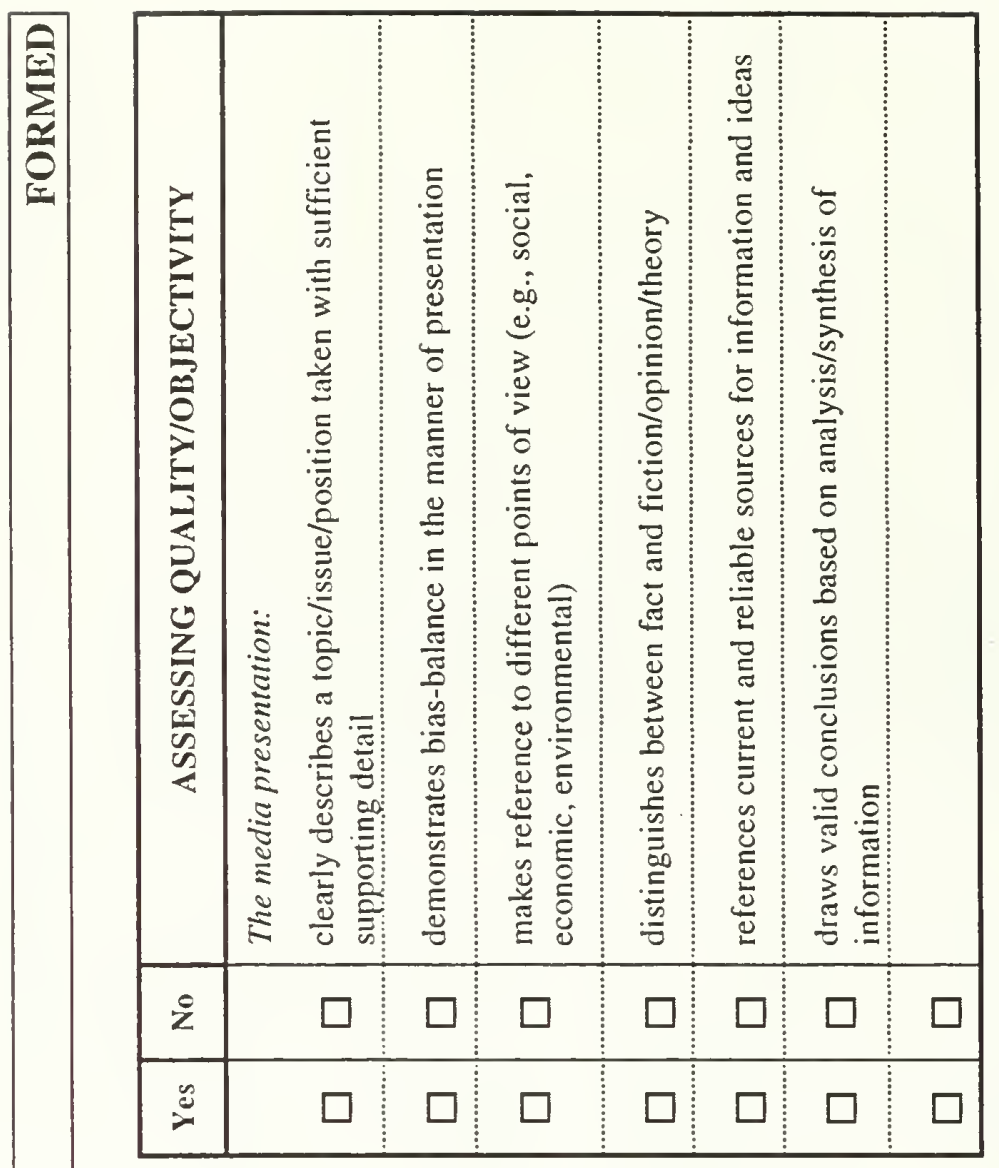

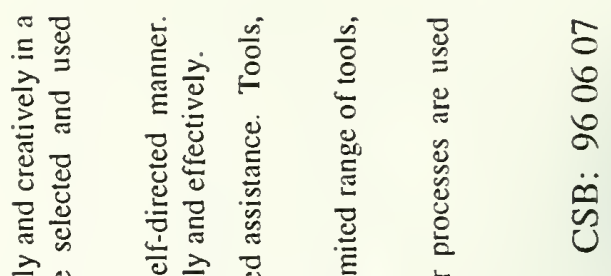

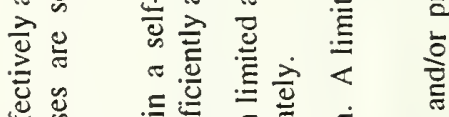

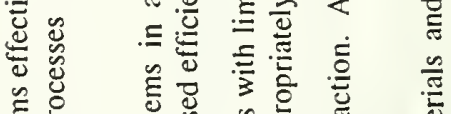

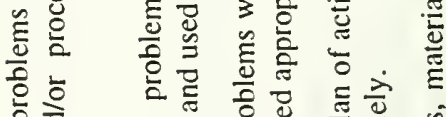

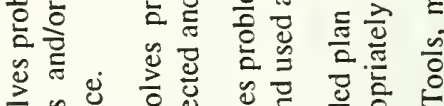

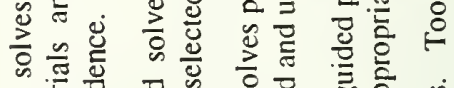

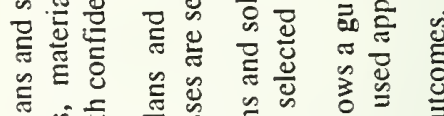

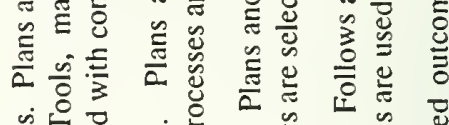

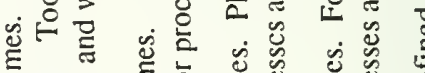

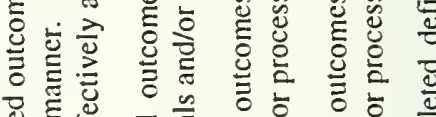

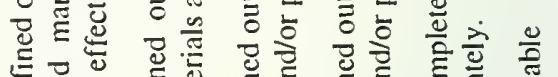

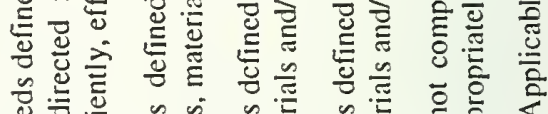

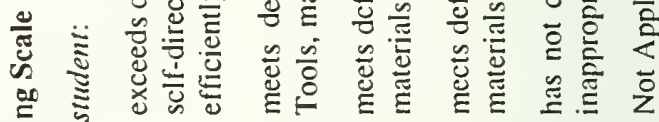

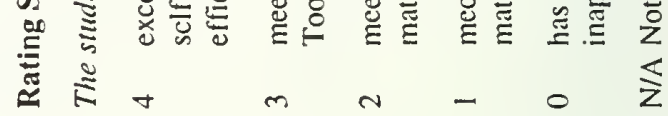

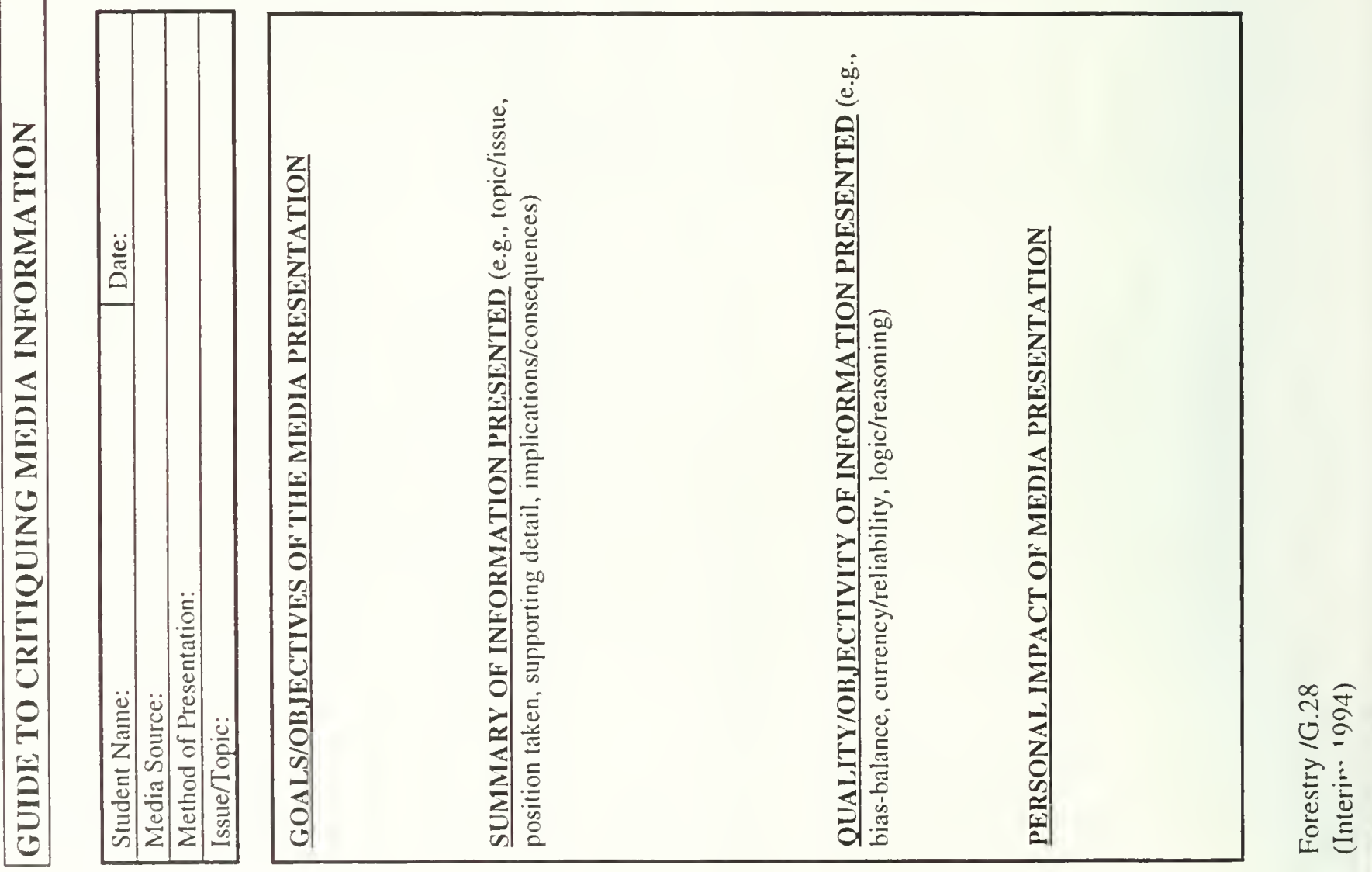




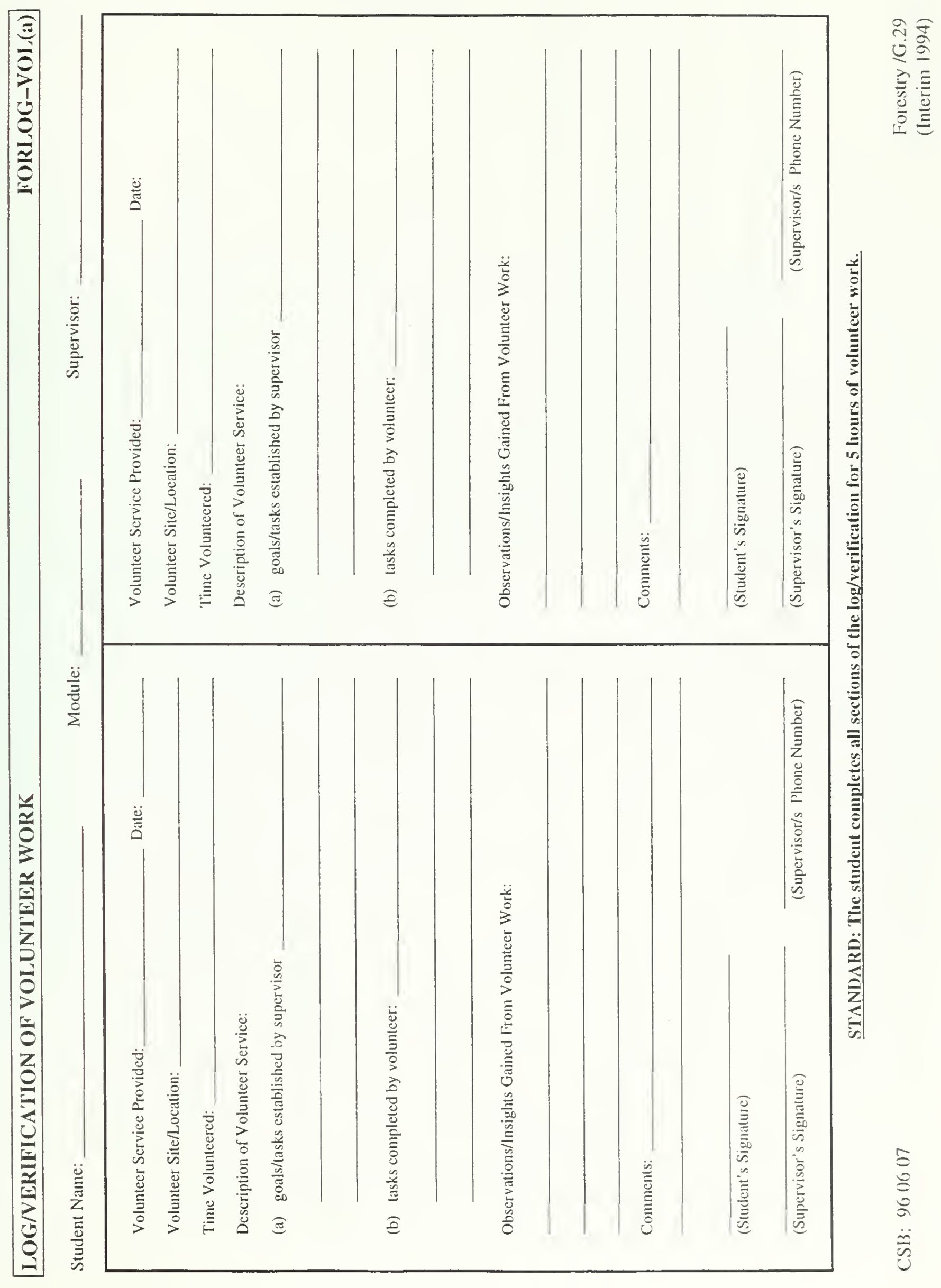




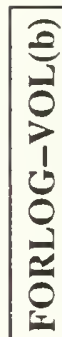
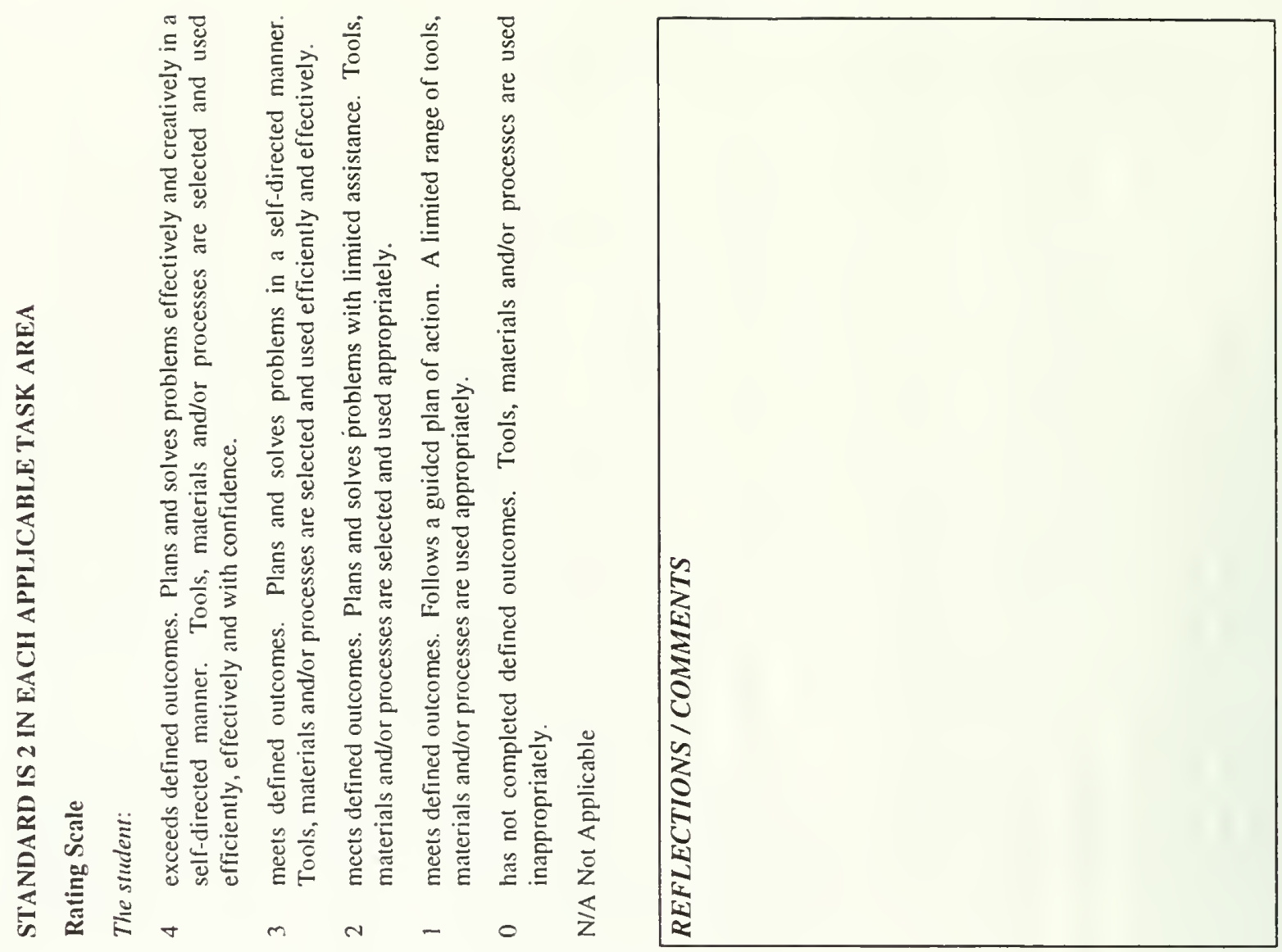

5
0
8
0
0
$\ddot{0}$
0
0
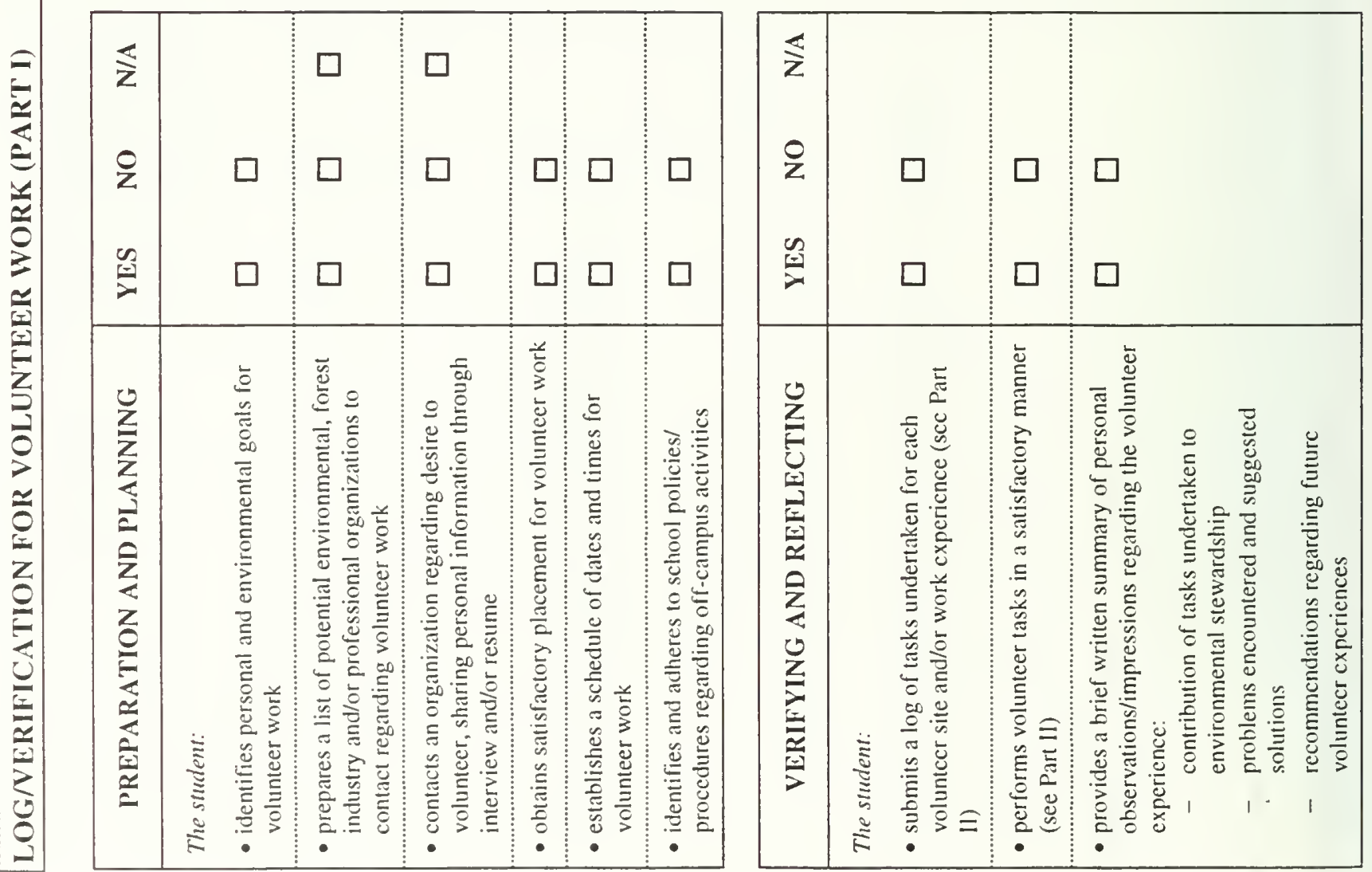

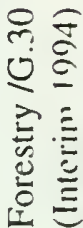




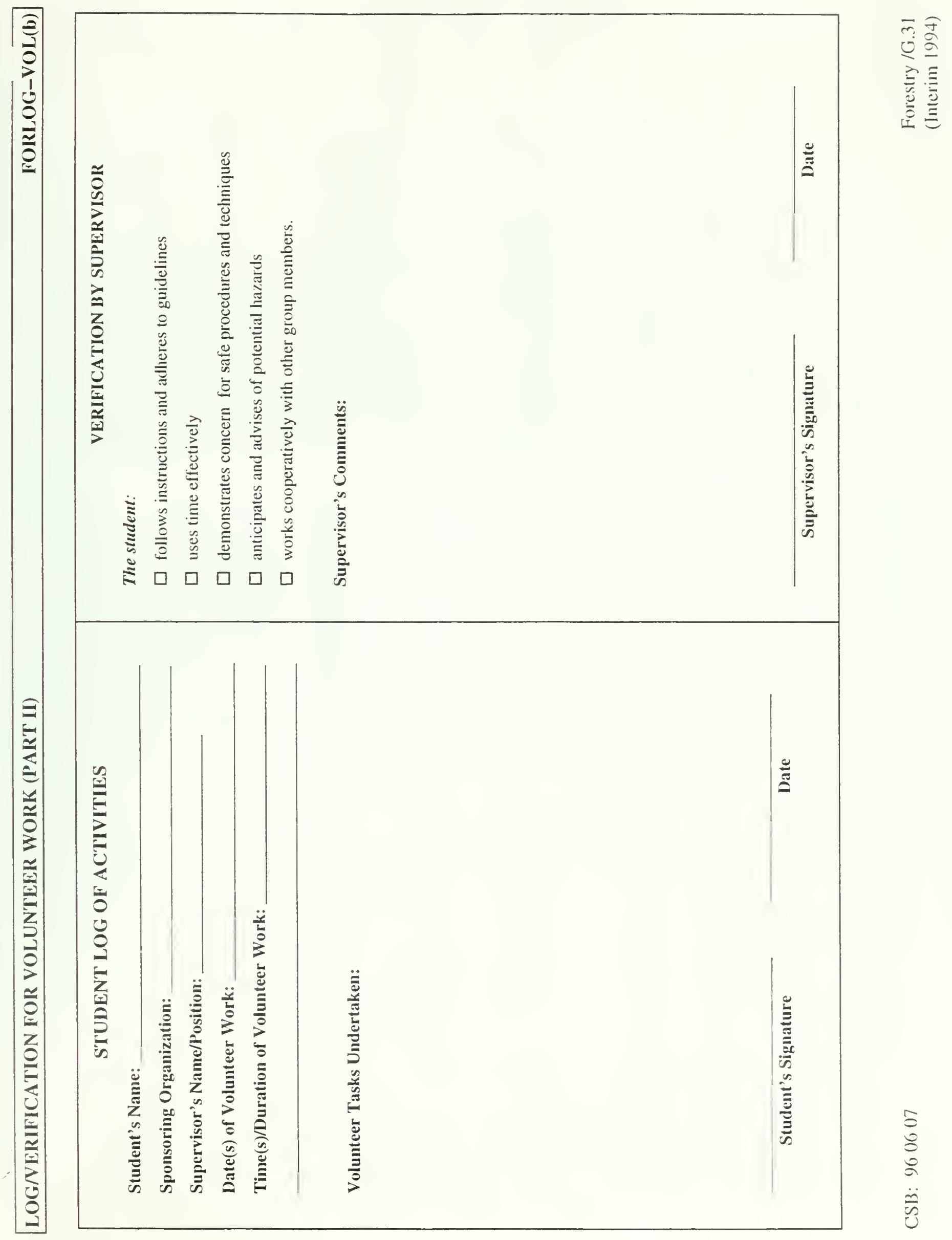




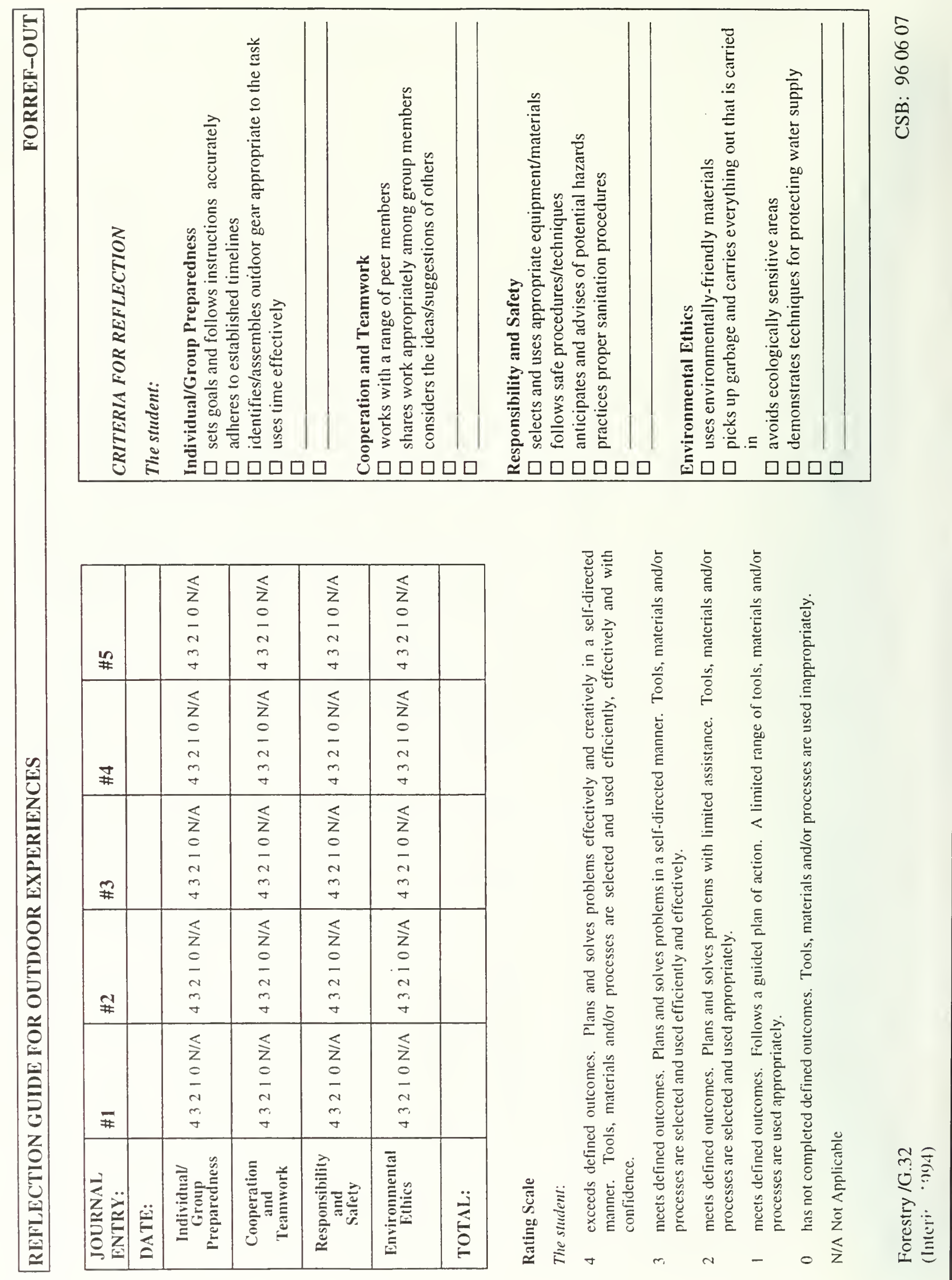




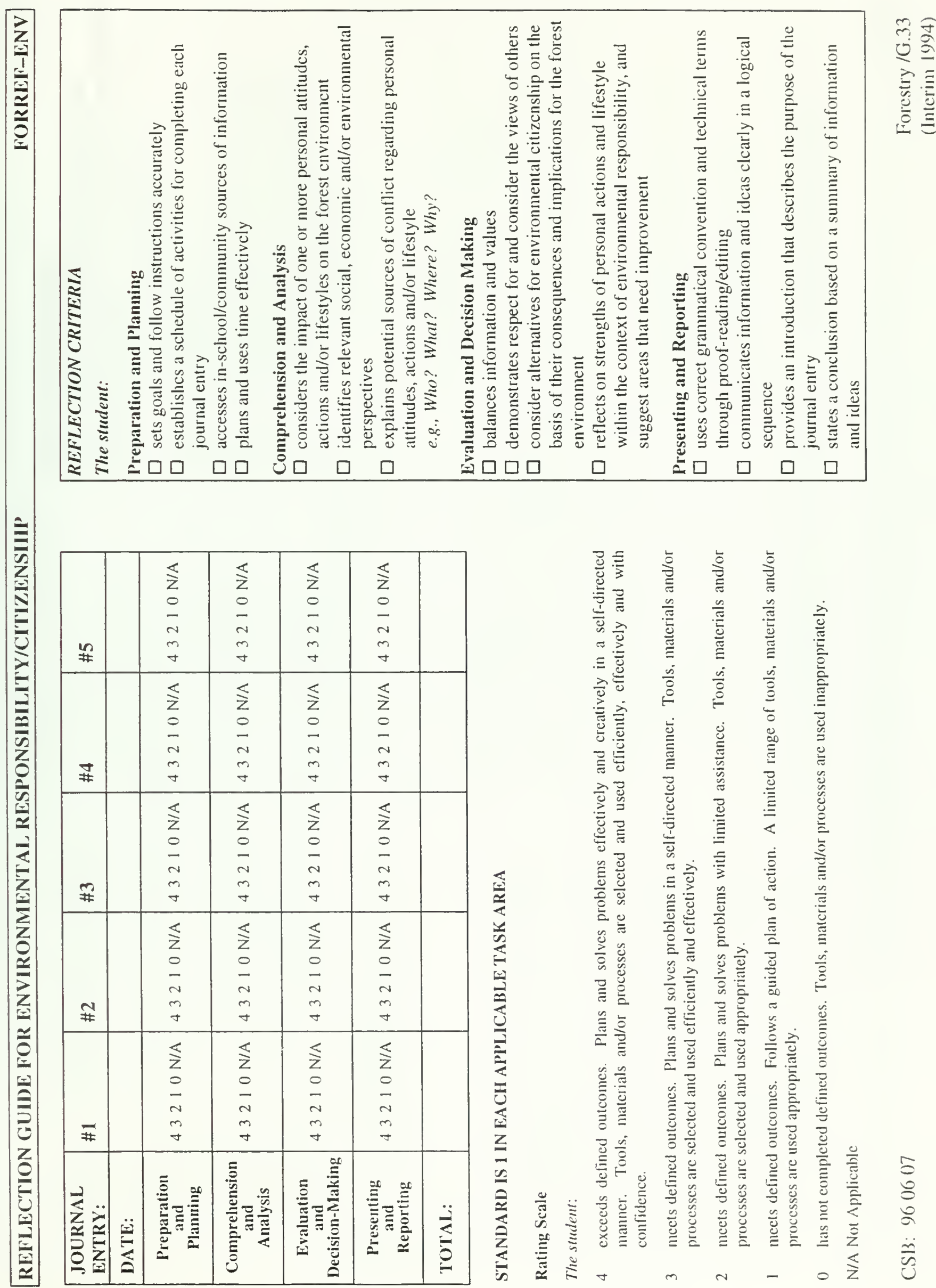



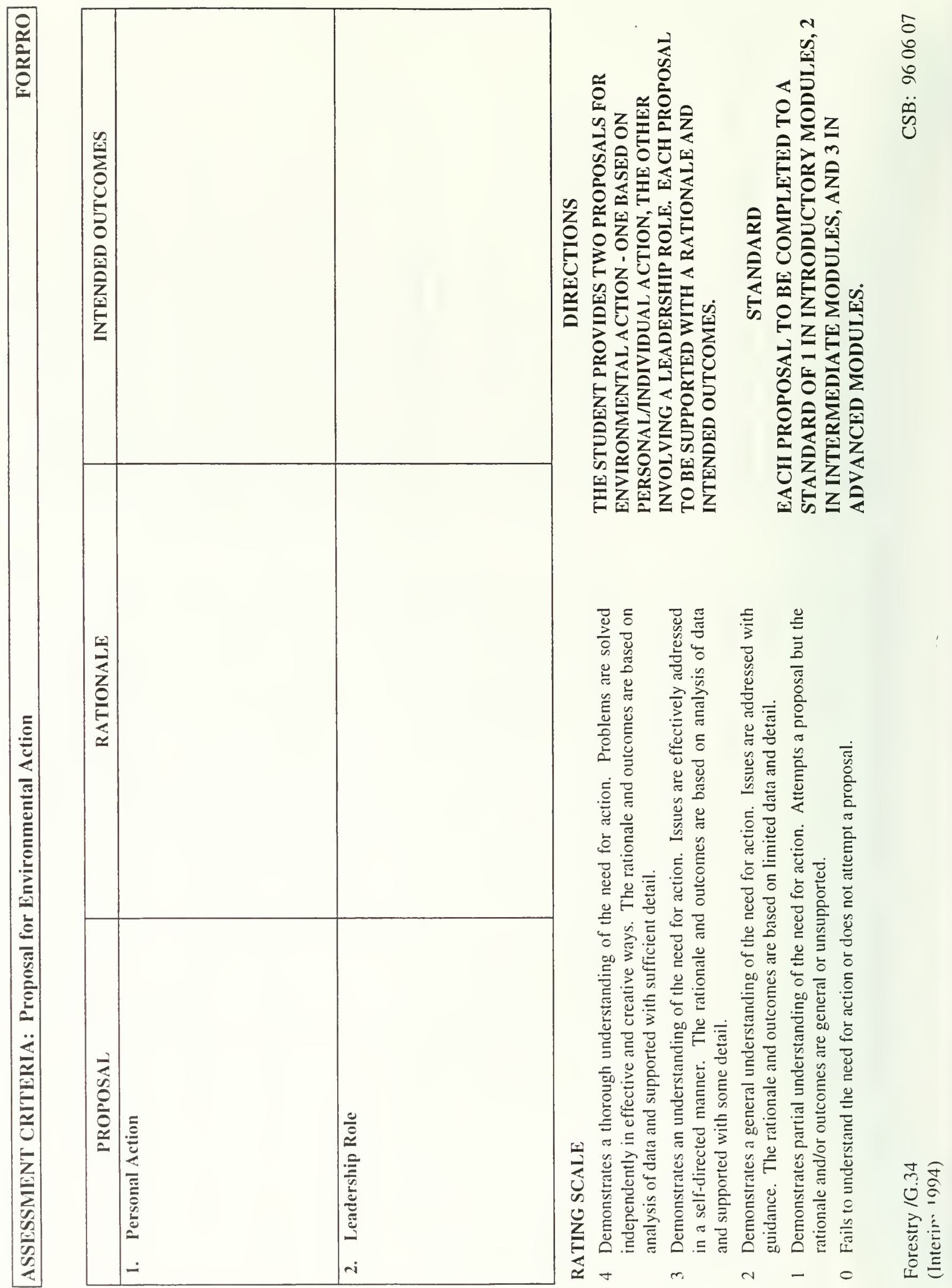

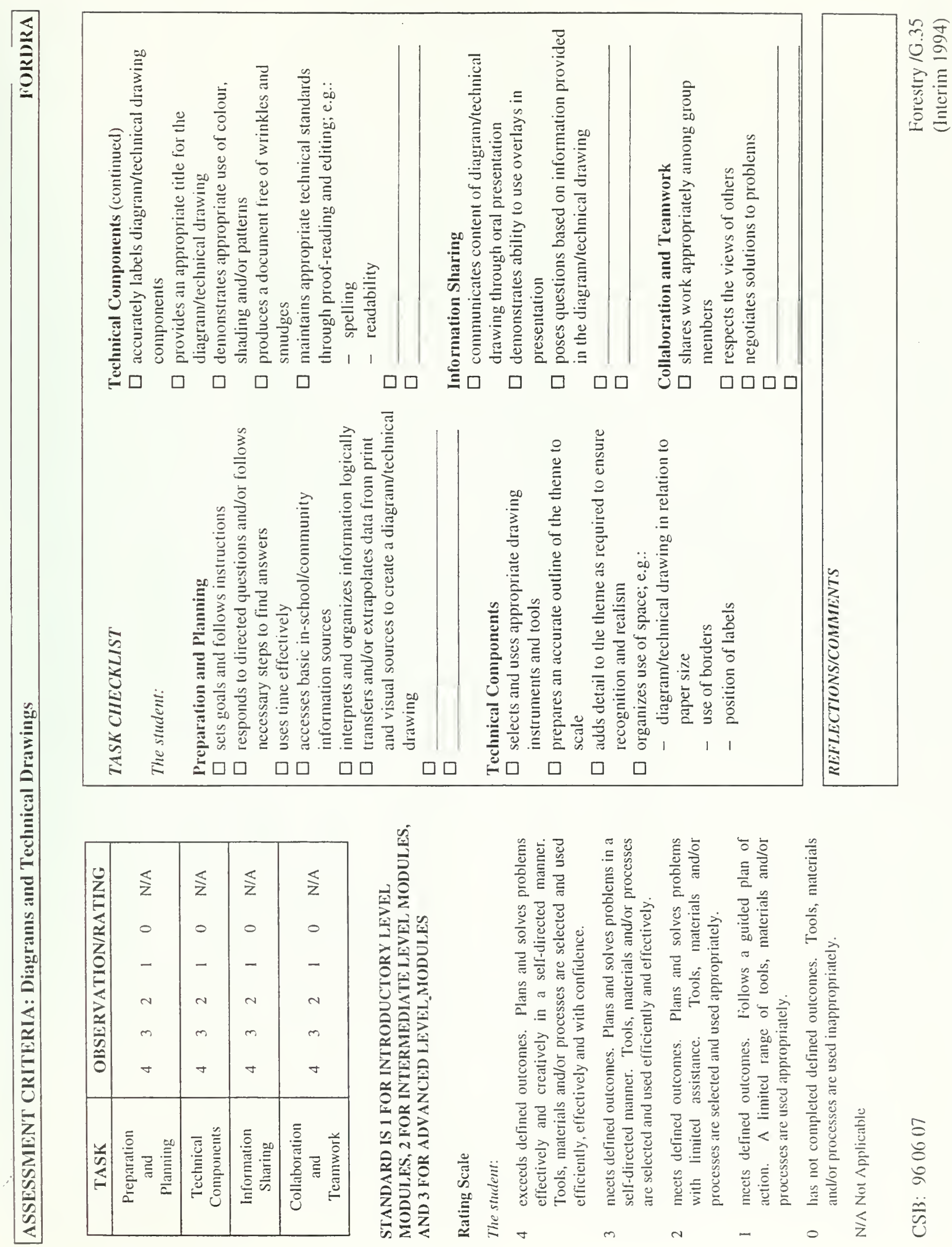


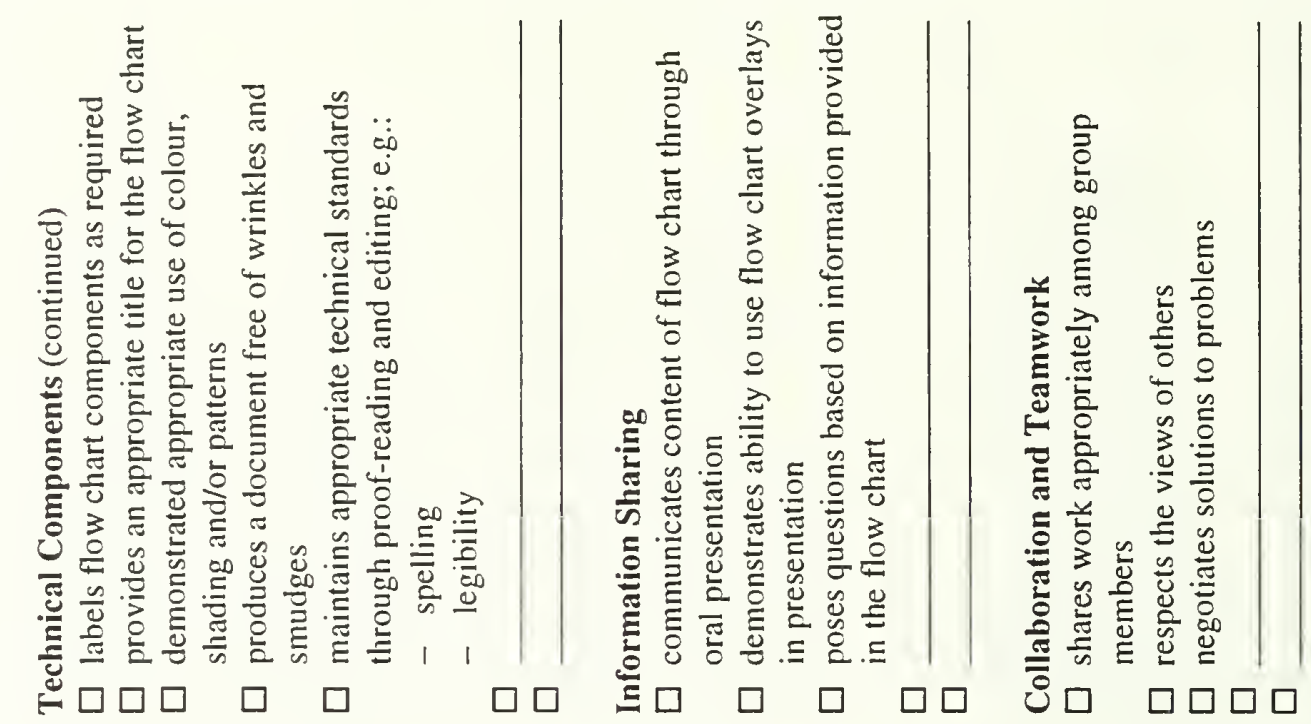

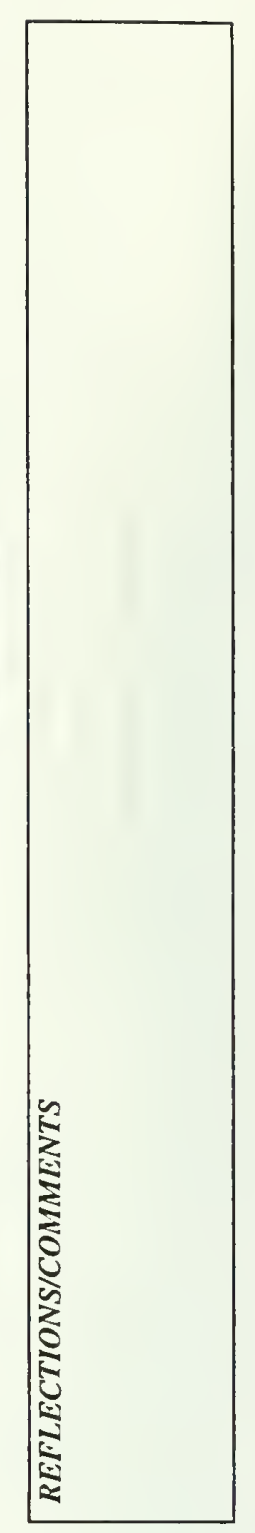

5
8
8
0
$\ddot{v}$
v
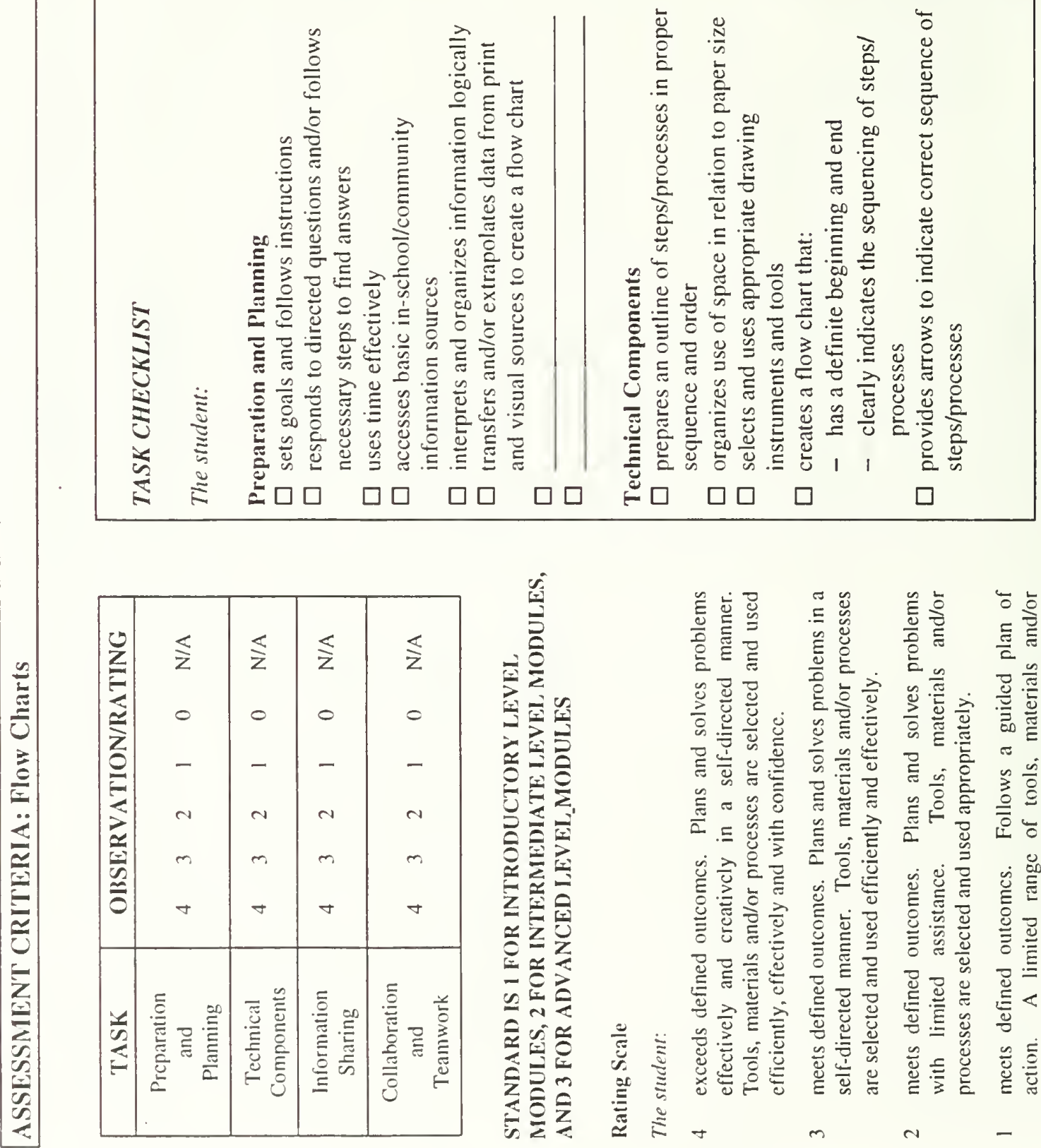

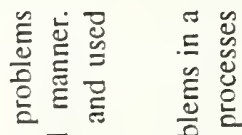

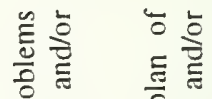

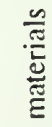

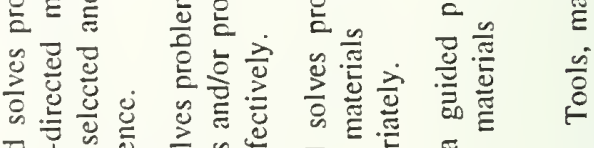

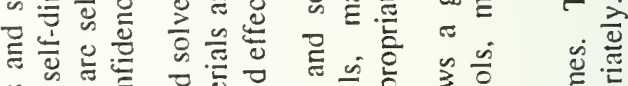

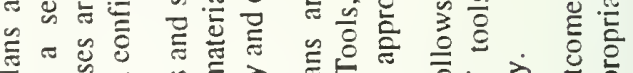

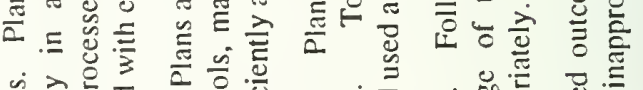

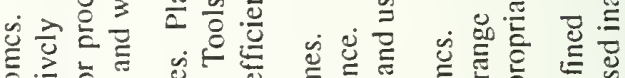

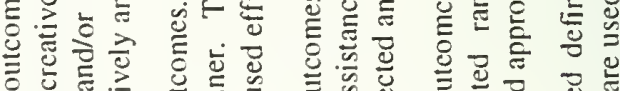

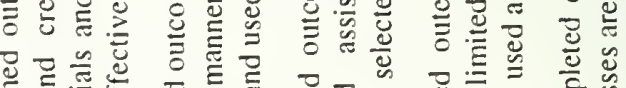

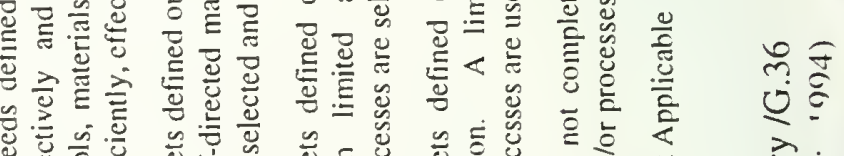

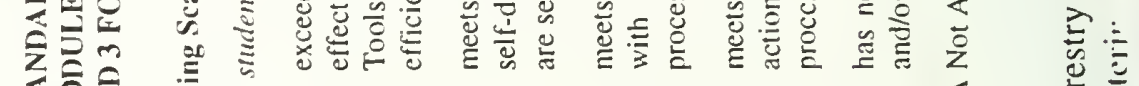

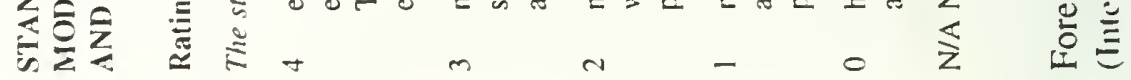



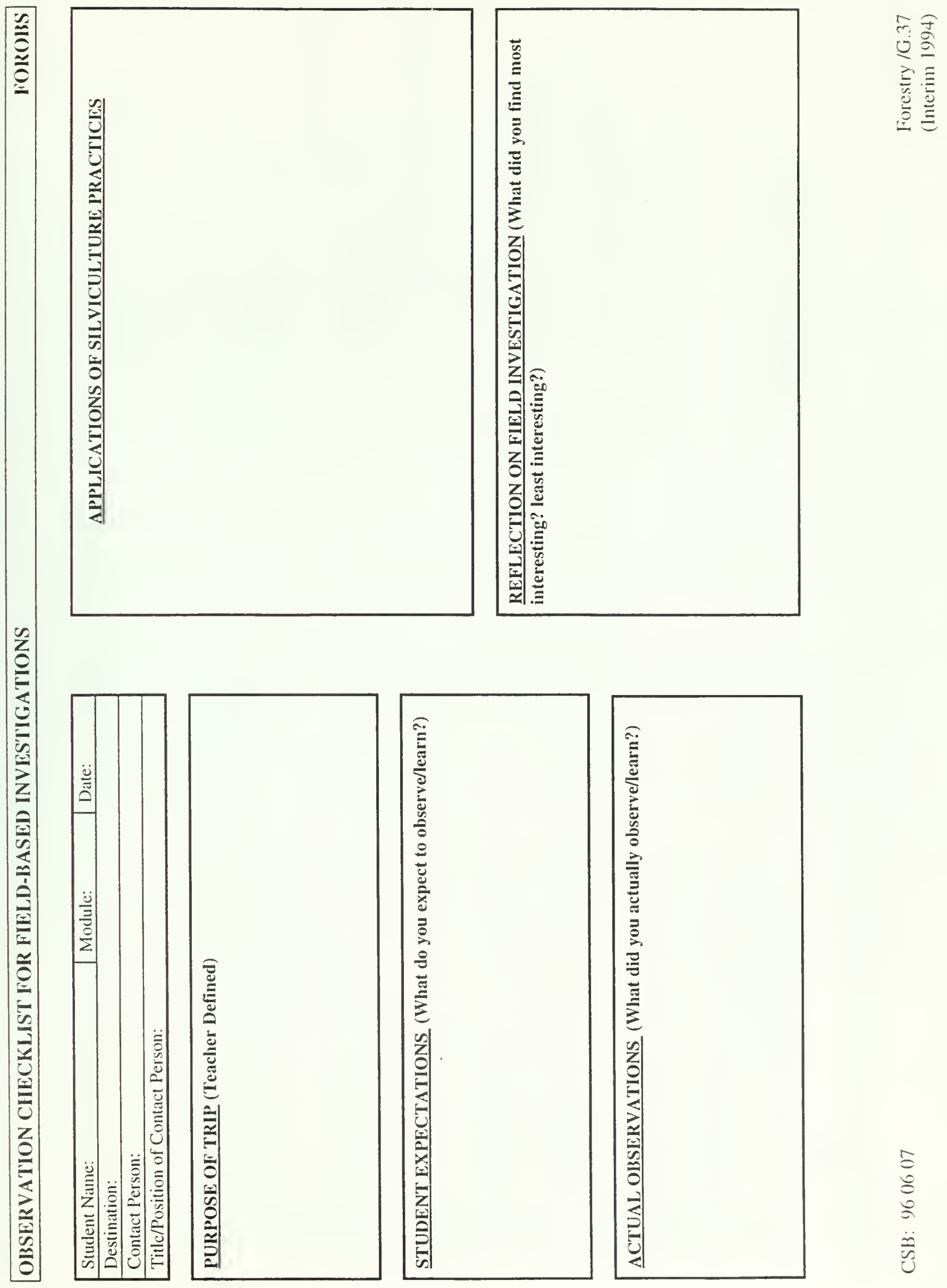

5
$\Xi$
0
$\vdots$
0
0 


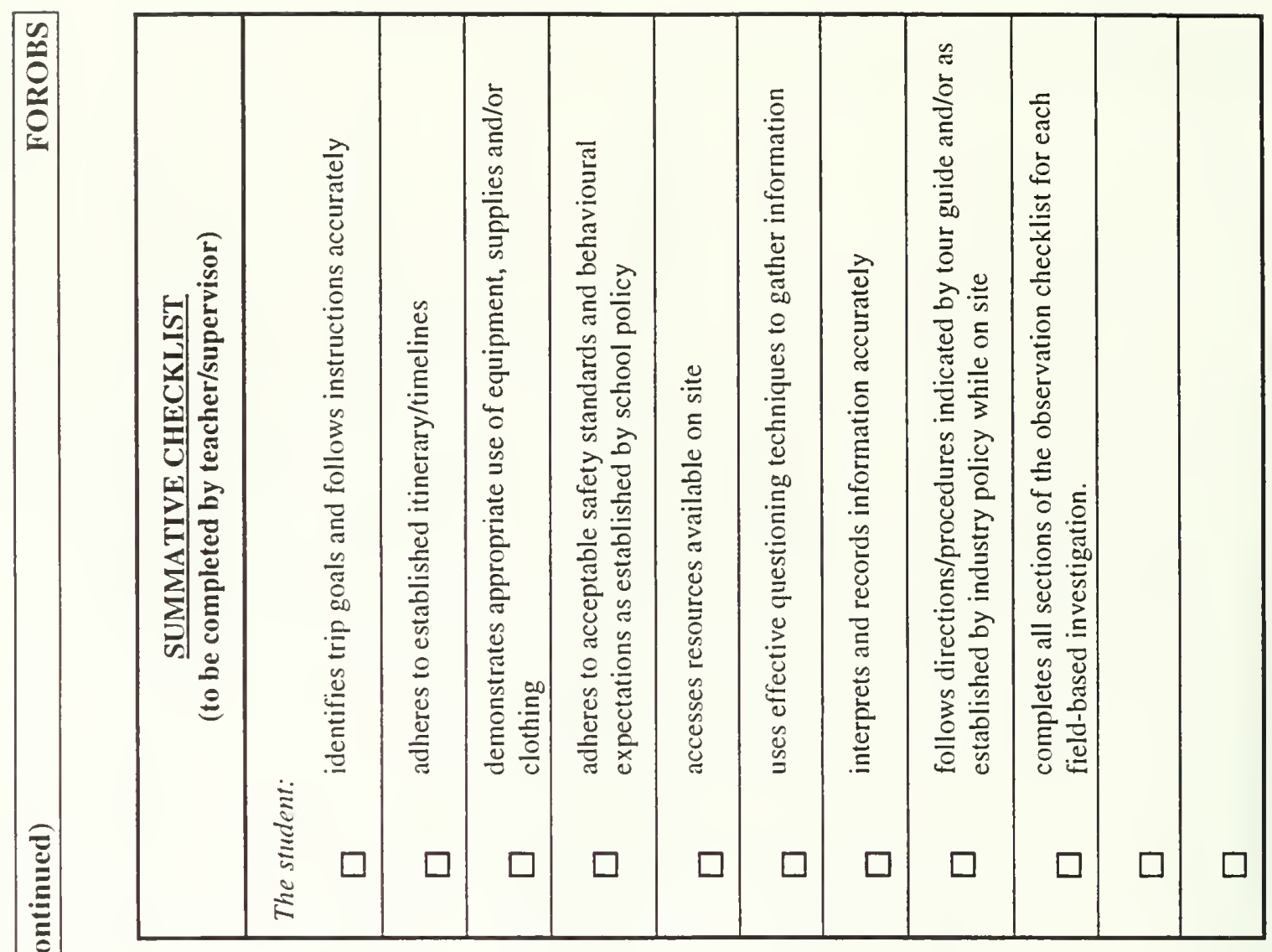

5
8
8
8
0
0
0
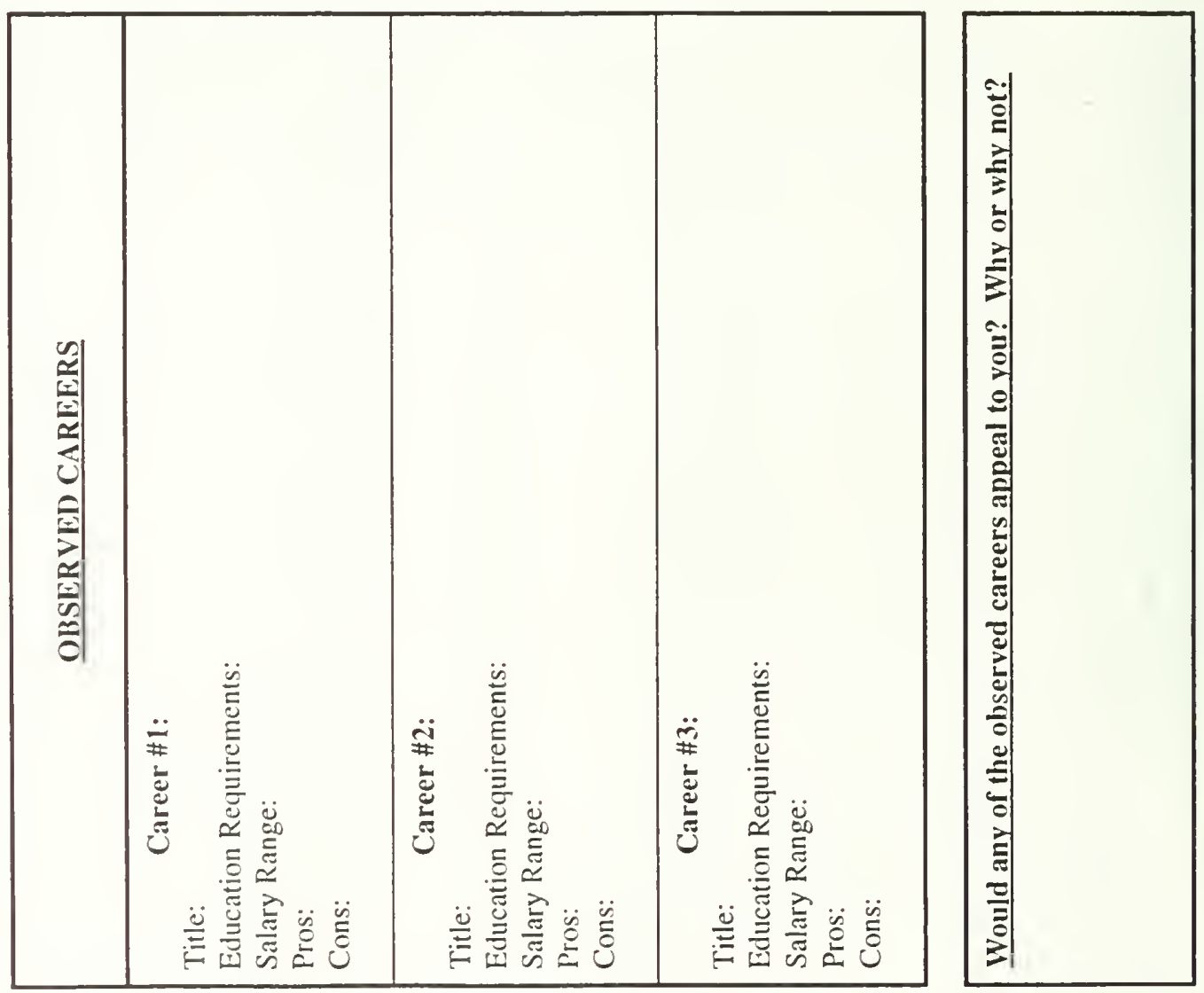

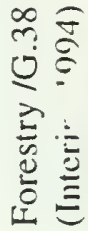




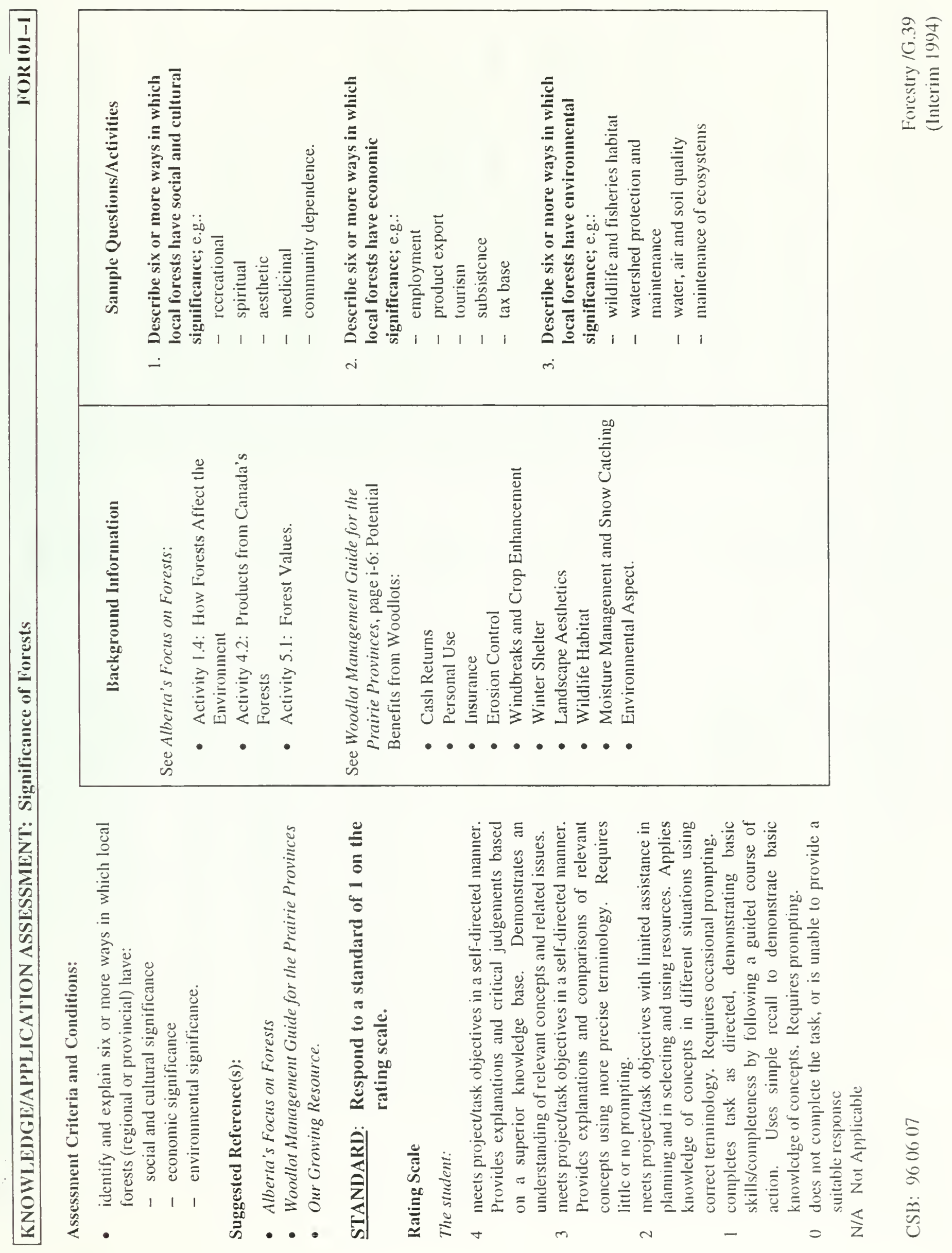




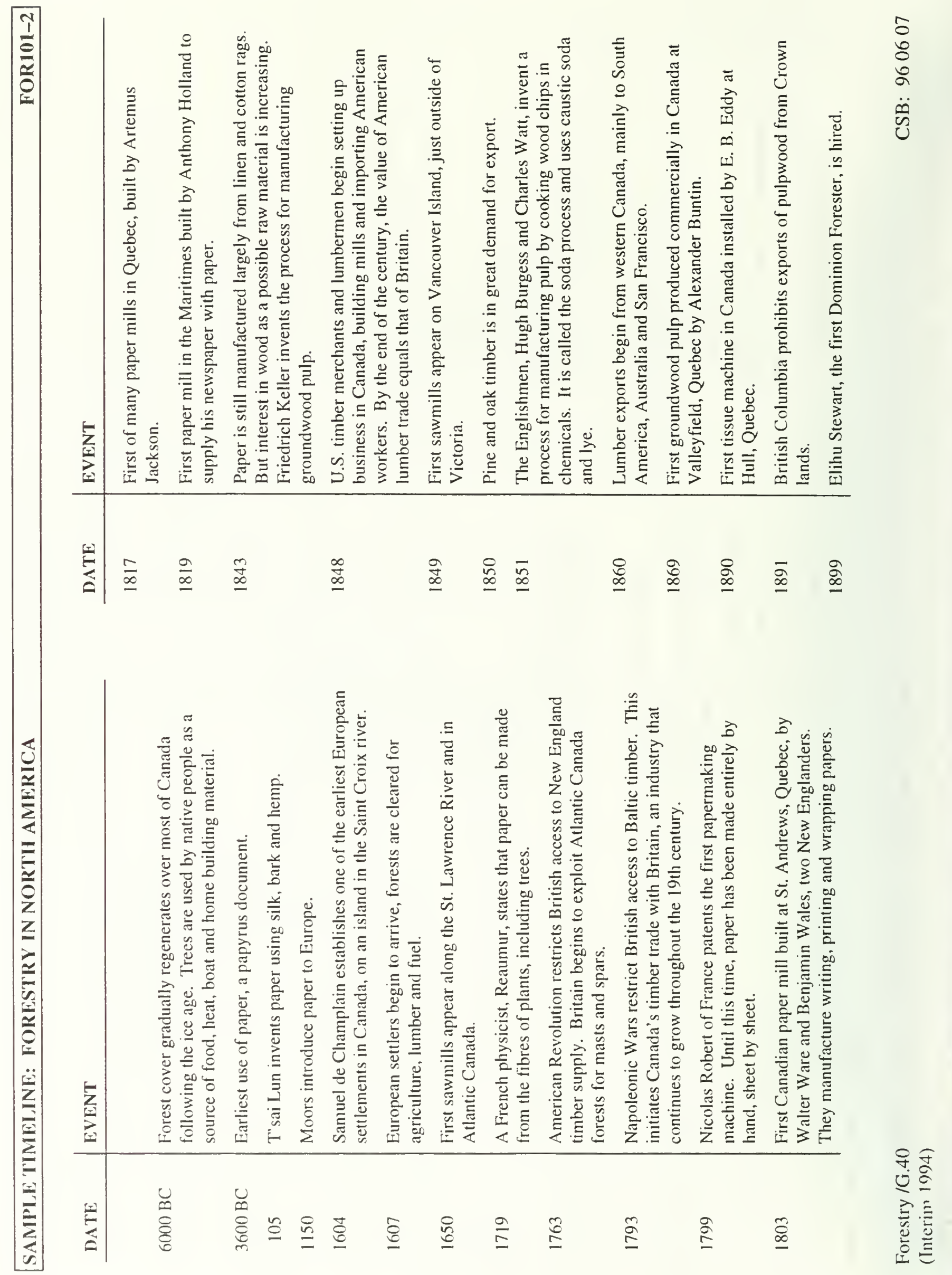




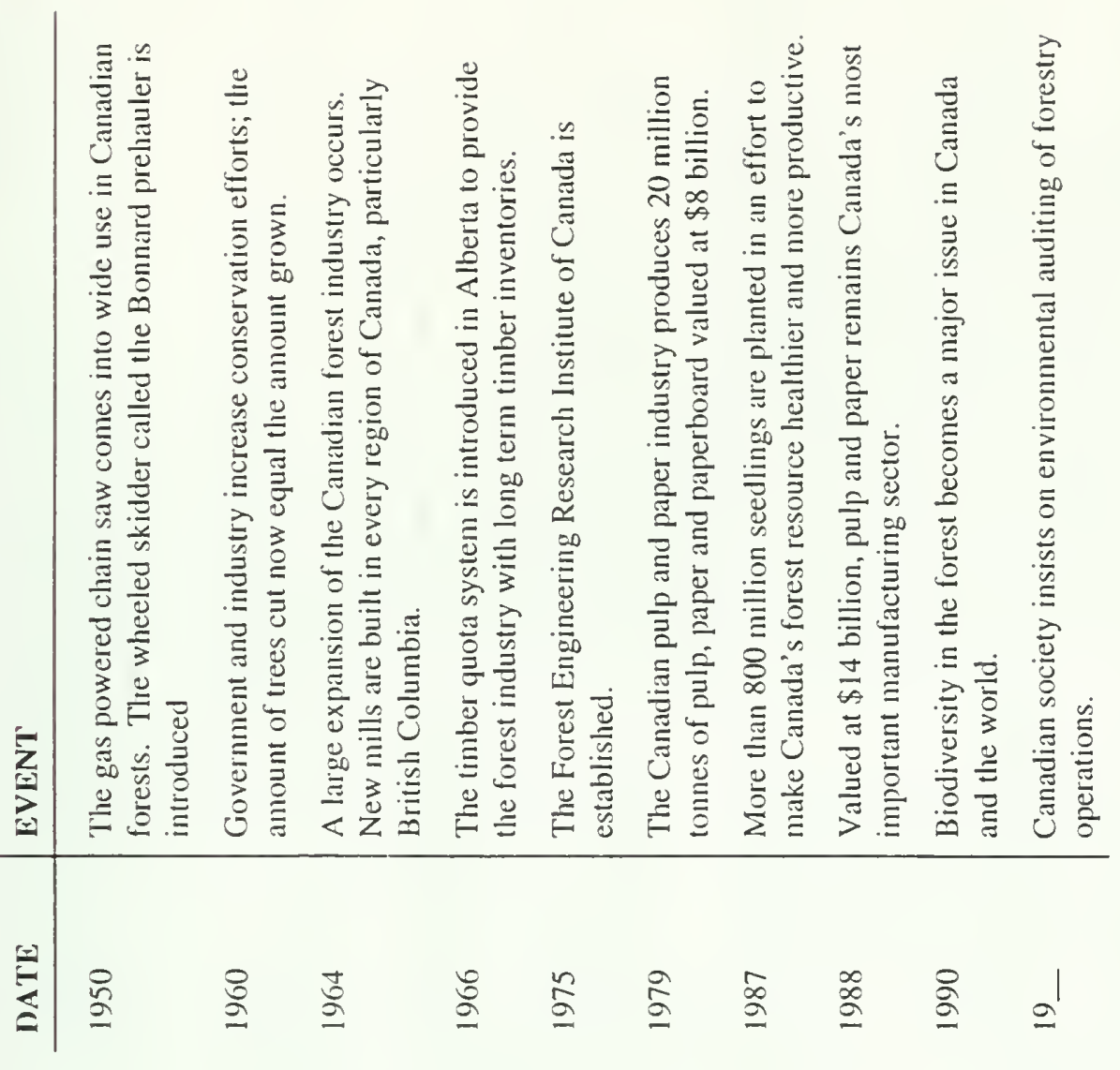

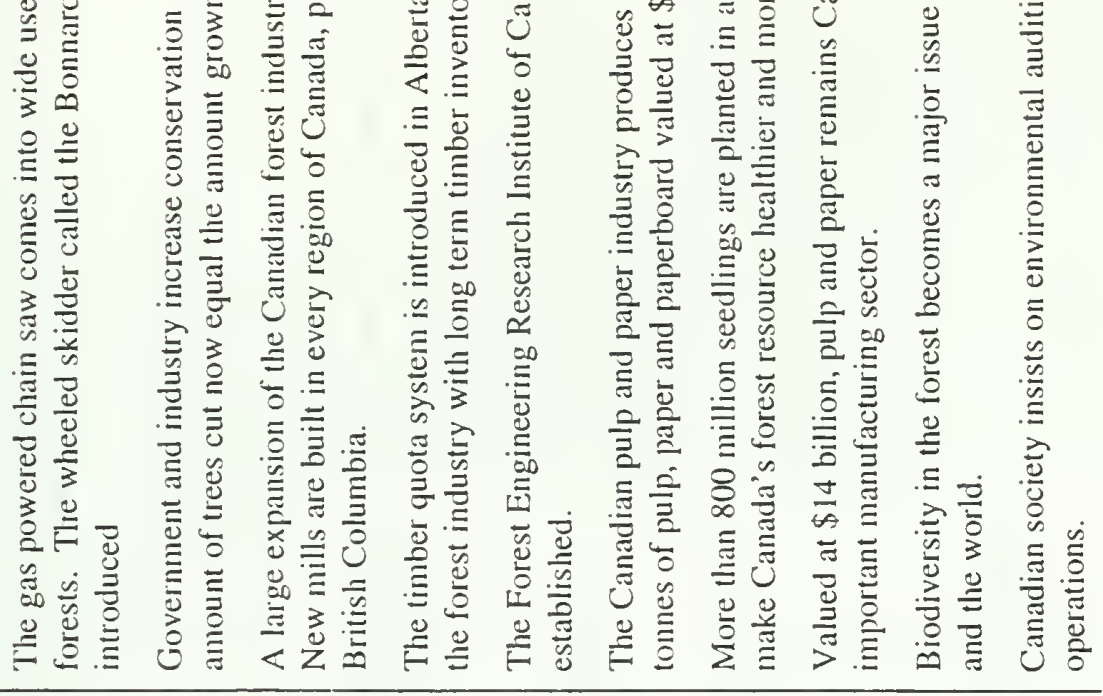



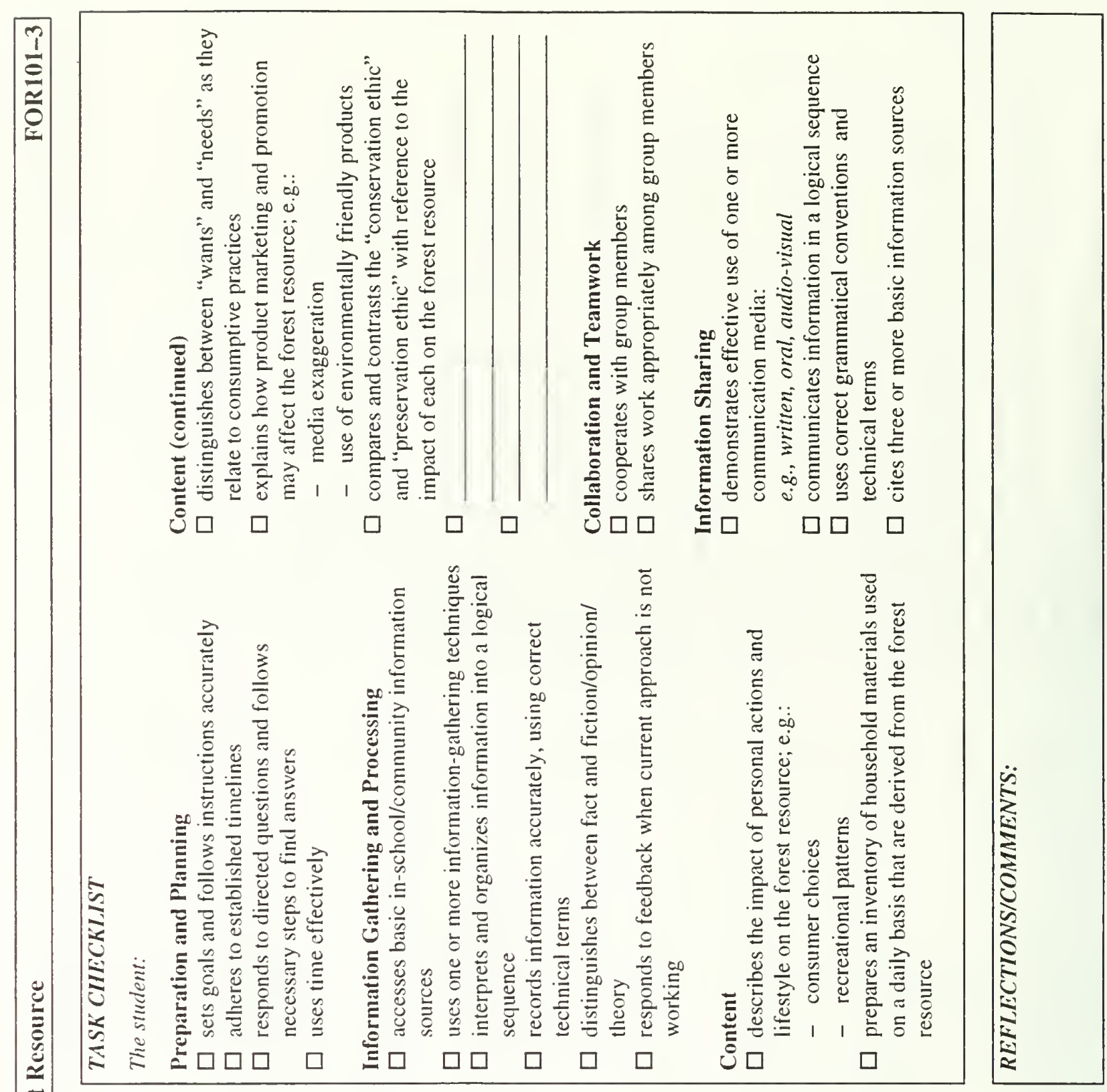
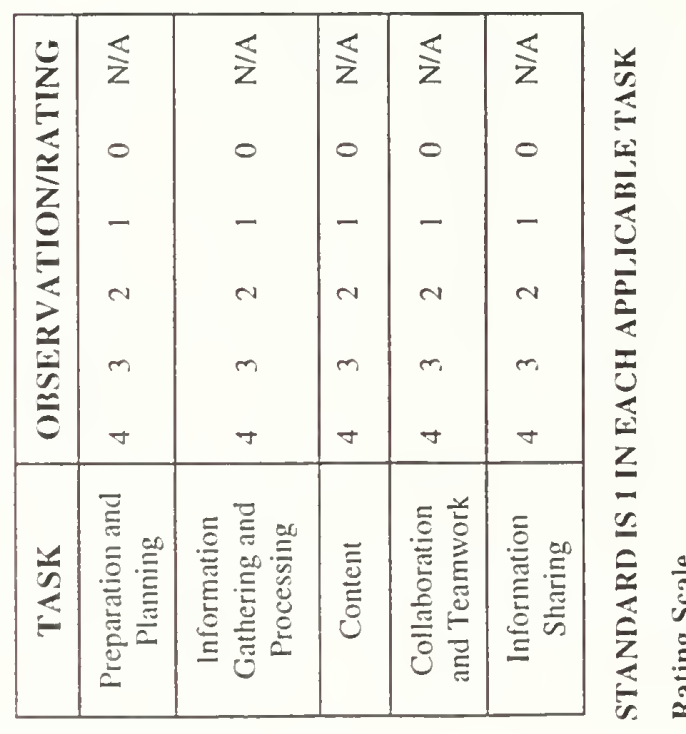

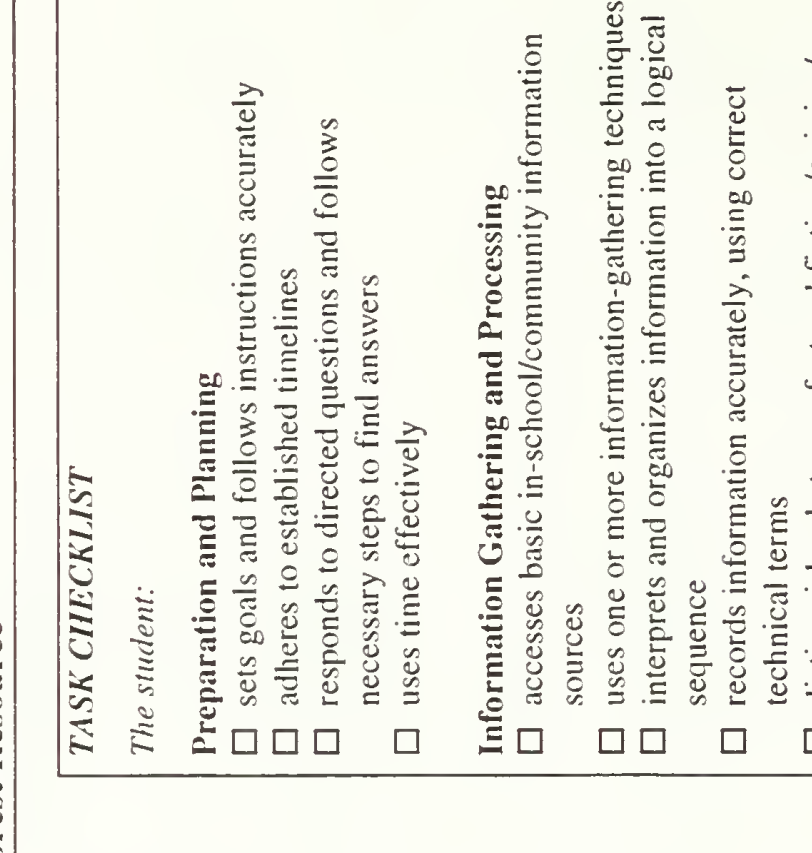

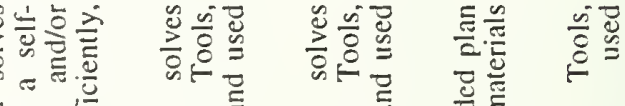

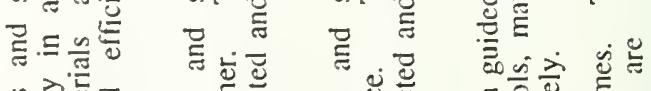

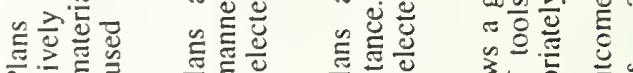

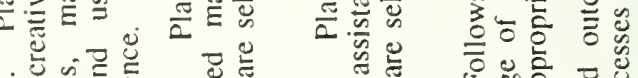

.

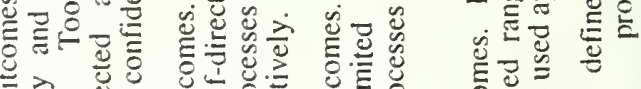

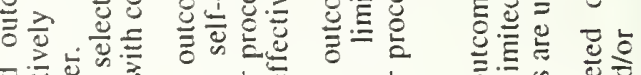

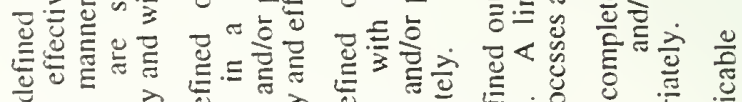

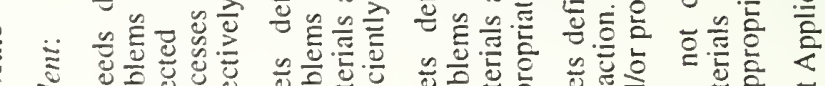

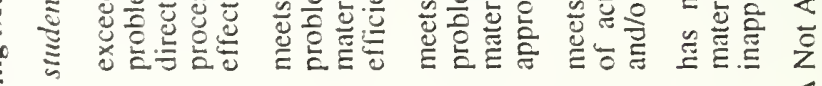

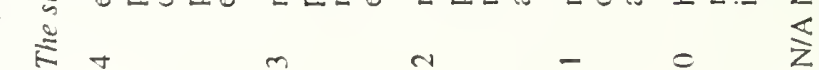



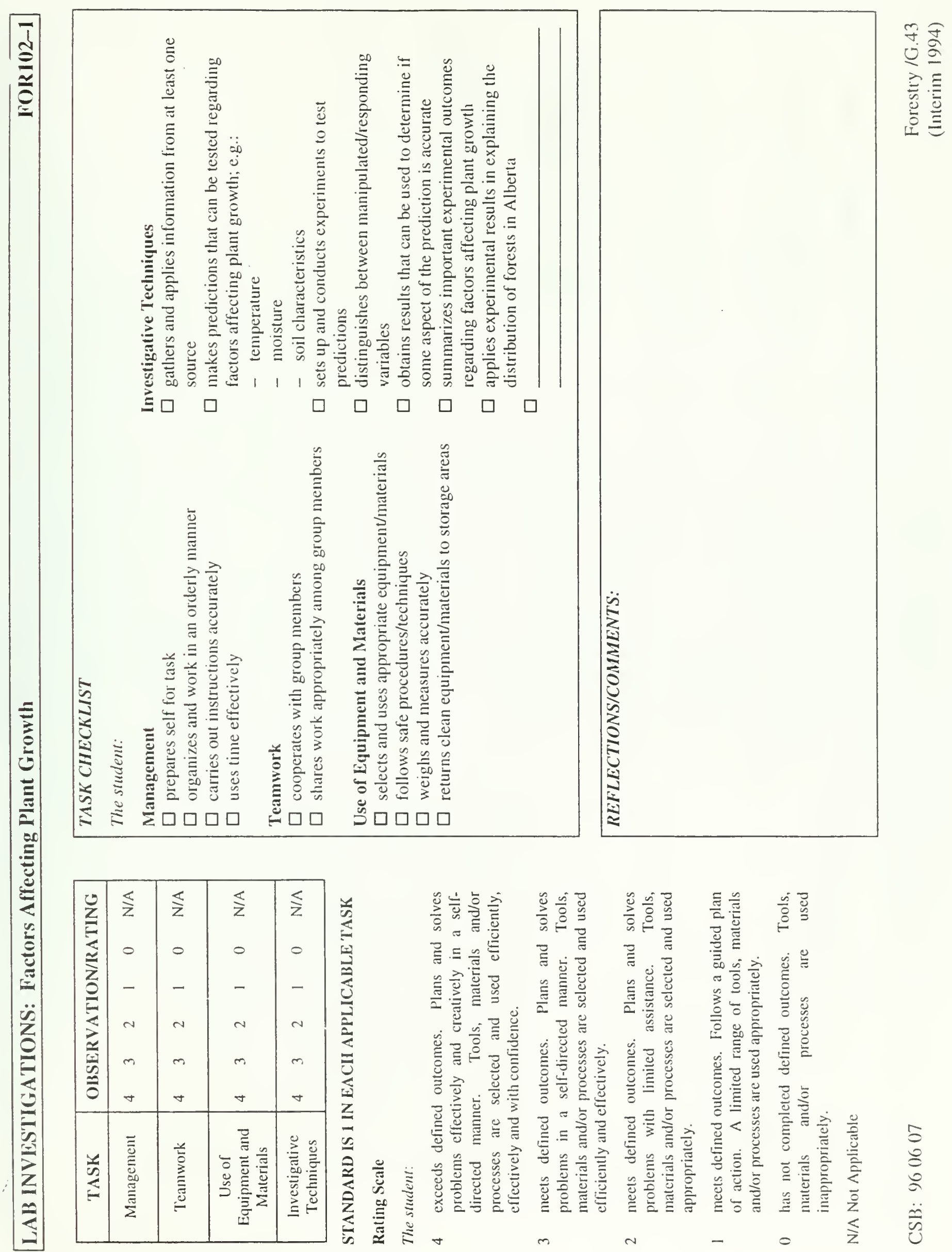


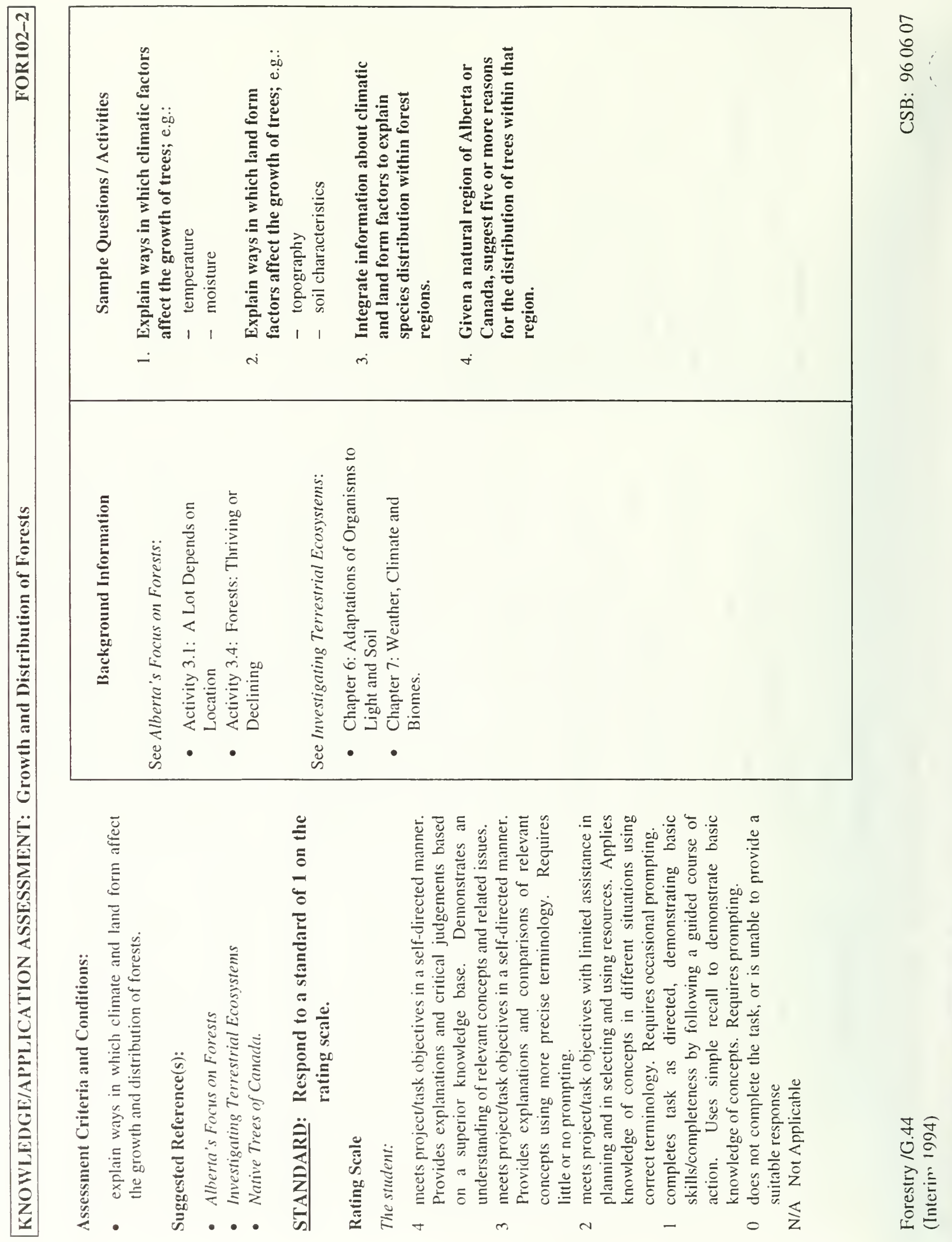




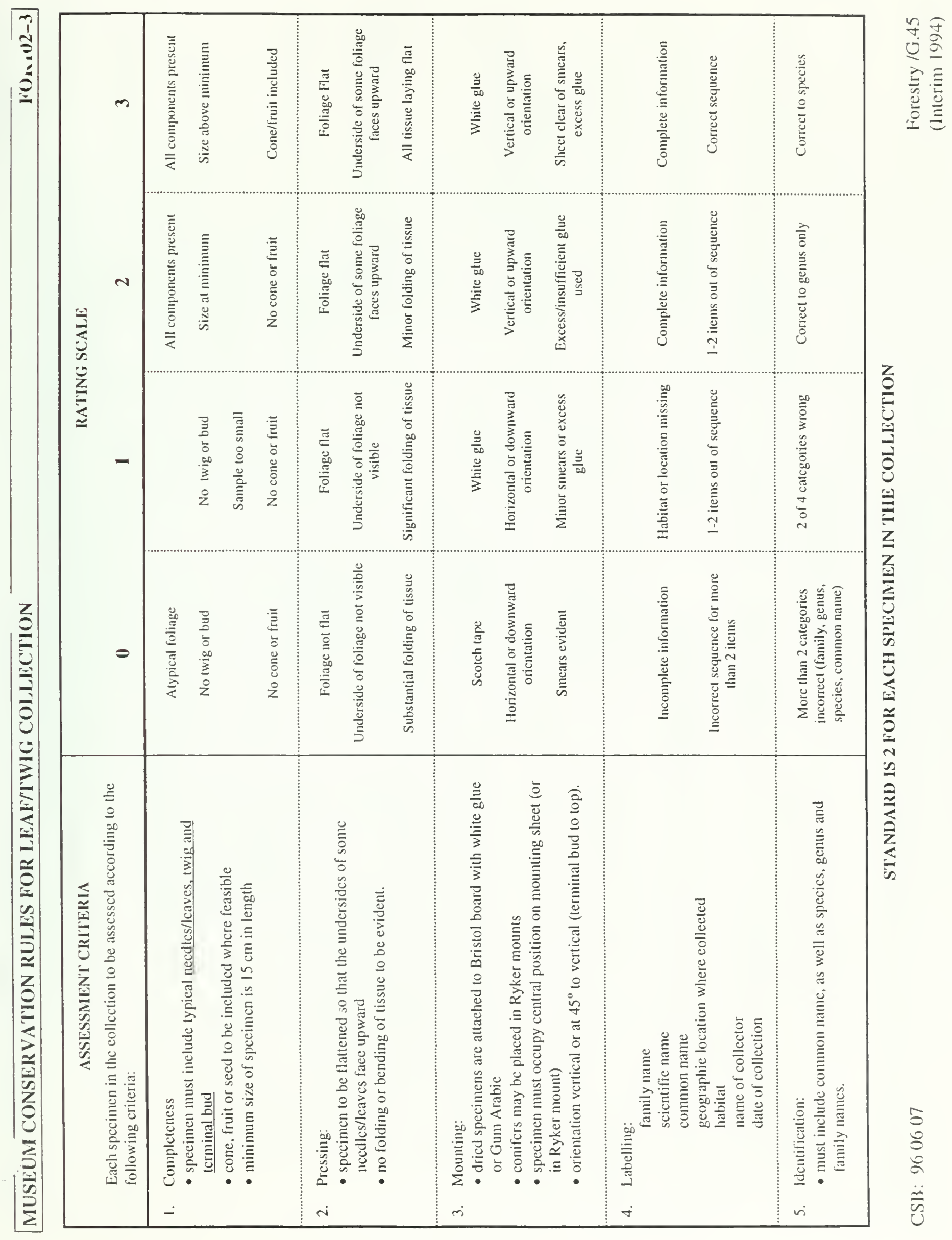




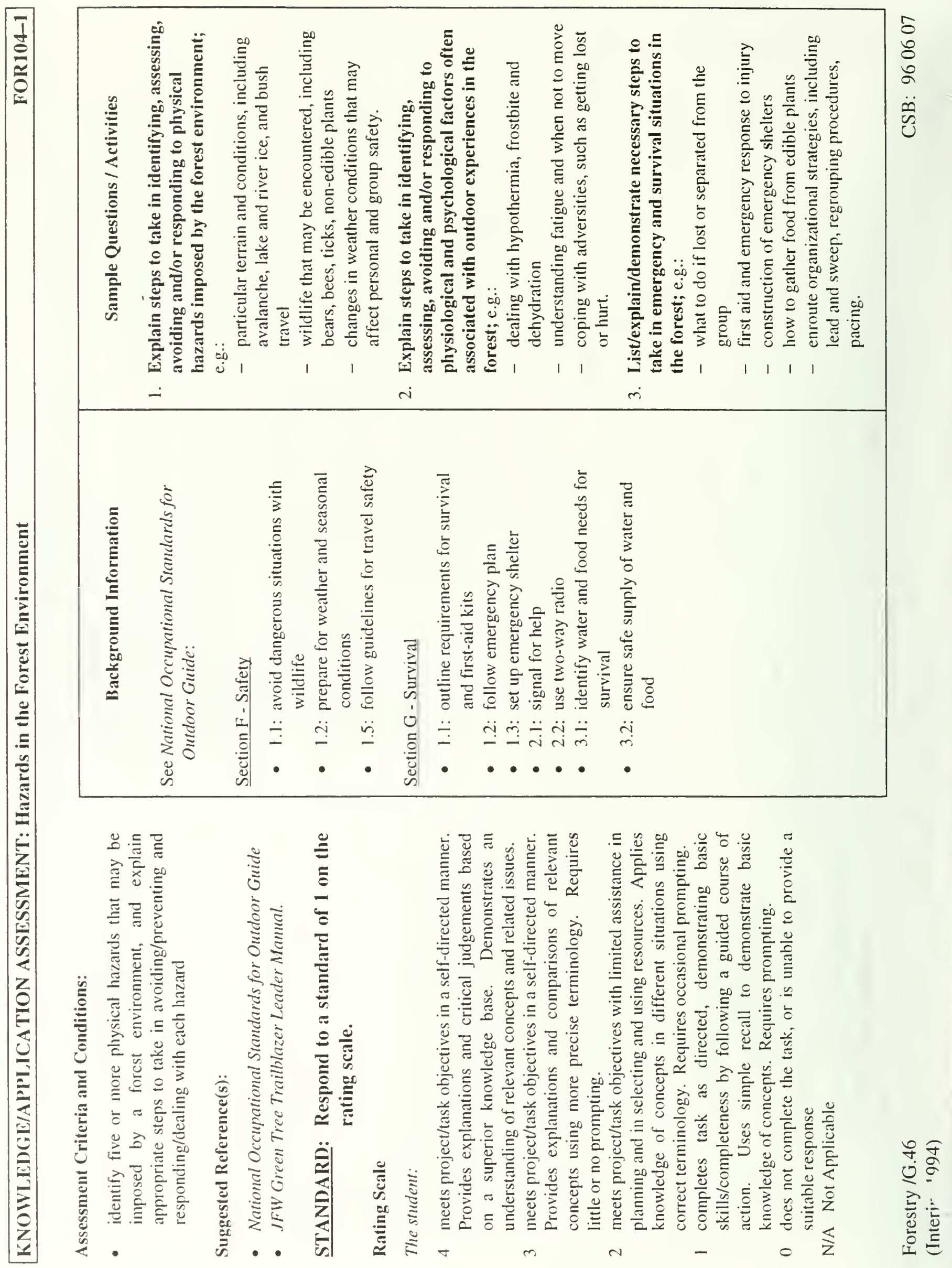




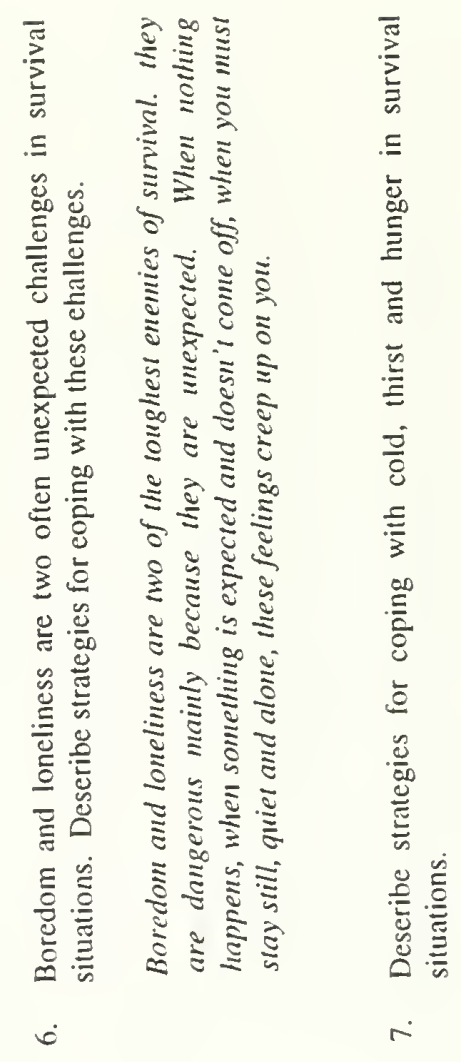

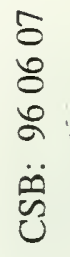

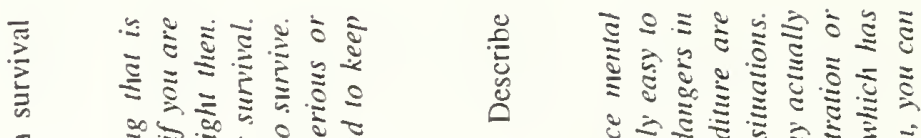
-

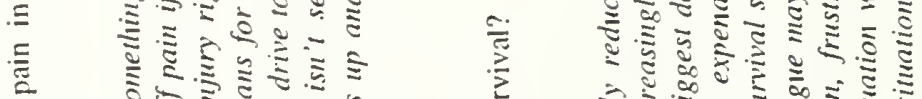

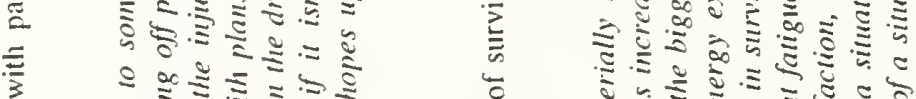

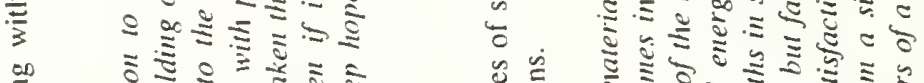
ठ

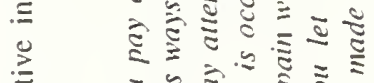

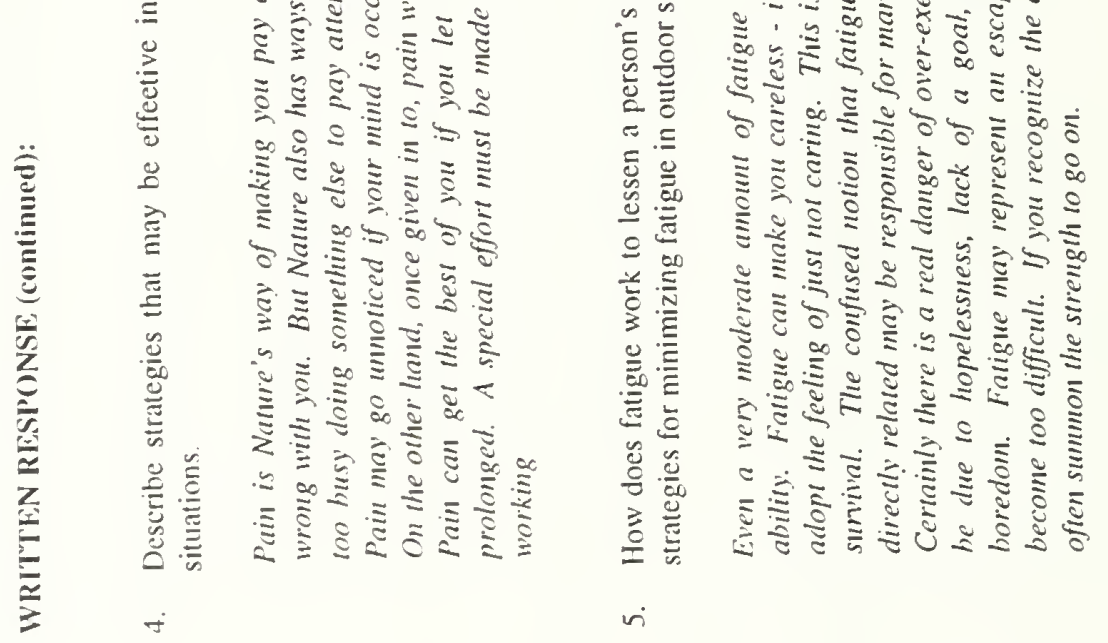



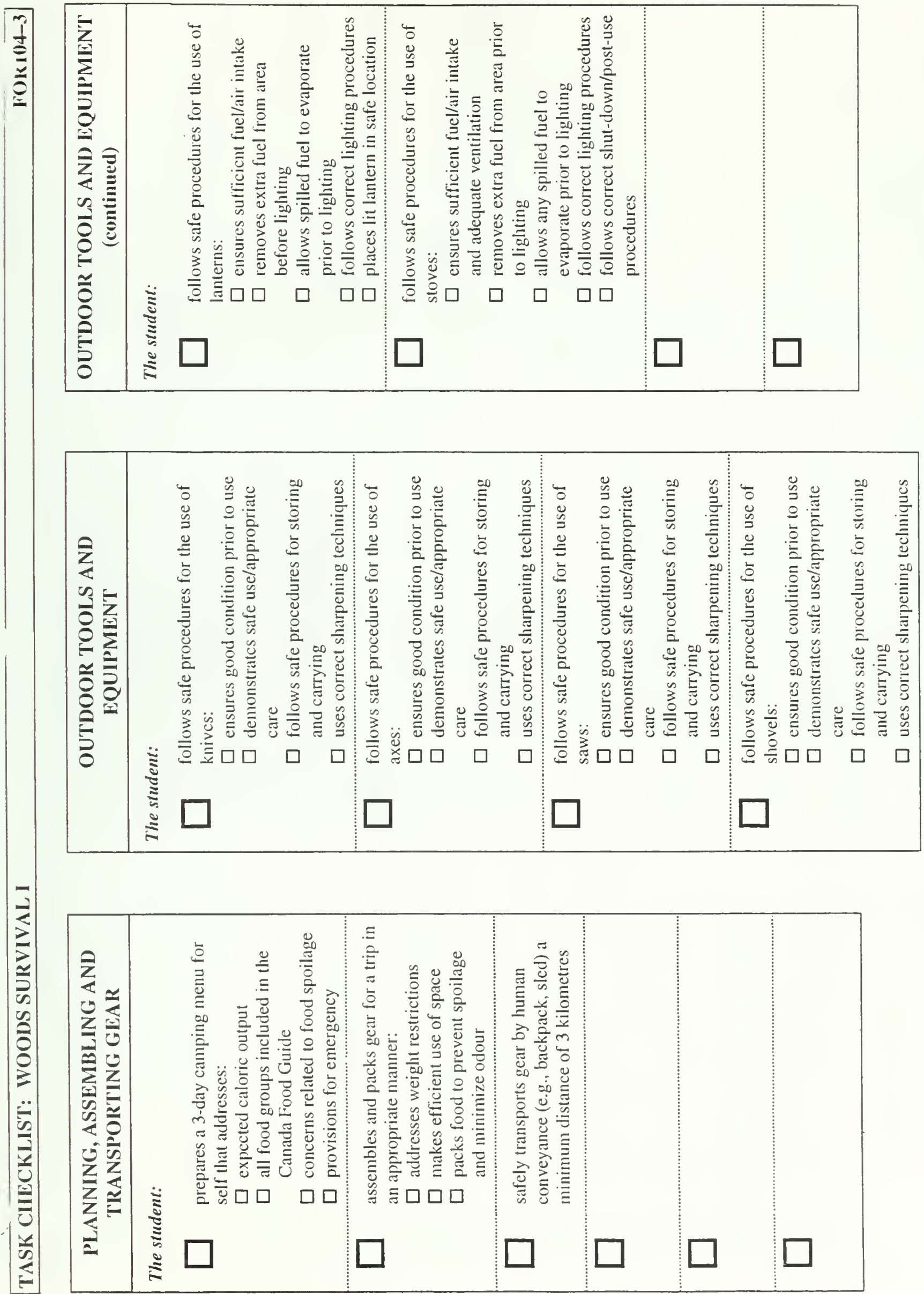

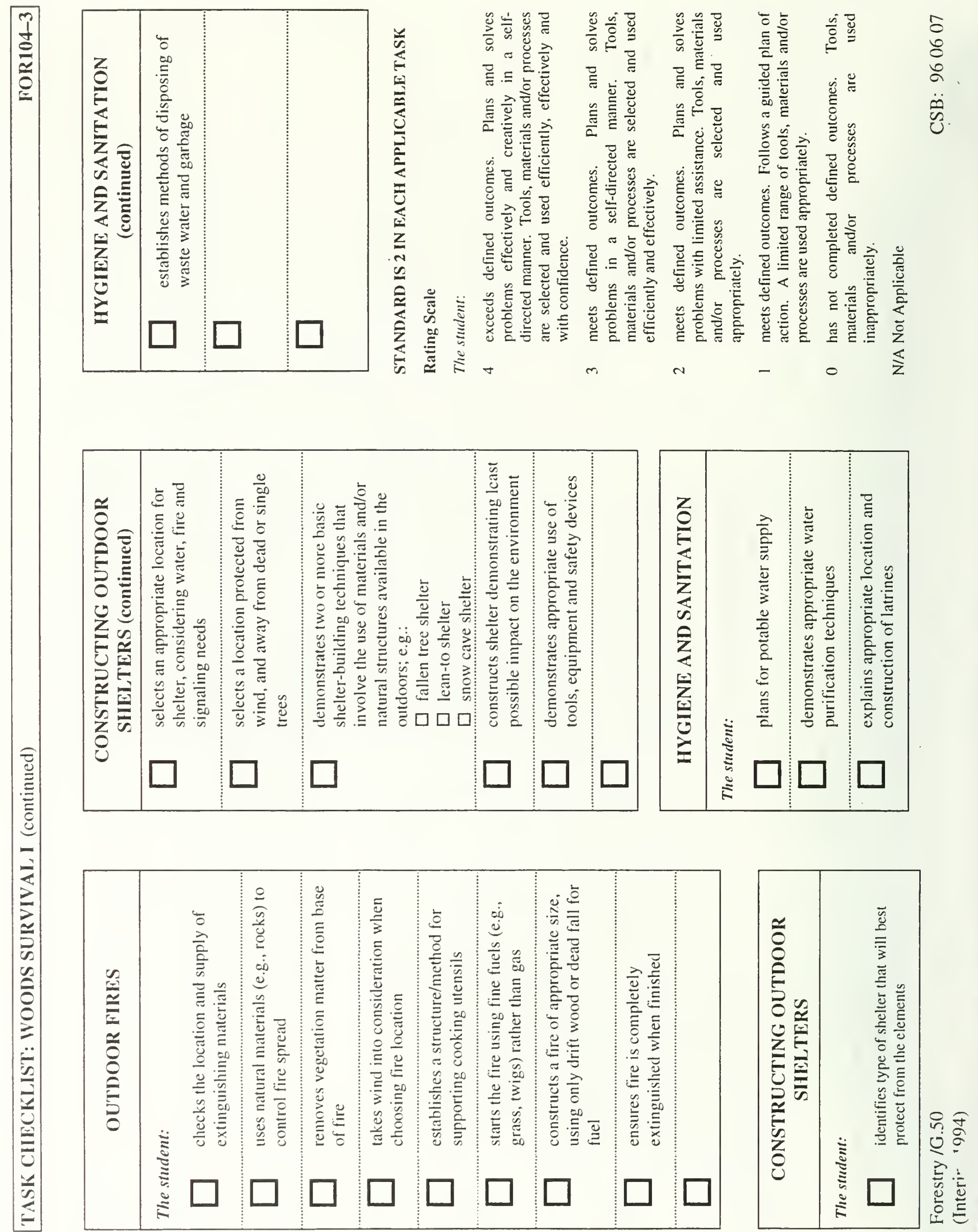

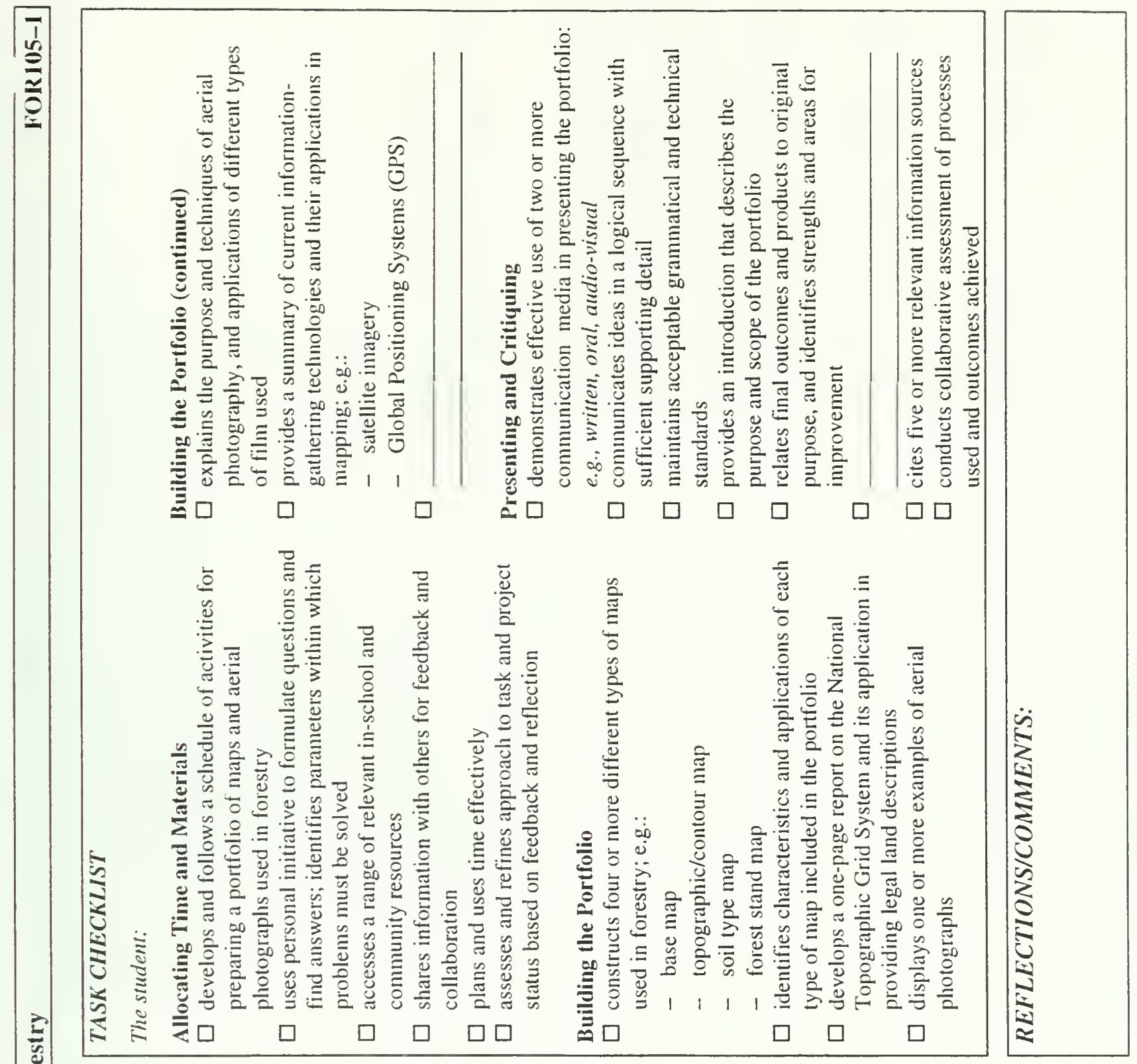

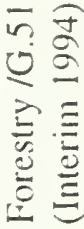
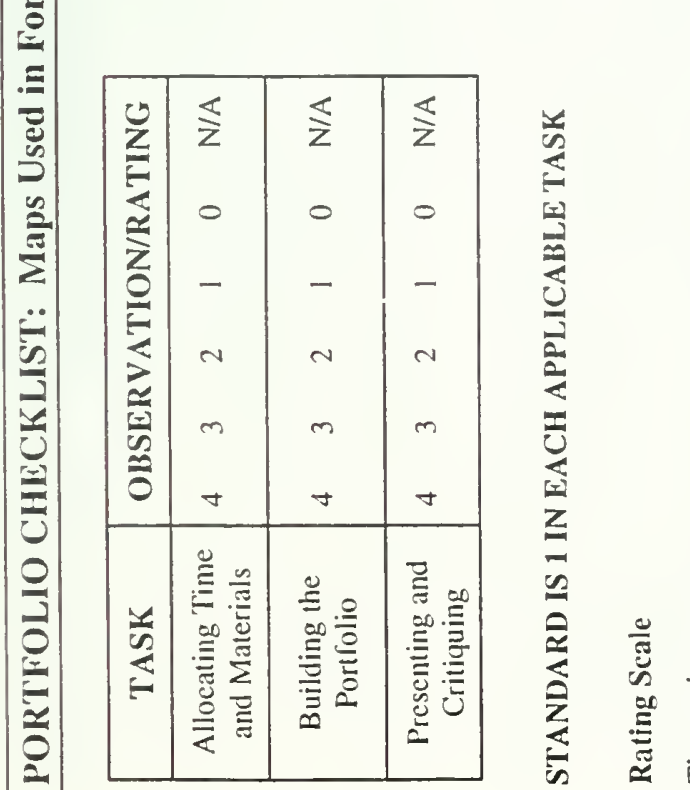

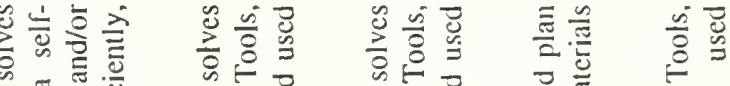

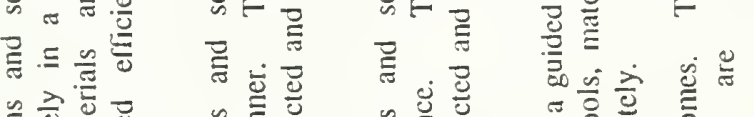

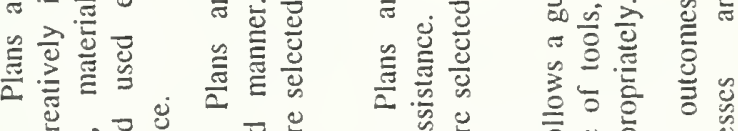

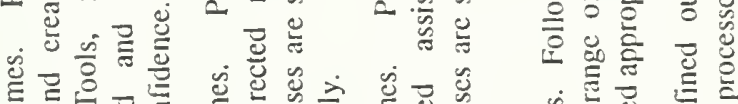

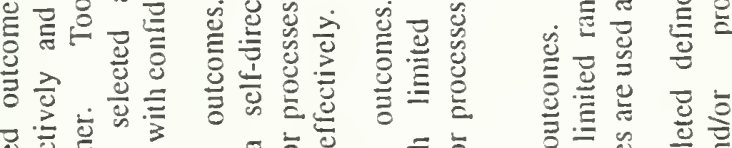

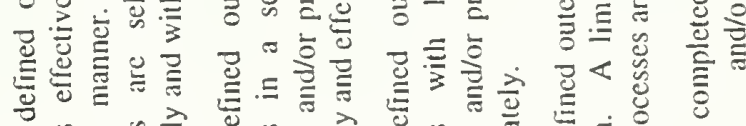

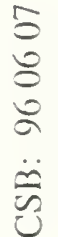



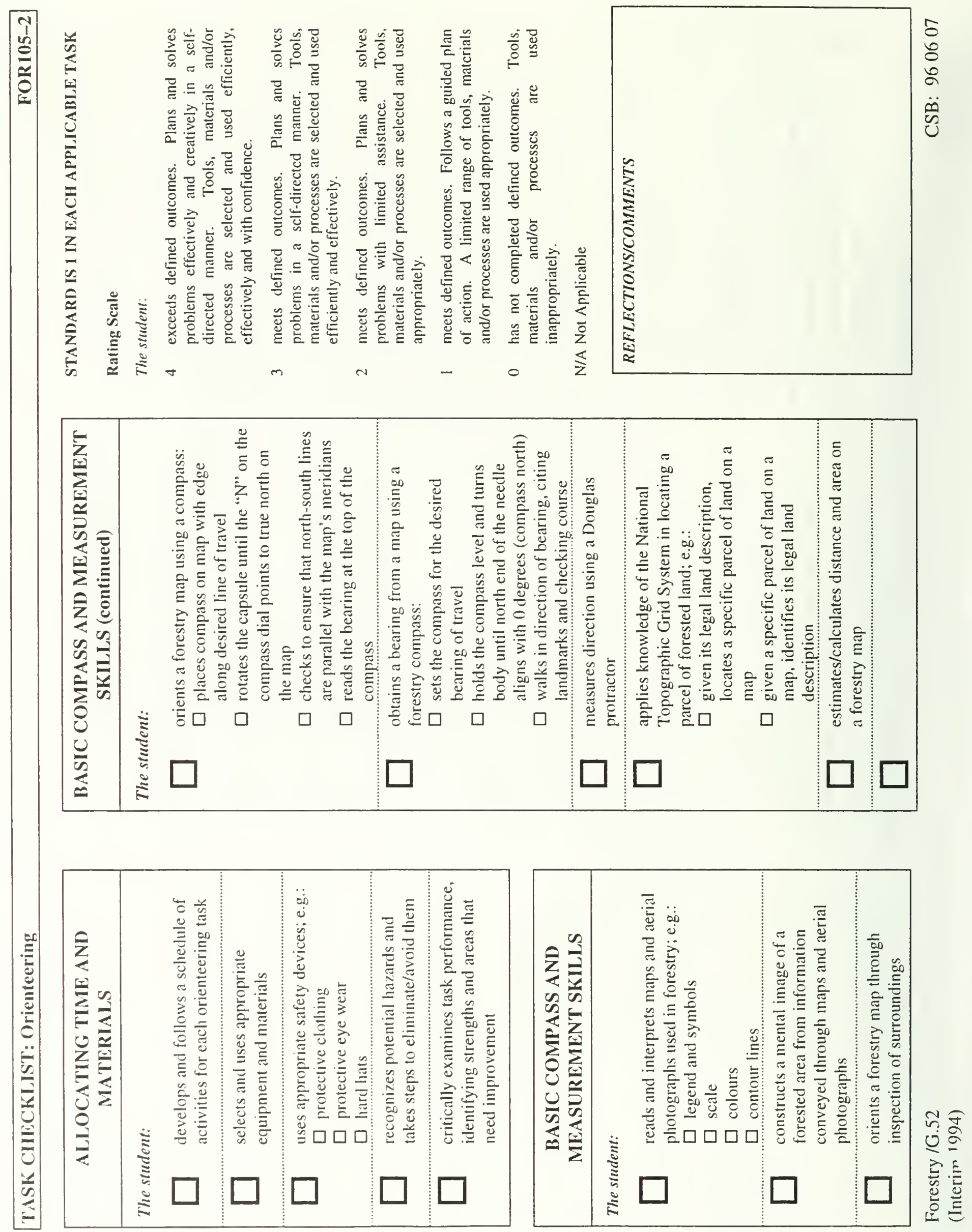


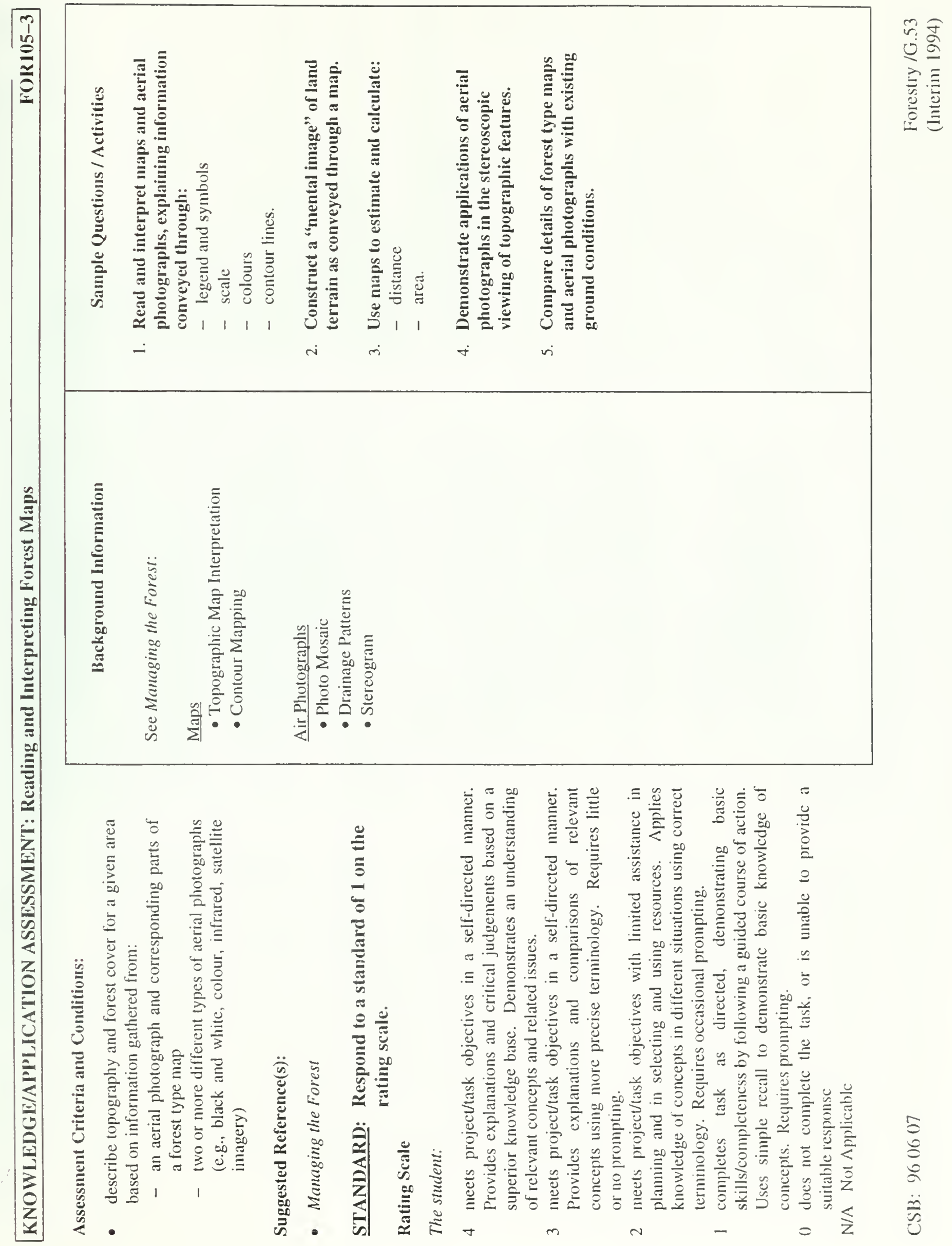




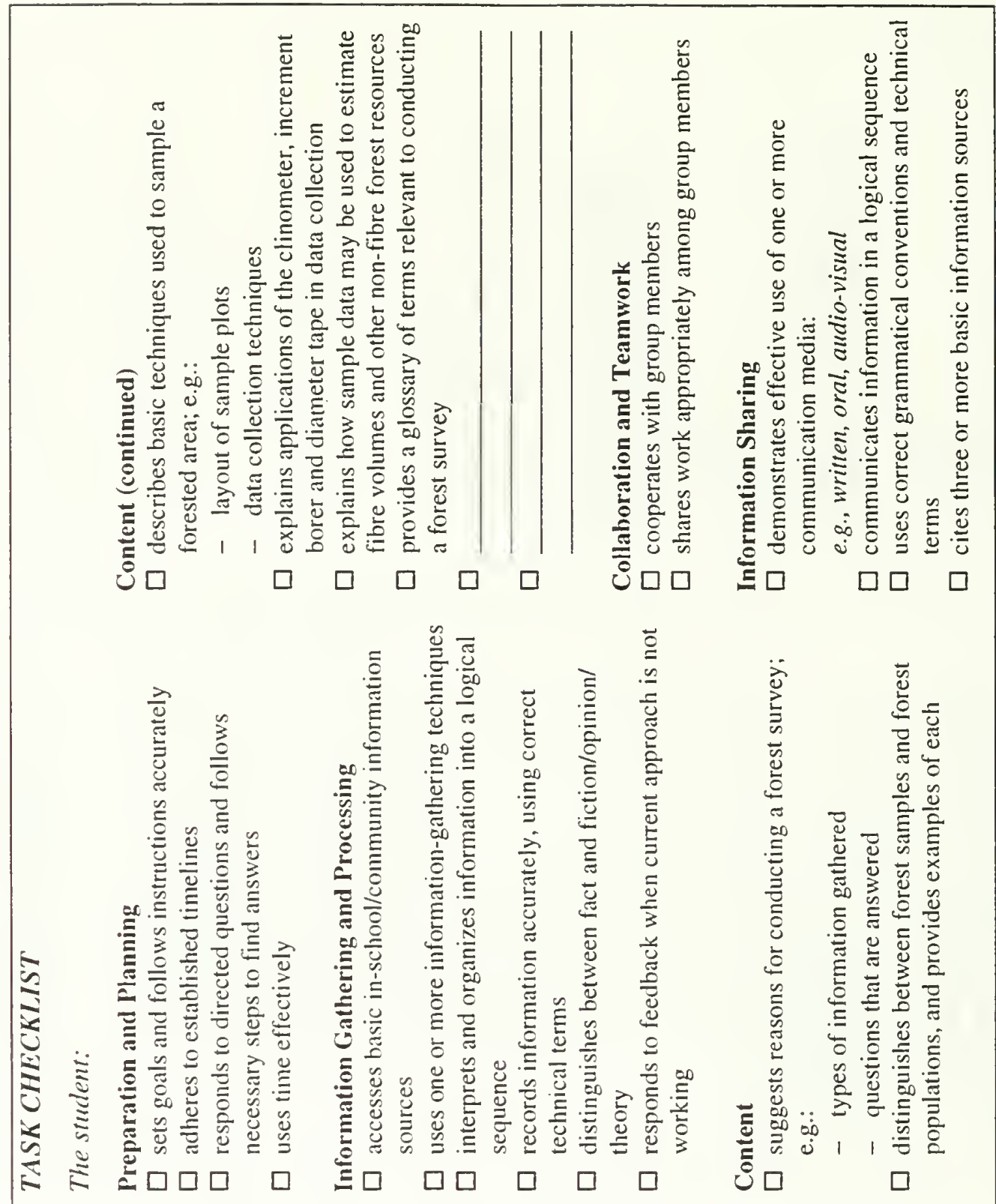

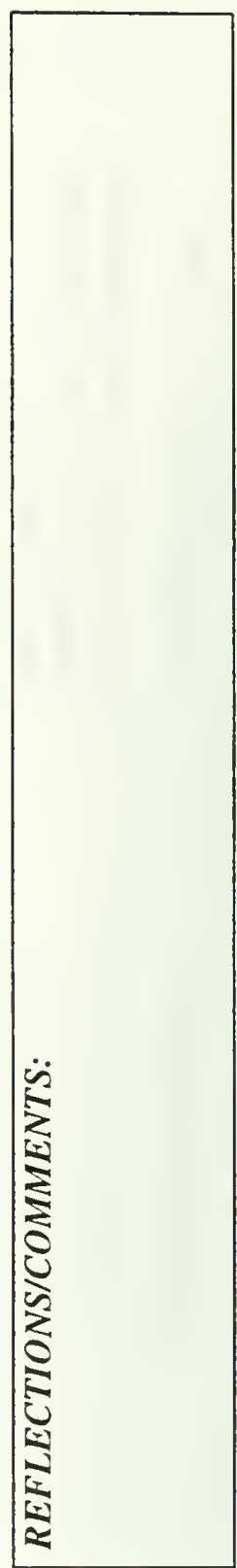

5
8
0
0
0
0
0
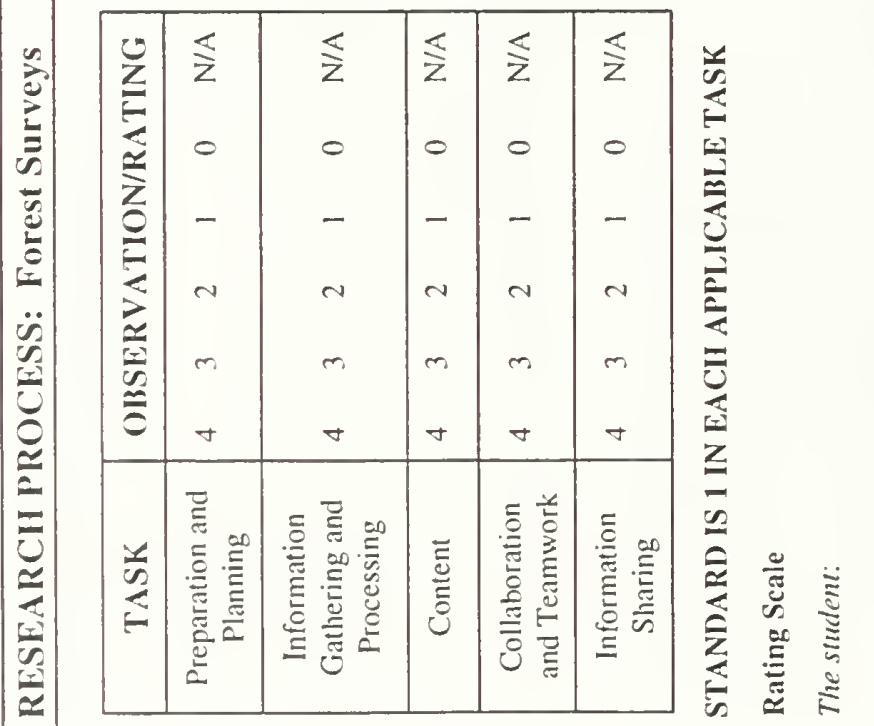

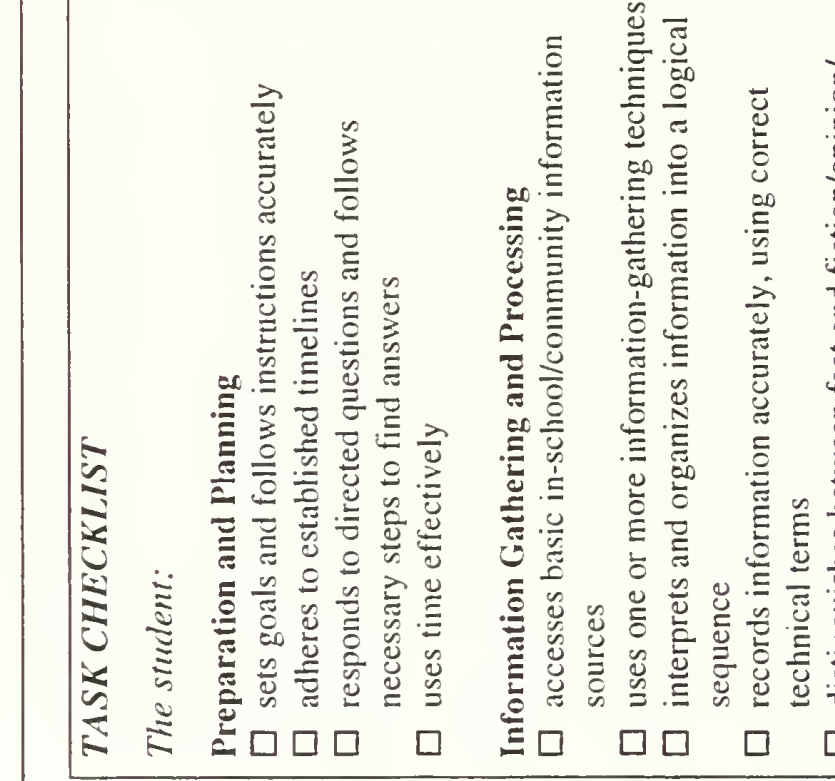

的部.

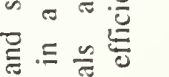

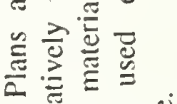

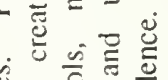

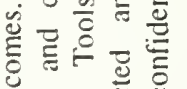

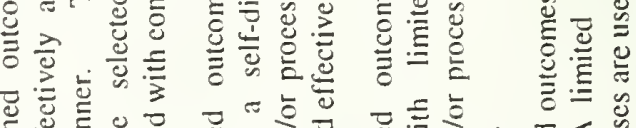

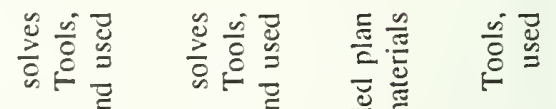

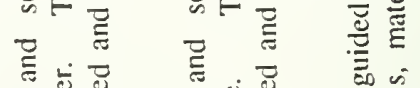

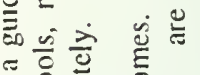

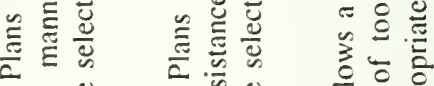

它言苍

व

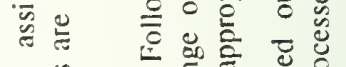

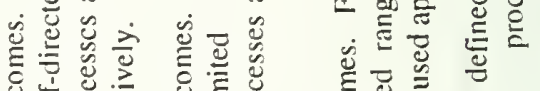

¿্口

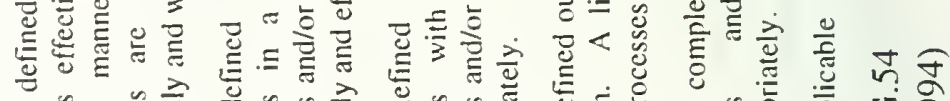

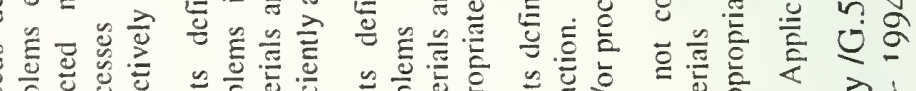

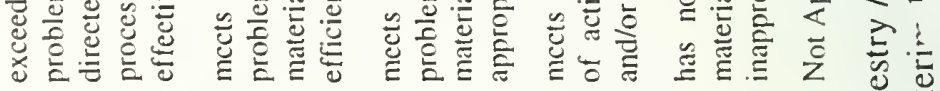
乙 


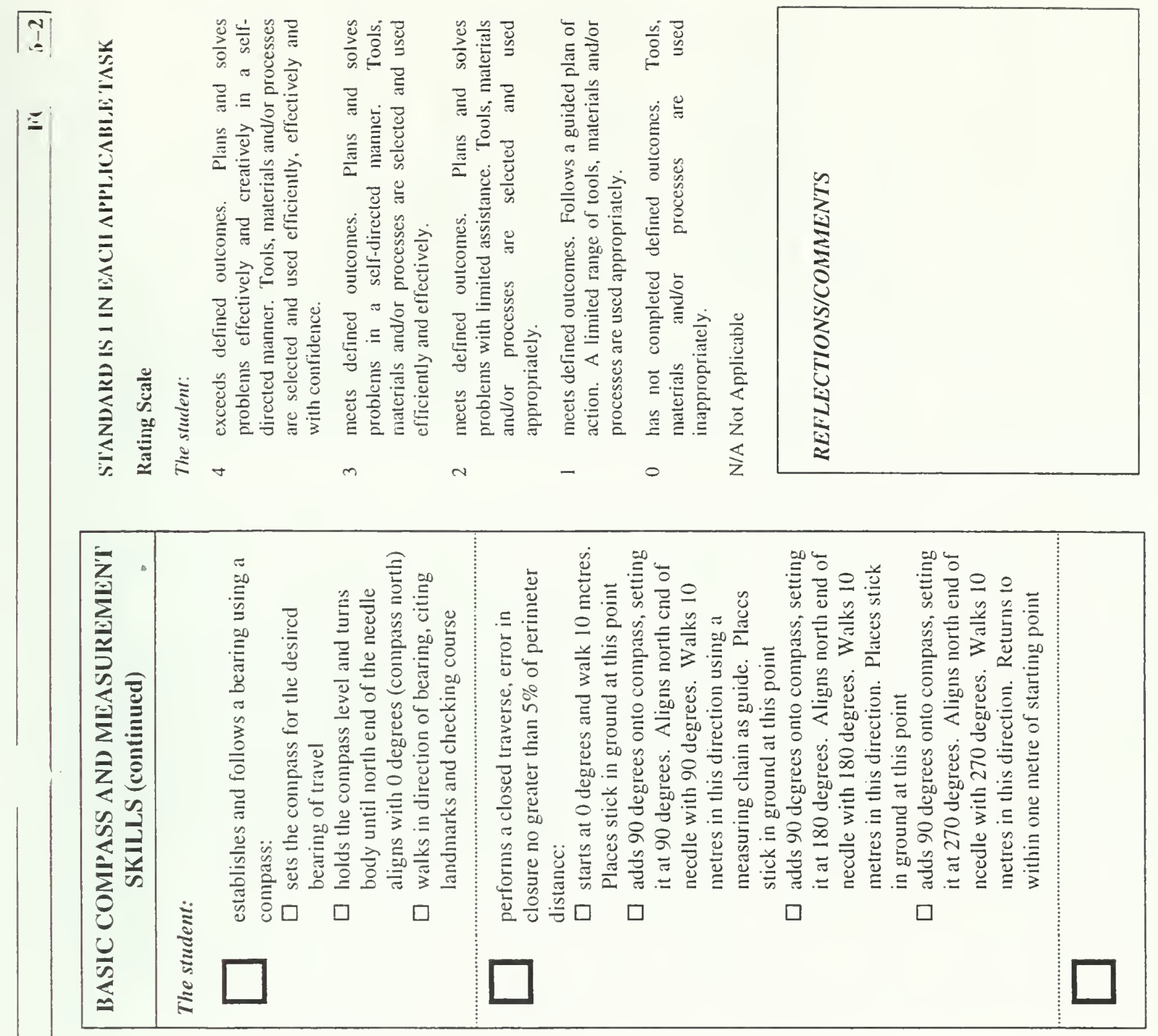
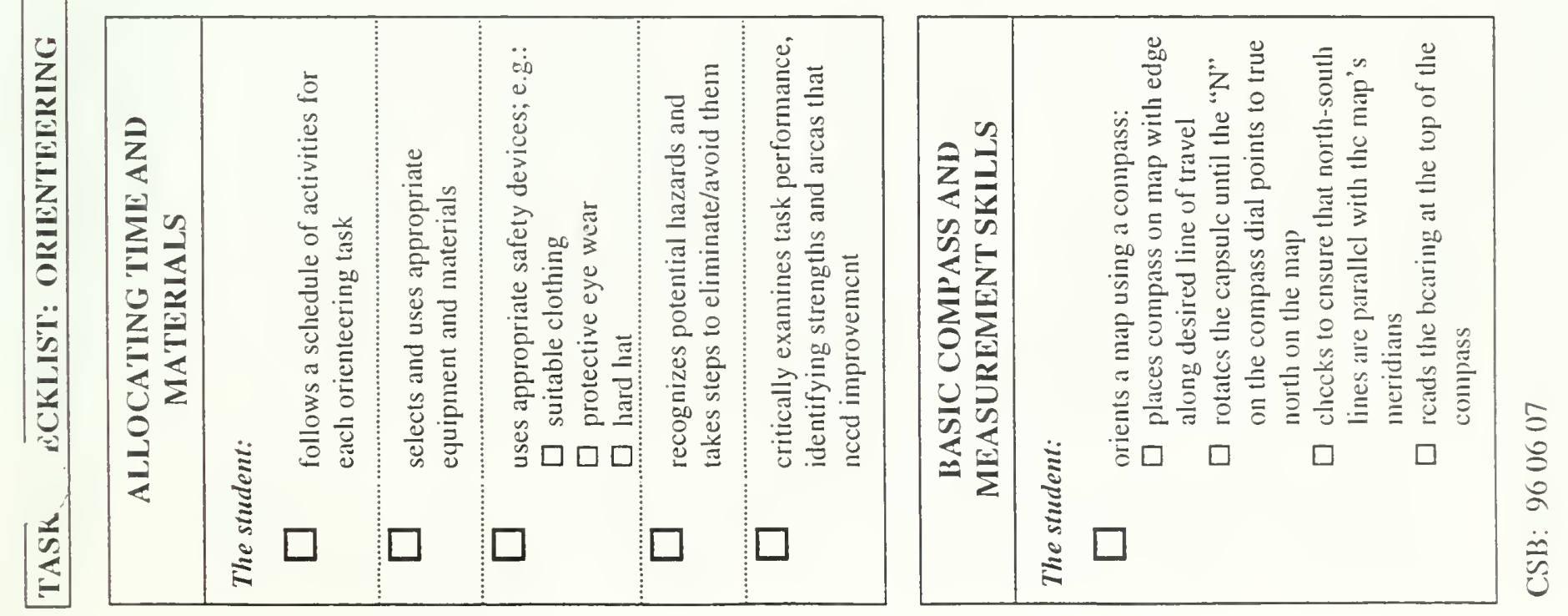

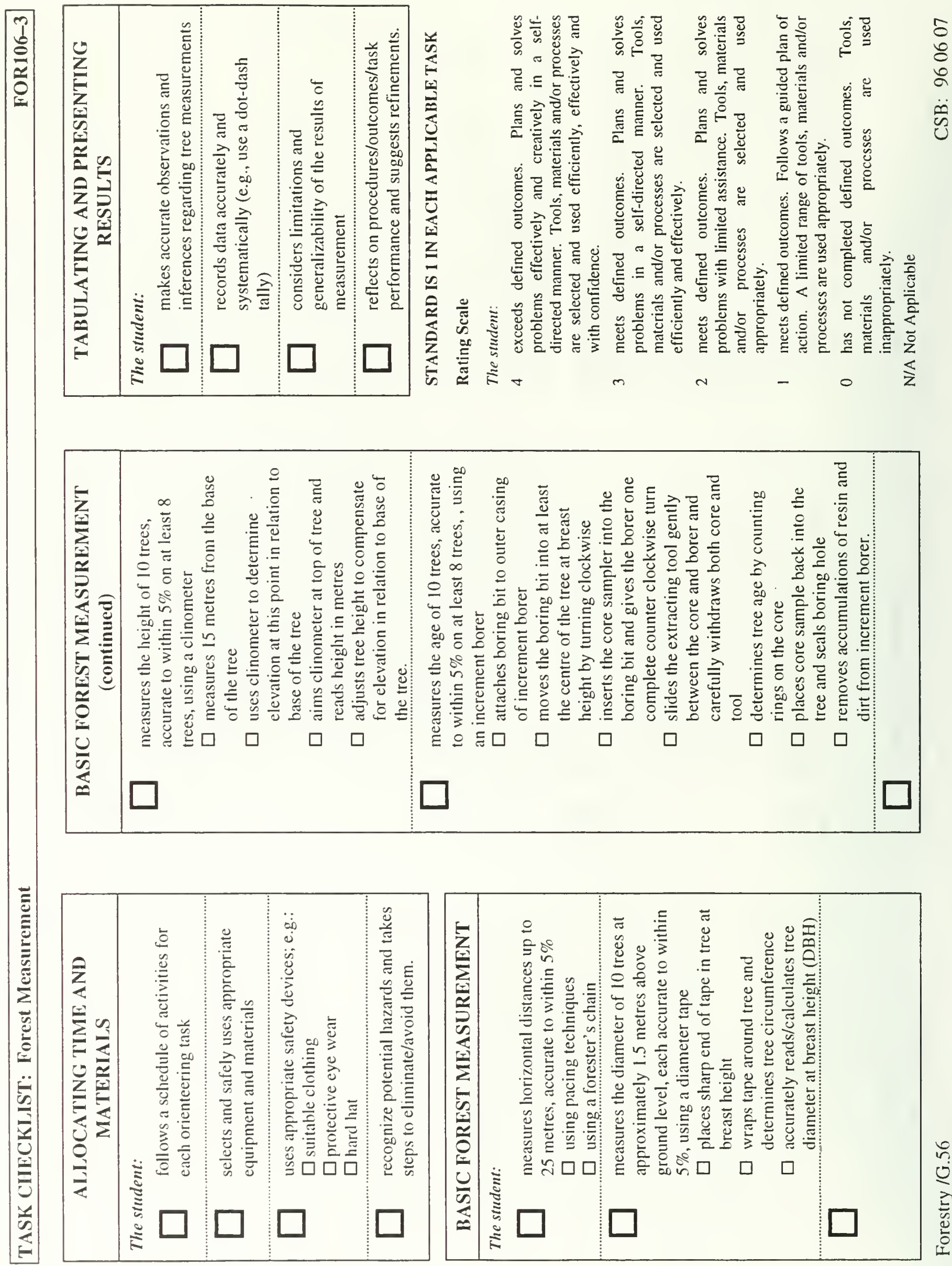

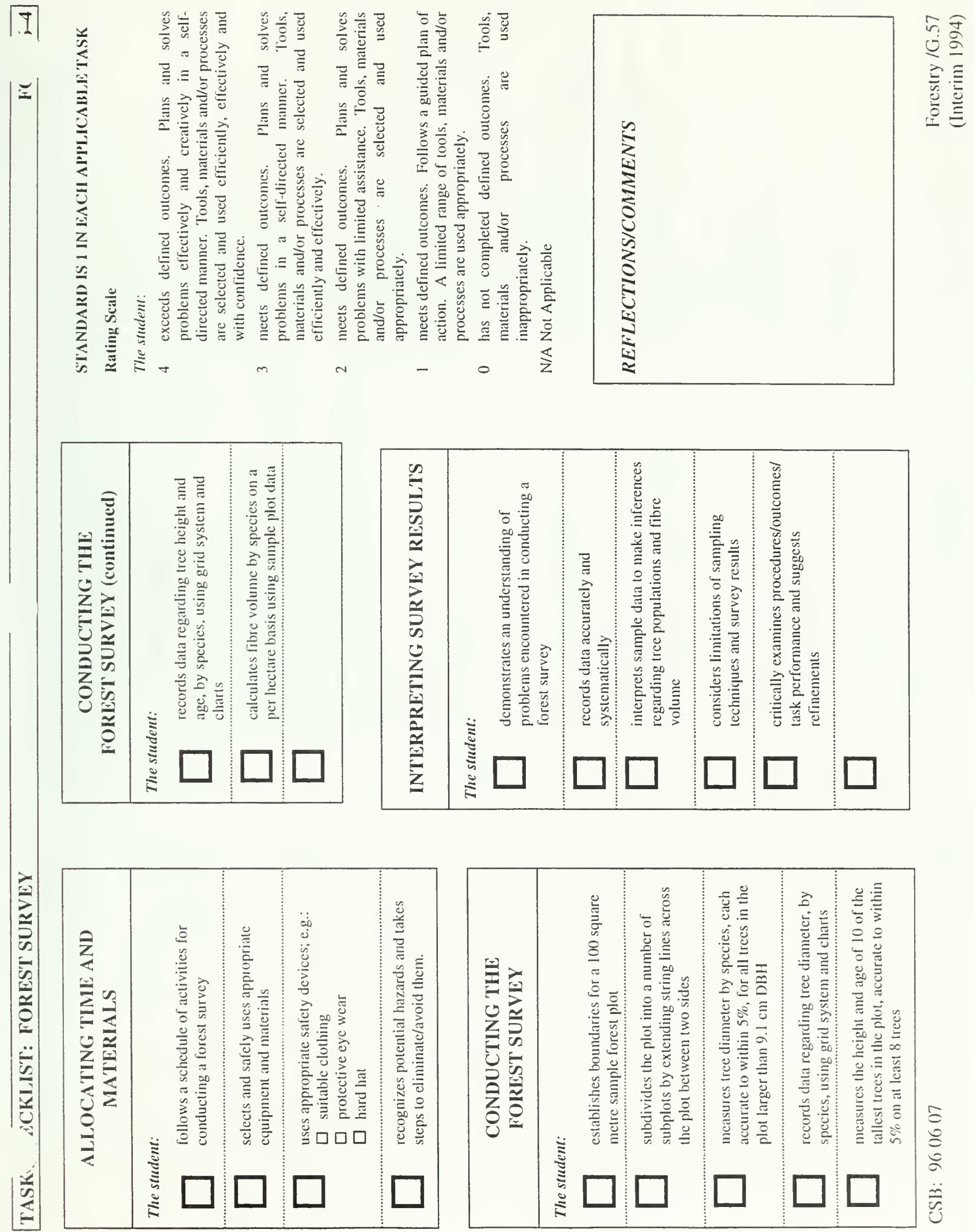

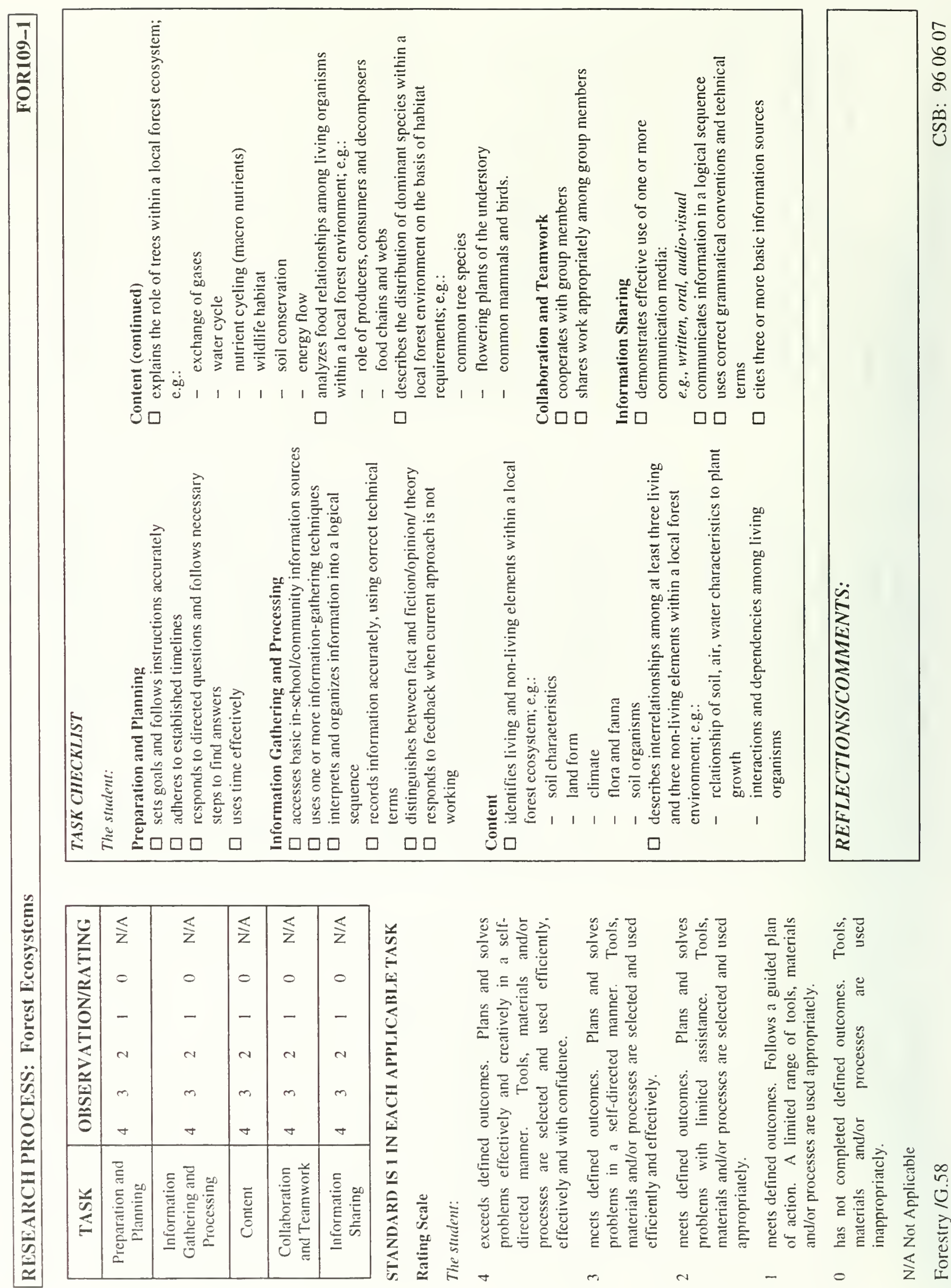

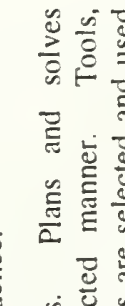

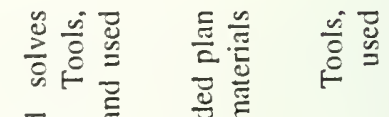

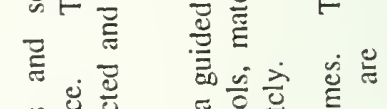

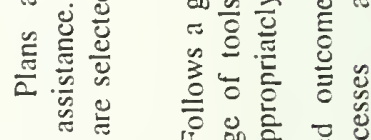

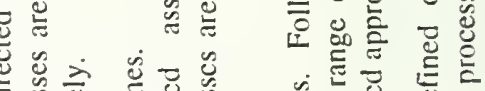

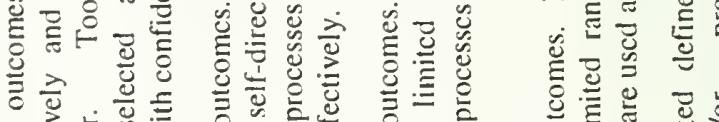

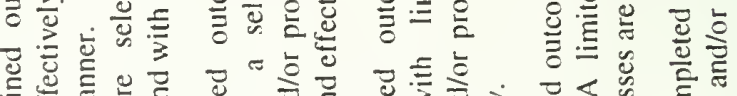

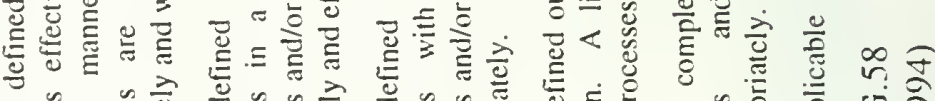

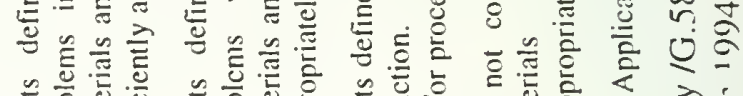

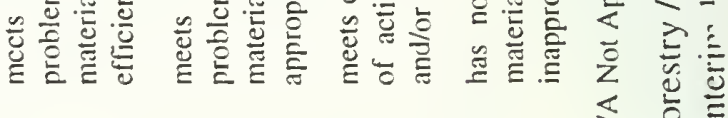




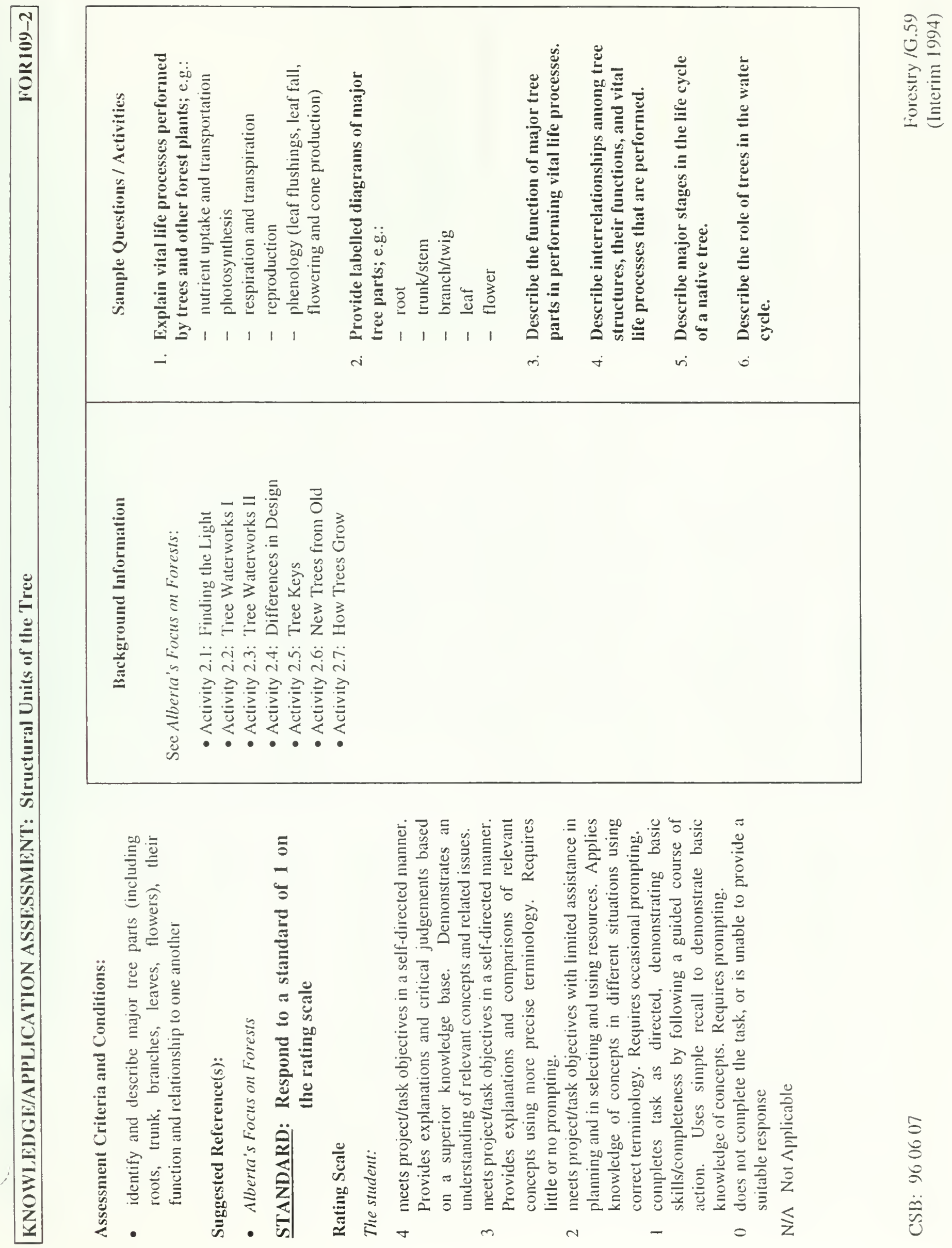



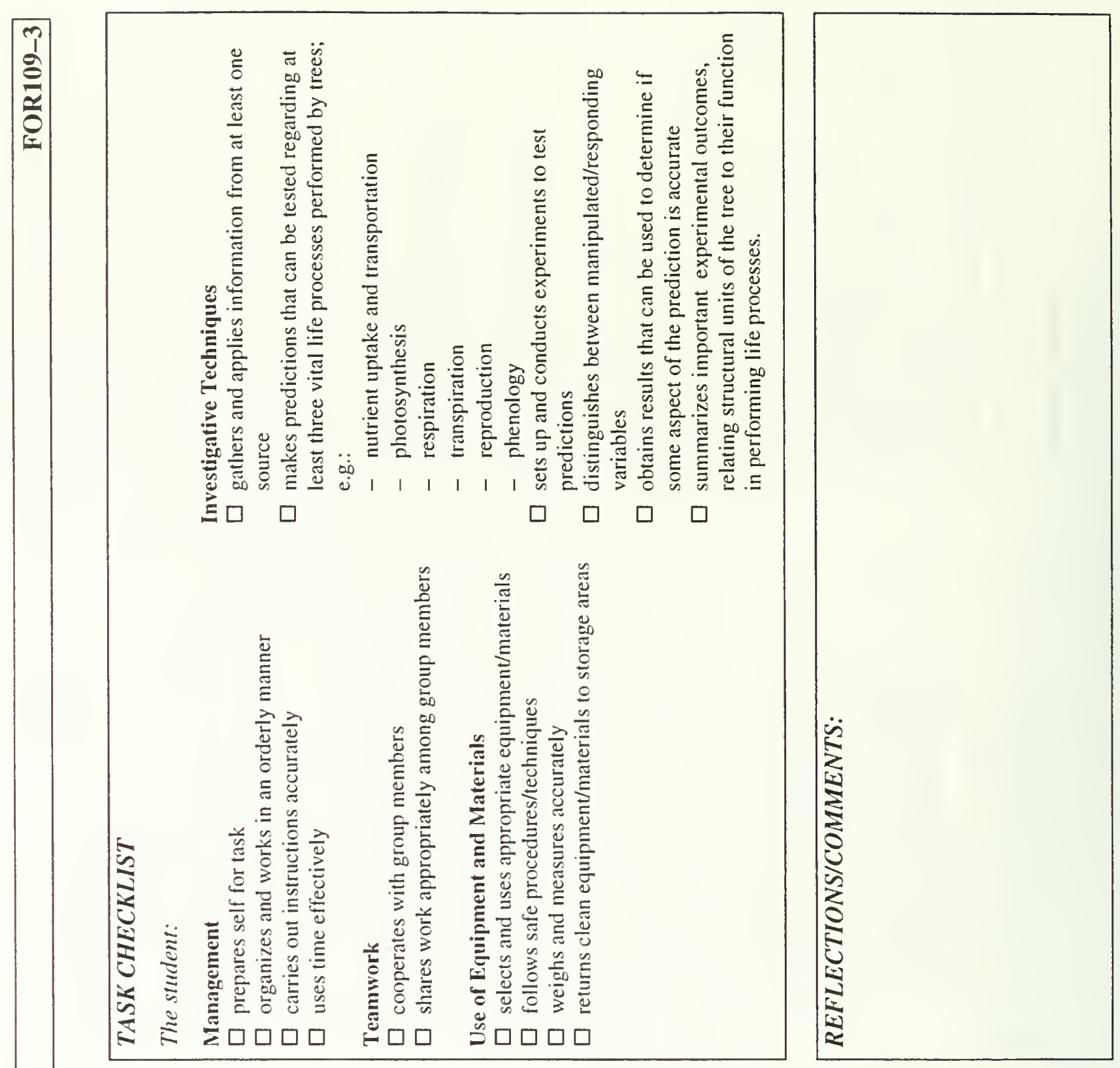

5
8
8
0
$\ddot{v}$
0
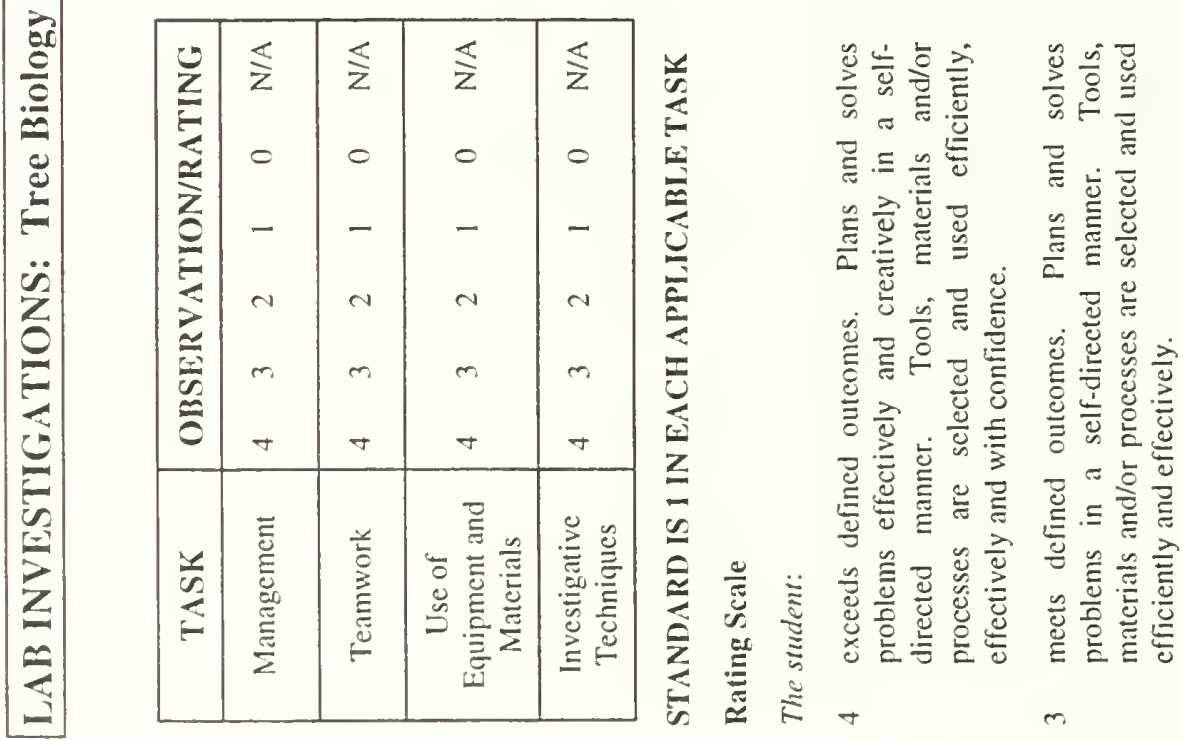

$\dddot{2}$

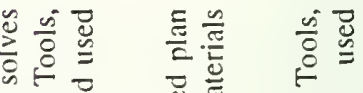
ज्ञ 就的案

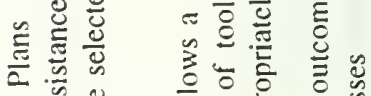

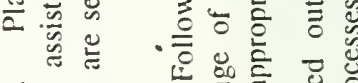

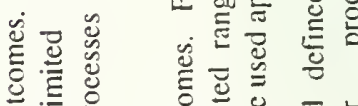

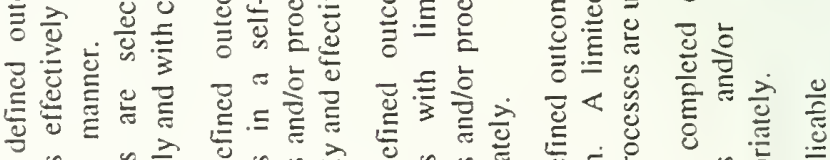

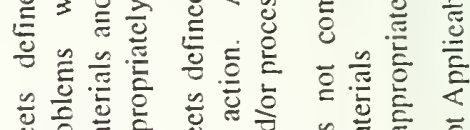
ชิ す

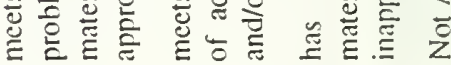
紊. 


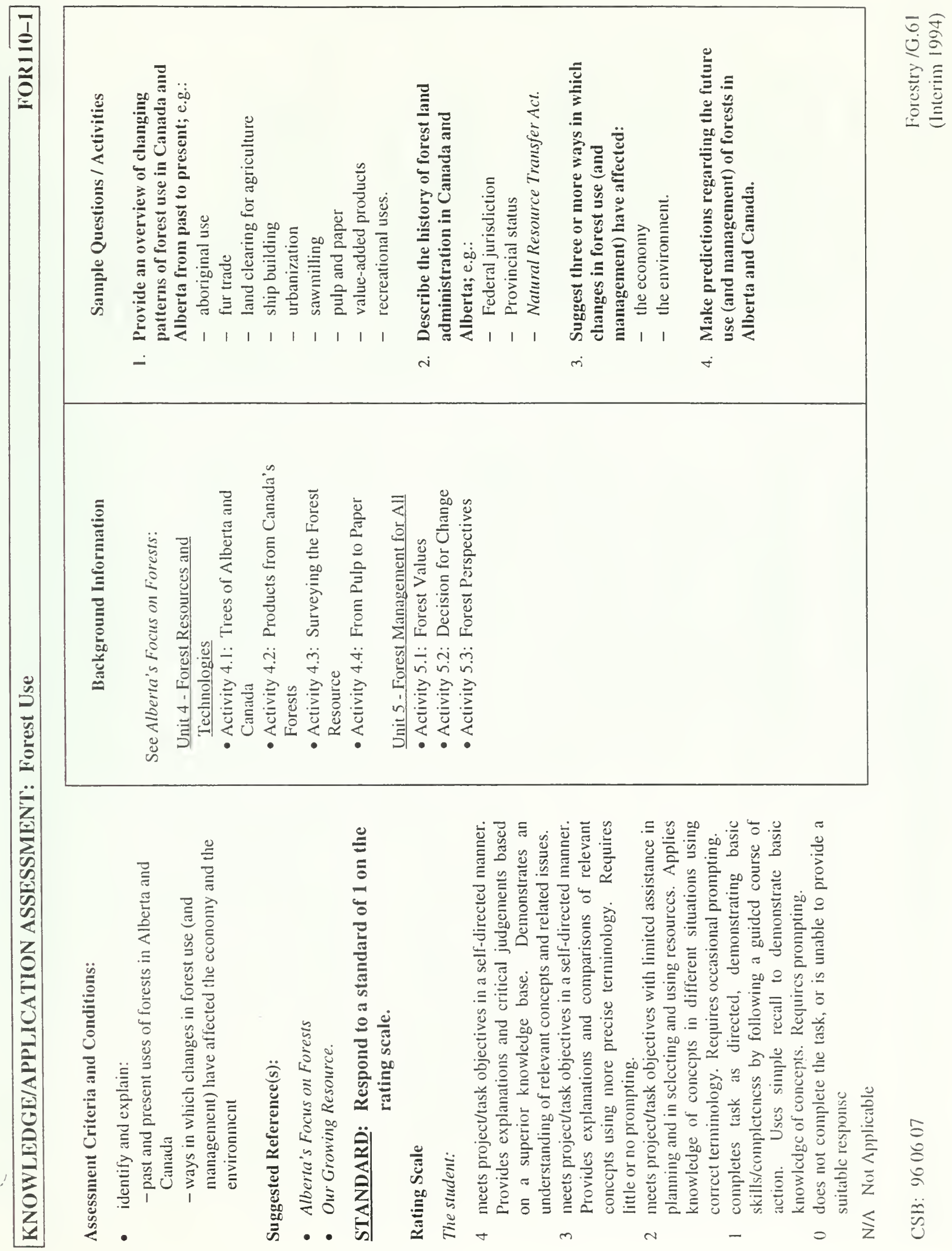




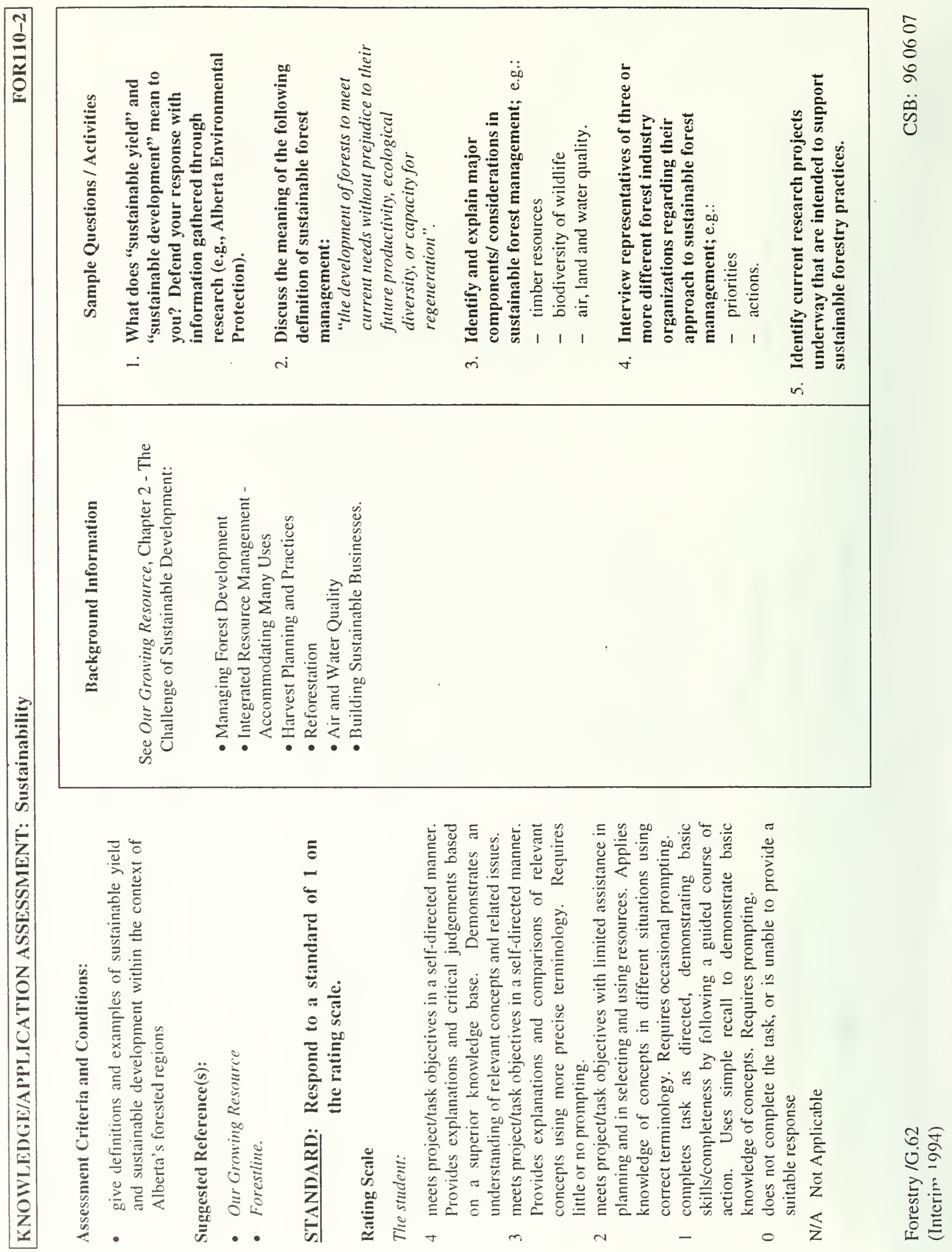



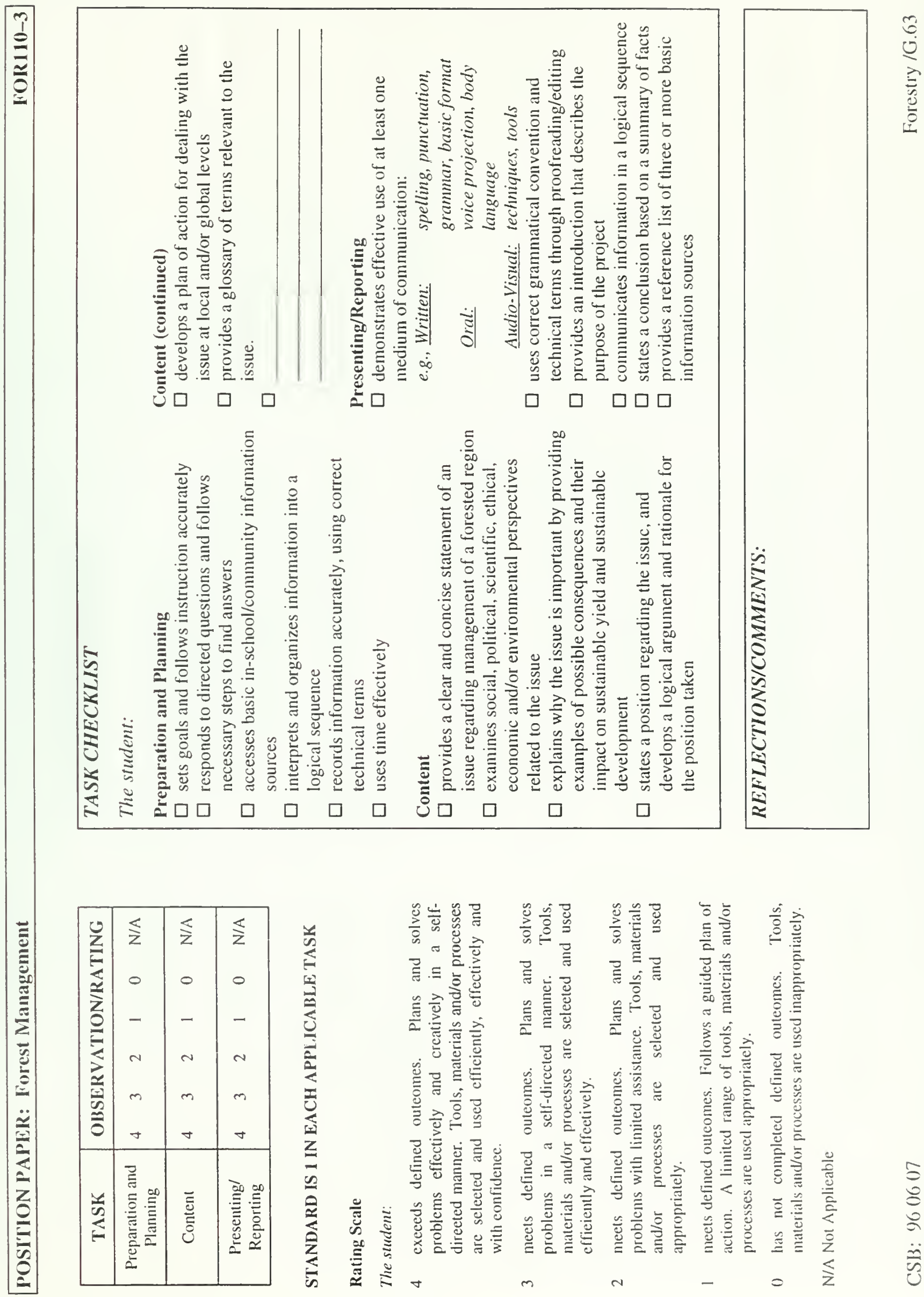

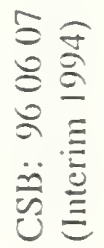




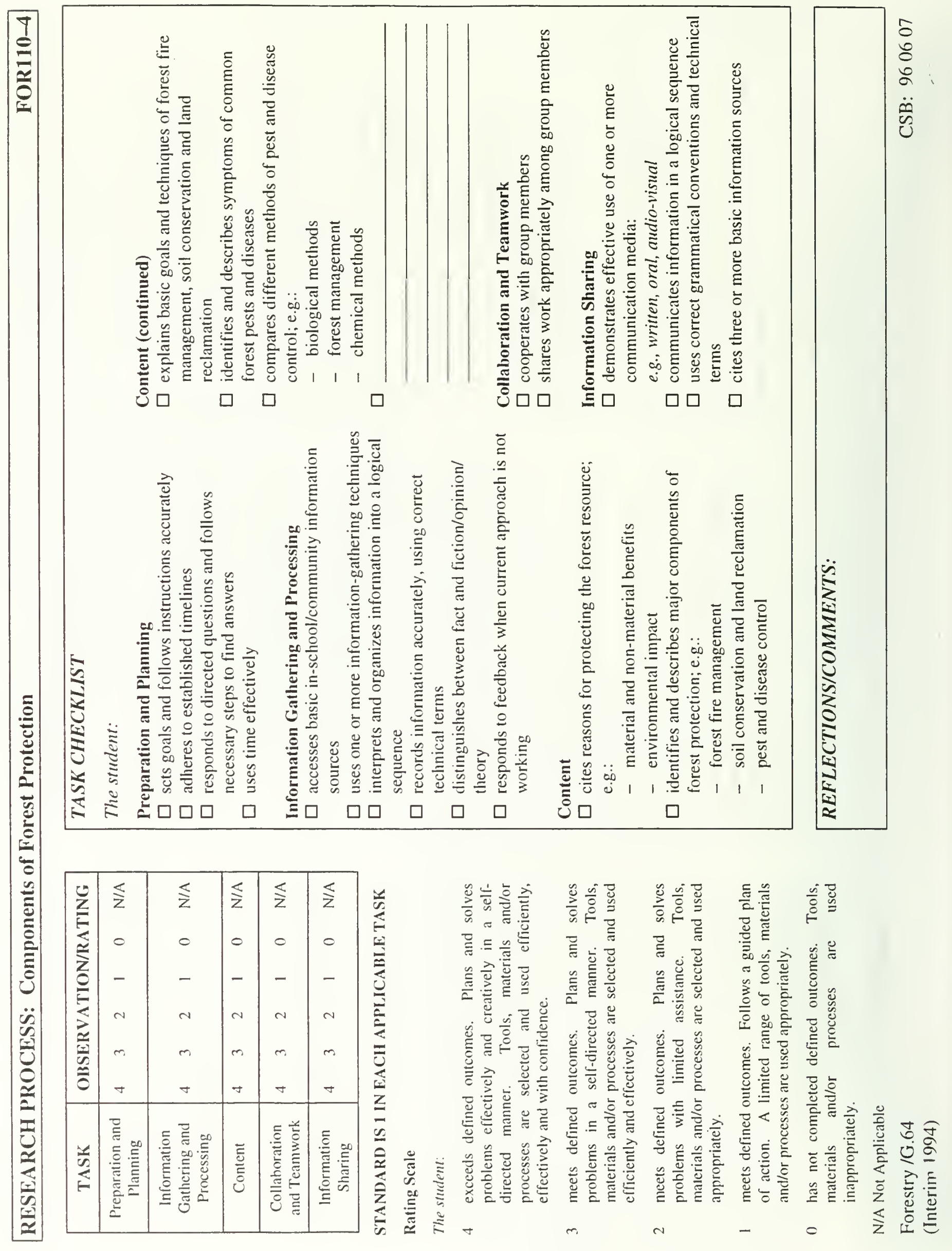




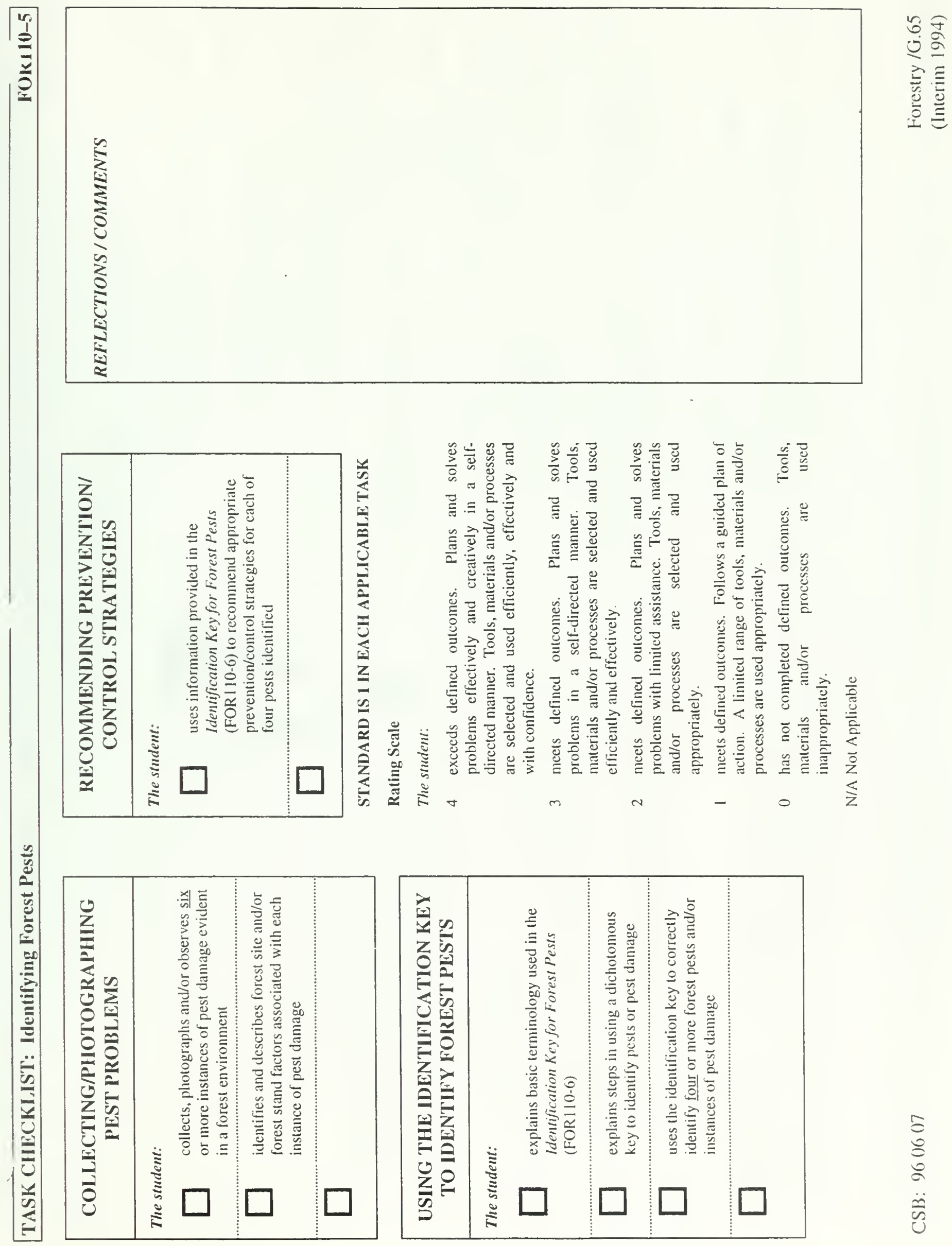




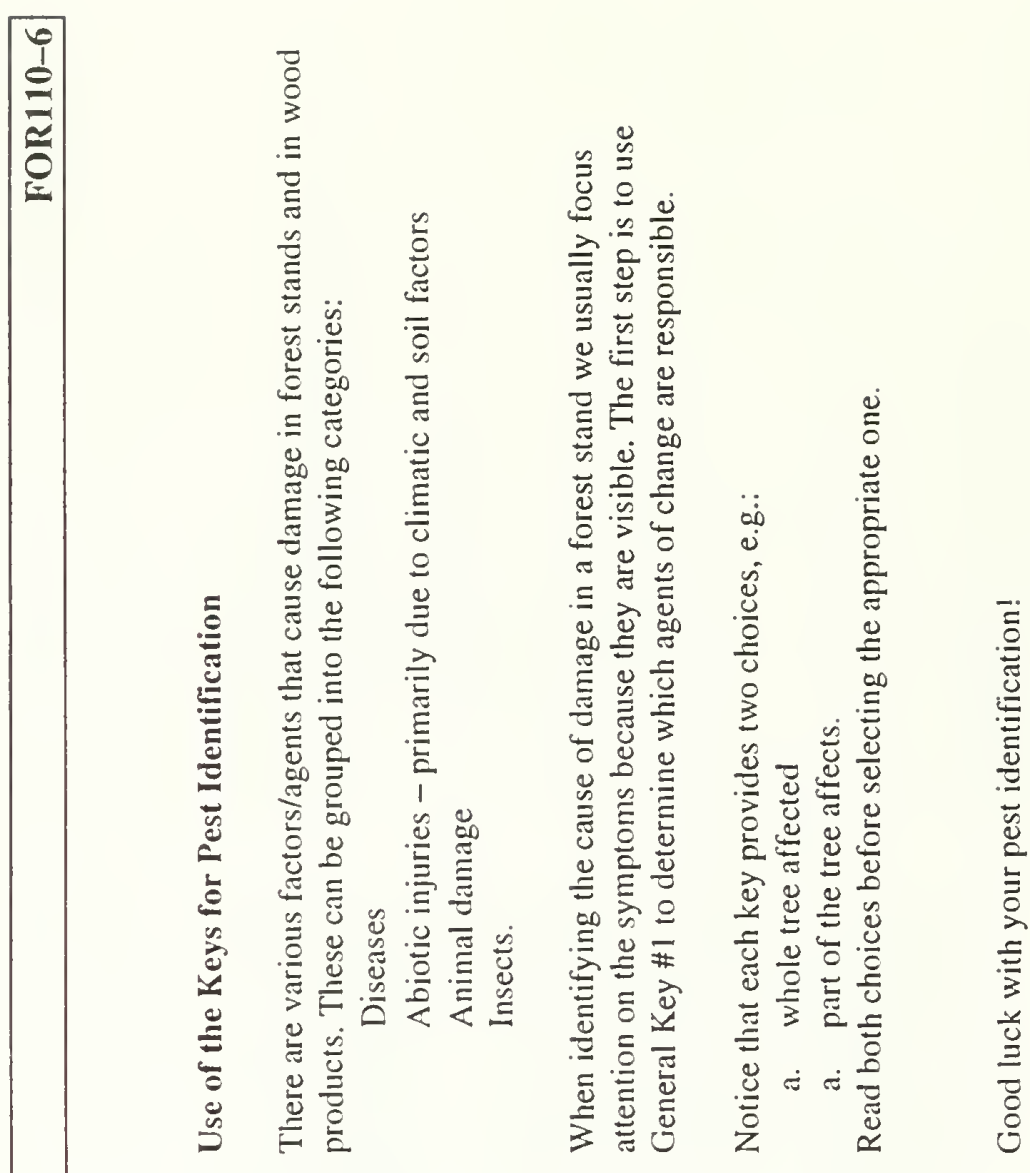

$\hat{\sigma}$
8
0
$o$
$\ddot{v}$
$\tilde{v}$

$\ddot{\mathscr{c}} \equiv \overline{\bar{\Xi}}$

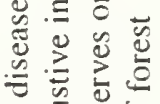

כै

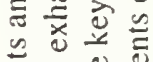

Чั.

$\Xi 9^{\circ}$

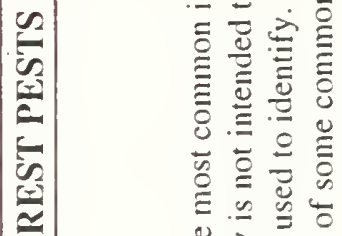

小气

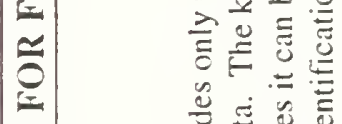

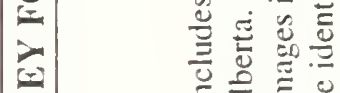

正 导㤩恶

는

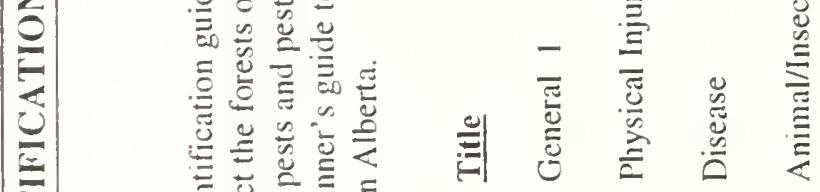

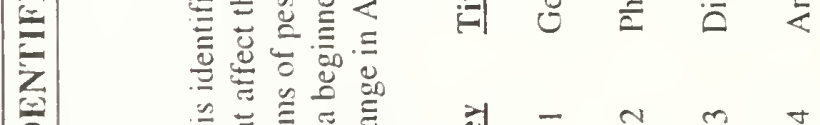

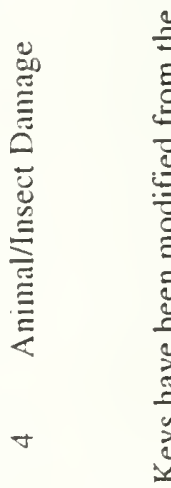

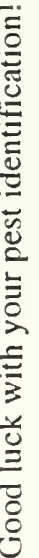




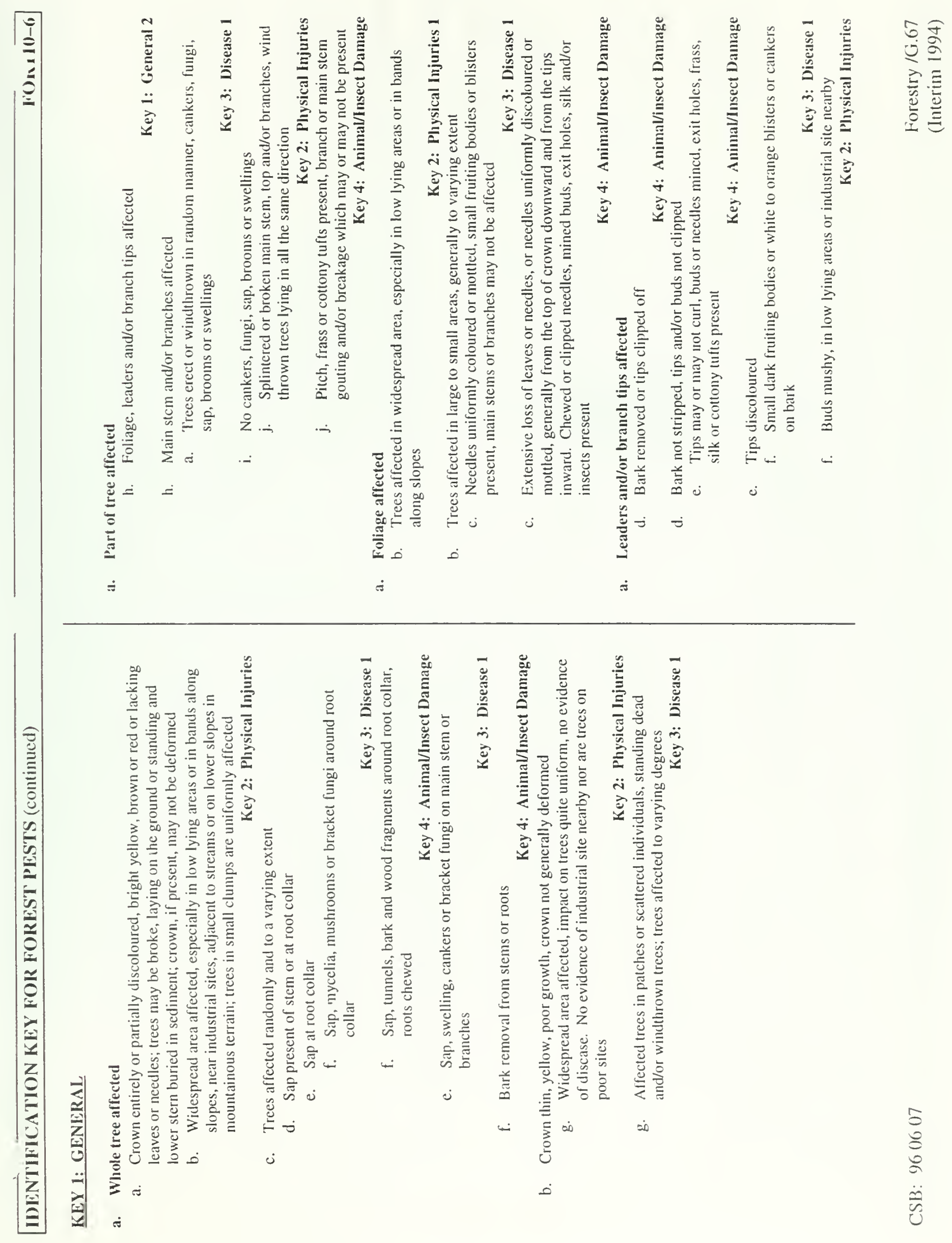




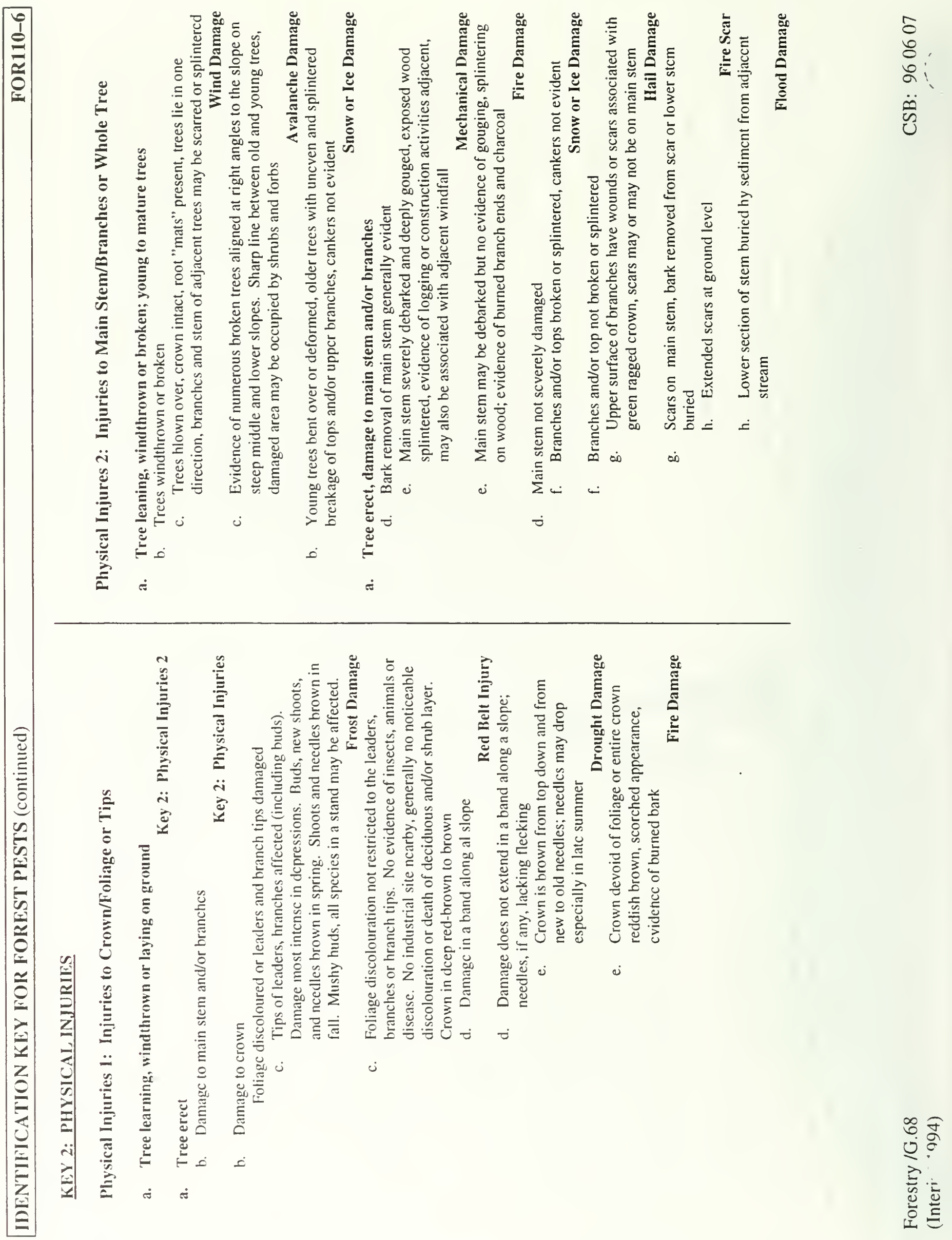




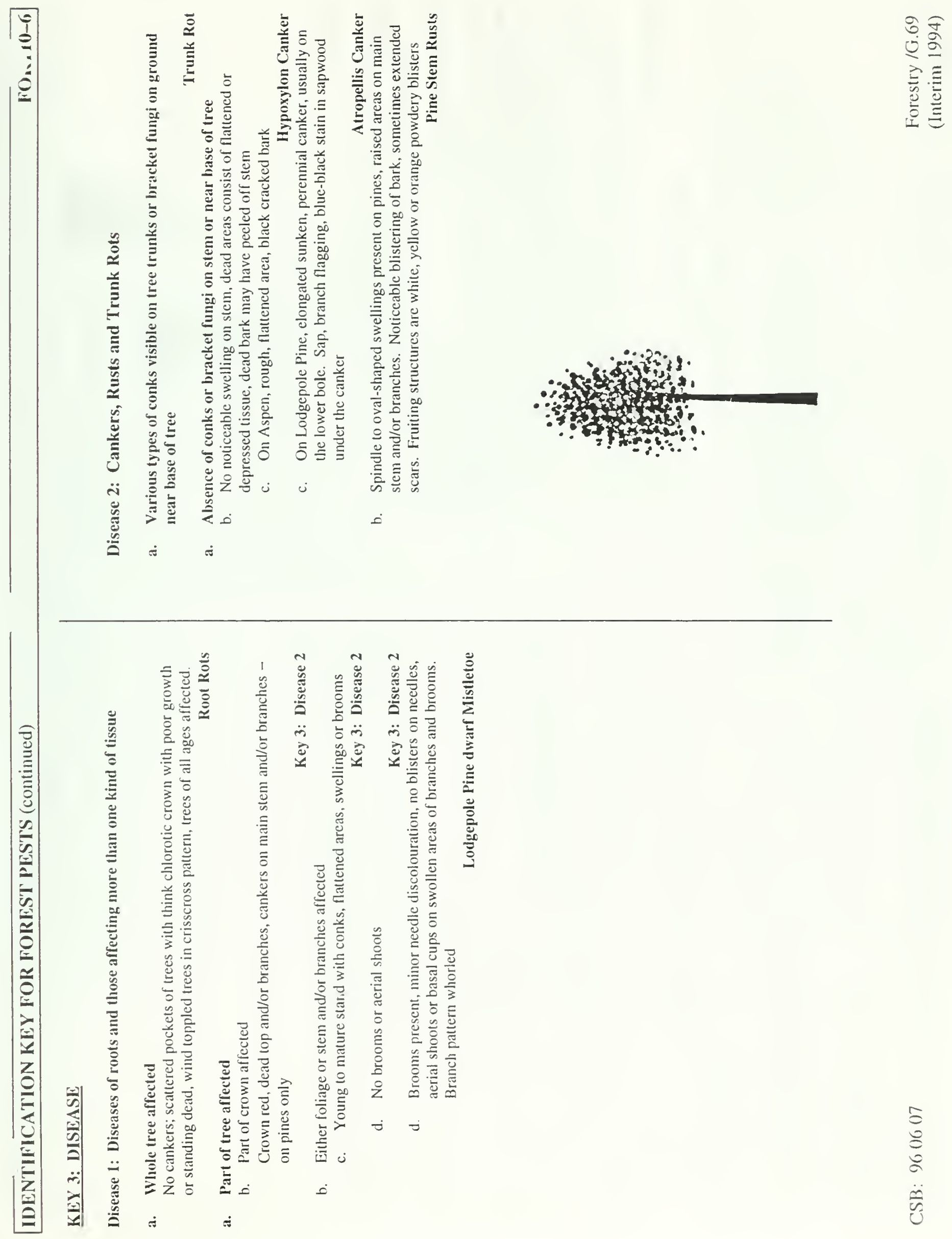




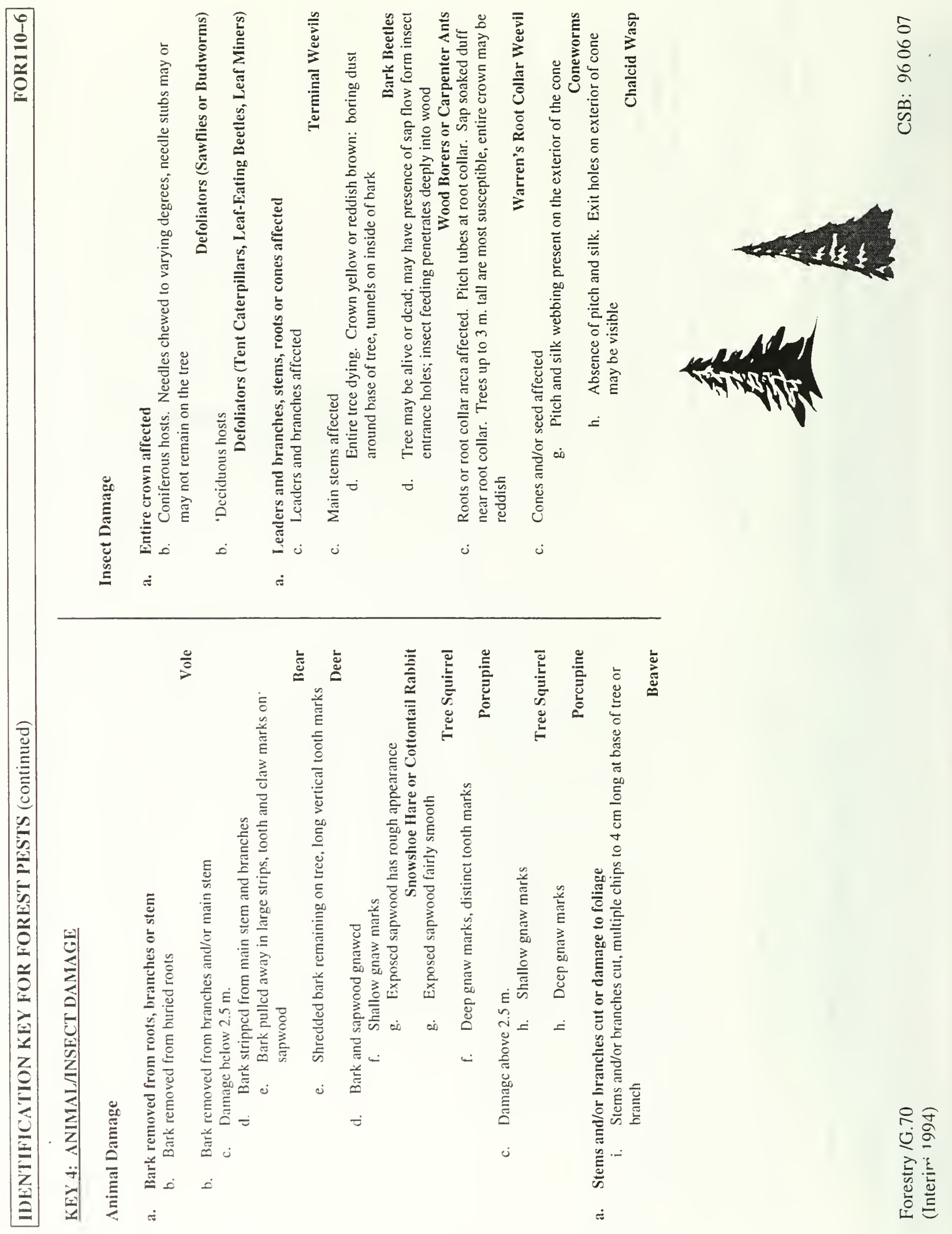




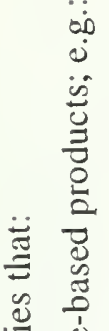

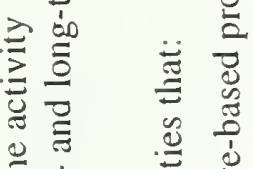

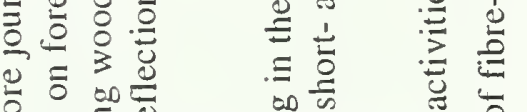

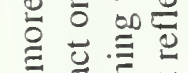

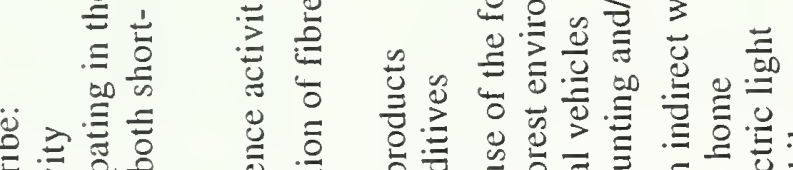

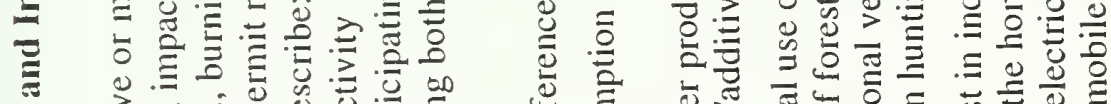

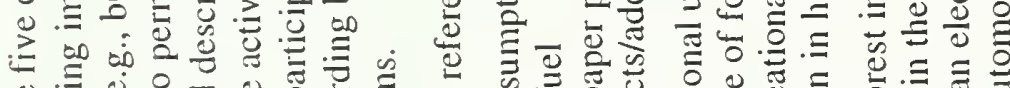

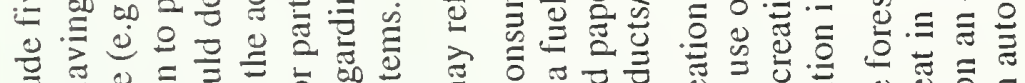

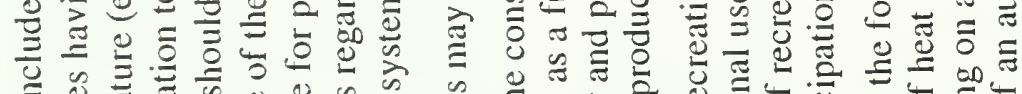

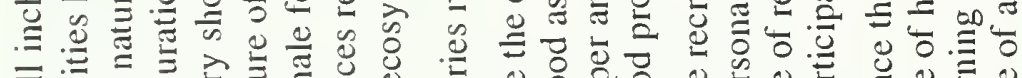

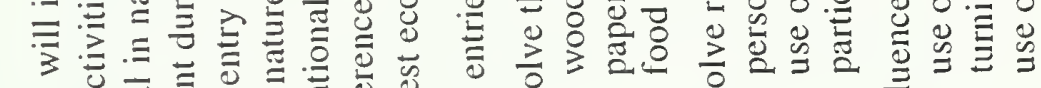

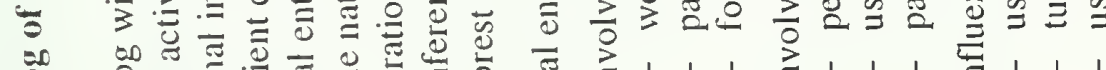
总

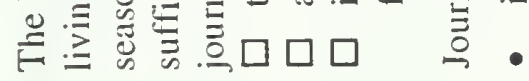

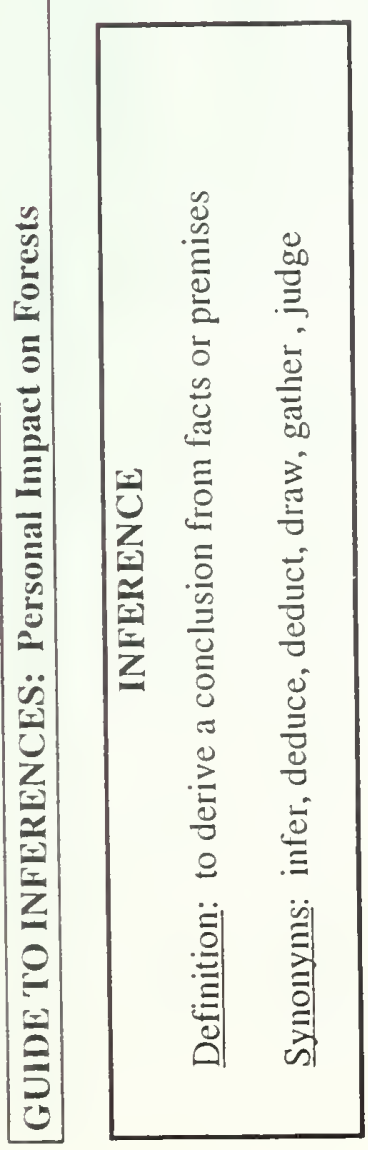

밀 吾

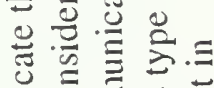

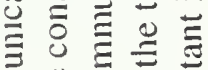

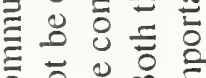

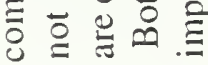

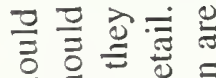

흠 흫

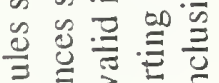

을

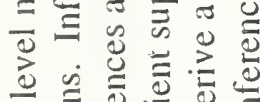

递 은.

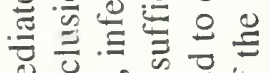

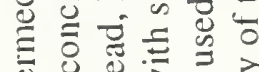

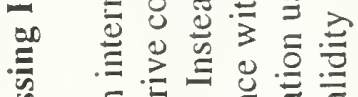

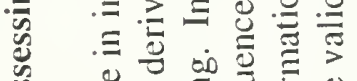

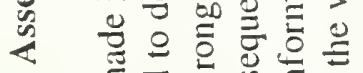

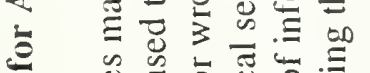

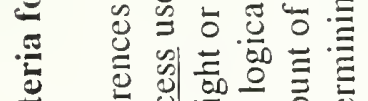

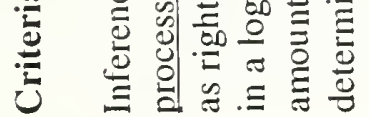

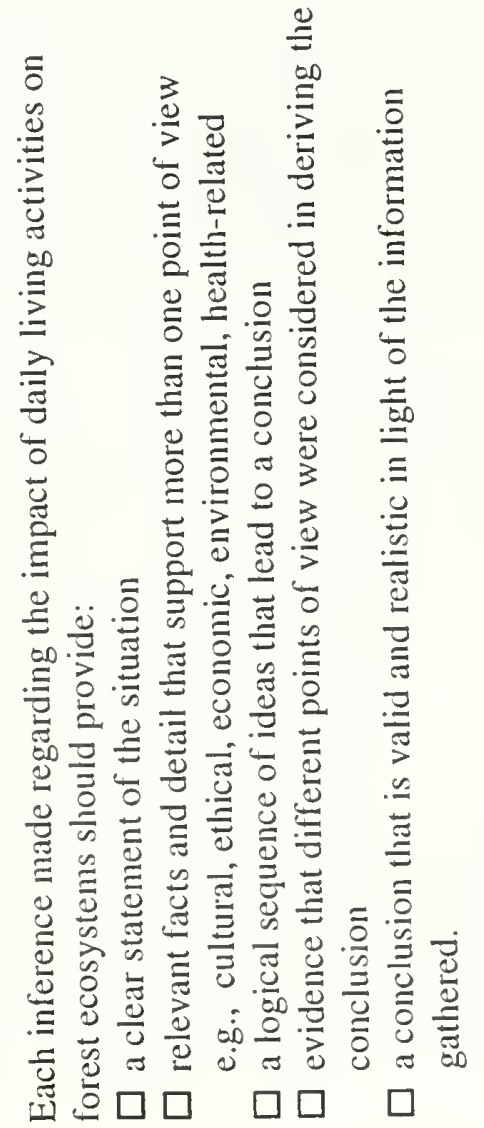

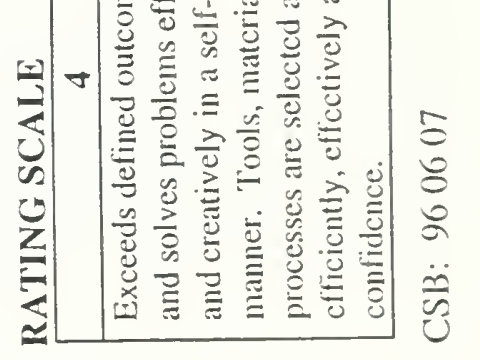



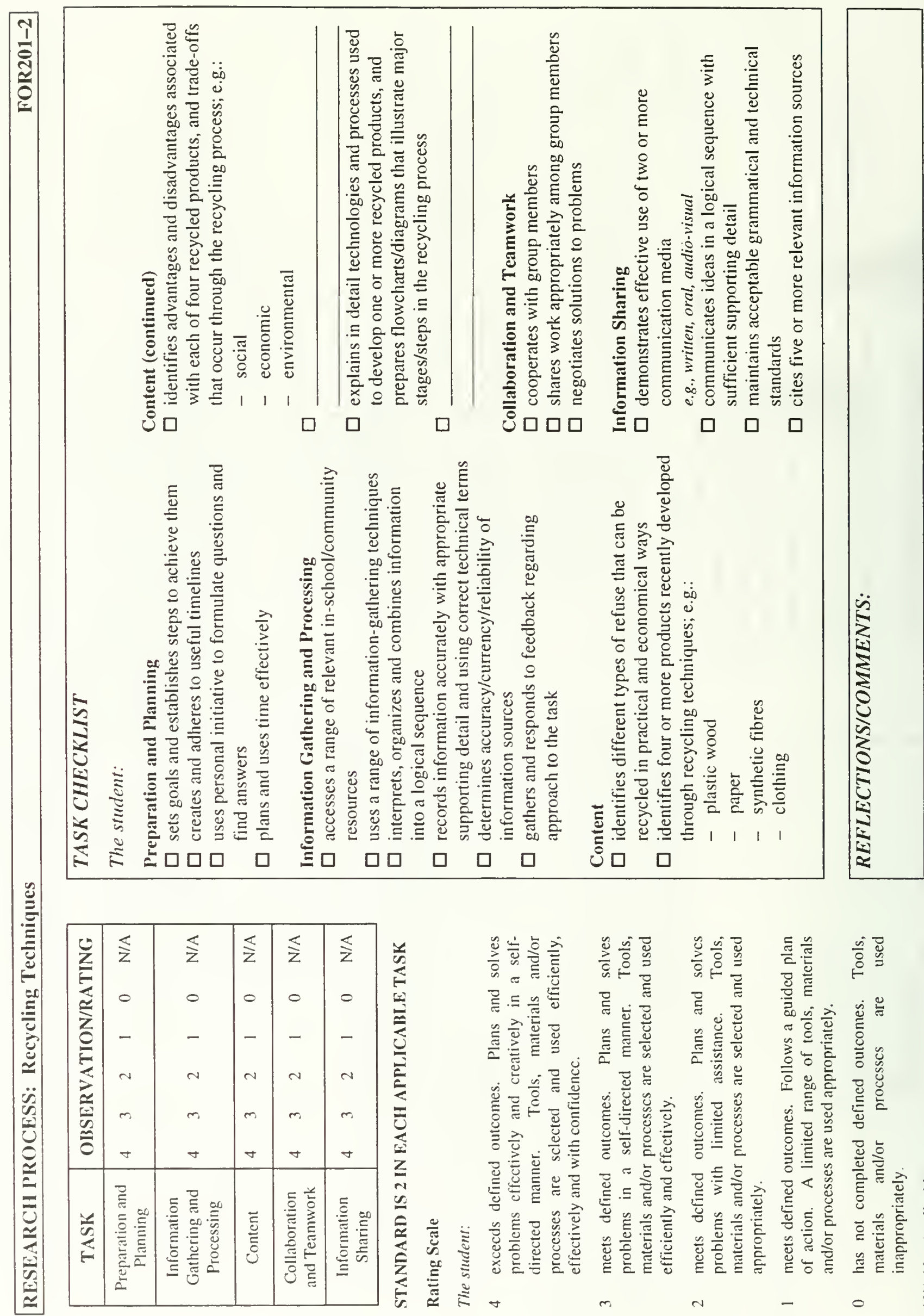

这

5
0
0
0
01
0
0 


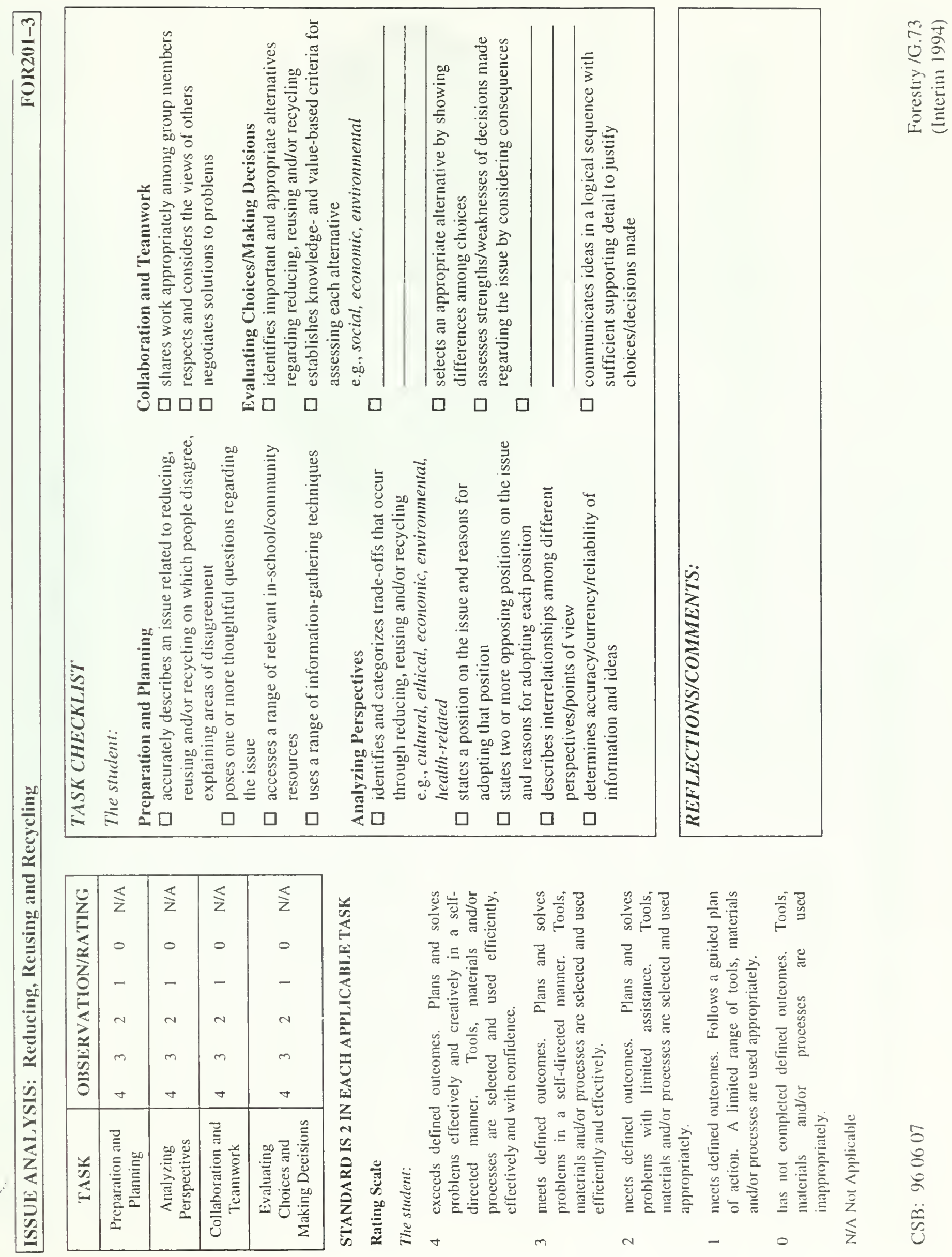




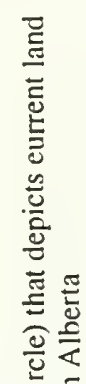

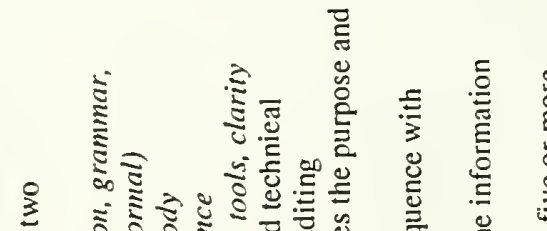

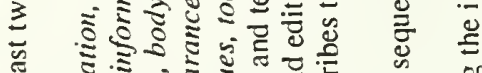

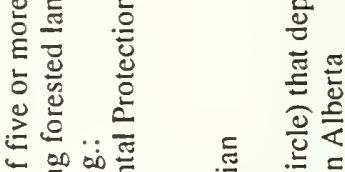

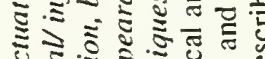

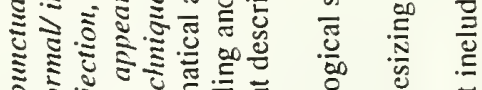
०

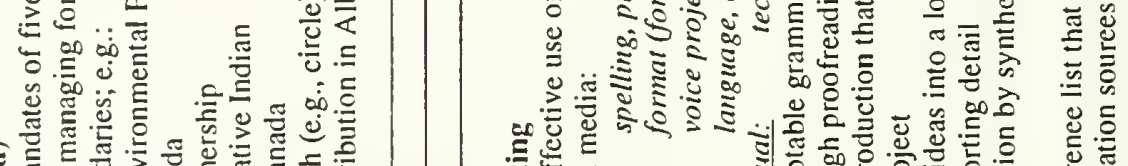

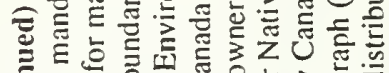

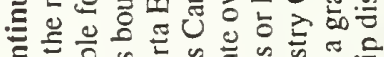

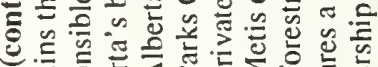

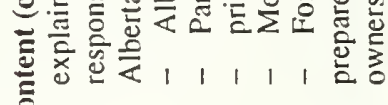

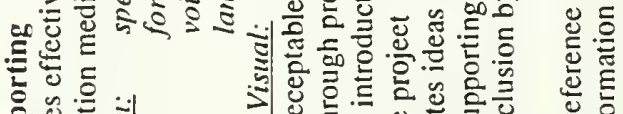

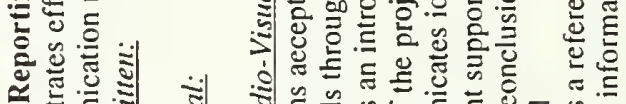

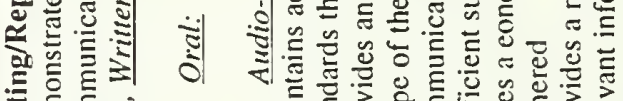

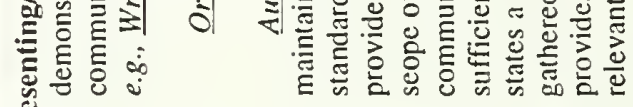
है।

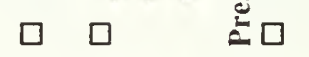
$\square \square \square \square \square$

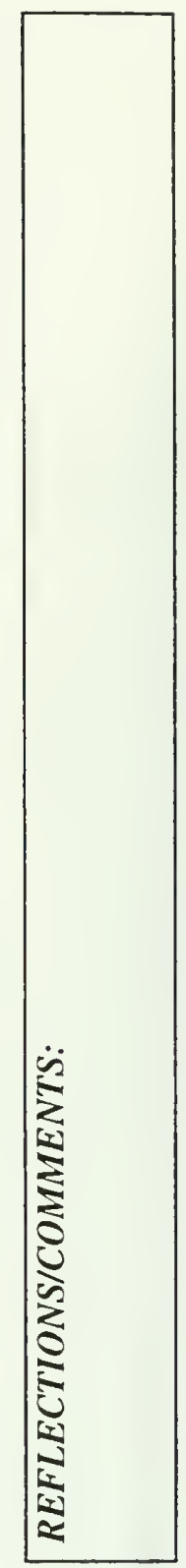

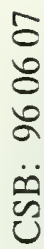
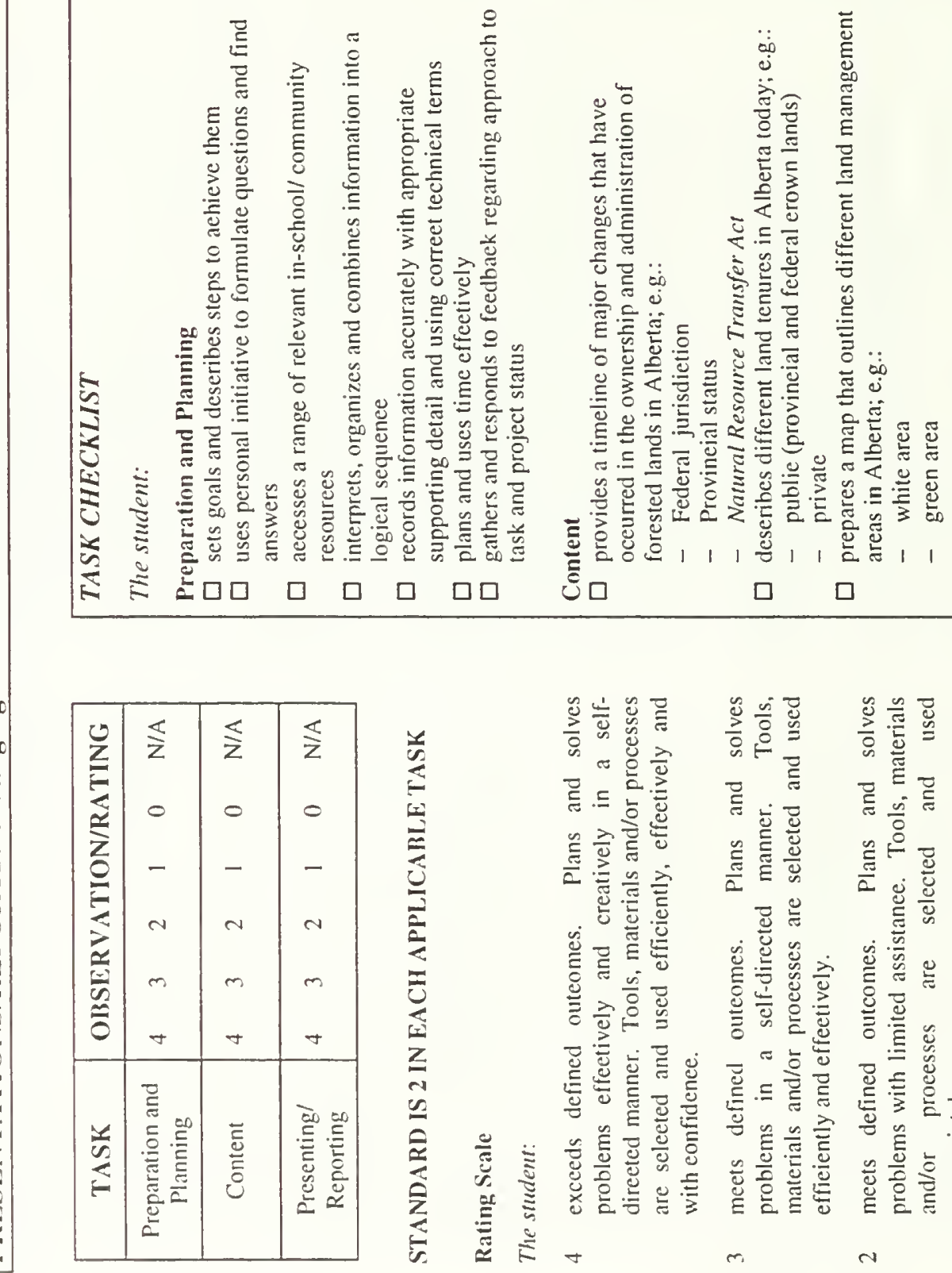

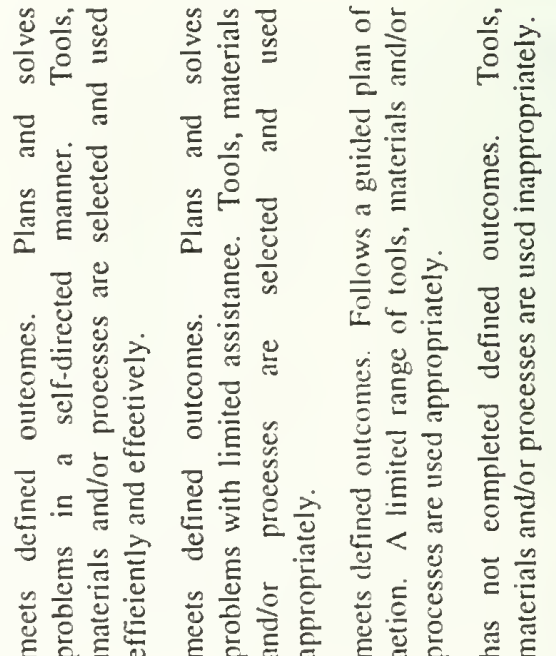




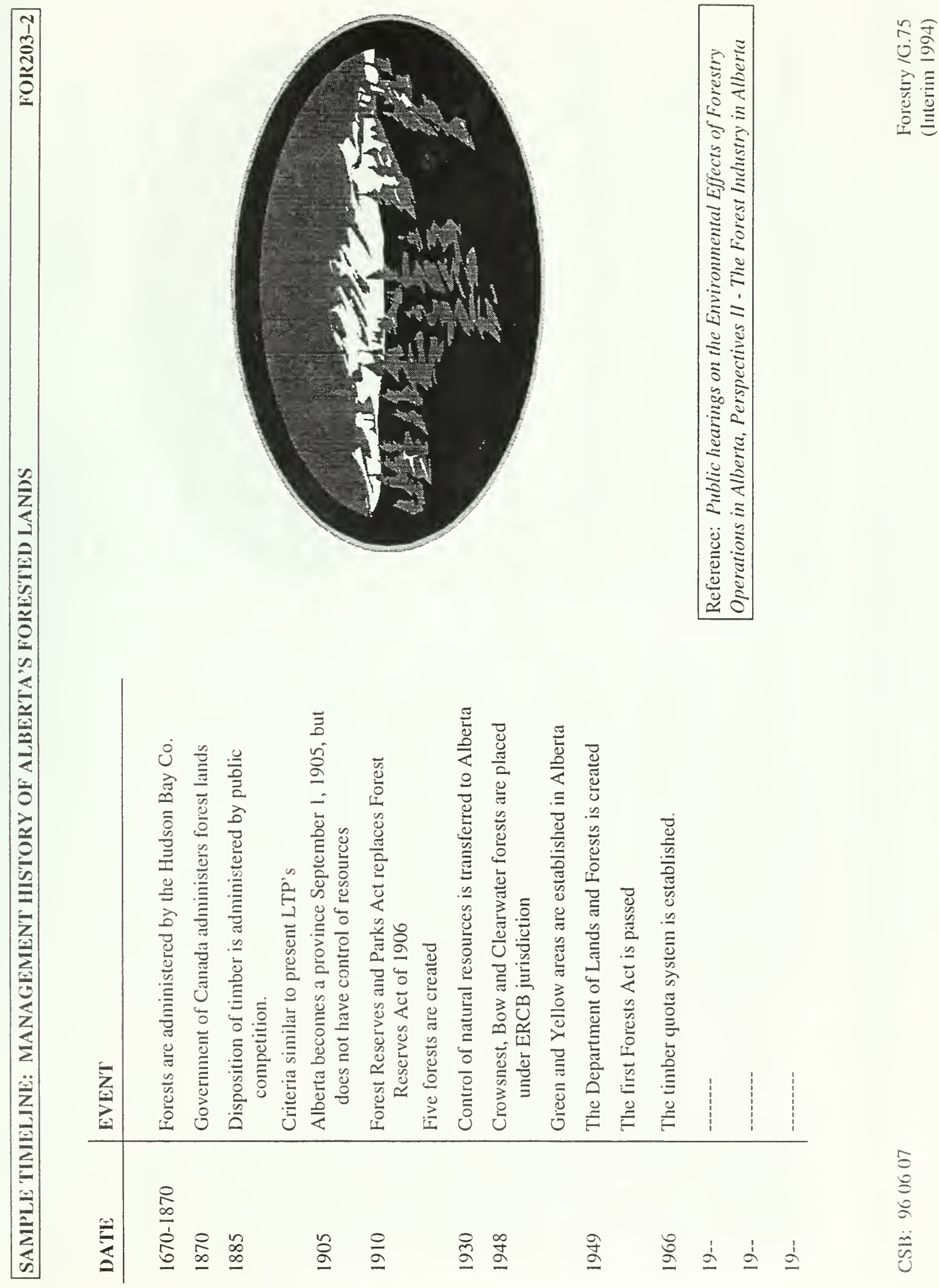




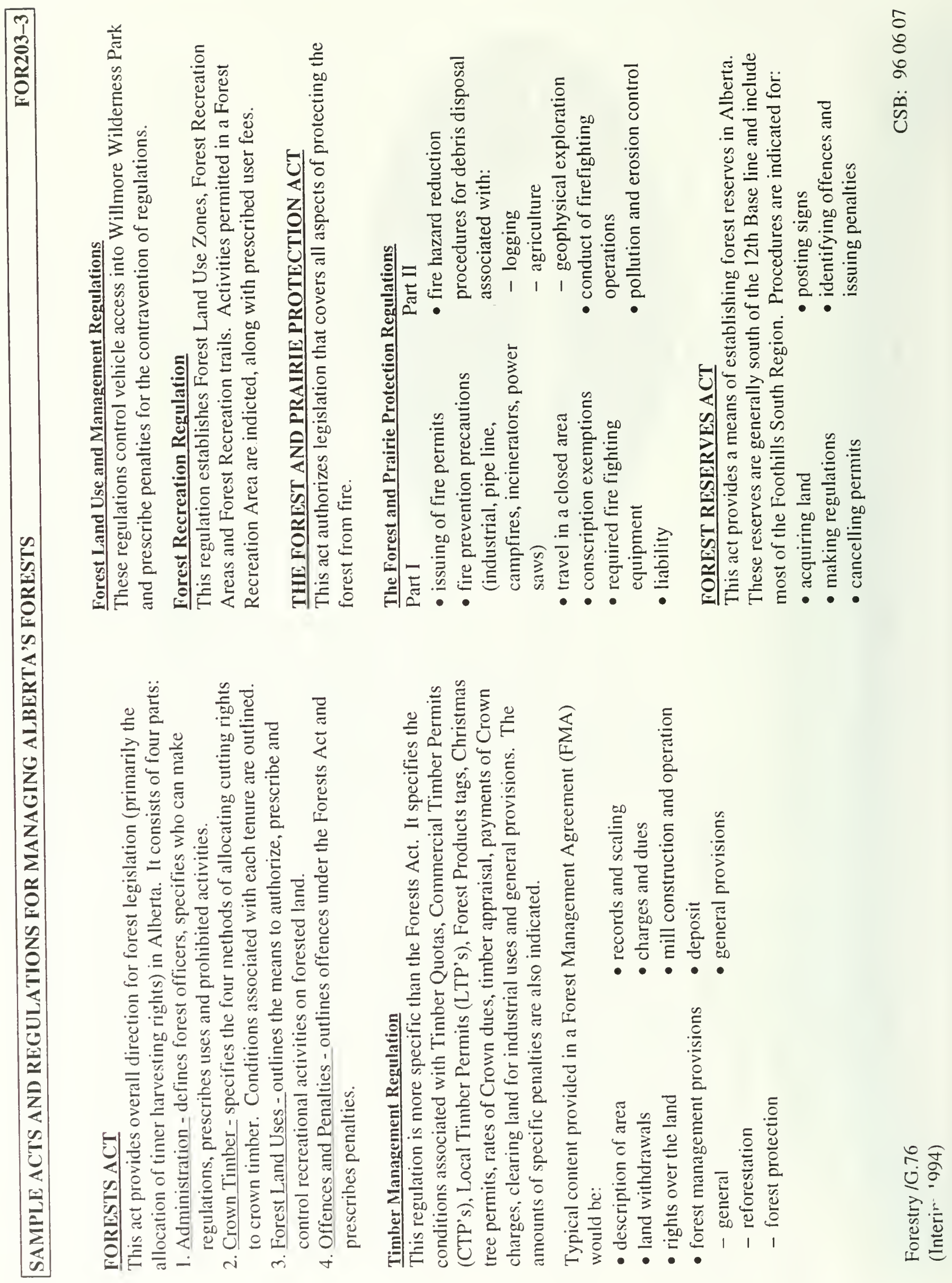




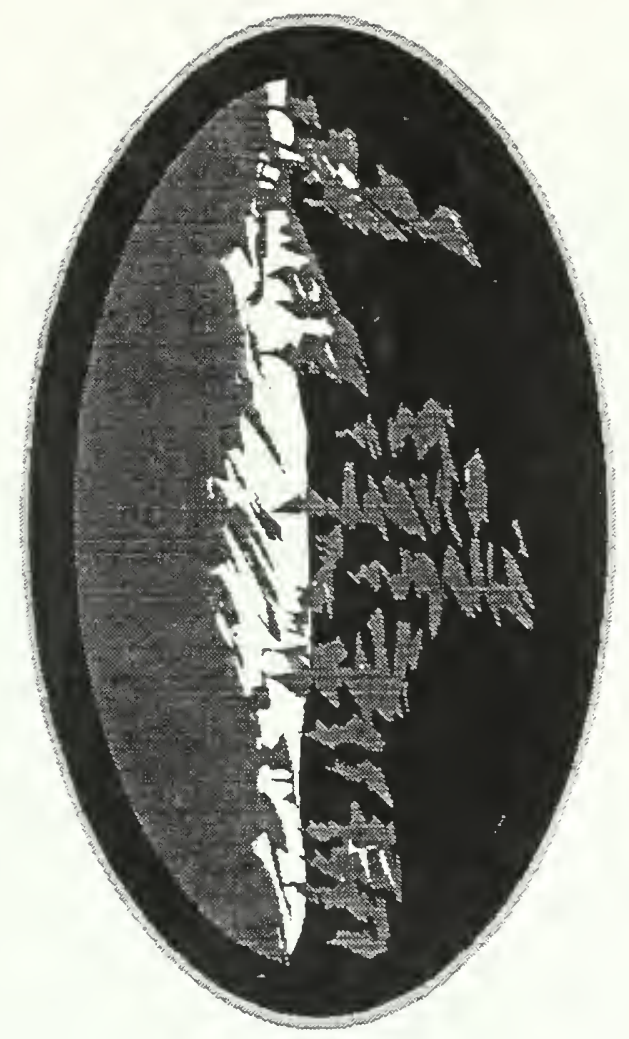




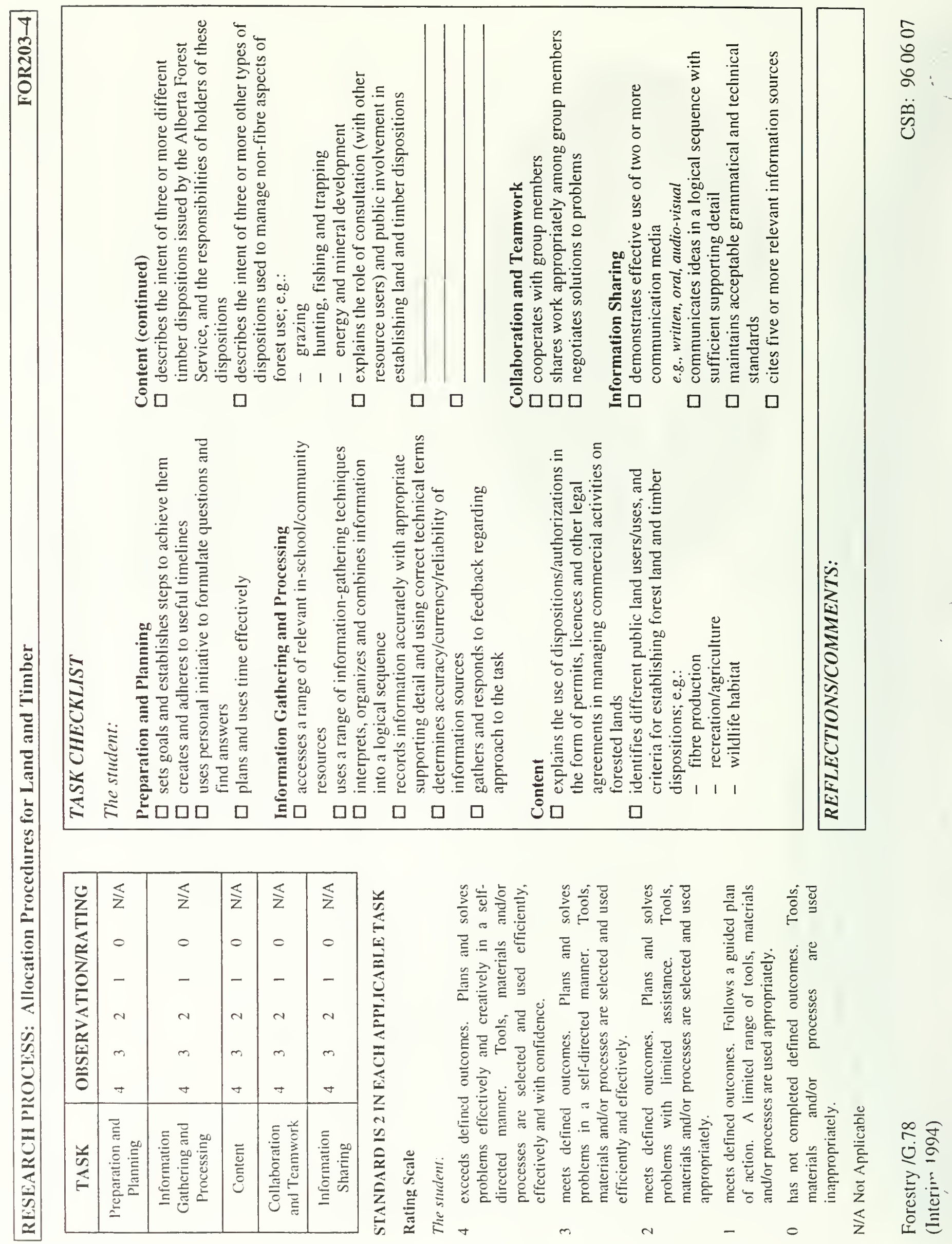



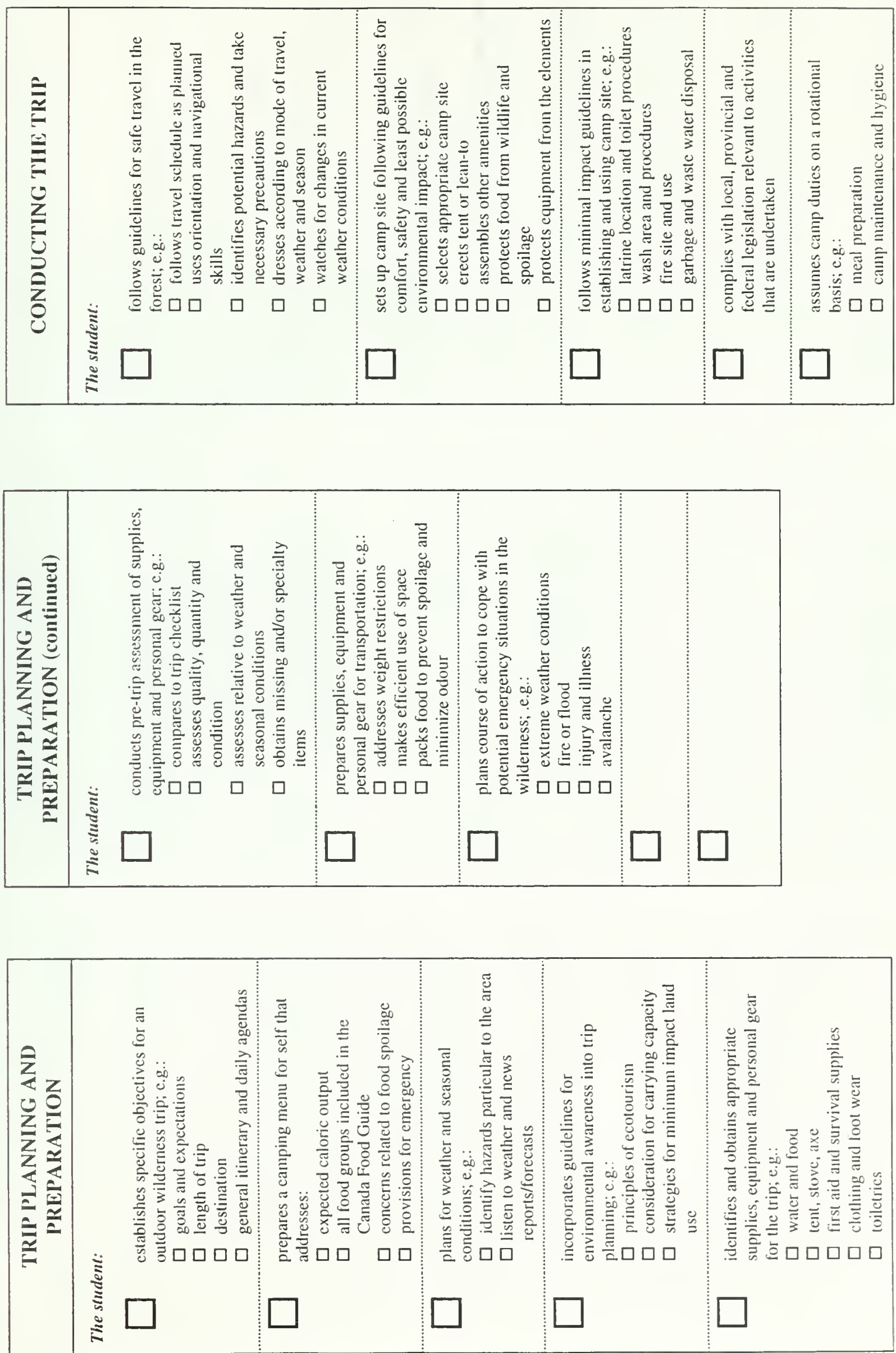


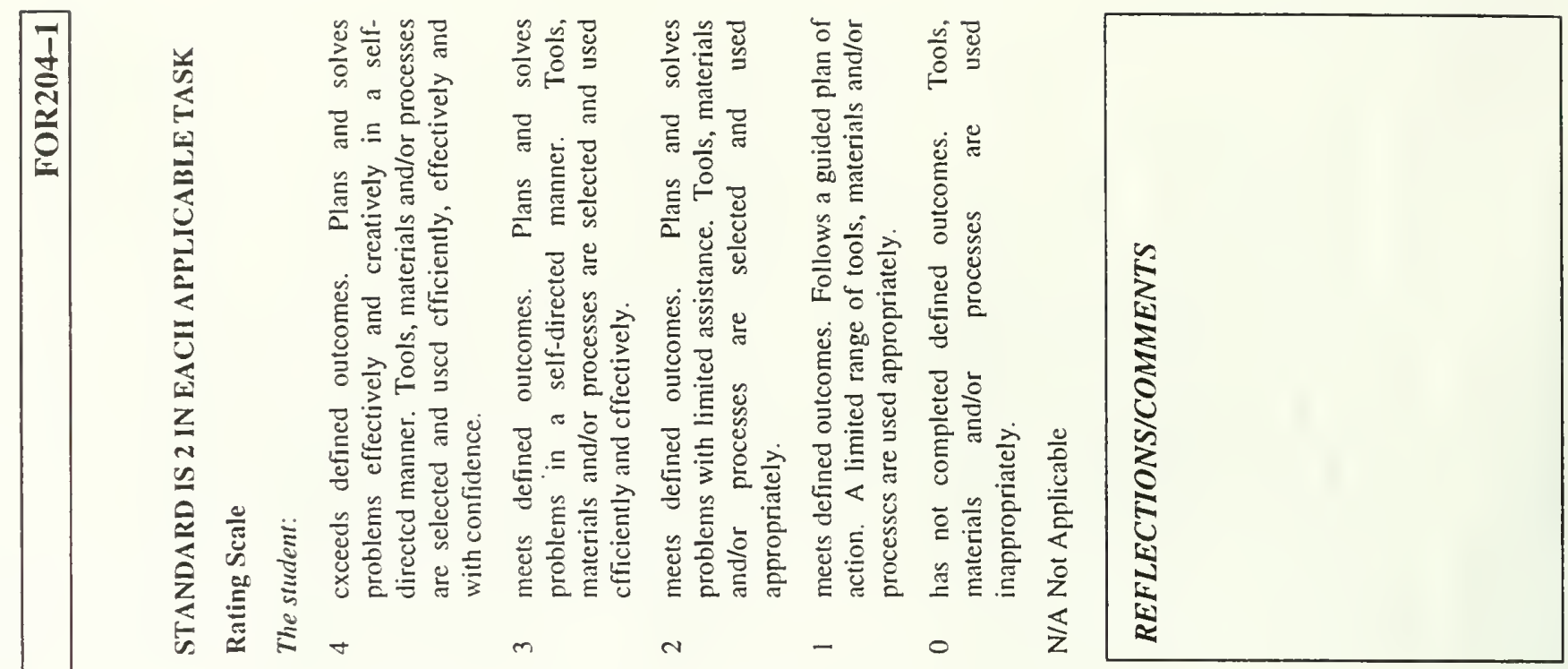

5
8
0
0
$\ddot{0}$
0
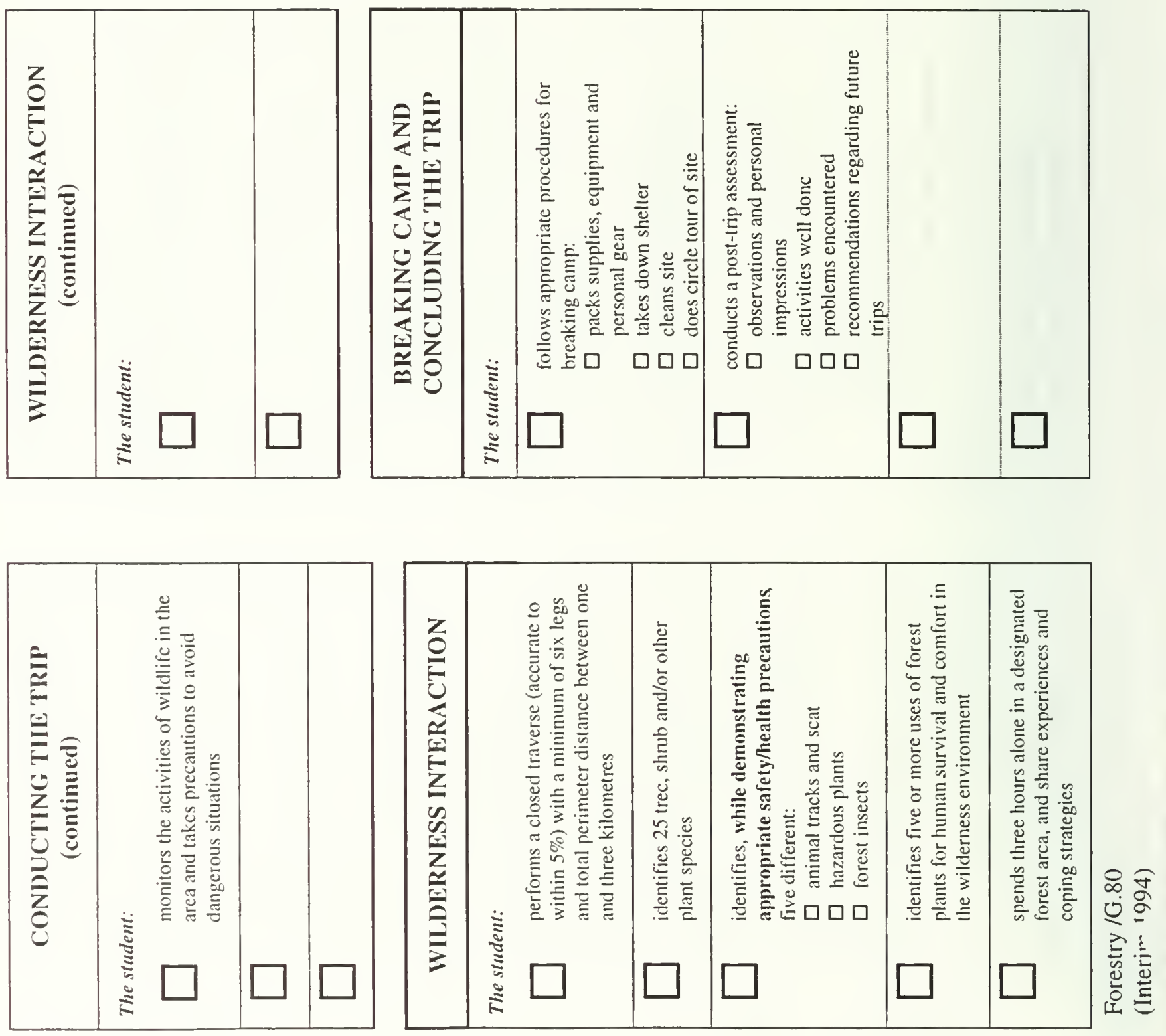

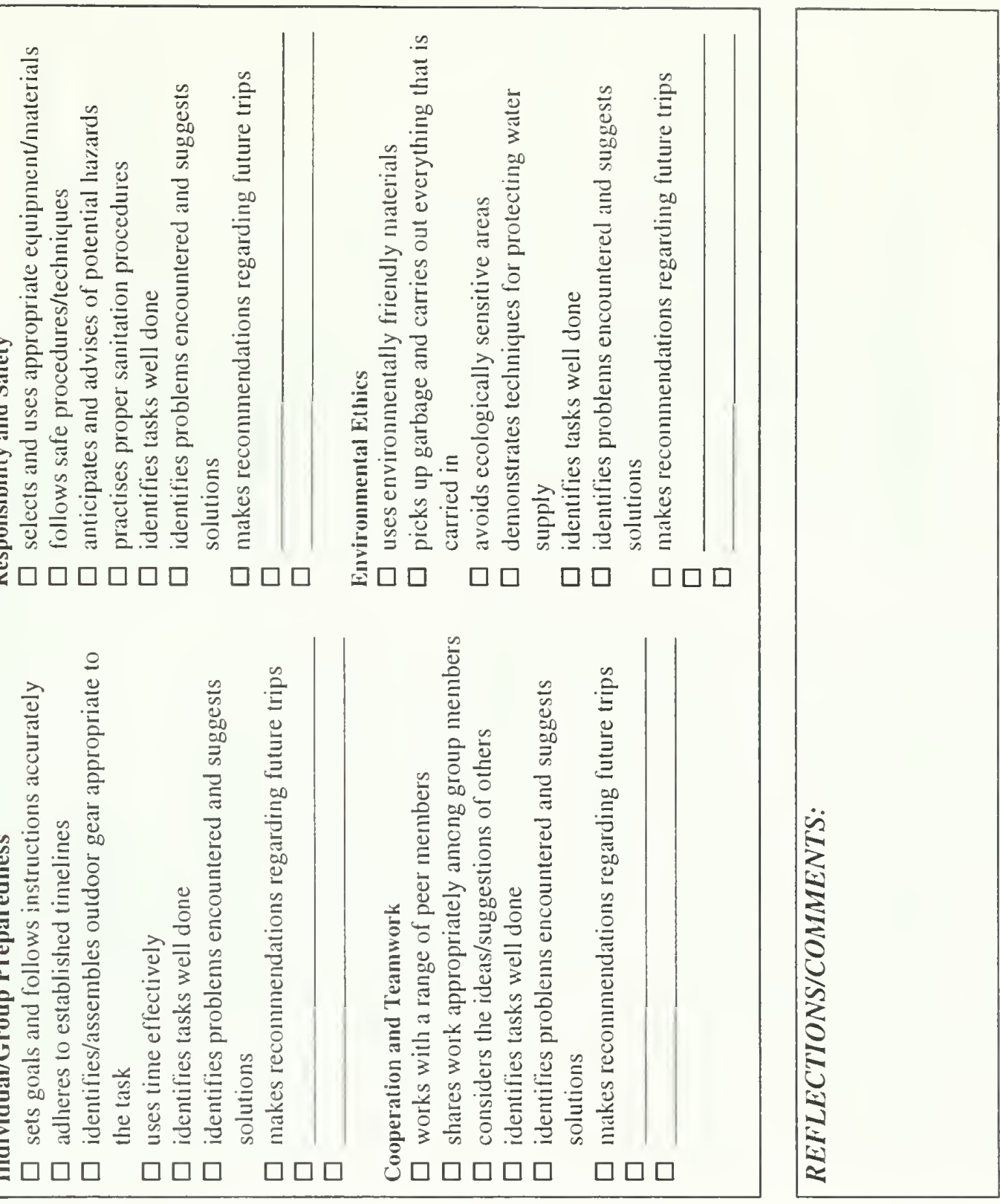

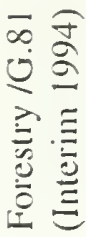

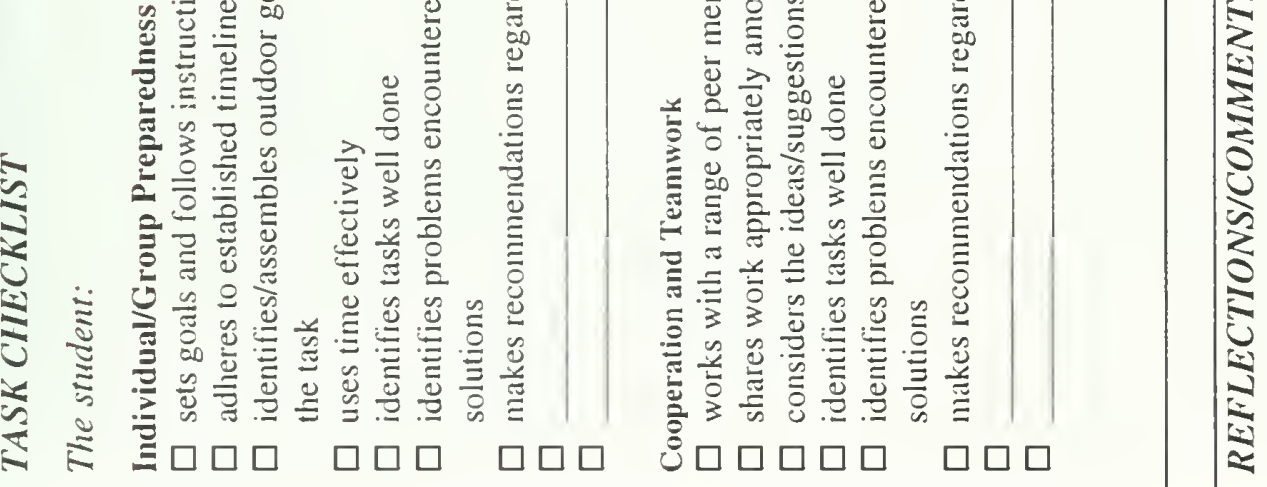

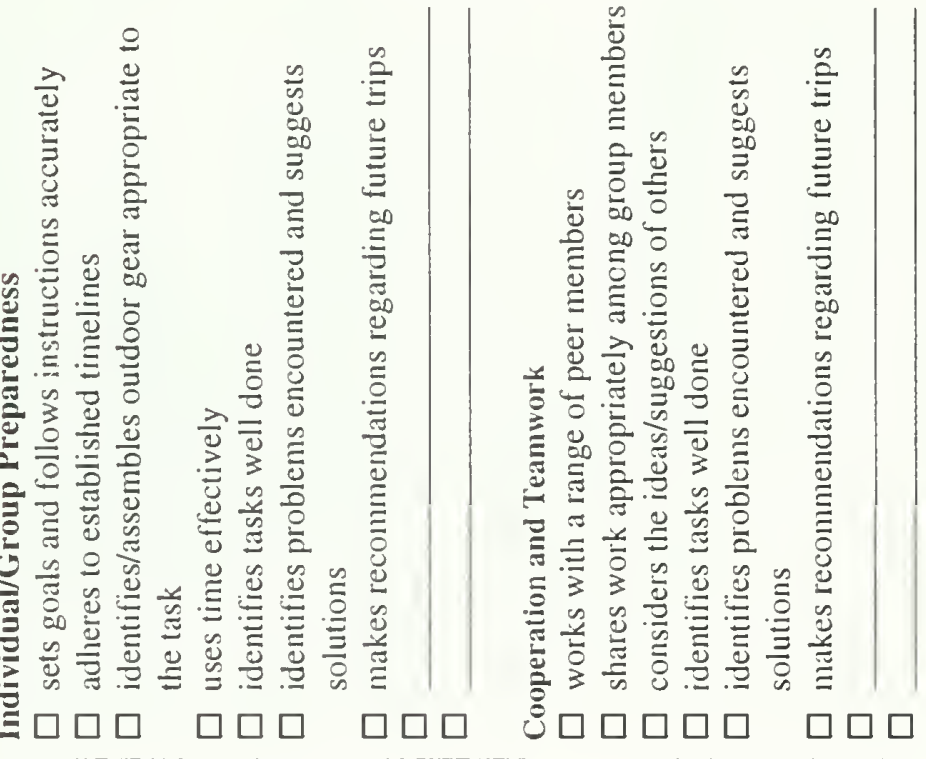

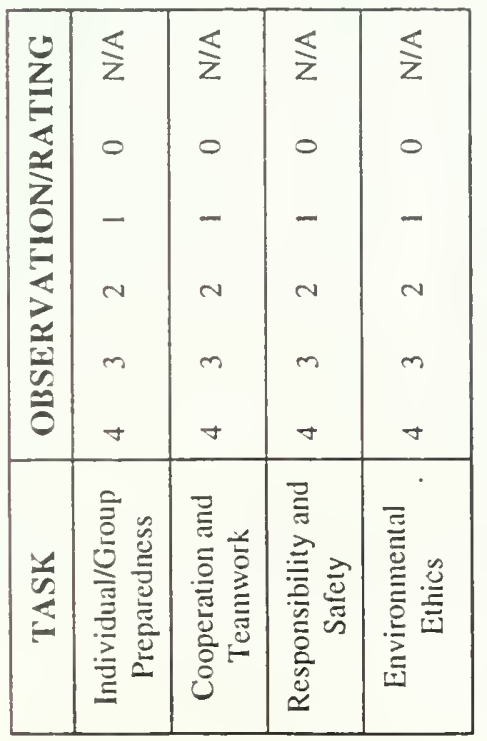

产

总岕高竞

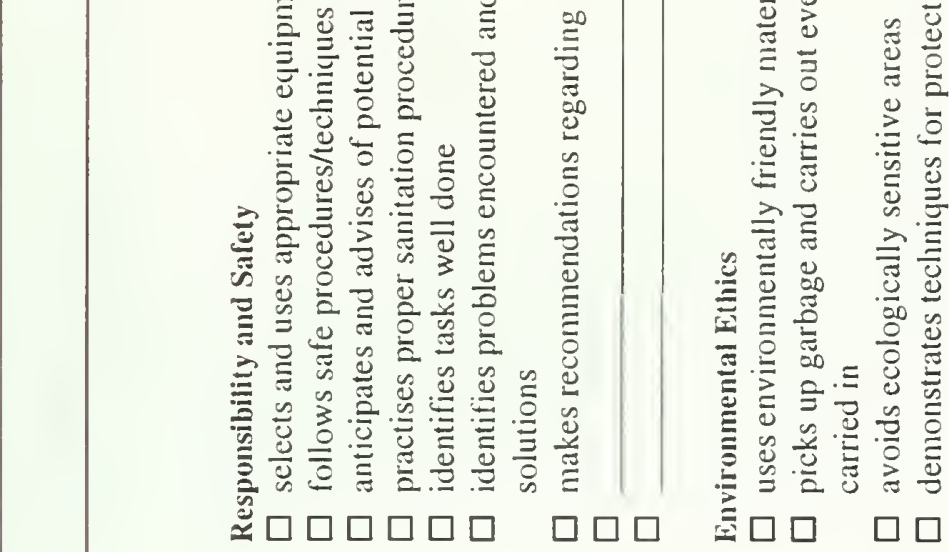

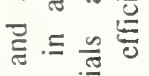

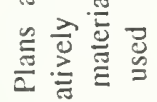

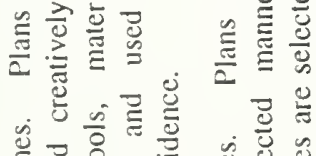

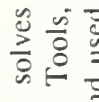

$\stackrel{0}{0} \frac{0}{0}$

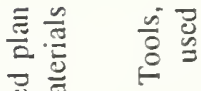

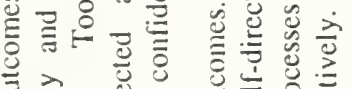

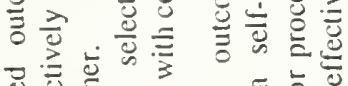

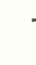

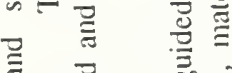

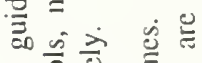

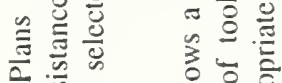

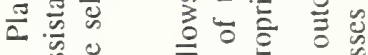

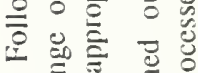

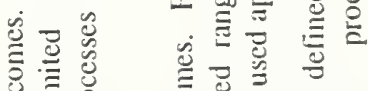

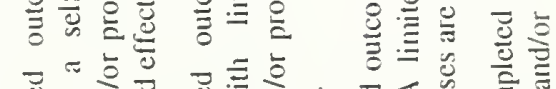

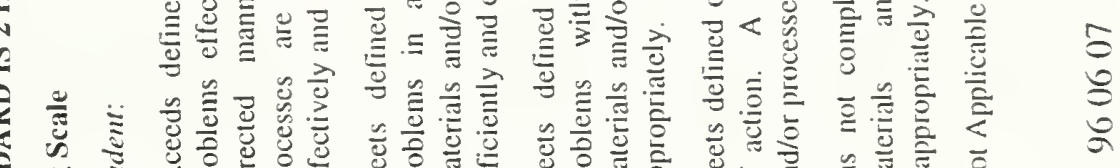

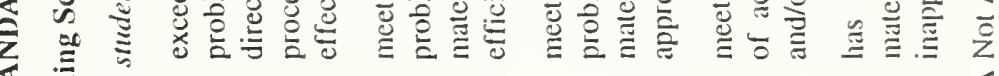




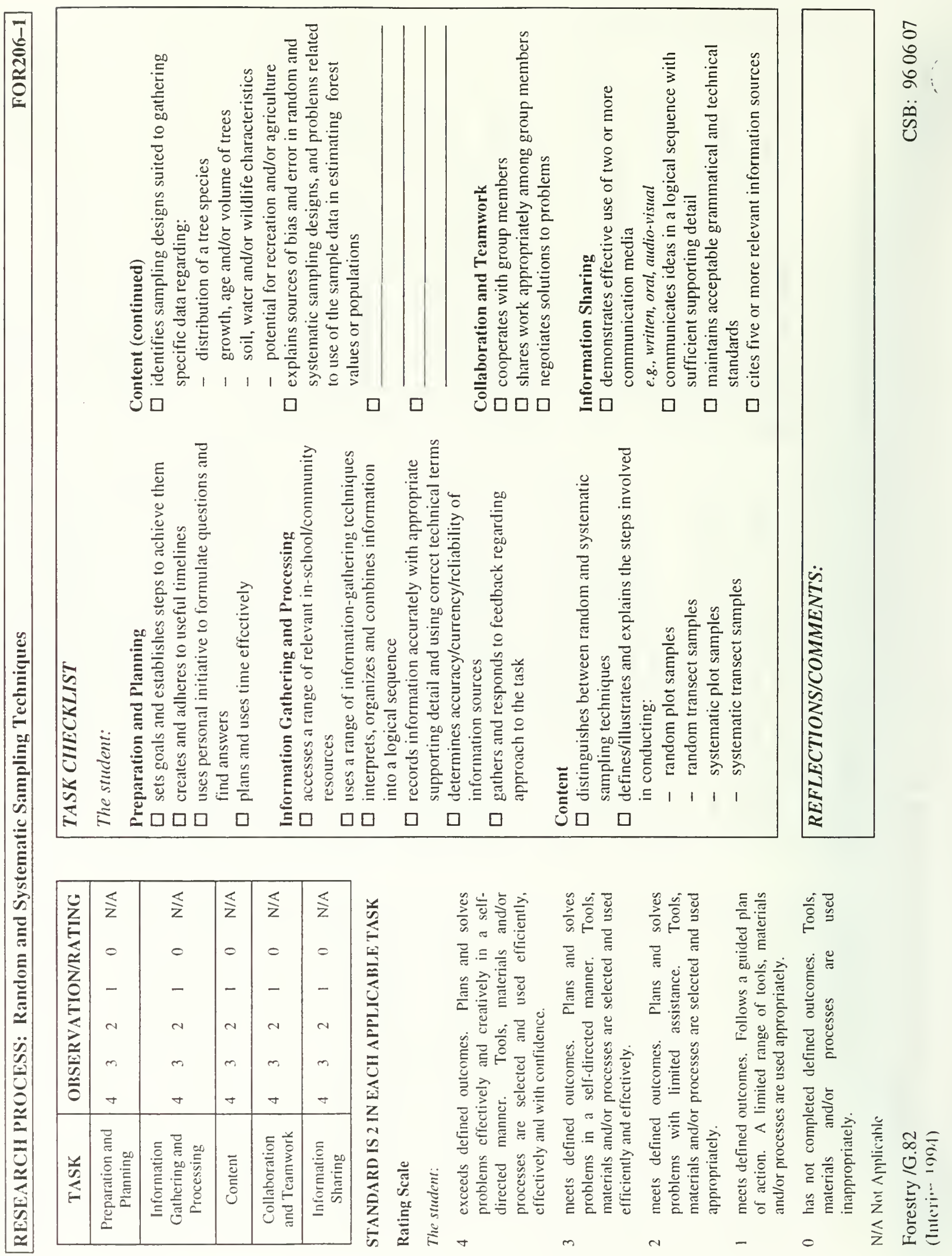



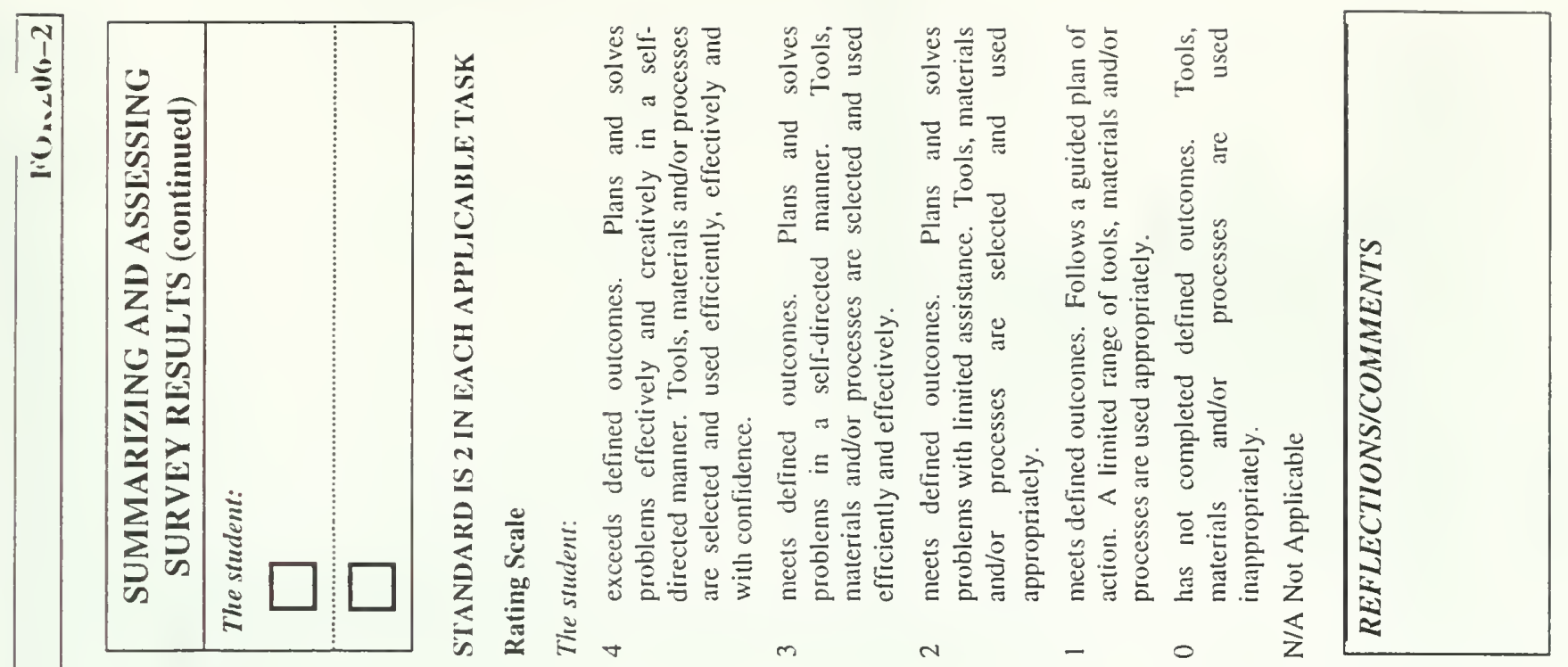

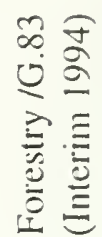
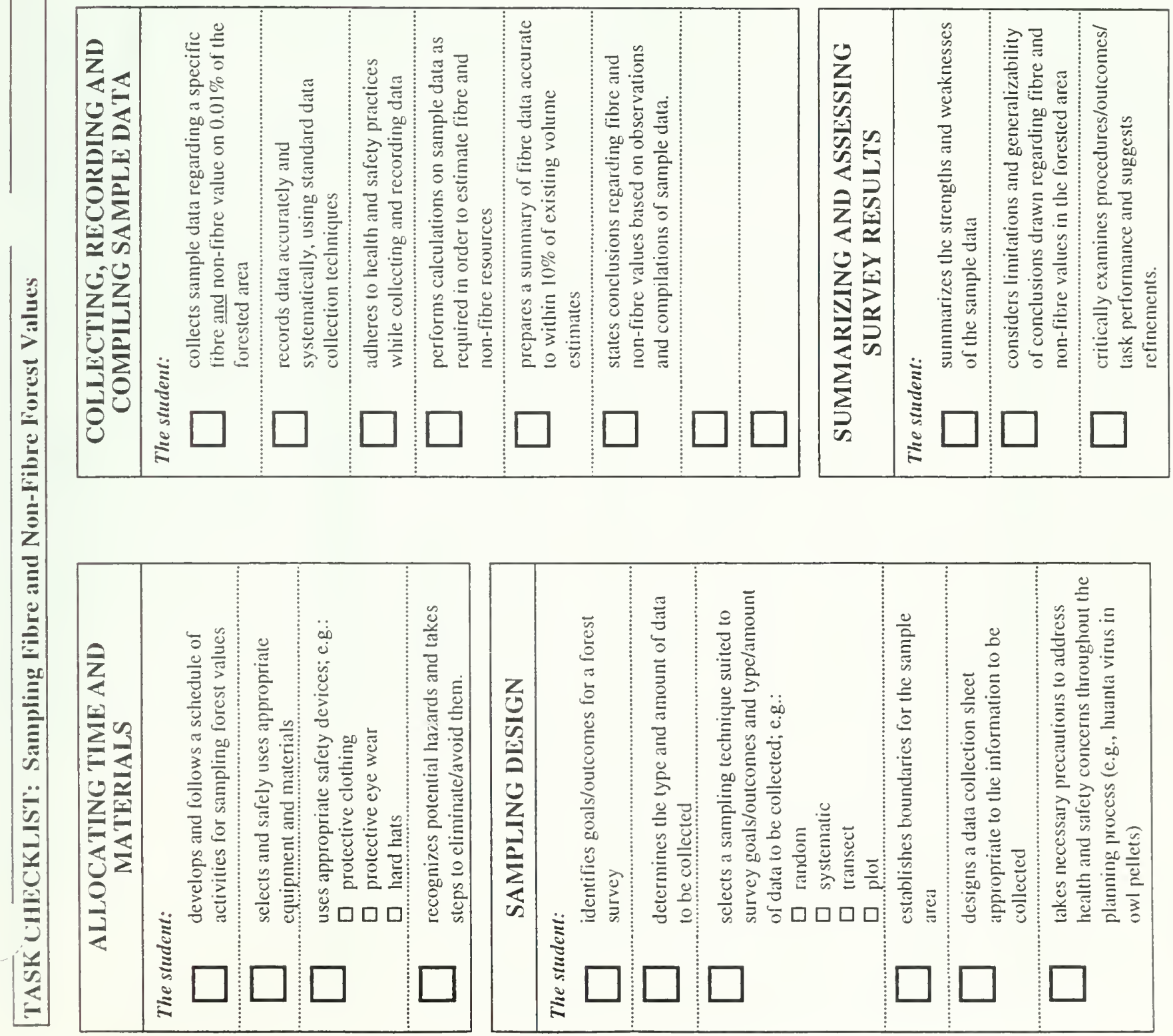

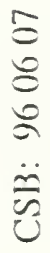




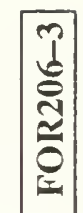

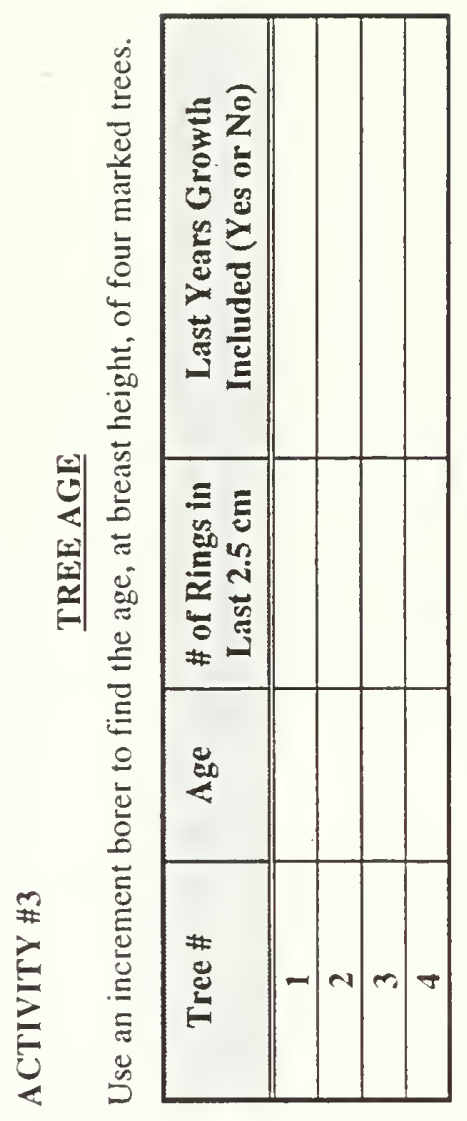

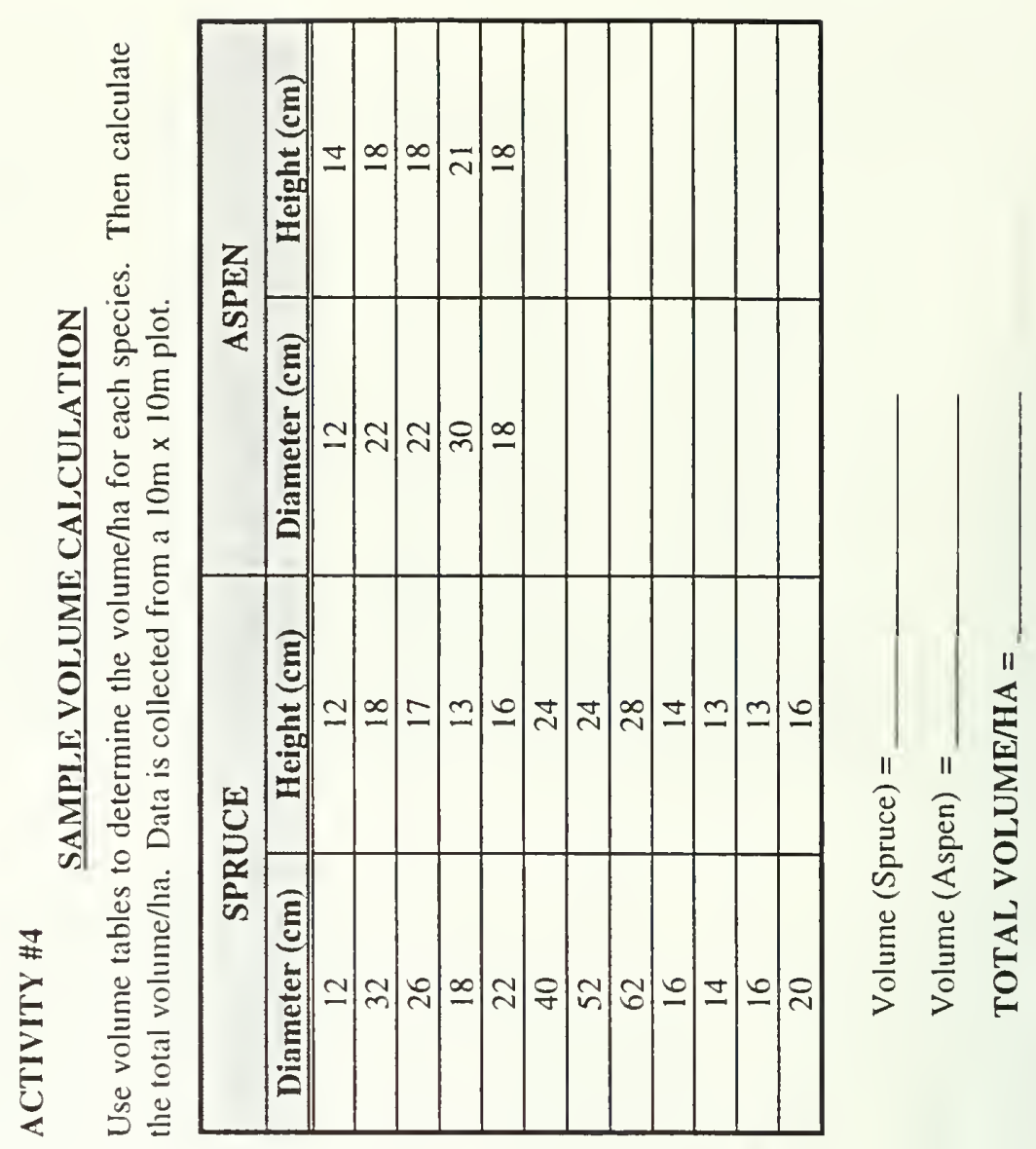

5
8
0
0
0
0
0
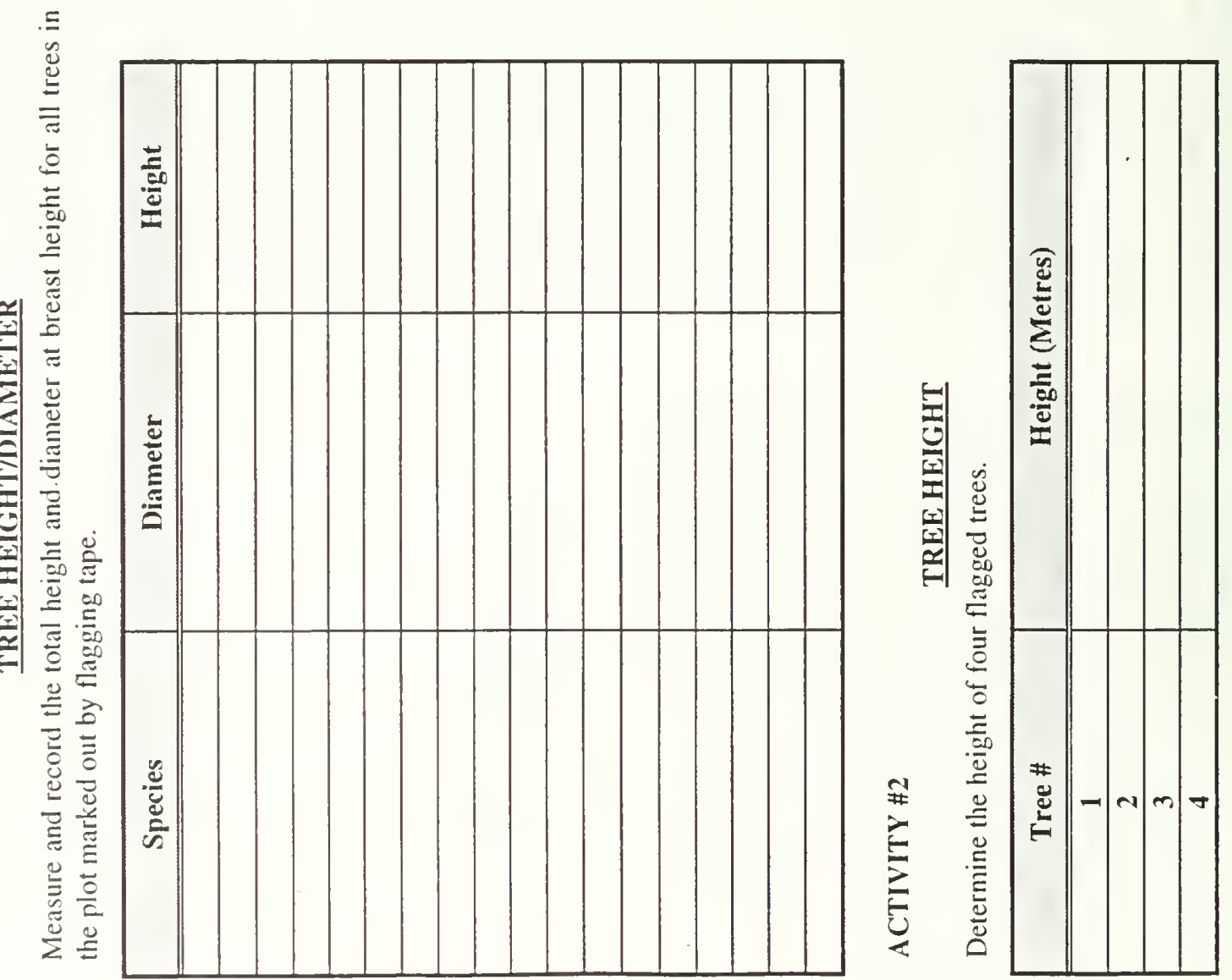

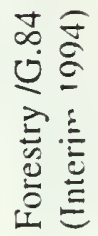


?

造重

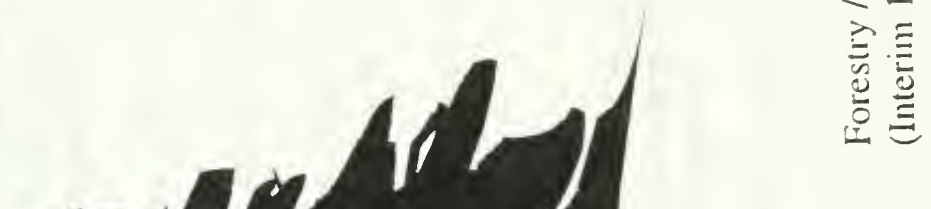

$=$

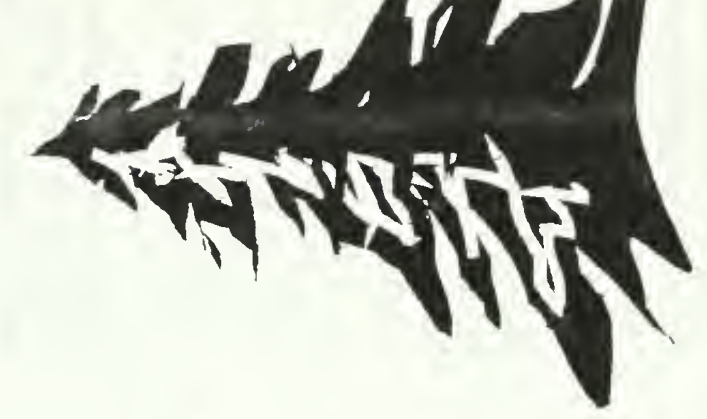

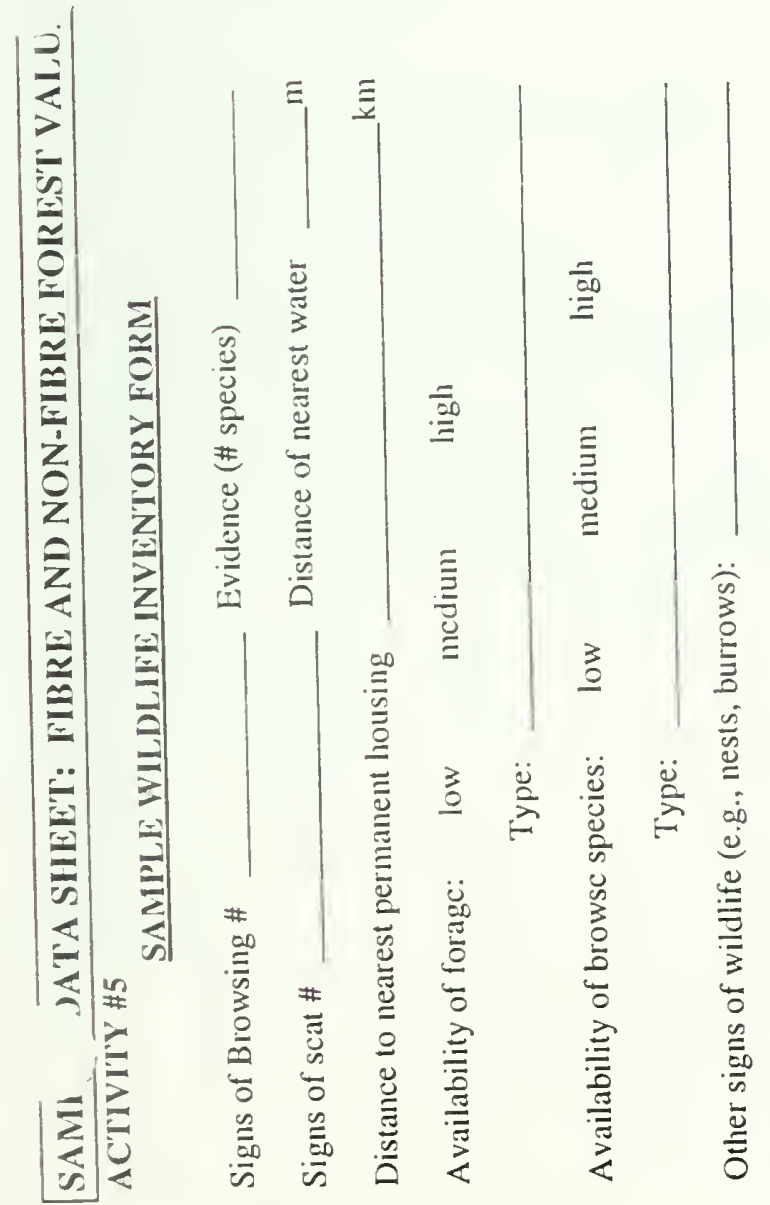

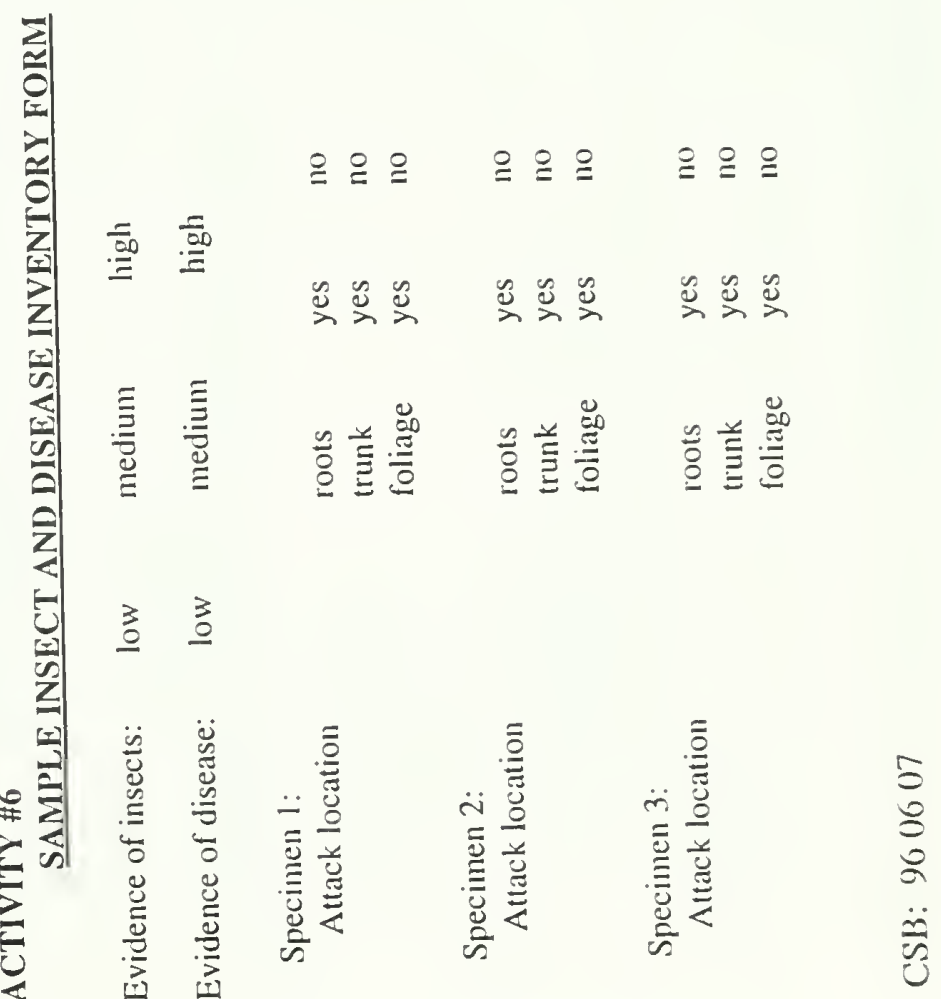




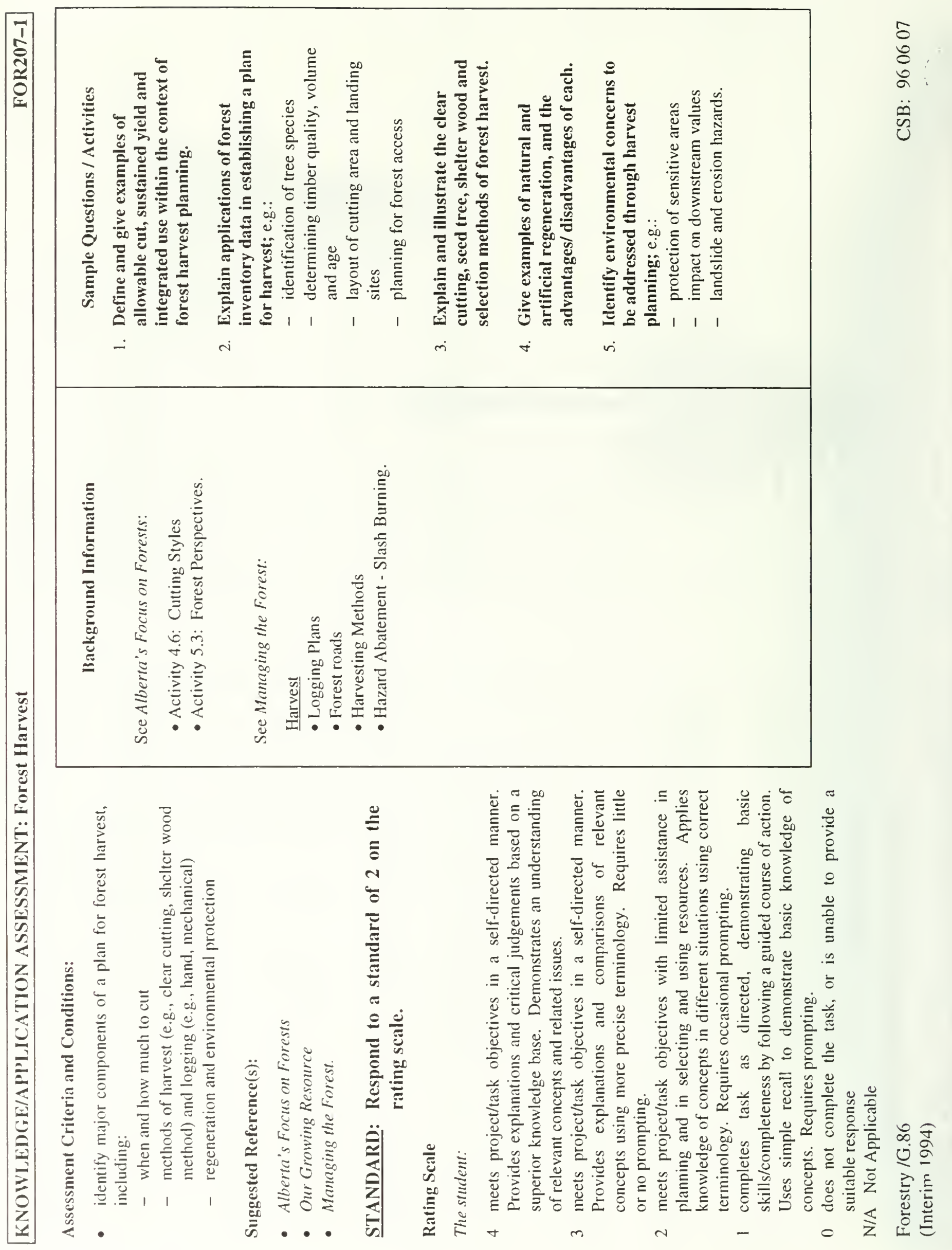




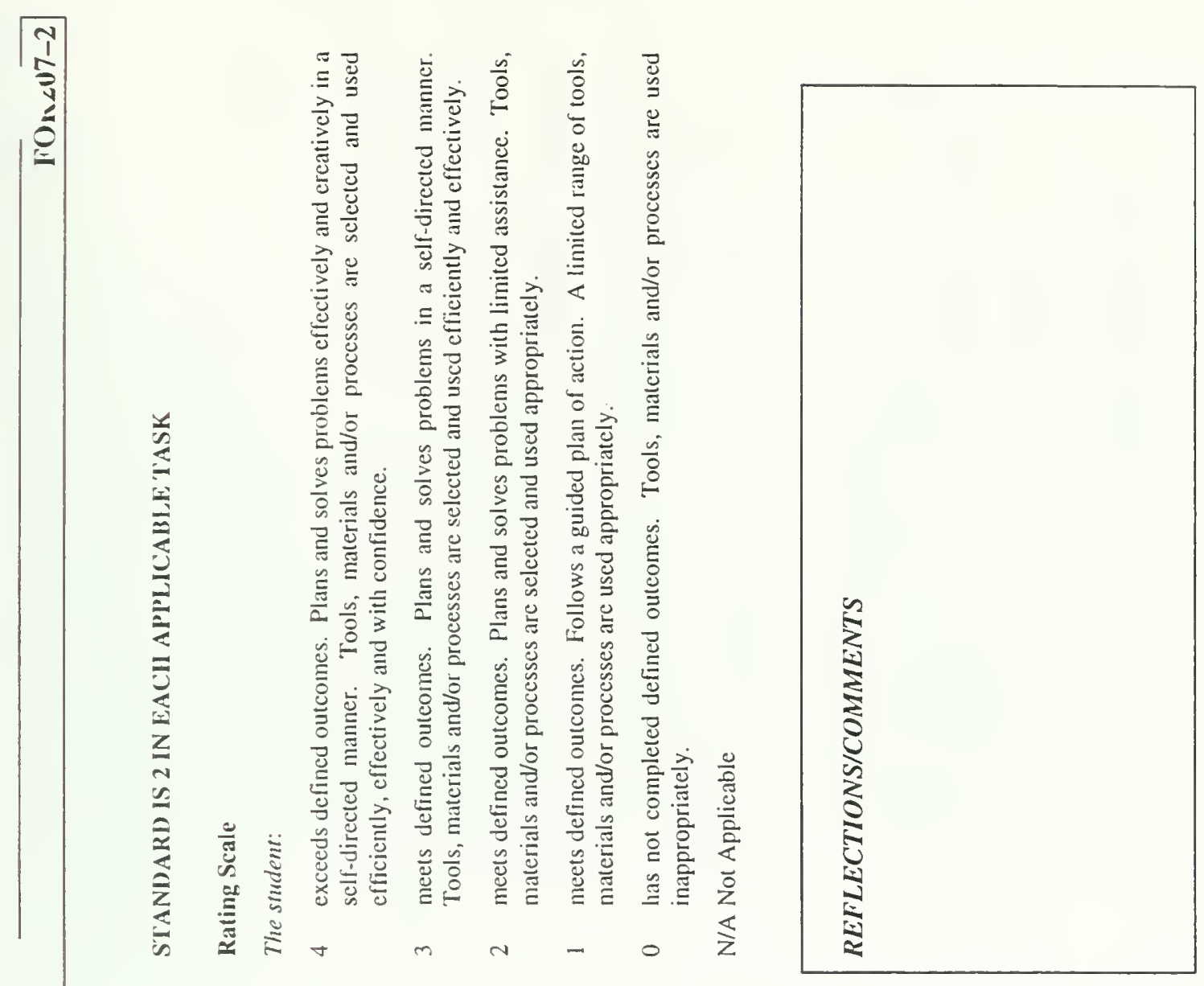

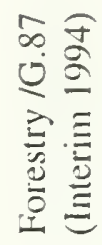

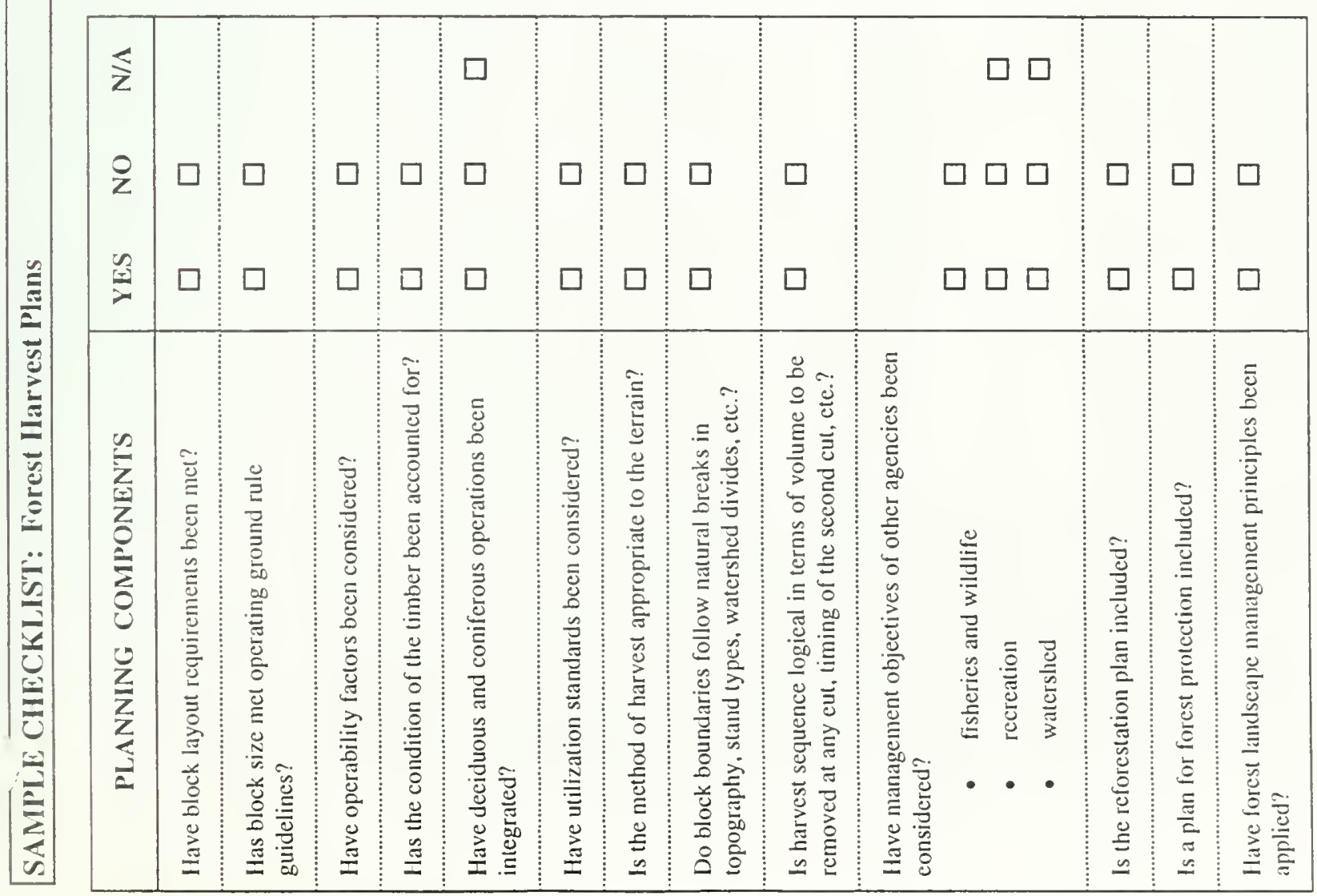




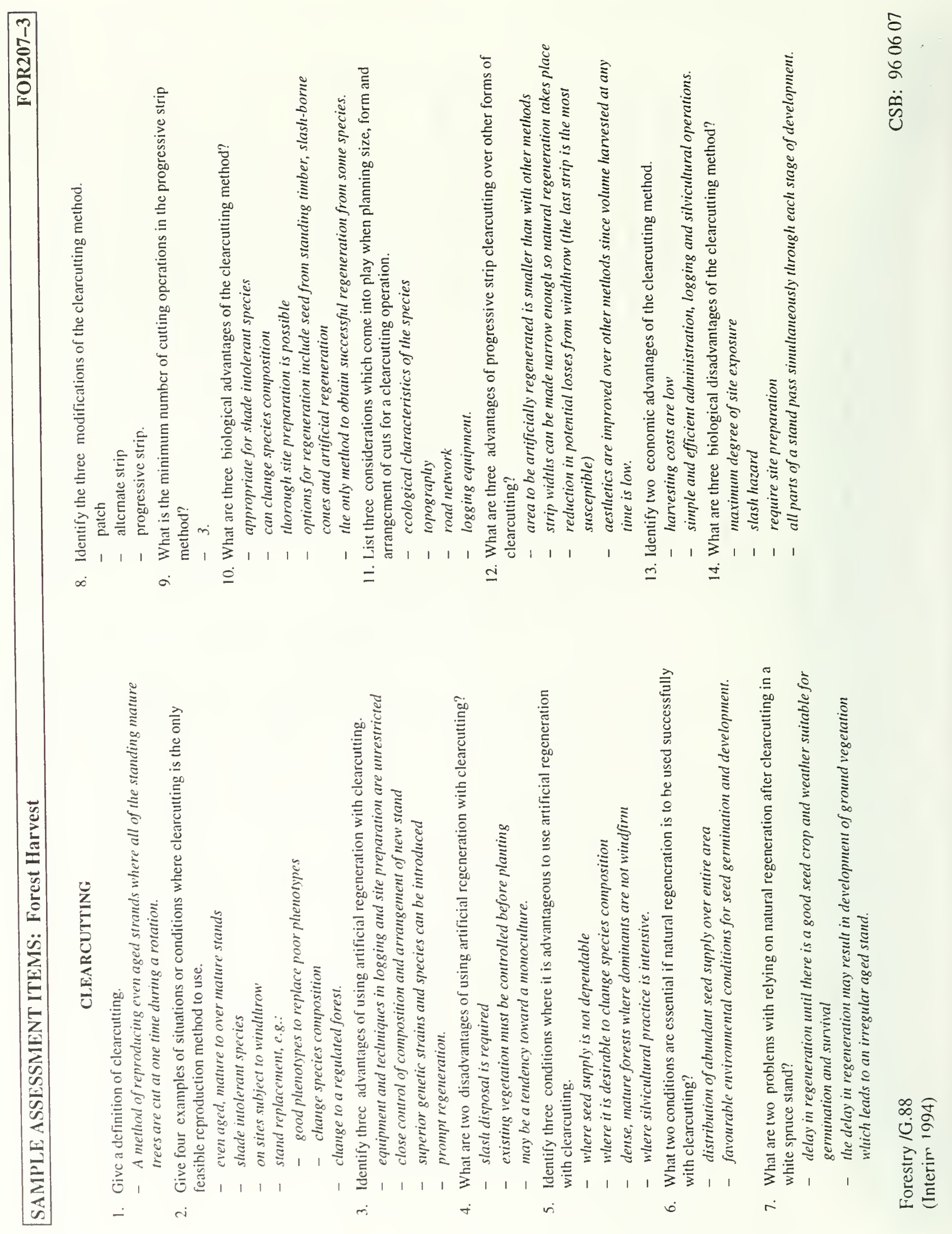


$?$

$=$

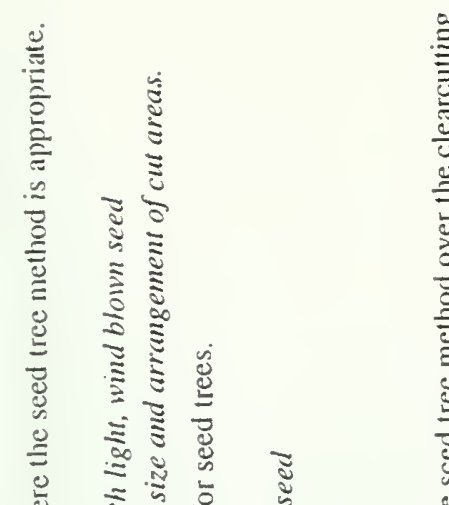

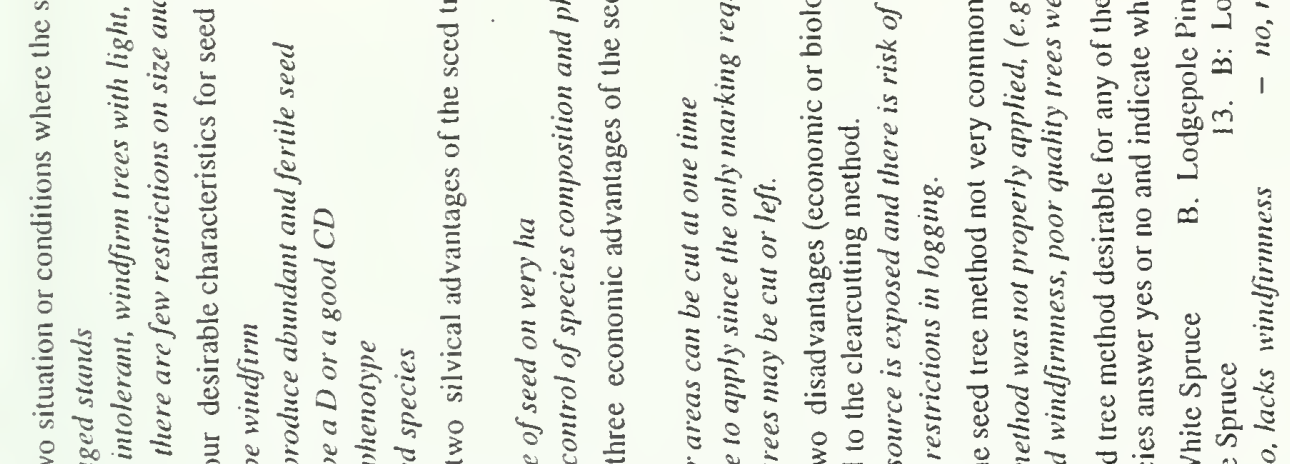

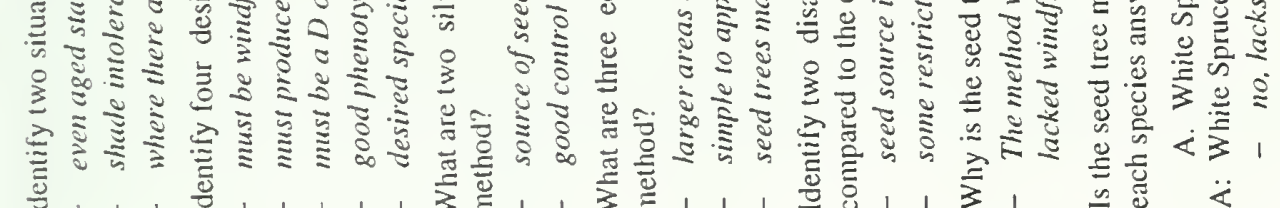
처
ते
迆
जे
ते
i

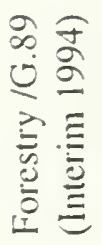

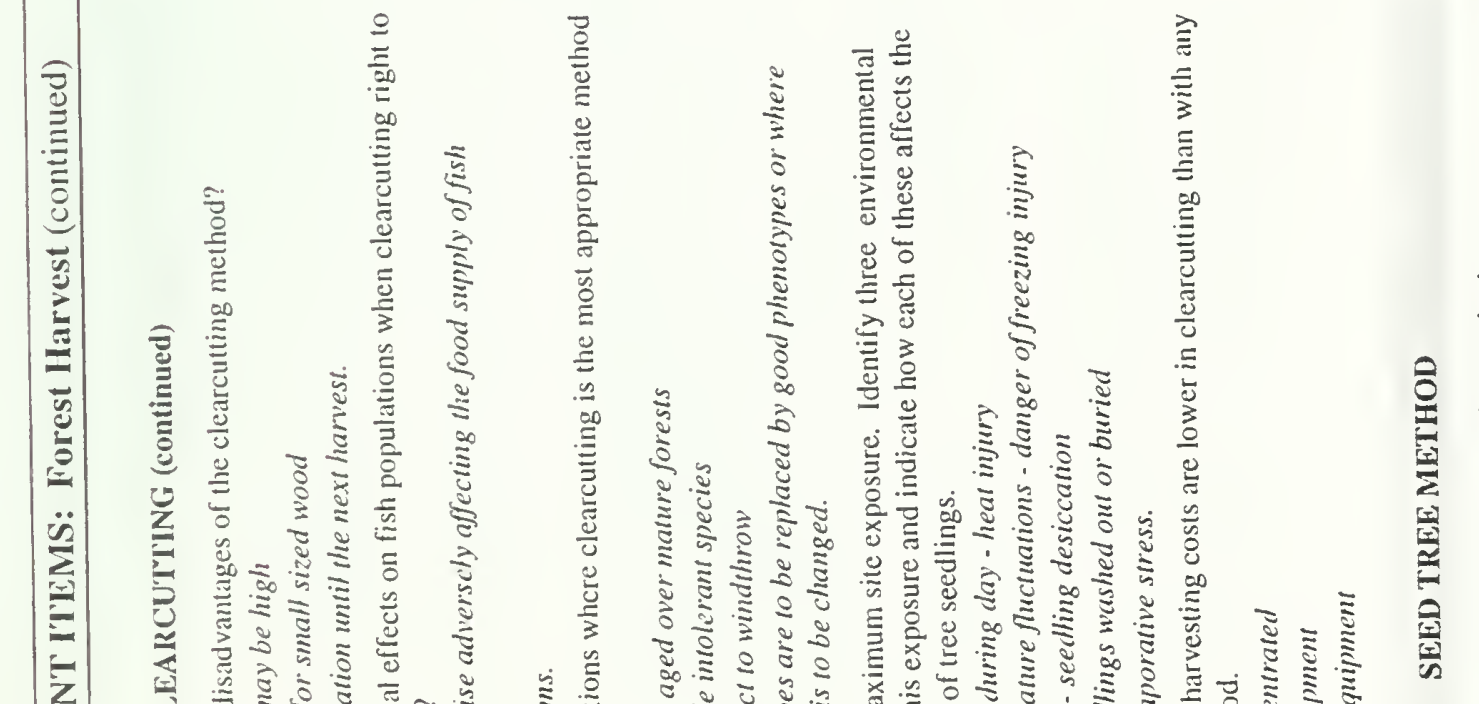

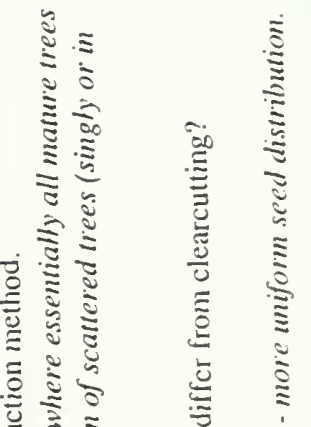

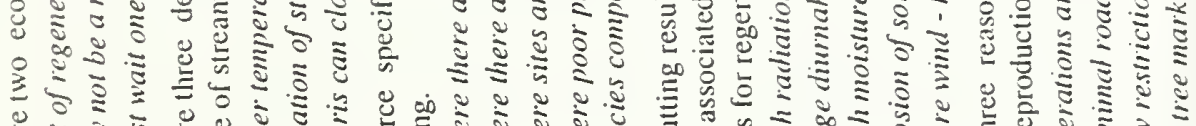

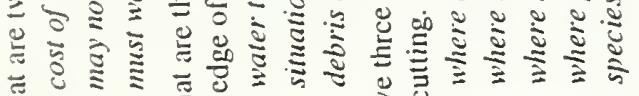

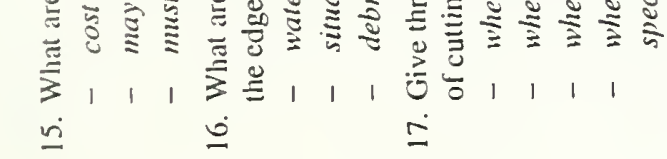
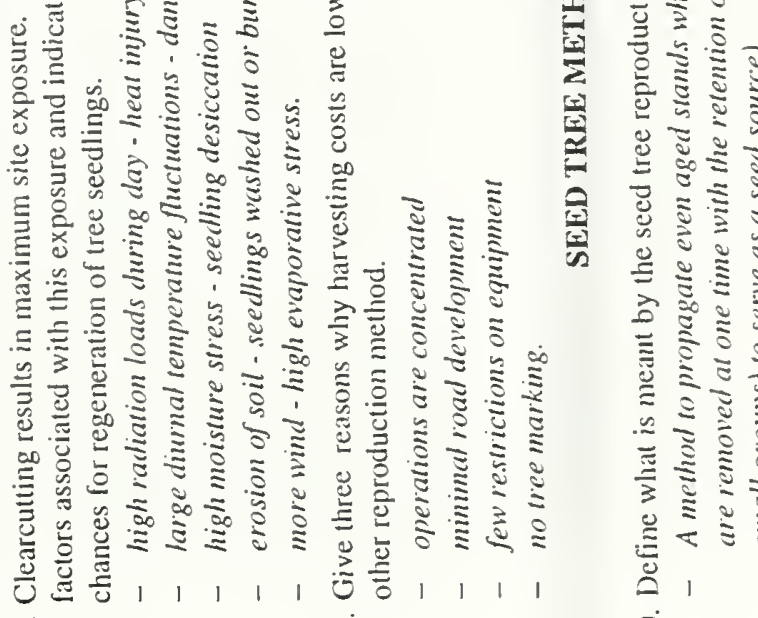

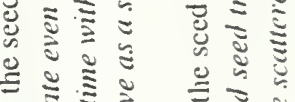

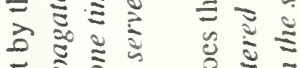

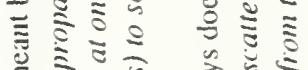

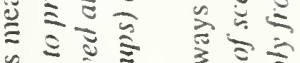

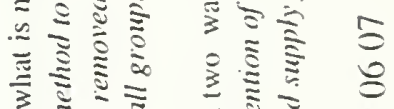

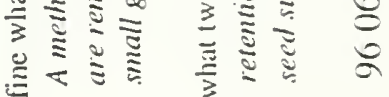

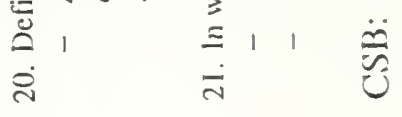




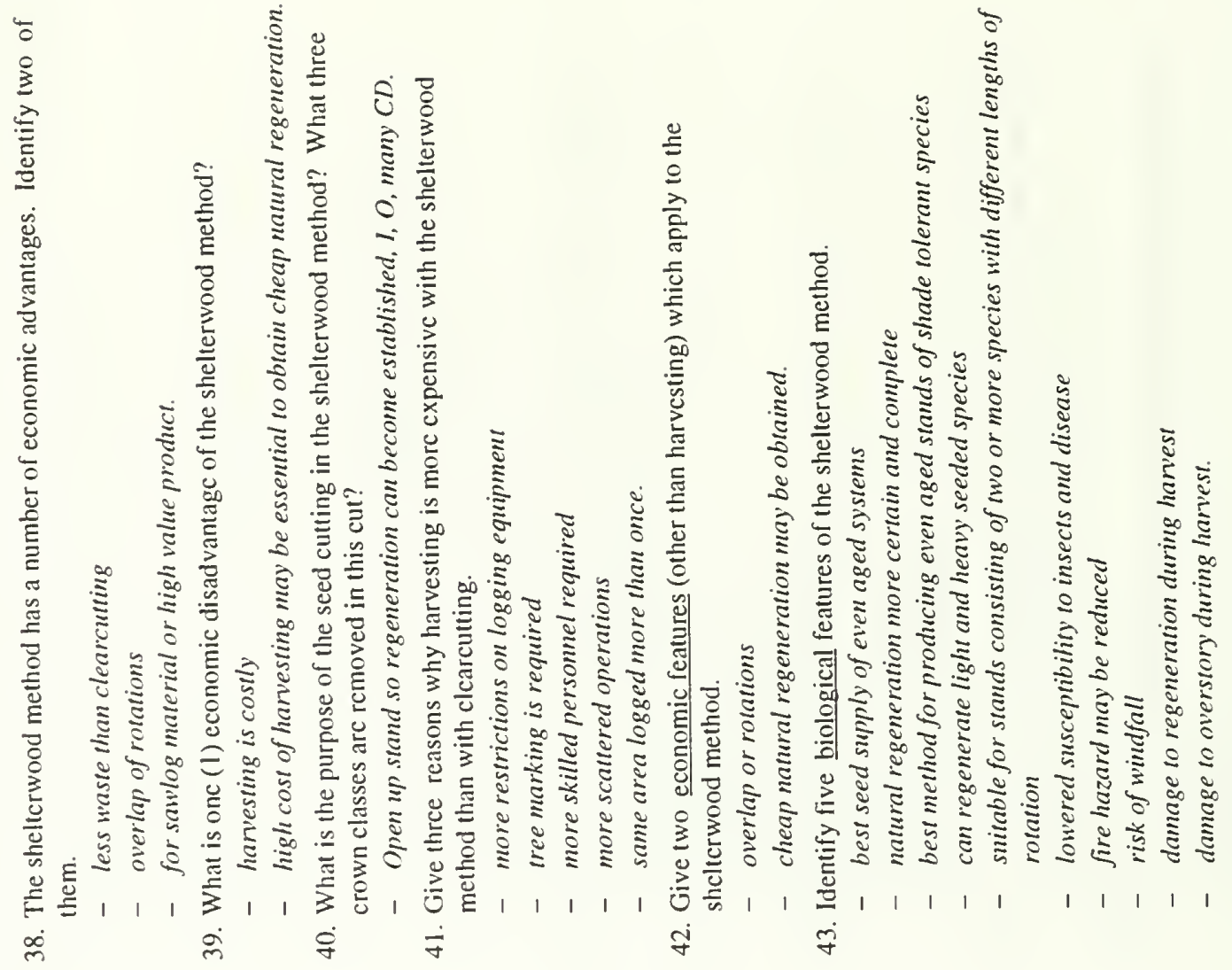

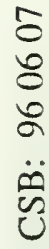

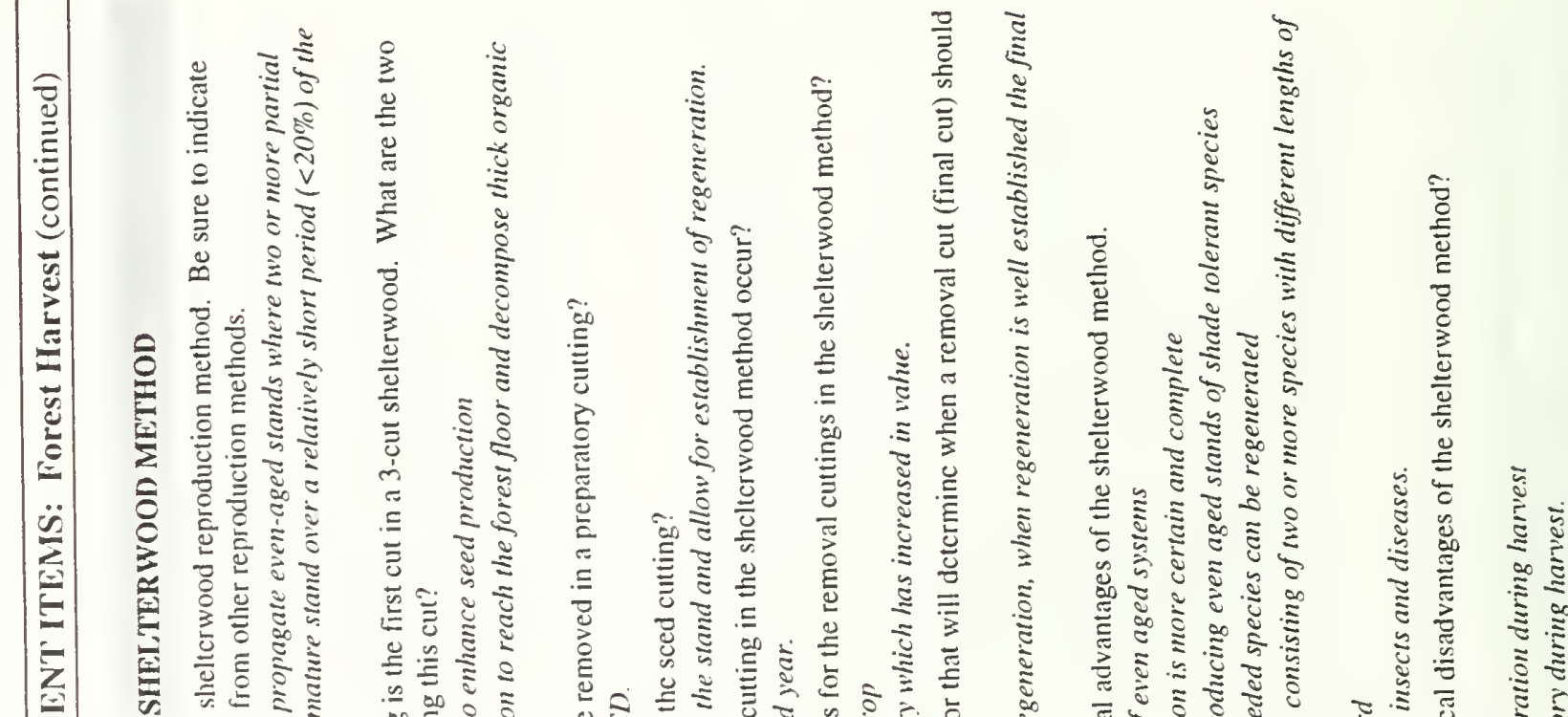

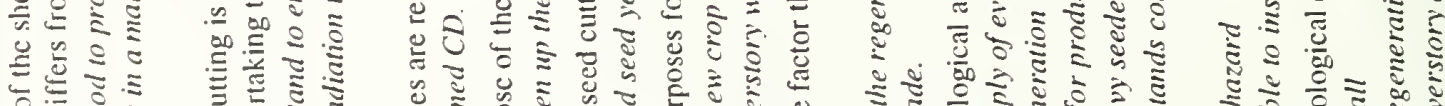

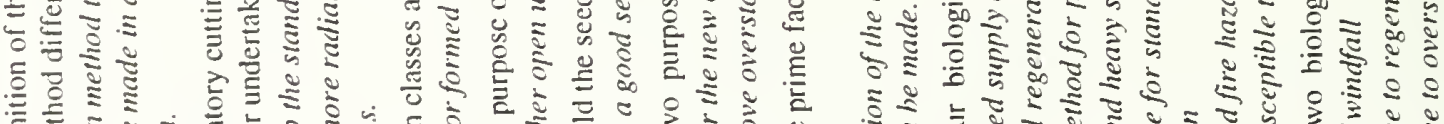

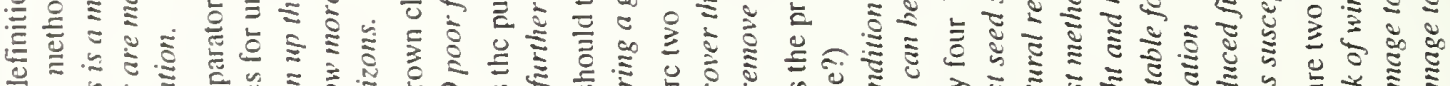

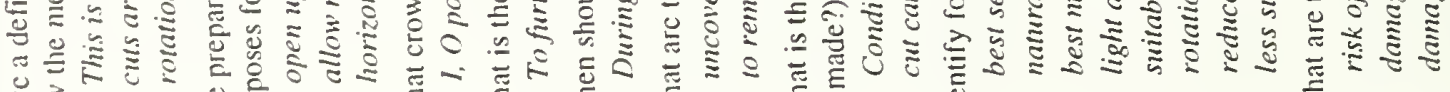
要,

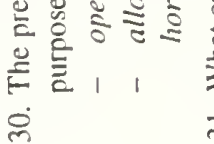

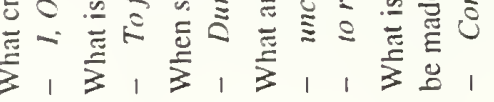


?
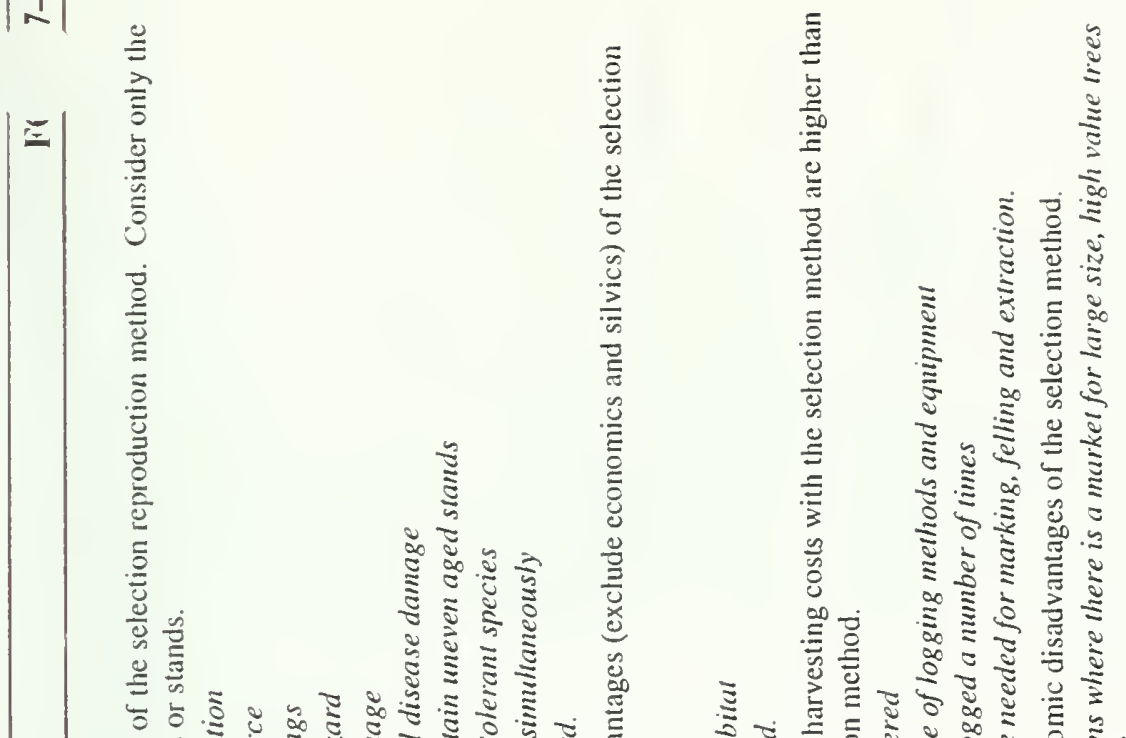

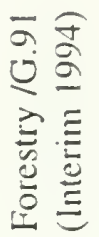

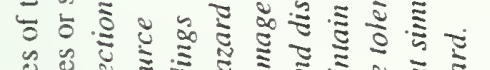

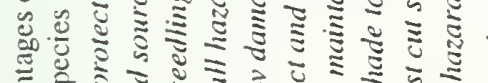

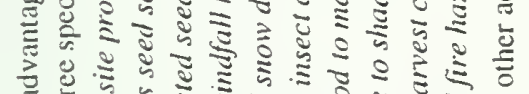

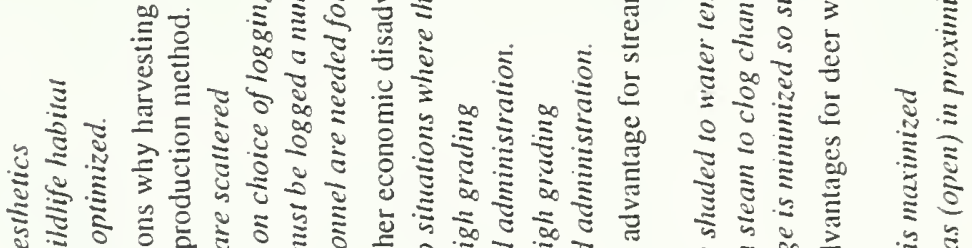

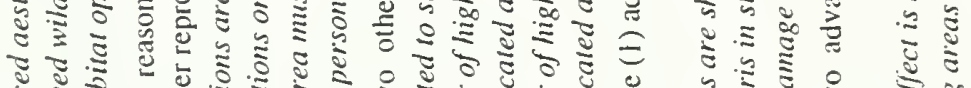

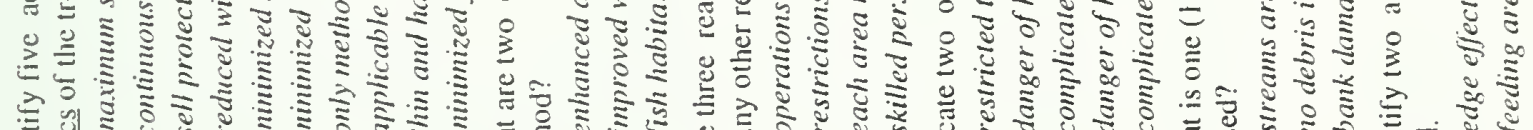

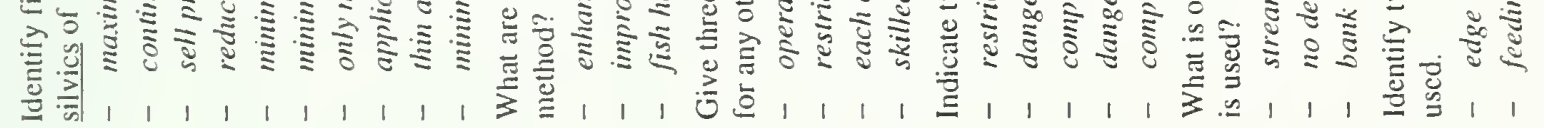
ก่

in

它

官

in

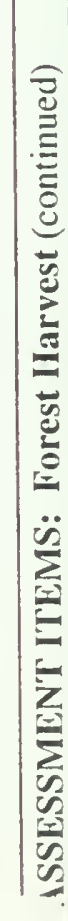

㹡

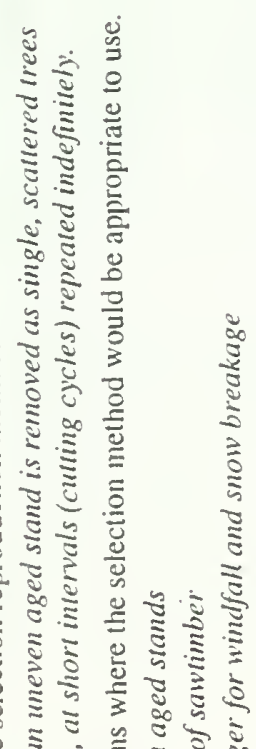

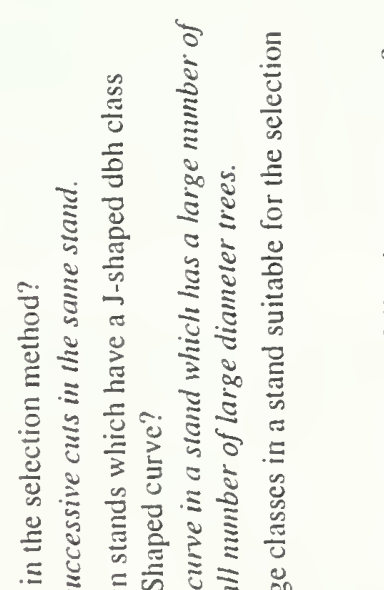

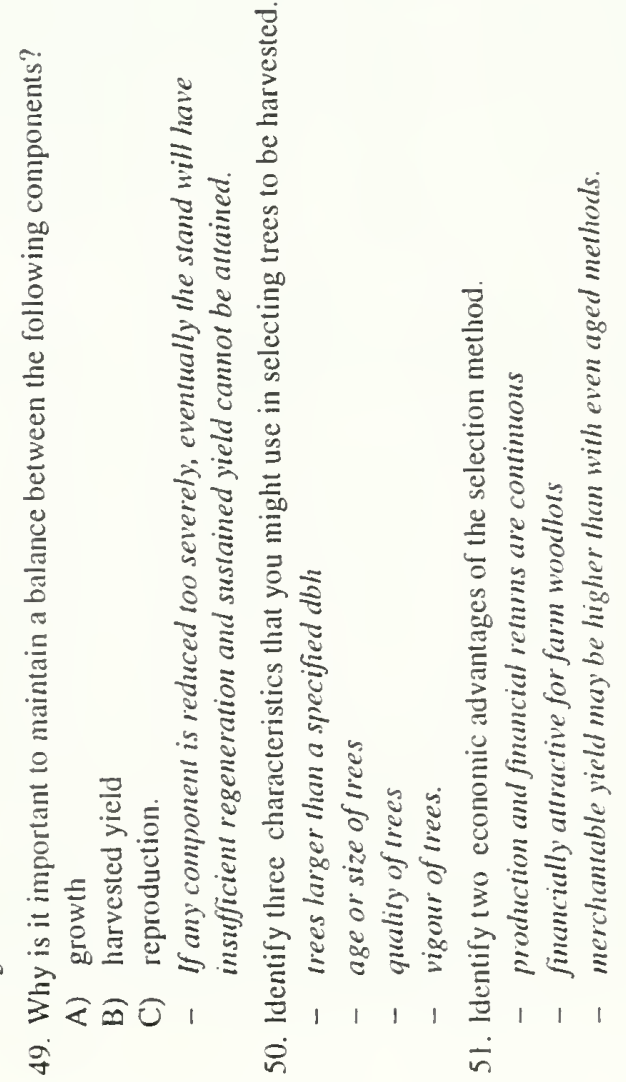




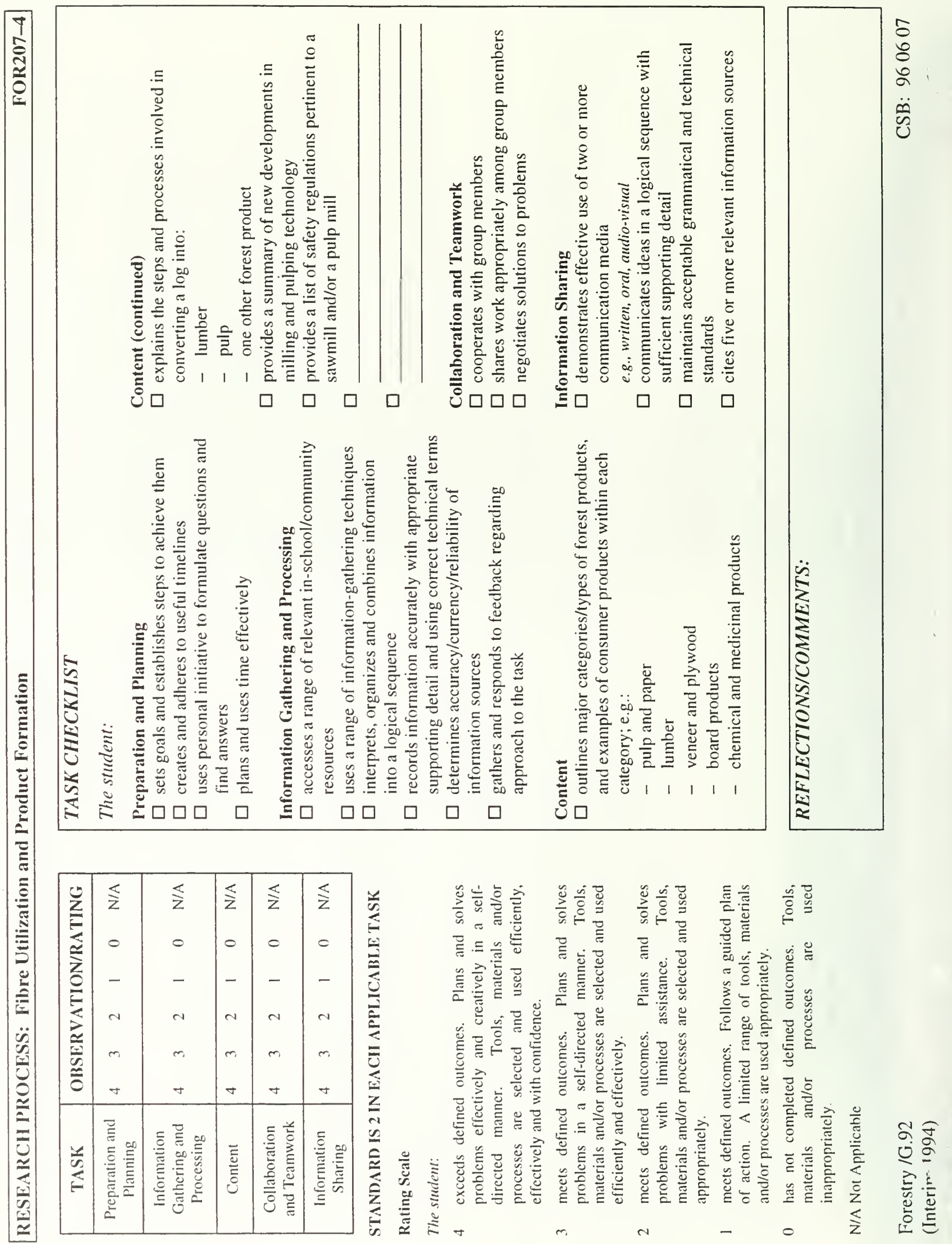




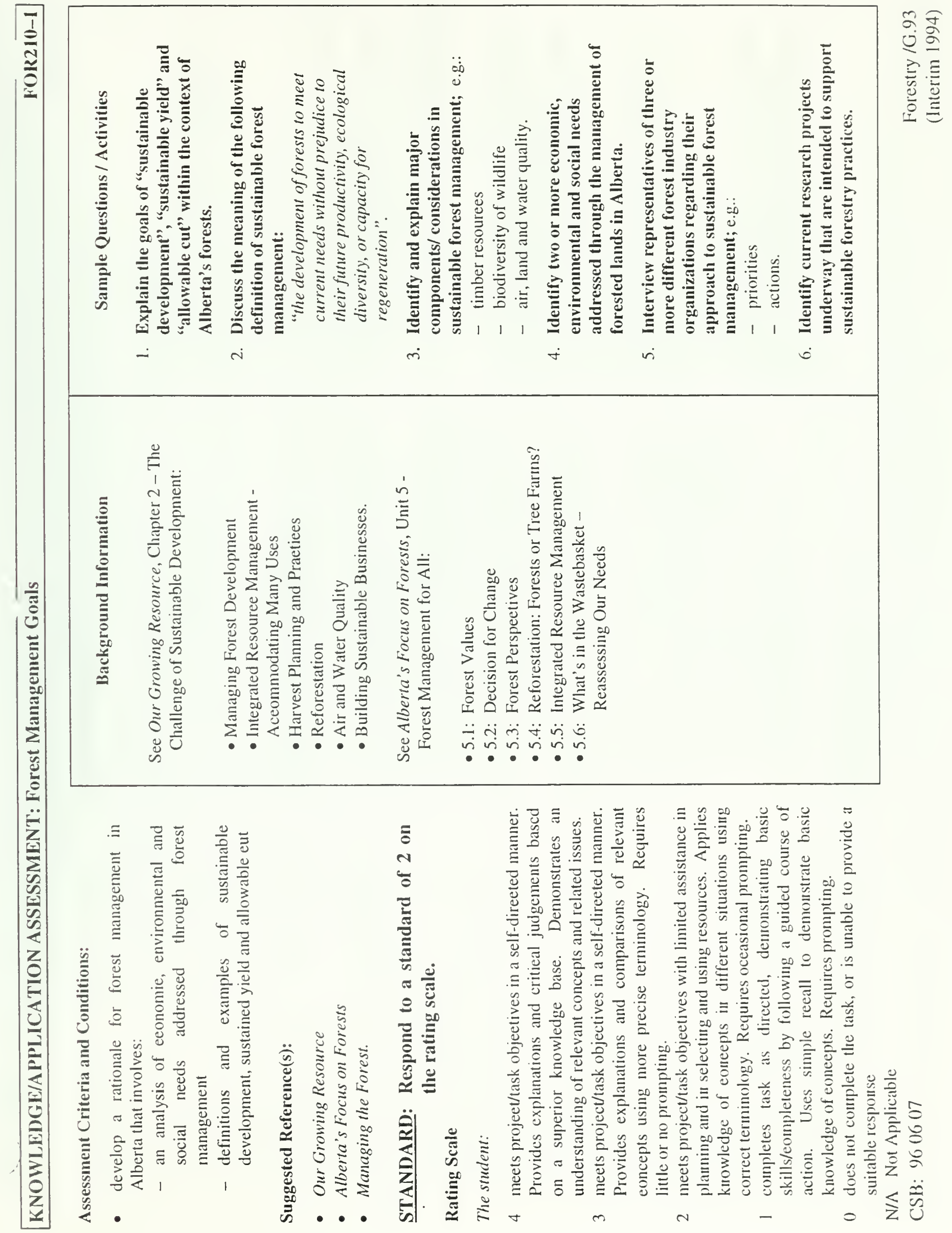



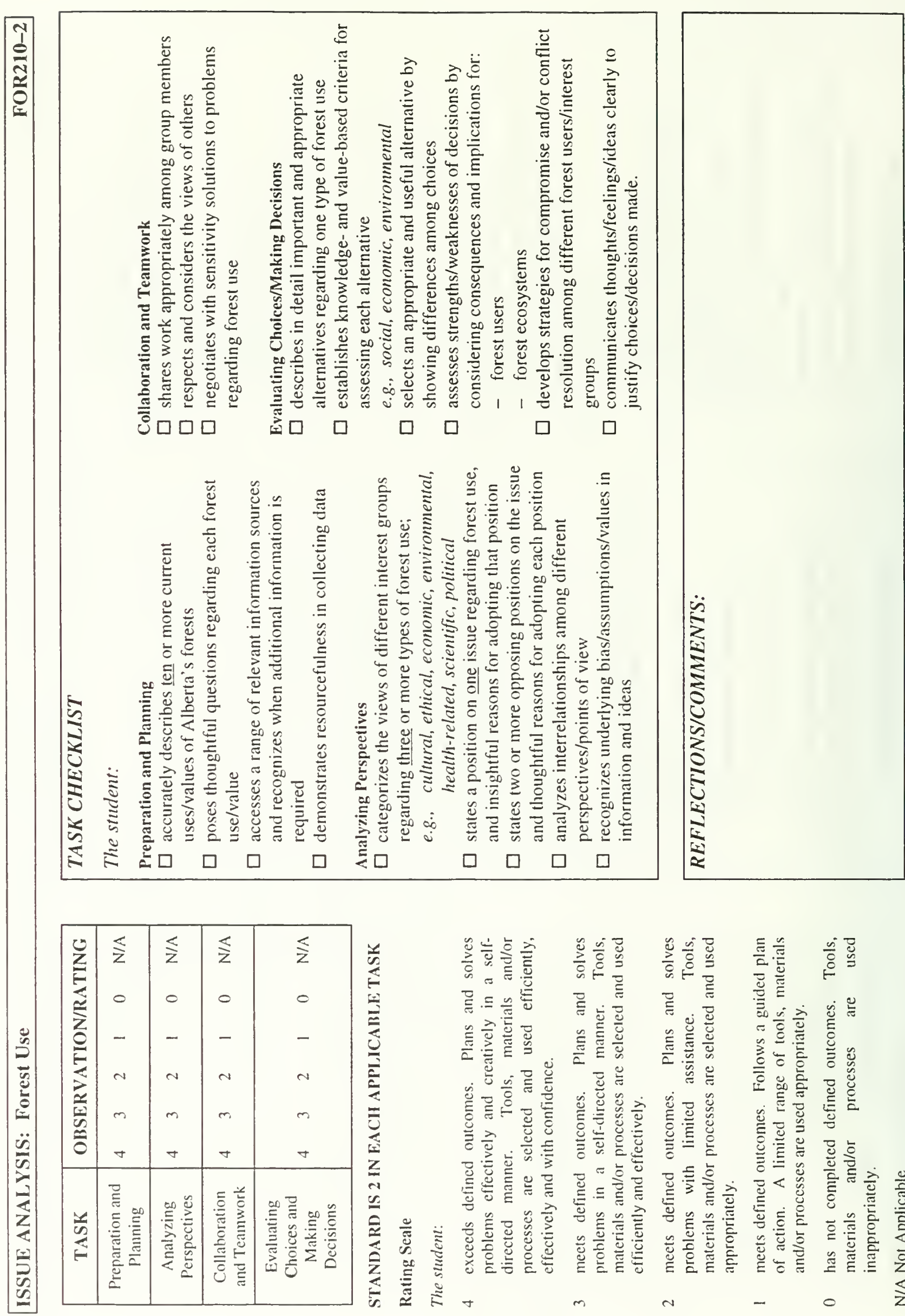

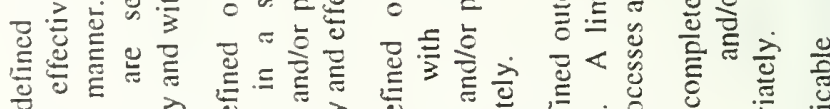




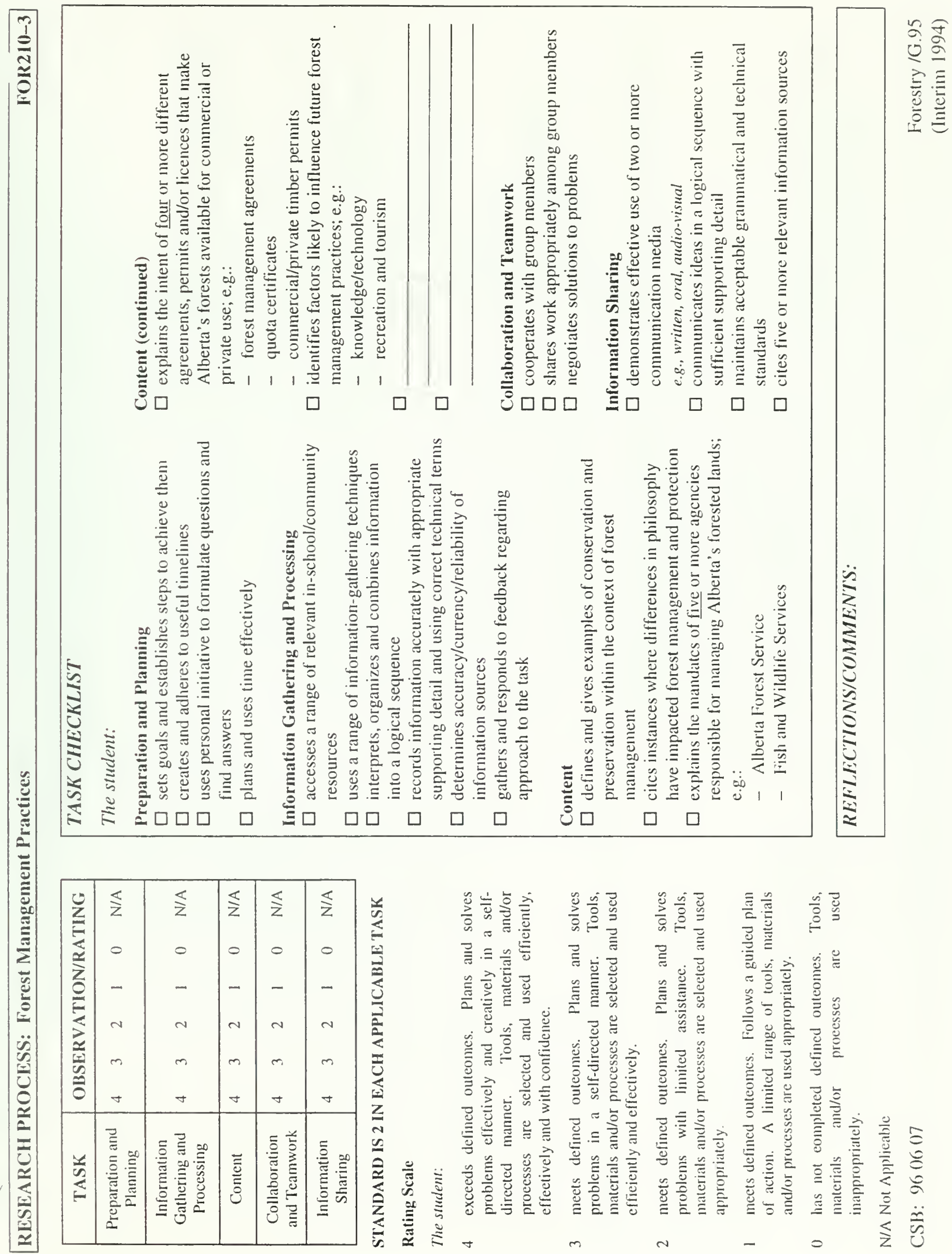




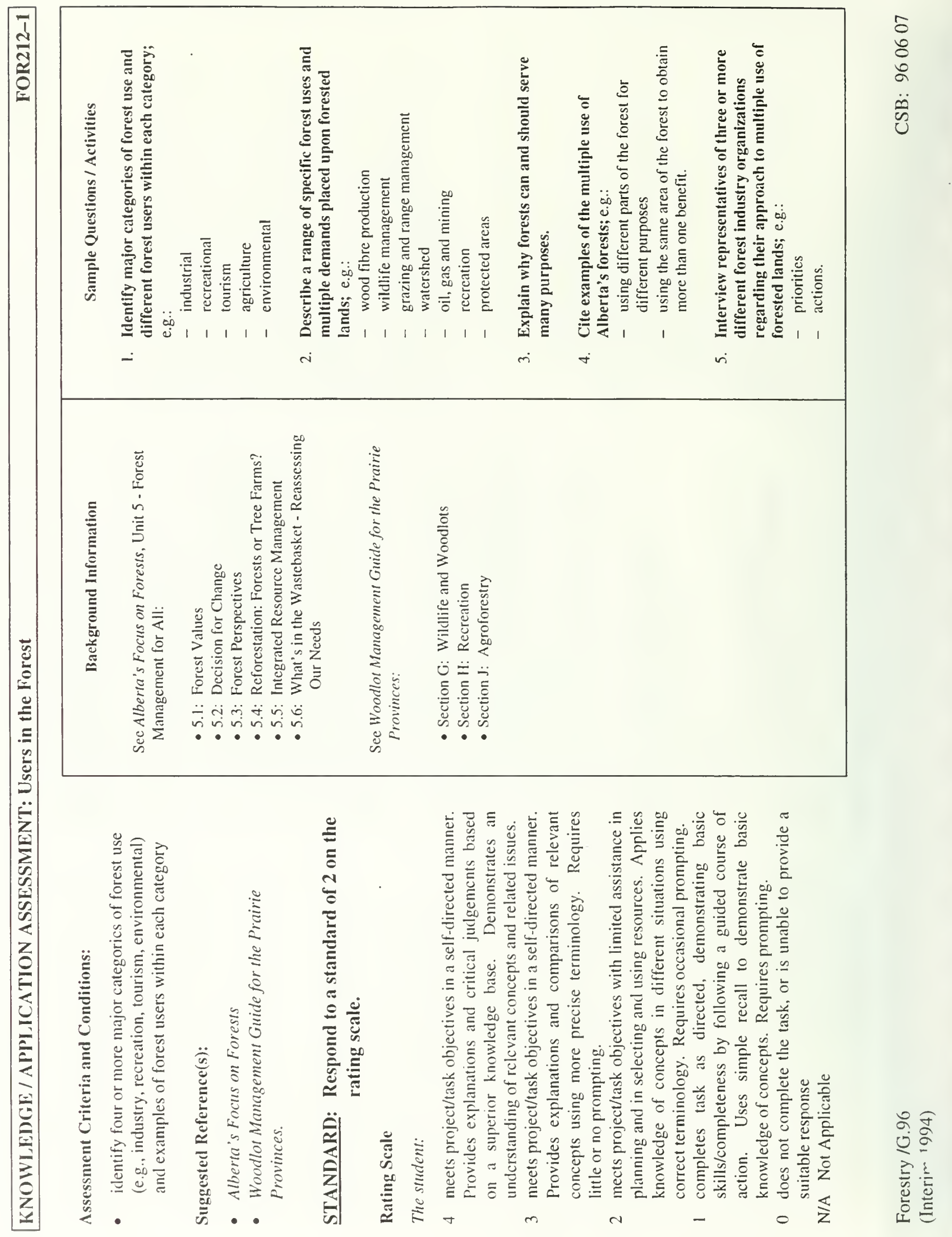




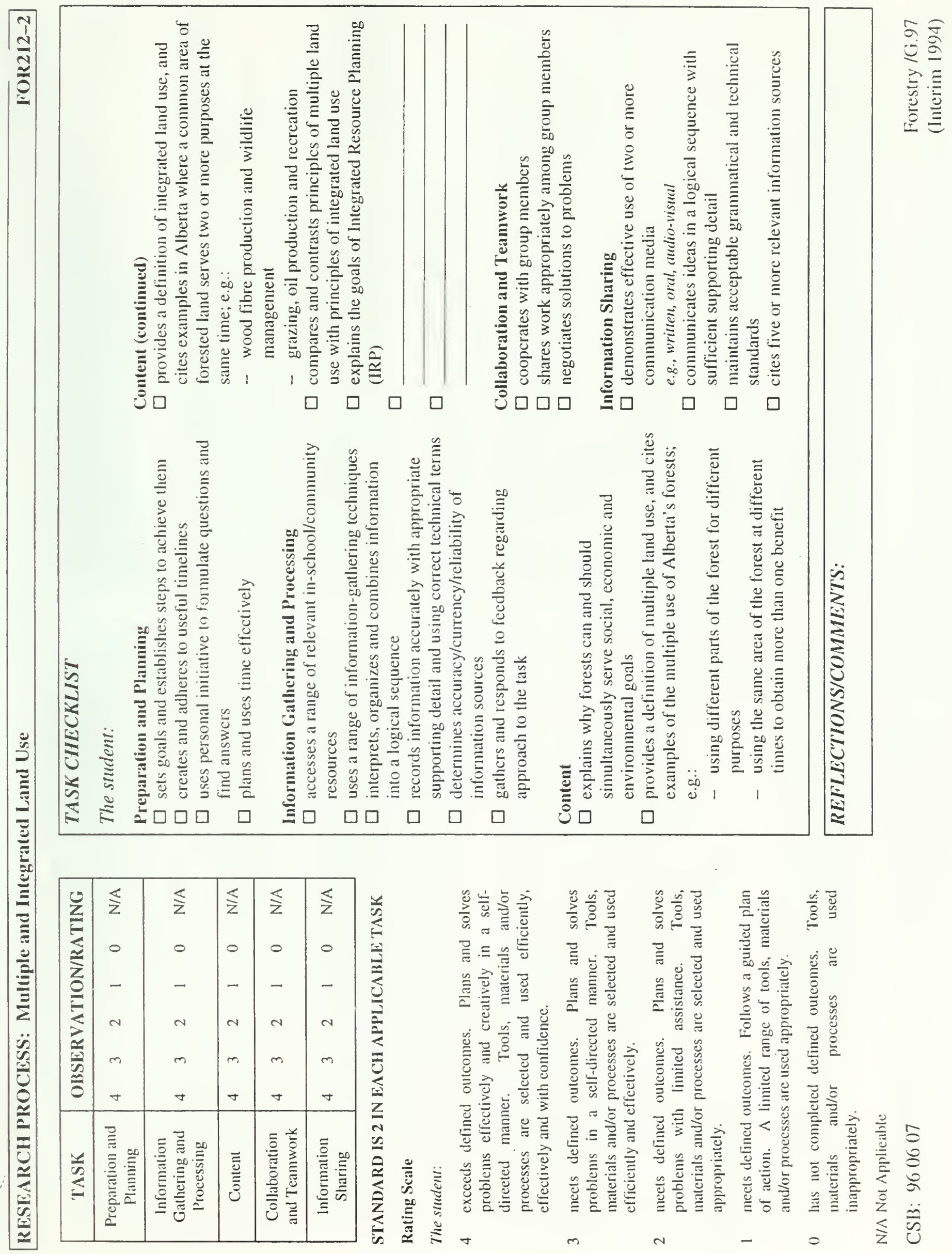




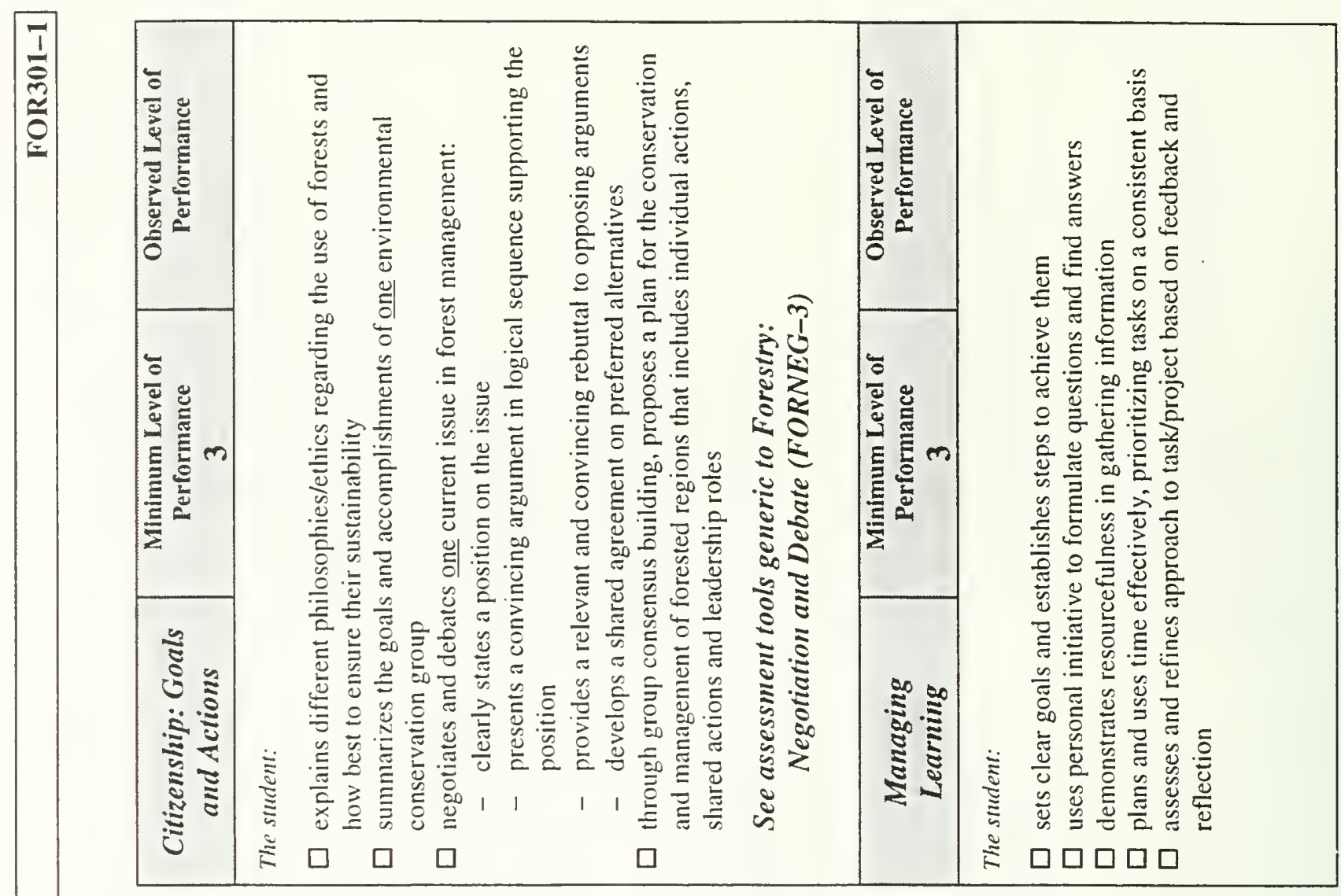

5
0
0
0
$\ddot{0}$
$\tilde{0}$

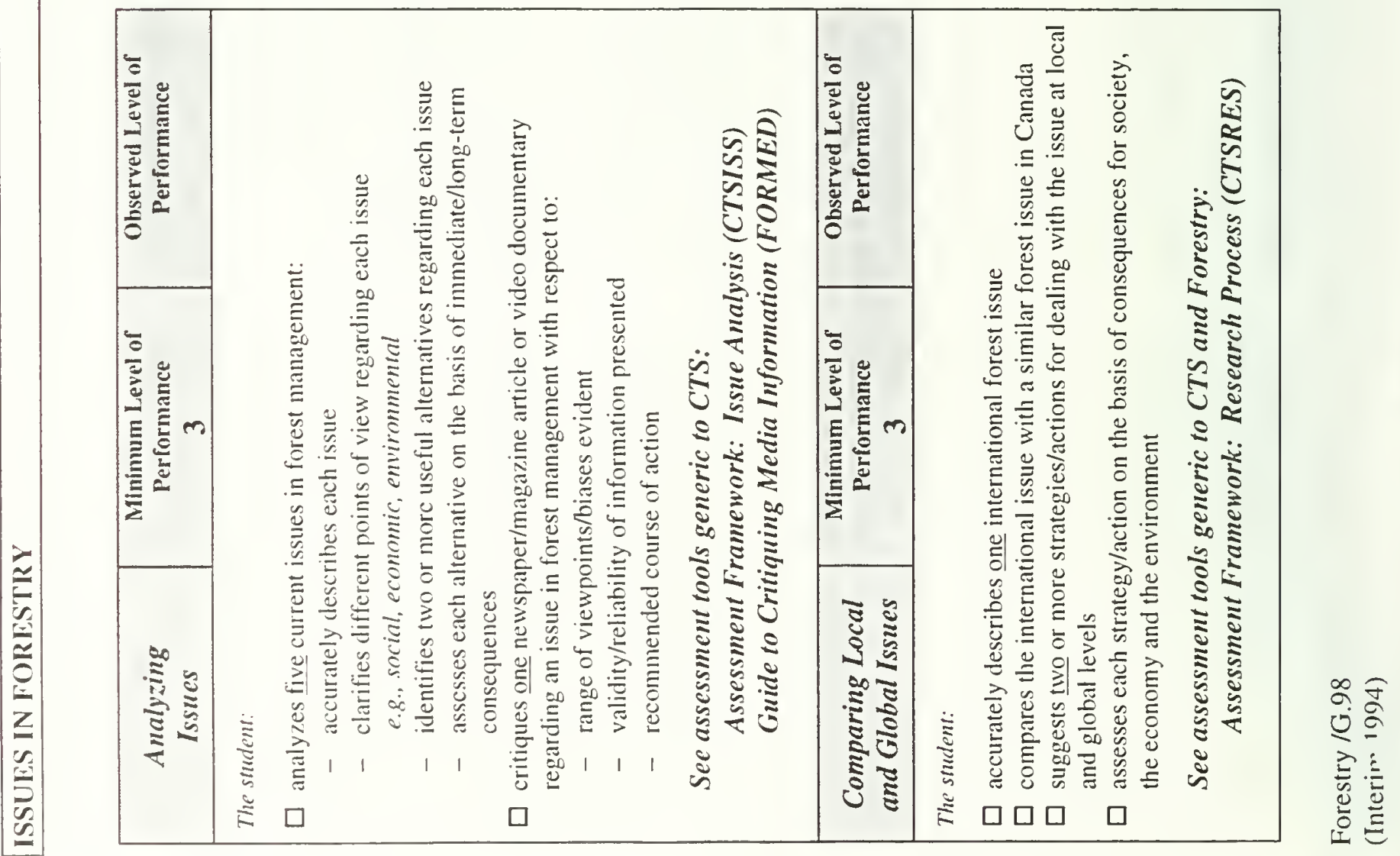



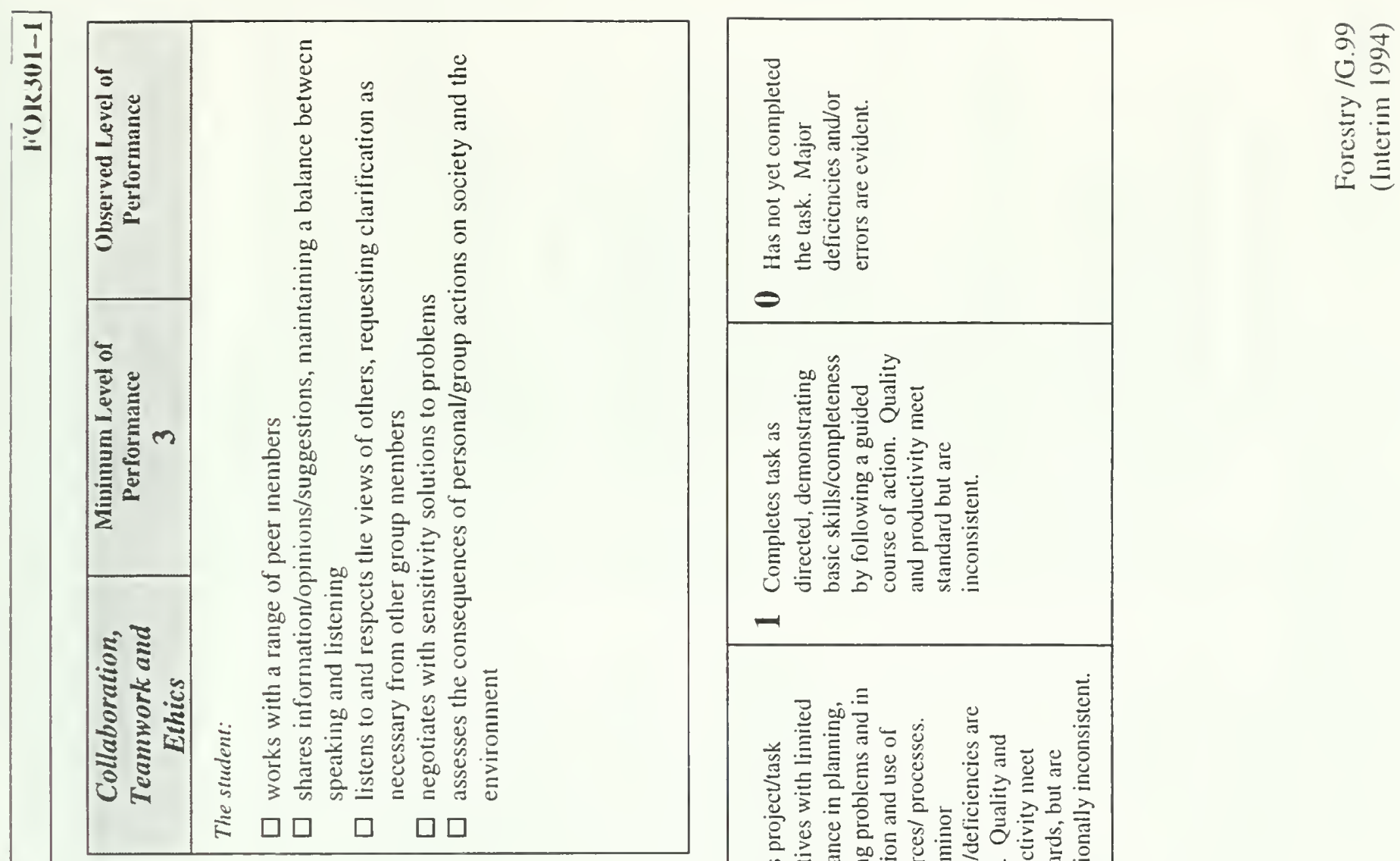

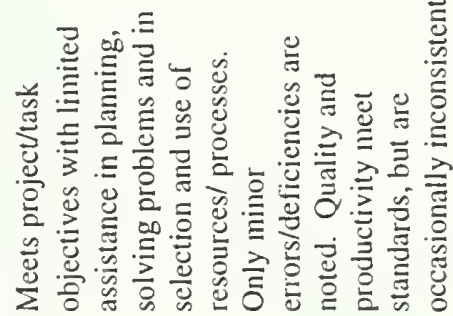

N

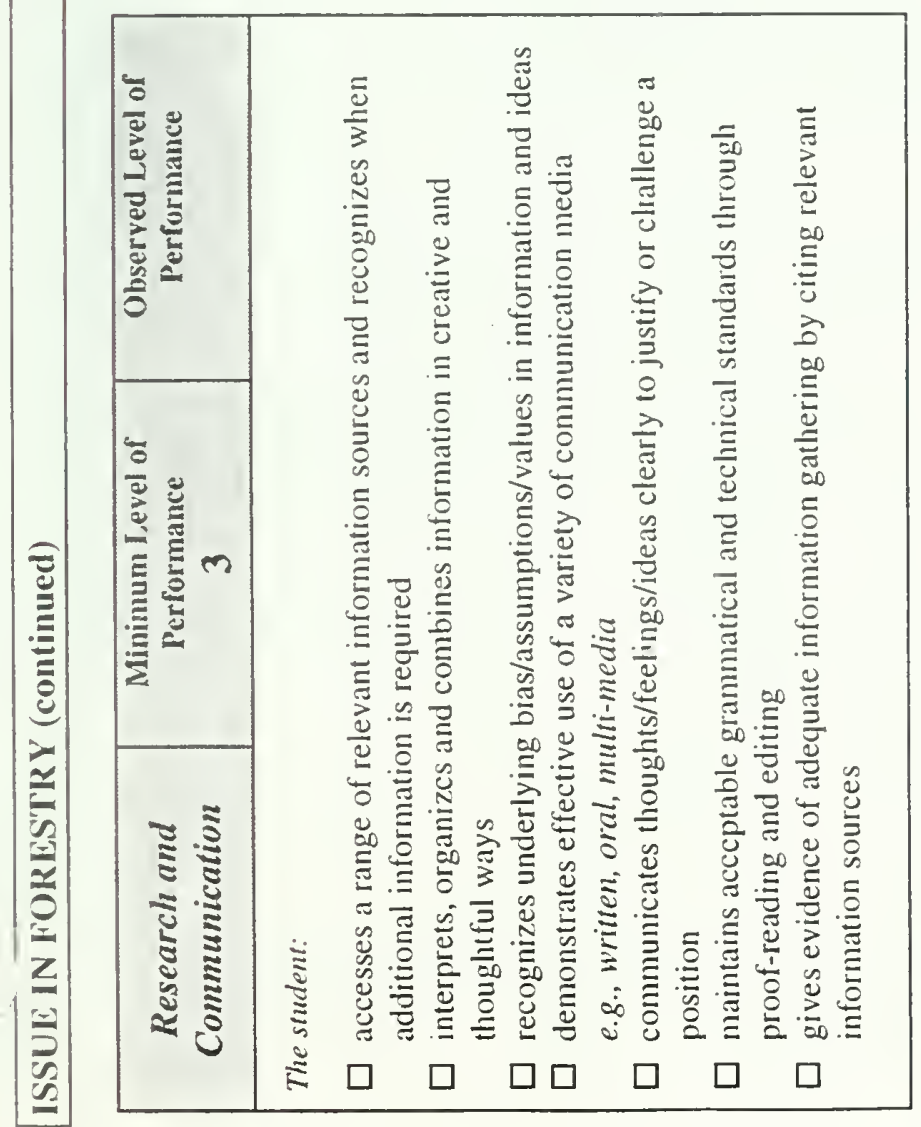

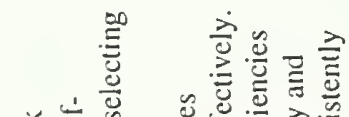

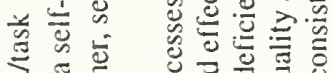

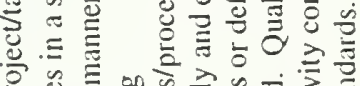

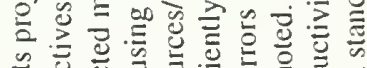

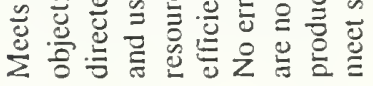

$n$

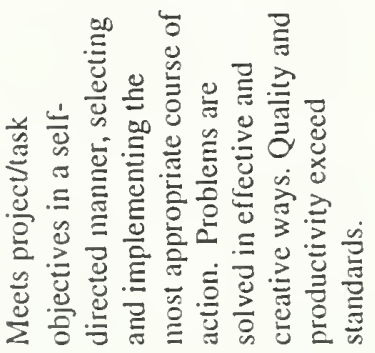

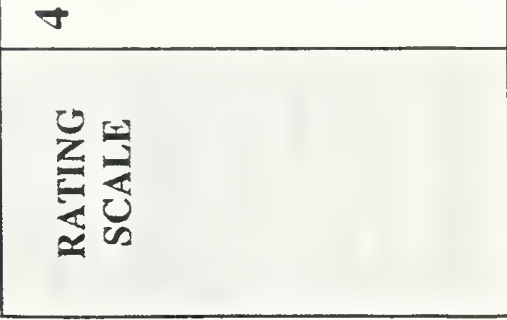




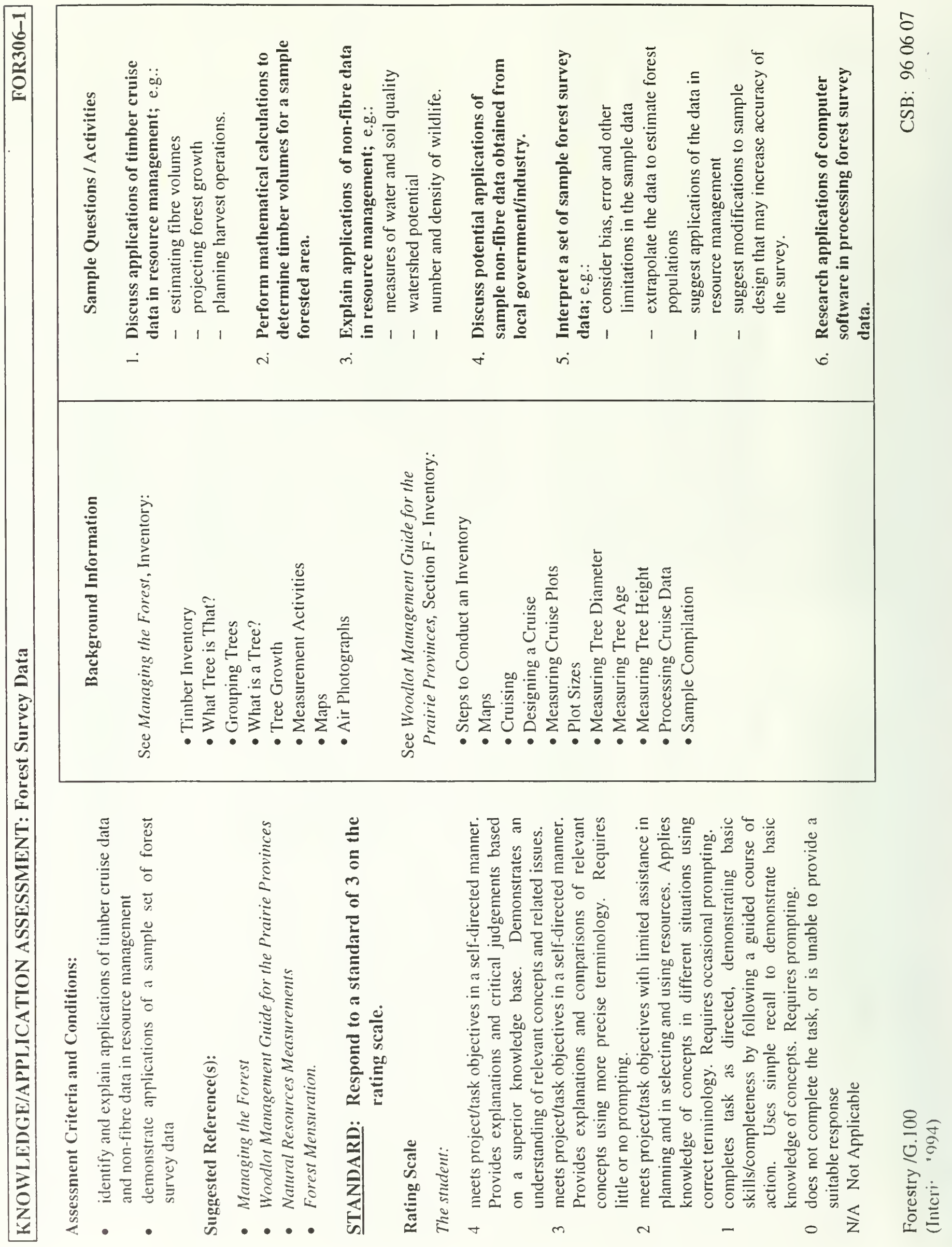



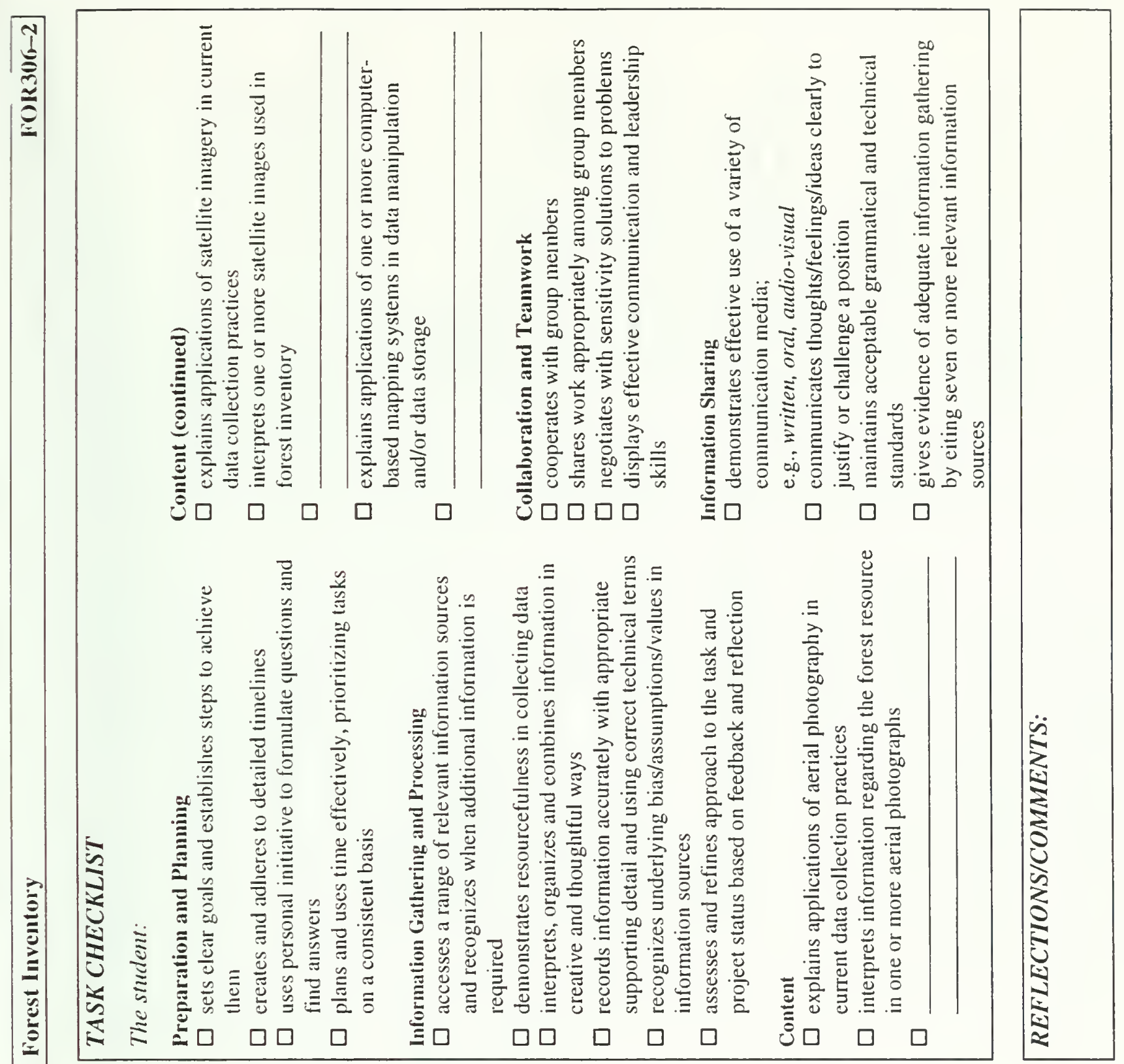

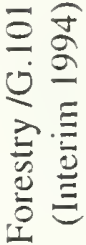

\begin{tabular}{|c|c|c|c|c|c|}
\hline 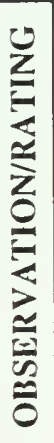 & $\begin{array}{l}\frac{\zeta}{Z} \\
0 \\
- \\
N \\
m \\
+\end{array}$ & $\begin{array}{l}\vdots \\
\vdots \\
0 \\
- \\
d \\
m\end{array}$ & $\begin{array}{l}\frac{K}{z} \\
0 \\
- \\
N \\
\infty \\
+\end{array}$ & $\begin{array}{l}\leqslant \\
\vdots \\
0 \\
- \\
N \\
m \\
\sigma\end{array}$ & 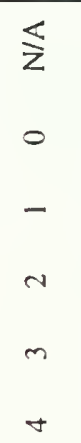 \\
\hline$\stackrel{5}{5}$ & 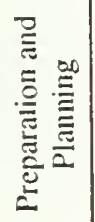 & 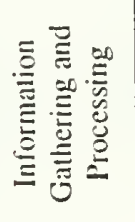 & & 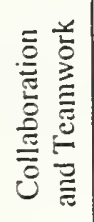 & 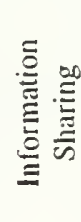 \\
\hline
\end{tabular}

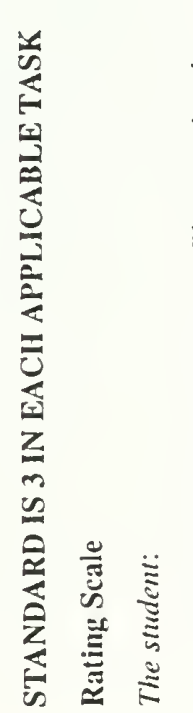

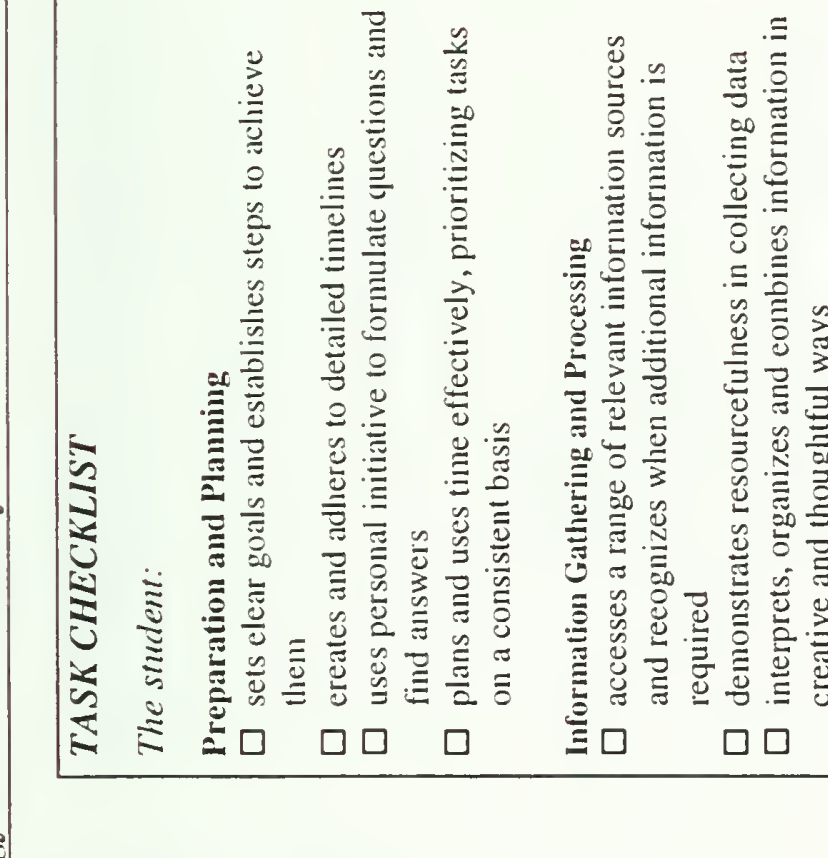

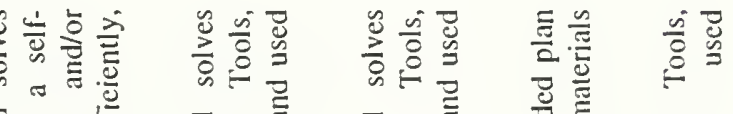

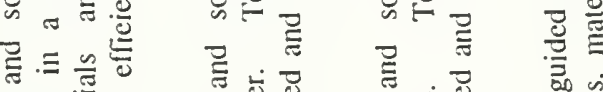

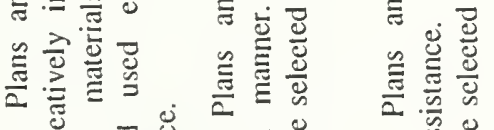

唹我它

.

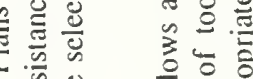

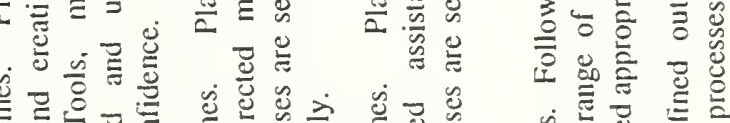

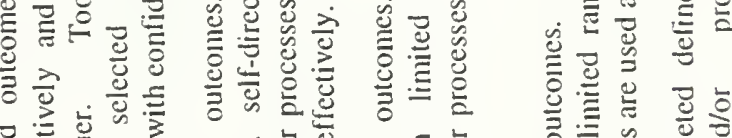

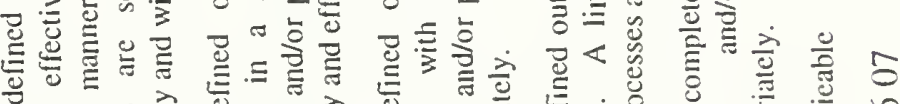

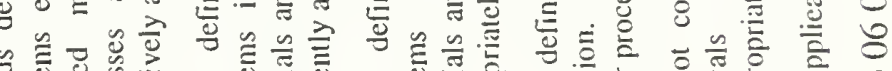

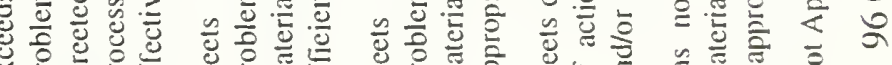

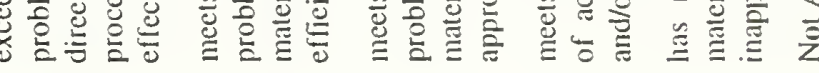




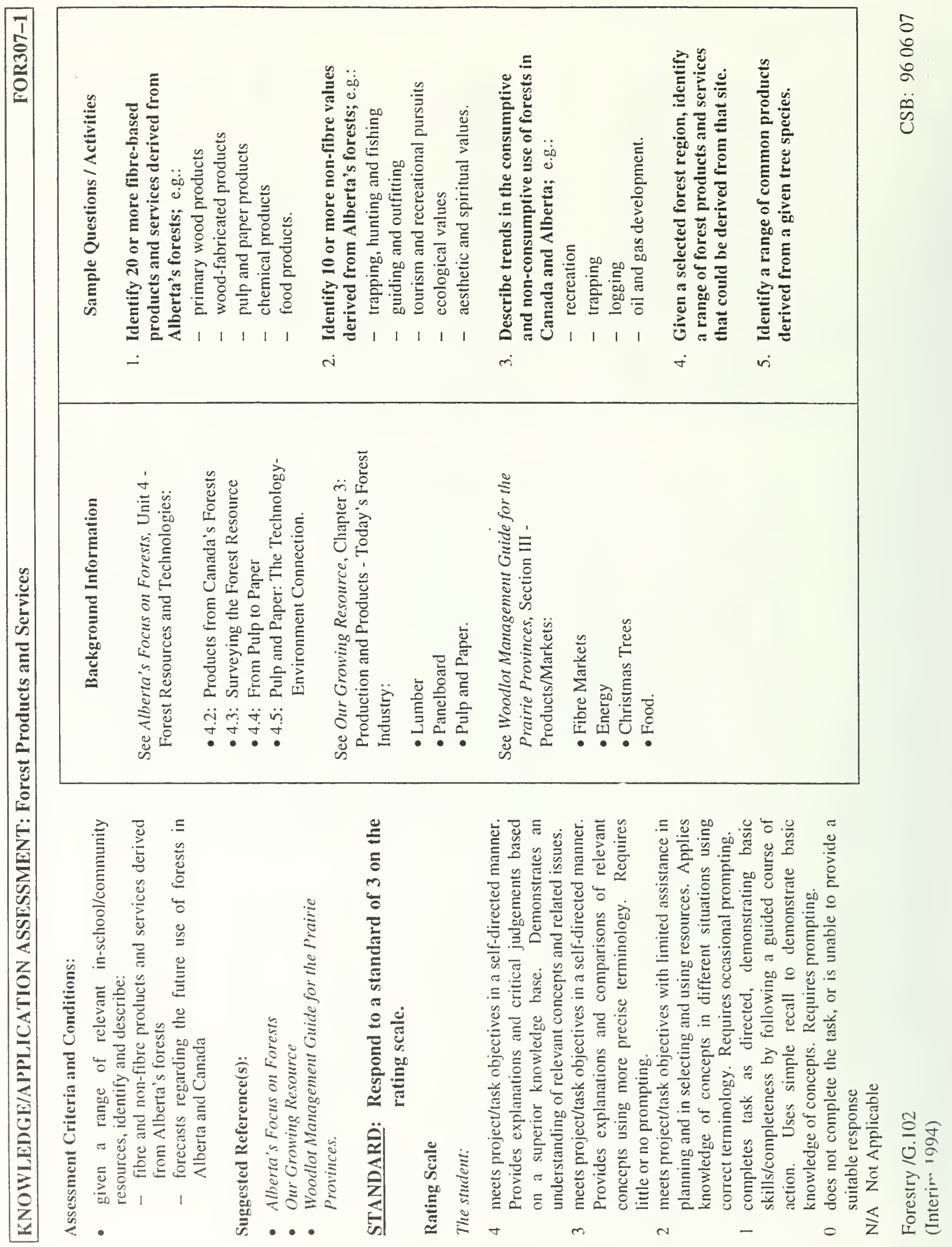



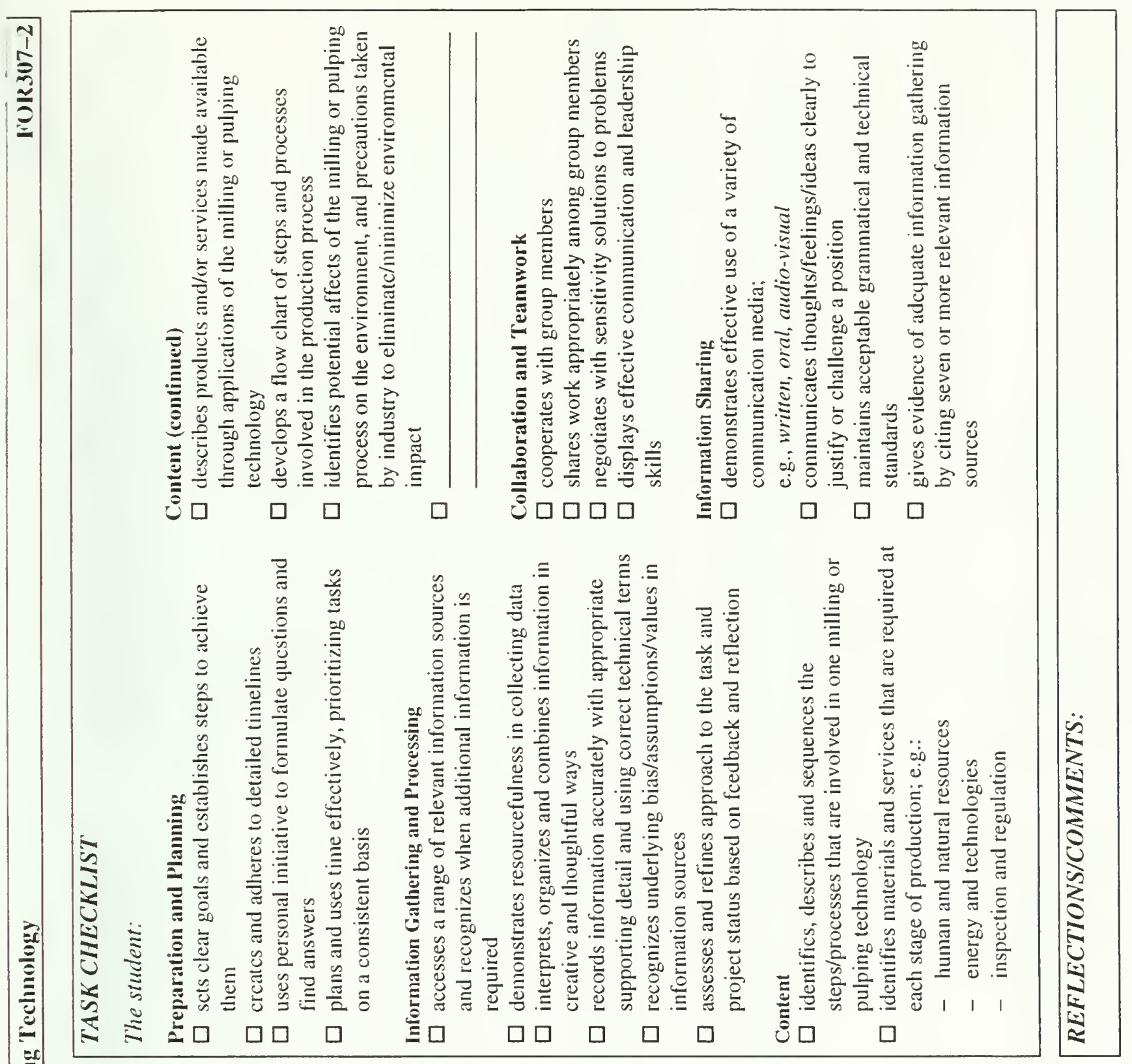

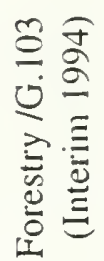

氖

.

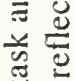

气

氖

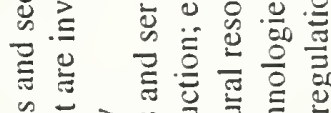

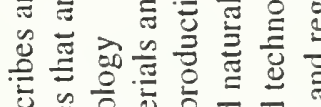

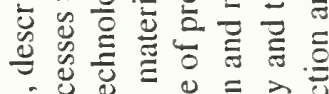

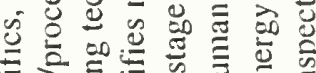

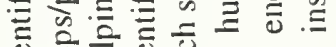
!

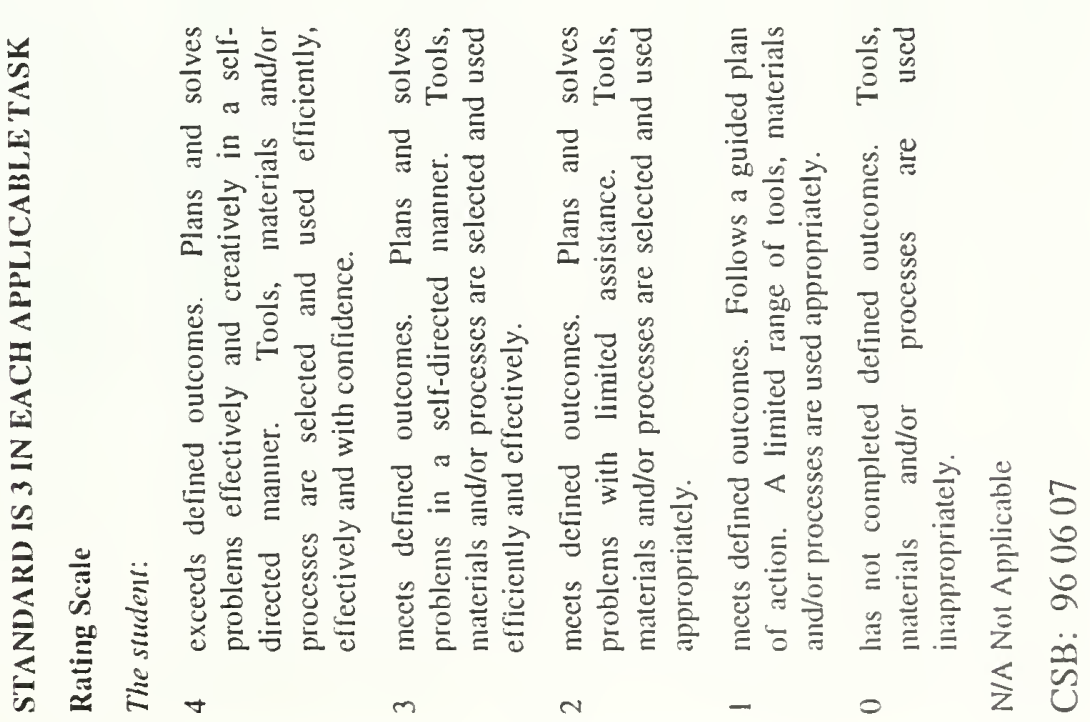




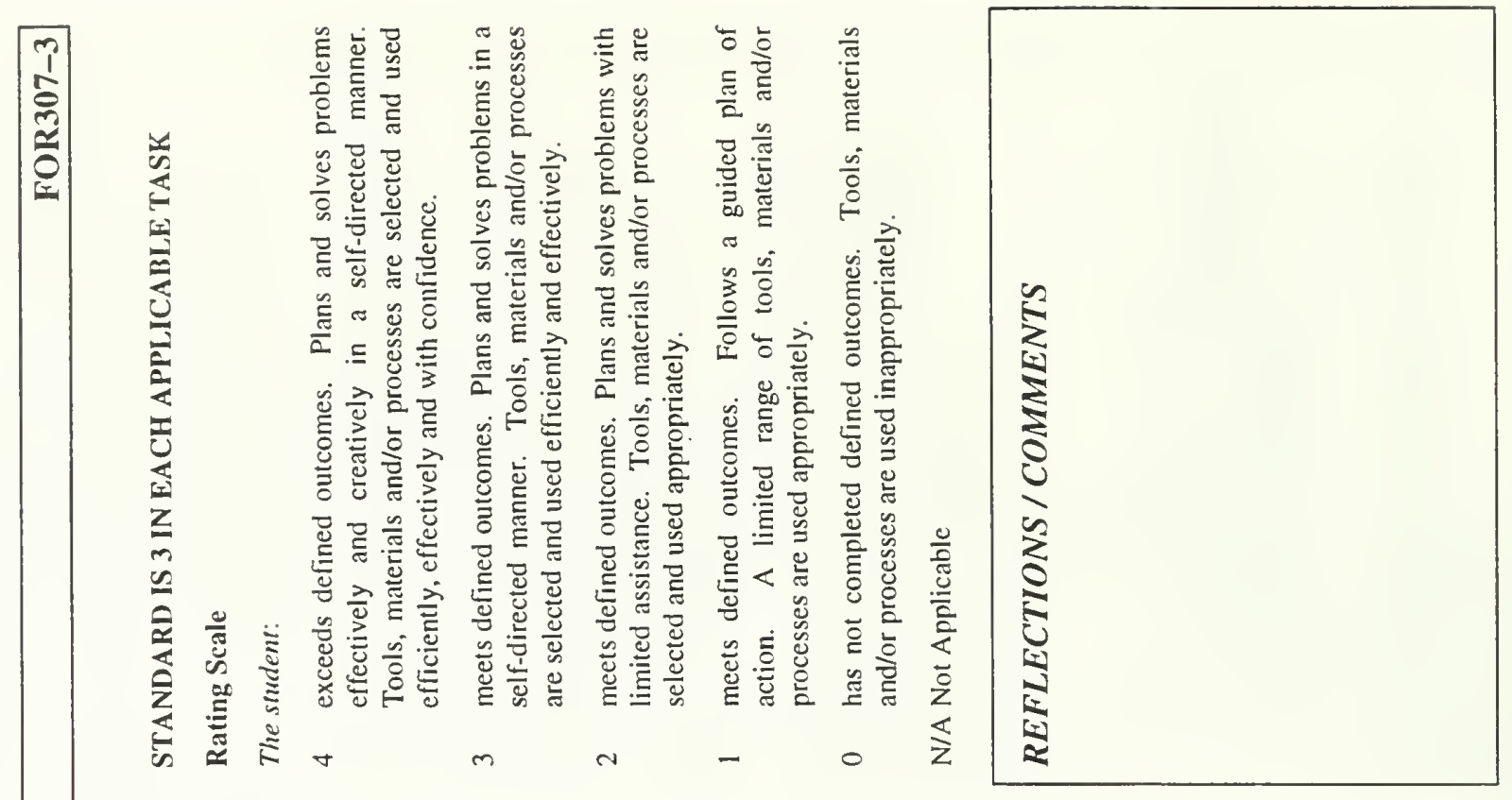

5
8
0
0
0
0
0

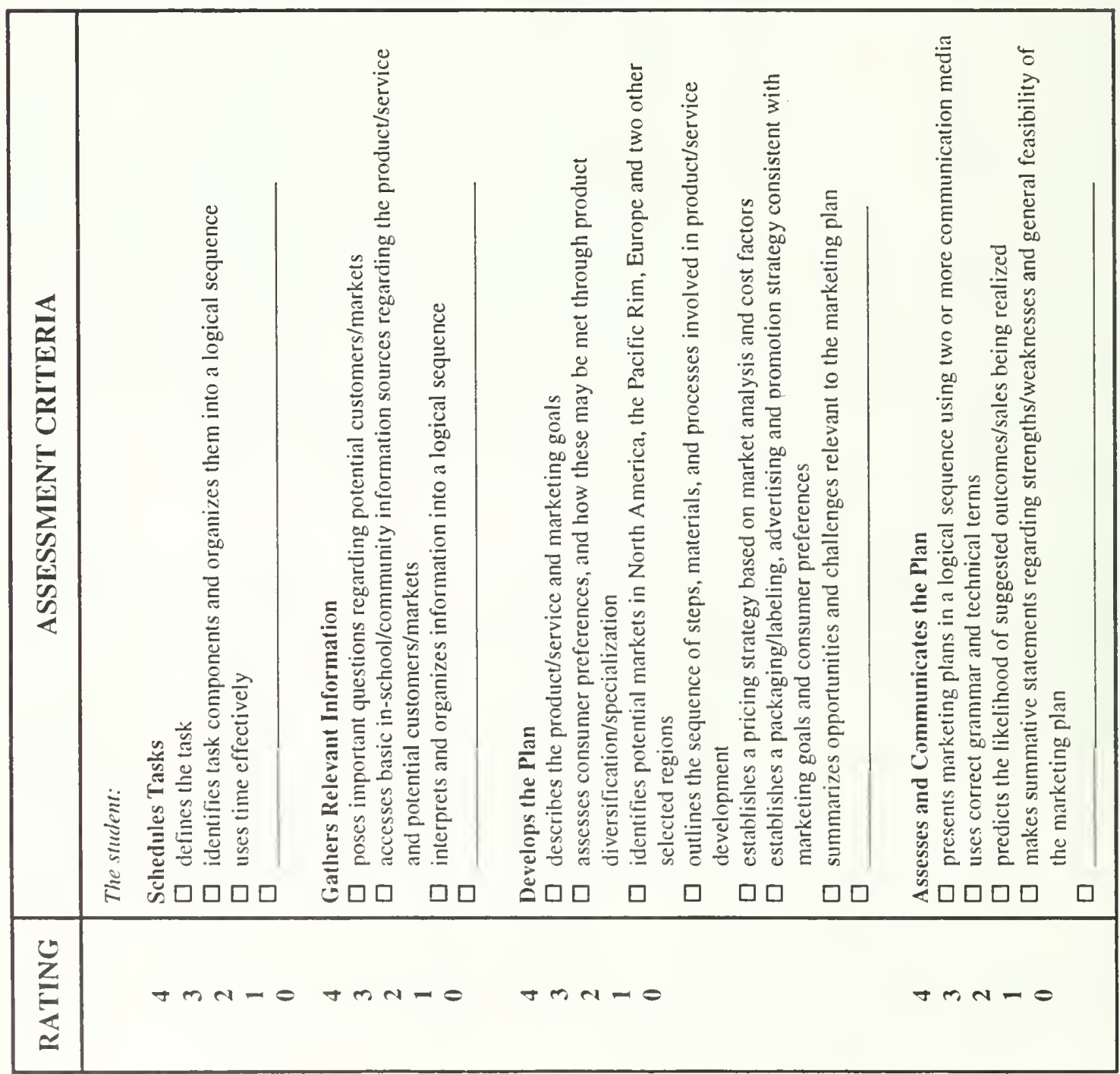

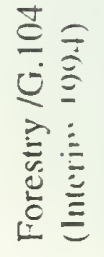



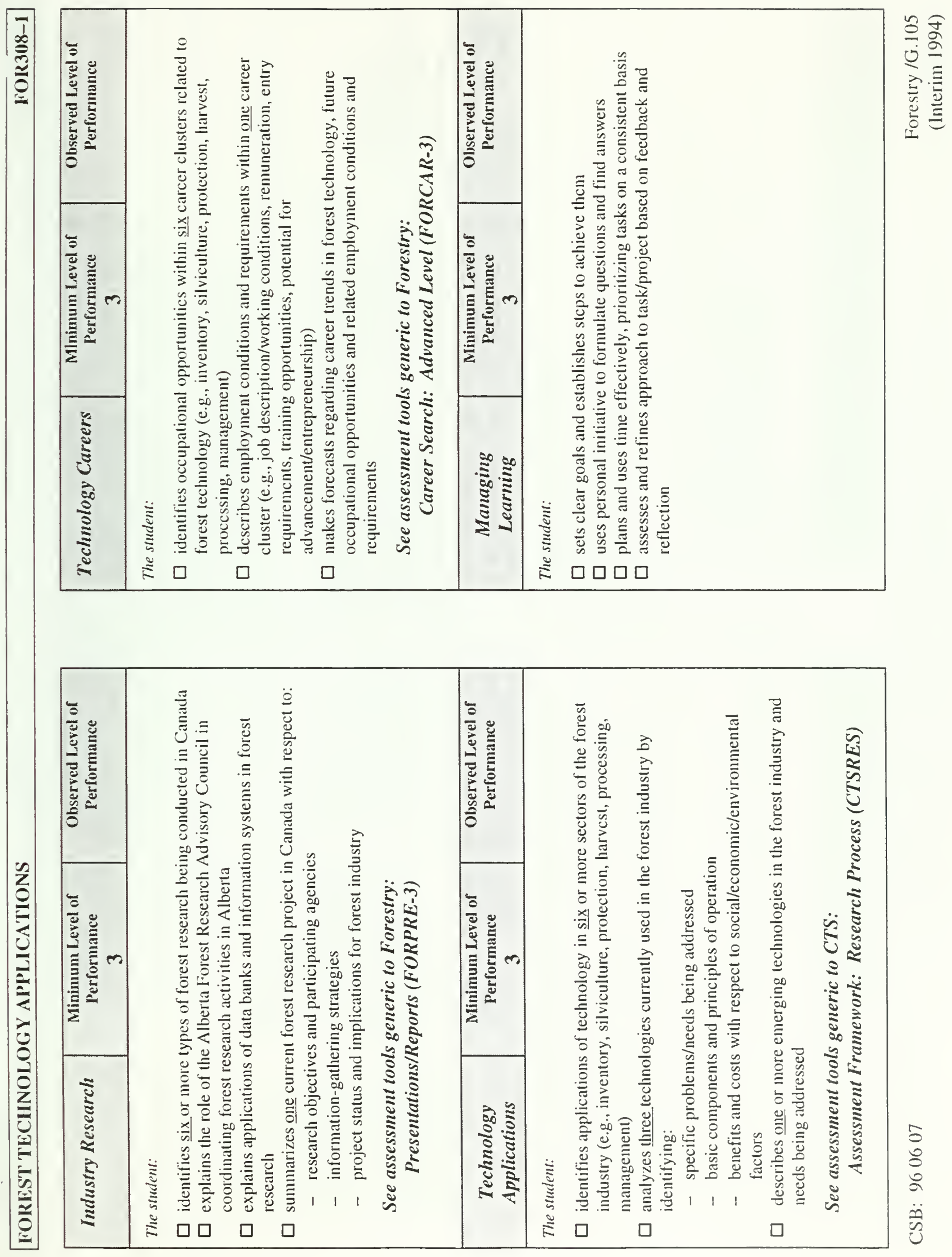

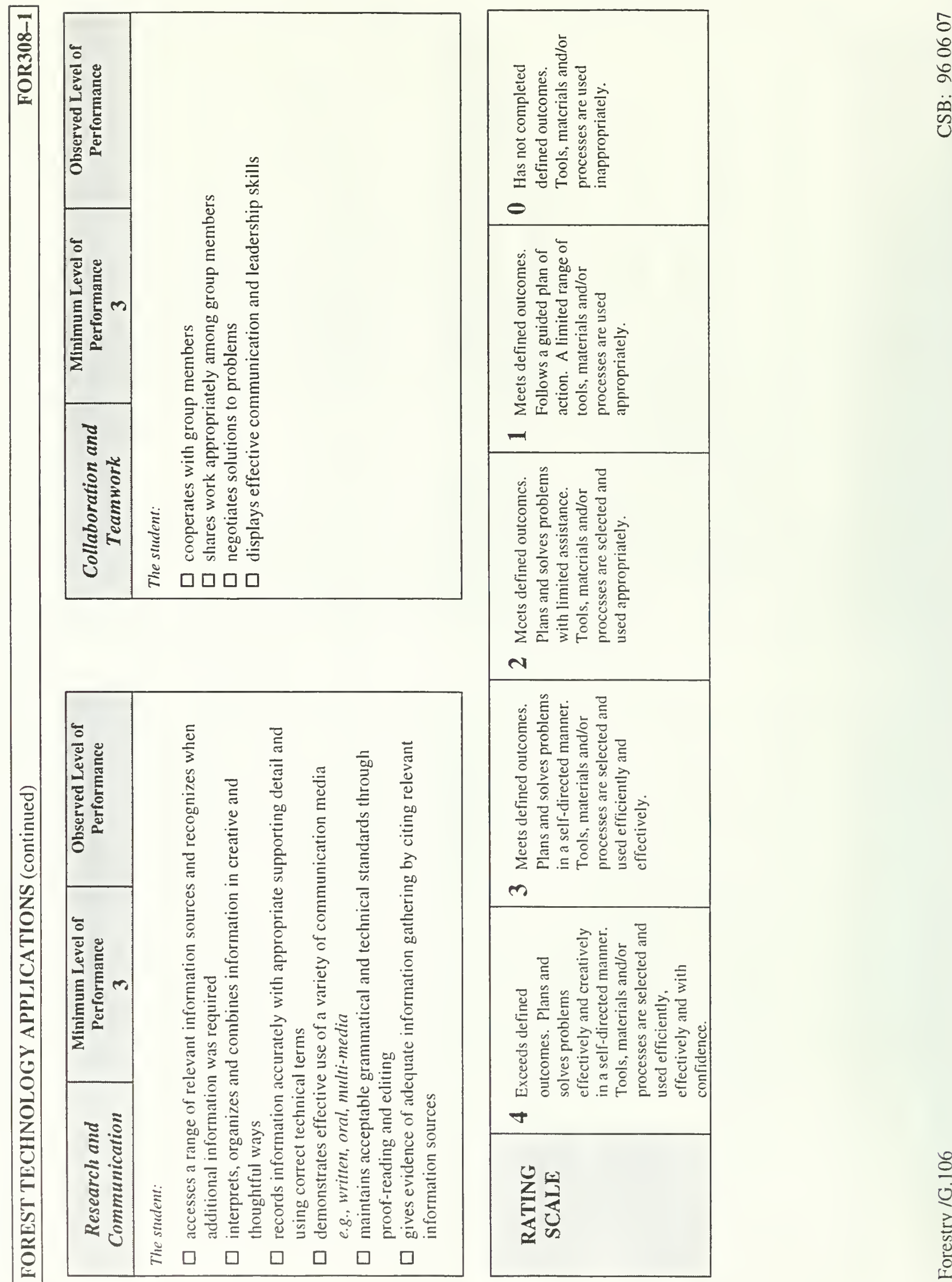


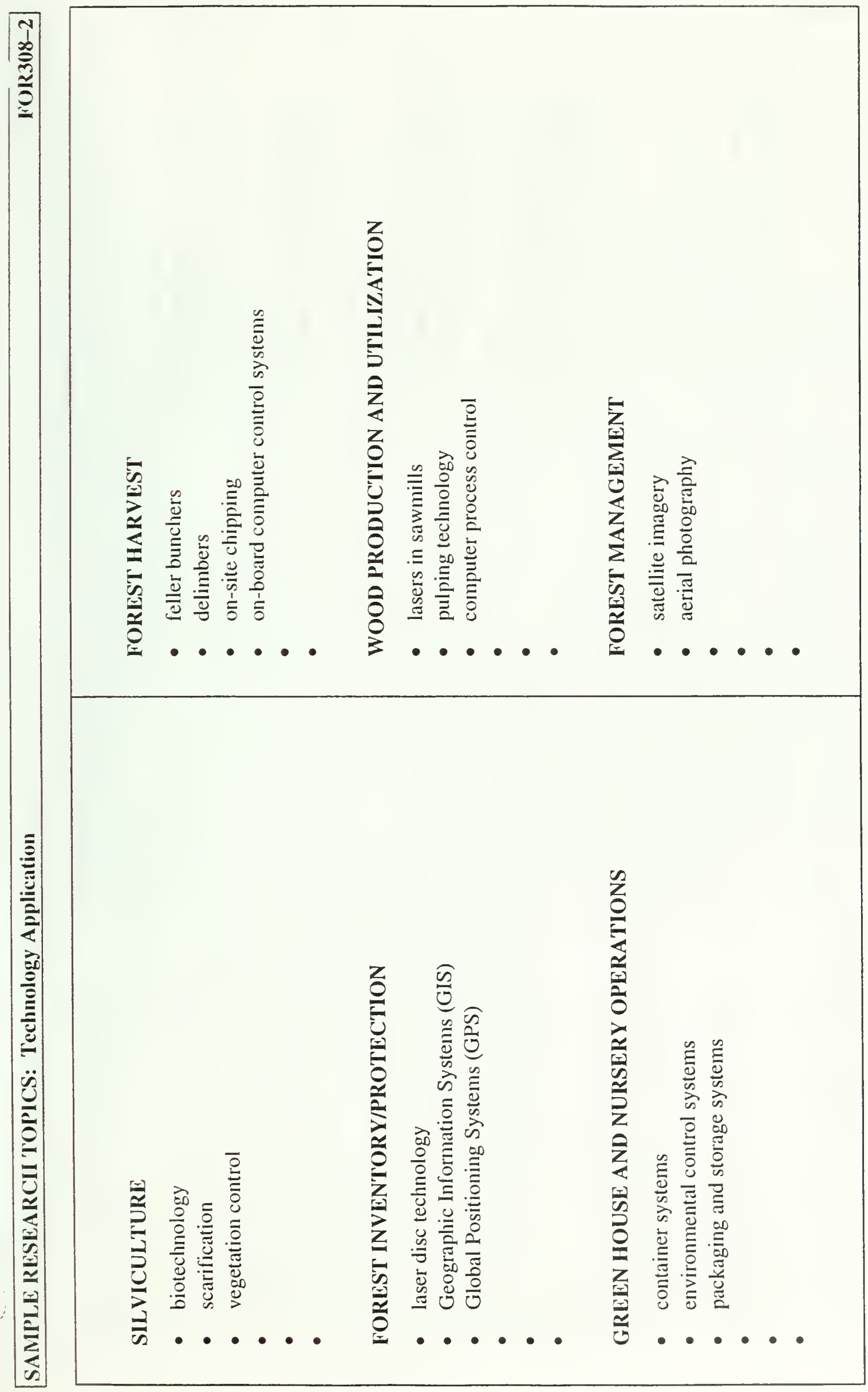

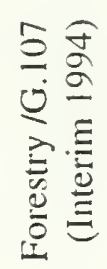




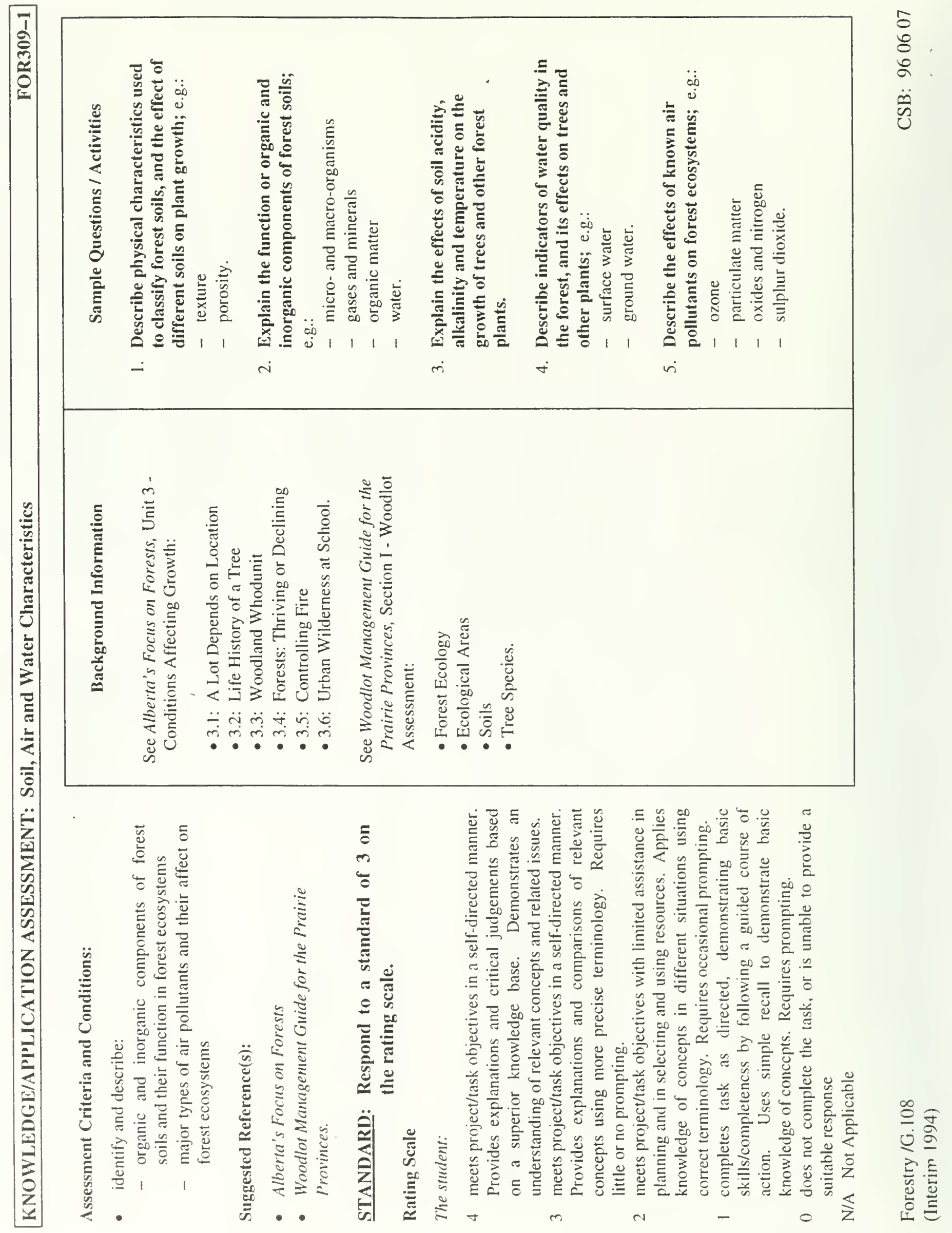



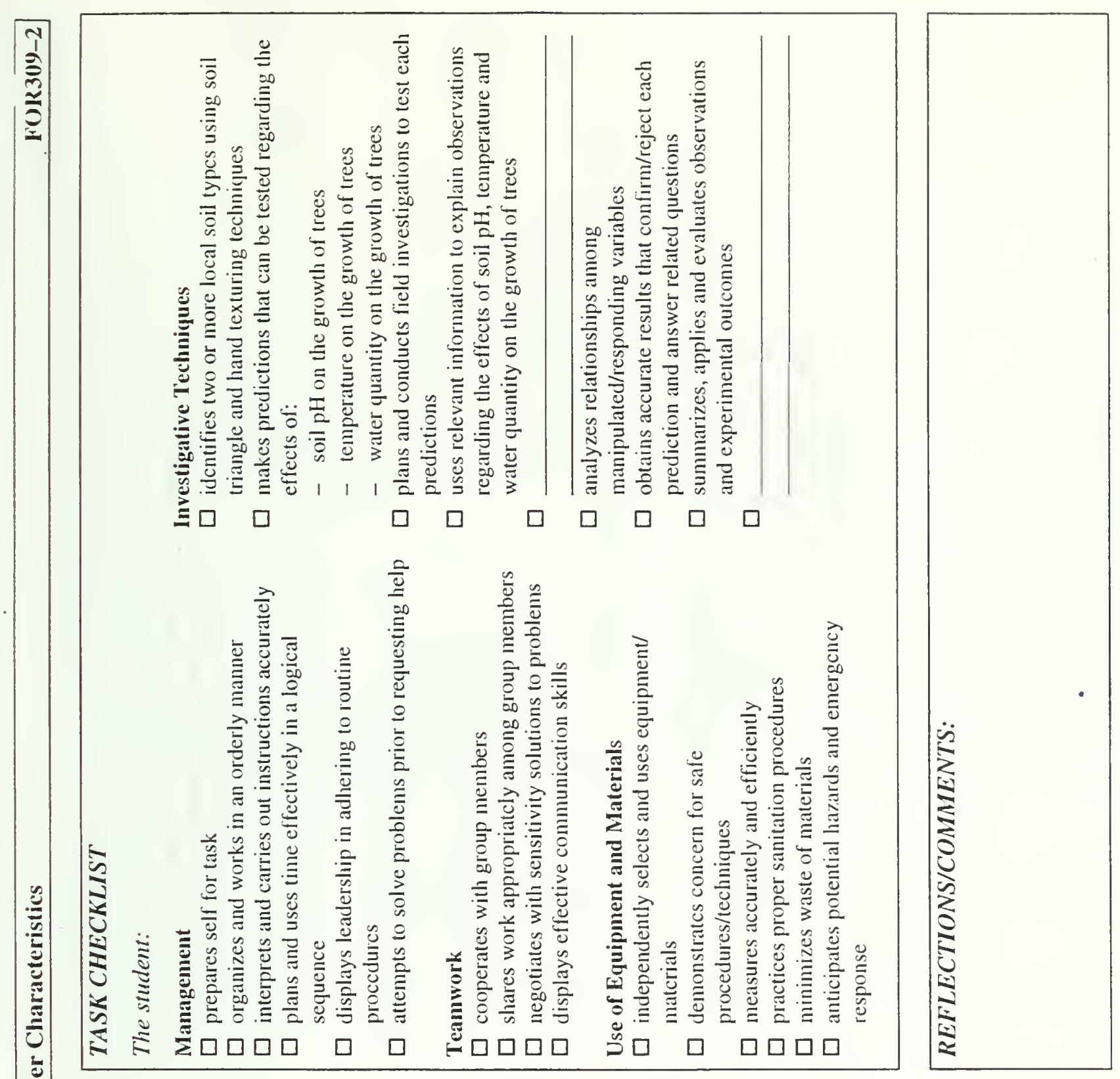

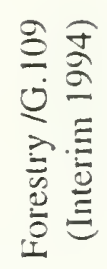
论

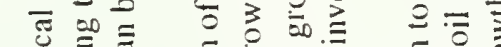

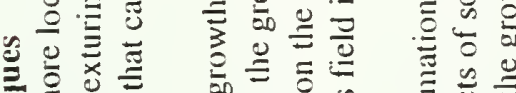

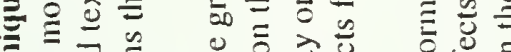

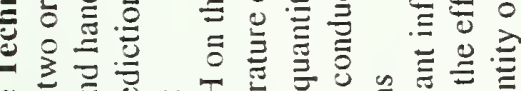

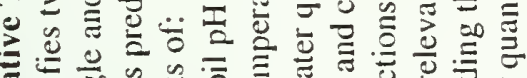

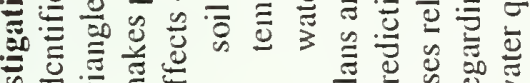

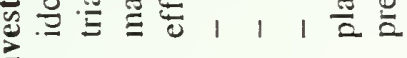

.

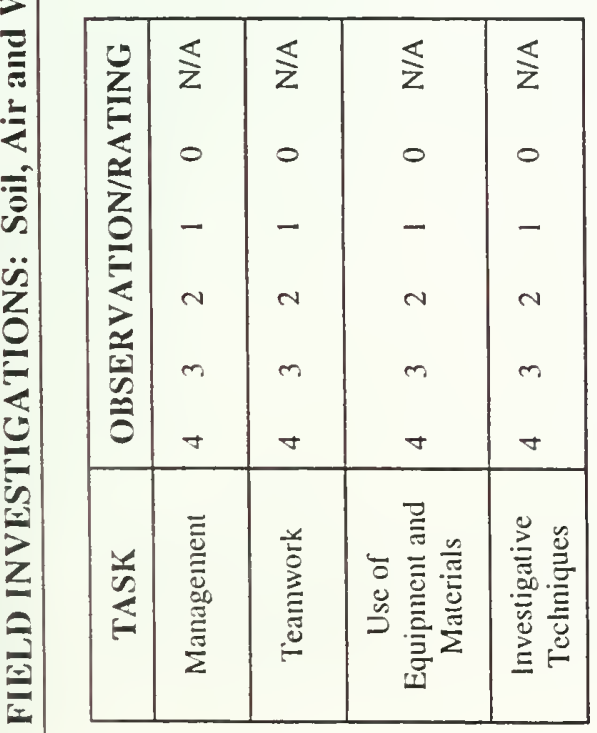

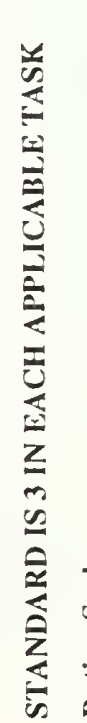

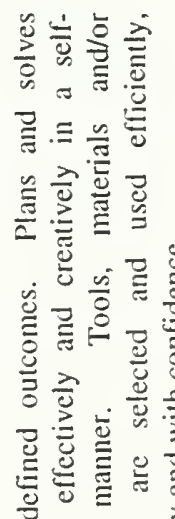

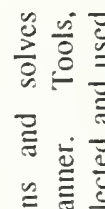

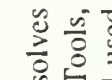

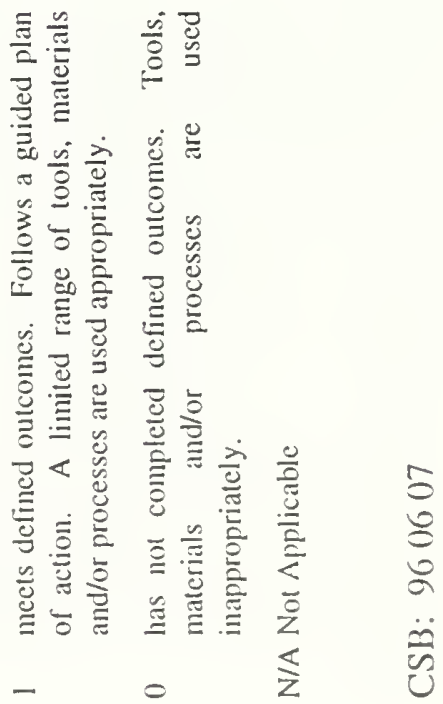




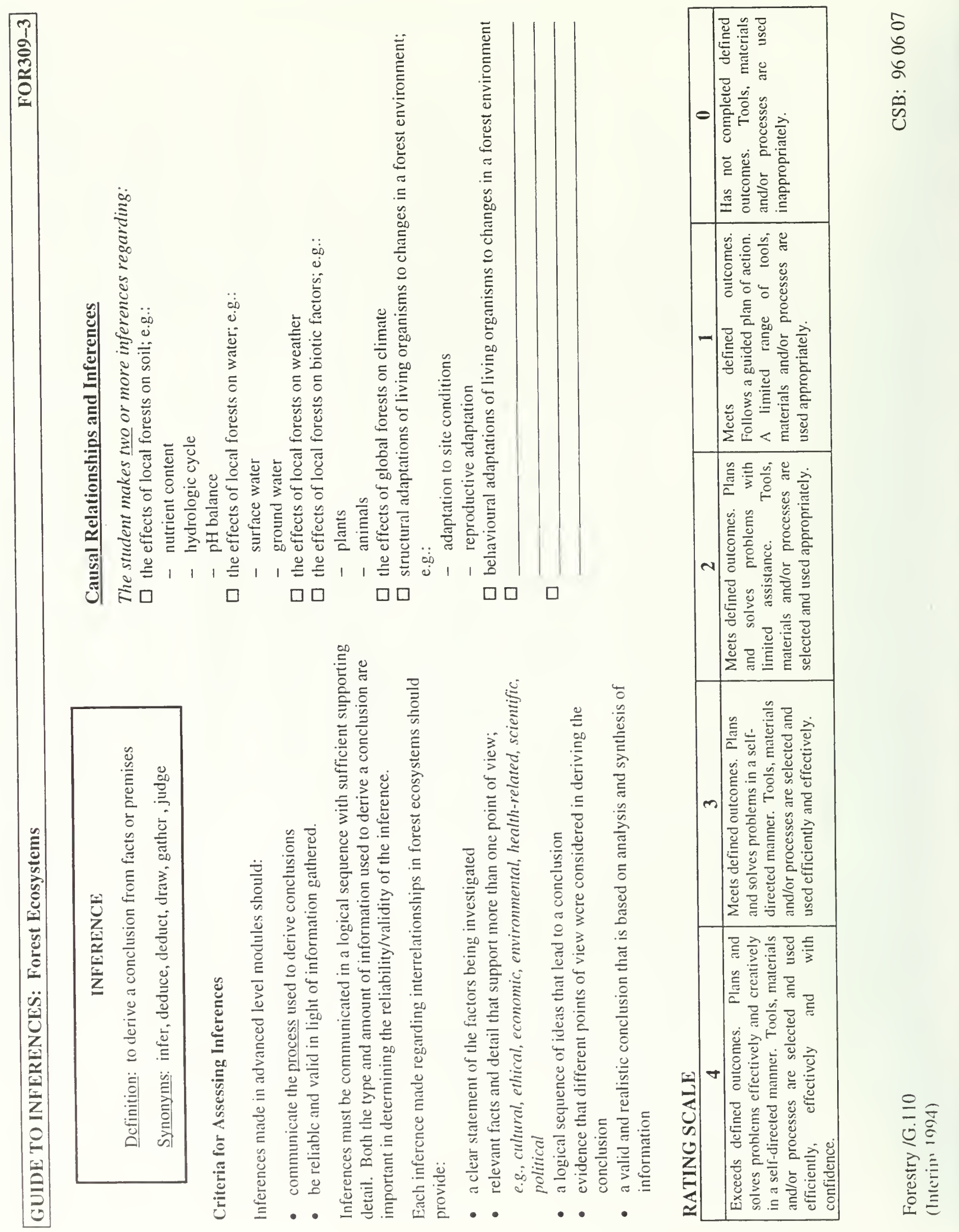



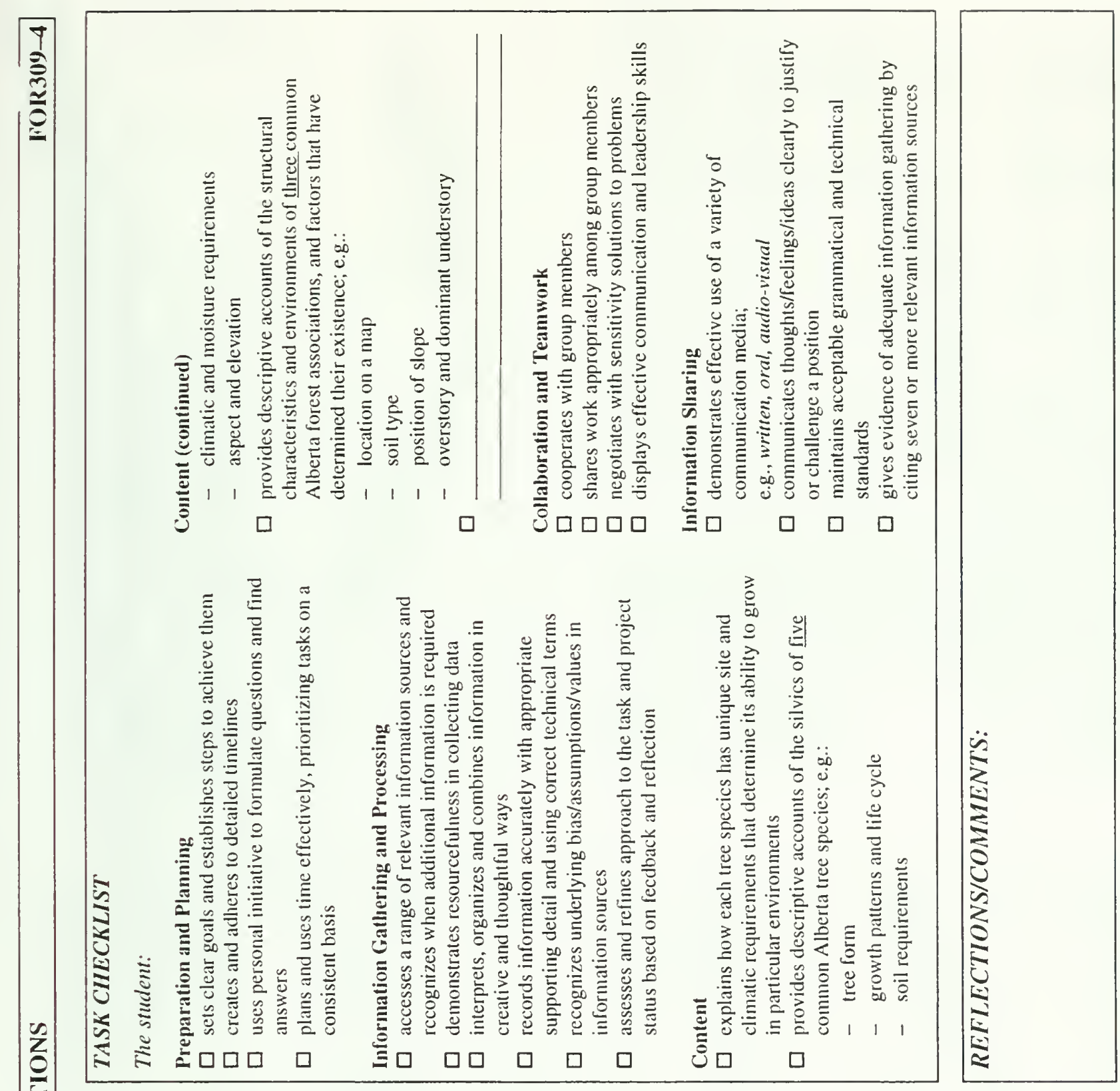

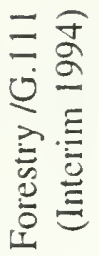

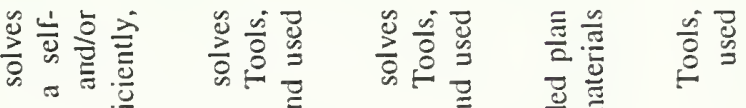

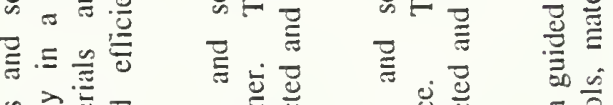

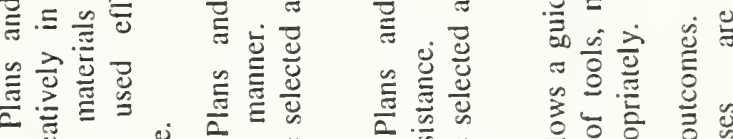

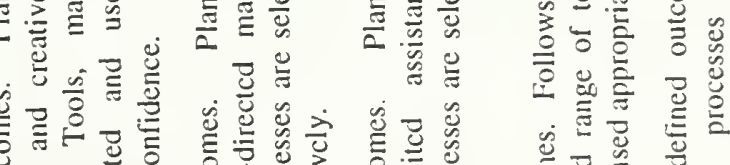

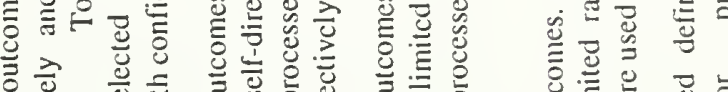

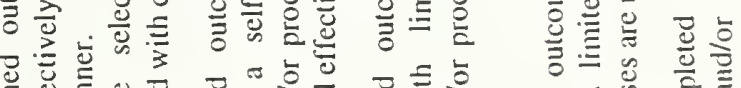

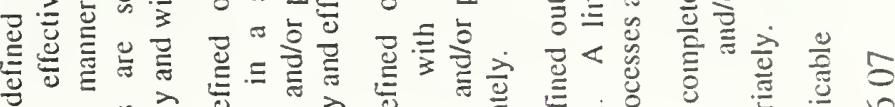

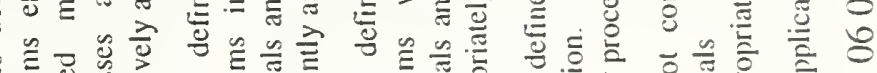

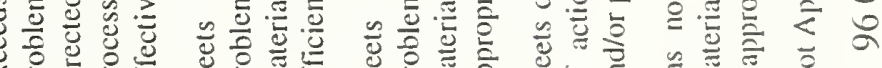

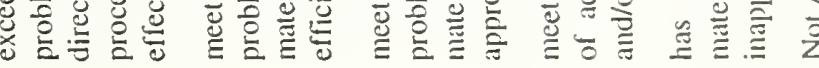


结

. है हू

通员

긍

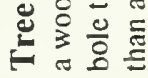

\begin{tabular}{|c|c|c|c|c|c|c|c|c|c|}
\hline 冚 & 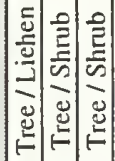 & 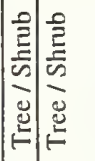 & 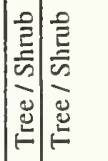 & 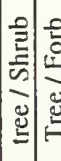 & $=\left[\begin{array}{ll}0 \\
0\end{array}\right.$ & 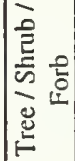 & 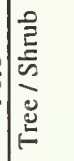 & 递 & 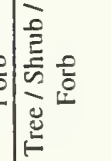 \\
\hline 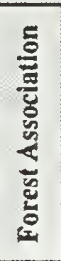 & 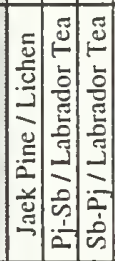 & 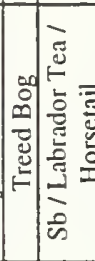 & 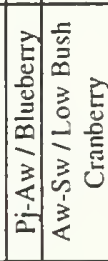 & 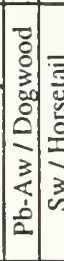 & 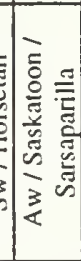 & 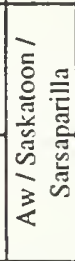 & 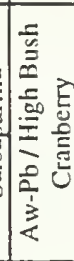 & 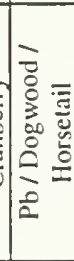 & 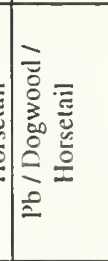 \\
\hline$\frac{1}{2}$ & 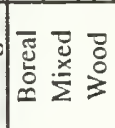 & & & & 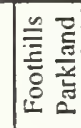 & 焉产 & & & 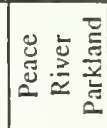 \\
\hline
\end{tabular}

\begin{tabular}{|c|c|c|c|c|c|c|c|c|c|c|c|c|c|c|}
\hline 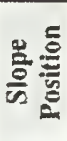 & 产 & $\stackrel{\circ}{\circ}$ & 离 & 彦 & 学 & 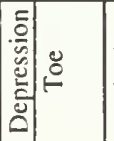 & $\frac{0}{\overline{\frac{\pi}{2}}}$ & \begin{tabular}{l|l} 
& \\
\end{tabular} & 离 & 彦 & 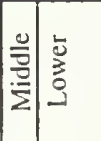 & 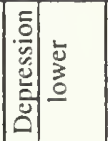 & 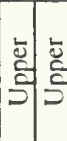 & ๕ \\
\hline 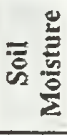 & $\begin{array}{l}2 \\
2 \\
0 \\
2 \\
0 \\
0 \\
>\end{array}$ & $\bar{\Xi}$ & $\frac{\bar{m}}{\frac{\pi}{2}}$ & $\mid$ & $\left|\overline{\frac{m}{2}}\right| \overline{\overline{0}}$ & 3 & $\frac{\bar{n}}{\overline{0}}$ & $\overline{\frac{\bar{v}}{\partial}} \frac{\overline{\underline{x}}}{\frac{\partial}{2}}$ & 2 & $\begin{array}{l}3 \\
\frac{3}{2} \\
\frac{2}{2} \\
2\end{array}$ & $\left.\frac{\bar{m}}{\bar{a}}\right)^{\bar{a}}$ & 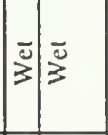 & $\left|\frac{\bar{b}}{\frac{0}{2}}\right| \frac{2}{2}$ & $\sum_{\bar{s}}$ \\
\hline$\overline{\bar{B}}$ & 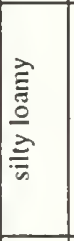 & 彥 & 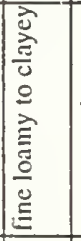 & 产 & 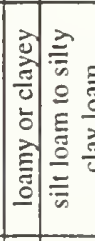 & 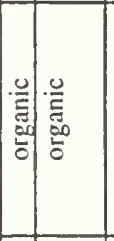 & 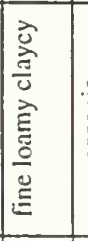 & 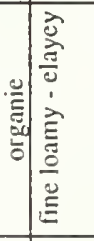 & 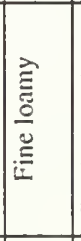 & 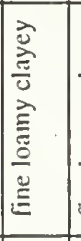 & 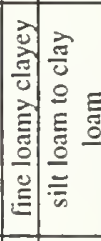 & 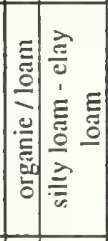 & 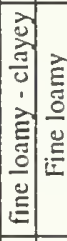 & 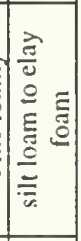 \\
\hline 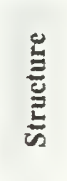 & 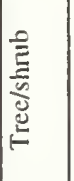 & 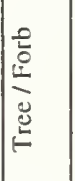 & 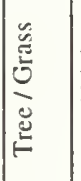 & 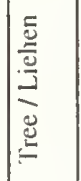 & 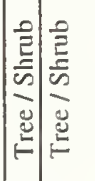 & 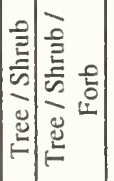 & 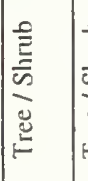 & 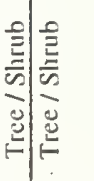 & 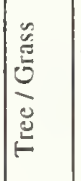 & 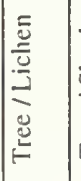 & 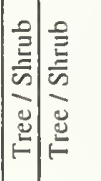 & 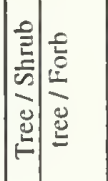 & 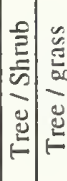 & $\frac{\partial}{2}$ \\
\hline 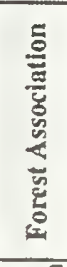 & 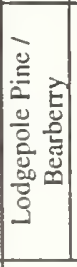 & 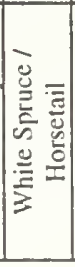 & 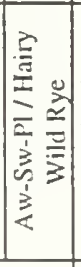 & 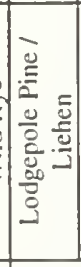 & 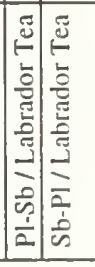 & 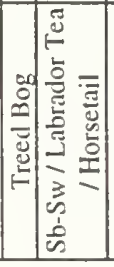 & 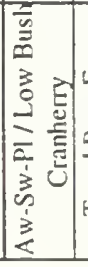 & 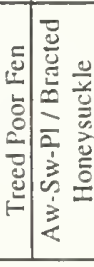 & 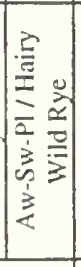 & 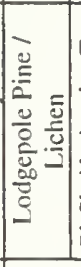 & 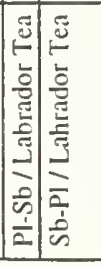 & 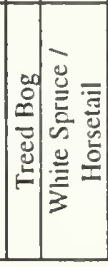 & 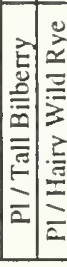 & 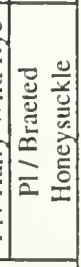 \\
\hline 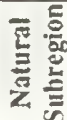 & 总 & & & 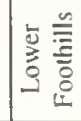 & & & & & & 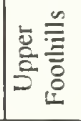 & & & & \\
\hline
\end{tabular}

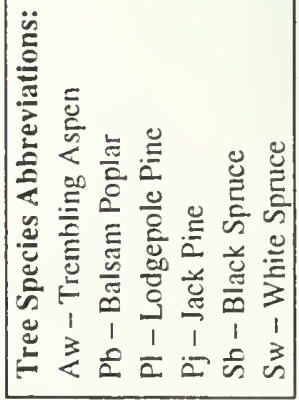

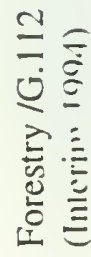



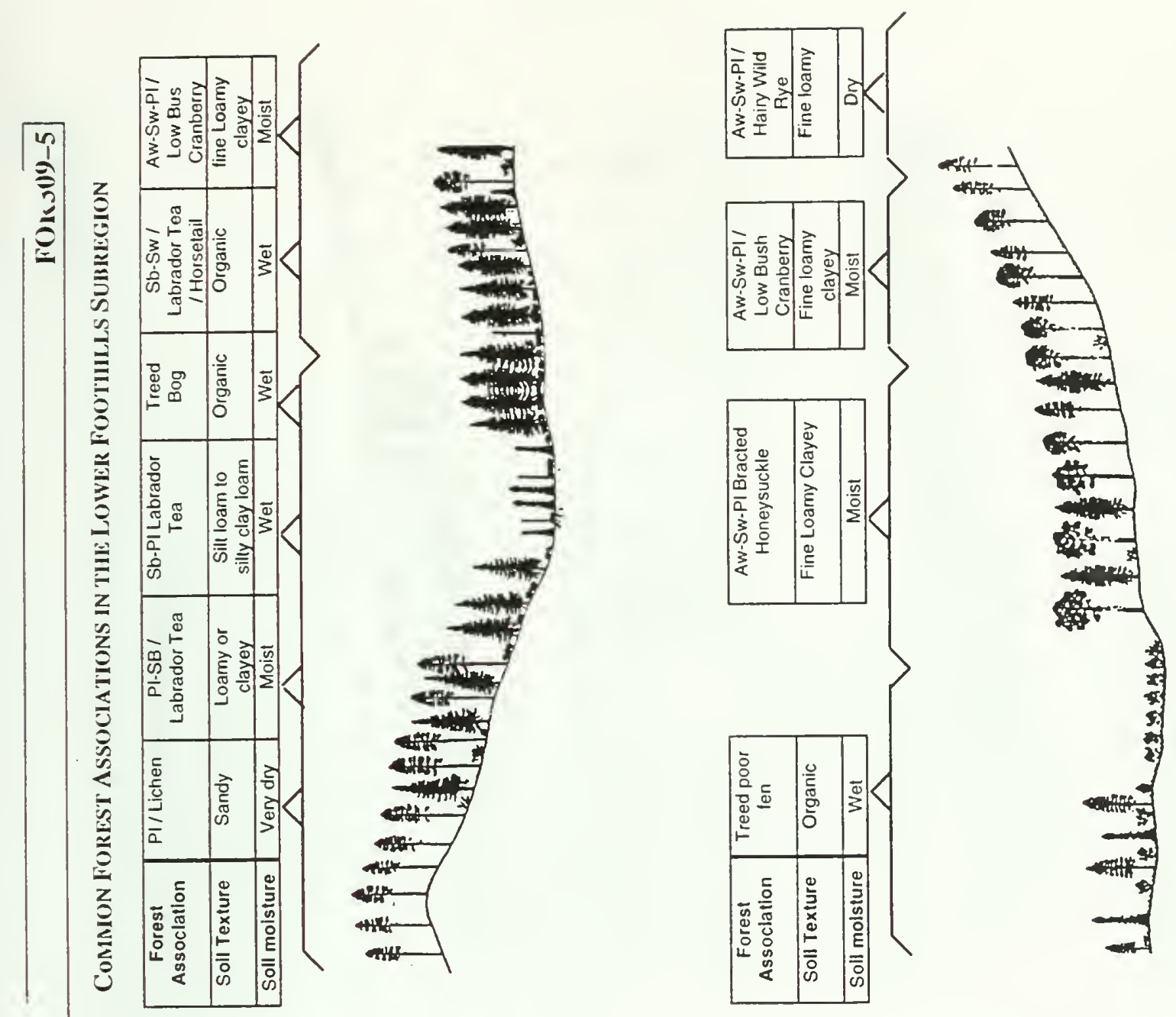

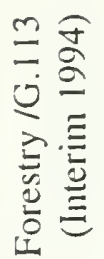
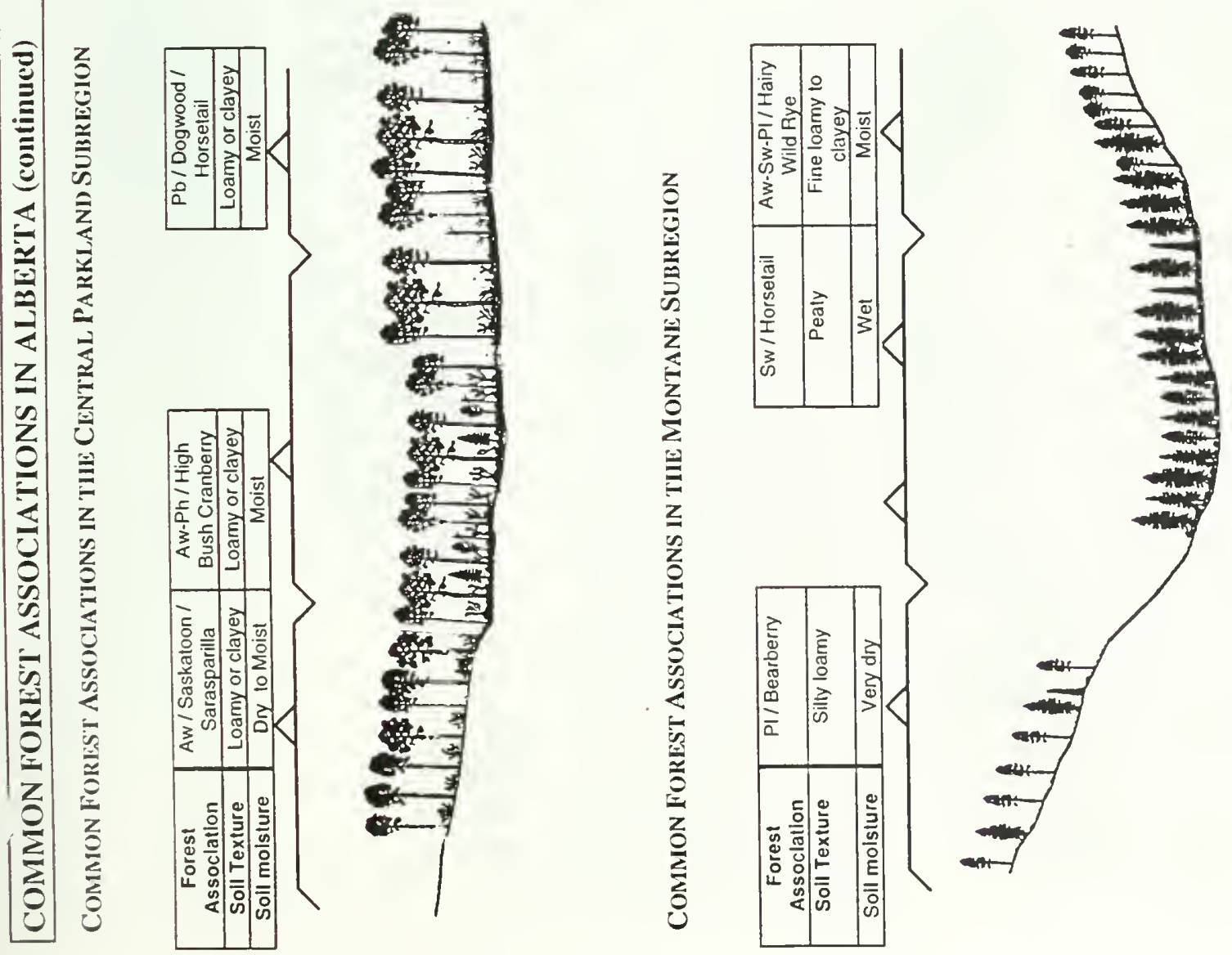

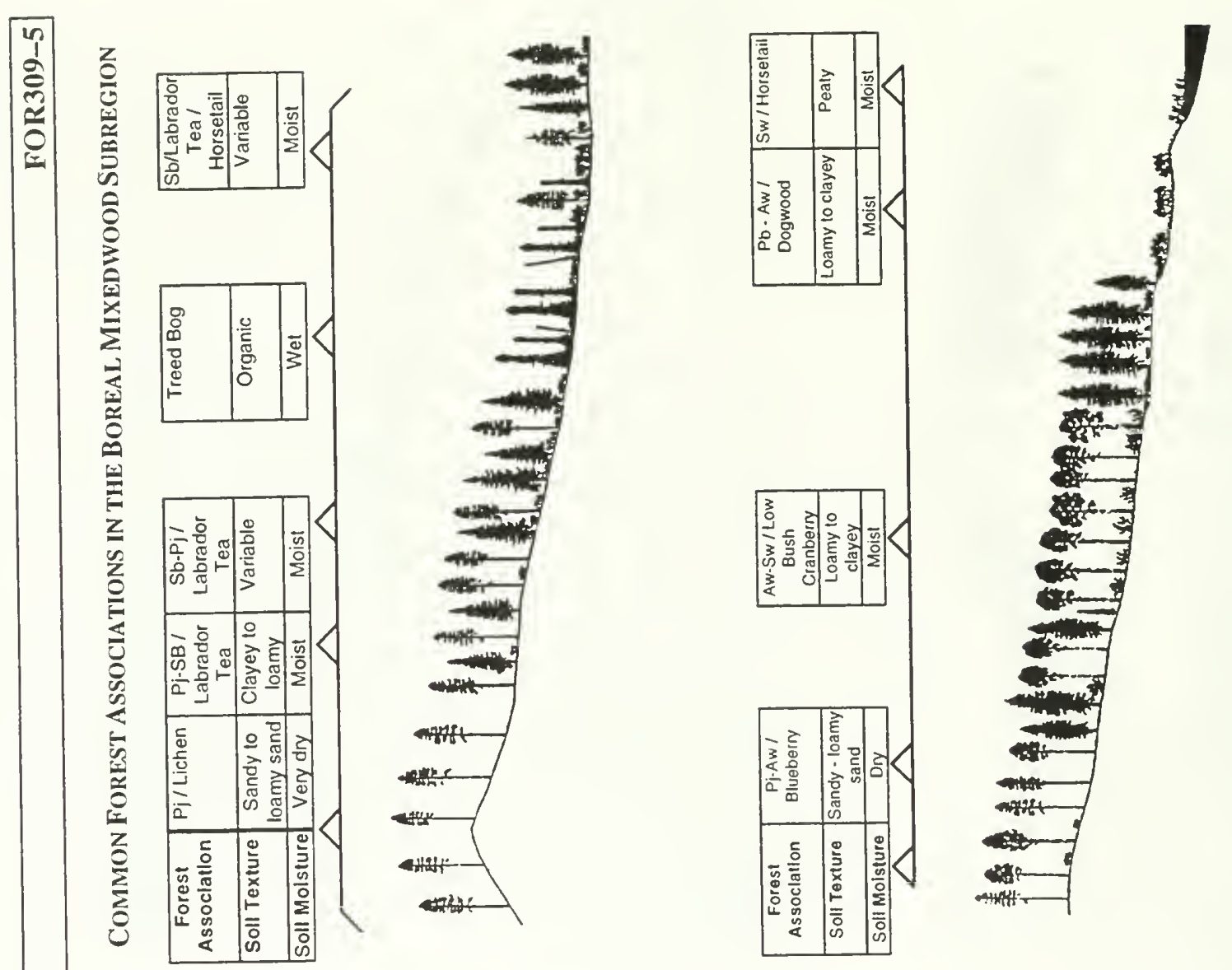

5
8
8
0
$\ddot{0}$
0
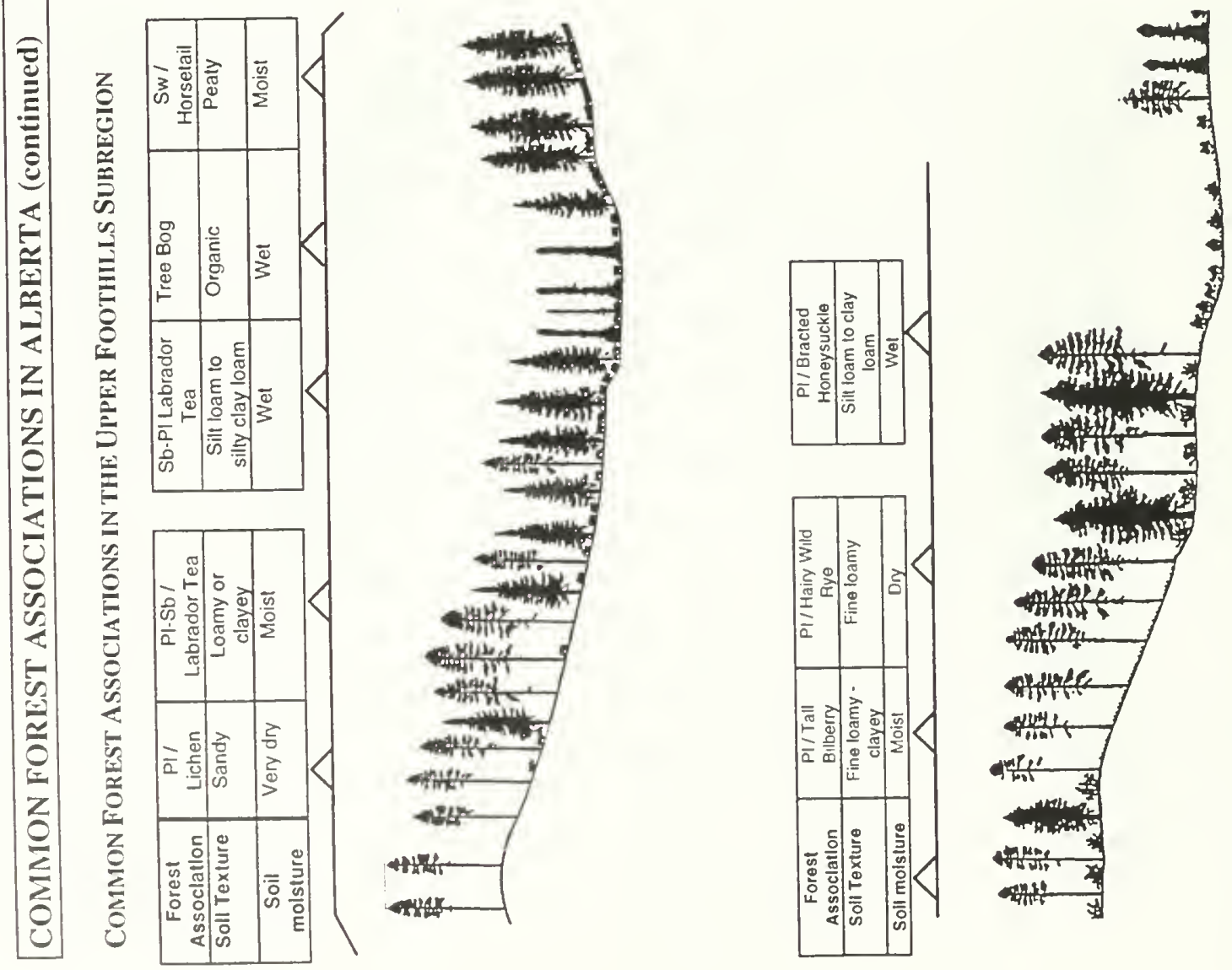

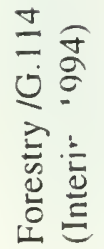




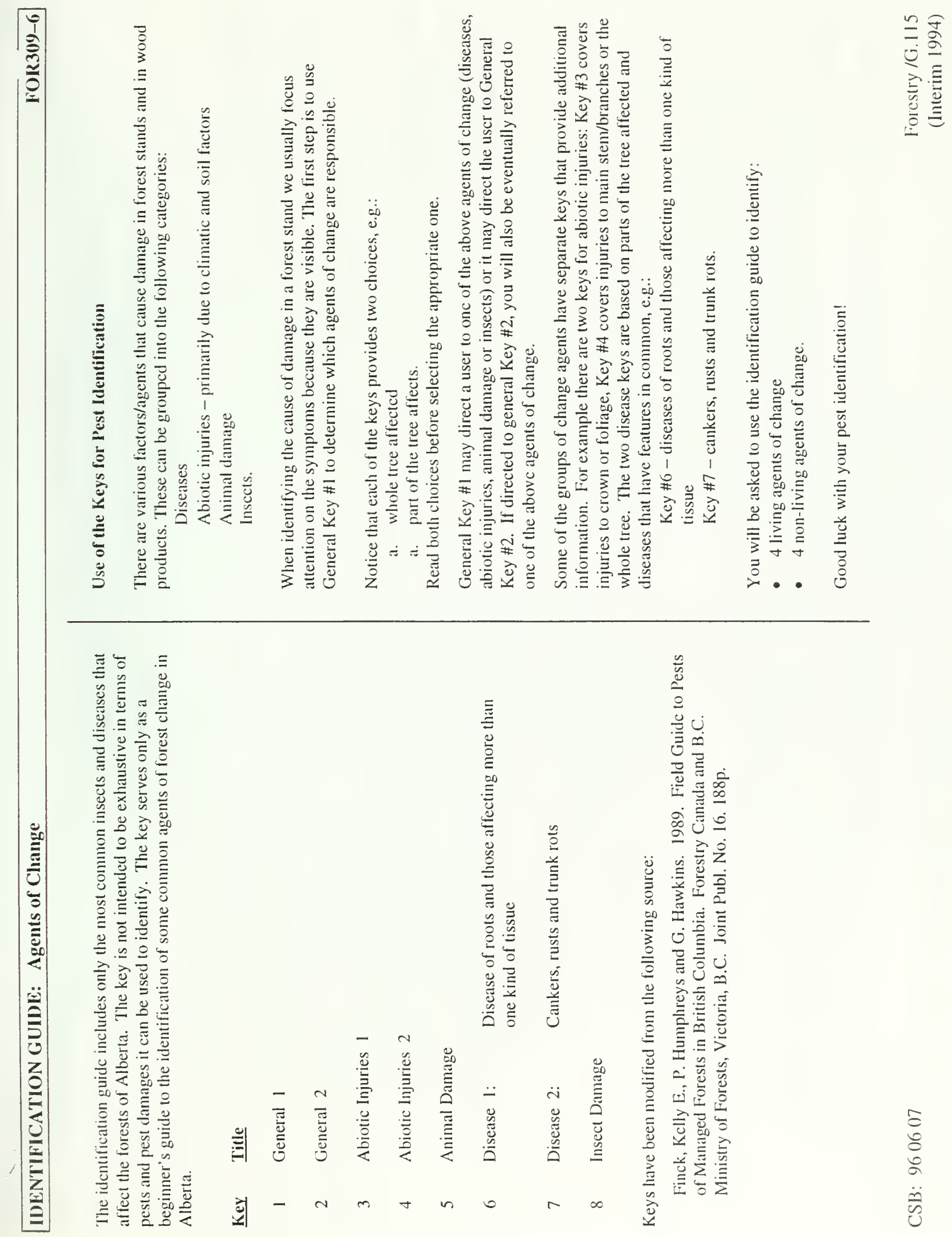




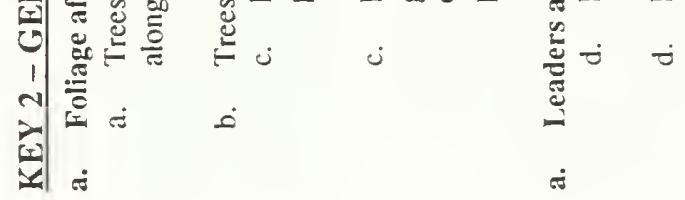

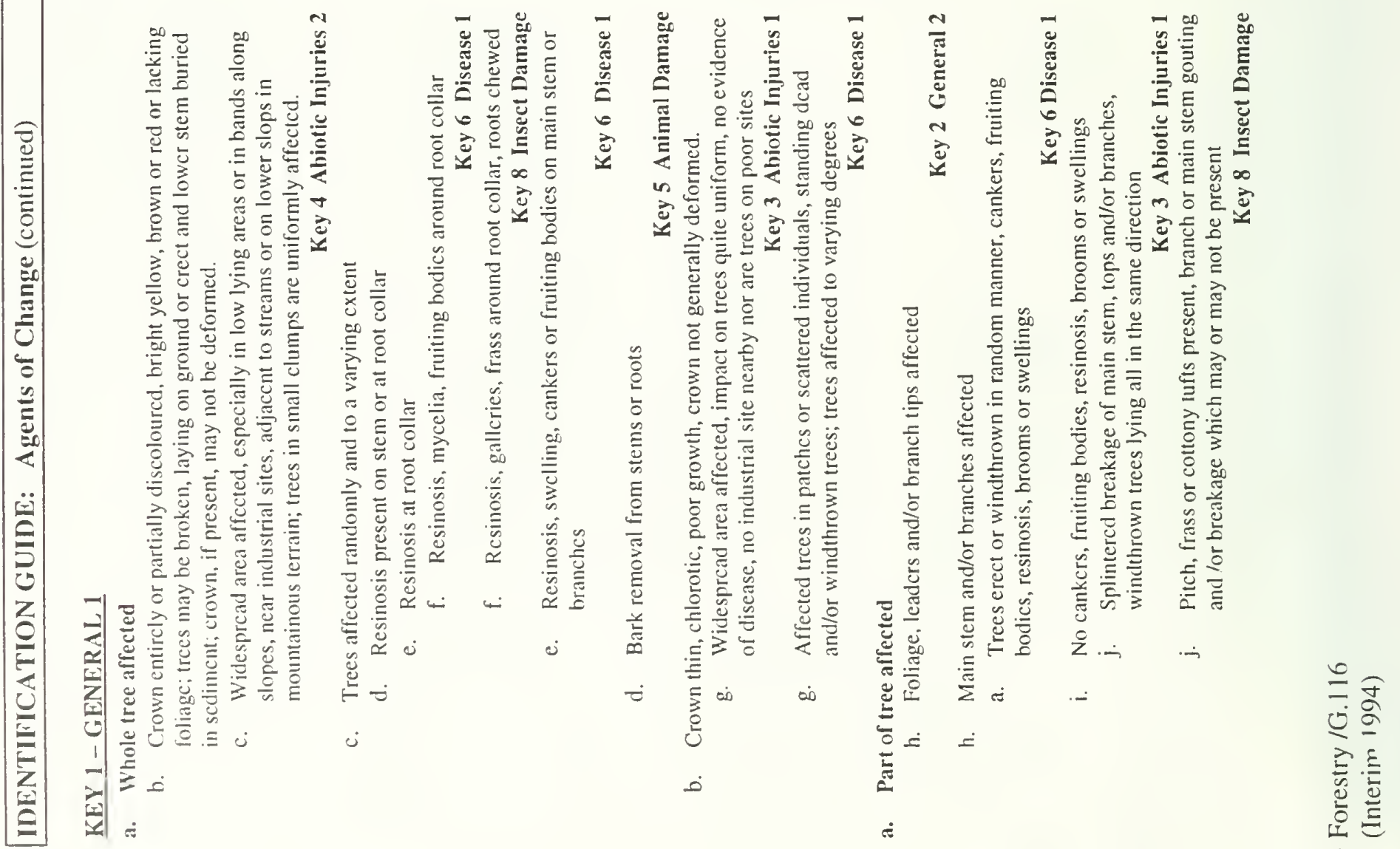




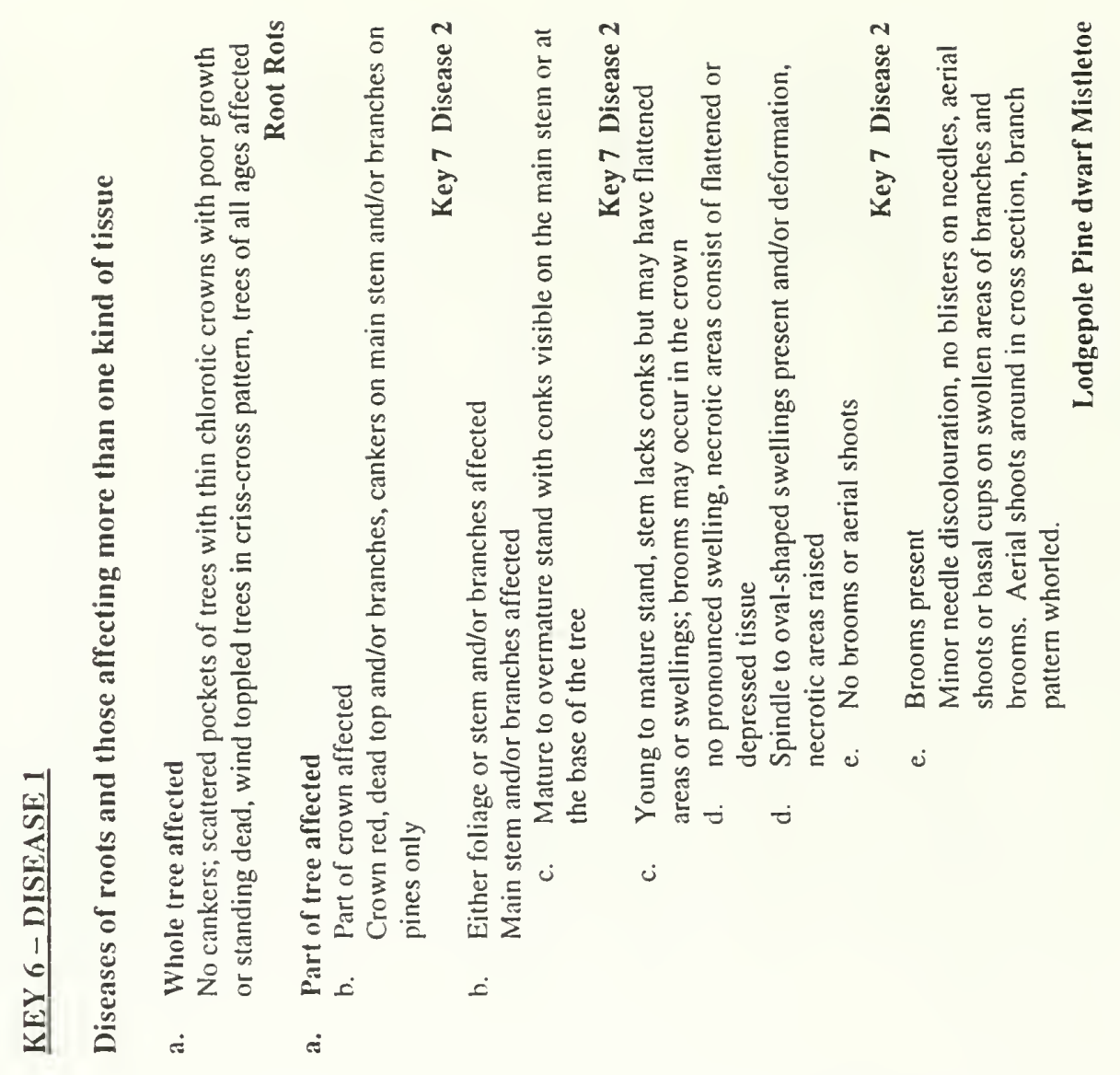

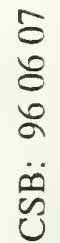

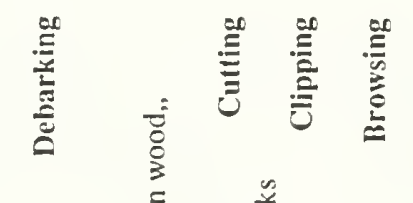

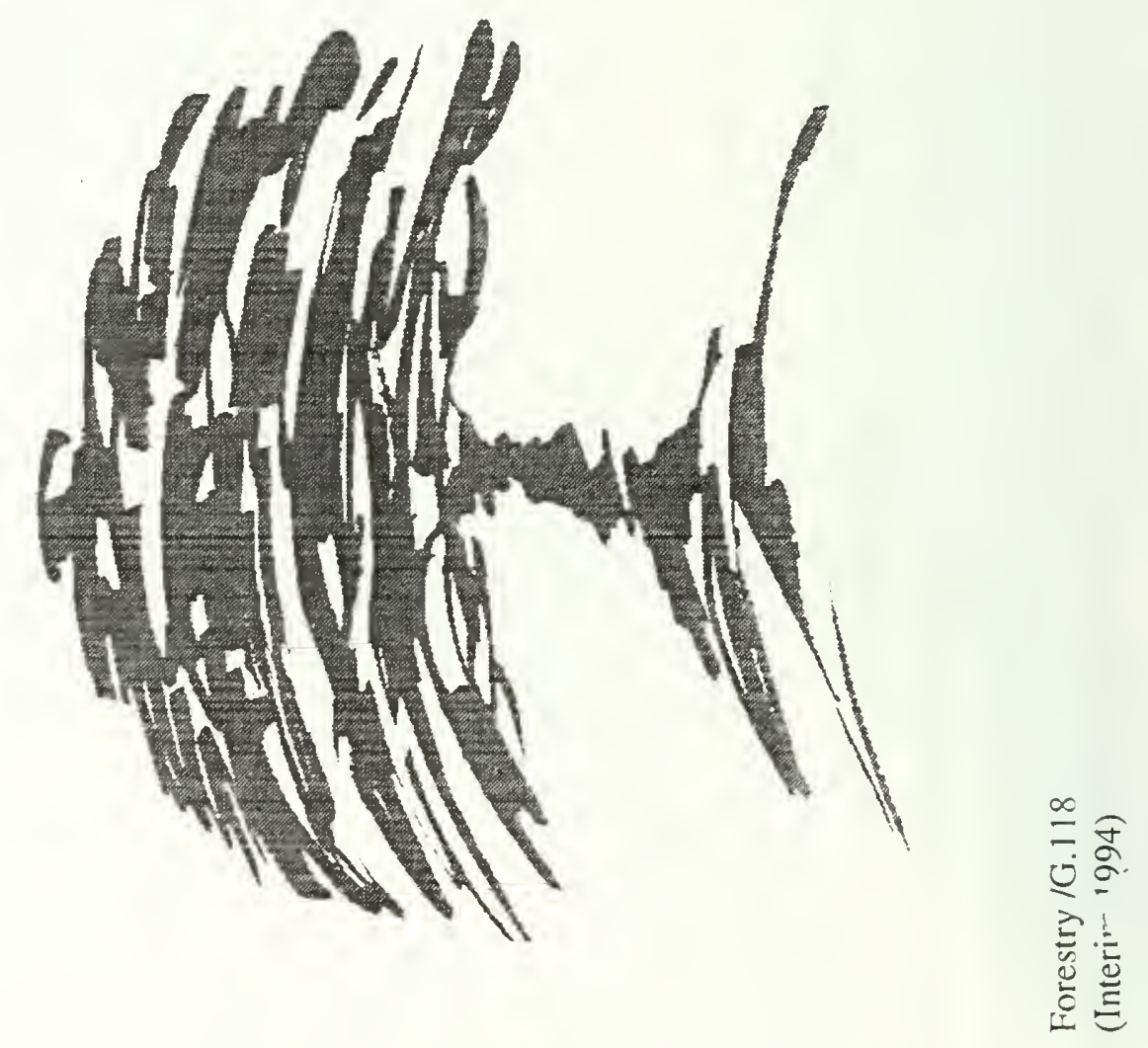




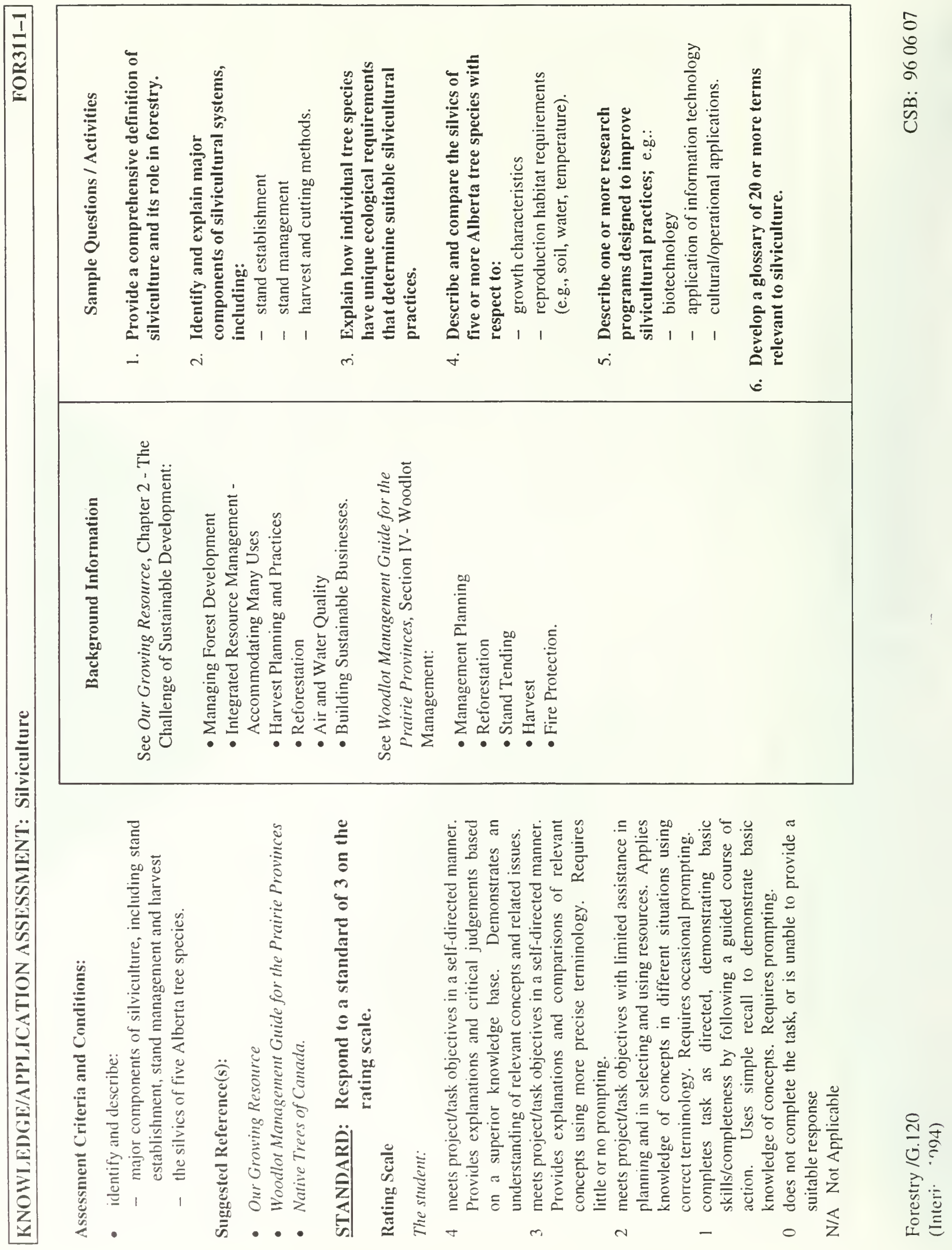




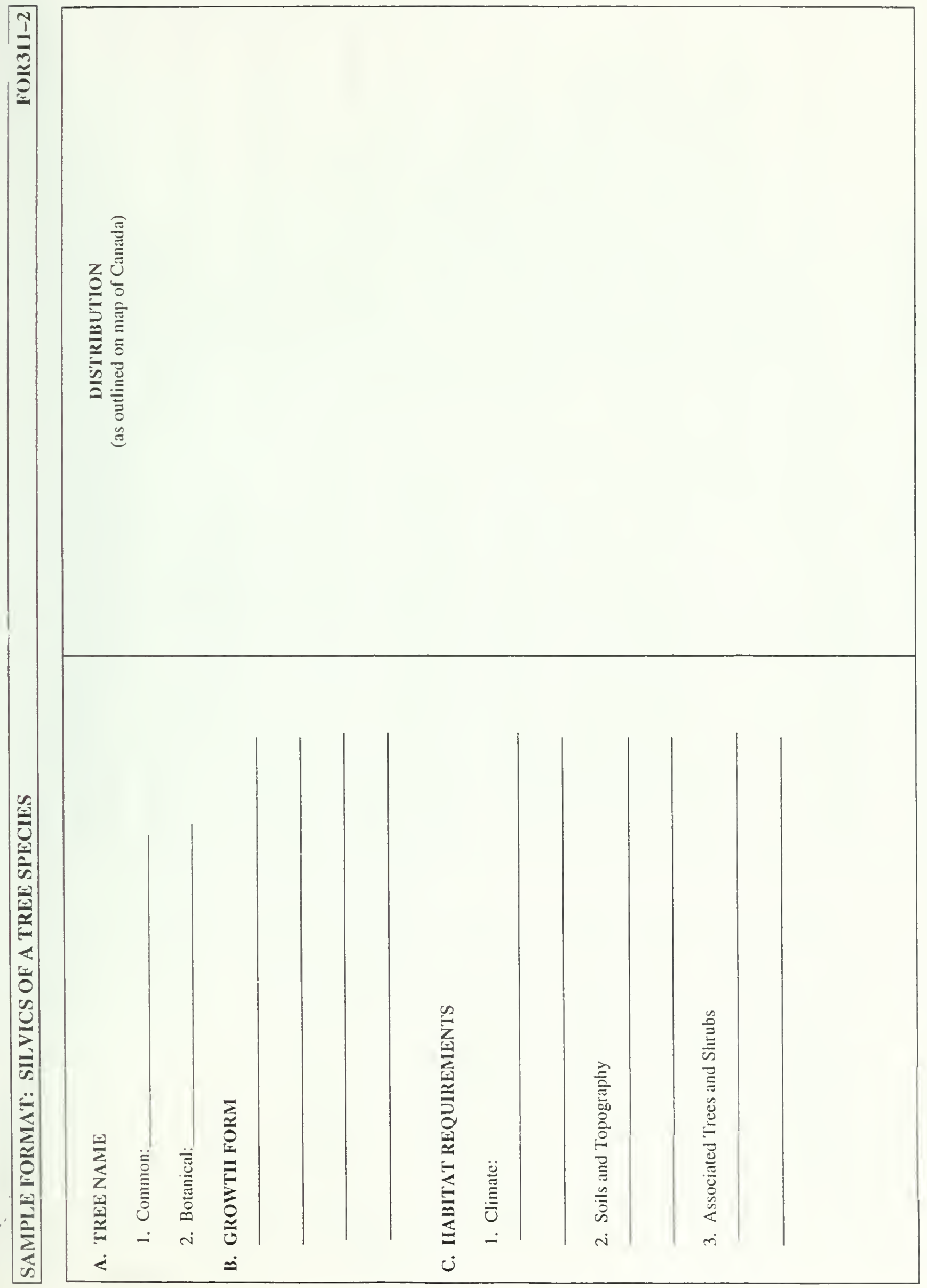

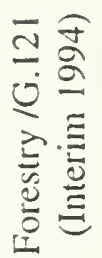

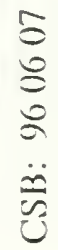




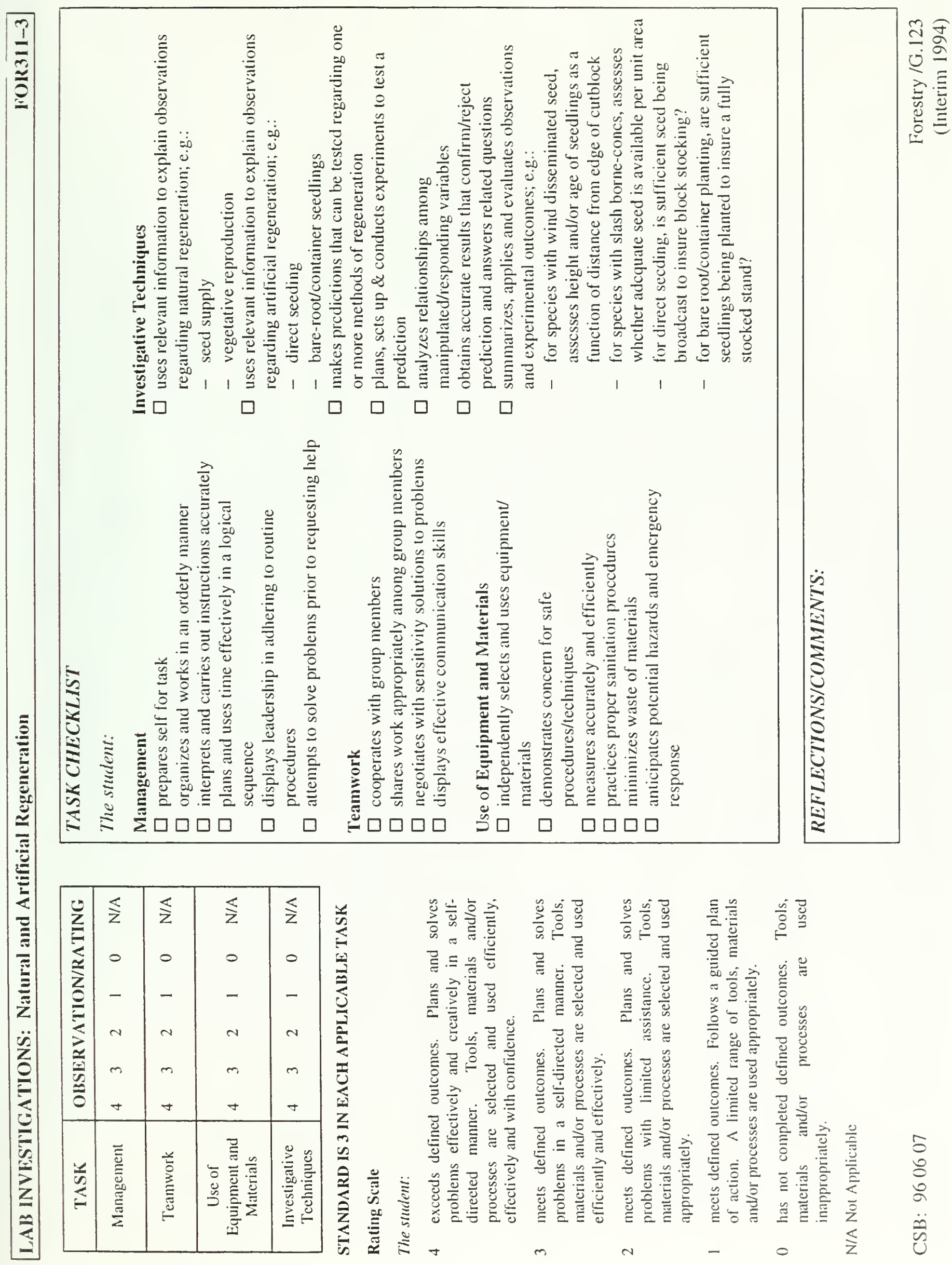




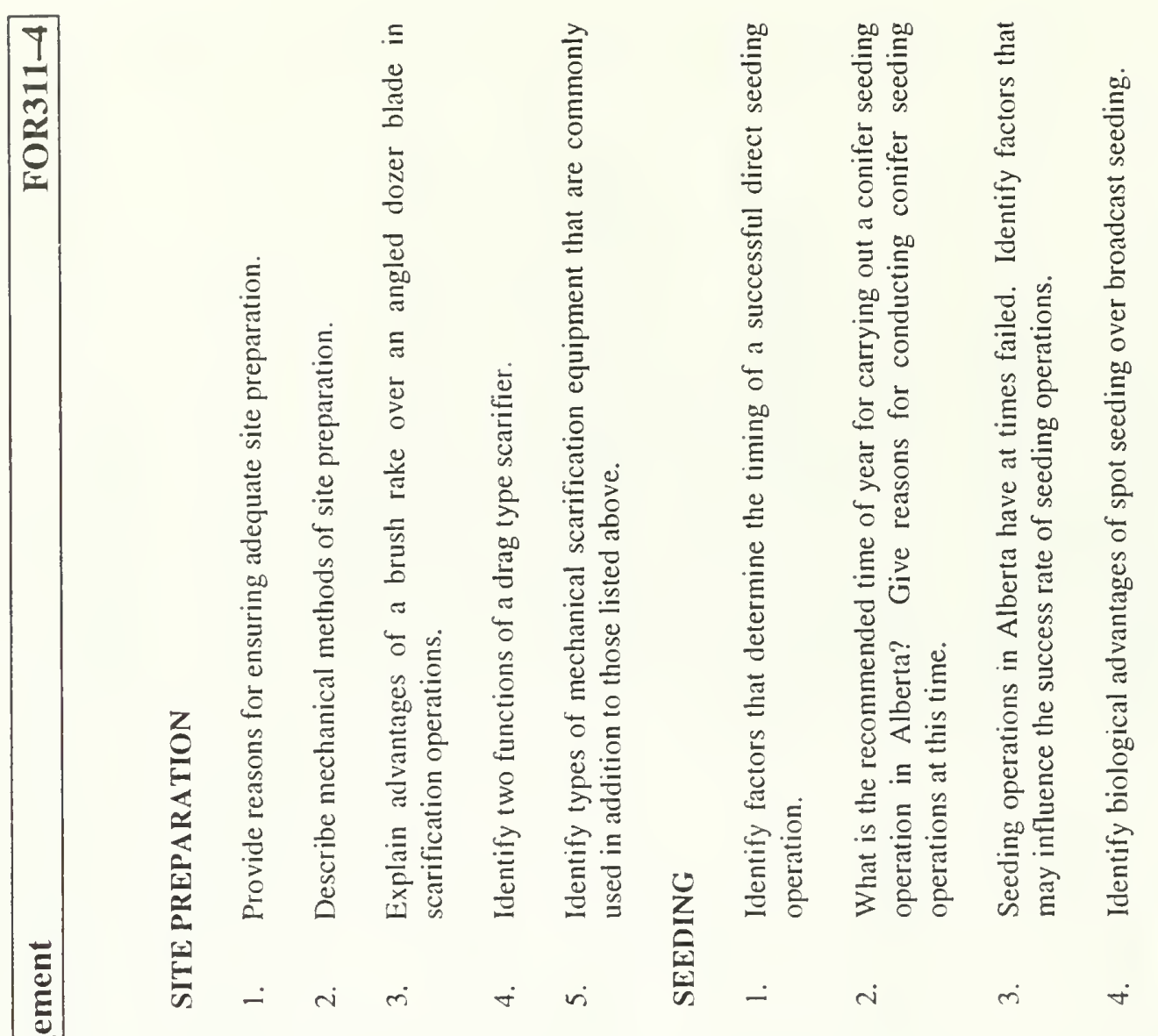

$\tilde{8}$
$\dot{8}$
8
0
$\ddot{0}$
0
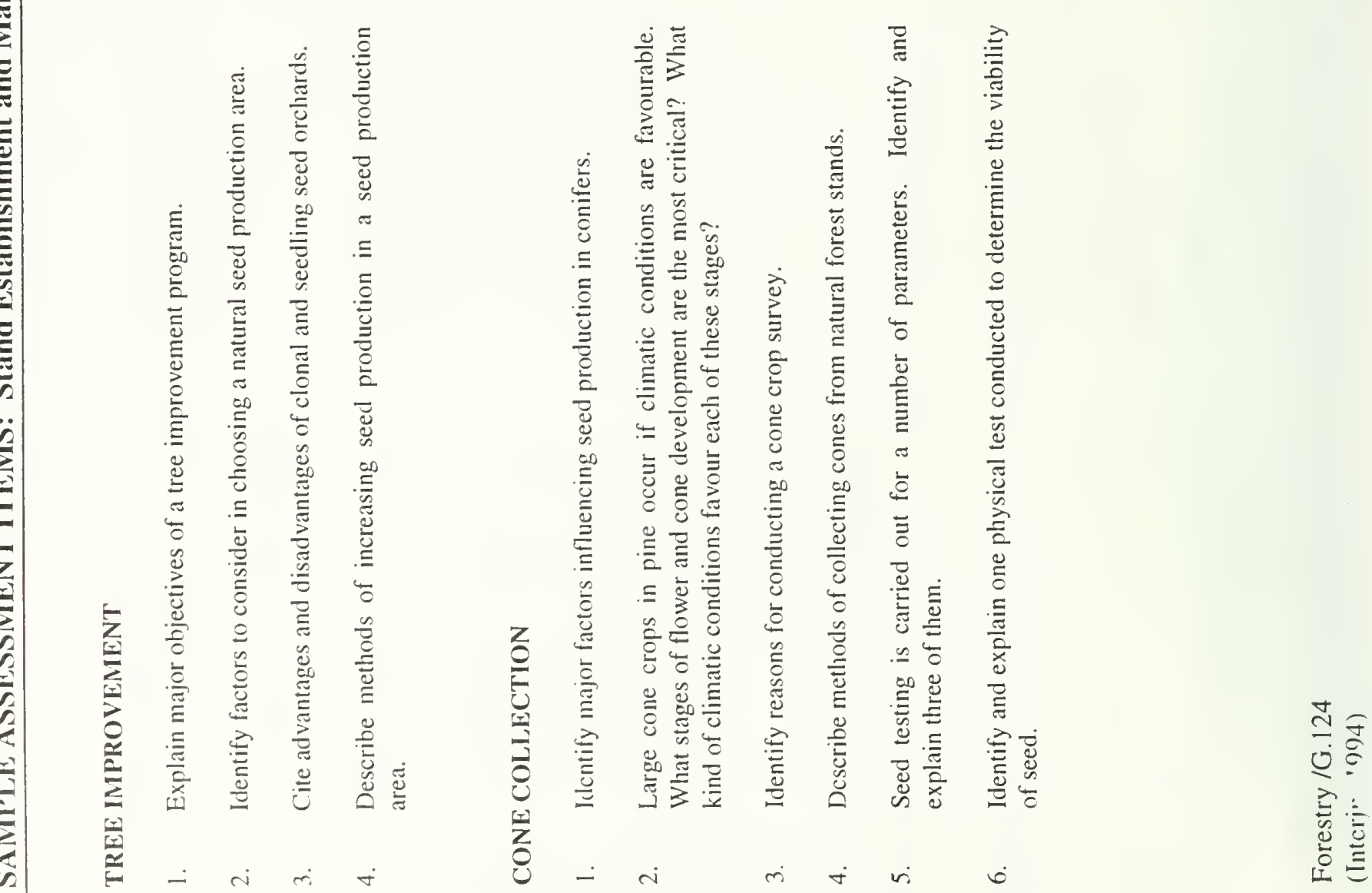


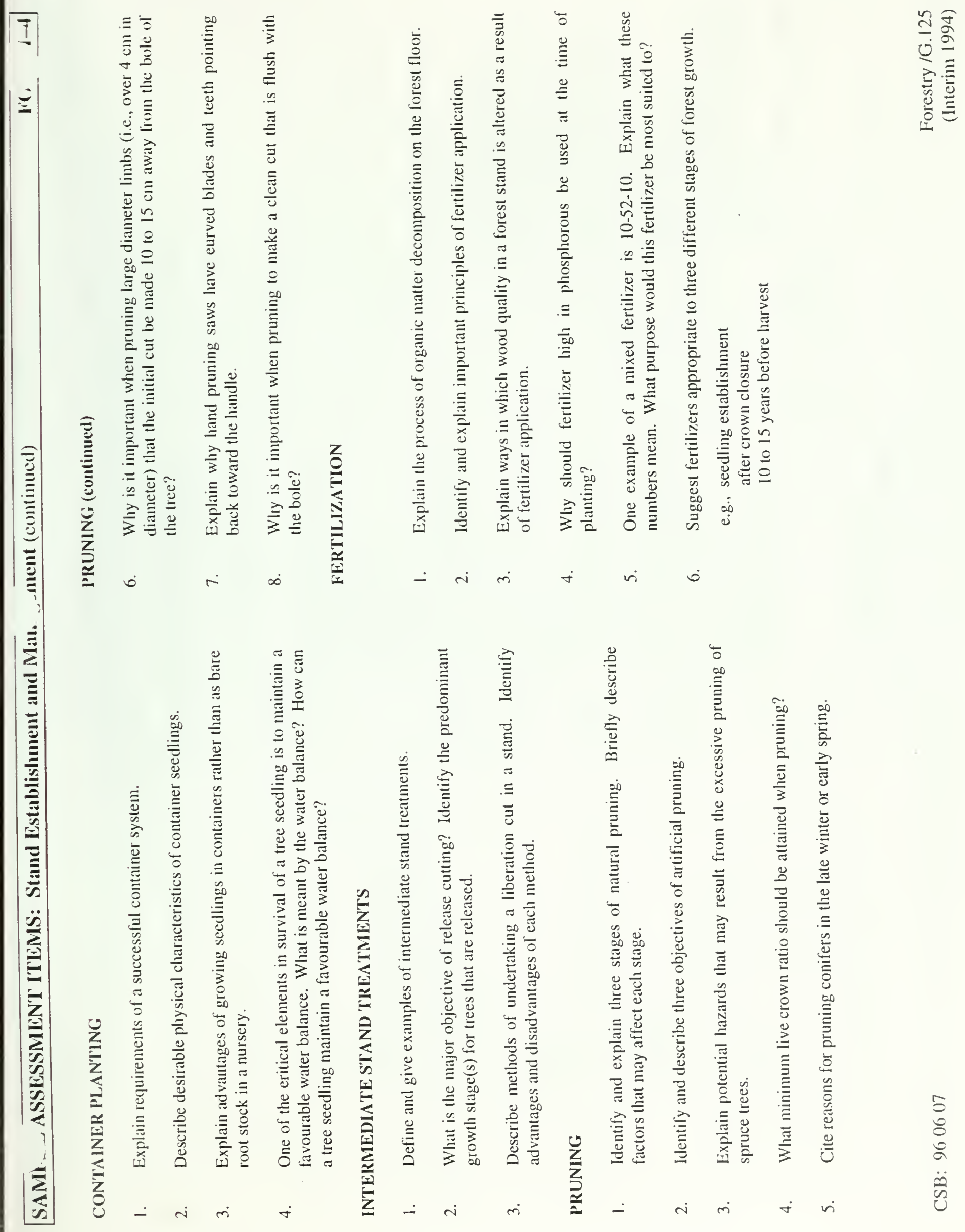




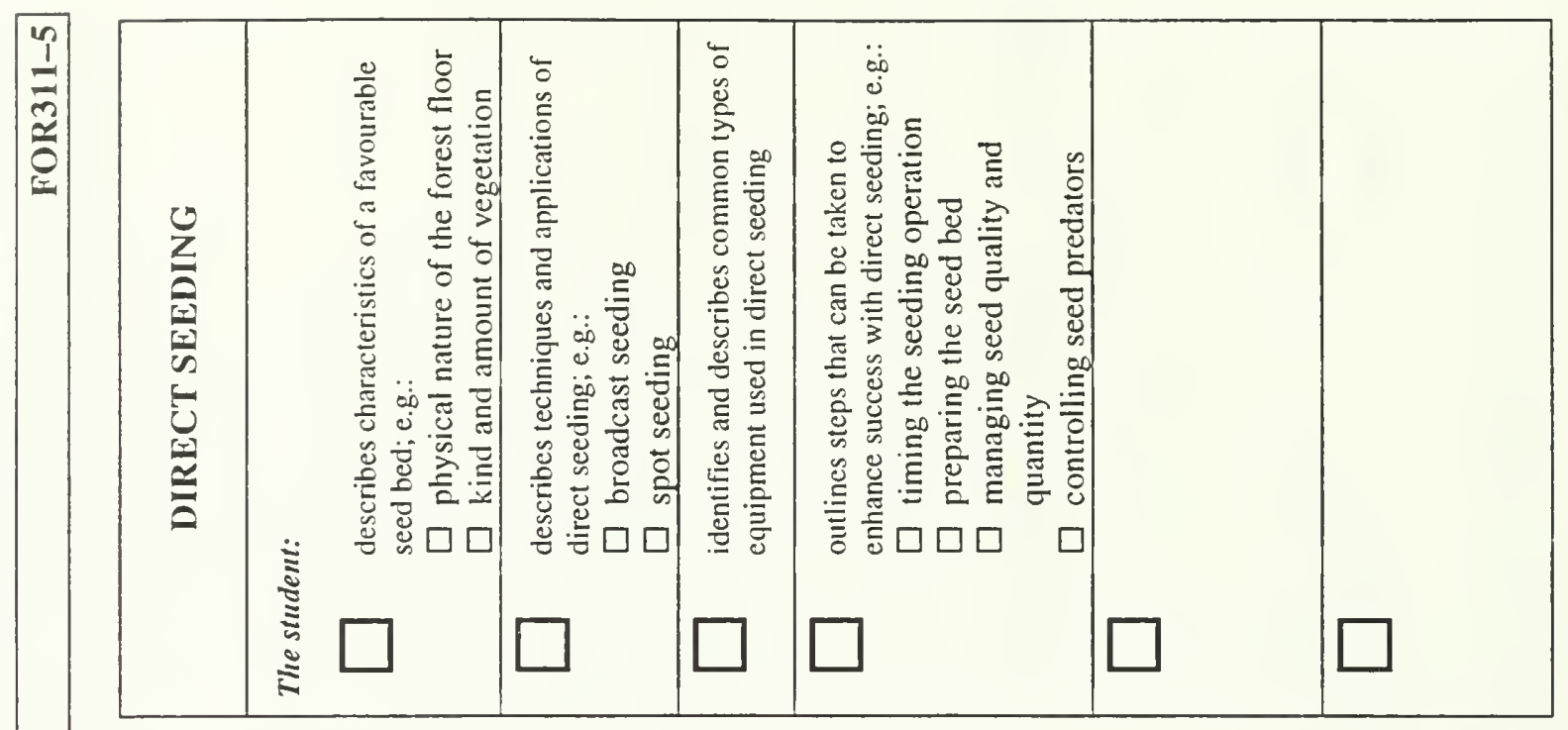

5
0
0
0
0
0
0

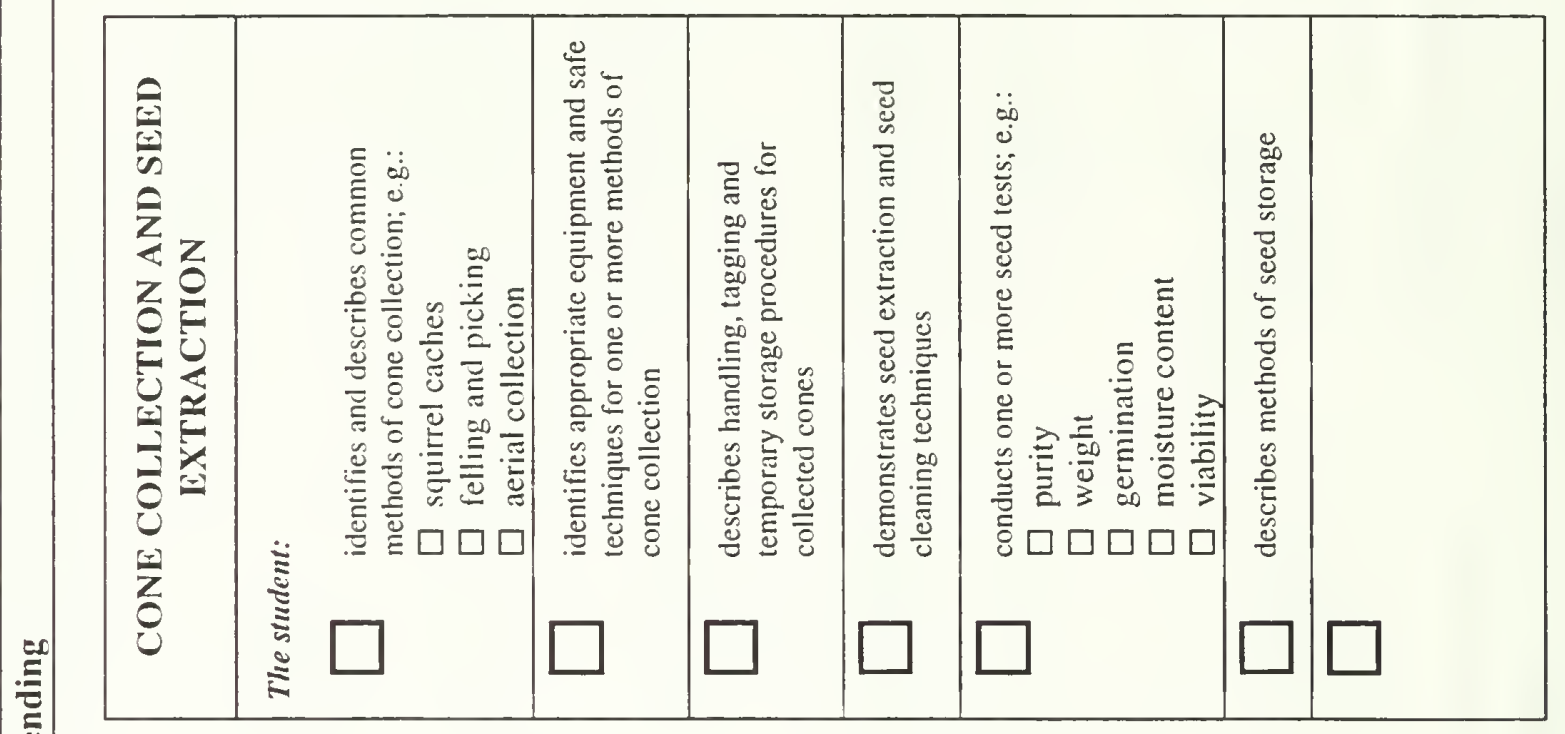



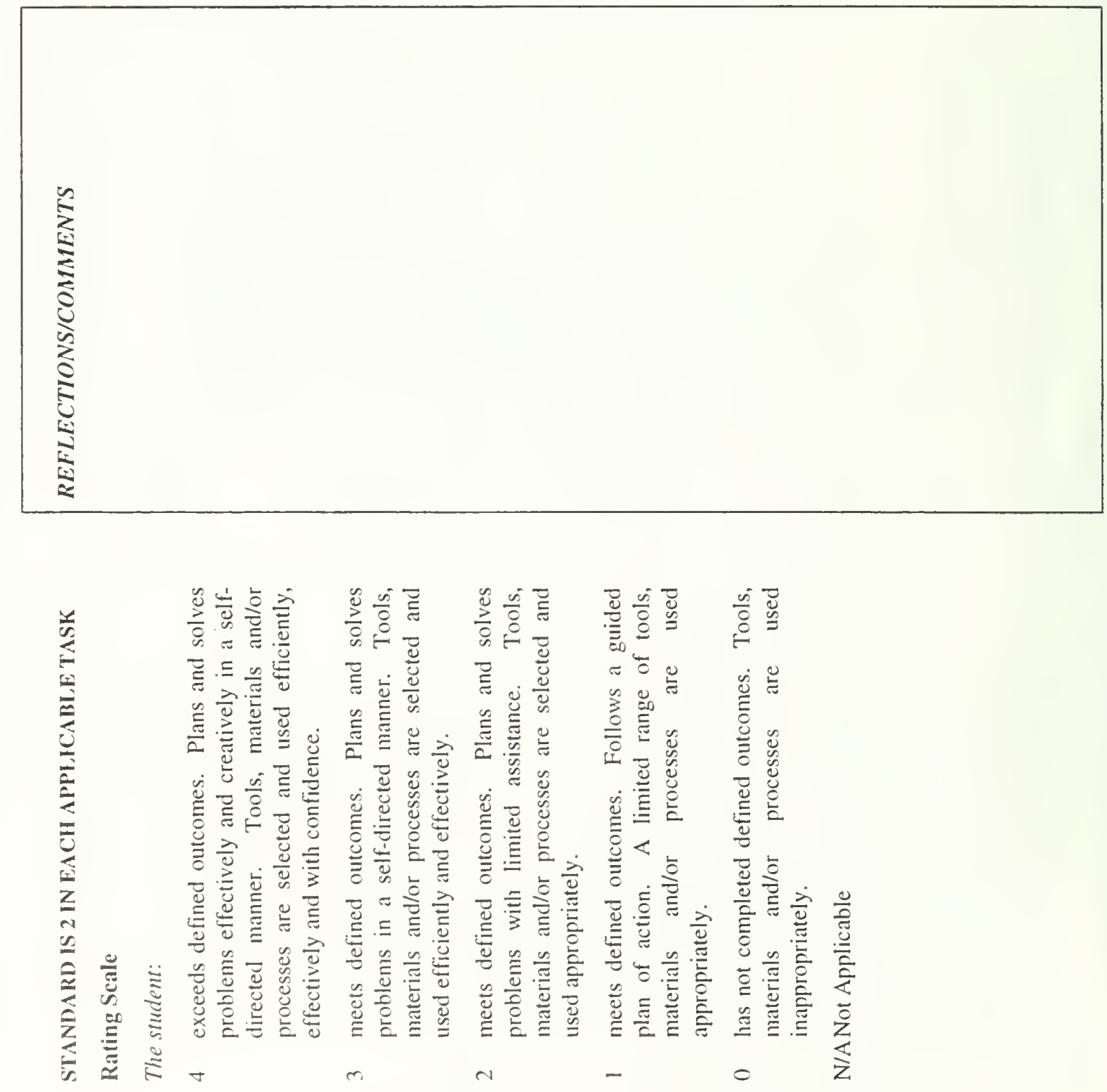

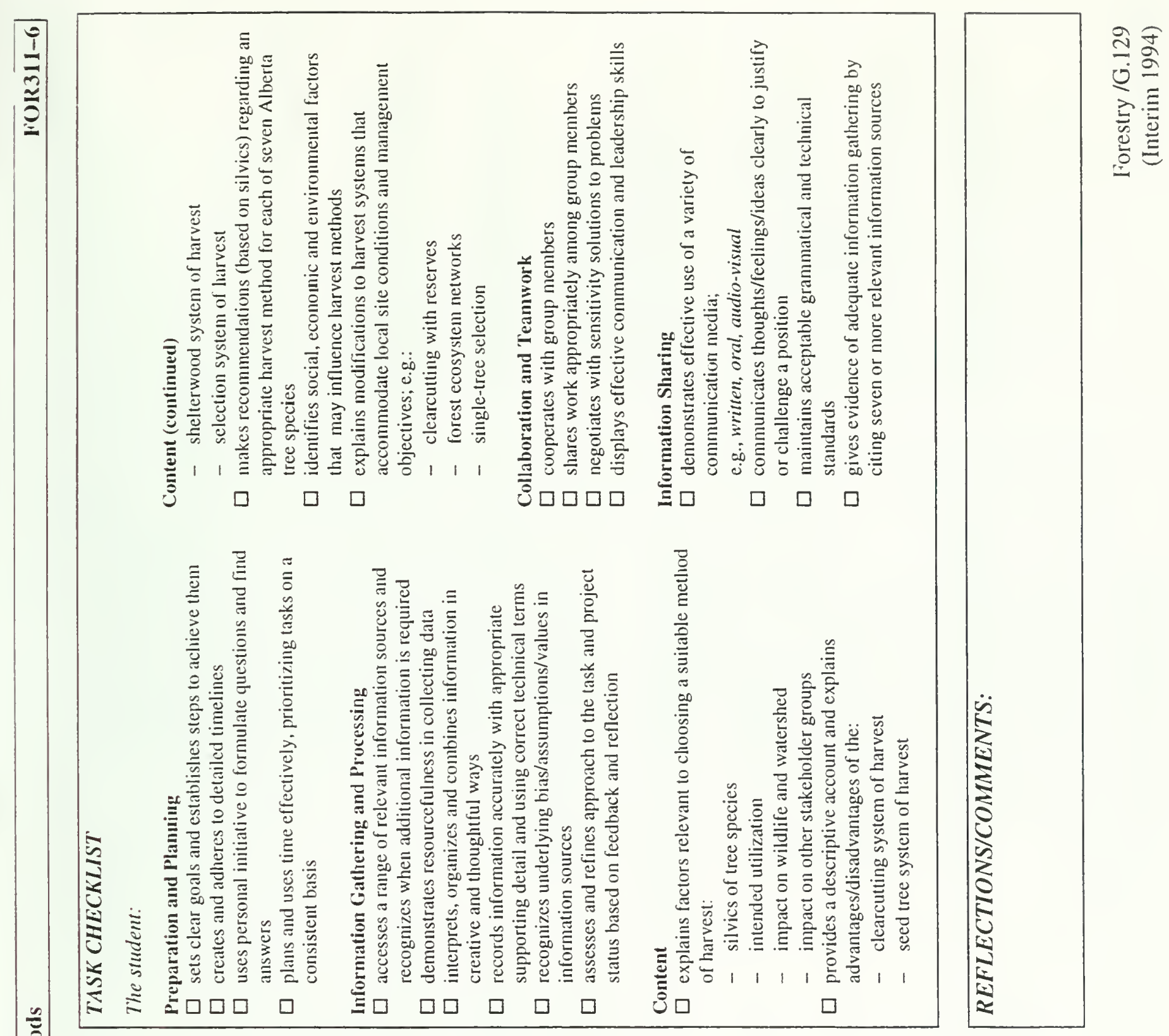

\begin{tabular}{|c|c|c|c|c|c|}
\hline 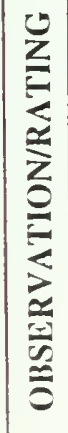 & 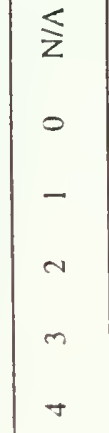 & $\begin{array}{l}\leqslant \\
0 \\
- \\
+ \\
m \\
+\end{array}$ & $\mid \begin{array}{l}j \\
0 \\
- \\
0 \\
0 \\
0\end{array}$ & $\begin{array}{l}\aleph \\
0 \\
- \\
N \\
m \\
+\end{array}$ & $\begin{array}{l}0 \\
- \\
\sim \\
m \\
\sigma\end{array}$ \\
\hline$<$ & 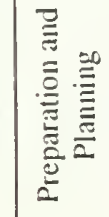 & 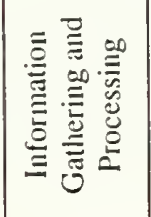 & 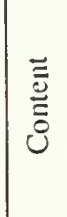 & 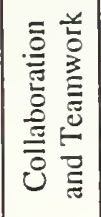 & 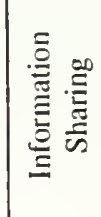 \\
\hline
\end{tabular}

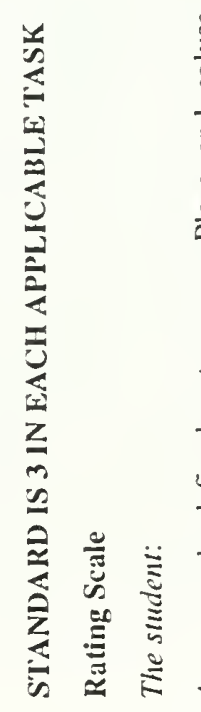

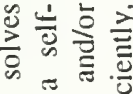

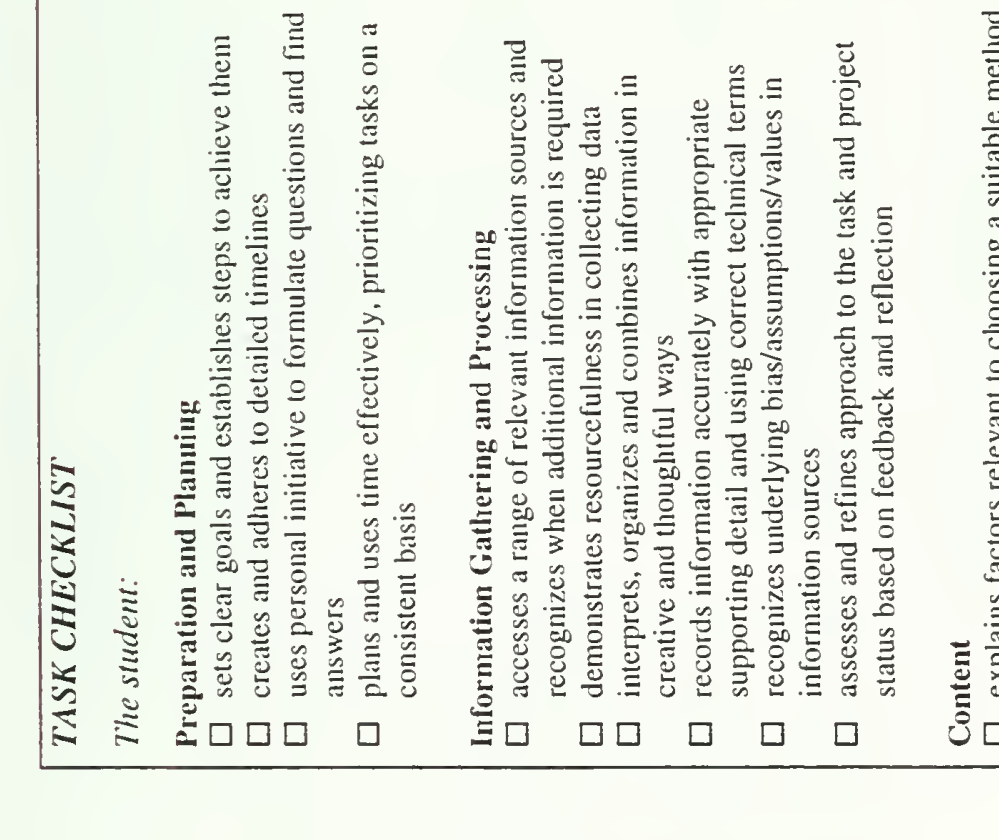

등

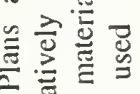

它的芯造

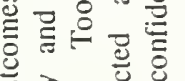

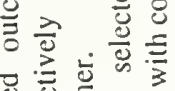

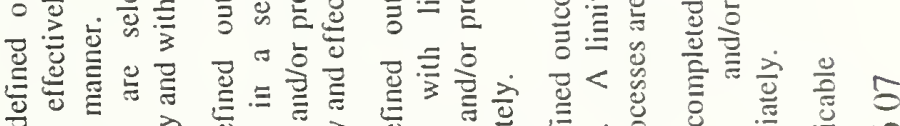

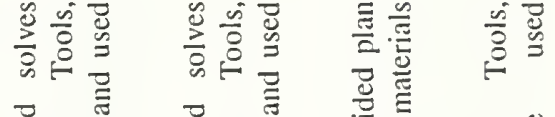

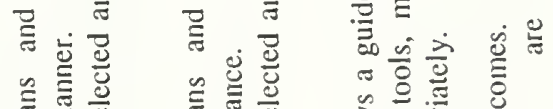

衰

उ

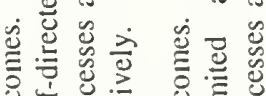

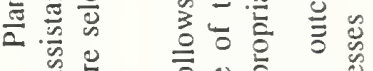

票告

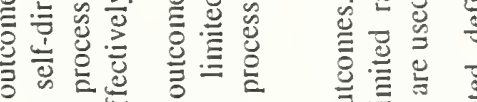

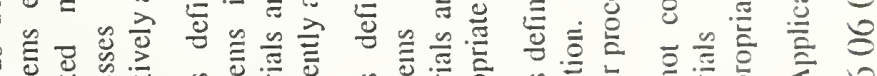

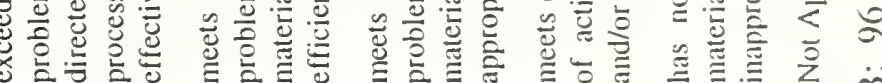
. 


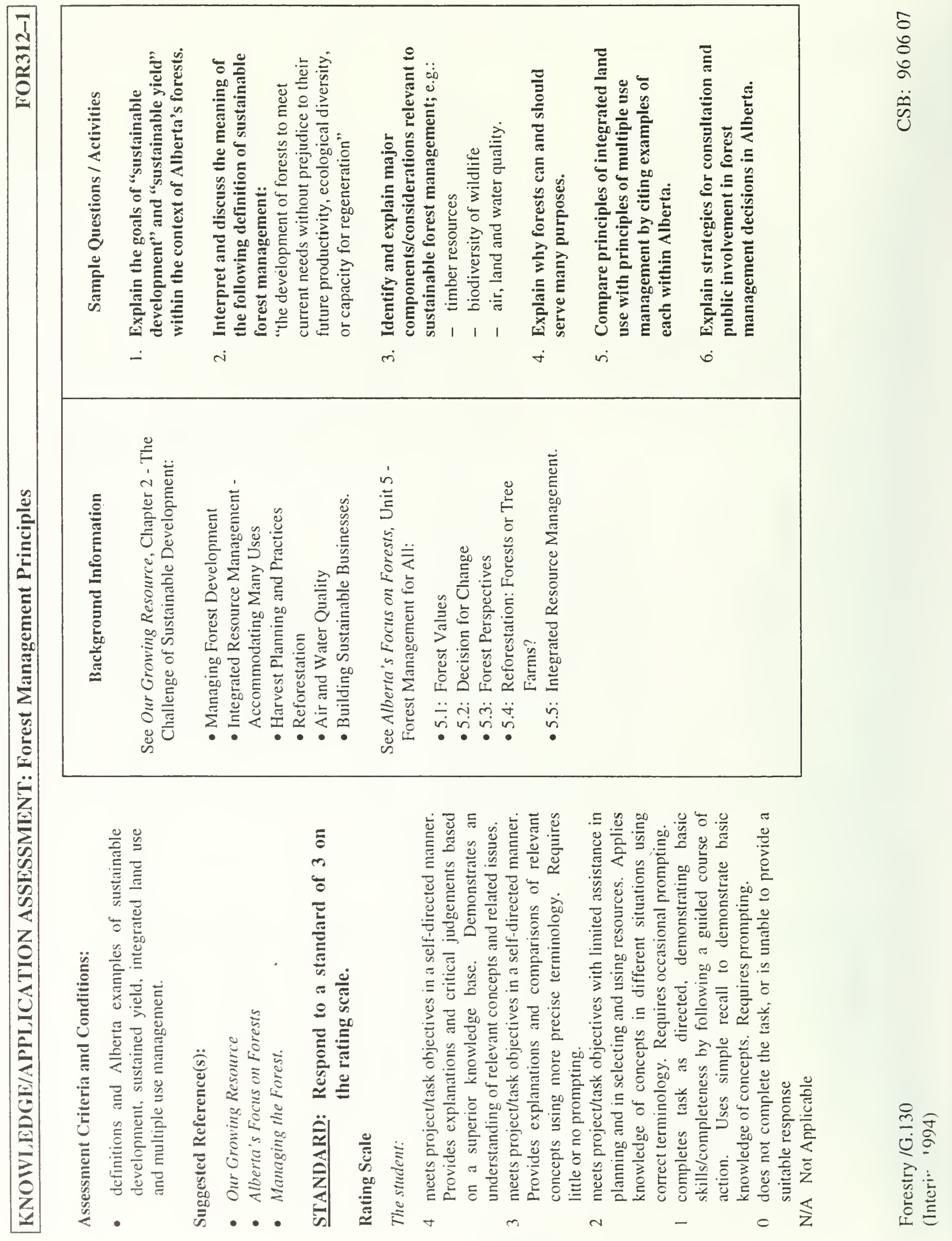



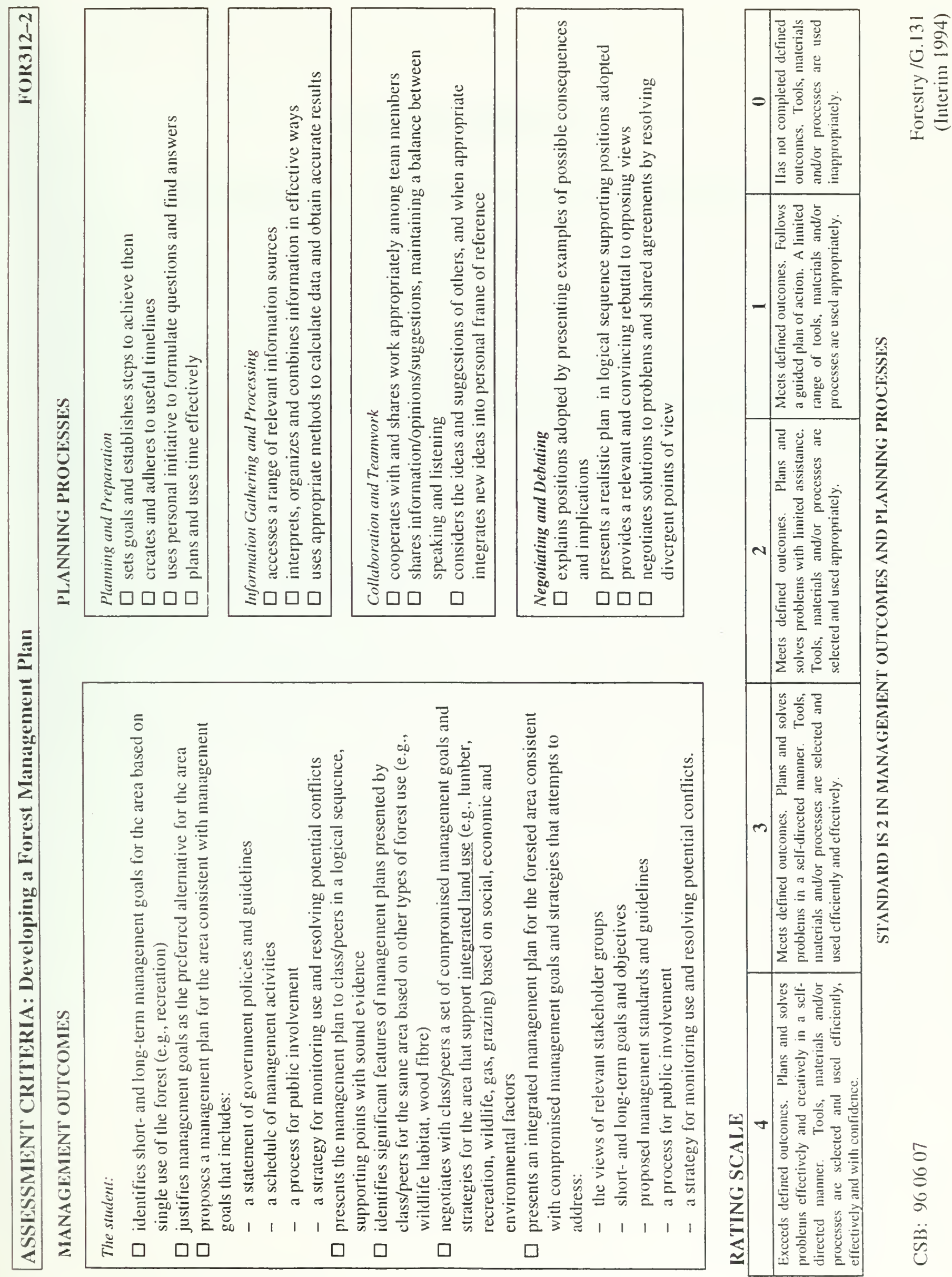


\title{
FORESTRY
}

\section{SECTION H: LINKAGES/TRANSITIONS}

\author{
(INTERIM)
}

TABLE OF CONTENTS

This section of the GSI has been designed to provide an overview of linkages and transitions of CTS modules with a number of organizations. The charts and information presented in this section will assist CTS students and teachers in understanding the potential application of CTS modules as students move into the workplace.

\section{LINKAGES}

With Other CTS Strands H.1

With Other Secondary Programs.

With Practical Arts Courses*

\section{TRANSITIONS}

To the Workplace

Charts

Forestry: Connections with Other CTS Strands.

Forestry in Junior High

Forestry in Senior High

Forestry: Connections Across the Curriculum.

Forestry: Correlations with Practical Arts Courses:*

Environmental and Outdoor Education 7,8 and 9.

Forestry: Related Occupations.

Forestry: Summary of Related Post-secondary Programs

Credentialling Opportunities in Forestry

*All practical arts courses will be replaced by Career and Technology Studies in September, 1997. 



\section{LINKAGES/TRANSITIONS}

\section{LINKAGES}

\section{With Other CTS Strands}

The Forestry strand provides opportunities for students to develop competencies in one or more forestry-related areas, including:

- personal and/or recreational use

- silviculture

- forest inventory

- forest harvest

- forest products

- forest management.

Each area of forestry links with competencies that are developed in other CTS strands. To facilitate and strengthen these linkages, courses may be designed by combining Forestry modules with modules from other CTS strands (e.g., Agriculture, Community Health, Energy and Mines, Legal Studies, Management and Marketing, Mechanics, Tourism Studies, Wildlife). Potential linkages of Forestry with other CTS strands, determined by the areas of course emphasis and industry specialization, are identified in the chart in this section (see "Connections with Other CTS Strands", page H.3).

The Career Transitions strand of CTS provides project, practicum, safety and leadership modules that may be combined with modules in Forestry to increase the opportunity for students to develop expertise and refine their competencies. For example, a silviculture or forest inventory project may require more than the 25,50 or 75 hours available through modules by that name. In these cases project and/or practicum modules from the Career Transitions strand can be accessed so as to provide sufficient time for completion of learning and the task.

Sample courses in Forestry that involve linkages with other CTS strands are provided in the charts in this section (see "Forestry in Junior High", page H.4 and "Forestry in Senior High", page H.5).

\section{With Other Secondary Programs}

The Forestry strand has many links with other core and complementary subject areas across the curriculum. For example, many of the modules in Forestry link with the junior and senior high Science programs, and provide opportunities for students to extend and apply related knowledge and skills in practical ways.

Potential linkages of Forestry with other core and complementary subject areas across the curriculum are identified in the chart in this section (see "Forestry: Connections Across the Curriculum”, page H.6).

\section{With Practical Arts Courses}

Modules in the Forestry strand replace existing content in the junior high Environmental and Outdoor Education 7, 8 and 9 programs. A detailed correlation of the Forestry strand to these practical arts courses can be found in this section (see "Forestry: Correlations with Practical Arts Courses: Environmental and Outdoor Education 7, 8 and 9", pages H.7-8).

\section{TRANSITIONS}

\section{To the Workplace}

Intermediate and advanced modules are designed to develop knowledge, skills and attitudes that provide transitions to occupations in forestryrelated areas. Some career sectors welcome individuals who have basic skills and are prepared to learn through further training from the employer. 
Information from the National Occupational Classification (NOC) regarding occupations in forestry-related areas that can be accessed upon completion of high school is provided in this section (see "Forestry: Related Occupations", pages $H .9$ ).

\section{To Related Post-secondary Programs}

Advanced level modules will assist students to make plans regarding further studies in forestry at post-secondary levels. The Forestry modules provide desirable background and skills for entry into related programs at public and private colleges, technical institutes, universities and vocational colleges in Alberta.

An outline of post-secondary institutions in Alberta currently offering programs in forestryrelated areas is provided in this section (see "Forestry: Summary of Related Post-secondary Programs", page H.10).

\section{CREDENTIALLING}

Students may earn partial or complete credentials recognized in the workplace and/or postsecondary institutions by demonstrating specified competencies within the CTS curriculum. The Forestry strand, in conjunction with modules from the Career Transitions strand, may provide opportunities for students to develop competencies that link with:

- First Aid certificate courses

- National Occupational Standards for Outdoor Guide

- Alberta Conservation and Hunter Education Program

- Alberta Fishing Education Program

- Pesticide Applicator certificate courses.

In addition, formal agreements have been established with Olds College for the recognition of CTS competencies developed in soils management (see Agriculture strand).

Teachers may wish to explore opportunities for linking courses in Forestry with these and/or other credentialling programs. Further information regarding credentialling in Forestry is provided in this section (see "Credentialling Opportunities in Forestry", page H.11). 
Forestry Modules

\begin{tabular}{|c|c|c|c|c|c|c|c|c|c|c|c|c|c|c|c|c|c|c|c|c|c|}
\hline \multicolumn{22}{|c|}{ Other CTS Strands } \\
\hline 总 & 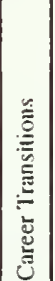 & 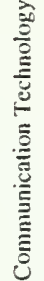 & 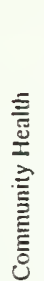 & 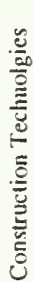 & 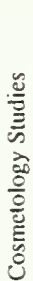 & 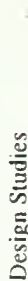 & 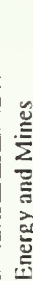 & 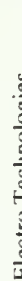 & 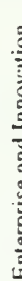 & & & 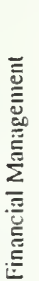 & $\frac{2}{8}$ & 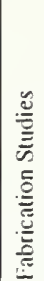 & 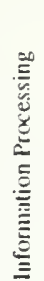 & 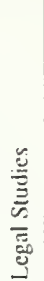 & 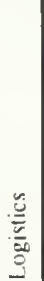 & 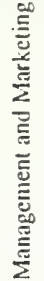 & 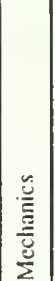 & 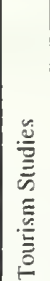 & 总 \\
\hline
\end{tabular}

Theme: Social \& Cultural Perspectives

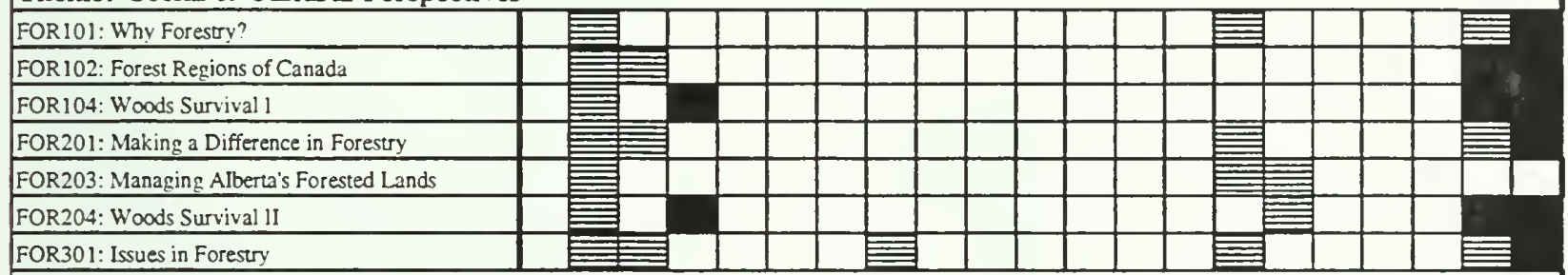

Theme: Technology \& Applications

FORI05: Mapping \& Aerial Photography

FOR 106: Measuring the Forest I

FOR206: Measuring the Forest Il

FOR207: Harvesting \& Forest Products

FOR306: Measuring the Forest III

FOR307: The Forest Marketplace

FOR308: Forest Technology Application

Theme: Management \& Conservation

FOR 109: Basic Forest Ecolog

FOR 110: Forests Forever 1

FOR2 10: Forests Forever II

FOR212: Users in the Forest

FOR309: Advanced Forest Ecology

FOR311: Silviculture: Growing the Forest

FOR312: Stewardship: Balancing Needs

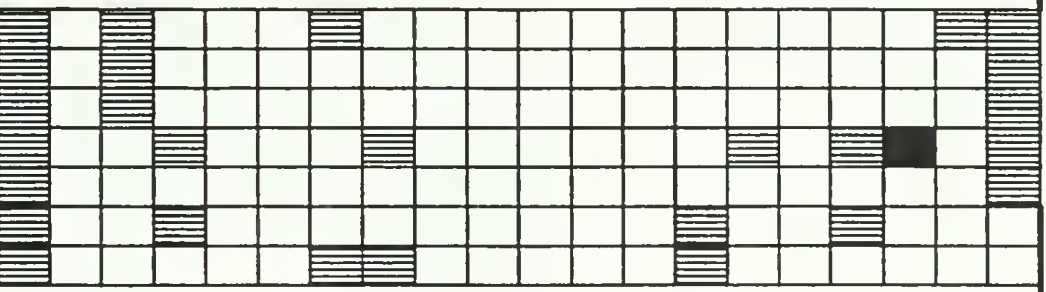

\begin{tabular}{|l|l|l|l|l|l|l|l|l|l|l|l|l|l|l|l|l|}
\hline \\
\hline
\end{tabular}

Provides many direct links with competencies in this strand. Students will reinforce, extend and apply a substantial number of knowledge and/or skill components in pracical situations.

Provides some links with competencies developed in this strand, usually through the

application of related technologies and/or processes. 
LINKAGES - Forestry in Junior High

\begin{tabular}{lcccc}
\hline \multicolumn{1}{c}{ Course Emphasis } & $\begin{array}{c}\text { Forestry } \\
\text { Modules }\end{array}$ & $\begin{array}{c}\text { Mechanics } \\
\text { Modules }\end{array}$ & $\begin{array}{c}\text { Wildlife } \\
\text { Modules }\end{array}$ & $\begin{array}{c}\text { Tourism Studies } \\
\text { Modules }\end{array}$ \\
\hline $\begin{array}{l}\text { Forest Ecology } \\
(3 \text { modules) }\end{array}$ & Why Forestry? & $\begin{array}{c}\text { Natural History } \\
\text { of Alberta } \\
\text { Wildife }\end{array}$ \\
\hline $\begin{array}{c}\text { Basic Forest } \\
\text { Ecology }\end{array}$ & & \\
\hline
\end{tabular}

\begin{tabular}{l}
$\begin{array}{l}\text { Forest Inventory } \\
\text { (4 modules) }\end{array}$ \\
$\qquad$\begin{tabular}{c|} 
Why Forestry? \\
Mapping \& \\
Aerial \\
Photography
\end{tabular} \\
$\qquad \begin{array}{c}\text { Measuring the } \\
\text { Forest I }\end{array}$ \\
\hline
\end{tabular}

Measuring the

Value of Wildlife

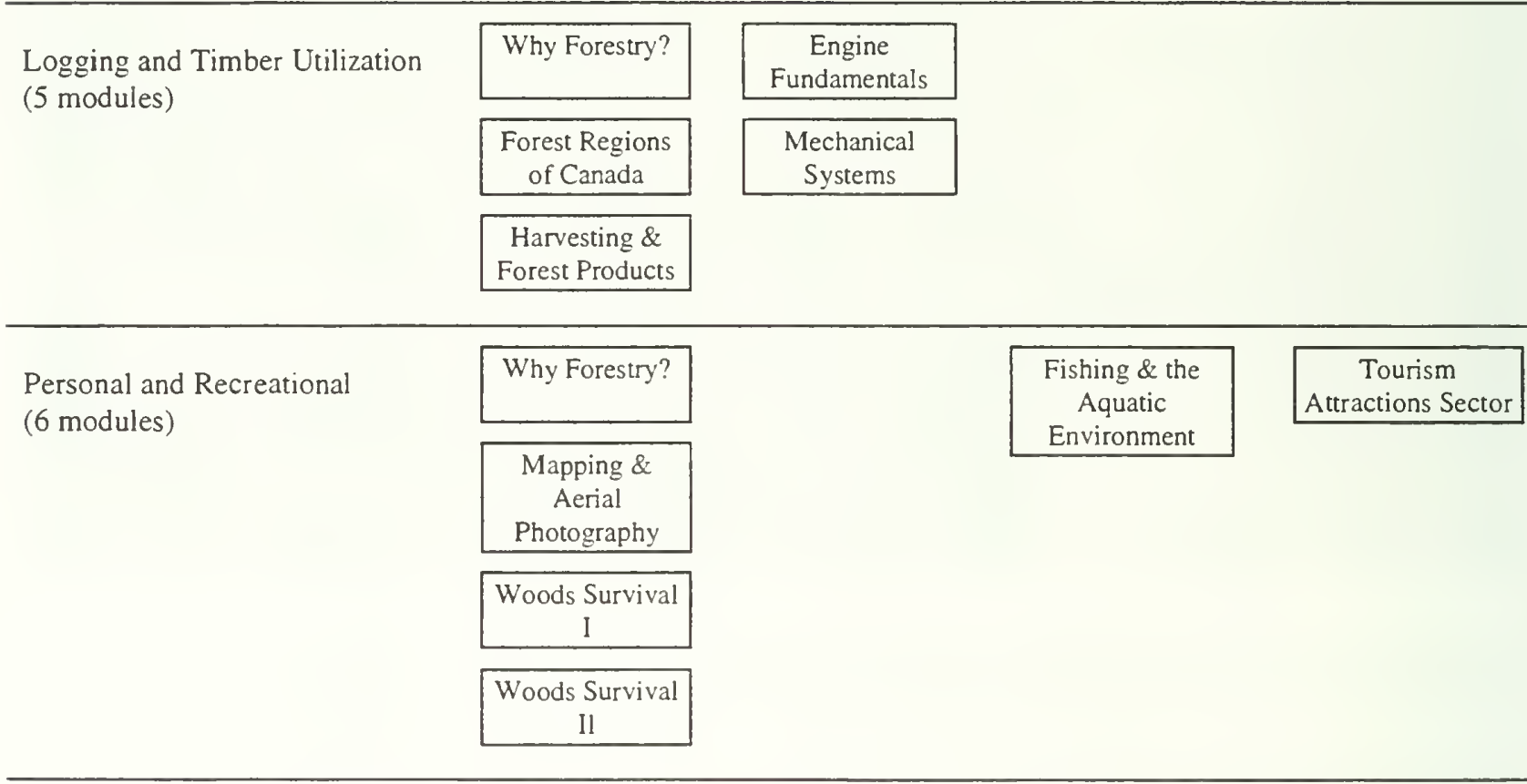




\section{LINKAGES - Forestry in Senior High}

\begin{tabular}{|c|c|c|c|c|}
\hline $\begin{array}{l}\text { Area of Course } \\
\text { Emphasis }\end{array}$ & Forestry Modules & Wildlife Modules & $\begin{array}{l}\text { Tourism Studies } \\
\text { Modules }\end{array}$ & $\begin{array}{c}\text { Career Transitions } \\
\text { Modules } \\
\end{array}$ \\
\hline $\begin{array}{l}\text { Personal and } \\
\text { Recreational }\end{array}$ & $\begin{array}{l}\text { Making a Difference } \\
\text { in Forestry }\end{array}$ & & $\begin{array}{l}\text { Adventure and } \\
\text { Ecotourism }\end{array}$ & \\
\hline $\begin{array}{l}\text { (3 credits) } \\
\text { Prerequisite: } \\
\text { Woods Survival I }\end{array}$ & $\begin{array}{c}\text { Woods } \\
\text { Survival II } \\
\end{array}$ & & & \\
\hline \multirow{4}{*}{$\begin{array}{l}\text { Silviculture } \\
\text { (5 credits) } \\
\text { Prerequisite: } \\
\text { None }\end{array}$} & $\begin{array}{l}\text { Basic Forest } \\
\text { Ecology }\end{array}$ & & & $\begin{array}{c}\text { Project } \\
2 \mathrm{~A}\end{array}$ \\
\hline & $\begin{array}{l}\text { Advanced Forest } \\
\text { Ecology }\end{array}$ & & & \\
\hline & $\begin{array}{l}\text { Silviculture: } \\
\text { Growing the Forest }\end{array}$ & & & \\
\hline & $\begin{array}{l}\text { Forest Technology } \\
\text { Applications }\end{array}$ & & & \\
\hline \multirow{4}{*}{$\begin{array}{l}\text { Harvest and Forest } \\
\text { Products } \\
\text { ( } 5 \text { credits) } \\
\text { Prerequisite: } \\
\text { Meauring the Forest I } \\
\text { and II }\end{array}$} & $\begin{array}{l}\text { Managing Alberta's } \\
\text { Forested Lands }\end{array}$ & & & $\begin{array}{c}\text { Project } \\
2 \mathrm{~A}\end{array}$ \\
\hline & $\begin{array}{l}\text { Harvesting and } \\
\text { Forest Products } \\
\end{array}$ & & & \\
\hline & $\begin{array}{l}\text { The Forest } \\
\text { Marketplace }\end{array}$ & & & \\
\hline & $\begin{array}{l}\text { Measuring the } \\
\text { Forest III }\end{array}$ & & & \\
\hline \multirow{2}{*}{$\begin{array}{l}\text { Environmental } \\
\text { Stewardship } \\
\text { ( } 3 \text { credits) } \\
\text { Prerequisite: } \\
\quad \text { None }\end{array}$} & $\begin{array}{l}\text { Making a Difference } \\
\text { in Forestry }\end{array}$ & $\begin{array}{l}\text { Issues in } \\
\text { Wildlife I }\end{array}$ & & $\begin{array}{c}\text { Project } \\
2 \mathrm{~A}\end{array}$ \\
\hline & & & & \\
\hline \multirow[t]{3}{*}{$\begin{array}{l}\text { Forest Management } \\
(5 \text { credits })\end{array}$} & $\begin{array}{l}\text { Issues in } \\
\text { Forestry }\end{array}$ & $\begin{array}{c}\text { Interactions of } \\
\text { Wildlife and Society }\end{array}$ & & $\begin{array}{l}\text { Project } \\
2 \mathrm{~A}\end{array}$ \\
\hline & $\begin{array}{l}\text { Users in the } \\
\text { Forest }\end{array}$ & & & \\
\hline & $\begin{array}{c}\text { Stewardship: } \\
\text { Balancing Needs }\end{array}$ & & & \\
\hline
\end{tabular}


Forestry Modules

Across the Curriculum

\begin{tabular}{|c|c|c|c|c|c|c|c|c|c|c|c|c|c|c|c|c|c|c|}
\hline \multicolumn{7}{|c|}{ Junior High } & \multicolumn{12}{|c|}{ Senior High } \\
\hline 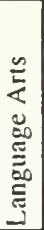 & 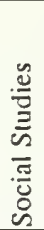 & 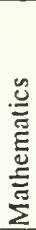 & 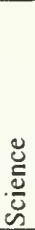 & $\begin{array}{l}\tilde{y} \\
\tilde{E} \\
\tilde{\Xi} \\
\underline{\Xi}\end{array}$ & 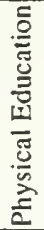 & 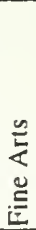 & $\frac{\frac{1}{n}}{\frac{00}{E}}$ & $\frac{\frac{\mathscr{d}}{\tilde{J}}}{\frac{\tilde{J}}{\tilde{J}}}$ & 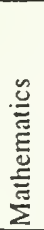 & 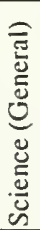 & $\begin{array}{l}\frac{20}{0} \\
\frac{0}{0} \\
0\end{array}$ & 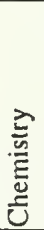 & $\frac{\tilde{s}}{\frac{y}{n}}$ & $\frac{\sum}{3}$ & 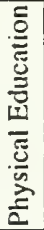 & 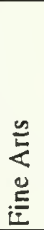 & 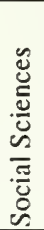 & 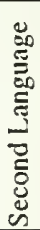 \\
\hline
\end{tabular}

\section{Theme: Social \& Cultural Perspectives}

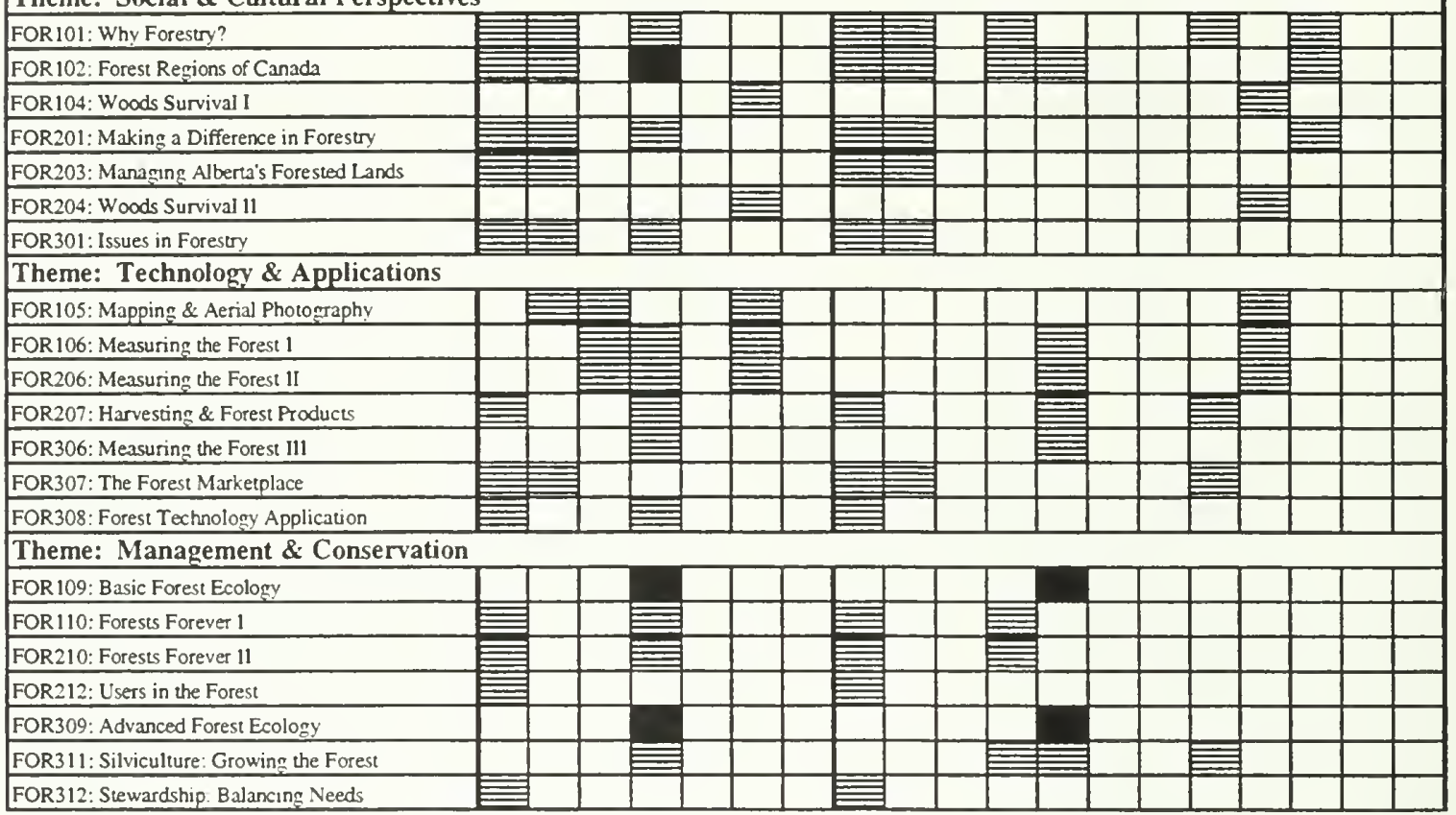

Provides many direct links with course content. Students will reınforce, extend

and apply a substantial number of knowledge and/or skill components in practical contexts.

Provides some links with course content, usually through the application of related

technologies and/or processes. 


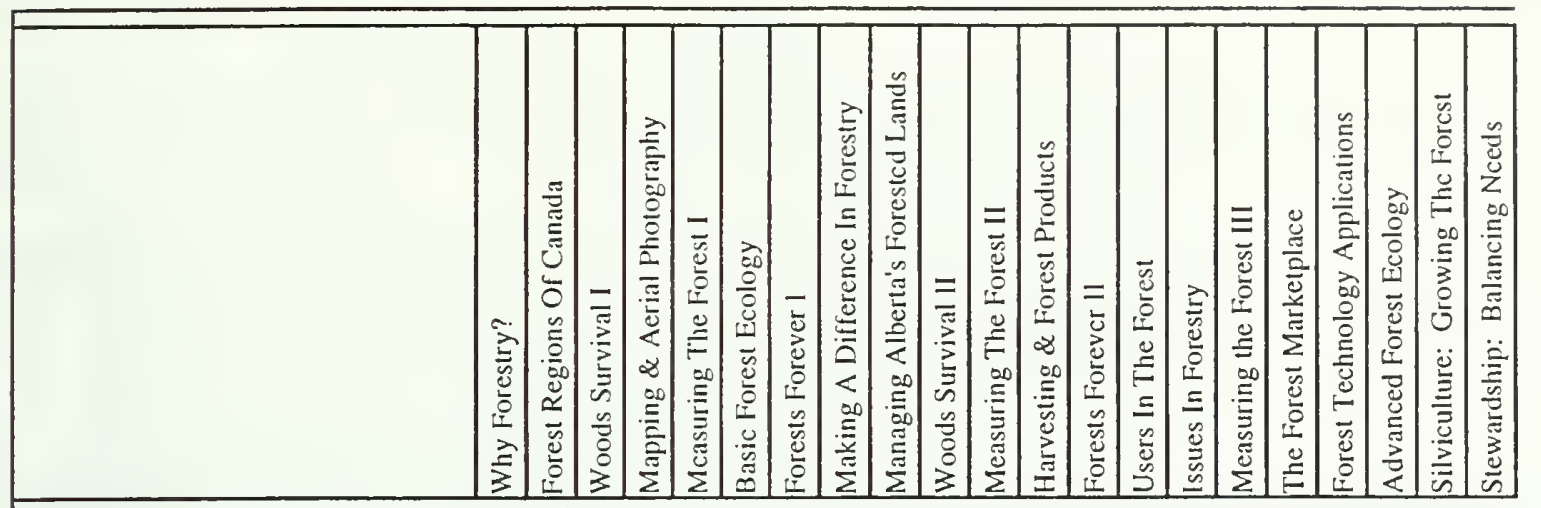

\section{OUTDOOR CORE}

regard for self, others and the environment

\begin{tabular}{lll}
$x$ & $x$ & $x$ \\
\hline
\end{tabular}

trip preparation and safety

safe and comfortable outdoor

living skills

applying information for safe route planning

environmentally responsible

outdoor activities

physical fitness for outdoor

activities

PERSONAL AND GROUP

DEVELOPMENT

respect and appreciation for self

and others

setting realistic goals

personal communication skills

relationship of individuals to

groups

group process skills

ENVIRONMENTAL CORE

diversity of environments and life forms

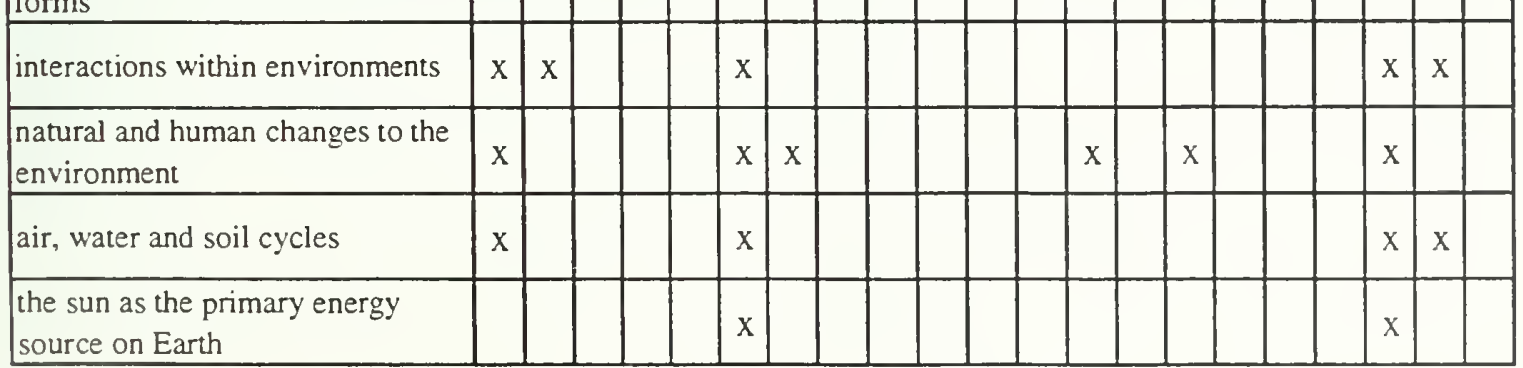

*All practical arts courses will be replaced by Career and Technology Studies in September, 1997. 


\begin{tabular}{|c|c|c|c|c|c|c|c|c|c|c|c|c|c|c|c|c|c|c|c|c|c|}
\hline & 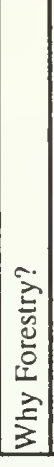 & 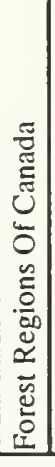 & 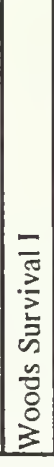 & 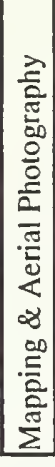 & 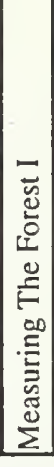 & 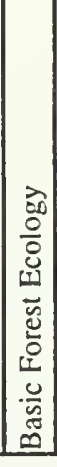 & 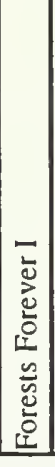 & 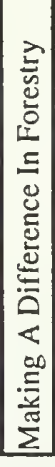 & 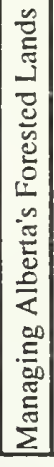 & 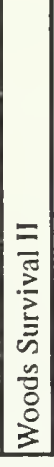 & 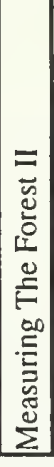 & 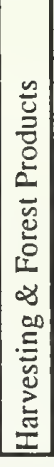 & 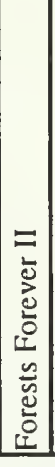 & 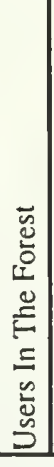 & 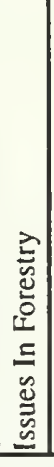 & 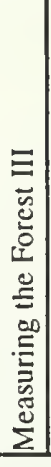 & 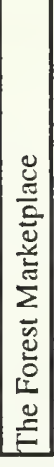 & 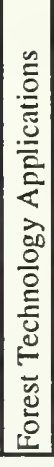 & 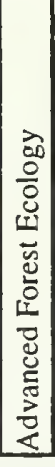 & 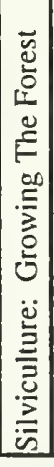 & 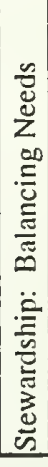 \\
\hline \multicolumn{22}{|l|}{ OUTDOOR EXPEDITIONS } \\
\hline $\begin{array}{l}\text { skill and judgment in outdoor } \\
\text { expeditions }\end{array}$ & & & $\mathrm{x}$ & $\mathrm{x}$ & $x$ & & & & & $\mathrm{x}$ & $x$ & & & & & $\mathrm{x}$ & & & & $x$ & \\
\hline $\begin{array}{l}\text { positive self-concept and regard } \\
\text { for others }\end{array}$ & & & $\mathrm{x}$ & & & & & & & $\mathrm{x}$ & & & & & & & & & & & \\
\hline $\begin{array}{l}\text { group problem solving and group } \\
\text { living skills }\end{array}$ & & & $\mathrm{x}$ & & & & & & & $\mathrm{x}$ & & & & & & & & & & & \\
\hline $\begin{array}{l}\text { regard for environments and } \\
\text { responsible outdoor judgment }\end{array}$ & & & $x$ & $\mathrm{x}$ & $\mathrm{x}$ & & & & & $\mathrm{x}$ & $\mathrm{x}$ & & & & & $\mathrm{x}$ & & & & $\mathrm{x}$ & \\
\hline \multicolumn{22}{|l|}{$\begin{array}{l}\text { ENVIRONMENTAL } \\
\text { INVESTIGATIONS }\end{array}$} \\
\hline environmental investigation skills & & $\mathrm{x}$ & & & & $\mathrm{x}$ & & & & & & & & & & & & & $\mathrm{x}$ & $\mathrm{x}$ & \\
\hline $\begin{array}{l}\text { strategies for responding to } \\
\text { environmental concerns }\end{array}$ & & & & & & & $\mathrm{x}$ & $\mathrm{x}$ & & & & & $\mathrm{x}$ & & $\mathrm{x}$ & & & & & & $\mathrm{x}$ \\
\hline \multicolumn{22}{|l|}{ COMMITMENT TO ACTION } \\
\hline $\begin{array}{l}\text { outdoor recreation as part of } \\
\text { healthy lifestyle }\end{array}$ & & & $\mathrm{X}$ & & & & & & & $\mathrm{x}$ & & & & & & & & & & & \\
\hline $\begin{array}{l}\text { appreciation of environments } \\
\text { through respectful use }\end{array}$ & $\mathrm{x}$ & & $\mathrm{X}$ & & & & $\mathrm{x}$ & $\mathrm{x}$ & & $x$ & & & $x$ & & $\mathrm{x}$ & & & & & & $x$ \\
\hline $\begin{array}{l}\text { responsible use of local and global } \\
\text { environments }\end{array}$ & $\mathrm{x}$ & & $\mathrm{X}$ & & & & $\mathrm{x}$ & $x$ & & $x$ & & & $x$ & & $\mathrm{x}$ & & & & & & $\mathrm{x}$ \\
\hline $\begin{array}{l}\text { plans to make personal growth a } \\
\text { lifelong process }\end{array}$ & & & & & & & & $\mathrm{x}$ & & & & & & & $\mathrm{x}$ & & & & & & \\
\hline
\end{tabular}

*All practical arts courses will be replaced by Career and Technology Studies in September, 1997. 


\section{TRANSITIONS - Forestry: Related Occupations}

Information for this chart was obtained from the National Occupations Classification (NOC) descriptions:

Educational Requirements:

D: High School Education

B: College or Vocational Education

C: Apprenticeship

A: University

\begin{tabular}{|c|c|c|c|c|c|}
\hline Occupation Profile & NOC\# & D & $\mathrm{C}$ & B & $\mathbf{A}$ \\
\hline Arborist & 2225 & & & $\checkmark$ & $\checkmark$ \\
\hline Biochemist & 2112 & & & & $\checkmark$ \\
\hline Biologist and Related Scientist & 2121 & & & & $\checkmark$ \\
\hline Botanist & 2121 & & & & $\checkmark$ \\
\hline Chemist & 2112 & & & & $\checkmark$ \\
\hline Chainsaw and Skidder Operators & 8421 & $\checkmark$ & & & \\
\hline Environmental Auditor & 2263 & & & & $\checkmark$ \\
\hline Environmental Education Specialist & 4161 & & & & $\checkmark$ \\
\hline Environmental Engineer & 2131 & & & & $\checkmark$ \\
\hline Forest Technologist & 2223 & & & $\checkmark$ & \\
\hline Forester/Forestry Scientist & 2122 & & & & $\checkmark$ \\
\hline Forestry Professionals & 2122 & & & & $\checkmark$ \\
\hline Forestry Worker & 8422 & & & $\checkmark$ & \\
\hline Hazardous Waste Management Technician & 2263 & & & $\checkmark$ & \\
\hline Hydrologist & 2113 & & & & $\checkmark$ \\
\hline $\begin{array}{l}\text { Inspectors in Public and Environmental Health and } \\
\text { Occupational Health and Safety }\end{array}$ & 2263 & & & $\checkmark$ & $\checkmark$ \\
\hline Interpretive Naturalist & 2121 & & & $\checkmark$ & $\checkmark$ \\
\hline Labourers in Wood, Pulp and Paper Processing & 9614 & $\checkmark$ & & & \\
\hline Land Surveyor & 2154 & & & & $\checkmark$ \\
\hline $\begin{array}{l}\text { Land Use/Community Planner (Urban, Regional, } \\
\text { Park) }\end{array}$ & 2153 & & & & $\checkmark$ \\
\hline Logging and Forestry Labourers & 8616 & $\checkmark$ & & & \\
\hline Logging Machinery Operators & 8241 & $\checkmark$ & & & \\
\hline $\begin{array}{l}\text { Lumber Graders and Other Wood Processing } \\
\text { Inspectors and Graders }\end{array}$ & 9436 & $\checkmark$ & & & \\
\hline Other Wood Processing Machine Operators & 9434 & $\checkmark$ & & & \\
\hline Paper Converting Machine Operators & 9435 & $\checkmark$ & & & \\
\hline Papermaking and Coating Control Operators & 9234 & $\checkmark$ & & & \\
\hline Papermaking and Finishing Machine Operators & 9433 & $\checkmark$ & & & \\
\hline Pollution Control Technician & 2231 & & & $\checkmark$ & \\
\hline Pulp Mill Machine Operators & 9432 & $\checkmark$ & & $\checkmark$ & \\
\hline Pulping Control Operators & 9233 & $\checkmark$ & & $\checkmark$ & \\
\hline Primary Production Managers (except Agriculture) & 0911 & & & & $\checkmark$ \\
\hline Sawmill Machine Operators & 9431 & $\checkmark$ & & & \\
\hline Silviculture and Forestry Workers & 8422 & $\checkmark$ & & $\checkmark$ & \\
\hline Supervisors, Forest Products Processing & 9215 & $\checkmark$ & & $\checkmark$ & \\
\hline Supervisor, Logging and Forestry & 8211 & $\checkmark$ & & $\checkmark$ & \\
\hline Utilities Managers & 0912 & & & $\checkmark$ & $\checkmark$ \\
\hline
\end{tabular}




\begin{tabular}{|c|c|c|c|c|c|c|c|c|c|c|}
\hline \multirow{4}{*}{ 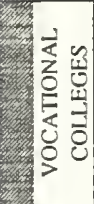 } & 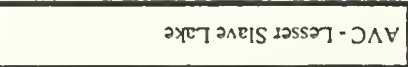 & & & $\bar{d} 3$ & 0 & $u$ & 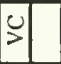 & & & u \\
\hline & 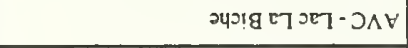 & & & & & & 0 & & & 0 \\
\hline & 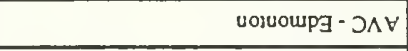 & & & & & & & & & \\
\hline & 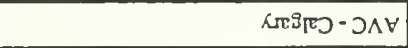 & & & & & & & & & \\
\hline \multirow{4}{*}{ 结 } & 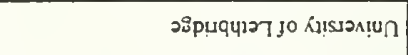 & $\sum_{m}$ & & $\infty$ & & $=$ & & $\sum_{\infty}$ & $\sum_{\infty}$ & \\
\hline & 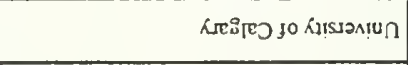 & $\sum_{m}^{\hat{a}} p$ & & ह & & & & $\infty$ & $\sum_{m}$ & \\
\hline & 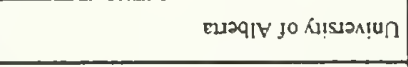 & $\sum_{\infty}^{\infty} \rho$ & & $\approx$ & & $\sum_{i} 0$ & & $\sum$ & $\sum_{\mathrm{E}}^{\hat{2}}$ 오 & \\
\hline & 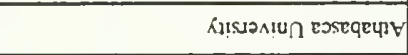 & $\infty$ & & & & & & & & \\
\hline 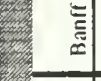 & 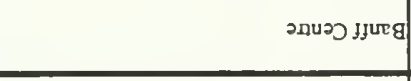 & & & $>$ & & & $>$ & & & \\
\hline & 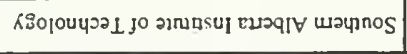 & & & & & & $>$ & & & 0 \\
\hline$\leq$ & К: & & 0 & 0 & 0 & 0 & & & & \\
\hline \multirow{6}{*}{ 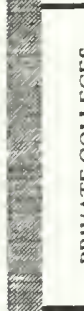 } & 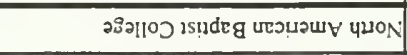 & & & & & & & & & \\
\hline & 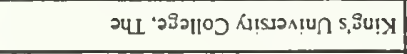 & $\infty$ & & $\infty$ & & & & & & \\
\hline & 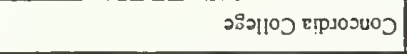 & $\infty$ & & $\bar{c}$ & & $=$ & & $=$ & $=$ & \\
\hline & 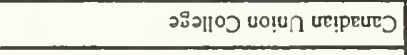 & $\infty$ & & & & & & & $\bar{\pi}$ & \\
\hline & 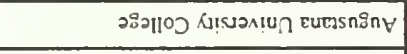 & $\infty$ & & & & $=$ & & $=$ & $\infty$ & \\
\hline & 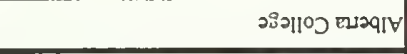 & & & & & & & & & \\
\hline \multirow{8}{*}{$\begin{array}{l}0 \\
0 \\
0 \\
0 \\
0 \\
0 \\
0 \\
0 \\
0 \\
0\end{array}$} & GGYYL dIHSGJLLNGYddV & & & & & & & & & \\
\hline & 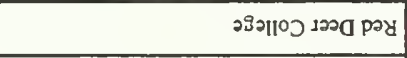 & $\tilde{\sim}$ & $=$ & & & $=$ & & $\overline{4}$ & $\tilde{\sim}$ & \\
\hline & 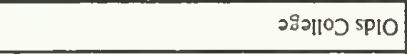 & & & ह & & & 0 & & & \\
\hline & 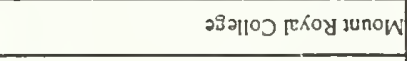 & $\bar{\Lambda}$ & & & 8 & $=$ & & & $\overline{\overline{0}}$ & $\circ$ \\
\hline & 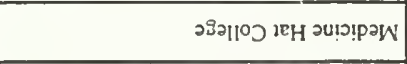 & $\bar{\Xi}$ & & & & $=$ & & $=$ & $\tilde{N}$ & 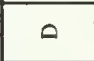 \\
\hline & 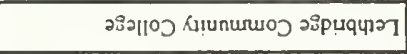 & & & $\overline{8}$ & & & & & & 8 \\
\hline & 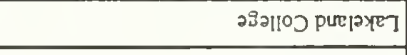 & $=$ & & 0 & & $=$ & & 0 & $=$ & \\
\hline & 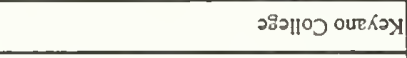 & & & $=$ & & & & & & \\
\hline & 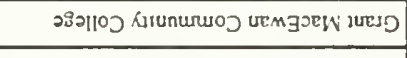 & $\overline{4}$ & & & & & & & $=$ & \\
\hline & 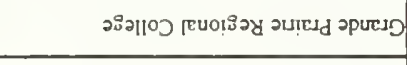 & $\underline{\Xi}$ & & & & $=$ & & & $\bar{\sim}$ & \\
\hline & 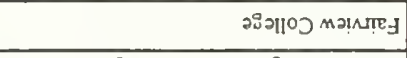 & & & & & & & & & \\
\hline & 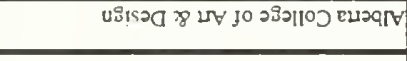 & & & & & & & & & \\
\hline \multicolumn{2}{|c|}{ 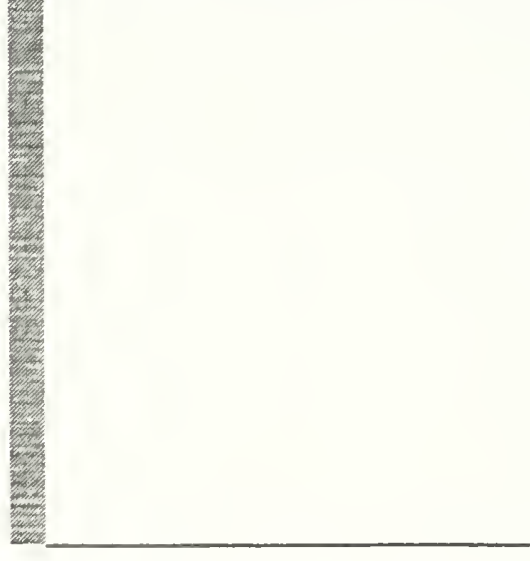 } & 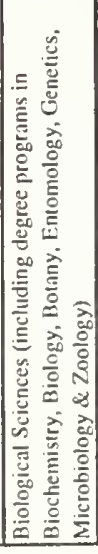 & 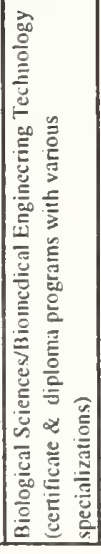 & 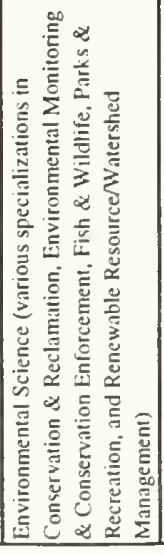 & 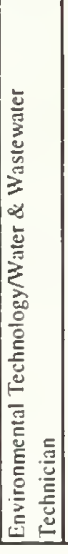 & 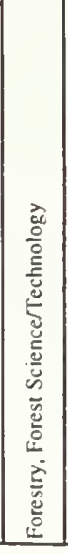 & 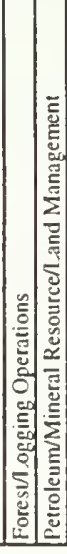 & 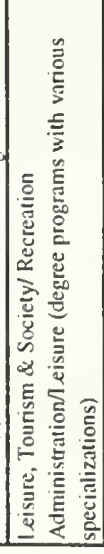 & 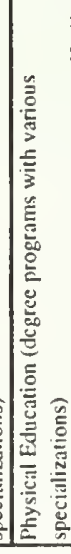 & 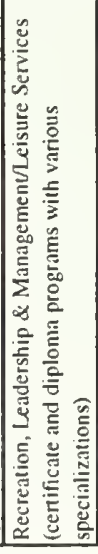 \\
\hline
\end{tabular}


CREDENTIALLING - Credentialling Opportunities in Forestry

\begin{tabular}{|c|c|c|c|c|c|}
\hline Certificate & Agency & $\begin{array}{l}\text { Other } \\
\text { Strands }\end{array}$ & Modules & $\begin{array}{c}\text { Instructor } \\
\text { Qualifications }\end{array}$ & Comments \\
\hline $\begin{array}{l}\text { Alberta } \\
\text { Conservation and } \\
\text { Hunter Education } \\
\text { Program }\end{array}$ & $\begin{array}{l}\text { Alberta } \\
\text { Environmental } \\
\text { Protection, Fish } \\
\text { and Wildlife } \\
\text { Services }\end{array}$ & WLD & $\begin{array}{l}\text { Regulated Hunting } \\
\text { and Game } \\
\text { Management I } \\
\text { (WLDI07) } \\
\text { Regulated Hunting } \\
\text { and Game } \\
\text { Management II } \\
\text { (WLD207) }\end{array}$ & $\begin{array}{c}\text { Yes } \\
\text { with } \\
\text { Environmental } \\
\text { Protection }\end{array}$ & \multirow{2}{*}{$\begin{array}{l}\text { Contact Alberta } \\
\text { Environmental Protection, } \\
\text { Fish and Wildlife Services, } \\
\text { at } \\
\text { (403) } 944-0313 \text { or } \\
\text { (403) } 297-6423 \text { for } \\
\text { information regarding } \\
\text { instructor and student } \\
\text { certification }\end{array}$} \\
\hline $\begin{array}{l}\text { Alberta Fishing } \\
\text { Education Program }\end{array}$ & $\begin{array}{l}\text { Alberta } \\
\text { Environmental } \\
\text { Protection, Fish } \\
\text { and Wildlife } \\
\text { Services } \\
\end{array}$ & WLD & $\begin{array}{l}\text { Fishing and the } \\
\text { Aquatic } \\
\text { Environment } \\
\text { (WLD108) }\end{array}$ & $\begin{array}{c}\text { Yes } \\
\text { with } \\
\text { Environmental } \\
\text { Protection }\end{array}$ & \\
\hline $\begin{array}{l}\text { Alberta Tourism } \\
\text { Industry Standards } \\
\text { - Outdoor Guide } \\
\text { - Freshwater } \\
\text { Angling Guide } \\
\text { - Hunting Guide }\end{array}$ & $\begin{array}{l}\text { Alberta Tourism } \\
\text { Education Council } \\
\text { (ATEC) }\end{array}$ & & $\begin{array}{l}\text { Woods Survival I } \\
\text { (FOR104) } \\
\text { Woods Survival II } \\
\text { (FOR204) }\end{array}$ & No & $\begin{array}{l}\text { Industry standards currently } \\
\text { available - certification } \\
\text { under development. } \\
\text { Evaluation by industry peer- } \\
\text { based or written exam and } \\
\text { demonstration of practical } \\
\text { skills. Contact ATEC at } \\
1-800-265-1283 \\
\end{array}$ \\
\hline $\begin{array}{l}\text { Canadian Firearms } \\
\text { Safety Course }\end{array}$ & $\begin{array}{l}\text { Alberta Justice, } \\
\text { Chief Provincial } \\
\text { Firearms Office }\end{array}$ & CTR & $\begin{array}{l}\text { Project modules } \\
\text { (CTR211-215) } \\
\text { (CTR311-315) }\end{array}$ & $\begin{array}{c}\text { Yes } \\
\text { with Alberta } \\
\text { Justice }\end{array}$ & $\begin{array}{l}\text { Contact Alberta Justice at } \\
\text { (403) } 427-0437 \text { for } \\
\text { information regarding } \\
\text { instructor and student } \\
\text { certification }\end{array}$ \\
\hline Emergency First Aid & $\begin{array}{l}\text { St. John } \\
\text { Ambulance }\end{array}$ & CTR & $\begin{array}{l}\text { Personal Safety } \\
\text { Management } \\
\text { (CTR121) }\end{array}$ & Yes & \multirow{2}{*}{$\begin{array}{l}\text { See Community Health } \\
\text { and/or Career Transitions }\end{array}$} \\
\hline Standard First Aid & $\begin{array}{l}\text { St. John } \\
\text { Ambulance } \\
\end{array}$ & $\mathrm{CMH}$ & $\begin{array}{l}\text { First Aid/CPR } \\
(\mathrm{CMH} 212)\end{array}$ & Yes & \\
\hline $\begin{array}{l}\text { Basic Wilderness } \\
\text { First Aid }\end{array}$ & $\begin{array}{l}\text { Canadian Red } \\
\text { Cross Society }\end{array}$ & CTR & $\begin{array}{l}\text { Project modules } \\
\text { (CTR211-215) } \\
\text { (CTR311-315) }\end{array}$ & $\begin{array}{c}\text { Yes } \\
\text { with Canadian } \\
\text { Red Cross }\end{array}$ & $\begin{array}{l}\text { Evaluation done by } \\
\text { instructor certified with } \\
\text { Canadian Red Cross. } \\
\text { Contact: } \\
\text { Calgary (403) } 541-4446 \\
\text { Edmonton (403) } 423-2680 \\
\text { Lethbridge (403) 327-7117 } \\
\text { Grande Prairie (403) 539- } \\
7127 \\
\text { Red Deer (403) 346-1241 } \\
\text { Medicine Hat (403) 526- } \\
3048\end{array}$ \\
\hline
\end{tabular}




\title{
FORESTRY
}

\section{SECTION I: LEARNING RESOURCE GUIDE}

\author{
(INTERIM)
}

\section{TABLE OF CONTENTS}

This section of the GSI has been designed to provide a list of resources that support student learning. Three different types of resources are identified:

- Authorized: Resources authorized by Alberta Education for CTS curriculum; these resources are categorized as basic, support, or teaching

- Other: Titles provided as a service to assist local jurisdictions to identify resources that contain potentially useful ideas for teachers. Alberta Education has done a preliminary review of these resources, but further review will be necessary for use in school jurisdictions

- Additional: A list of local and provincial sources of information available to teachers, including the community, government agencies, resource centres and organizations.

INTRODUCTION

CTS and the Resource-based Classroom

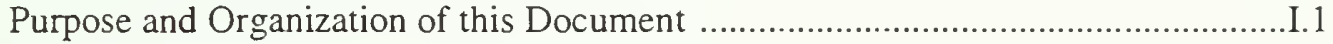

How to Order .........................................................................................................

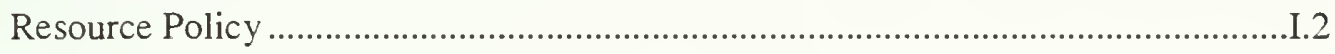

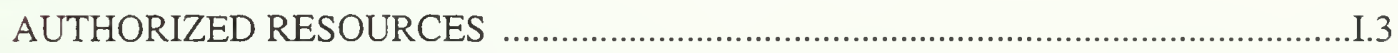

Basic Learning Resources ...............................................................................

Support Learning Resources ..............................................................................

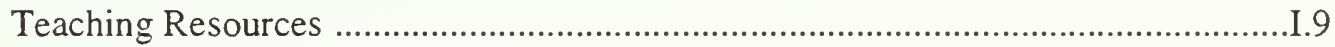

Resource Correlation ................................................................................... 13

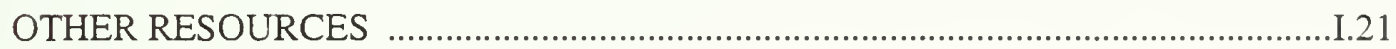

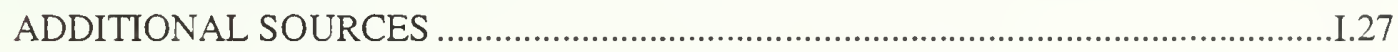

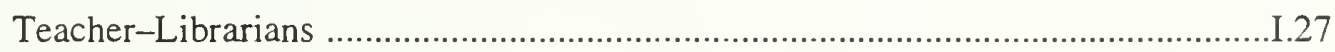

Alberta Education Resources ..........................................................................27

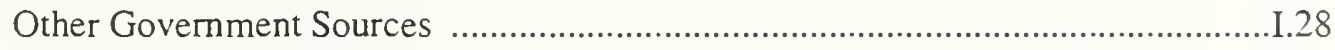

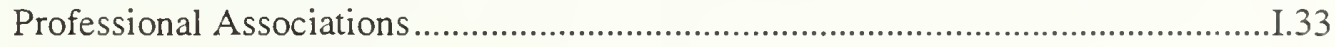

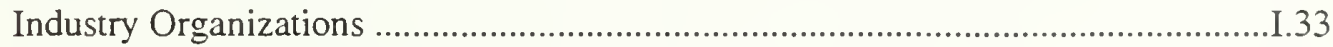

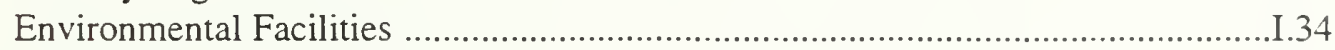

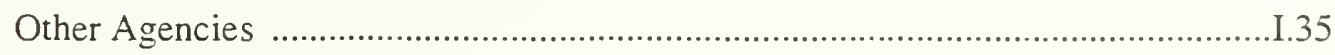

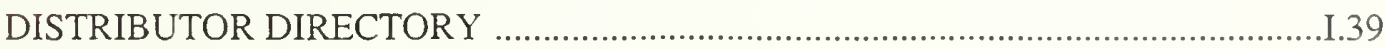




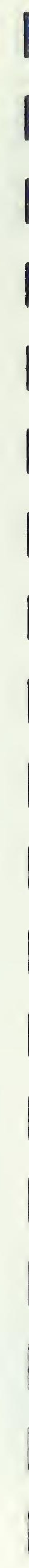




\section{INTRODUCTION}

\section{CTS AND THE RESOURCE-BASED CLASSROOM}

Career and Technology Studies (CTS) encourages teachers to establish a resource-based classroom, where a variety of appropriate, up-to-date print and non-print resources are available. Learning resources identified for CTS strands include print, software, interactive videos, manipulatives, student learning guides and tutorials.

The resource-based classroom approach accommodates a variety of instructional strategies and teaching styles, and supports individual or small group planning. It provides students with opportunities to interact with a wide range of information sources in a variety of learning situations. Students in CTS are encouraged to take an active role in managing their own learning. Ready access to a strong resource base enables students to learn to screen and use information appropriately, to solve problems, to meet specific classroom and learning needs, and to develop competency in reading, writing, speaking, listening and viewing.

\section{PURPOSE AND ORGANIZATION OF THIS DOCUMENT}

The purpose of this document is to help teachers identify a variety of resources to meet their needs and those of the students taking the new Forestry curriculum. It is hoped that this practical guide to resources will help teachers develop a useful, accessible resource centre that will encourage students to become independent, creative thinkers.

This document is organized as follows:

- Authorized Resources:

- basic learning resources

- support learning resources

- teaching resources

- Other Resources

- Additional Sources.

Some resources in the guide have been authorized for use in some or all of the CTS strands, e.g., the 11 video Career and Technology Studies series produced by ACCESS: The Education Station. Full information is provided in the appropriate section of this resource guide.

Each resource in the guide provides bibliographic information, an annotation where appropriate, and a correlation to the Forestry modules. The distributor code for each entry will facilitate ordering resources. It is recommended that teachers preview all resources before purchasing, or purchase one copy for their reference and additional copies as required.

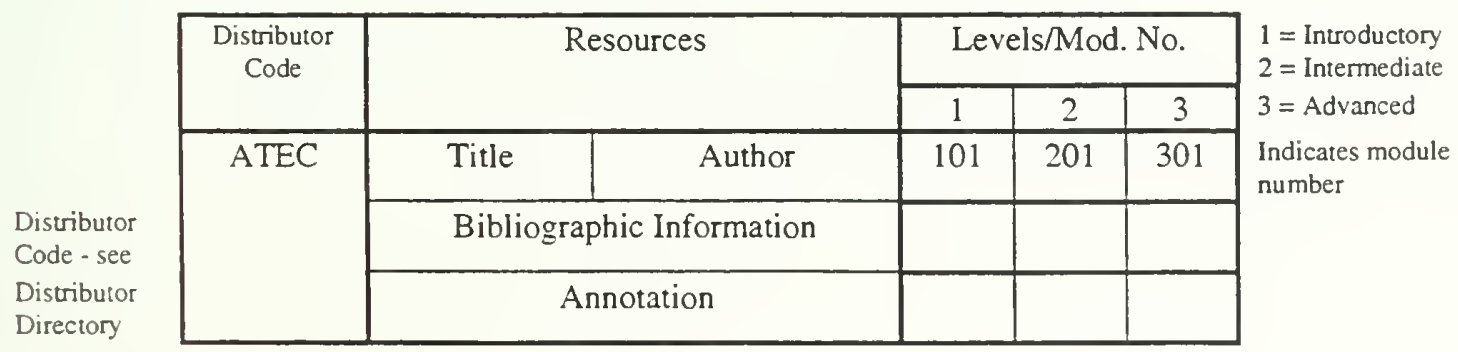




\section{HOW TO ORDER}

Most authorized resources are available from the Learning Resources Distributing Centre (LRDC) at:

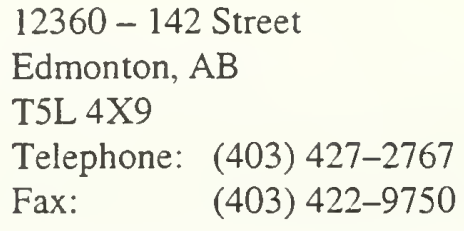

Please check LRDC for availability of videos.

The section on Additional Sources lists a variety of other places to find information related to this strand. In addition, at the back of this document is a Distributor Directory, which contains the name and address of each publisher/distributor referred to in the resource list. Note that in some cases a resource may be published by one company but distributed through another.

The information contained is as complete and accurate as possible.

\section{RESOURCE POLICY}

For further information on resource policy and definitions, refer to the Student Learning Resources Policy and Teaching Resources Policy or contact:

Learning Resources Unit

Curriculum Standards Branch

Alberta Education

5th Floor, Devonian Building, East Tower

11160 Jasper Avenue

Edmonton, $\mathrm{AB}$

T5K 0L2

Telephone: (403) 422-4872

Fax: (403) 422-0576 


\section{AUTHORIZED RESOURCES}

\section{BASIC LEARNING RESOURCES}

The following basic learning resources have been authorized by Alberta Education for use in the Forestry curriculum. These resources address the majority of the learner expectations in one or more modules and/or levels. A curriculum correlation appears in the right-hand column.

\begin{tabular}{|c|c|c|c|c|}
\hline \multirow{2}{*}{$\begin{array}{l}\text { Distributor } \\
\text { Code }\end{array}$} & \multirow[t]{2}{*}{ Resources } & \multicolumn{3}{|c|}{ Level/Module No. } \\
\hline & & 1 & 2 & 3 \\
\hline LRDC & $\begin{array}{l}\text { Ecosystems. B. Herridge and B. Chernin. Gage Educational } \\
\text { Publishing, } 1995 \text {. } \\
\text { The } 72 \text { page student text provides an illustrated introduction to ecosystems } \\
\text { and a more in-depth look at living and non-living factors and the roles they } \\
\text { play in ecosystems. The text concludes with examples of human impacts on } \\
\text { ecosystems and examines current issues from a variety of perspectives. The } \\
500 \text { page teacher's resource book provides teaching ideas correlated to the } \\
\text { student text and suggestions regarding evaluation, supplementary resources } \\
\text { and integrated projects. Blackline master, reproducible for classroom use, are } \\
\text { provided. }\end{array}$ & $\begin{array}{l}101 \\
102 \\
109 \\
110\end{array}$ & $\begin{array}{l}201 \\
209\end{array}$ & $\begin{array}{l}301 \\
309 \\
312\end{array}$ \\
\hline LRDC & $\begin{array}{l}\text { Global Environment, The. Steven Sterling and Sue Lyle. } \\
\text { Mississauga, ON: Copp Clark Pitman, } 1991 . \\
\text { This text addresses a broad range of environmental issues within a global } \\
\text { context. Issues are examined through a variety of stimulating activities, } \\
\text { including case studies, discussion and role-playing. }\end{array}$ & $\begin{array}{l}109 \\
110\end{array}$ & $\begin{array}{l}203 \\
210\end{array}$ & 301 \\
\hline LRDC & $\begin{array}{l}\text { Investigating Terrestrial Ecosystems. William A. Andrews. } \\
\text { Scarborough, ON: Prentice-Hall Canada Inc., } 1986 . \\
\text { This student textbook focuses attention on the ecology of our planet and } \\
\text { more specifically terrestrial ecosystems. The content is intended to assist } \\
\text { students to identify and resolve environmental issues. The textbook } \\
\text { investigates basic concepts of terrestrial ecosystems and examines specific } \\
\text { biomes. Each chapter includes student-centred activities, case studies and } \\
\text { suggestions for field studies. }\end{array}$ & $\begin{array}{l}101 \\
102 \\
109\end{array}$ & & 309 \\
\hline LRDC & $\begin{array}{l}\text { Native Trees of Canada. ( } 8^{\text {th }} \text { edition.) R.C. Hosie. Markham, ON: } \\
\text { Fitzhenry and Whiteside Limited, 1990. } \\
\text { This reference book serves as a guide to the history of Canadian forests and } \\
\text { more than } 140 \text { species of trees in Canada. The book provides detailed notes } \\
\text { and illustrations on the habitat, size, shape, leaves, bark and wood for every } \\
\text { Canadian tree species. A glossary and identification key are included. }\end{array}$ & $\begin{array}{l}102 \\
104\end{array}$ & 204 & 309 \\
\hline
\end{tabular}


Basic Learning Resources (Continued.)

\begin{tabular}{|c|c|c|c|c|}
\hline \multirow{2}{*}{$\begin{array}{c}\text { Distributor } \\
\text { Code }\end{array}$} & \multirow[t]{2}{*}{ Resources } & \multicolumn{3}{|c|}{ Level/Module No. } \\
\hline & & 1 & 2 & 3 \\
\hline LRDC & $\begin{array}{l}\text { Which Future? Investigating World Environmental Issues. Don } \\
\text { Harris and Chris Dolan. Mississauga, ON: Copp Clark Pitman, } \\
1992 . \\
\text { This text deals with a variety of environmental issues and cites examples } \\
\text { from many parts of the world. Topics covered include food and population, } \\
\text { land degradation, forest clearing, pollution and alternative energy sources. }\end{array}$ & 110 & $\begin{array}{l}203 \\
210 \\
212\end{array}$ & $\begin{array}{l}301 \\
312\end{array}$ \\
\hline
\end{tabular}




\section{SUPPORT LEARNING RESOURCES}

The following support learning resources are authorized by Alberta Education to assist in addressing some of the learner expectations of a module or components of modules.

\begin{tabular}{|c|c|c|c|c|}
\hline \multirow{2}{*}{$\begin{array}{c}\text { Distributor } \\
\text { Code }\end{array}$} & \multirow[t]{2}{*}{ Resources } & \multicolumn{3}{|c|}{ Level/Module No. } \\
\hline & & 1 & 2 & 3 \\
\hline LRDC & $\begin{array}{l}\text { Birders of a Feather. Vancouver, BC: T.H.A. Media Distributors } \\
\text { Ltd., 1993. Videotape. } \\
\text { This video deals with the ecotourism dilemma in Beaverhill Lake, Mount } \\
\text { Verde and Point Pellee. The positive and negative effects that ecotourism } \\
\text { brings to human and natural communities are vividly portrayed. }\end{array}$ & $\begin{array}{l}109 \\
110\end{array}$ & $\begin{array}{l}203 \\
210\end{array}$ & $\begin{array}{l}301 \\
309\end{array}$ \\
\hline $\mathrm{ACC}$ & $\begin{array}{l}\text { Boreal Forest Issues. Edmonton, AB: Friends of the } \\
\text { Environmental Education Society of Alberta (FEESA), } 1993 . \\
\text { Videotape. } \\
\text { This } 59 \text {-minute video explains the characteristics of Alberta's boreal forests, } \\
\text { outlines the nature of forest use in society today, and examines strategies } \\
\text { used in forest management. Issues surrounding the use of our boreal forests } \\
\text { are analyzed from both economic and environmental perspectives. The need } \\
\text { for responsible decision making in forestry-related areas is emphasized } \\
\text { throughout the video. }\end{array}$ & $\begin{array}{l}101 \\
102 \\
109 \\
110\end{array}$ & $\begin{array}{l}201 \\
203 \\
210 \\
212\end{array}$ & $\begin{array}{l}301 \\
309 \\
312\end{array}$ \\
\hline $\mathrm{ACC}$ & $\begin{array}{l}\text { Career and Technology Studies: Key Concepts. Edmonton, AB: } \\
\text { ACCESS: The Education Station. } \\
\text { Series of videos and utilization guides relevant to all CTS strands. Series } \\
\text { consists of Anatomy of a Plan, Creativity, Electronic Communication, The } \\
\text { Ethics Jungle, Go Figure, Innovation, Making Ethical Decisions, Portfolios, } \\
\text { Professionalism, Project Planning, Responsibility and Technical Writing. }\end{array}$ & all & all & all \\
\hline LRDC & $\begin{array}{l}\text { Forest is in Our Hands, The. Edmonton, AB: Caterpillar } \\
\text { Incorporated, 1991. Videotape. } \\
\text { This video explores the need to make informed decisions regarding our use of } \\
\text { forests and other natural resources. Information is presented in three parts: } \\
\text { "Tending the Forest" (describes the science of silviculture); "Sharing the } \\
\text { Forest" (explores the concept of multiple-use management); and "Sustaining } \\
\text { the Forest" (examines the crucial area of decision making). Viewers are } \\
\text { reminded that there are at least two sides to every issue. A print component } \\
\text { entitled "Forest Facts: The Forest is in our Hands" is available in booklet } \\
\text { format. }\end{array}$ & & 212 & $\begin{array}{l}301 \\
311 \\
312\end{array}$ \\
\hline SSC & $\begin{array}{l}\text { From the Mountains to the Sea - A Journey in Environmental } \\
\text { Citizenship. Ottawa, ON: Environment Canada, } 1992 . \\
\text { Booklet. } \\
\text { This student booklet provides a brief directory of various "eco" activities that } \\
\text { can be implemented in the community, home and/or school. }\end{array}$ & & 203 & 301 \\
\hline
\end{tabular}




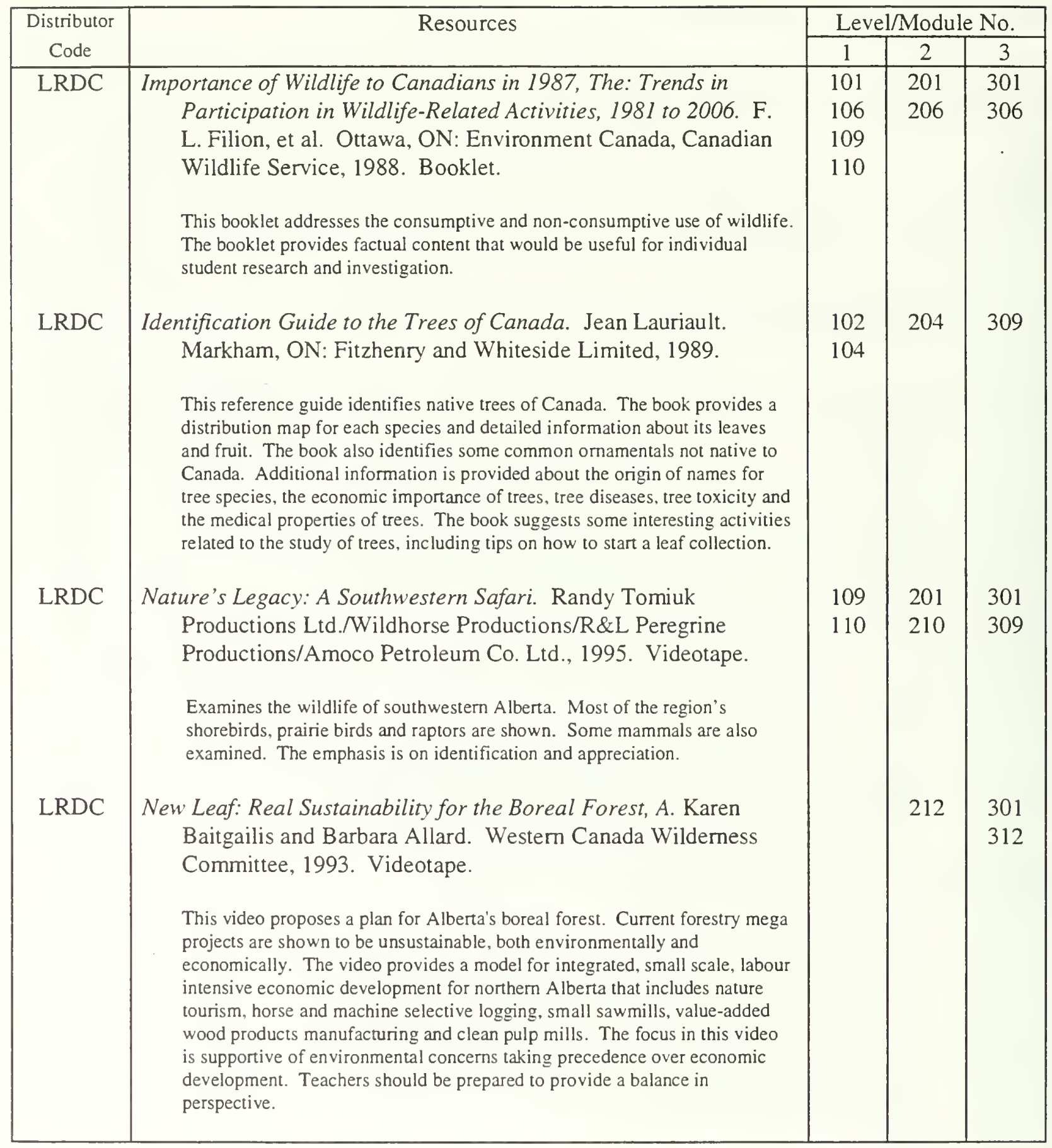


Support Learning Resources (continued)

\begin{tabular}{|c|c|c|c|c|}
\hline \multirow{2}{*}{$\begin{array}{c}\text { Distributor } \\
\text { Code }\end{array}$} & \multirow[t]{2}{*}{ Resources } & \multicolumn{3}{|c|}{ Level/Module No. } \\
\hline & & 1 & 2 & 3 \\
\hline LRDC & $\begin{array}{l}\text { One-Minute Readings: Issues in Science, Technology and Society. } \\
\text { R.F. Brinckerhoff, et al. Don Mills, ON: Addison-Wesley } \\
\text { Publishing Company, } 1992 \text {. } \\
\text { This book contains readings and questions related to issues in science, } \\
\text { technology and society. Applications of science are raising difficult } \\
\text { questions and are creating problems that cannot be answered. The book is } \\
\text { intended to give students practice in making the kinds of decisions they will } \\
\text { experience in life. Students need a knowledge of science to find the best } \\
\text { possible answers. }\end{array}$ & & & 301 \\
\hline LRDC & $\begin{array}{l}\text { Personal Equipment. N. Kelba, et al. Calgary, AB: Calgary Board } \\
\text { of Education, 1983. Booklet. } \\
\text { This booklet examines the role of personal equipment (its selection and use) } \\
\text { in safe and comfortable outdoor experiences. Topics addressed include } \\
\text { temperature regulation, essential equipment for various situations, selection } \\
\text { of quality equipment, sources of equipment, care and maintenance of } \\
\text { equipment, packing equipment and safety considerations. }\end{array}$ & 104 & 204 & \\
\hline LRDC & $\begin{array}{l}\text { Place For Wildlife, A: A Way Is No Longer There. Edmonton, AB: } \\
\text { ACCESS: The Education Station, 1990. Videotape and print. } \\
\text { This video was produced with the goal of increasing public understanding of } \\
\text { pressures facing Canadian wildlife; in particular, the continuing loss of } \\
\text { habitat. The program features "A Way Is No Longer There", an original song } \\
\text { about the common fate of wildlife and humans in our changing environment. } \\
\text { A utilization guide in print format is available to teachers. }\end{array}$ & 109 & 203 & $\begin{array}{l}301 \\
309\end{array}$ \\
\hline LRDC & $\begin{array}{l}\text { Shelters. N. Kelba, et al. Calgary, AB: Calgary Board of } \\
\text { Education, 1983. Booklet. } \\
\text { This booklet develops knowledge of planned and emergency shelters } \\
\text { essential to outdoor experiences. Topics addressed include site selection, } \\
\text { summer and winter constructed shelters, tents, bivouac sacks, improvised and } \\
\text { permanent shelters. }\end{array}$ & 104 & 204 & \\
\hline LRDC & $\begin{array}{l}\text { Singing In The Rain Forest (Warblers). Vancouver, BC: T.H.A. } \\
\text { Media Distributors Ltd. 1993. Videotape. } \\
\text { This video describes the plight of many North American (Boreal) songbirds. } \\
\text { Warblers are the main focus of attention. It provides a good overview of the } \\
\text { bird's life cycle and migratory patterns. The video should be viewed with the } \\
\text { understanding that many factors have attributed to the warblers' population } \\
\text { decline (e.g., forest fires, urban expansion, agriculture). }\end{array}$ & $\begin{array}{l}109 \\
110\end{array}$ & $\begin{array}{l}203 \\
210\end{array}$ & $\begin{array}{l}301 \\
309\end{array}$ \\
\hline
\end{tabular}


Support Learning Resources (continued)

\begin{tabular}{|c|c|c|c|c|}
\hline \multirow{2}{*}{$\begin{array}{l}\text { Distributor } \\
\text { Code }\end{array}$} & \multirow[b]{2}{*}{ Resources } & \multicolumn{3}{|c|}{ Level/Module No. } \\
\hline & & 1 & 2 & 3 \\
\hline LRDC & $\begin{array}{l}\text { This Living World: The Forest. Edmonton, AB: Recreation, Parks } \\
\text { and Wildlife Foundation, } 1992 \text {. Videotape. } \\
\text { The video present a historical perspective on the development of forests and } \\
\text { the forest industry in Canada. Because forests provide a home for wildlife } \\
\text { and serve many uses for human, it is necessary to protect and conserve them. }\end{array}$ & $\begin{array}{l}101 \\
109 \\
110\end{array}$ & $\begin{array}{l}203 \\
210\end{array}$ & 301 \\
\hline LRDC & $\begin{array}{l}\text { This Living World: Wildlife Habitat. Edmonton, AB: Recreation, } \\
\text { Parks and Wildlife Foundation, } 1992 \text {. Videotape. } \\
\text { This video informs viewers of the importance of "habitat" for living things. } \\
\text { Interviews provide insight on issues concerning wildlife and its habitat (e.g., } \\
\text { the need for ecological literacy, how habitat affects quality of life, the } \\
\text { worldwide disappearance of natural habitats). }\end{array}$ & $\begin{array}{l}101 \\
109 \\
110\end{array}$ & $\begin{array}{l}203 \\
210\end{array}$ & 301 \\
\hline LRDC & $\begin{array}{l}\text { Three Environmental Concerns: Science Show The. Francois St. } \\
\text { Laurent. Montreal, PQ: The Multi Media Group of Canada, } \\
\text { 1991. Videotape. } \\
\text { This video explores the possible effects of electromagnetic waves, noise and } \\
\text { radiation on living things. Conclusive evidence regarding the effects of these } \\
\text { sources of pollution on ecosystems in not available. Nevertheless, the video } \\
\text { examines related scientific principles and emerging societal issues. }\end{array}$ & $\begin{array}{l}109 \\
110\end{array}$ & $\begin{array}{l}203 \\
210\end{array}$ & 301 \\
\hline LRDC & $\begin{array}{l}\text { Trees. N. Kelba, et al. Calgary, AB: Calgary Board of Education, } \\
\text { 1992. Booklet. } \\
\text { This booklet provides a variety of environmental investigations that are } \\
\text { suited to the classroom and school yard. The investigations involve students } \\
\text { in hands-on and participatory learning situations. }\end{array}$ & $\begin{array}{l}102 \\
104 \\
109 \\
110\end{array}$ & $\begin{array}{l}203 \\
204\end{array}$ & \\
\hline $\mathrm{AFA}$ & $\begin{array}{l}\text { Woodlot Management Information Series. Edmonton, AB: Alberta } \\
\text { Forestry Association, 1993. Brochures. } \\
\text { This resource includes a series of } 10 \text { brochures that explain aspects of } \\
\text { woodlot management in clear statements that use non-technical vocabulary. } \\
\text { The series includes Taking Inventory of Your Forest Resources; Forests, } \\
\text { Fish \& Wildlife; Preparing a Management Plan; Business Plans for } \\
\text { Woodlots; Logging \& Selling Your Timber; Environmental Protection; } \\
\text { Reforesting Your Woodlot; Practising Agroforestry in the Praines; Add } \\
\text { Value to Your Forest Products; and Woodlot Management to Diversify Farm } \\
\text { Income. }\end{array}$ & $\begin{array}{l}101 \\
110\end{array}$ & $\begin{array}{l}203 \\
206 \\
207 \\
210 \\
212\end{array}$ & $\begin{array}{l}301 \\
307 \\
311 \\
312\end{array}$ \\
\hline
\end{tabular}




\section{TEACHING RESOURCES}

The following teaching resources are authorized by Alberta Education to assist teachers in the instructional process.

\begin{tabular}{|c|c|c|c|c|}
\hline \multirow{2}{*}{$\begin{array}{l}\text { Distributor } \\
\text { Code }\end{array}$} & \multirow[t]{2}{*}{ Resources } & \multicolumn{3}{|c|}{ Level/Module No. } \\
\hline & & 1 & 2 & 3 \\
\hline LRDC & $\begin{array}{l}\text { Alberta's Focus on Forests. Edmonton, AB: Alberta Forestry } \\
\text { Association, } 1993 . \\
\text { This guidebook for teachers focuses attention on the nature of forests and } \\
\text { forest management in Alberta. Lessons outlined in the manual incorporate } \\
\text { activity-based learning, cooperative learning and critical/creative thinking } \\
\text { skills. Materials have been organized into five modules which include } \\
\text { Adaptations For Life (forest ecology), The Forest Tree, Conditions Affecting } \\
\text { Growth, Forest Resources and Technologies, and Forest Management For } \\
\text { All. }\end{array}$ & $\begin{array}{l}101 \\
102 \\
105 \\
106 \\
109 \\
110\end{array}$ & $\begin{array}{l}207 \\
210\end{array}$ & $\begin{array}{l}307 \\
309\end{array}$ \\
\hline LRDC & $\begin{array}{l}\text { Ecology Studies of Lakes in Alberta. Edmonton, AB: Alberta } \\
\text { Environment, 1988. Resource materials include book and } \\
\text { teacher's package, } 1989 \text {. } \\
\text { This print package deals with the ecology of freshwater environments. The } \\
\text { unit of study discusses human impact on lake environments and involves } \\
\text { students in the methods and technology employed to study lakes. Workshops } \\
\text { on how to use the materials are provided by Alberta Environment. }\end{array}$ & $\begin{array}{l}109 \\
110\end{array}$ & $\begin{array}{l}203 \\
206 \\
210\end{array}$ & $\begin{array}{l}301 \\
309\end{array}$ \\
\hline LRDC & $\begin{array}{l}\text { Ecosystems. B. Herridge and B. Chernin. Gage Educational } \\
\text { Publishing, 1995. Teacher's resource booklet. } \\
\text { See Basic Learning Resources for annotation and module correlation. }\end{array}$ & & & \\
\hline LRDC & $\begin{array}{l}\text { Managing The Forest: Support Materials for a Secondary School } \\
\text { Course in Intensive Forest Management. Don Jacques. } \\
\text { Vancouver, BC: The University of British Columbia, Western } \\
\text { Education Development Group, 1985. Teacher resource } \\
\text { manual. } \\
\text { This resource manual provides ideas and activities to support a high school } \\
\text { forestry course. The book is not a course in itself, but places activities in a } \\
\text { developmental sequence so that teachers may use it as a guide to develop and } \\
\text { present a variety of forestry concepts. }\end{array}$ & $\begin{array}{l}105 \\
106\end{array}$ & $\begin{array}{l}206 \\
207 \\
212\end{array}$ & $\begin{array}{l}306 \\
307 \\
308 \\
311 \\
312\end{array}$ \\
\hline
\end{tabular}


Teaching Resources (continued)

\begin{tabular}{|c|c|c|c|c|}
\hline \multirow{2}{*}{$\begin{array}{l}\text { Distributor } \\
\text { Code }\end{array}$} & \multirow[t]{2}{*}{ Resources } & \multicolumn{3}{|c|}{ Level/Module No. } \\
\hline & & 1 & 2 & 3 \\
\hline LRDC & $\begin{array}{l}\text { Matter of Degrees, A: Primer on Global Warming: Environmental } \\
\text { Citizenship Series. Christine Hogan. Ottawa, ON: Environment } \\
\text { Canada, 1993. Teacher's booklet. } \\
\text { This instructor source book provides information about climate change, the } \\
\text { greenhouse effect, human activities contributing to the greenhouse effect, } \\
\text { current scientific initiatives, potential impacts (especially on Canada), and } \\
\text { strategies for personal response to the issue. This book will assist the teacher } \\
\text { to develop learning projects and programs that address global warming. }\end{array}$ & & $\begin{array}{l}203 \\
210\end{array}$ & $\begin{array}{l}301 \\
309\end{array}$ \\
\hline \multirow[t]{3}{*}{ LRDC } & $\begin{array}{l}\text { Nature's Legacy: A Southwestern Safari. Randy Tomiuk } \\
\text { Productions Ltd./Wildhorse Productions/R\&L Peregrine } \\
\text { Productions/Amoco Petroleum Co. Ltd., 1995. Teacher's } \\
\text { resource guide. }\end{array}$ & & & \\
\hline & $\begin{array}{l}\text { The annotation for this resource requests teachers to ensure that a } \\
\text { balanced viewpoint is presented regarding the drainage of wetlands. }\end{array}$ & & & \\
\hline & See Support Learning Resources for annotation and module correlation. & & & \\
\hline \multirow[t]{2}{*}{ GEP } & $\begin{array}{l}\text { Nature of Canada, The: A Primer on Spaces and Species. } \\
\text { Agincourt, ON: Gage Educational Publishing Co., } 1993 . \\
\text { Booklet. }\end{array}$ & $\begin{array}{l}101 \\
109 \\
110\end{array}$ & 201 & $\begin{array}{l}301 \\
309 \\
312\end{array}$ \\
\hline & $\begin{array}{l}\text { This resource is designed to provide information that will help Canadians } \\
\text { make environmentally responsible decisions. It provides short information } \\
\text { anecdotes, maps and charts, and questions and answers designed to promote } \\
\text { critical thinking. The resource includes activities that can be initiated in the } \\
\text { classroom or community. The book is one of a series of Environmental } \\
\text { Citizenship Primers. }\end{array}$ & & & \\
\hline \multirow[t]{2}{*}{ LRDC } & $\begin{array}{l}\text { National Occupational Standards For the Canadian Tourism } \\
\text { Industry: Outdoor Guide. Tourism Industry Association of } \\
\text { Canada. Edmonton, AB: Alberta Tourism Education Council, } \\
\text { 1991. Teacher booklet. }\end{array}$ & 104 & 204 & \\
\hline & $\begin{array}{l}\text { This document contains competency standards that the tourism industry } \\
\text { deems necessary for effective performance in the occupation of Outdoor } \\
\text { Guide. The standards establish a base from which certification programs can } \\
\text { be developed. }\end{array}$ & & & \\
\hline \multirow[t]{2}{*}{ LRDC } & $\begin{array}{l}\text { Northern Bushcraft. (Expanded edition.) Mors Kochanski. } \\
\text { Edmonton, AB: Lone Pine Publishing Company, } 1988 .\end{array}$ & 104 & 204 & \\
\hline & $\begin{array}{l}\text { This book provides practical information for everyday living in the northern } \\
\text { forest. It discuses basic existence skills that allow survival in challenging } \\
\text { situations. Topics such as firecraft, axecraft, knifecraft, sawcraft, rope work } \\
\text { and shelter are discussed. }\end{array}$ & & & \\
\hline
\end{tabular}


Teaching Resources (continued)

\begin{tabular}{|c|c|c|c|c|}
\hline \multirow{2}{*}{$\begin{array}{l}\text { Distributor } \\
\text { Code }\end{array}$} & \multirow{2}{*}{ Resources } & \multicolumn{3}{|c|}{ Level/Module No. } \\
\hline & & 1 & 2 & 3 \\
\hline LRDC & $\begin{array}{l}\text { One-Minute Readings: Issues in Science, Technology and Society. } \\
\text { R.F. Brinckerhoff, et al. Don Mills, ON: Addison-Wesley } \\
\text { Publishing Company, 1992. Teacher's Manual. } \\
\text { See Basic Learning Resources for annotation and module correlation. }\end{array}$ & & & \\
\hline LRDC & $\begin{array}{l}\text { Orienteering, Level I. R. Robertson. Calgary, AB: Calgary Board } \\
\text { of Education, 1982. Booklet. } \\
\text { This booklet is designed to develop locomotor skills, map skills and } \\
\text { space/time skills as they relate to orienteering. By using a variety of maps, } \\
\text { the student's ability to "find his/her way" is developed. Activities for rural } \\
\text { and urban geographical areas have been included. }\end{array}$ & $\begin{array}{l}104 \\
105\end{array}$ & 204 & \\
\hline LRDC & $\begin{array}{l}\text { Orienteering, Level II. R. Robertson. Calgary, AB: Calgary Board } \\
\text { of Education, } 1980 \text {. Booklet. } \\
\text { This booklet is designed to add the use of a compass to the fundamental } \\
\text { orienteering skills of map reading, map making and map orientation. } \\
\text { Activities address physical fitness and skills, knowledge and understanding, } \\
\text { social skills, attitudes and appreciation. The material has been prepared for } \\
\text { junior and senior high school students. }\end{array}$ & $\begin{array}{l}104 \\
105\end{array}$ & 204 & \\
\hline GEP & $\begin{array}{l}\text { Primer on Environmental Citizenship, A. Agincourt, ON: Gage } \\
\text { Educational Publishing Co., } 1993 . \\
\text { This resource is designed to provide information that will help Canadians } \\
\text { make environmentally responsible decisions. It provides short informational } \\
\text { anecdotes, maps and charts, and questions/answers designed to provide } \\
\text { critical thinking. The resource includes information on ecological processes, } \\
\text { relationships of human societies with the environment, and key } \\
\text { environmental issues that Canadians face today. The book is one of a series } \\
\text { of Environmental Citizenship Primers. }\end{array}$ & $\begin{array}{l}101 \\
109\end{array}$ & 201 & $\begin{array}{l}301 \\
309 \\
312\end{array}$ \\
\hline LRDC & $\begin{array}{l}\text { Project Wild Activity Guide. Ottawa, ON: Canadian Wildlife } \\
\text { Federation, 1993. Book. } \\
\text { This book provides a collection on interdisciplinary environmental education } \\
\text { materials and activities that emphasize wildlife conservation and } \\
\text { environmental stewardship. Activities are indexed by topic, grade, subject } \\
\text { and skill, and foster responsible behaviour and constructive actions } \\
\text { concerning wildlife and the environment. }\end{array}$ & $\begin{array}{l}101 \\
109 \\
110\end{array}$ & $\begin{array}{l}201 \\
210 \\
212\end{array}$ & $\begin{array}{l}301 \\
309 \\
312\end{array}$ \\
\hline
\end{tabular}


Teaching Resources (continued)

\begin{tabular}{|c|c|c|c|c|}
\hline \multirow{2}{*}{$\begin{array}{c}\text { Distributor } \\
\text { Code }\end{array}$} & \multirow[t]{2}{*}{ Resources } & \multicolumn{3}{|c|}{ Levels/Module No. } \\
\hline & & 1 & 2 & 3 \\
\hline LRDC & $\begin{array}{l}\text { Trip Planning. N. Kelba, et al. Calgary, AB: Calgary Board of } \\
\text { Education, 1984. Booklet. } \\
\text { This booklet outlines essential steps in planning successful outdoor education } \\
\text { experiences. Planning should be based on an understanding of the potential } \\
\text { hazards in the wilderness environment. The isolation factor of an outdoor } \\
\text { trip shows the need for knowledge of emergency response, first aid and } \\
\text { evacuation procedures. The booklet provides basic knowledge for the safety } \\
\text { and enjoyment of outdoor experiences. }\end{array}$ & 104 & 204 & \\
\hline $\mathrm{AFA}$ & $\begin{array}{l}\text { Woodlot Management Guide for the Prairie Provinces. Farm } \\
\text { Woodlot Association of Saskatchewan. Edmonton, AB: } \\
\text { Alberta Forestry Association, } 1993 \text {. } \\
\text { This guide in binder format provides an introduction to forestry and a } \\
\text { general overview of woodlot Management. The guide is divided into four } \\
\text { sections covering woodlot assessments, multiple land use, products and } \\
\text { markets and woodlot management. Information provided is intended to } \\
\text { help landowners understand their woodlots and develop appropriate goals } \\
\text { for land use. }\end{array}$ & $\begin{array}{l}101 \\
110\end{array}$ & $\begin{array}{l}203 \\
206 \\
207 \\
210 \\
212\end{array}$ & $\begin{array}{l}301 \\
307 \\
311 \\
312\end{array}$ \\
\hline
\end{tabular}




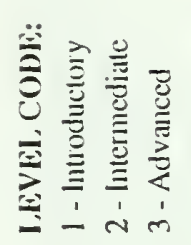

\begin{tabular}{|c|c|c|c|c|c|c|c|}
\hline$m$ & U & 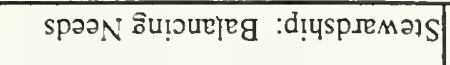 & & $\times$ & & $x$ & \\
\hline$m$ & $U$ & 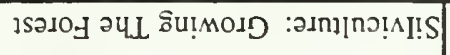 & $\bar{z}$ & & & & \\
\hline$m$ & 0 & Кลิอ & 류 & $x$ & $x>$ & & $x$ \\
\hline$m$ & $=$ & 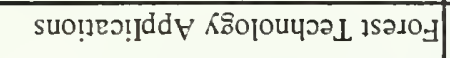 & $\infty$ & & & & \\
\hline
\end{tabular}

ఏ

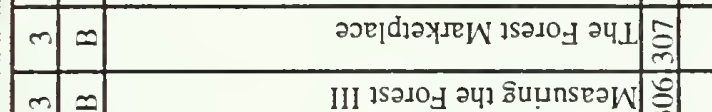

$m=$

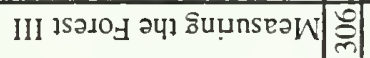

$\sim 0$ KIISarot UI Sanssi

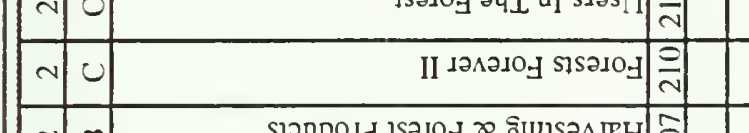

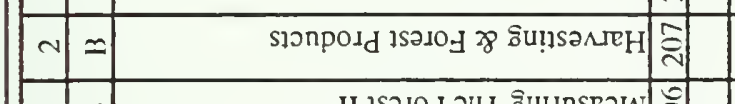

$\sim 2$

í

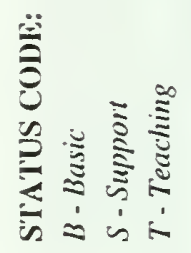

\begin{tabular}{|c|c|c|}
\hline$\sim$ & $<$ & II ן ן \\
\hline$\sim$ & $<$ & 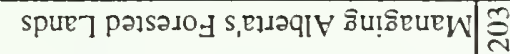 \\
\hline$\sim$ & $<$ & ${ }^{10} \mathrm{I}$ \\
\hline
\end{tabular}

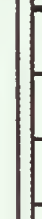

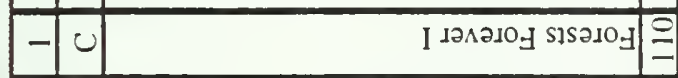

\begin{tabular}{|c|c|}
\hline \begin{tabular}{l|l}
-1 & 0 \\
-1 &
\end{tabular} & 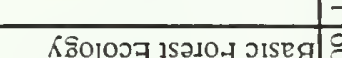 \\
\hline \begin{tabular}{|l|l}
-1 & $m$
\end{tabular} & 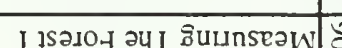 \\
\hline
\end{tabular}

$-\infty$

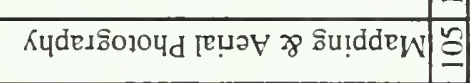

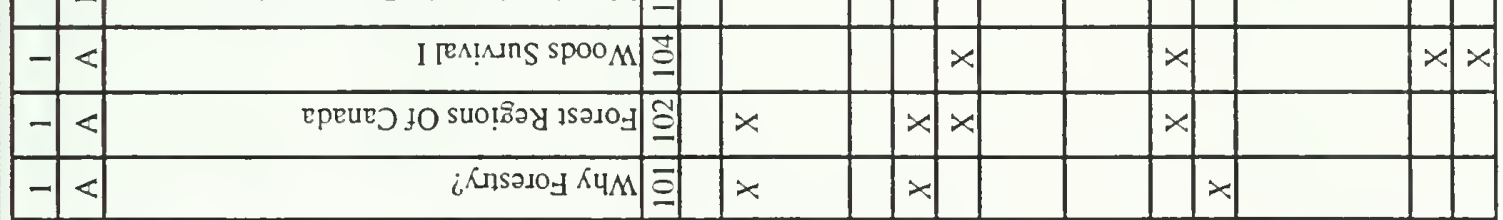

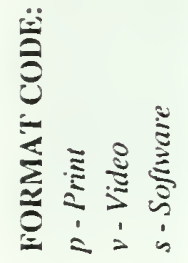

$48 ! \mathrm{H}$ 1014วS/1014nก

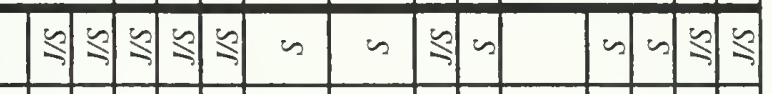

snipis

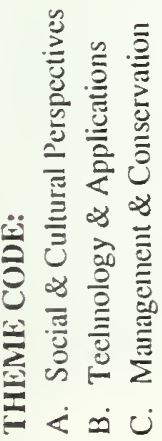

$x \mid x$

$\times$

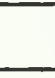




\begin{tabular}{|c|c|c|c|c|c|c|c|c|c|c|c|c|c|c|c|c|c|c|}
\hline \multirow{11}{*}{ 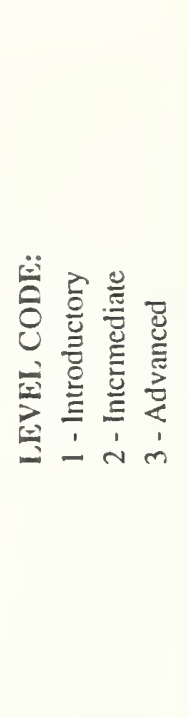 } & $m$ & ul & 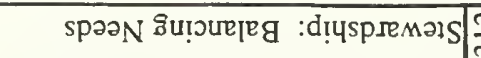 & $\frac{m}{m}$ & & $x$ & & & & $x$ & $x$ & & & & & & & $\delta$ \\
\hline & $m$ & u) & 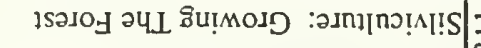 & $=$ & & $x$ & & & & $x$ & & & & & & & & 0 \\
\hline & $m$ & $u$ & 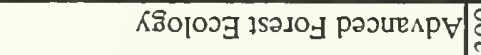 & क्ले & & & $x$ & $x$ & $x$ & & $\cdot x$ & & & & $x$ & & $x \times$ & $\ddot{\oplus}$ \\
\hline & $m$ & $\infty$ & 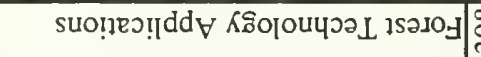 & 离 & & & & & & $x$ & & & & & & & & j \\
\hline & $m$ & $\infty$ & 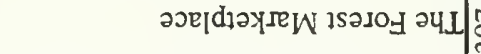 & 잉 & & $\times$ & $x$ & & & $x$ & & & & & & & & \\
\hline & $m$ & $\infty$ & III 15ว10 J วપ] ธิuบnSEวW| & 8 & & & & & & $x$ & & & & & & & & \\
\hline & $m$ & $<$ & א̃IsəIOJ UI SənssI & ह) & & $x \mid$ & & $x$ & $x$ & & $x$ & & & & $x$ & & $x$ & \\
\hline & $N$ & $u$ & ISวJOJ วЧL UI SJәS $\Omega$ & $\frac{n}{a}$ & & $x \mid$ & & & & $x$ & & & & & & & $x$ & \\
\hline & N & 0 & 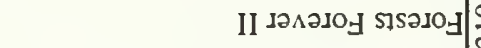 & $\frac{0}{2}$ & & $x$ & $x$ & $x$ & $x$ & & & & & & $x$ & & $x$ & \\
\hline & $\sim$ & $\infty$ & 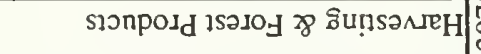 & 이 & & $x \mid$ & $x$ & & & $x$ & & & & & & & & \\
\hline & 4 & $\approx$ & 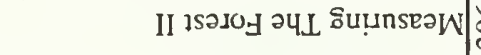 & ्ֻरे| & & $x$ & & $x$ & & $x$ & & & & & & & & \\
\hline$\stackrel{ \pm}{\equiv}$ & N & $<$ & II [ENININS SpooM & ఫ్ & $x$ & & & & & & & $x$ & $x$ & $\times$ & & $x$ & & \\
\hline 0 & 4 & $\varangle$ & 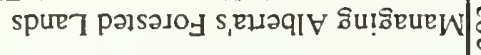 & లి & $x$ & $x$ & & $x$ & $\times$ & & & & & & $x$ & & & \\
\hline & 4 & $\varangle$ & 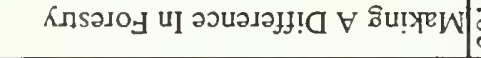 & ह्ते & & 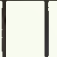 & & & & & $x$ & & & & & & $x \times$ & \\
\hline & - & $u$ & I әАәЈо' & 의 & $x$ & $x \mid$ & $x$ & $x$ & & & $\times$ & & & & & & $x$ & \\
\hline 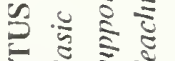 & - & $u$ & 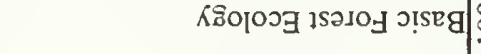 & of & $x$ & & $\times$ & $x$ & & & $\times$ & & & & & & $x \times$ & \\
\hline 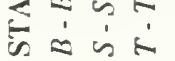 & - & $\infty$ & 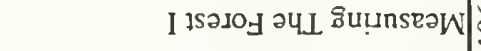 & 의 & & & $\times$ & & & $x$ & & & & & & & & \\
\hline & - & $\infty$ & 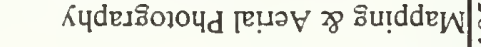 & 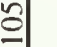 & & & 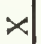 & & & $x$ & & & $x$ & $x$ & & & & \\
\hline & - & $<$ & 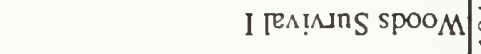 & 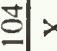 & $x$ & & 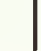 & & & & & $x$ & $x$ & $x$ & & $x$ & 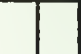 & \\
\hline & - & $<$ & 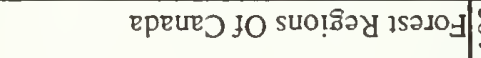 & อิ & $x$ & & $x$ & & & & & & & & & & & \\
\hline$\stackrel{1}{=}$ & - & $<$ & $i^{\mathrm{N} \cap \mathrm{S} \partial \mathrm{IO}_{\mathrm{J}}}$ КЧM & 의 & & $x$ & $x$ & & & & $x$ & & & & & & $x$ & \\
\hline อัป & & & 4จ!H so!นวS/so!unf & 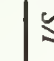 & - & $\leqslant$ & - & $\approx$ & $\backsim$ & $\infty$ & $\leqslant$ & -1 & - & $\approx$ & s & $\approx$ & $\leqslant \leqslant$ & \\
\hline$=8$ & & & SnגDis & c & $a$ & $\infty$ & 4 & $H$ & $H$ & A & N & $H$ & $H$ & $H$ & t & $\pi$ & $\sqrt{R}$ & \\
\hline $01=\dot{n}$ & & & 2014 & 5 & $\theta=$ & $=$ & $=$ & $\theta$ & of & $=$ & $=$ & a & a & of & $=$ & a & $\Rightarrow=$ & \\
\hline 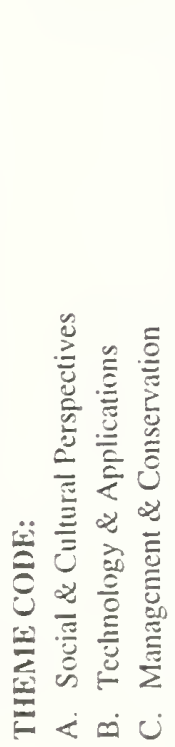 & & 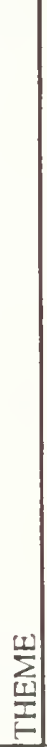 & & 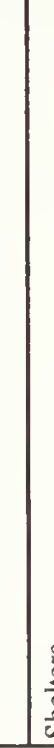 & 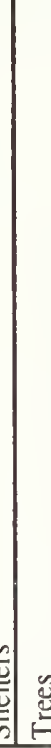 & 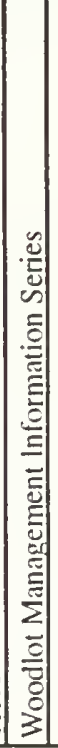 & 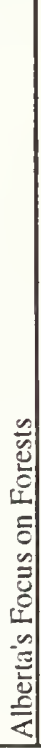 & 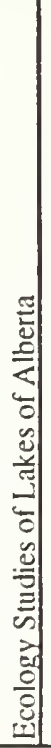 & 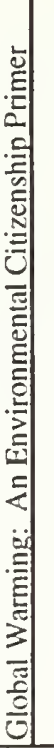 & 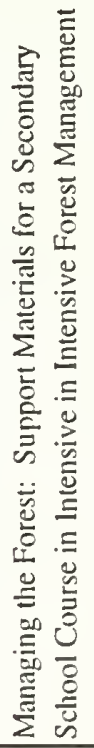 & 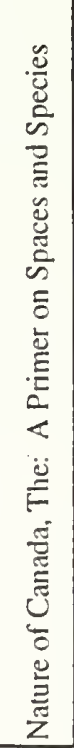 & 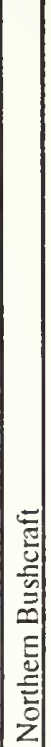 & 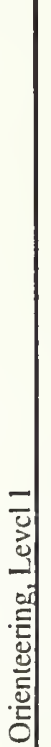 & $\begin{array}{l}= \\
\overline{0} \\
0 \\
0 \\
0 \\
0 \\
0 \\
\text { : } \\
\text { : } \\
0\end{array}$ & 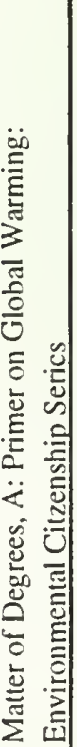 & 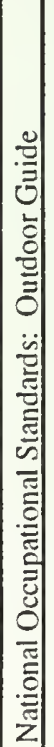 & 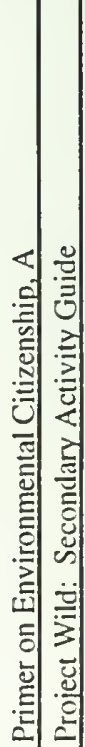 & 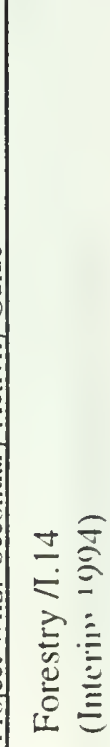 \\
\hline
\end{tabular}




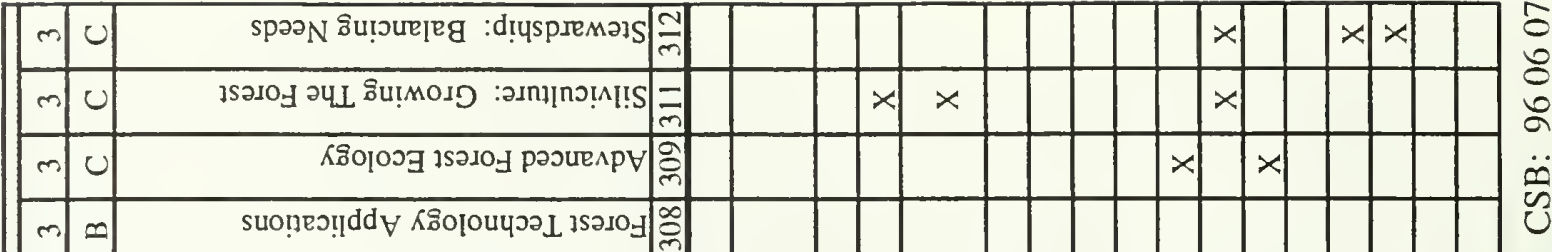

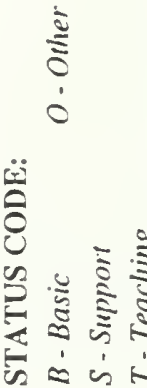

\begin{tabular}{|c|c|c|}
\hline$m$ & $\simeq$ & 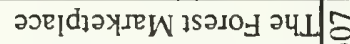 \\
\hline$m$ & 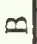 & 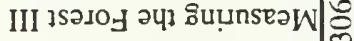 \\
\hline$m$ & $<$ & אISว \\
\hline
\end{tabular}

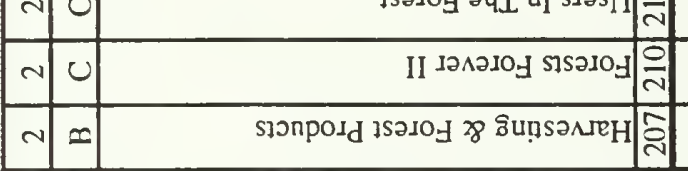

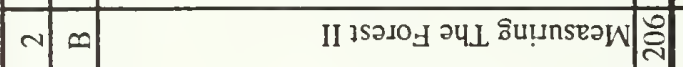

\begin{tabular}{|c|c|c|}
\hline$\sim$ & $<$ & II Ien! \\
\hline$N$ & $<$ & 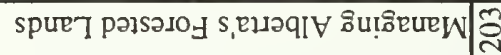 \\
\hline$\sim$ & $<$ & 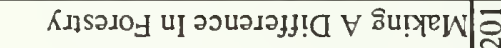 \\
\hline
\end{tabular}

\begin{tabular}{|c|c|}
\hline-0 & I Іәәләно \\
\hline-0 & $\widehat{\kappa s 0}$ \\
\hline
\end{tabular}

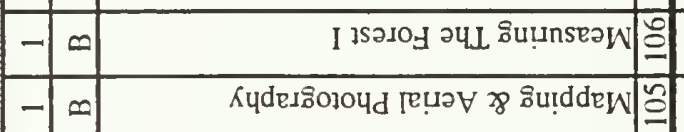

\begin{tabular}{|c|c|c|}
\hline- & $<$ & I IEA!MUS SpooM \\
\hline- & $<$ & 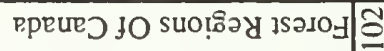 \\
\hline - & $<$ & 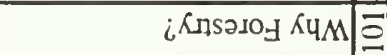 \\
\hline
\end{tabular}

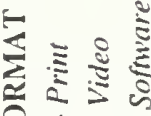

48?

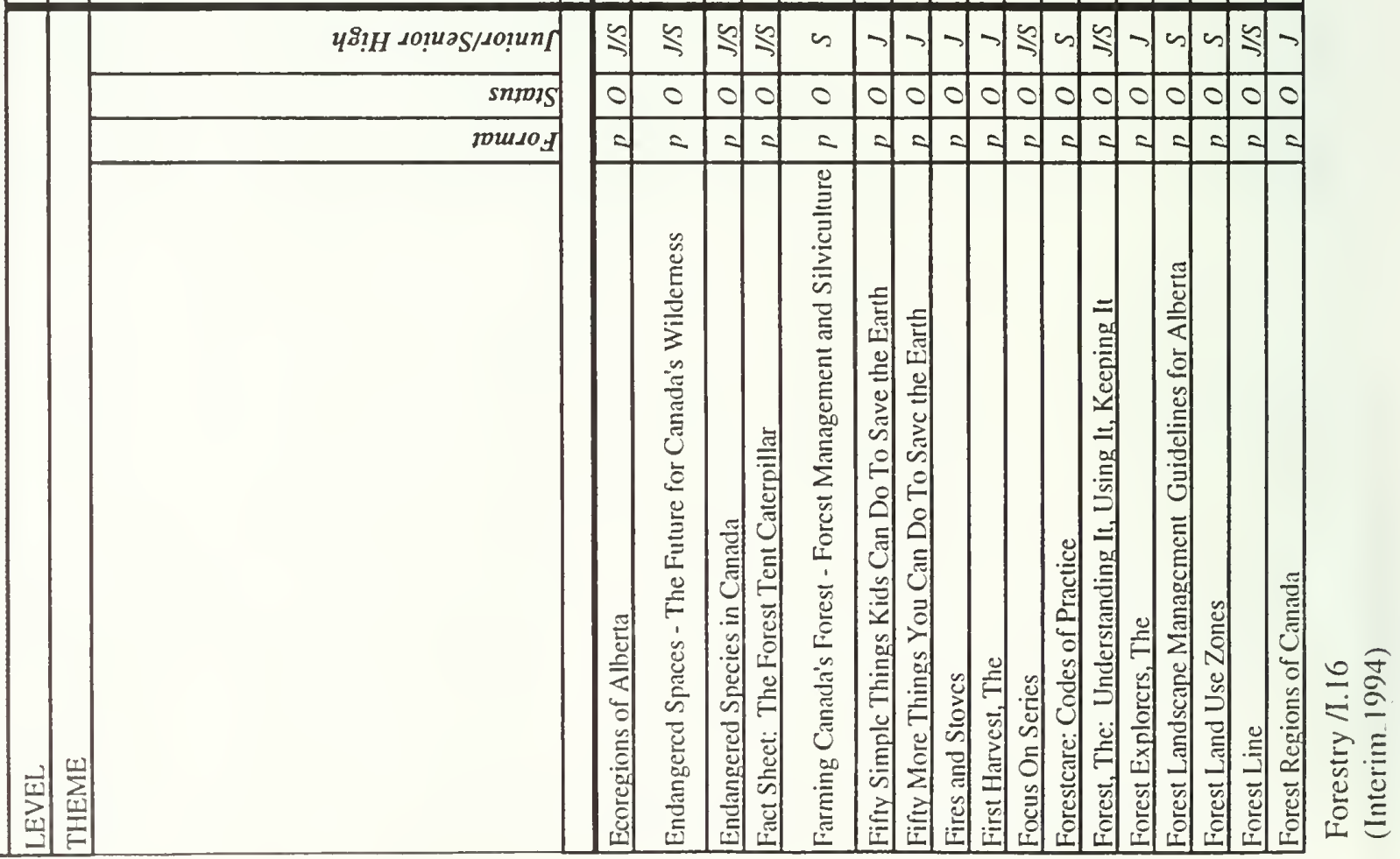




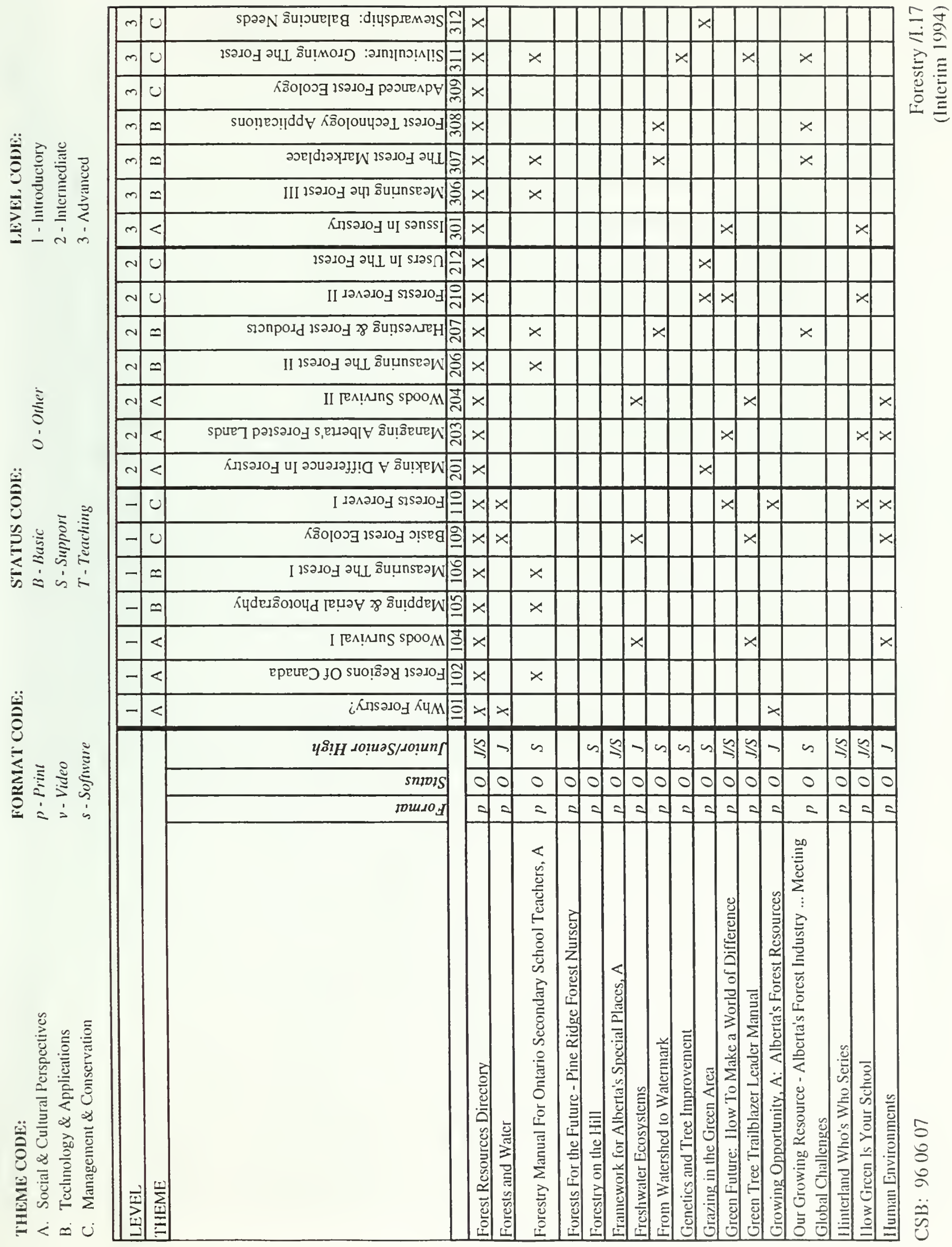




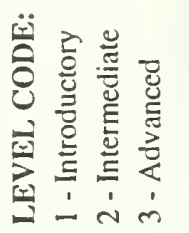

ఫ
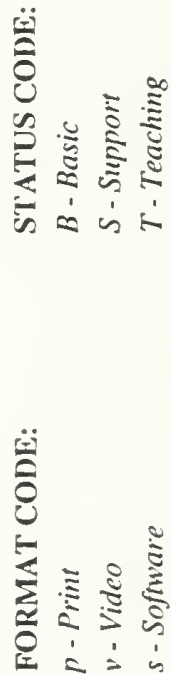

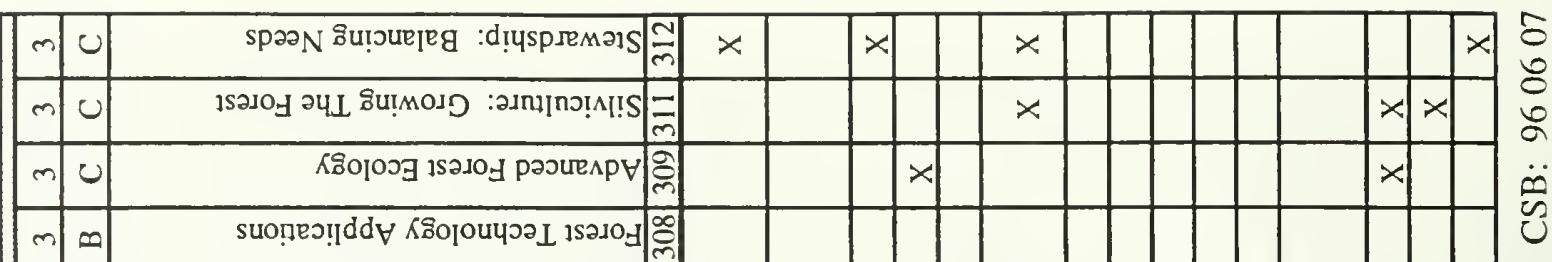

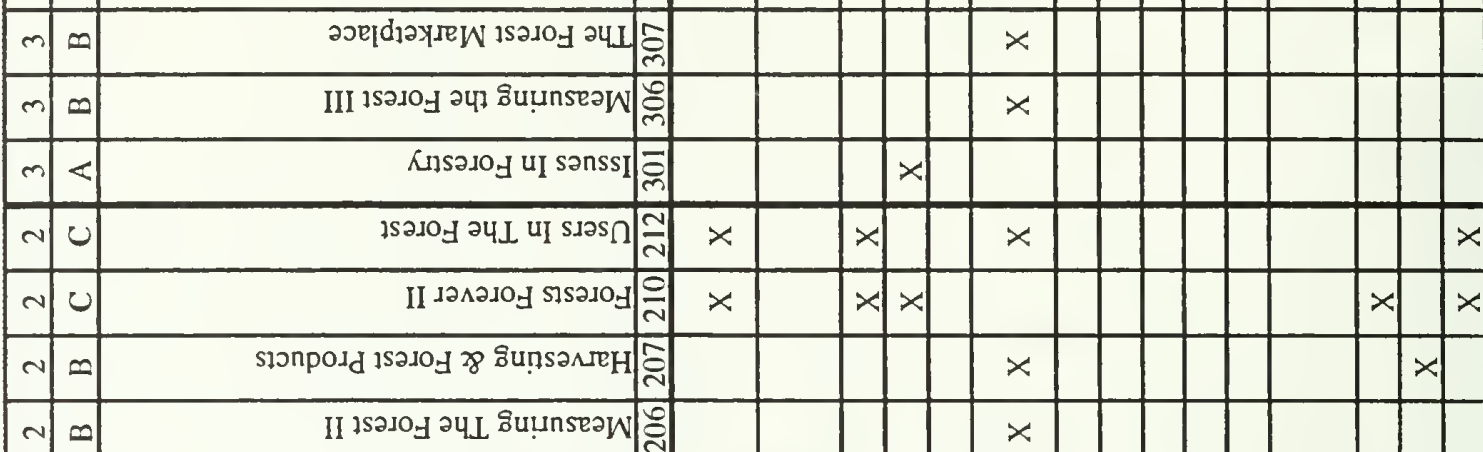

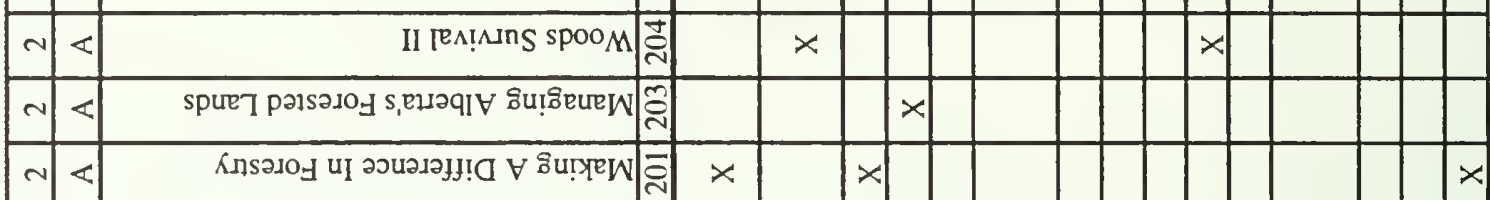

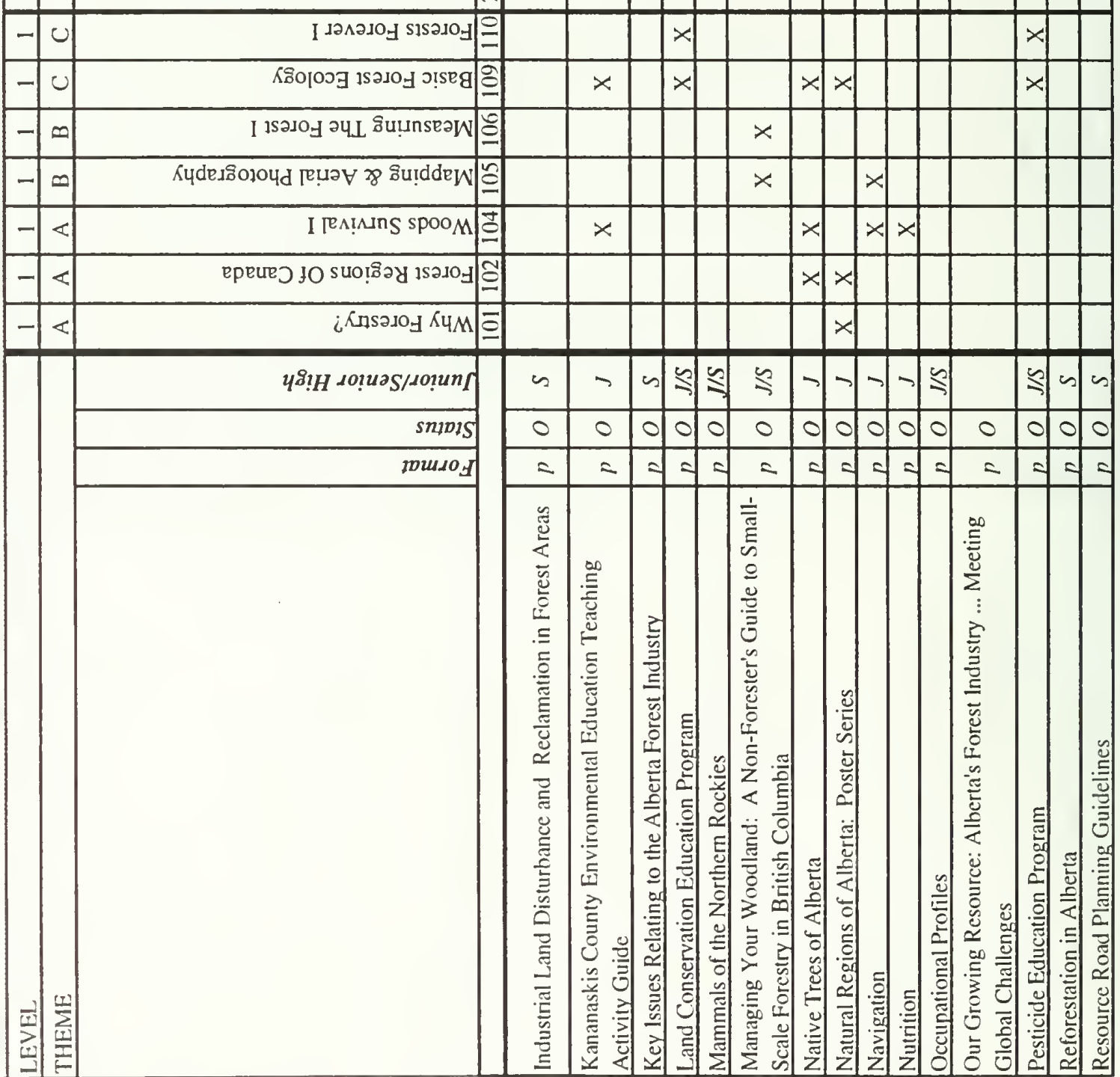




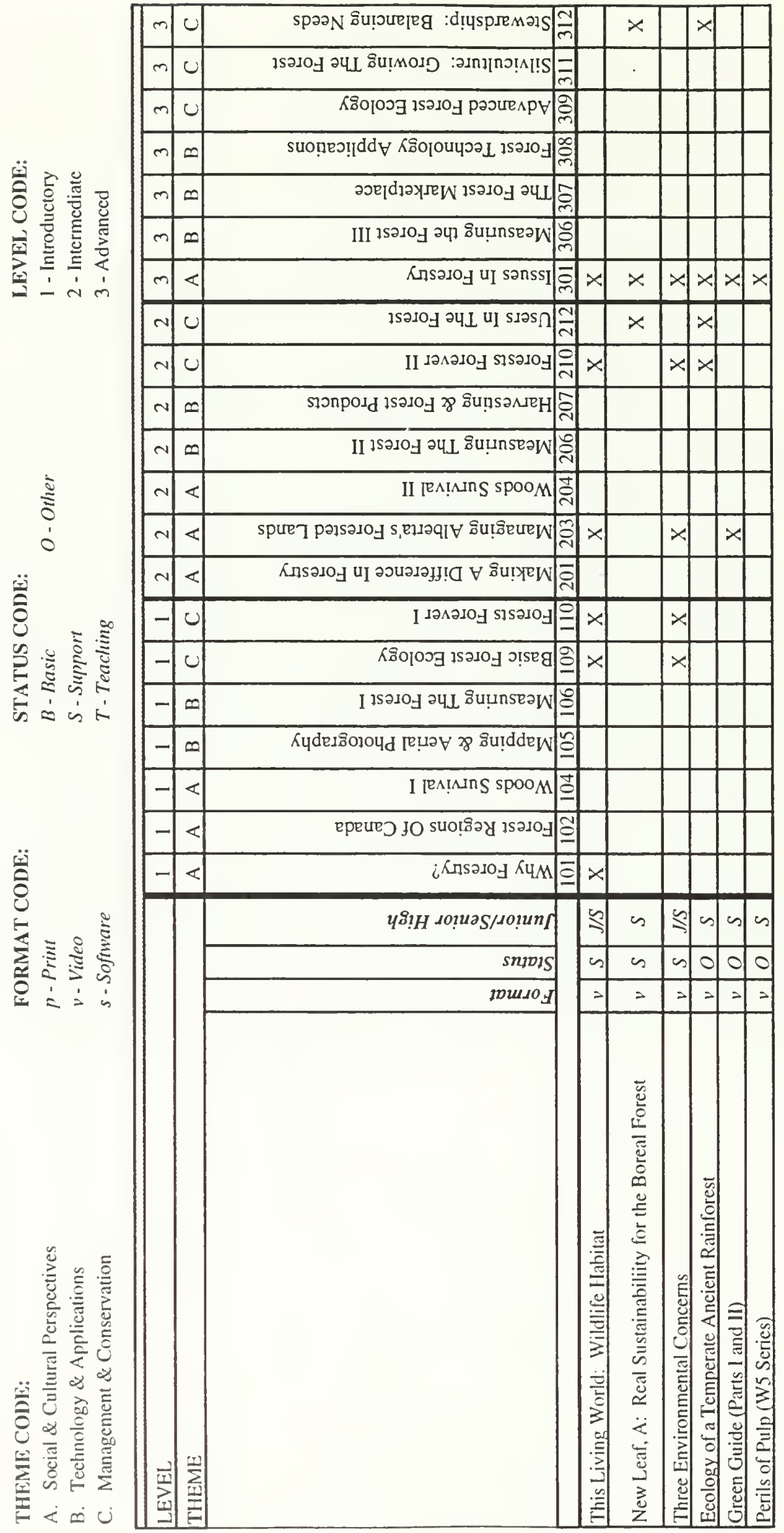




\section{OTHER RESOURCES}

These titles are provided as a service only to assist local jurisdictions to identify resources that contain potentially useful ideas for teachers. Alberta Education has done a preliminary review of the resources. However, the responsibility to evaluate these resources prior to selection rests with the user, in accordance with any existing local policy.

\begin{tabular}{|c|c|}
\hline $\begin{array}{c}\text { Distributor } \\
\text { Code }\end{array}$ & Other Resources \\
\hline EPPC & $\begin{array}{l}\text { Alberta Timber Harvest Planning and Operating Ground Rules. Edmonton, AB: } \\
\text { Alberta Forestry, Lands and Wildlife, 1986. Book. }\end{array}$ \\
\hline ECA & $\begin{array}{l}\text { Alberta's Clean Air Act. Edmonton, AB: Environment Council of Alberta, } 1985 . \\
\text { Booklet. }\end{array}$ \\
\hline $\mathrm{ECA}$ & $\begin{array}{l}\text { Alberta's Clean Water Act. Edmonton, AB: Environment Council of Alberta, } \\
\text { 1985. Booklet. }\end{array}$ \\
\hline EPPC & Alberta's Forests. Edmonton, AB: Alberta Forestry, Lands and Wildlife, 1988. \\
\hline EPPC & Alberta's Managed Forests. Edmonton: Alberta, AB Forest Service. Book. \\
\hline EPPC & $\begin{array}{l}\text { Alberta's Public Land and Resources - Planning for the Future. Edmonton, AB: } \\
\text { Alberta Forestry, Lands and Wildlife. Book. }\end{array}$ \\
\hline EPPC & $\begin{array}{l}\text { Alberta's Threatened Wildlife Series. Edmonton, AB: Alberta Environmental } \\
\text { Protection. Factsheet Series. }\end{array}$ \\
\hline LPP & $\begin{array}{l}\text { Animal Tracks of Western Canada. Joanne Barwise. Edmonton, AB: Lone Pine } \\
\text { Publishing, 1989. Book. }\end{array}$ \\
\hline SSC & $\begin{array}{l}\text { Benefits of Wildlife, The. Ottawa, Canada: Canadian Wildlife Service, } 1990 . \\
\text { Booklet. }\end{array}$ \\
\hline SSC & $\begin{array}{l}\text { Canada's Eight Forest Regions. Ottawa, ON: Environment Canada, Forestry } \\
\text { Service, 1974. Pamphlet. }\end{array}$ \\
\hline FOCA & $\begin{array}{l}\text { Canada's Forest Heritage. Canadian Council of Forest Ministers. Ottawa, ON: } \\
\text { Forestry Canada, 1986. Book. }\end{array}$ \\
\hline PIAD & $\begin{array}{l}\text { Canadian Environmental Education Catalogue, The. Drayton Valley, AB: } \\
\text { Pembina Institute for Appropriate Development, 1991. Catalogue. }\end{array}$ \\
\hline CBE & $\begin{array}{l}\text { Canoe Tripping. N. Kelba, et al. Calgary, AB: Calgary Board of Education, } \\
\text { 1983. Booklet. }\end{array}$ \\
\hline
\end{tabular}


Other Resources (continued)

\begin{tabular}{|c|c|}
\hline $\begin{array}{l}\text { Distributor } \\
\text { Code }\end{array}$ & Other Resources \\
\hline $\mathrm{CBE}$ & $\begin{array}{l}\text { Canoeing. B. Hans, et al. Calgary, AB: Calgary Board of Education, } 1980 . \\
\text { Booklet. }\end{array}$ \\
\hline ENED & $\begin{array}{l}\text { Caring For the Land Teaching Kit (Grades 7-9). Edmonton, AB: Alberta } \\
\text { Environmental Protection, Education Branch, 1993. Teacher's guide and } \\
\text { student material. }\end{array}$ \\
\hline NDM & $\begin{array}{l}\text { Ecology of a Temperate Ancient Rain Forest. Survival/Anglia. Eugene, OR: } \\
\text { New Dimension Media. 1991. Videotape. }\end{array}$ \\
\hline EPPC & $\begin{array}{l}\text { Ecoregions of Alberta. Edmonton, AB: Alberta Forestry, Lands and Wildlife, } \\
\text { 1992. Book. }\end{array}$ \\
\hline SSC & $\begin{array}{l}\text { Endangered Species in Canada. Ottawa, ON: Canadian Wildlife Service, } 1990 . \\
\text { Brochure. }\end{array}$ \\
\hline SSC & $\begin{array}{l}\text { Fact Sheet: The Forest Tent Caterpillar. Ottawa, ON: Canadian Forestry } \\
\text { Service, 1975. Pamphlet. }\end{array}$ \\
\hline CPPA & $\begin{array}{l}\text { Farming Canada's Forests: Forest Management and Silviculture. Montreal, PQ: } \\
\text { Canadian Pulp and Paper Association. Booklet. }\end{array}$ \\
\hline LRDC & $\begin{array}{l}\text { Fifty More Things You Can Do To Save The Earth. Earthworks Group. } \\
\text { Berkeley, CA: Andrews and McMeel, } 1989 .\end{array}$ \\
\hline LRDC & $\begin{array}{l}\text { Fifty Simple Things Kids Can Do To Save The Earth. John Javna. Berkeley, CA: } \\
\text { Andrews and McMeel, 1990. Book. }\end{array}$ \\
\hline $\mathrm{CBE}$ & $\begin{array}{l}\text { Fires \& Stoves. N. Kelba, et al. Calgary, AB: Calgary Board of Education, } \\
\text { 1983. Booklet. }\end{array}$ \\
\hline EPPC & $\begin{array}{l}\text { First Harvest, The. Edmonton, AB: Alberta Energy and Natural Resources. } \\
\text { Pamphlet. }\end{array}$ \\
\hline ENED & $\begin{array}{l}\text { Focus On Series (Acidic Deposition, Air Quality, Environment, Greenhouse } \\
\text { Effect, Land Reclamation, Ozone Depletion, Pesticides, Pollution, Recycling, } \\
\text { Water Conservation). Edmonton, AB: Alberta Environmental Protection, } \\
\text { Education Branch. Booklets. }\end{array}$ \\
\hline DEEF & $\begin{array}{l}\text { Forest, The: Understanding It, Using It, Keeping It. Don Harris and Wendy } \\
\text { Pobjoy. Charlottetown, PEI: Department of Energy and Forestry, } 1991 . \\
\text { Guidebook. }\end{array}$ \\
\hline
\end{tabular}


Other Resources (continued)

\begin{tabular}{|c|c|}
\hline $\begin{array}{c}\text { Distributor } \\
\text { Code }\end{array}$ & Other Resources \\
\hline AFPA & $\begin{array}{l}\text { Forest Care: Codes of Practice. Edmonton, AB: Alberta Forest Products } \\
\text { Association. 1994. Pamphlet. }\end{array}$ \\
\hline FOCA & $\begin{array}{l}\text { Forest Explorers, The. Canadian Council of Forest Ministers. Ottawa, ON: } \\
\text { Forestry Canada. Booklet. }\end{array}$ \\
\hline EPPC & $\begin{array}{l}\text { Forest Land Use Zones. Edmonton, AB: Alberta Forestry, Lands and Wildlife. } \\
\quad \text { Pamphlet. }\end{array}$ \\
\hline EPPC & $\begin{array}{l}\text { Forest Landscape Management Guidelines for Alberta. Edmonton, AB: Alberta } \\
\quad \text { Forestry, Lands and Wildlife, 1986. Book. }\end{array}$ \\
\hline AFPA & $\begin{array}{l}\text { Forest Line. Edmonton, AB: Alberta Forest Products Association. Quarterly } \\
\text { newsletter. }\end{array}$ \\
\hline SSC & $\begin{array}{l}\text { Forest Regions of Canada. J.S. Rowe. Ottawa, ON: Canadian Forestry Service, } \\
\text { Supply and Services Canada. } 1977 \text {. Student text. }\end{array}$ \\
\hline AFA & $\begin{array}{l}\text { Forest Resources Directory. Edmonton, AB: Alberta Forestry Association, } 1993 . \\
\text { Directory. }\end{array}$ \\
\hline OFA & $\begin{array}{l}\text { Forestry Manual For Ontario Secondary School Teachers, A. G.R. Morrison. } \\
\text { Ottawa, ON: The Ontario Forestry Association, 1990. Guidebook. }\end{array}$ \\
\hline CFA & $\begin{array}{l}\text { Forestry on the Hill (Series: Clearcutting, Biodiversity and Monocultures, } \\
\text { Herbicides, Forest Wildfires). Ottawa, ON: Canadian Forestry Association. } \\
\text { 1991-1993. Booklets. }\end{array}$ \\
\hline EPPC & $\begin{array}{l}\text { Forests and Water. Edmonton, AB: Alberta Energy and Natural Resources, } \\
\text { 1985. Pamphlet. }\end{array}$ \\
\hline EPPC & $\begin{array}{l}\text { Forests For The Future: Pine Ridge Forest Nursery. Edmonton, AB: Alberta } \\
\text { Forestry, Lands and Wildlife, 1986. Pamphlet. }\end{array}$ \\
\hline EPPC & $\begin{array}{l}\text { Framework for Alberta's Special Places, A (Natural Regions Report No. 1). } \\
\text { Edmonton, AB: Alberta Parks Service. Booklet. }\end{array}$ \\
\hline CBE & $\begin{array}{l}\text { Freshwater Ecosystems. N. Kelba, et al. Calgary, AB: Calgary Board of } \\
\text { Education, 1992. Booklet. }\end{array}$ \\
\hline CPPA & $\begin{array}{l}\text { From Watershed to Watermark. Montreal, PQ: Canadian Pulp and Paper } \\
\text { Association, 1987. Booklet. }\end{array}$ \\
\hline
\end{tabular}


Other Resources (continued)

\begin{tabular}{|c|c|}
\hline $\begin{array}{c}\text { Distributor } \\
\text { Code }\end{array}$ & Other Resources \\
\hline EPPC & $\begin{array}{l}\text { Genetics and Tree Improvement: Better Forests for the Future. Edmonton, AB: } \\
\text { Alberta Energy and Natural Resources, 1983. Booklet. }\end{array}$ \\
\hline EPPC & $\begin{array}{l}\text { Grazing in the Green Area. Edmonton, AB: Alberta Energy and Natural } \\
\text { Resources, 1984. Pamphlet. }\end{array}$ \\
\hline $\mathrm{PBC}$ & $\begin{array}{l}\text { Green Future: How To Make A World of Difference. Lorraine Johnson. } \\
\text { Markham, ON: Penguin Books, 1990. Textbook. }\end{array}$ \\
\hline $\mathrm{ACC}$ & $\begin{array}{l}\text { Green Guide, The (Series I and II). Edmonton, AB: ACCESS: The Education } \\
\text { Station, 1991. Videotapes. }\end{array}$ \\
\hline EPPC & $\begin{array}{l}\text { Green Tree Trailblazer Leader Manual. Edmonton, AB: Alberta Provincial } \\
\text { Advisory Council, Junior Forest Warden Association, 1992. Book. }\end{array}$ \\
\hline EPPC & $\begin{array}{l}\text { Growing Opportunity, A: Alberta's Forest Resources. Edmonton, AB: Alberta } \\
\quad \text { Forestry, Lands and Wildlife. Booklet. }\end{array}$ \\
\hline SSC & $\begin{array}{l}\text { Hinterland Who's Who (Series). Ottawa, ON: Canadian Wildlife Service. } \\
\text { Monographs. }\end{array}$ \\
\hline $\mathrm{OCV}$ & $\begin{array}{l}\text { How Green Is Your School? Don E. McAllister. Ottawa, ON: Ocean Voice, } \\
\text { 1991. Booklet. }\end{array}$ \\
\hline $\mathrm{CBE}$ & $\begin{array}{l}\text { Human Environments. N. Kelba, et al. Calgary, AB: Calgary Board of } \\
\text { Education, 1993. Teacher Resource Manual. }\end{array}$ \\
\hline EPPC & $\begin{array}{l}\text { Industrial Land Disturbance and Reclamation in Forestry Areas. Edmonton, } \\
\text { AB: Alberta Forestry, Lands and Wildlife, 1992. Pamphlet. }\end{array}$ \\
\hline CBE & $\begin{array}{l}\text { Kananaskis Country Environmental Education Teaching Activity Guide: Earth } \\
\text { Science. R. Lengsfeld, et al. Calgary, AB: Calgary Board of Education, } \\
\text { 1987. Guidebook. }\end{array}$ \\
\hline AFPA & $\begin{array}{l}\text { Key Issues Relating to the Alberta Forest Industry. Edmonton, AB: Alberta } \\
\text { Forest Products Association, 1992. Pamphlet. }\end{array}$ \\
\hline ENED & $\begin{array}{l}\text { Land Conservation Education Program. Edmonton, AB: Alberta Environmental } \\
\text { Protection, Education Branch. Teacher's guide and student materials. }\end{array}$ \\
\hline FHW & $\begin{array}{l}\text { Mammals of the Northern Rockies. Tom J. Ulrich. Missoula, MT: Mountain } \\
\text { Press Publishing Company, 1990. Book. }\end{array}$ \\
\hline
\end{tabular}


Other Resources (continued)

\begin{tabular}{|c|c|}
\hline $\begin{array}{l}\text { Distributor } \\
\text { Code }\end{array}$ & Other Resources \\
\hline FOCA & $\begin{array}{l}\text { Managing Your Woodland: A Non-Forester's Guide To Small-Scale Forestry in } \\
\text { British Columbia. Canadian Forestry Service. Ottawa, ON: Forestry } \\
\text { Canada, 1988. Book. }\end{array}$ \\
\hline EPPC & $\begin{array}{l}\text { Native Trees of Alberta. Edmonton, AB: Alberta Forestry, Lands and Wildlife. } \\
\text { Pamphlet. }\end{array}$ \\
\hline EPPC & $\begin{array}{l}\text { Natural Regions of Alberta: Poster Series. Edmonton, AB: Alberta } \\
\text { Environmental Protection, 1990. Posters and manual. }\end{array}$ \\
\hline $\mathrm{CBE}$ & $\begin{array}{l}\text { Navigation. N. Kelba, et al. Calgary, AB: Calgary Board of Education, } 1983 . \\
\text { Booklet. }\end{array}$ \\
\hline $\mathrm{CBE}$ & $\begin{array}{l}\text { Nutrition. N. Kelba, et al. Calgary, AB: Calgary Board of Education, } 1983 . \\
\text { Booklet. }\end{array}$ \\
\hline EPPC & $\begin{array}{l}\text { Occupational Profile: (Forest Technologist, Forester/Forestry Scientist, Heavy } \\
\text { Duty Equipment Operator, Logging and Forestry Workers). Edmonton, AB: } \\
\text { Alberta Career Development and Employment. Pamphlet. }\end{array}$ \\
\hline AFPA & $\begin{array}{l}\text { Our Growing Resource: Alberta's Forest Industry.....Meeting Global Challenges. } \\
\text { Edmonton, AB: Alberta Forest Products Association, 1992. Booklet. }\end{array}$ \\
\hline ENED & $\begin{array}{l}\text { Pesticide Education Program. Edmonton, AB: Alberta Environmental } \\
\text { Protection, Education Branch. Teacher's guide and student materials. }\end{array}$ \\
\hline CTV & Perils of Pulp. Toronto, ON: CTV Television Network Ltd., 1992. Videotape. \\
\hline EPPC & $\begin{array}{l}\text { Reforestation in Alberta. Edmonton, AB: Alberta Forestry, Lands and Wildlife. } \\
\text { Booklet. }\end{array}$ \\
\hline EPPC & $\begin{array}{l}\text { Resource Road Planning Guidelines. Edmonton, AB: Alberta Energy and } \\
\text { Natural Resources, 1985. Book. }\end{array}$ \\
\hline EPPC & $\begin{array}{l}\text { Spruce Budworm Management. Edmonton, AB: Alberta Forestry, Lands and } \\
\text { Wildlife Forest Service, 1992. Pamphlet. }\end{array}$ \\
\hline FOCA & $\begin{array}{l}\text { Sustainable Forests: A Canadian Commitment. Canadian Council of Forest } \\
\text { Ministers. Ottawa, ON: Forestry Canada. 1992. Book. }\end{array}$ \\
\hline EPPC & $\begin{array}{l}\text { Timber Harvesting. Edmonton, AB: Alberta Energy and Natural Resources, } \\
\text { 1983. Pamphlet. }\end{array}$ \\
\hline
\end{tabular}


Other Resources (continued)

\begin{tabular}{|l|l|}
\hline $\begin{array}{c}\text { Distributor } \\
\text { Code }\end{array}$ & \multicolumn{1}{c|}{ Other Resources } \\
\hline EPPC & $\begin{array}{c}\text { Timber Harvesting and the Environment. Edmonton, AB: Alberta Forestry, } \\
\text { Lands and Wildlife. Pamphlet. }\end{array}$ \\
LPP & $\begin{array}{l}\text { Timber Quota Policy. Edmonton, AB: Alberta Energy and Natural Resources, } \\
\text { 1984. Book. }\end{array}$ \\
ENED & $\begin{array}{l}\text { Trees and Shrubs of Alberta. Kathleen Wilkinson. Edmonton, AB: Lone Pine } \\
\text { Publishing, 1990. Book. } \\
\text { Water In Alberta: The Living Flow. Edmonton, AB: Alberta Environmental } \\
\text { Protection, Education Branch, 1993. Teacher resource kit. }\end{array}$ \\
& $\begin{array}{c}\text { Water Quality Questions: The Nature and Importance of Water Quality Variables } \\
\text { in Alberta. Edmonton, AB: Alberta Environmental Protection, Education } \\
\text { Branch, 1990. Teacher guide and student booklet. }\end{array}$ \\
SSC & $\begin{array}{l}\text { What We Can Do For Our Environment: Hundreds of Things To Do Now. (4th } \\
\text { edition.) Hull, PQ: Environment Canada, Minister of Supply and Services, } \\
1991 . \text { Booklet. }\end{array}$
\end{tabular}




\section{ADDITIONAL SOURCES}

Available to Forestry teachers, both locally and provincially, are many resources that can be used to enhance Career and Technology Studies courses. These resources can be accessed through the community, government agencies, resource centres and organizations. Some of these sources, e.g., government departments, undergo frequent name and/or telephone number changes. Please check your telephone directory or an appropriate government directory.

The following is a partial list of sources to consider:

\section{TEACHER-LIBRARIANS}

Planned and purposeful use of library resources helps students grow in their ability to gather, process and share information. Research activities require access to an adequate quantity and variety of appropriate, up-to-date print and non-print resources from the school library, other libraries, the community and additional sources. Some techniques to consider are:

- planning together

- establishing specific objectives

- integrating research skills into planning.

Cooperation between the teacher-librarian and the subject area teacher in the development of effectively planned resource-based research activities ensures that students are taught the research skills as well as the subject content.

Also see Focus on Research: A Guide to Developing Student's Research Skills referenced in the Alberta Education Resources section.

\section{ALBERTA EDUCATION SOURCES}

The following monographs are available for purchase from:
Learning Resources Distributing Centre

12360 - 142 Street

Edmonton, $\mathrm{AB}$

T5L 4X9

Telephone: 427-2767

Fax: 422-9750

Please consult the "Support Documents" section or the "Legal, Service and Information Publications" section in the Buyers Guide for ordering information and costs.

\section{Developmental Framework Documents}

- The Emerging Student: Relationships Among the Cognitive, Social and Physical Domains of Development, 1991

This document looks at the whole child, or student, as a productive learner, integrating all the domains of development: cognitive, social and physical. It emphasizes the need for providing balanced curriculum and instruction.

- Students' Interactions Developmental Framework: The Social Sphere, 1988

This document focuses on the student as a social being. It looks at the student's affective or emotional growth and examines moral development. These three domains make up the social sphere.

- Students' Physical Growth: Developmental Framework Physical Dimension, 1988

This document examines children's normal physical growth in three areas: perceptual, structural and motor development. In none of these areas is the child's growth in a single continuous curve throughout the first two decades of life. Physical growth is characterized by periods of rapid growth and periods of slower growth. Consequently, differences and changes in growth patterns may affect the timing of certain learning processes. 
- Students' Thinking: Developmental Framework Cognitive Domain, 1987

This document explores children's cognitive development from infancy to adolescence. The Piagetian stages of pre-operational, concrete operational and formal operational thinking are explained. Suggestions for improving the learning process are also presented.

\section{Others}

- Focus on Research: A Guide to Developing Students' Research Skills, 1990

This document outlines a resource-based research model that helps students manage information efficiently and effectively, and in this process, to gain skills that are transferable to all school and work situations. This model provides a developmental approach to teaching students how to do research.

- Teaching Thinking: Enhancing Learning, 1990

Principles and guidelines for cultivating thinking, ECS to Grade 12, have been developed in this resource. It offers a definition of thinking, describes nine basic principles on which the suggested practices are based, and discusses possible procedures for implementation in schools and classrooms.

\section{OTHER GOVERNMENT SOURCES}

\section{ACCESS: The Education Station}

ACCESS: The Education Station offers a variety of resource and services to teachers. For a nominal dubbing and tape fee, teachers may have ACCESS: The Education Station audio and video library tapes copied.

ACCESS: The Education Station publishes a listing of audio and video cassettes as well as a comprehensive programming schedule.
Of particular interest are the Career and Technology Studies videos that are available with teacher utilization guides. The guides outline key points in each video and suggest questions for discussion, classroom projects and other activities. Video topics are listed in the Support Learning Resources section of this Guide. The videos listed and accompanying support material can be obtained from:

ACCESS: The Education Station

3720 - 76 Avenue

Edmonton, $\mathrm{AB}$

T5B 2N6

Telephone: 440-7777 (in Edmonton)

1-800-352-8293

(outside Edmonton)

\section{Agriculture Canada}

Communications Branch

Ottawa, ON

K1A $0 C 7$

Telephone: (819) 994-0246

General and Technical Publications (a comprehensive listing of free and inexpensive print materials on a variety of topics in agriculture; updated each year).

\author{
Alberta Advanced Education and Career \\ Development \\ Information Development and Marketing \\ 9th Floor, City Centre Building \\ $10155-102$ Street \\ Edmonton, $\mathrm{AB}$ \\ T5J 4L5 \\ Telephone: 422-1794 \\ Fax: 422-5126
}

Career Information Catalogue Update, 1994

The Career Planner

Children Challenges Choice

Entrepreneur: A Big Word for Small Business

Rural Women as Business Entrepreneurs

Positive Works

Skills are your Passport. 
Videos on career planning and entrepreneurial topics are available through the library of this department. Call 422-4752 for more information. The following videos are representative of the library's holdings:

The Entrepreneur

Get a Job

A Head for Business

The Seven Phases of a Job Interview.

Alberta Agriculture, Food And Rural

Development

Print Media Branch

7000 - 113 Street

Edmonton, $\mathrm{AB}$

T6H 5 T6

Telephone: $427-2121$

Fax: 427-2861

Publications List (a comprehensive listing of free and inexpensive print materials on a variety of topics in agriculture; updated each year).

Broadcast Media Branch

7000 - 113 Street

Edmonton, $\mathrm{AB}$

T6H 5 T6

Telephone: 427-2127

Fax: 427-2861

Audio Visual Catalogue (an annotated listing of films and videos available for loan upon request; updated each year).

Alberta Tree Nursery and Horticulture Centre R.R. \#6

Edmonton, $\mathrm{AB}$

T5B $4 \mathrm{~K} 3$

Telephone: 422-1789

Fax: 427-6096

Alberta Economic Development and Tourism (formerly Alberta Economic Development and Trade)

Strategic Planning and Research

9th Floor, Sterling Place

9940 - 106 Street

Edmonton, $\mathrm{AB}$

T5K 2 P6

Telephone: 422-9494

Fax: 422-5922
Financing a Small Business

Marketing a Small Business

Starting a Small Business.

\author{
Alberta Environmental Protection \\ Education Branch \\ 12th Floor, 9820 - 106 Street \\ Edmonton, $\mathrm{AB}$ \\ T5K $2 \mathrm{~J} 6$ \\ Telephone: 427-6310 \\ Fax: 427-2512 \\ Land Conservation Education Program \\ Pesticide Education Program \\ The Water Literacy Program \\ Focus On Series \\ Poster Education Series \\ (Workshops and presentations on these program \\ materials can be arranged.)
}

Alberta Environmental Protection

Land and Forest Services

9920 - 108 Street

10th Floor, Bramalea Building

Edmonton, $\mathrm{AB}$

T5K 2M4

Telephone: 427-3551

Fax: 427-0292

Junior Forest Wardens Program.

Alberta Environmental Protection

Fish and Wildlife Services

9920 - 108 Street

Edmonton, $\mathrm{AB}$

T5K 2M4

Telephone: 944-0313

Or

200 Sloan Square

5920 - 1A Street SW

Calgary, AB

T2H 0G3

Telephone: 297-6423

Fax: 297-2843 
Project Wild

Alberta Conservation and Hunter Education

Program

Alberta Fishing Education Program.

\section{Alberta Environmental Protection}

Alberta Parks Service Division

8th Floor, Standard Life Centre

10405 Jasper Avenue

Edmonton, $\mathrm{AB}$

T5J $3 \mathrm{~N} 4$

Telephone: 427-6781

Fax: 427-5980

Alberta Justice

Chief Provincial Firearms Office

Ground Floor, 10365 - 97 Street

Edmonton, $\mathrm{AB}$

T5J 3W5

Telephone: 427-0437

Fax: 427-1100

Canadian Firearms Safety Course.

\section{Alberta Labour}

9940 - 106 Street

Edmonton, $\mathrm{AB}$

T5K 2N2

Telephone: 427-8848

Offices are also in Calgary, Camrose, Edson, Fort McMurray, Grande Prairie, Lethbridge, Medicine Hat, Red Deer and Vermillion.

Alberta Tourism Education Council (ATEC)
12th Floor, Sterling Place
$9940-106$ Street
Edmonton, AB
T5K 2N2
Telephone: $422-0781$
Fax: 422-3069

Employment Standards Code (Teacher resource package).

\section{Energy Conservation and Renewable Energy}

Western Regional Office

200 Grandin Park Plaza

22 Winston Churchill Avenue

St. Albert, AB

T8N $1 B 4$

Or

Regional Communications

355, 200 - 4 Avenue SE

Calgary, AB

$\mathrm{T} 2 \mathrm{G} 4 \mathrm{X} 3$

\section{Environment Canada}

Inquiry Centre

1st Floor, 10 Wellington Street

Hull, Quebec

$\mathrm{K} 1 \mathrm{~A} \mathrm{OH} 3$

Telephone: (819) 997-2800

Fax: (613) 953-2225

Or

Environment Canada

Canadian Wildlife Service

Communications Directorate

Western and Northern Region

200, 4999 - 98 Avenue

Edmonton, $\mathrm{AB}$

T6B $2 \times 3$

Telephone: 951-8720

Fax: 495-2615

Or

\section{Environment Canada}

Canadian Parks Service

Room 552, 220 - 4 Avenue SE

Calgary, $\mathrm{AB}$

T2P $3 \mathrm{H} 8$

Telephone: $292-4401$

Environmental Council of Alberta

400, 9925 - 109 Street

Edmonton, AB T5K 2J8

Telephone: 427-5792

Fax: 427-0388 


\section{Forestry Canada}

351 St. Joseph Boulevard

Hull, Quebec

K1A 1G5

Telephone: (819) 997-1107

Or

$5320-122$ Street

Edmonton, $\mathrm{AB}$

T6H 3S5

Telephone:

Industry and Science Canada

Consumer Affairs

10225-100 Avenue

Edmonton, $\mathrm{AB}$

T5J 0A1

Telephone: 495-2485

Fax: 495-6451

Or

$301,510-12$ Avenue SW

Calgary, $\mathrm{AB}$

T2R OH3

Telephone: 292-5604

Fax: 292-6175

\section{National Film Board of Canada (NFB)}

The NFB has numerous films and videotapes that may be suitable for Forestry. For a listing of NFB films and videotapes indexed by title, subject and director, or for rental or purchase of NFB films and videotapes, call 1-800-2677710 (toll-free).

Educational Marketing Officers in Calgary and Edmonton are available, province wide, for workshops, conferences, professional development days and similar activities. For northern Alberta and the Northwest Territories, the Educational Marketing Officer can be reached at 495-3012 (fax, 4956412). For southern Alberta, contact the Educational Marketing Officer at 292-5411 (fax, 292-5458).
ACCESS: The Education Station and some school boards have acquired duplication rights to some NFB videotapes. Please consult the relevant catalogues in your school or school district.

The Calgary Public Library has a selection of NFB films and videotapes that can be borrowed free of charge with a Calgary Public Library borrower's card. For further information, contact:

Calgary Public Library

Films and Recordings Department

616 Macleod Trail SE

Calgary, AB

T2G $2 \mathrm{M} 2$

Telephone: 260-2781

Fax: 292-5458

\section{Resource Centres}

\section{Urban Resource Centres}

Calgary Board of Education

Supervisor, Education Media

3610 - 9 Street SE

Calgary, AB

T2G 3C5

Telephone: 294-8540

Fax: 287-9739

Calgary Separate School Board

Supervisor, Instructional Materials

1000 - 5 Avenue SW

Calgary, AB

T2P 4T9

Telephone: 246-6663

Fax: 249-3054

\section{County of Strathcona}

Director, Learning Resource Service

2001 Sherwood Drive

Sherwood Park, AB

T8A 3W7 
Edmonton Public School Board

Learning Resource Consultant

Centre for Education

One Kingsway Avenue

Edmonton, $\mathrm{AB}$

T5H 4G9

Telephone: $429-8320$

Fax: 429-8318

Lakeland School District No. 5460

Area Superintendent

Postal Bag 1001

6005 - 50 Avenue

Bonnyville, $\mathrm{AB}$

T9N 2L4

Telephone: 826-3145

Fax: 826-4600

\section{Medicine Hat School District No. 76}

IMC Manager

601 - 1 Avenue SW

Medicine Hat, AB

T1A 4 Y7

Telephone: 526-1323

Fax: 529-5339

\section{Red Deer Public School Board}

Coordinator of Instruction

4747 - 53 Street

Red Deer, AB

T4N 2E6

Telephone: 343-1405

Fax: $347-8190$

St. Anthony's Teacher Centre

Supervisor, Curricular Resources

10425 - 84 Avenue

Edmonton, $\mathrm{AB}$

T6E $2 \mathrm{H} 3$

Telephone: 439-7356

Fax: 433-0181

\section{Regional Resource Centres}

\section{Zone I}

Zone I Regional Resource Centre

Film Supervisor

10020 - 101 Street

P.O. Box 6536

Peace River, AB
T8S 1S3

Telephone: 624-3187

Fax: 624-5941

Zone II and III

Central Alberta Media Services (CAMS)

Film Supervisor

182 Sioux Road

Sherwood Park, AB

T8A 3K5

Telephone: 464-5540

Fax: 467-5469

Zone IV

Alberta Central Regional Education

Services (ACRES)

Operations Manager

County of Lacombe

Parkland Regional Library Building

56 Avenue and 53 Street Corner

Box 3220

Lacombe, $\mathrm{AB}$

TOC 1S0

Telephone: 782-5730

Fax: 782-5831

Zone V

South Central Alberta Resource Centre

(SCARC)

c/o County of Wheatland

435 B Hwy \#1

Strathmore, AB

T1P $1 \mathrm{~J} 4$

Telephone: 934-5028

Fax: $934-4889$

Zone VI

Southern Alberta Learning Resource Centre (SALRC)

Film Supervisor

Provincial Government Administration

Building

120, 909 Third Avenue North

Box 845

Lethbridge, $A B$

T1J $3 Z 8$

Telephone: $320-7807$

Fax: 320-7817 
Statistics Canada

Regional Office

8th Floor, Park Square

10001 Bellamy Hill

Edmonton, $\mathrm{AB}$

T5J 3B6

Telephone: 495-3023

Fax: 495-5318

\section{PROFESSIONAL ASSOCIATIONS}

\author{
Alberta Teachers' Association \\ Specialist Council \\ Environmental and Outdoor Education \\ Barnett House \\ 11010 - 142 Street \\ Edmonton, $\mathrm{AB}$ \\ T5N 2R1
}

Association of Canada Land Surveyors

Box 5378

Station F

Ottawa, ON

$\mathrm{K} 2 \mathrm{C} 3 \mathrm{~J} 1$

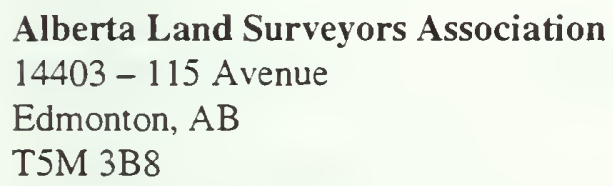

Alberta Logging Association

10916 - 97 Avenue

Grande Prairie, AB

T8V 3 J8
Alberta Registered Professional Foresters
Association
55, 9912 - 106 Street
Edmonton, $\mathrm{AB}$
T5K 1C5
Canadian Association of Plant Physiologists
c/o Department of Botany
University of Guelph
Guelph, ON
N1G 2W1

Canadian Botanical Association

Agriculture Canada

Biosystems Research Centre

Saunders Building, CDF

Ottawa, ON

K1A 0C6

\section{Canadian Society of Environmental}

Biologists

Box 962 Postal Station F

Toronto, ON

M4Y 2N9

Industrial Vegetation Management

Association of Alberta

9205 - 37 A venue

Edmonton, AB

T6E 5K9

\section{INDUSTRY ORGANIZATIONS}

\author{
Alberta Forest Products Association \\ 11710 Kingsway Avenue \\ Edmonton, $\mathrm{AB}$ \\ T5G 0X5 \\ Telephone: 452-2841 \\ Fax: 455-0505
}

Canadian Forest Products Ltd.

Postal Bag 100

Grande Prairie, AB

T8V 3 A3

Telephone: 538-7711

Fax: 538-7800

Spray Lake Sawmills (1980) Ltd.

P.O. Box 100

Cochrane, AB

TOL OWO

Telephone: 932-2234

Fax: 932-6675

Weldwood of Canada Limited

760 Switzer Drive

Hinton, $A B$

T7V 1V7

Telephone: 865-2251

Fax: 865-8129 
Weyerhaeuser Canada Ltd.

P.O. Bag 1020

Grande Prairie, AB

T8V 3A9

Telephone: $539-8500$

Fax: 539-8597

Blue Ridge Lumber (1981) Ltd.

1200, 10707 - 100 Avenue

Edmonton, $\mathrm{AB}$

T5J 3M1

Telephone: 423-7560

Fax: 423-7550

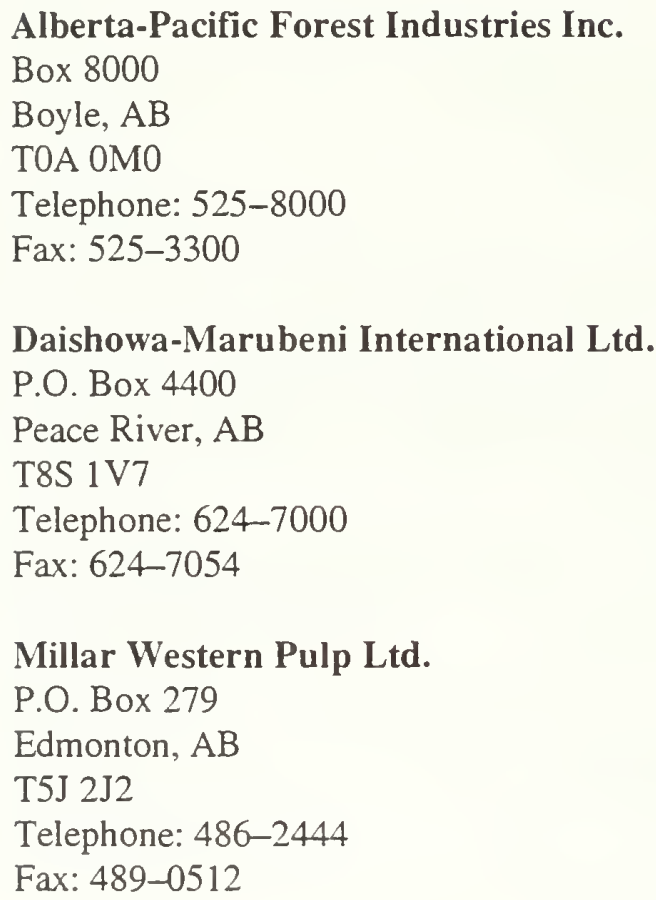

\author{
Alberta Newsprint Company Ltd. \\ P.O. Bag 9000 \\ Whitecourt, $\mathrm{AB}$ \\ T7S 1P9 \\ Telephone: 778-7000 \\ Fax: 778-7070 \\ Canadian Pulp and Paper Association \\ 23rd Floor, Sun Life Building \\ 1155 Metcalfe Street \\ Montreal, Quebec \\ H3B $2 \times 9$ \\ Telephone: (514) 866-6621
}

\author{
Alberta Special Waste Management Corp. \\ 610, 10909 Jasper Avenue \\ Edmonton, $\mathrm{AB}$ \\ T5J 3L9 \\ Telephone: $422-5029$ or

$$
1-800-272-8873
$$ \\ Fax: 428-9627
}

\section{ENVIRONMENTAL FACILITIES}

The following is a partial list of facilities that provide hands-on experience for student in aspects of resource management and environmental education. Contact should be made directly with the facility to obtain details of what is offered to school groups or students.

\author{
Alberta Forest Service Museum \\ Forest Technology School \\ 1176 Switzer Drive \\ Hinton, $\mathrm{AB}$ \\ TOE $1 \mathrm{~B} 0$ \\ Telephone: $865-8211$
}

\author{
Alberta Tree Nursery and Horticulture \\ RR \#6 \\ Centre \\ 17507 Fort Road \\ Edmonton, $\mathrm{AB}$ \\ T5B 4K3 \\ Telephone: 422-1789 (in Edmonton) \\ 198-5272 (toll-free through any \\ government R.I.T.E. Operator)
}

Alford Lake Conservation Education Centre c/o Fish and Wildlife Division

Box 369

Caroline, $\mathrm{AB}$

TOM OM0

Telephone: 722-2423

\section{Bennett Environmental Education Centre}

Edmonton Public Schools

9703 - 94 Street

Edmonton, $\mathrm{AB}$

T6C 3W 1

Telephone: 468-1439 
Calgary Zoo

Botanical Gardens and Prehistoric Park

P.O. Box 3036, Station "B"

Calgary, AB

T2M 4R8

Telephone: 265-9310

\section{Crowsnest Portable Camp}

c/o Fish and Wildlife Division

200 Sloane Square

5920 - 1A Street SW

Calgary, AB

T2H $0 \mathrm{G} 3$

Telephone: 297-7639

Devonian Botanic Garden

University of Alberta

Edmonton, $\mathrm{AB}$

T6G 2E1

Telephone: 987-3054

\section{Energeum}

(Energy Resources Conservation Board)

640 - 5 Avenue SW

Calgary, AB

T2P 3G4

Telephone: $297-4293$

Environmental Resource Centre

10511 Saskatchewan Drive

Edmonton, $\mathrm{AB}$

T6E 4S1

Telephone: 433-4808

Fort Calgary Preservation Society

P.O. Box 2100, Station "M", \#106

Calgary, AB

T2P 2M5

Telephone: $290-1875$

Ft. McMurray Oil Sands Interpretive Centre

515 MacKenzie Blvd.

Ft. McMurray, AB

T9H 4X3

Telephone: 743-7167
Glenbow Museum

130 - 9 Avenue SE

Calgary, AB

T2G OP3

Telephone: 264-8300

John Janzen Nature Centre

P.O. Box 2359

Edmonton, $\mathrm{AB}$

T5J 2R7

Telephone: 434-7446

Kananaskis Field Station

Coordinator of School Programs

Bio Sciences 186

University of Calgary

2500 University Drive NW

Calgary, AB

T2N 1 N4

Telephone: 220-5355

Fax: 673-3671

McKinnon Flats Resource Education Centre

c/o Fish and Wildlife Division

200 Sloane Square

5920 - 1A Street SW

Calgary, AB

T2H 0G3

Telephone: 297-7639

Narrow Lake Conservation Education Centre

c/o Fish and Wildlife Division

Provincial Building

Athabasca, AB

TOB OBO

Telephone: 675-9137

OTHER A GENCIES

Alberta Debate and Speech Association

202, 17308 - 108 Avenue

Edmonton, $\mathrm{AB}$

T5X 3 Y8

Telephone: 484-7929

Fax: 484-2710 
Alberta Forestry Association

101, 10526 Jasper Avenue

Edmonton, $\mathrm{AB}$

T5J 1 Z7

Telephone: $428-7582$

Fax: 428-7557

Alberta's Focus on Forests

Woodlot Management Information Series

Woodlot Management Guide for the Prairie

Provinces

Alberta Foundation for Economic Education

901, 10179 - 105 Street

Edmonton, $A B$ T5J $1 E 2$

Telephone: 421-9331

Fax: 426-2987

The Chartered Banks and Canada's Economy

Labour in the Canadian Economy (teacher resource)

Retail Marketing in Canada

Using Money Wisely.

Canadian Co-operative Association

400, 275 Bank Street

Ottawa, ON K2P 2L6

Cooperative Entrepreneurship: A Case Study in Worker Ownership

\section{Canadian Foundation for Economic}

Education

501, 2 St. Clair Avenue West

Toronto, ON M4V 1L5

Telephone: (416) 968-2236

Fax: (416) 968-0488

Entrepreneurship: A Primer for Canadians (teacher resource)

Labour Market: Teacher's Resource Package (teacher resource)

Money and Youth

Women in the Work Force.

Canadian Wildlife Federation

1673 Carling Avenue

Ottawa, ON K2A 3Z1

Telephone: (613) 725-2191

Fax: (613) 725-2902
Canadian Parks and Wilderness Society

160 Bloor Street East

Suite 1150

Toronto, ON

M4W 1B9

Telephone: (416) 972-0868

The Conference Board of Canada

255 Smyth Road

Ottawa, ON

K1H 8M7

Telephone: (613) 526-3280

Fax: (613) 526-4857

Economic Forecast: Provincial Outlook (research reports, personalized information services).

\section{Ducks Unlimited Canada}

1190 Waverly Street

Winnipeg, Manitoba

R3T 2E2

\section{FEESA}

320, 9939 Jasper Avenue

Edmonton, $\mathrm{AB}$

T5J 2 X5

Telephone: $421-1497$

Fax: 425-4506

FEESA offers education training and resource materials focusing on a variety of environmental and educational needs. Programs are developed in partnership with business, industry, government, environmental and education groups.

Harmony Foundation of Canada

P.O. Box 4016, Station C

Ottawa, ON K1Y 4P2

Telephone: (613)230-7353

Junior Achievement of Northern Alberta

(Alberta north of Lacombe, and NWT)

161, 10700 - 104 Avenue

Edmonton, $\mathrm{AB}$

T5J 4S2

Telephone: 482-1421

Fax: 428-1031 
Junior Achievement of Southern Alberta

(Lacombe and south)

739 - 10 Avenue SW

Calgary, $A B$

T2R 0B3

Telephone: 263-2545

Fax: 261-6988

Materials are available only where Junior Achievement has identified community business consultants and provided inservice.

\section{Kananaskis Country}

Coordinator of Environmental Education

Box 280

Canmore, $\mathrm{AB}$

TOL OMO

Telephone: 678-5508

Fax:

The Pembina Institute for Appropriate

Development

P.O. Box 7558

Drayton Valley, AB

TOE OMO

Telephone: 542-6272

Fax: 542-6464

The Canadian Environmental Education

Catalogue.

\section{Rural Education and Development}

\section{Association}

14815 - 119 Avenue

Edmonton, $\mathrm{AB}$

T5L 2N9

Telephone: 451-5959

Fax: 452-5385

List of speakers for schools

Several modules on cooperatives and entrepreneurship

Teacher resource package on cooperatives.
The SEEDS Foundation

440, 10169 - 104 Street

Edmonton, $\mathrm{AB}$

T5J 1 A5

Telephone: 424-0971

Fax: 424-2444 


\section{DISTRIBUTOR DIRECTORY}

The entries in the distributor directory are arranged alphabetically by code.

\begin{tabular}{|c|c|c|}
\hline CODE & Distributor/Address & Telephone/Fax \\
\hline $\mathrm{ACC}$ & $\begin{array}{l}\text { ACCESS: The Education Station } \\
3270-76 \text { Avenue } \\
\text { Edmonton, AB } \\
\text { T5B 2N9 }\end{array}$ & $\begin{array}{l}(403) 440-777 \\
1-800-252-9363\end{array}$ \\
\hline AFA & $\begin{array}{l}\text { Alberta Forestry Association } \\
101 \text { Alberta Block } \\
10526 \text { Jasper Avenue } \\
\text { Edmonton, AB } \\
\text { T5J } 127\end{array}$ & $\begin{array}{l}\text { (403) 428-7582 } \\
\text { Fax: (403) 428-7557 }\end{array}$ \\
\hline AFPA & $\begin{array}{l}\text { Alberta Forest Products Association } \\
200,11738 \text { Kingsway Avenue } \\
\text { Edmonton, AB } \\
\text { T5G 0X5 }\end{array}$ & $\begin{array}{l}\text { (403) 452-2841 } \\
\text { Fax: (403) 455-0505 }\end{array}$ \\
\hline $\mathrm{CBE}$ & $\begin{array}{l}\text { Calgary Board of Education } \\
\text { Education Centre Building } \\
515 \text { Macleod Trail SE } \\
\text { Calgary, AB } \\
\text { T2G 2L9 }\end{array}$ & $\begin{array}{l}\text { (403) 294-8211 } \\
\text { Fax: (403) 294-8336 }\end{array}$ \\
\hline$\overline{\mathrm{CFA}}$ & $\begin{array}{l}\text { Canadian Forestry Association } \\
\text { 203, } 185 \text { Somerset Street West } \\
\text { Ottawa, ON } \\
\text { K2P 0J2 }\end{array}$ & $\begin{array}{l}\text { (613) 232-1815 } \\
\text { Fax: (613) } 232-4210\end{array}$ \\
\hline CPPA & $\begin{array}{l}\text { Canadian Pulp and paper Association } \\
\text { 23rd Floor, Sun Life Building } \\
1155 \text { Metcalfe Street } \\
\text { Montreal, PQ } \\
\text { H3B 2X9 }\end{array}$ & (514) 866-6621 \\
\hline CTV & $\begin{array}{l}\text { CTV Program and Archive Sales } \\
42 \text { Charles Street East } \\
\text { Toronto, ON } \\
\text { M4Y 1T5 }\end{array}$ & (416) 928-6096 \\
\hline
\end{tabular}




\begin{tabular}{|c|c|c|}
\hline CODE & Distributor/Address & Telephone/Fax \\
\hline DEEF & $\begin{array}{l}\text { Prince Edward Island } \\
\text { Department of Energy and Forestry } \\
\text { Forestry Branch } \\
\text { P.O. Box } 2000 \\
\text { Charlottetown, Prince Edward Island } \\
\text { C1A 7N8 }\end{array}$ & $\begin{array}{l}\text { (902) 368-4700 } \\
\text { Fax: (902) 368-5544 }\end{array}$ \\
\hline ECA & $\begin{array}{l}\text { Environment Council of Alberta } \\
\text { 8th Floor, Weber Centre } \\
\text { 5555 Calgary Trail South } \\
\text { Edmonton, AB } \\
\text { T6H 5P9 }\end{array}$ & $427-5792$ \\
\hline ENED & $\begin{array}{l}\text { Alberta Environmental Protection, } \\
\text { Education Branch } \\
\text { 12th Floor, } 9820-106 \text { Street } \\
\text { Edmonton, AB } \\
\text { T5K 2J6 }\end{array}$ & (403) 427-6310 \\
\hline EPPC & $\begin{array}{l}\text { Environmental Protection Publications Centre } \\
\text { 14th Floor, Oxbridge Place } \\
9820 \text { - 106 Street } \\
\text { Edmonton, AB } \\
\text { T5K 2J6 }\end{array}$ & (403) 427-6132 \\
\hline FHW & $\begin{array}{l}\text { Fitzhenry and Whiteside } \\
\text { See LRDC Buyers Guide for information }\end{array}$ & \\
\hline FOCA & $\begin{array}{l}\text { Forestry Canada } \\
\text { Place Vincent Massey } \\
351 \text { St. Joseph Boulevard } \\
\text { Hull, PQ } \\
\text { K1A 1G5 }\end{array}$ & $\begin{array}{l}\text { (819) 997-1 107 } \\
\text { Fax: (819) 953-7048 }\end{array}$ \\
\hline GEP & $\begin{array}{l}\text { Gage Educational Publishing Company } \\
164 \text { Commander Blvd. } \\
\text { Agincourt, ON } \\
\text { M1S 3C7 }\end{array}$ & (416) 293-8141 \\
\hline KPB & $\begin{array}{l}\text { Key Porter Books Ltd. } \\
2775 \text { Matheson Boulevard East } \\
\text { Mississauga, ON } \\
\text { L4W 4P7 }\end{array}$ & $\begin{array}{l}\text { (416) 238-0709 } \\
\text { Fax: (416) 625-8008 }\end{array}$ \\
\hline
\end{tabular}




\begin{tabular}{|c|c|c|}
\hline CODE & Distributor/Address & Telephone/Fax \\
\hline LPP & $\begin{array}{l}\text { Lone Pine Publishing } \\
\text { 206, 10426-81 Avenue } \\
\text { Edmonton, AB } \\
\text { T6E 1X5 }\end{array}$ & $\begin{array}{l}(403) 433-9333 \\
\text { 1-800-661-9017 } \\
\text { Fax: (403) 433-9646 }\end{array}$ \\
\hline LRDC & $\begin{array}{l}\text { Learning Resources Distributing Centre } \\
12360-142 \text { Street } \\
\text { Edmonton, AB } \\
\text { T5L 4X9 }\end{array}$ & (403) 427-2767 \\
\hline NDM & $\begin{array}{l}\text { New Dimension Media } \\
\text { 85803 Lorane Highway } \\
\text { Eugene, OR } \\
\text { USA } 97405\end{array}$ & $\begin{array}{l}\text { (503) 484-7125 } \\
\text { Fax: (503) 484-5267 }\end{array}$ \\
\hline $\mathrm{OCV}$ & $\begin{array}{l}\text { Ocean Voice } \\
2883 \text { Otterson Drive } \\
\text { Ottawa, ON } \\
\text { K1V } 7 \text { B2 }\end{array}$ & (613) 996-9915 \\
\hline OFA & $\begin{array}{l}\text { Ontario Forestry Association } \\
502,150 \text { Consumers Road } \\
\text { Willowdale, ON } \\
\text { M2J 1P9 }\end{array}$ & $(416) 493-4565$ \\
\hline PBC & $\begin{array}{l}\text { Penguin Books } \\
1220 \text { Nicholson Road } \\
\text { Hewmarket, ON } \\
\text { L3Y 7V1 }\end{array}$ & (905) 836-6730 \\
\hline PIAD & $\begin{array}{l}\text { Pembina Institute for Appropriate Development } \\
\text { Box } 7558 \\
\text { Drayton Valley่, AB } \\
\text { TOE 0M0 }\end{array}$ & $\begin{array}{l}\text { (403) 542-6272 } \\
\text { Fax: (403) 542-6464 }\end{array}$ \\
\hline SSC & $\begin{array}{l}\text { Canada Communications Group } \\
\text { Place du Portage } \\
\text { Phase } 3 \text { 16A1 } \\
\text { IL Laurier Street } \\
\text { Hull, PQ } \\
\text { K1A 0S5 }\end{array}$ & (819) 956-4802 \\
\hline
\end{tabular}




\section{FORESTRY}

\section{SECTION J: SAMPLE STUDENT LEARNING GUIDES}

(INTERIM, 1996)

\section{TABLE OF CONTENTS}

A student learning guide presents information and direction to help students attain the expectations defined in a specified CTS module. It is designed to be used by students under the direction of a teacher.

The student learning guides included in this section are organized as follows:

- Why take this module?

- What do you need to know before you start?

- What will you know and be able to do when you finish?

- When should your work be done?

- How will your mark for this module be determined?

- Which resources may you use?

- Activities/Worksheets

A student learning guide is not a self-contained learning package (e.g., Distance Learning Module), such as you might receive from the Alberta Distance Learning Centre (ADLC) or Distance Learning Options South (DLOS).

\section{SAMPLE STUDENT LEARNING GUIDES}

Forest Regions of Canada (FOR102).

Woods Survival I (FOR104).

Basic Forest Ecology (FOR109). 



\section{FORESTRY}

Forest Regions of Canada (FOR102)

\section{TAKE THIS MODULE?}

- A fundamental requirement for anyone working in the forest is to be able to identify the types of vegetation present. This often gives clues as to the location and climate of the area. FOR 102 is an introduction to dendrology, the study of trees. This is a module for students interested in being able to identify local tree species and to explain the reasons for the locations of the forest regions of Canada and Alberta.

- This course should be taken in the late spring or early in the fall to make it much easier to identify trees, by their leaves rather than the bare twigs in winter.

\section{DO YOU NEED TO KNOW BEFORE YOU START?}

- Locate and describe the geographic regions of Canada

- Use and understand maps

- Know the Scientific Method of Inquiry 


\section{FORESTRY}

Forest Regions of Canada (FOR102)

\section{WILL YOU KNOW AND BE ABLE TO DO WHEN YOU FINISH?}

- Identify factors that enhance the development of forests and determine the distribution of living organisms within forest regions.

- Describe relationships between climatic factors and the growth of trees.

- Describe relationships between land forms and the distribution of forests.

- Suggest reasons for the distribution of trees in natural regions in Canada and Alberta.

- Locate and describe the eight forest regions of Canada.

- Read, interpret and create visual representations or species distribution in Canada and Alberta.

- Identify common trees and other plants that grow specific regions of Canada and Alberta.

- Prepare a display of details that help to identify local trees, shrubs and non-woody plants.

\section{SHOULD YOUR WORK BE DONE?}




\section{FORESTRY}

Forest Regions of Canada (FOR102)

\section{WILL YOUR MARK FOR THIS MODULE BE DETERMINED?}

\begin{tabular}{|c|c|}
\hline & PERCENTAGE \\
\hline $\begin{array}{l}\text { You must first demonstrate all of the competencies } \\
\text { required for this module. } \\
\text { When you have done this, your percentage mark for } \\
\text { the module will be determined as follows: } \\
\text { - Moisture Lab } \\
\text { - Test on Factors } \\
\text { - Forest Region Maps (Canada) } \\
\text { - Leaf Collection }\end{array}$ & $\begin{array}{l}10 \% \\
10 \% \\
25 \% \\
15 \% \\
40 \%\end{array}$ \\
\hline
\end{tabular}

\section{RESOURCES MAY YOU USE?}

- Trees and Shrubs of Alberta

- Native Trees of Canada

- Flora of Alberta

- Visions

- Guide to Common Native Trees and Shrubs of Alberta 
FORESTRY

Forest Regions of Canada (FOR102)

Assignments:

1. Research and prepare a detailed list of factors that act independently and together to determine the type of forest on a given area. These factors should include information on climate, soil, landforms and topography, and the interactions between the three.

2. Using the Scientific Method develop a hypothesis that tests plant growth rates against moisture availability. Write up the experiment, conduct it, and interpret the data collected. Remember to practise safe laboratory habits.

3. Forest Regions of Canada

- on a large sheet of paper (min. 11x17) pencil in the boundaries of this country. Add the provincial boundaries

- pencil in the forest regions

- make sure your map is neat and clearly understandable. It must have a key, scale, north arrow and legend

- on the next page is a sample sheet you can use to fill in information on each forest region

- repeat the above list for Alberta and its forest regions.

4. Leaf collection

Collect and prepared for formal presentation the leaves (twigs if winter) of five grasses (omit in winter), five local shrubs, willow, aspen, balsam poplar, white birch, jack pine, lodgepole pine, white and black spruce, larch and balsam fir. The species list may be altered by your teacher to fit local conditions. 


\section{FORESTRY}

\section{Woods Survival I (FOR104)}

\section{TAKE THIS MODULE?}

- This is a two-part module that will teach you safe and enjoyable skills and attitudes that will aid you in working and/or recreationing in the forest environment.

- This module will introduce you to the physical demands faced by a person travelling in the forest and provide structure and direction to learn from these experiences.

- It is recommended that this module be taken in conjunction with Woodmanship II (FOR203) and that you do this module in the spring (April-May).

- Remember that when in the forest the attitude of Minimal Impact interaction should direct all your activities.

\section{DO YOU NEED TO KNOW BEFORE YOU START?}

- Standard St. John's Ambulance First Aid course.

- You should have the attitude that you want to experience the forest environment first hand, in a positive fashion. If you are not interested you may find the field activities distasteful or even dangerous. 


\section{WILL YOU KNOW AND BE ABLE TO DO WHEN YOU FINISH?}

- Identify, assess, avoid and/or respond to physical hazards that may be imposed by the forest environment

- Identify, assess, avoid and/or respond to physiological and psychological factors often associated with outdoor experiences in the forest

- List and explain necessary steps to take in emergency and survival situations in the forest

- Select appropriate personal and group gear for outdoor forest activities

- Demonstrate safe use and appropriate care of outdoor handtools, including knives, axes and saws

- Demonstrate safe procedures for building and using outdoor fires

- Explain techniques used to plan, pack, carry and prepare foods during outdoor forest expeditions

- Explain techniques required for maintaining hygiene during outdoor forest expeditions

- Plan and conduct safe outdoor expeditions in the forest

- Use different modes of travel to participate in a variety of forest activities

- Acquire and apply minimal impact skills while participating in outdoor forest expeditions

\section{SHOULD YOUR WORK BE DONE?}




\section{FORESTRY}

\section{Woods Survival I (FOR104)}

\section{WILL YOUR MARK FOR THIS MODULE BE DETERMINED?}

\begin{tabular}{|l|c|}
\hline & PERCENTAGE \\
\hline $\begin{array}{l}\text { You must first demonstrate all of the competencies } \\
\text { required for this module. }\end{array}$ \\
$\begin{array}{l}\text { When you have done this, your percentage mark for } \\
\text { the module will be determined as follows: }\end{array}$ \\
- Hazardous list and test & \\
- Adverse conditions (discussion) & $5 \%$ \\
- Shelter construction & $5 \%$ \\
- Fire construction & $20 \%$ \\
- Pack and walk & $10 \%$ \\
- Tater management & $30 \%$ \\
\hline
\end{tabular}

\section{RESOURCES MAY YOU USE?}

- The Common Sense and Medical Guide and Outdoor Reference.

- Wilderness Survival

- Wilderness Survival Handbook

- Finding Your Way in the Outdoors

- Two in One Survival Library

- Local Forest Station and it's employees 


\section{FORESTRY}

\section{Woods Survival I (FOR104)}

- Prepare a list of possible hazards one may encounter in the natural environment, and on a test explain in detail several of the hazards.

- Explain why one must always be prepared for adverse conditions in the forest i.e.;

- having adequate and sufficient food

- having adequate and sufficient water

- adequate and sufficient first aid equipment

- Demonstrate the proper construction of a quinze, or lean-to if there isn't enough snow in the area.

- correctly build, use and contain a small campfire, making sure you address all safety precautions.

- prepare a list of equipment, food, and clothing required for a three day hiking trip. Assemble the list and walk all of it a minimum of three kilometres without removing the pack.

- Explain and demonstrate proper water management i.e.;

- drinking water

- disposal of waste water

- proper latrine location

- Demonstrate the following skill:

- correct axe and knife carrying

- correct axe and knife use

- correct axe and knife maintenance 


\section{FORESTRY}

Basic Forest Ecology (FOR109)

\section{TAKE THIS MODULE?}

- Being able to work with living things means you have to understand how things work. The easiest way is to look at the component parts of a system. Therefore, in this module you will look at several parts of the forest. These include tree structure, biotic and abiotic factors of the forest ecosystem, and the role of the tree in the forest.

- Remember you must practise safe work habits in anything you do, especially lab or outdoor activities. If you are not sure how to do something, ask someone having knowledge for instructions first.

\section{DO YOU NEED TO KNOW BEFORE YOU START?}

- Use the Scientific Method of Inquiry.

- Know the lab safety measures and procedures of your school.

- Access a copy of Investigating Terrestrial Ecosystems

- Have access to a laboratory. 


\section{WILL YOU KNOW AND BE ABLE TO DO WHEN YOU FINISH?}

- Identify living and non-living elements within a local forest ecosystem.

- Describe the interrelatedness of elements within a local forest environment.

- Explain the role of trees within a local forest ecosystem.

- Analyze food relationships among living organisms within a local forest ecosystem.

- Analyze food relationships among living organisms within a local forest environment.

- Compare the ecological niches of selected plant and animal species native to Alberta.

- Explain the vital life processes performed by trees and other forest plants.

- Describe structural units and component parts of the tree, and their function in performing vital life processes.

- Infer interrelationships among tree structures, their functions and vital life processes that are performed.

- Illustrate the approximate range of one or more tree species throughout North America.

\section{SHOULD YOUR WORK BE DONE?}




\section{WILL YOUR MARK FOR THIS MODULE BE DETERMINED?}

\begin{tabular}{|l|c|}
\hline & PERCENTAGE \\
\hline $\begin{array}{l}\text { You must first demonstrate all of the competencies } \\
\text { required for this module. }\end{array}$ \\
When you have done this, your percentage mark for \\
the module will be determined as follows: \\
- Tree Biology: \\
Activity 1.6 \\
Activity 3.2 \\
Tree Drawing \\
Test & \\
Forest Ecosystems & $10 \%$ \\
Activity 2.8 & $10 \%$ \\
Food Web & $10 \%$ \\
Test & $20 \%$ \\
& \\
\hline
\end{tabular}

\section{RESOURCES MAY YOU USE?}

- Alberta Parks and Recreation: Learning Resources Manual (Alberta Government)

- Investigating Terrestrial Ecosystems

- Field and Laboratory Methods for General Ecology

- Managing Your Wood Lot (Canadian Forest Service)

- Seeing the Forest Among the Trees

- Ecology

- Biology 


\section{FORESTRY}

\section{Basic Forest Ecology (FOR109)}

\section{Section 1: Tree Biology}

- Activity 1.6 on page 11 in Investigating Terrestrial Ecosystems.

- Activity 3.7 on page 47 in Investigating Terrestrial Ecosystems.

- On a large sheet of paper, draw a cross-section of a tree (top to bottom) that shows all components. Label each component. Then, on a separate sheet of paper (one for each component; see page 5) explain the importance of each structure as well as the processes it carries out. List the percentage by weight and volume that each structure makes up of the tree total; e.g., the leaves make up $1 \%$ of the tree's weight and $1.7 \%$ of its volume. As well, explain what would happen to the tree if the specific structure had its function impaired or destroyed.

- Completed a written test that will examine you on the structural components of trees, and the function of these components.

\section{Section 2: Forest Ecosystems}

- Read chapters 1,2 and 3 in Investigating Terrestrial Ecosystems.

- Activity 2.8 on page 33 of Investigating Terrestrial Ecosystems.

- Visit a forested area and prepare a comprehensive food web of the area. Plan this trip with your teacher. Make sure you address all aspects of safety. Plan two trip dates so that if the weather is bad on the first you can go on the second. Once at the area collect data on:

- types of animals present. Determine numbers and area in which animals are found.

Look for: scat

tracks

bones

actual sightings

- types of grass/shrubs/fungi and mosses present.

Determine numbers and area in which species are found.

- types and numbers of trees present and area in which trees are found.

- types and numbers of insects present

- soil quality (use a soil test kit).

Return to classroom with the data. On a large sheet of paper draw a food web using the data you collected. Explain the interrelationships that your food web shows. Prepare it for presentation (make it look good) and hand it in with your field notes.

- Write a test on the material presented in the three chapters and your observations on the field trip. 

DATE DUE SLIP

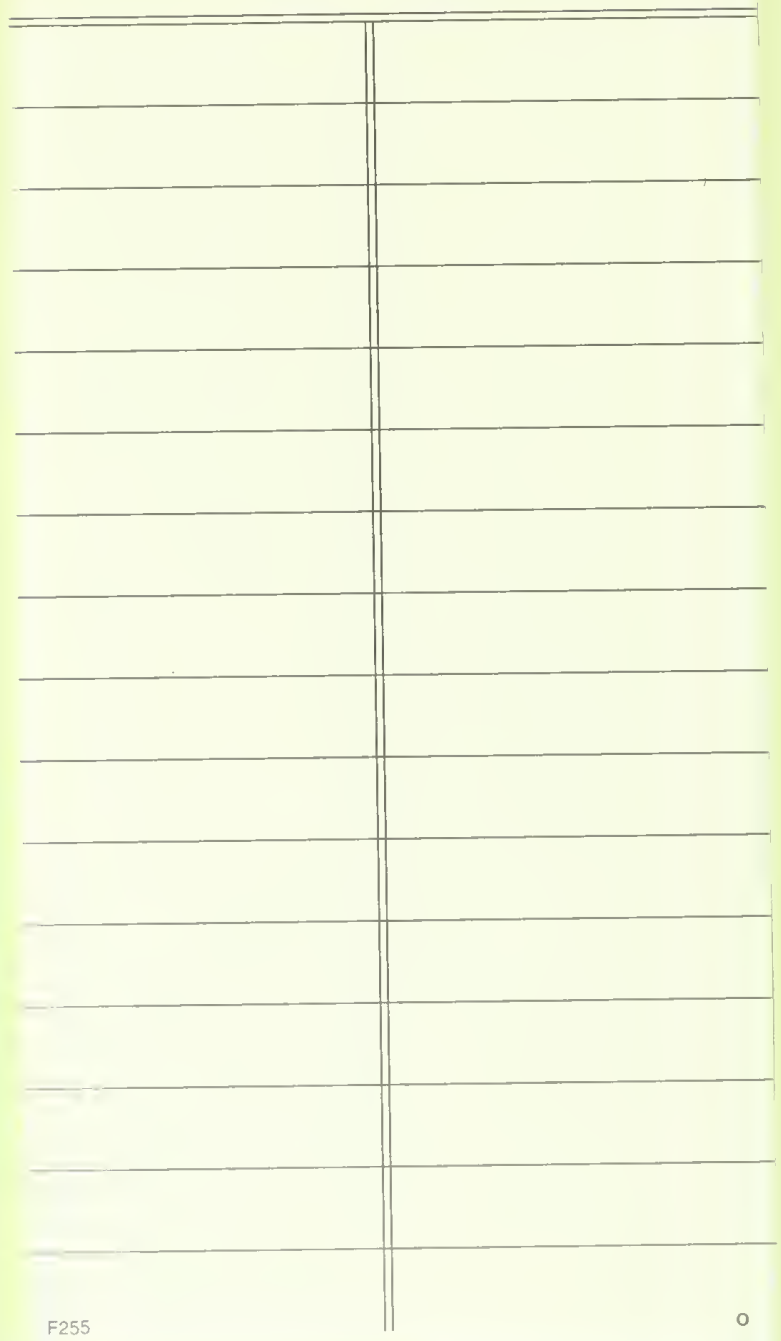

Alborita 

L'niversity of Alberta Library

$\begin{array}{llll}0 & 1620 & 0489 & 2038\end{array}$ 